\title{
Metafoor tussen magie en methode : narratief leren in organisaties en therapie
}

Citation for published version (APA):

Muijen, H. S. C. A. (2001). Metafoor tussen magie en methode : narratief leren in organisaties en therapie. [Doctoral Thesis, Maastricht University]. Agora. https://doi.org/10.26481/dis.20011004hm

Document status and date:

Published: 01/01/2001

DOI:

10.26481/dis.20011004hm

Document Version:

Publisher's PDF, also known as Version of record

\section{Please check the document version of this publication:}

- A submitted manuscript is the version of the article upon submission and before peer-review. There can be important differences between the submitted version and the official published version of record. People interested in the research are advised to contact the author for the final version of the publication, or visit the DOI to the publisher's website.

- The final author version and the galley proof are versions of the publication after peer review.

- The final published version features the final layout of the paper including the volume, issue and page numbers.

Link to publication

\footnotetext{
General rights rights.

- You may freely distribute the URL identifying the publication in the public portal. please follow below link for the End User Agreement:

www.umlib.nl/taverne-license

Take down policy

If you believe that this document breaches copyright please contact us at:

repository@maastrichtuniversity.nl

providing details and we will investigate your claim.
}

Copyright and moral rights for the publications made accessible in the public portal are retained by the authors and/or other copyright owners and it is a condition of accessing publications that users recognise and abide by the legal requirements associated with these

- Users may download and print one copy of any publication from the public portal for the purpose of private study or research.

- You may not further distribute the material or use it for any profit-making activity or commercial gain

If the publication is distributed under the terms of Article $25 \mathrm{fa}$ of the Dutch Copyright Act, indicated by the "Taverne" license above, 
METAFOOR TUSSEN MAGIE EN METHODE 



\title{
METAFOOR TUSSEN MAGIE EN METHODE
}

\section{Narratief leren in organisaties en therapie}

\author{
PROEFSCHRIFT
}

ter verkrijging van de graad van doctor aan

de Universiteit Maastricht,

op gezag van de Rector Magnificus, Prof. dr. A.C. Nieuwenhuijzen Kruseman

volgens het besluit van het College van Decanen, in het openbaar te verdedigen

op donderdag 4 oktober 2001 om 14.00 uur

door

Heidi S.C.A. Muijen 


\section{Promotiecommissie:}

Promotor:

Prof. dr. G.A.M. Widdershoven

Co-promotor:

Dr. Ph. van Engeldorp Gastelaars (Erasamus Universiteit Rotterdam)

Beoordelingscommissie:

Prof. dr. R.Vos (voorzitter)

Prof. dr. H.P. Kunneman (Universiteit voor Humanistiek, Utrecht)

Prof. dr. J. de Mul (Erasmus Universiteit Rotterdam)

Prof. dr. H. Philipsen

Prof. dr. H. Pott (Erasmus Universiteit Rotterdam)

- 2001, H.S.C.A. Muijen/ Uitgeverij Agora - Kampen

Postbus 5018, 8260 GA Kampen

Omslag Inge Steenhuis

Illustratie p. 275: M.C. Esscher 'Sky \& Water I' ${ }^{\circ}$ Cordon Art B.V. - Baarn - The Netherlands

ISBN 9039108587

NUGI 611

Alle rechten voorbehouden. Niets uit deze uitgave mag worden verveelvoudigd, opgeslagen in een geautomatiseerd gegevensbestand, of openbaar gemaakt, in enige vorm of op enige wijze, hetzij elektronisch, mechanisch, door fotokopieën, opnamen, of op enige andere manier, zonder voorafgaande schriftelijke toestemming van de uitgever.

All rights reserved. No part of this publication may be reproduced, stored in a retrieval system, or transmitted, in any form or by any means, electronic, mechanical, photocopying, recording, or otherwise, without the prior written permission of the publisher. 


\section{METAFOOR TUSSEN MAGIE EN METHODE}

\section{Narratief leren in organisaties en therapie}

INHOUD

VOORWOORD: "En het woord is vlees geworden..." 9

HOOFDSTUK 1: Een nieuw humanisme achter de hype van creativiteit?15

1.1 Inleiding 15

1.2 Beeldende creatieve therapie 20

1.2.1 Een historisch schets van creatieve therapie 21

1.2.2 De therapeutische (meer)waarde van creatieve therapie 25

1.2.3 Methodiekontwikkeling en professionalisering 29

1.2.4 Organisatorisch-maatschappelijke aspecten van professionalisering 31

1.3 Creatieve trajecten in training, coaching en advisering 33

1.3.1 Een hype van creativiteit 35

1.3.2 Een oude sofistenkunst in een nieuw jasje? 38

1.3.3 Naar een creatieve methodiek voor organisatievraagstukken 41

1.3.4 De organisatorisch-maatschappelijke context 47

1.4 Humanisering versus rationalisering? 48

1.5. Grondslagen van wetenschappelijke en intuïtieve kennis 53

1.5.1 Een (post-)romantische grondslag voor intuïtieve praktijkkennis 55

1.5.2 Een derde weg tussen een rationalistische en een romantische onderzoeksroute 58

1.6 De onderzoeksvraagstelling vanuit het derde perspectief 61

1.6.1 Samenvatting 63

1.6.2 Hoofdstukindeling 64 


\subsection{Inleiding 67}

2.2 Drie benaderingen van creatieve therapie 70

2.2.1 De antropologische benadering 71

2.2.2 Een instrumentele oriëntatie 74

2.2.2.1 De psycho-therapeutische benadering 74

2.2.2.2 De pragmatische benadering 78

2.2.3 De kunstgeoriënteerde benadering 80

2.3 Drie perspectieven op metaforische betekenisgeving 83

2.4 Een romantische ontwikkelingsmetafoor 86

2.4.1 Betekenisgeving vanuit een oorspronkelijke zijnsordening 86

2.4.2 Een symbolisch-rituele ordening 90

2.5 Een instrumentele optiek op ontwikkeling 93

2.6 Naar een hermeneutische ontwikkelingsmetafoor 97

2.7 Grondslaggevende dialectiek tussen verbeelding en verwoording 100

2.8 Samenvatting en conclusie 103

HOOFDSTUK 3: Metaforen in het organisatie-discours 105

3.1 Inleiding 105

3.2 Drie genres in het organisatie-discours 106

3.2.1 Metaforen, concepten en hybriden 106

3.2.2 Pro en contra de metafoor 111

3.3 Metaforen in organisatie-onderzoek 114

3.3.1 Morgans onderzoek 115

3.3.2 Metaforen, creativiteit en andere management hypes 117

3.3.3 Het metaforische masker van de instrumentele rede 121

3.4 Een gemaskeerde retoriek van agressie en competitie 124

3.4.1 Over het succes van de 'basketbal-organisatie' 125

3.4.2 Over het succes van de basketbal-metafoor 126

3.4.3 De dubbele boodschap van succes 128

3.4.4 De geestelijke dwangbuis van succes 131

3.5 Een metaforische benadering van organisaties 133

3.5.1 Metaforen en rationaliteit 135

3.5.2 Naar een communicatieve rationaliteit 139

3.5.3 Een dialogisch principe 144

3.6 Samenvatting en conclusie 146 
HOOFDSTUK 4: Een hermeneutische interpretatie van metaforische communicatie 149

4.1 Inleiding 149

4.2 Retorisch aspecten van communicatie 152

4.2.1 De retorische traditie 152

4.2.2 Logica van de metafoor 155

4.3 De metafoor als middel tot betekenisgeving 161

4.3.1 Dialectiek van metaforisering en conceptualisering 161

4.3.2 Het gezag van Metaphora en de macht van Logos 163

4.3.3 Een conceptuele omkadering van de metafoor 165

4.3.4 Metaforische communicatie 168

4.4. Regressieve, progressieve en transgressieve dynamiek 173

4.4.1 De metafoor als katalysator van ontwikkelingsprocessen 174

4.4.2 Hermes tussen hoofd en hart 178

4.4.3 Een hermeneutische interpretatie van de middenpositie 182

4.4.4 Een hermeneutisch interpretatiekader voor intuiltieve praktijkkennis 184

4.5 Rationalisme en romantiek als wereldbeelden 188

4.5.1 Rationalisering èn humanisering 188

4.5.2 De dialectiek tussen beelddenken en denkbeelden 191

4.5.3 Wereldbeelden en de esthetisering van ons bestaan 193

4.6 Levende metaforen en de dialogische grondhouding 199

4.7 Samenvatting en conclusie 201

HOOFDSTUK 5: Een veldstudie naar metaforische communicatie 204

5.1 Inleiding 204

5.2 Een hermeneutische methodologie van de middenpositie 205

5.3 Reconstructie van het onderzoekstraject 208

5.4 De context van het uitwisselingsproject 213

5.4.1 Uitwisseling van kennis en ervaring voor gezamelijk gewin 213

5.4.2 Een choreografie van methodologische keuzes 215

5.5 De veldstudie als onderzoeksdialoog 217

5.3.1 Dialectiek van afstand en betrokkenheid 217

5.3.2 Naar een 'model van metaforische communicatic en interactie'? 221

5.6 De verbeelding van organsaties en het organiseren van de verbeelding 230 
5.6.1 De groep creatieve organisatie-trainers 230

5.6.2 De groep beeldend therapeuten 237

5.6.3 De interdisciplinaire uitwisselingsbijeenkomst 244

5.7 De empirische winst uit het veldonderzoek 252

5.7.1 Professionele motto's en profilering 253

5.7.2 Professionalisering en organisatiecultuurverandering 259

5.7.3 Van 'metaforische communicatie' naar 'narrativiteit vanuit een kritisch humanisme' 261

5.8 Samenvatting en conclusie 266

HOOFDSTUK 6: Een kritisch-humanistische maat voor metaforen 269

6.1 Inleiding 269

6.2 Een dialogische wending in organisaties, therapie en filosofie $\mathbf{2 7 0}$

6.3 Speels denken en het andere van de rede 272

6.4 Naar een dialogische intuiltie voor creatieve therapie 276

6.5 De dialogische verrijking van de organisatorische rede 278

6.6 (G)één maat voor metaforen? 281

6.7 Thaan veth tarratieve 'ieeromgeving in organisaties en therapie? 284

6.8 Samenvatting en conclusie 289

LITERATUUR 294

ZAKENREGISTER 307

NAMENREGISTER 319

SAMENVATTING 321

SUMMARY 330

CURRICULUM VITAE 335 
In den beginne was het Woord en het Woord was bij God. Alle dingen zijn door het

Woord geworden en zonder dit is geen ding geworden dat geworden is. In het Woord was leven en het leven was het licht der mensen; en het licht schijnt in de duisternis en de duisternis heeft het niet gegrepen (...)

Het woord is vlees geworden en het heeft onder ons gewoond en wij hebben zijn heerlijkheid aanschouwd...

De geciteerde woorden uit het Evangelie van Johannes gebruik ik op metaforische wijze om aan te geven dat aan mijn onderzoek een aanhoudende fascinatie voor beelden en metaforen ten grondslag ligt. Voortgekomen uit dit zaadje van inspiratie is het schrijven van een dissertatie zoals gewoonlijk vooral een vrucht van perfectionering en transpiratie, een moeizaam proces van 'vleeswording'. Bovendien is het groeien van een vrucht afhankelijk van ecologische omstandigheden: het zaadje moet in goede bodem vallen, genoeg regen en zonlicht krijgen. Een nog diepere betekenis van de geleende heilige woorden gaat over mijn betrokkenheid bij 'het zijnsmysterie': het feit dàt ik ben geboren verdient mijn dagelijkse verwondering. Hoe ik aan mijn existentie invulling geef ervaar ik als een uiterste daad van creativiteit en vrijheid maar vanuit een verbondenheid met een omvattendere en sacrale zijns-ordening, waaraan veel mensen de naam 'God' geven.

Idealiter zijn vorm en inhoud van een geschrift congruent. Een proefschrift dient aan academische voorschriften, geschreven en ongeschreven vormeisen te voldoen. Bij het schrijven ondervond ik deze formele kant van het promotietraject enerzijds als een helpende hand, die mij heeft geholpen een kader te ontwerpen om mijn onderzoekstocht in te plaatsen. Anderzijds als een keurslijf waardoor aan het onderzoeksproces te weinig recht gedaan wordt: een raster waarin de 'levende woorden' van het onderzoeksmateriaal 'rastervormig' dreigen te worden. Overeenkomstig 'de middenweg' die ik in dit proefschrift verdedig heb ik, gegeven de algemeengeldige dissertatievorm, toch zoveel mogelijk een eigen betoogopbouw en schrijfstijl willen hanteren zodat ook het unieke en individuele van het gevolgde onderzoekspad voor de lezer bespeurbaar blijft.

Mijn fascinatie voor het creatieve aspect, voor 'de muziek' van taal en voor beeldspraak gaat wellicht terug tot mijn kinderjaren in een huiselijke en schoolomgeving waarin creativiteit, muziek en schilderkunst werden gestimuleerd. Deze fascinatie heeft zich sinds mijn filosofiestudie geconcentreerd op het wonder hoe 'de levende geest' dode letters kan bezielen. Gaandeweg deze studie echter raakte ik ook steeds meer geboeid door de omgekeerde dynamiek: hoe 'de geest' pas 
leven krijgt in en door de behuizing van het woord. In het bijzonder boeide mij de metafoor als een wonderlijke botsing en een creatief samenspel van 'taalregisters': hoe de taal van beelden het discursieve vertoog met een analoge semantiek onderbreekt en tot beeldspraak ombuigt. Theorieën en beschouwingen in discursieve vorm blijven versleten metaforen zolang ze niet door betrokkenheid van onderzoekers, auteurs en lezers levend worden. Persoonlijk en maatschappelijk engagement vervullen modellen en theorieën met zin en geven het vleesgeworden woord vleugels.

Het onderzoeken en verwoorden is een proces dat de grenzen van de individuele, bewuste en autonome persoon overstijgt. Volgens een klassieke opvatting vindt de geboorte van inzicht plaats als een 'dialectische kunst' in een gesprekscontext. Plato liet in een dialoog zijn leermeester Socrates het filosoferen vergelijken met de vroedvrouwen-kunst. Ook Aristoteles omschreef het denken als een vorm van dialectiek, namelijk als een gesprek met zichzelf. Veel zelf-gesprekken en 'toevallige' gesprekken met collega's, belangstellenden en vrienden hebben aan dit onderzoek vorm gegeven. Behalve de dialogische wijze waarop ik door woordvoerders van de westerse filosofische traditie ben gevormd, waren vooral de richtinggevende gesprekken met mijn twee onderzoeksbegeleiders van belang alsmede de ontworpen onderzoekscontext van individuele interviews en groepsgesprekken met respondenten. Fascinerend vind ik Derrida's radicale standpunt ten aanzien van de beperkte rol van de 'eigenlijke' auteur van een tekst in de grotere context van de filosofische traditie en binnen de 'speelruimte' van de taal. Als schrijfster heb ik inderdaad ervaren hoe ik in een fundamentele zin 'gevangen' ben in de reflectieve ruimte van de Nederlandse (filosofen-)taal die mij ter beschikking staat. Juist in de ervaring van deze beperkingen en in het beluisteren van de stemmen van vele mede-auteurs heb ik vrijheid hervonden door mijn eigen stem te laten klinken. Hoe ik in dit voorwoord mijn erkentelijkheid jegens anderen uitspreek doet hieraan onvoldoende recht. Nog andere, niet genoemde personen, levende en dode wezens en bijzondere gebeurtenissen zijn 'mede-auteur' van dit geschrift. Dit proefschrift is aldus een 'coproductie', niettemin blijft de uiteindelijke vorm en inhoud mijn ver(ant)woording.

Geboorte van inzicht door de dialoog met anderen, met jezelf en met de traditie vindt plaats langs de weg van verwoording. De metafoor van 'het vleesgeworden woord' verleidt tot een platoonse interpretatie: de vleeswording van zuivere ideeën in ideële vorm tot een aardse schaduw, een 'materieel weefsel', een tekst met 'dode letters'. Dat de metafoor deze verleidingskunst zo meesterlijk beheerst en de geest in een bepaalde denkrichting voert, bewijst de eenzijdigheid van een platoonse interpretatie en wijst op een verkeersstroom in omgekeerde richting. Het transport van betekenis vindt niet anders plaats dan door middel van eeuwenoude betekenisdragers die, op bepaalde wijze gerangschikt, de transformatie van ideeën en visies bewerkstelligen. Door die betekenisverschuiving in het ideële veld ondergaan de materiële tekens zelf ook weer een verandering. Dat kennis langs deze dialectische weg wordt vergaard en geboorte van inzicht aldus fundamenteel 
verweven is met een herschikking van woorden en metaforen tot een nieuw tekstueel verband, is mij een waarlijk wonder. Ik heb de klassieke filosofentaal, het vlugge en vluchtige management-jargon en de humanistische metaforen uit de taal van therapeuten omgebouwd tot een nieuw verhaal. De ambachtelijke kant van het schrijven van een boek door middel van velerlei versies van 'hetzelfde' verhaal heeft mij de ervaring gegeven dat dit 'materialiserende' proces van het opnieuw en weer herschrijven van het onderzoeksverslag een wezenlijke schakel vormt in het 'geestelijke' proces van kennisverwerving. Geboorte van inzicht door middel van de vleeswording van het woord. 'Vlees' met een 'academisch keurmerk' door de inpassing binnen een wetenschappelijk onderzoeksstramien en de onderwerping aan een wetenschappelijke toetsing. Pas na de verdediging van het proefschrift blijkt uiteindelijk de maatschappelijke levensvatbaarheid van wat er in de academische 'in vitro'-fase is geboren.

Zoals een boreling met de eerste ademhaling zich losmaakt van het moederlichaam of zoals $\mathrm{z}(\mathrm{h}) \mathrm{ij}$ autonomie bereikt op het ultieme moment van de eerste zelfstandige stap, zo geeft de auteur het heft uit handen wanneer het boek van de drukpers rolt. Als schrift gaat het woord zijn eigen weg, van boekwinkel naar lezers en zaait daar evenzovele zaadjes voor receptie en interpretatie van het betoogde. Dan nemen anderen het woord over, bijvoorbeeld tijdens de promotie, om het gestelde te bevragen en te becommentariëren. Mogelijk dienen zich nog andere contexten aan, waarnaar het hier vertelde onderzoeksverhaal wordt verplaatst, aangevuld, gecorrigeerd en naverteld... Een verhaal kan lezers inspireren of vervelen, boeien of irriteren; verwondering, bewondering of verachting oproepen. Naar ik mag hopen blijft mijn inspiratie voor de lezer bespeurbaar als de rode draad die door het weefsel van woorden heenloopt.

Een boek als een 'geestelijk kind' mag een versleten metafoor zijn, niettemin creëert de ambiguë betekenis van 'vleeswording' een mimesis ten opzichte van de geboorte van mijn letterlijke vlees en bloed. Hoewel dit geschrift natuurlijk meer van letterlijks weg heeft dan mijn dochter, herken ik een spoor van de existentiële hoop en vrees, de vreugde en pijn, de dankbaarheid en trots, de wanhoop en kracht, de schroom en moed, die ik voelde bij de geboorte en het opgroeien van mijn dochter. Netzomin als je als 'ouder in spé' weet wat ouderschap werkelijk inhoudt, was dat het geval met mijn voornemen om aan een promotie-onderzoek te beginnen en een proefschrift te gaan schrijven. Ik hoop dat ik over het resultaat enige blijdschap en tevredenheid kan blijven ervaren, al was het maar een vleugje van hetgeen ik jegens mijn dochter door de jaren heen voel. Tijdens het beproevende werk van het schrijven van deze tekst kreeg ik van een bekende per email een aantal stellingen toegestuurd over het verschil tussen de bevalling van een baby en van een proefschrift. Op een twaalftal punten sloeg de vergelijking, in de zin van een kosten/baten-analyse, uit in het voordeel van het krijgen van een biologisch kind. Tegenover de zekerheid van de negenmaanden-periode staat de onzekerheid over de duur van het onderzoeks- en schrijfproces, weliswaar met de zekerheid het ten minste één keer te moeten herschrijven en met het risico het nog 
enkele malen over te moeten doen. De laatste stelling overtuigde mij het meest: 'In tegenstelling tot het schrijven van een dissertatie en ongeacht hoe groot de moeite en pijn ook waren, mensen zijn blij bereid om nog meer kinderen te krijgen'! Hoewel het schrikbeeld van een proefschrift als 'levenswerk' inmiddels antiek is geworden in deze vluchtige tijd van virtualisering van kennis, is het toch zo dat de zinvolheid van zulk monnikenwerk zelfs door begripsvolle vrienden met regelmaat in twijfel wordt getrokken in het licht van de vervreemdende en soms ontmenselijkende effecten die het promotieproces met zich mee brengt.

$\mathrm{Nu}$ dan deze beproeving bijna is doorstaan zal haar moeizame kant door de stroom van de tijd verzacht worden zoals de herinnering aan een inspannende bergbeklimming. Met de terugblik op het afgelegde pad is het goed ook de reisgenoten te bedanken zonder wie het reisdoel niet bereikt ware. Natuurlijk geldt dat in de eerste plaats voor mijn ouders, die helaas niet meer in levende lijve van deze afronding getuige kunnen zijn. Mijn dochter Quintra, die inmiddels zelfstandig en met aanstekelijke levenslust haar eigen levenspad vervolgt, komt een groot deel van mijn dank toe. Ook twee 'geestelijke vaderfiguren', een Indiaanse antropoloog en een woordvoerder van een Gnostieke wijsheidstraditie, hebben mij met hun woorden en daden voor deze reis toegerust. Om daadwerkelijk de eerste stappen op de weg naar promotie te zetten, hebben de oriënterende gesprekken met aan universiteiten verbonden bereidwillige mensen mij gehopen, waarvan ik enkele bij naam wil noemen: Heinz Kimmerle, Ilse Bulhof en Joop Hellendoorn. In een meer directe zin hebben mijn co-promotor Frits van Engeldorp Gastelaars en promotor Guy Widdershoven mij op uiterst prettige en zeer deskundige wijze begeleid op het onderzoekspad. Alle respondenten wil ik niet alleen voor hun moeite en medewerking bedanken maar vooral ook voor de bereidwilligheid waarmee zij met hun kennis en ervaring een wezenlijke bijdrage aan het onderzoek hebben geleverd. Mijn studenten van de module 'metaforische methode' in het kader van het methodologieonderwijs aan de bedrijfskundefaculteit van de Erasmus Universiteit Rotterdam bedank ik, daar dat zij met hun feedback op deze experimentele operationalisering van de onderzoeksresultaten hebben bewezen meer dan alleen 'proefkonijn' te zijn. In het bijzonder wil ik in dat kader het enthousiasme van Caroline Molenaar noemen, die mij bovendien als studentassistente kranig en kundig bij de verslaglegging van de groepsinterviews heeft geholpen. Van groot belang voor het welslagen van deze groepssessies was de bijdrage van twee gastsprekers, Marjet Woudenberg en Albert Berman. In dat verband geldt mijn dank vooral ook de stichting Humanitas, die geheel belangeloos hun sfeervolle locatie ter beschikking stelde. Wat betreft de wetenschappelijke inbedding van het onderzoek in de vorm van een vierjarige A.I.O.-aanstelling aan de bedrijfskunde-faculteit van de Rotterdamse universiteit wil ik de aangename collegiale contacten binnen de vakgroep methodologie benadrukken, waaraan ik behalve door middel van individuele gesprekken ook tijdens de vakgroepseminars belangrijke feedback op mijn onderzoek heb te danken. Overigens gaat mijn dank uit naar de Erim-onderzoeksschool die de uitvoering van het onderzoek in formele en materiële zin heeft mogelijk gemaakt. Aangezien in dat kader aan de formele eis 
van een vierjarige arbeidsovereenkomst streng de hand werd gehouden, dank ik in het bijzonder George Hendrikse, die als voorzitter van de vakgroep methodologie tegen de cultuuromslag van vercommercialisering van het universitaire bestel in, mij ook na afloop van het aanstellingscontract organisationele gastvrijheid heeft geboden om mijn proefschrift af te ronden. Last but not least wil ik zowel de beoordelingscommissie als de meelezers bedanken, die met hun waardevolle commentaar hebben bijgedragen aan de tot standkoming van de hoofdstukken in hun definitieve vorm: Cees en Martin Luijendijk, Bram Moerland, Marja Hendriksen, Louis van Marissing, Fiety Meijer en Joke Dinklage, Douwe Tiemersma, Joop Ramondt, Tony Hak en Tineke Abma.

Heidi Muijen

Rotterdam, 09 augustus 2001 
'Het leven is een schouwtoneel...' in een 'aards tranendal', zoals een god in Frankrijk of met een Spaans levensgevoel van 'La vida es un carnaval': we bevinden ons hoe dan ook op de weg van het menselijk bestaan: de 'ene weg' voor het transport van geboorte naar dood èn de vele wegen voor het dragen van de tijd tussen onstaan en vergaan. Met het opgroeien en verzamelen van steeds meer kenniskaarten om loopbaan en levenswandel uit te stippelen, verzwaart de tijd. Met het groeiende besef dat ons de juiste routebeschrijving ontbreekt, keert de lichtvoetigheid terug om zoals de bergen de tijd te laten verstillen en te zijn zoals de rivier die het water laat gaan.

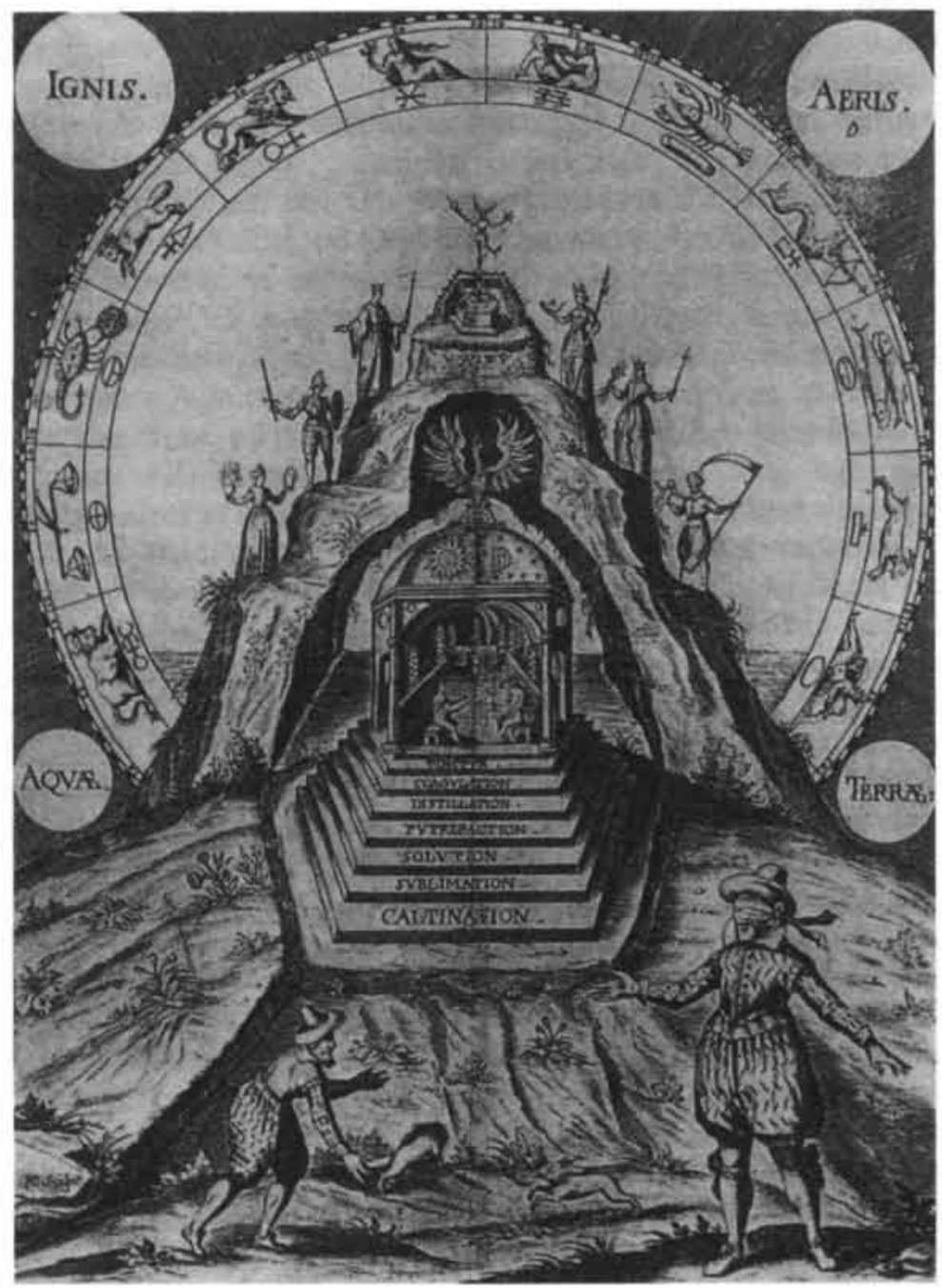




\section{HOOFDSTUK 1:}

Een nieuw humanisme achter de hype van creativiteit?

\subsection{Inleiding}

Van de grottekeningen van Lascaux tot onze huidige zapcultuur spelen beelden een fundamentele rol in het geven van betekenis aan onze wereld. De geschetste jachttaferelen en dierfiguren op de Zuid-Franse grotwanden ${ }^{l}$ worden in verband gebracht met een rituele en magische omgang met de natuur en zouden aldus integraal deeluitmaken van het dagelijkse leven. Hier tegenover is de beeldenwerkelijkheid waarin wij 24 uur per dag leven gefragmenteerd, vluchtig en autonoom: t.v.-beelden, symbolen op het monitorscherm, droombeelden, posters op straat, reclamebeelden, beelden in musea, logo's, bill-boards, neon-reclame, etc. De werkelijkheid verschijnt 'hyperreëel' en losgescheurd van een 'natuurlijke verankering'. Kan een 'postmodern levensgevoel' ons een baken bieden voor de afgevuurde beeldenstorm? Of hebben we als tegenwicht tegen de virtualisering en digitalisering van het leven een degelijker oriëntatiepunt nodig, een rehabilitering van humanistische waarden?

Bezien vanuit een 'post-moderne werkelijkheidservaring' komen de mythische beelden van onze verre voorouders op ons over als een magische verbondenheid met de natuur. De 'mythisch-magische werkelijkheidservaring' is natuurlijk nooit als beleving te achterhalen. Via archeologisch en antropologisch materiaal zijn er pogingen ondernomen om haar als een 'metafysische versluiering van de werkelijkheid' te reconstrueren. ${ }^{2}$ Ten opzichte van deze gereconstrueerde mythische oorsprong heeft men de volgende fasen in de geschiedenis veelal geïnterpreteerd als een 'rationele onttovering' van onze verhouding tot de wereld. ${ }^{3}$ Een onbetwijfelbaar geloof in onze rationele vermogens waarmee we de natuur haar geheimen ontfutselen en onze 'overwinning' op haar bezegelen met wetenschappelijke kennis en technologische manipulaties, staat aan de basis van het vooruitgangsoptimisme van de moderne tijd. Hierdoor is de rol van goden, geesten en demonen die eertijds de natuur en ons universum bestierden gemarginaliseerd en vervangen door mechanische wetmatigheden tussen onbezielde fysieke krachten en atomaire eigenschappen van dode materie ${ }^{4}$. Maar zouden onze verre voor-

1. Bataille: De tranen van Eros 39 e.v.

2. Bijvoorbeeld: Frazer: De Gouden Tak. Cassirer: An essay on man.

3. Jaspers: Vom Ursprung und Ziel der Geschichte. Gebser: Ursprung und Gegenwart I, II.

4. Dijksterhuis: De Mechanisering van het Wereldbeeld. 
ouders, verplaatst naar het huidige Europa, onze technologische omgang met de natuur niet als een even mysterieuze bezwering van de werkelijkheid ervaren?

\begin{abstract}
Aldus kunnen we ook, andersom, onze post-moderne werkelijkheidservaring reconstrueren in termen van een 'primitievere' magische omgang met de werkelijkheid. Ook in een 'rationeel onttoverde wereld' zijn symbolen en rituelen belangrijk voor het instandhouden van de zijnsordening. In onze huidige wereldorde speelt het economische verkeer een cruciale rol, waarbij de hoogte van de dollar, de euro en de olieprijs essentiële psychologische en magische functies vervullen. De dagelijks bekend gemaakte beursnoteringen via het journaal vertegenwoordigen een onmisbaar symbolisch ritueel, gericht op de bezwering van Economische Krachten die de wereldorde bestieren.
\end{abstract}

Wanneer we een beeld schetsen van 'de primitieve mens' gebruiken we antropologische verhalen om ons een voorstelling te maken van iets dat nooit te achterhalen valt. Voortdurend creëren we mensbeelden, maatschappij-beelden en wereldbeelden om ons te oriënteren in de werkelijkheid, om haar te ordenen en te manipuleren. Dit vermogen om beelden te creëren lijkt mij primair te zijn, ongeacht het feit of de geschetste ontwikkeling inderdaad heeft plaatsgevonden. De vooronderstelling van een uniforme, rechtlijnige en opwaartse ontwikkeling van 'de mensheid', waarbij het Westen een voorsprong zou hebben op 'niet-Westerse' culturen $^{5}$, is onder invloed van ontwikkelingen in deze eeuw ongeloofwaardig geworden. Is er een 'niet-ethnocentrische' benadering van deze problematiek mogelijk ? ${ }^{6}$ Zijn onze huidige beelden 'wezenlijk' anders, gedemystificeerd en 'naakt', in vergelijking met de mythische van eertijds?

In wervingscampagnes van bedrijven wordt ingespeeld op het carrièreperspectief van studenten, dat op een of andere wijze geënt is op de metafoor van 'de maatschappelijke ladder', zoals in de slogan "Wie hogerop wil komen kan beter niet te laag beginnen".

Deze metafoor zinspeelt op een rationalistisch geloof in 'de maakbaarheid' van de eigen levensloop door midddel van carrière planning. Dit geloof wordt ook via een ander reclamebeeld overgebracht: een uitnodigende ronde tafel met lege stoelen en één bezette stoel, waarop een jonge 'model'-studente zit, helder invallend licht daarachter, onder dit beeld de wervende woorden "Voor welke STOEL ga jij?"

Tekenend voor de fundamentele rol van het zien en de verbeelding in onze opvatting van de werkelijkheid zijn woorden als 'wereldbeeld', 'mensbeeld', 'perspectief', 'optiek' en 'paradigma'. Het primaat van beelden en het gezichtsvermogen in onze conceptuele constructies wordt door sommigen typerend geacht voor onze huidige, westerse, wetenschappelijke en mannelijke benadering van de

5. De Gouden Tak 84-85.

6. Lemaire: Over de waarde van kulturen. De indiaan in ons bewustzijn. 
werkelijkheid. ${ }^{7}$ Strikt genomen zouden we dus deze 'verbeelding' niet naar andere tijden, plaatsen en culturen mogen verplaatsen. In die zin zegt de reconstructie van 'het primitieve wereldbeeld' meer over de 'geciviliseerde' waarnemer dan over het waargenomene. Door de post-moderne kritiek op 'Grote Verhalen' zijn we ten aanzien van 'de' werkelijkheid en 'de' maatschappij bescheidener geworden en spreken we over mensbeelden, maatschappijbeelden en wereldbeelden in het meervoud.

Verwoording en verbeelding zijn twee fundamentele kenwijzen om ons historische, culturele en maatschappelijke bestaan op aarde te begrijpen. De machine ${ }^{8}$ is een treffende metafoor om de mens van het Industriële Tijdperk te verbeelden. In plaats van de stoommachine van toen zou de computer een geschiktere metafoor opleveren om de huidige mens in het Informatie Tijdperk te conceptualiseren. Deze beelden suggeren een enorme historische en psychologische afstand tussen onze werkelijkheidservaring en de 'mythisch-magische', die wij toeschrijven aan een 'primitievere' ervaringswijze. Kunnen wij nog wel toegang verkrijgen tot deze andere ervaringswerkelijkheid? Gaat het om een vergelijkbare 'primitieve' ervaringswijze welke in creatieve therapie door middel van 'regressie' en beeldende expressie wordt bewerkstelligd? Gaapt er werkelijk een kloof in de ervaringswerkelijkheid van 'toen' en 'nu'? Is er een onachterhaalbaar verschil tussen 'hier' en 'daar'? Of is de afstand tussen een 'primitieve' en een 'geciviliseerde' werkelijkheidsbeleving slechts gradueel, oppervlakkig of schijn? Is er onder die ogenschijnlijke distantie een gelijkblijvende 'kern', op grond waarvan we ons juist kunnen vergelijken en meten met het verleden en met andere culturen? Hoe zouden we ons daarover een oordeel kunnen vormen, dat anders tot stand komt dan een ideologisch gekleurd vooroordeel in termen van 'primitief' en 'geciviliseerd'?

Waar kunst zich op laat voorstaan - om door middel van zintuiglijke modaliteiten een werkelijkheid te vertolken - daar neemt de wetenschap geen genoegen mee. $\mathrm{Zij}$ wil niet slechts een beeld creëren, maar de fundamentele principes waarop de werkelijkheid berust inzichtelijk maken. De filosofie onderzoekt onder meer de veronderstelde verschillen tussen beide en de vraag in hoeverre de wetenschap haar pretentie waar kan maken. Praktische disicplines, zoals de psychotherapie en de organisatiekunde creëren beelden over de mens en over organisaties die wat betreft hun theoretische status een tussenvorm lijken te representeren tussen ideologisch gekleurde metaforen en theoretisch geladen (voor)oordelen van de wetenschap. Wat betekent in dit verband de recente aandacht voor creativiteit in wetenschap en praktijkkennis, waaronder het gebruik van metaforen om een diagnose van de 'organisatorische status quo' te stellen of om een wenselijker toekomst voor mens en organisatie te typeren? Behoren de management- en de therapeutische metaforen tot de wereld van fictie, kunst en beeldspraak of tot de wetenschappelijke orde van modellen en begrippen? Wat is het statuut van deze hybriden? Dit zijn

7. Heidegger: Vorträge und Aufsätze I, II. Jaspers: Psychologie der Weltanschauungen. Braidotti: Beelden van de Leegte. Vrouwen in de hedendaagse filosofie.

8. Bijvoorbeeld La Mettrie: L'homme Machine (1747) 
enkele vragen die de aanzet hebben gegeven tot dit onderzoek naar de toepassing van creatieve middelen en metaforen in het kader van organisatorische en therapeutische processen.

Mogelijk weerspiegelt de toegenomen belangstelling voor creativiteit in therapie en organisaties een algemenere maatschappelijke en wetenschappelijke ontwikkeling. In de (geestelijke) gezondheidszorg heeft creatieve therapie naast traditionelere vormen van therapeutische dienstverlening inmiddels een vaste plaats verkregen. Creatieve therapie is een verzamelnaam voor beeldende therapie, muziektherapie, dramatherapie, danstherapie en tuintherapie, die alle deel uit (kunnen) maken van het multi disciplinaire behandelaanbod. Als kunstgerelateerde 'doe'therapieën vertegenwoordigen ze, volgens betrokkenen, een 'meerwaarde' ten opzichte van reguliere therapieën door middel van 'praten' en 'pillen'. ${ }^{9}$ Het werken met creatieve middelen, of het in gang zetten van een creatief proces, zou een bijzondere genezende werking voor de patiënt behelzen. Ook in het bedrijfsleven wordt veel aandacht en geld geschonken aan de factor 'creativiteit'. Steeds vaker verschijnen ludieke evenementen tussen gebruikelijkere onderwerpen op de bedrijfsagenda. Behalve de populaire overlevingstochten in de Ardennen bestaat het alternatieve aanbod bijvoorbeeld uit 'management als kunst van het paardenmennen', 'mental coaching', 'jongleren als (management)kunst van het loslaten', 'het stimuleren van creatief denken', 'theatertrainingen in bedrijven'. ${ }^{10}$ Creativiteitsbevorderende ideeën en praktijken, afkomstig uit de 'non-profit sector', worden kennelijk op de managementpraktijk toegesneden in de vorm van workshops, trainingen en personeelsdagen. Aldus investeert het bedrijfsleven in nieuwe vormen van psychologische en creatieve ondersteuning van werkprocessen.

In dit onderzoek worden beide, ogenschijnlijk los van elkaar staande kennispraktijken in deze verschillende maatschappelijke sectoren met elkaar verbonden. De geschetste problematiek wordt niet zozeer aangesneden vanuit een bepaalde toegepaste wetenschappelijke optiek, bijvoorbeeld aan de hand van een psychologische, historische of bedrijfskundige aanpak. De onderzoeksvraagstelling wordt vooral filosofisch benaderd als vraag naar de grondslag van creatieve therapie beeldend en van de wijze waarop creatieve middelen worden gebruikt in organisatietrainingen, coaching en advisering. Door deze onderzoeksinsteek is het mogelijk om een verband te leggen tussen beide ontwikkelingen. Bovendien vermag het filosofisch bevragen van de impliciete uitgangspunten en vooronderstellingen ten aanzien van de bestudeerde kennis(praktijken) een licht te werpen op de (wetenschappelijke en maatschappelijke) vooroordelen, die mede bepalend zijn voor de heersende opvattingen over en de dagelijkse praktijk in beide sectoren. Langs deze weg zullen de beschreven fenomenen zowel ideologie-kritisch als methodologisch worden onderzocht. Richtinggevend voor deze dubbele insteek is de vraag of de toegenomen aandacht voor creatieve en psychologische aspecten

9. Berman: Perspectief voor Creatieve Therapie? Trends en ontwikkelingen in de gezondheidszorg. Tijdschrift voor Creatieve Therapie 1998/ 2, 20-23.

10. Zie Studieweek. 1998/ 46. 
van ons (werk)leven als een teken van humanisering moet worden verstaan, dus als een tegenbeweging tegen rationaliseringstendenzen, of juist als een voortzetting hiervan onder een andere noemer. De geboorte van onze huidige wetenschap stond in het teken van de rationalisering van mens en maatschappij. Dit ideaal betekende een bevrijding uit dogmatische metafysische denkbeelden en religieuze praktijken die men belemmerend achtte voor maatschappelijke vooruitgang. Een opgeroepen tegenbeweging beantwoordde dit eenzijdige rationalistische vooruitgangsgeloof met romantische denkbeelden ${ }^{11}$ over de bevrijding van onze 'oorspronkelijke', 'natuurlijke' en 'niet-rationele' vermogens uit de greep van het technische verstand. Als voorbeelden van een 'niet-rationele' omgang met de werkelijkheid gelden artistieke en spirituele expressievormen. Niet wetenschap, maar kunst en religie zouden vanuit dit romantische bevrijdingsideaal het voortouw in de ontwikkeling moeten nemen. Tegen de achtergrond van dergelijke ideologisch geladen vooronderstellingen over ontwikkelingsprocessen van mensen (in organisaties) en van de samenleving, welke in kennis(praktijken) vervat zijn, krijgt de onderzoeksvraagstelling reliëf. Hierbij wordt de naieve opvatting dat de introductie van creativiteit in organisatorische en therapeutische processen als zodanig humaniserend werkt onder kritiek gesteld. Het zou immers kunnen zijn dat een 'naïef humanisme' de dekmantel vormt voor verregaande rationalisering van ons (werk) leven tot in de psychologische vertakkingen van het maatschappelijke bestel. Met dit onderzoek beoog ik dusdanige duidelijkheid over deze vraag te verschaffen, dat kan worden nagegaan of een 'kritisch-humanistische' grondslag voor intuïtieve praktijkkennis de toepassing van creatieve communicatie-middelen in organisaties en therapie vermag te legitimeren.

Een filosofische vraagstelling naar 'de grondslag' van een bepaald type kennis is in een tijd waarin 'post-modern relativisme' en 'metafysica-kritiek' zegevieren een hachelijke onderneming geworden. In dit verband is het onderzoekspad op sommige kruispunten afgegrensd voor mogelijke 'metafysische dwaalwegen' èn voor 'doodlopende nihilistische routes'. Vanuit de methodologische vraagstelling worden de onderzochte vormen van praktijkkennis getypeerd in vergelijking met wetenschappelijke kennis. Deze onderzoeksaanpak suggereert een tegenstelling tussen wetenschappelijke rationele kennis versus irrationele praktijkkennis. De gesuggereerde tegenstelling lijkt echter voort te komen uit een rationalistisch vooroordeel. Derhalve wordt de vraag gesteld of de 'eigenheid' van de betreffende praktijkkennis buiten deze dichotomie gevonden kan worden, in een 'grondhouding' die aan de 'intuïtieve kennisvorm' ten grondslag ligt. Mijn vooronderstelling bij de gekozen onderzoeksroute is dat hierdoor aan de ene kant wordt vermeden dat het gebruik van creatieve middelen in organisaties en therapie eenzijdig opportunistisch en instrumenteel wordt benaderd, terwijl aan de andere kant de 'intuïtieve benadering' evenmin wordt afgedaan als een vorm van 'irrationele' en bij gevolg onverantwoordbare kennis.

11. De Mul: Het romantische verlangen in (post)moderne kunst en filosofie 6-10. 
In paragraaf twee wordt de ontwikkeling van creatieve therapie in Nederland geschetst met speciale aandacht voor haar methodiek en het belang van professionalisering. In de volgende paragraaf volgt een beschrijving van de toenemende populariteit en groeiende variëteit van creatieve en psychologische, ondersteunende trajecten voor organisatieprocessen. Daarna worden de ontwikkelingen in beide sectoren in de vierde paragraaf met elkaar in verband gebracht en kritisch belicht vanuit de hierboven aangegeven onderzoeksinsteek van humanisering versus (?) rationalisering. De vijfde paragraaf betrekt de ideologie-kritische vraagstelling op de method(olog)ische vraag naar de 'meerwaarde' resp. de 'eigenheid' van de intütieve kennisvorm. In dat verband wordt het onderzochte opgevat als een vorm van praktijkkennis welke voortkomt uit een empathisch-intuittieve kenwijze en die tekenend is voor een romantische grondhouding. Deze kenwijze vormt het tegenbeeld van de rationalistische wijze waarop wetenschappelijke kennis tot stand komt. De problematisering van de hiermee opgeroepen tegenstelling van 'rationalisme' versus 'romantiek' leidt tot de vraag naar een 'derde filosofische weg' die tussen beide eenzijdige grondhoudingen door koerst. Of het gewenste fundament voor intuittieve praktijkkennis in de vorm van een 'bemiddelende' grondhouding voorbij beide extremen van 'rationalisme' en 'romantiek' gevonden kan worden, wordt daarna als onderzoeksvraagstelling geherformuleerd. In de laatste paragraaf volgt een samenvatting en wordt de gekozen onderzoeksroute geschetst aan de hand van de hoofdstukindeling.

\subsection{Beeldende creatieve therapie}

Door het Nederlands Centrum voor Geestelijke Volksgezondheid is er in de periode 1994 - 1995 een grootschalig, verkennend onderzoek verricht naar de positie van vaktherapeuten en vakbegeleiders in de gezondheidszorg. ${ }^{12}$ Op grond van de daarmee verkregen empirische gegevens valt af te leiden dat het om een niet te verwaarlozen zich gestaag professionaliserende beroepsgroep gaat. De op basis van dit onderzoek gemaakte schatting geeft aan dat deze groep bestaat uit ongeveer 1100 creatief therapeuten in de gezondheidszorg, waaronder 530 beeldend therapeuten, 300 muziektherapeuten en 150 dramatherapeuten. ${ }^{13}$ De dans-, bewegingsen tuintherapeuten vormen met 60 ten opzichte van deze andere disciplines een minderheidsgroep. Tussen de verschillende specialisaties van creatieve therapie zijn aanmerkelijke verschillen geconstateerd met betrekking tot de graad van professionalisering. Beeldend therapeuten komen wat dit betreft vooraan (gemeten naar percentage therapeuten dat lid is van de beroepsvereniging, een erkende opleiding heeft genoten en zich heeft laten registreren), gevolgd door drama- en muziektherapeuten. Parallel aan deze onderlinge verschillen onder-scheiden creatief therapeuten beeldend en dramatherapeuten zich van muziek-therapeuten in

12. Neijmeijer (e.a.): Beroep: Vaktherapeut/ vakbegeleider. Een verkennend onderzoek naar persoon, werk en werkplek van vaktherapeuten en vakbegeleiders in de gezondheidszorg.

13. Beroep: Vaktherapeut/ vakbegeleider 91-96. 
de aard van de zorgtaken, namelijk dat de eerstgenoemden zich vooral met de behandeling van patiēnten bezig houden, terwijl de muziek-therapeuten meer begeleidingstaken zouden hebben, hetgeen dienovereenkomstige verschillen in $\mathrm{CAO}$-inschaling met zich meebrengt. Een opmerkelijk gegeven van de totale groep creatief therapeuten is dat driekwart van hen vrouw is en werkzaam in part-time functies (gemiddeld werken creatief therapeuten 24,3 uur per week). Voor alle groepen geldt dat het grootste deel van de werktijd patiënten-contacturen betreft, namelijk $51 \%$, tegenover $16 \%$ zorgcoördinatie en overleg, en $13 \%$ administratie en rapportage. Een analoog verschil wat betreft genoten vooropleiding volgt ook uit deze gegevens: namelijk dat van de beeldend en drama-therapeuten het grootste percentage (erkend) HBO is opgeleid en vaker een vervolgopleiding heeft genoten in vergelijking met de muziektherapeuten. De conclusie die de onderzoekers aan deze gegevens verbinden is dat de muziek-therapeuten onder meer door het hogere percentage 'alternatief' opgeleiden en door de meer op 'care' dan op 'cure' gerichte werksetting, minder ver gevorderd zijn in het proces van professionalisering dan drama- en beeldend therapeuten.

In deze paragraaf zal in vier stappen een beeld worden geschetst van de ontwikkeling van (beeldende) creatieve therapie in Nederland. In de eerste subparagraaf volgt een typering van deze therapievorm en een beschrijving van haar historische ontwikkeling. Aan de hand hiervan worden er in de tweede subparagraaf een drietal methodische kenmerken van creatieve therapie onderscheiden en een aantal psychotherapeutische stromingen genoemd waarmee de gebruikte methodieken in verband staan. De derde subparagraaf belicht het belang van methodiekontwikkeling en kritische reflectie voor het proces van professionalisering. Ten slotte wordt het professionaliseringsproces verbonden met organisatorische en maatschappelijke aspecten van creatieve therapie.

\subsubsection{Een historische schets van creatieve therapie}

De doorbraak komt 'min of meer toevallig' op het moment dat Bart nog eens de 'grote en kleine Bart' geschilderd heeft en er per ongeluk een sliert verf op zijn tekening valt. Deze sliert verf wordt voor Bart een telefoonlijn tussen de grote en kleine Bart. In beeldtaal is er contact gemaakt, heeft 'kleine Bart' een manier gevonden om aan 'grote Bart' te laten horen wat hij wil en andersom. Deze 'toevallige' telefoonverbinding riep sterke emoties op bij Bart. ${ }^{14}$

Een creatief therapeute beeldend beschrijft een casus aan de hand van de betekenis van 'beeldspraak' en in het bijzonder de metafoor. Zij gebruikt de 'brugfunctie' van de metafoor, de brug die beeldspraak kan slaan tussen de beelden die in therapie gecreëerd worden en de betekenis die zij voor de patiënt en diens genezing

14. Korting: De creatief therapeut als brugwachter. Het gebruik van beeldspraak en metaforen in creatieve therapic. Tijdschrift voor Creatieve Therapie. 1999/1, 9. 
hebben. In het kader van de beeldenserie van de patiënt uit het citaat staat 'de grote Bart' voor zijn volwassen zelf en zijn verstand; terwijl 'de kleine Bart' voor 'het kind in hem' en zijn gevoel staat. De geciteerde passage beschrijft een cruciaal moment in de therapie: hoe een min of meer toevallig tot stand gekomen beeld aanleiding geeft voor een emotioneel geladen inzicht in het eigen functioneren. Dit moment staat model voor de specifieke waarde van deze therapievorm.

Beeldende creatieve therapie is een vorm van therapie, die zowel inzichtgevend als emotioneel en sociaal corrigerend kan werken. De beeldende expressie en vormgeving van dominante thema's uit het leven van de patiënt bieden de mogelijkheid om niet slechts 'over' problemen en klachten te praten, maar vooral 'vanuit' een (her)beleving door middel van gevoelsmatige verbeelding en beeldende vormgeving. Deze betekenis van het creatieve medium wordt veelal in verband gebracht met 'de meerwaarde' van creatieve therapie ten opzichte van meer verbale behandelvormen. In de maatschappelijke context van de geestelijke gezondheidszorg is creatieve therapie onder meer ontstaan in de bedding van een humaniseringsideaal. Het creatief bezig zijn van patiënten introduceerde een alternatieve vorm van dagbesteding en behandeling gericht op de ontplooïing van 'hogere' vermogens. Naast het minimaliseren van negatieve aspecten, zoals 'overlast' van patiënten, wat algemeen gebruikelijk was in psychiatrische klinieken, werd er steeds meer geld en ruimte vrijgemaakt voor 'de humanisering van de psychiatrie' en kwam er aandacht voor 'de mens achter de geesteszieke'. In die context zijn 'kunstzinnige expressie' en 'creatieve activiteiten' therapeutisch toegepast als vormen van activerende therapie. Zo zou 'creativiteit' in het kader van een therapeutische doelstelling het gezonde en vitaliserende 'deel' van de mens in plaats van de 'pathologie' van patiënten aanspreken. Deze aanvankelijke humanistische visie wijkt af van de latere instrumentele optiek, van waaruit men creatieve therapie inpast in functionele programma's om psychiatrische patiënten te normaliseren en te resocialiseren. Discussie bestaat er over wat de toegevoegde, humaniserende waarde van creatieve therapie nu precies inhoudt.

In de ontstaansgeschiedenis van creatieve therapie zijn drie opvattingen ten aanzien van haar 'meerwaarde' terug te vinden. Ten eerste de gedachte dat creatieve expressie een zinvolle dagbesteding voor psychiatrische patiënten biedt. Reeds aan het begin van deze eeuw waren er in psychiatrische klinieken de zogenaamde 'open afdelingen' ontstaan met nieuwe behandelvormen voor vrijwillig opgenomen patiënten, de zogenaamde 'zenuwzieken'. Deze nieuwe ontwikkeling leek tevens een oplossing te bieden voor de heersende ledigheid en onrust op afdelingen met chronische patiënten. ${ }^{15}$ Onder meer werden de zogenaamde 'actievere therapieën' naast de bestaande bad- en bedverpleging door psychiaters ingevoerd, waardoor de verpleging er specialistische taken bijkreeg.

15. Slangen: Van Koningsplein naar Lazarusklap. Fragmenten uit de geschiedenis van Psychiatrisch Centrum Joris te Delft (+/. 1394-1994). 
Was vroeger een psychiatrische inrichting niet veel meer dan een verpleegtehuis, om niet te zeggen 'opberg-instituut', van sociaal onhoudbare individuën, die nu eenmaal een of andere vorm van verzorging nodig hadden, sedert de invoering van de zg. 'actievere therapie', na de eerste wereldoorlog geinaugureerd door Hermann Simon in Guetersloh, is het karakter daarvan geheel veranderd. Thans schenkt men juist de grootste aandacht aan de chronische patiënten, met name de schizophrenen. ${ }^{16}$

Voor deze nieuwe taken werden later professionele kunstenaars en vaklieden aangetrokken. ${ }^{17}$ Een voordeel van de nieuwe therapievormen was bijvoorbeeld dat gemaakte producten in de 'arbeidstherapie' geld kon opleveren. Bovendien werkte het kunstzinnige bezig zijn activerend op de apathische, 'gehospitaliseerde' patiënten. Deze eerste opvatting over de 'meerwaarde' van creatieve therapie is ook terug te vinden in andere vernieuwingen in de hulpverlening, zoals arbeidstherapie, activiteitenbegeleiding, bezigheidstherapie, bewegingstherapie en psychomotorische therapie. Na de tweede wereldoorlog werden de nieuwe therapievormen samengevat onder de noemer 'a.b.c.- therapieên'. ${ }^{18}$

De psychiaters ${ }^{19}$ die in deze nieuwe ontwikkeling een voortrekkersrol speelden ontdekten nog een tweede betekenis van het door patiënten gemaakte creatieve werk. Ze beschouwden de in therapie tot stand gekomen werkstukken als curieuze vormen van 'pathologische' of 'primitieve' kunst. Het creatieve werk van psychiatrische patiënten vertegenwoordigt aldus ten tweede een esthetische waarde die bovendien diagnostisch kan worden gebruikt. Zo is bijvoorbeeld de bekende 'collectie van Plokker' met kunst van schizofrenen, aangevuld met werkstukken van andere patiẻnten, in 1995 in "De Stadshof" te Zwolle onder de naam "Ateliers van de Ziel" tentoongesteld. ${ }^{20}$ Het belang van deze vormen van 'primitieve' resp. 'pathologische' kunst ter ondersteuning van de diagnosestelling, trachtten de psychiaters wetenschappelijk te onderbouwen. Plokker en Kaas gingen er in hun studies bijvoorbeeld van uit dat je aan karakteristieken van het beeldende werk iets essentieels kan aflezen over de innerlijke gemoedstoestand van de maker.

Men moet tot de conclusie komen, dat de uiterlijke overeenkomst tussen de moderne schilderkunst uit een bepaalde periode (het expressionisme en het sur-

16. Plokker: Geschonden Beeld. Beeldende expressie bij schizophrenen 12.

17. Hutschemaekers \& Neijmeijer: Beroepen in beweging. Professionalisering en grenzen van een multidisciplinairre GGZ 12 e.v.

18. Beroepen in beweging 15. De afkorting staat voor Arbeid, Activiteit; Bezigheid, Beweging; Creatief.

19. In Duitsland staan Herman Simon en Prinzhorn als pioniers bekend, in Nederland volgden de psychiaters Kaas en Plokker met onderzoek naar de betekenis van het creatieve werk van 'geesteszieken': Plokker Geschonden Beeld. Beeldende expressie bij schizophrenen en Kaas: Een vergelijkend onderzoek naar de beeldende kunst van gezonden en geesteszieken.

20. Museum De Stadshof: Ateliers van de Ziel. Kunst en Creatieve Therapie. Zwolle, 1996. 
realisme, H.M.) en die van geesteszieken op een zekere innerlijke overeenkomst tussen twee groepen van scheppers berust. ${ }^{21}$

De pogingen ook de schizophrenie vanuit een ontwerp van de wereld te verklaren liepen echter op niets uit: het is duidelijk dat er heel verschillende mogelijkheden van wereld-ontwerp bij deze geestesziekte mogelijk zijn. Verschillende daarvan zijn beschreven, doch zeker niet alle. Vandaar dat het werk van schizophrenen veel bonter en uiteenlopender is dan de vrij eentonige productie van andere psychotici, waarop men al vrij gauw uitgekeken is. Over dat werk kunnen wij dan ook kort zijn... 22

Een basisaaname waarop zulk onderzoek berust, is kenmerkend voor de na de tweede wereldoorlog populaire antropologisch-fenomenologische benadering in de psychiatrie, namelijk dat een 'innerlijk wezen' in de vorm van een 'wereldontwerp' van de patiënt de uiterlijke kenmerken van beeldende expressie en vormgeving bepalen. Bovendien zou een zelfde gemoedsgesteldheid resp. wijze van denken typerend zijn voor de 'primitieve' èn de 'pathologische' mens. Tegenwoordig zijn opvattingen over de diagnostische waarde van creatief werk van patiënten democratischer, pluralistischer en genuanceerder. In het algemeen hebben creatief therapeuten niet de pretentie zelf het laatste woord te hebben over de betekenis van de tot stand gekomen beelden. Ze gaan met de patiënten in dialoog over de inhoud en vooral over de wijze waarop de creatieve werkstukken zijn ontstaan. De betekenis is derhalve niet als 'pathologische waarde' een gegeven maar vloeit uit deze dialoog voort. In tegenstelling tot de eerstgenoemde, door de psychiatrie ingeslagen weg, waarin men verbanden zoekt tussen stijlkenmerken van het creatieve werk en persoonlijke essentialia van verschillende groepen 'geesteszieken', richten creatief therapeuten zich nu veeleer op het individuele levens-verhaal van de patiënt. De eerstgenoemde weg heeft zich voortgezet in de nog steeds levende (wetenschappelijke) discussie over het verband tussen creativiteit en pathologie. ${ }^{23}$ Ook is deze benaderingswijze herkenbaar in het romantische thema van de kunstenaar als een persoon die 'buiten-zinnig' is, een gek èn genie, die tot in de geheime diepten van de werkelijkheid vermag door te dringen. $^{24}$

Een derde opvatting is besloten in het gegeven dat beeldende expressie niet alleen een diagnostische kunstwaarde vertegenwoordigt en activerend werkt, maar dat zij ook gericht therapeutisch ingezet kan worden. Patiënten ondervinden van de beeldende expressie en vormgeving van hun klachten aan de hand van therapeutische opdrachten een genezende werking. Dit ervaringsgegeven vormt het dominante uitgangspunt in huidige vormen van creatieve therapie (beeldend). Met

21. Een vergelijkend onderzoek naar de beeldende kunst van gezonden en geesteszieken 223.

22. Geschonden Beeld. Beeldende expressie bij schizophrenen 9.

23. Bijvoorbeeld De Groot: Scheppende processen en psychopathologie. Ateliers van de ziel.

24. Bijvoorbeeld Littlewood: The imitation of madness: the influence of psychopathology upon culture in Pictures at an exhibition 87 e.v. 
betrekking tot de onderzoeksvraagstelling naar de betekenis van beeldende expressie en vormgeving als een non-discursieve kennispraktijk en als een nonverbaal communicatiemiddel, is deze derde opvatting over de 'therapeutische meerwaarde' van het creatieve medium en de dialogische wijze waarop er aan de gemaakte beelden en beeldende processen betekenis wordt gegeven bijzonder relevant. Hoewel hierover geen eenduidigheid bestaat, volgen er uit deze discussie over de omstreden 'therapeutische meerwaarde' in de vakliteratuur enkele voor dit onderzoek relevante thema's, die in de volgende paragraaf aan de orde komen.

\subsubsection{De therapeutische (meer)waarde van creatieve therapie}

Aan de hand van Simhoffers ${ }^{25}$ 'antropologie van kunst en creatieve therapie' wordt een aantal essentiële kenmerken van creatieve therapie benoemd, die aan het genezingsproces van cliënten zou bijdragen.

In de eerste plaats wordt aandacht voor de individuele patiënt genoemd, waarbij de auteur ingaat op de speciale aard van deze 'belangeloze' of 'esthetische' aandacht. Deze vorm van aandacht is schijnbaar in tegenspraak met de genezingsdoelstelling die wel degelijk als 'het belang' van creatieve therapie voorop staat. Ten behoeve van het belang van de genezingsdoelstelling wordt aan de patiënt een belangeloze aandacht geschonken. Het behoort tot de professionele vaardigheid van de creatief therapeut om deze paradox vorm te geven. Het creatieve werk van de patiënt komt aldus tot stand in de bedding van de vertrouwensrelatie tussen patiënt en therapeut. Mogelijk vormt dit element van de therapeutische relatie het belangrijkste middel voor genezing. Dit geldt echter niet specifiek voor creatieve therapie maar voor alle vormen van therapie.

Het tweede punt heeft wel exclusief op creatieve therapie betrekking, namelijk het belang van het creatieve werkstuk. Gedragen door de 'belangeloze aandacht' resulteert de interactie tussen therapeut en patiënt in beeldende werkstukken. Deze verschijnen in de relatie therapeut - patiënt als een zogenaamde 'derde'. Door de aldus gevormde triadische relatie spreekt het creatieve werk mee in de dialoog tussen patiënt en therapeut. De beeldtaal van de werkstukken zet veeleer aan tot een spreken vamuit de ervaring dan dat er over objectiverend en analyserend gesproken wordt, in termen van de pathologie van de patiënt. Sprekend vanuit het creatief-therapeutische proces verschijnen de gecreëerde beelden als een metafoor, dat wil zeggen dat beeld- en vormgevingselementen van het creatieve werk 'op een of andere manier voor het leven van de cliënt staan. ${ }^{26}$ Op de werkstukken wordt een emotionele lading overgedragen. Ten opzichte van verbale psychotherapie biedt creatieve therapie wat dit betreft de toegevoegde waarde van een derde

25. Simhoffer: Ik heb nou allemaal dingen in mijn hoofd.. Een antropologie van kunst en creatieve therapie.

26. Ik heb nou allemaal dingen in mijn hoofd.. 129. 
'gesprekspartner': op het creatieve werk worden pijnlijke, heftige, onverwerkte, ... emoties van de patiënt op dusdanige wijze geprojecteerd, dat de patiënt ermee in dialoog kan gaan. Dat er een 'derde' verschijnt in de therapie betekent tevens dat de (tegen-)overdrachtsprocessen tussen patiënt en therapeut, welke van essentieel belang zijn voor het therapeutische effect, zich mede richten op het creatieve medium. In de beeldende expressie en vormgeving stelt de patiënt aspecten van zichzelf present, $\mathrm{z}(\mathrm{h}) \mathrm{ij}$ creëert verhalen en beelden van zichzelf. ${ }^{27}$ Het beeldende werk in dit proces kan als therapeutisch middel helpen om bepaalde ervaringen van de patiënt nadrukkelijk naar voren te brengen, teneinde het (traumatische) verleden te verwerken en tot begrip te brengen. Als zodanig vormen de beeldende processen en werkstukken een aangrijpingspunt voor doorleving en een aanzet tot betekenisgeving van de psychische problematiek van de patiënt. Hoewel het in beeld brengen van trauma's en emoties bij patiënten soms angst kan oproepen, kan deze 'verbeelding' ook dienen als 'bescherming': de patiënt kan van de buiten zichzelf gebrachte emotionele beelden letterlijk en figuurlijk afstand nemen. De beelden zijn het in beeld gebrachte 'emotioneel verleden', de ervaringsbasis voor het opbouwen van inzicht in zichzelf. Ze zijn niet 'slechts' een 'emotionele uitlaatklep' in de zin van een 'subjectief moment' van deze creatieve activiteit. Aanduidingen in termen van het 'subject-object'-dualisme schieten tekort en doen geen recht aan de 'dialogische kwaliteit' van de interactie tussen patiënt, therapeut en beeldend medium.

De creatieve werkstukken hebben niet alleen een expressieve waarde met betrekking tot de psychische problematiek maar ook een emotionele waarde als een verbindende schakel. Door middel van het creatieve werk komt een verbinding tot stand van de patiënt met aspecten van de eigen persoon, bijvoorbeeld een onverwerkt verleden. Deze verbinding zal ertoe bijdragen dat er 'een nieuwe organisatie van het zelf' wordt bewerkstelligd. Ze vormt tevens de basis voor het aangaan van een relatie met therapeut en medepatiënten. De in therapie opgedane ervaringen en de gemaakte beelden zetten aan tot 'het (her)schrijven van het levensverhaal'. Hiermee is nog een ander aspect van creatieve therapie benoemd: ze biedt een ervaringsbasis voor zingeving. Door de hernieuwde verbinding met zichzelf en met anderen ontwerpt de patiënt een nieuw 'script' van haar/ zijn leven en creẻert daarmee een nieuwe zin. De auteur benoemt deze vorm van zingeving als de "transcendente waarde ${ }^{28}$ van het beeldende werk. Dat wil zeggen dat de betekenis van het creatieve werk meer omvat dan de persoonlijke individualiteit van de maker. De betekenis van deze dimensie van 'transcendentie' overstijgt de strikt functionele waarde van het werk voor de genezing van de patiënt.

Met betrekking tot de onderbouwing van de hierboven aangegeven therapeutische meerwaarde van creatieve therapie wordt er onder meer gebruik gemaakt van diverse psychotherapeutische stromingen. Zo neemt 'de kreatief proces theorie' in de creatief therapeutische literatuur een belangrijke plaats in. Deze theorie gaat

27. Ibid. 141

28. Ibid. 135 
terug op het gedachtengoed van Kris, Milner en Ehrenzweig ${ }^{29}$ en is in Nederland vooral door Herman Smitskamp en Mortel Brom ontwikkeld en gedoceerd aan de HBO-opleiding voor creatieve therapie te Utrecht, bekend als de voormalige 'Middeloo-opleiding'. Uitgangspunt van deze theorie is een visie op de mens als wezen dat (im-)materiële behoeften heeft, onder invloed waarvan z(h)ij activiteiten ontplooit en relaties aangaat in de wereld. Een volgend uitgangspunt is het parallelle verloop van deze behoeftebevrediging en de relationele ontwikkeling van de mens onder invloed van normerende en normaliserende processen in de sociale omgeving. In dit spanningsveld ontstaat er veelal een discrepantie, mogelijk een weerspannige en disfunctionele verhouding tussen (behoeften van) mensen en de sociale context. Op dit punt haakt haar methodische visie in: door middel van interventie met creatieve materialen en opdrachten kan een verstoorde ontwikkeling en verhouding tot de sociale omgeving worden hersteld.

Binnen de therapie worden situaties geschapen, die vrij zijn van externe normerende invloeden, die zeer variabel zijn en de mogelijkheid bieden een beroep te doen op een breed scala van behoeften. ${ }^{30}$

Het begrip 'creativiteit' duidt in deze theorie vooral op het creatief-therapeutische proces dat in gang wordt gezet door middel van creatieve materialen (bijvoorbeeld krijt, verf, klei, steen, hout, enz.) die in het proces worden betrokken op grond van hun 'senso-pathische appèl-waarde'. Deze waarde verwijst naar de uitnodigende betekenis van het creatieve materiaal om emoties van de patiënt te katalyseren en te kanalyseren. Hierbij kan 'het terugvallen naar vroegere stadia van expressie', waarin de ontwikkeling van de patiënt geblokkeerd is geraakt, van vitaal belang zijn. Behalve aandacht voor de pathologie wordt er ook een beroep gedaan op 'gezonde aspecten' van de patiënt en nieuw te vormen waarden. Daarin klinkt een Rogeriaanse notie door van 'autonomie en authenticiteit' in de expressie van behoeften en gevoelens, hetgeen voor deze invalshoek op creatieve therapie minstens zo belangrijk wordt geacht als het werken aan 'verstoringen' in de ontwikkeling. Een 'cliënt-gecentreerde' benadering van therapie is gebaseerd op een humanistische visie op de mens als een individueel en sociaal wezen met een 'authentieke kern'. Vanuit die optiek wordt maatschappelijke normering en disciplinering gezien als een potentieel negatieve invloed, een proces waardoor de mens van zichzelf vervreemd kan raken. Vanuit een dergelijk humanistisch perspectief zou de creatief therapeutische behandeling vooral tot doel hebben om de verbinding met deze authentieke kern te herstellen.

In de 'kreatief proces theorie' zijn nog andere ontwikkelings-psychologische en psycho-therapeutische concepten en uitgangspunten te herkennen. Bijvoorbeeld ideeën van Piaget over de 'senso-motorische basis' van cognitieve vaardigheden. Daarnaast worden er ook psychodynamische grondconcepten gehanteerd, zoals

29. Smeijsters: Handboek Creatieve Therapie 108 e.v.

30. Brom: Over de kreatief Proces Theorie en haar toepassingsmogelijkheden 301. 
'regressie', 'overdracht' en 'afweermechanismen', ontleend aan het gedachtengoed van o.m. Freud, Winnicott en Klein. Een Freudiaanse gerichtheid op een onverwerkt of traumatisch verleden wordt in de 'kreatief proces theorie' aangevuld met een Maslowiaanse oriëntatie op toekomstig te ontwikkelen 'hogere' behoeften. Aldus worden er in de creatief-therapeutische praktijk en theorievorming op eclectische wijze psychotherapeutische, pedagogische en artistieke uitgangspunten en modellen toegepast. Werkwijzen uit de directieve therapie, de cognitieve therapie, de gedragstherapie en de systeemtherapie komen samen in allerlei methodische varianten en toegesneden op de betreffende praktijksituatie. ${ }^{31}$ Op de hogeschool te Nijmegen wordt bijvoorbeeld een soort 'art in therapy' gedoceerd, waarbij het hanteren van het creatieve medium als middel ten dienste staat aan een vorm van groepsdynamische psycho-therapie ${ }^{32}$. Hier tegenover staat een andere invalshoek die bekend staat als 'art as therapy', waarbij ervan uitgegaan wordt dat het creatief bezig zijn als zodanig een therapeutisch effect heeft. Volgens Smeysters ${ }^{33}$ stelt de eerstgenoemde richting de psycho-therapeutische context voorop, waarbinnen het creatieve middel een bemiddelende betekenis heeft, terwijl bij 'art as therapy' het creatieve proces zelf voorop staat als kader voor therapeutische veranderingen. Een voorbeeld van deze richting is de zogenaamde 'kunstzinnige therapie' die gebaseerd is op de antroposofische mensvisie en kleurenleer. In het algemeen berusten kunstgeoriënteerde benaderingen op een humanistische mensvisie en op onderzoek naar wetmatigheden en theorieën over creatieve processen en kunst.

In deze beschrijving van creatieve therapie valt vooral haar pluriformiteit op, zowel wat betreft theoretische uitgangspunten als gebruikte methodieken. In de jubileumuitgave $^{34}$ ter gelegenheid van het tienjarig bestaan van de 'sectie beeldend' van de 'Vereniging voor Kreatieve Therapie' worden in totaal acht methodieken beschreven van creatieve therapie in Nederland. De opsomming van beeldendtherapeutische werkwijzen maakt evenwel een voorlopige indruk. Zo wordt bijvoorbeeld niet duidelijk hoe de keuze voor en de samenhang tussen juist deze acht methodieken gezien moet worden. Tien jaar na dato loopt de inhoud achter bij de huidige creatief therapeutische praktijk. Vanuit de 'Vereniging voor Creatieve therapie' is aangekondigd dat het boekje zal worden herschreven met het oog op de situatie van creatieve therapie beeldend anno 2000. Uit het voorgaande valt af te leiden dat een eclectische en 'ad-hoc'-benaderingswijze kenmerkend voor haar ontwikkeling is.

31. Zie voor een vollediger overzicht Handboek Creatieve Therapie 61 e.v.

32. Beelen c.a: Interactief. Kreatieve Therapie met Groepen.

33. Handboek Creatieve Therapie 61.

34. Kreatieve Therapie Beeldend. Acht methodieken. Sectie Beeldend - Vereniging voor Kreatieve Therapie 


\subsubsection{Methodiekontwikkeling en professionalisering}

In deze paragraaf wordt ingegaan op de betekenis van methodiekontwikkeling en van kritische reflectie op het vak voor de professionalisering van creatieve therapie. Meta-theoretische reflecties op de praktijk van creatieve therapie zijn bijzonder schaars in de vakliteratuur. Vaker treft men gedachtevorming op een toegepast of methodisch niveau aan. In het algemeen geven de publicaties beschrijvingen van praktijkgevallen en van bijzondere creatief-therapeutische technieken, opdrachten, materialen of interventies. Daarnaast zijn er in de literatuur steeds meer aanzetten te vinden tot een systematisering van de casuïstiek, theoretische onderbouwing en het ontwikkelen van meetinstrumenten, veelal toegesneden op een specifieke psychische problematiek of belicht vanuit een bepaald werkveld: bijvoorbeeld 'speltherapie' voor kinderen of creatieve therapie voor ouderen ${ }^{35}$. Hieruit valt af te leiden dat creatief therapeuten in toenemende mate op hun vakdeskundigheid reflecteren. $\mathrm{Bij}$ gevolg worden er steeds meer 'methodische modellen' ontwikkeld die beschrijven en rechtvaardigen wat er in creatieve therapie gebeurt.

In de meeste publicaties over methodieken en werkwijzen van creatieve therapie wordt het begrip creativiteit niet verder geproblematiseerd. In het algemeen wordt het op een 'naieve' wijze gehanteerd als zijnde een voor deze therapievorm werkzame factor. Niettemin wordt deze vooronderstelling door de beroepsgroep ook als een probleem ervaren. Vooral Smeijsters ${ }^{36}$ heeft in dit verband een belangrijke bijdrage geleverd door het gedachtengoed van creatieve therapie kritisch te doordenken. Hij betoogt dat de naamgeving problematisch is omdat de verwijzing naar het begrip 'creativiteit' deze therapievorm niet adequaat beschrijft. Het beter leren hanteren van het creatieve middel is als zodanig geen voorwaarde voor het bewerkstelligen van een therapeutisch effect. Evenmin zou de term verwijzen naar de doelstelling van creatieve therapie: het gaat er immers niet om patiënten creatiever te maken. Noch kan het creatief-therapeutische proces worden gelijkgesteld met 'het creatieve proces' zoals dat een rol speelt in artistieke creaties en in wetenschappelijke ontdekkingen. De theoretische modellen die dit scheppingsproces beschrijven met de theoretische stylering in vier fasen, zouden een te grof raster heen leggen over de complexe en pluriforme creatief-therapeutische realiteit. Ook ten aanzien van de koppeling 'creativiteit' en 'expressie' brengt de auteur een nuancering aan. In plaats van een gebruikelijke aanduiding in het kader van artistieke creaties, 'symbolische expressie' ${ }^{37}$, gebruikt hij de term 'symptomatische expressie' met betrekking tot therapeutische processen. Hierdoor kan Smeijsters filosofische problemen met betrekking tot het meerduidige 'creatieve' proces

35 van der Drift: Kindertekeningen en kindergedrag. Toetsing van de OT-index als instrument voor het meten van het gedrag van kinderen. Junker \& Van de Rijdt: Creatieve therapie met ouderen.

36. Smeijsters Creatieve therapie: creatief of therapeutisch? Een kritische reflectie over het gedachtegoed van de creatieve therapie Tijdschrift voor Creatieve Therapie. 1998/4. En: Handboek Creatieve Therapie.

37. Handboek Creatieve Therapie 120. 
omzeilen en heeft hij een model ontwikkeld op basis van het analogie-concept. Hij gaat uit van een analogie tussen het psychische symptoom en de expressieve vormgeving in het creatieve medium. Om dit 'analoge proces'-model plausibel te maken refereert hij aan ideeën uit de ontwikkelingspsychologie van Stern. Centraal in deze theorie staat het concept 'vitality affects', hetgeen duidt op een 'vitaal''vitaliserend' substraat of een 'dynamisch'-'dynamiserend' principe dat aan de basis zou staan van het gevoelsleven van de mens. Op grond hiervan is het verschil tussen 'emoties' en 'moties' slechts een analytisch onderscheid dat in werkelijkheid als een 'lichamelijk en gevoelsmatig meebewegen' tegelijkertijd plaatsvindt. ${ }^{38}$ Smeysters noemt nog andere, voor de conceptualisering van creatieve therapie relevante dynamische begrippen van Stern, zoals: vorm, intensiteit, beweging, aantal en ritme.

Smeijsters maakt met zijn kritische reflecties een interessante denkbeweging. Door de nadruk te leggen op het analoge verband dat zou bestaan tussen psychischlichamelijke klachten en de 'symptomatische' vormgeving in het creatieve medium positioneert hij creatieve therapie enerzijds op een zekere afstand van artistieke en wetenschappelijke creativiteit en kenprocessen, terwijl hij anderzijds de mogelijkheid schept tot een empirische verankering en wetenschappelijke onderbouwing via een ontwikkelingspsychologische invalshoek. Door dit manoeuvre lijkt de auteur het risico van een filosofische discussie over moeilijk grijpbare begrippen zoals 'creativiteit', 'symbool' en 'metafoor' te kunnen vermijden. Aldus zou het vakgebied, via het kernbegrip 'analogie', op een wetenschappelijke en toetsbare beschrijving van de emotionaliteit en de lichamelijkheid van patiënten kunnen worden gegrondvest. Echter blijft het de vraag of de claim van een symptomatische analogie niet via de achterdeur ongemerkt dezelfde ('analoge') filosofische problematiek toch weer binnenhaalt.

Het kritische en systematiserende werk van Smeijsters en Simhoffers antropologische onderbouwing van de creatief therapeutische praktijk zijn belangrijk met betrekking tot de verdere professionalisering van deze discipline ${ }^{39}$. Ze dragen bij aan de ontwikkeling van het vak door het toegepaste niveau van intuitief handelen theoretisch te onderbouwen. In de (beeldend) creatief therapeutische literatuur zijn nog andere aanzetten te vinden die aan de creatief therapeutische praktijk een fundament beogen te geven door middel van methodiekontwikkeling en (wetenschappelijk) onderzoek. Rutten-Saris ${ }^{40}$ bijvoorbeeld onderzoekt en test een in de praktijk ontwikkeld instrumentarium om de in creatieve werkstukken gearticuleerde beeldtaal terug te kunnen voeren tot haar elementaire bouwstenen van waarneembare tekens en empirisch toetsbare lichaamstaal. Voor de wetenschap-

38. Ibid. 123.

39. In dit onderzoek wordt niet expliciet ingegaan op de verschillende theorieên hierover, zie hiervoor bijvoorbeeld van Griensven: Creatief Therapeuten en Professionalisering.

40. Rutten-Saris: Basisboek Lichaamstaal. Momenteel heeft de auteur het door haar ontworpen meetinstrument voor het isoleren en analyseren van constitieve beeldelementen, de zg. R-S-index, onderworpen aan een validerend, empirisch onderzoek. 
pelijke onderbouwing van deze empirische basis verwijst de auteur eveneens naar Sterns concept 'vitality affects'. Ook Van der Drift onderstreept in haar publicaties het belang van empirische toetsing ten behoeve van de theoretische onderbouwing van creatieve therapie. ${ }^{41}$ In de vakliteratuur worden nog andere pogingen ondernomen om creatieve therapie, vanuit een fenomenologisch ${ }^{42}$ georiënteerde invalshoek, aan de hand van wetmatigheden met betrekking tot kunst en esthetische processen te funderen. Deze analyse van de vakliteratuur lijkt de conclusie te rechtvaardigen dat creatief therapeuten in toenemende mate op de noodzaak van methodiek- en theorieontwikkeling doordrongen raken. Veel minder wordt onderkend dat deze onderneming ook aan fundamentele filosofische vraagstukken raakt, zoals bijvoorbeeld hiervoor is gesteld ten aanzien van de begrippen analogie, metafoor en symbool.

\subsubsection{Organisatorisch-maatschappelijke aspecten van professionalisering}

De toegenomen belangstelling in de vakliteratuur voor een systematische methodiekontwikkeling en voor kritische reflectie op de eigen vooronderstellingen, hangt wellicht samen met de steeds luider klinkende vraag naar meetbaarheid en efficiëntie vanuit de organisatorische omgeving waarin creatief therapeuten opereren. Hierdoor zijn creatief therapeuten genoopt om hun 'nonverbale' vak zodanig te vertalen dat voor buitenstaanders verstaanbaar wordt gemaakt in welke mate en met betrekking tot welke specifieke psychische problematiek creatieve therapie aan de genezing van patiënten bijdraagt. De noodzaak tot verdere professionalisering van deze beroepsgroep is versterkt door het negatieve rapport van de visitatiecommissie. ${ }^{43}$ Met het oog op samenwerking met andere disciplines in de (geestelijke) gezondheidszorg en voor voorlichting aan cliënten, verzekeraars en andere betrokkenen zou 'de meerwaarde' van creatieve therapie helder geformuleerd moeten worden. ${ }^{44}$ In dat verband is het voor creatief therapeuten bittere noodzaak om op kritischer en reflexievere wijze bestaande concepten, modellen en methodieken uit de therapeutische praktijk te onderzoeken dan langs de 'pragmatische weg' die zij 'van huis uit' gewend zijn. In deze zin zou methodiekontwikkeling bijdragen aan de professionalisering van het vak.

Het pragmatische karakter van creatieve therapie is onder meer terug te vinden in de beschrijving van het 'beroepsprofiel':

41. Drift, v.d.: Professionalisering van beeldende kreatieve therapie Tijdschrift voor ceatieve therapie 1995/1. Haalbare doelstellingen. Tijdschrift voor ceatieve therapie 1997/1,3-8.

42. Bijvoorbeeld Molenaar-Coppens: Krom en Recht. De Kromme en Rechte als symbool. Tijdschrift voor ceatieve therapie 1995/2, 3-10.

43. Volgens dit rapport Bij nader inzien uit 1997 zouden de HBO-opleidingen zijn blijven steken in een naĩeve humanistische visie uit de zeventiger jaren, zie Tijdschrift voor Creatieve Therapie 1998/1, 27. 29.

44. Zie ook Handboek Creatieve Therapie 297 e.v. 
Kreatieve therapie kent vele methodische concepten. De methodiek is enerzijds gebaseerd op de kenmerken en mogelijkheden van het medium, anderzijds wordt zij bepaald door de therapeutische situatie. Die therapeutische situatie is afhankelijk van de mogelijkheden van de cliënt en van de aard van de behandeling: individueel, met partners of groepen, in kort- of langdurende behandelingen. De methodieken en technieken zijn mede gebaseerd op bestaande kennisvelden zoals de psychologie en de pedagogiek. ${ }^{43}$

Het opstellen van een beroepsprofiel met de beschrijving van taken en verantwoorderlijkheden van creatief therapeuten betekent een belangrijke stap in het proces van professionalisering. Nog andere gebeurtenissen markeren dit proces. Sinds 1960 werden er studiedagen voor creatief therapeuten georganiseerd, hetgeen in 1962 leidde tot de formulering van de (voorlopige) statuten van de beroepsvereniging. Nadat aanvankelijk vooral psychiaters aan de wieg van deze ontwikkeling hadden gestaan, namen creatief therapeuten hun voorttrekkersrol steeds meer over. ${ }^{46}$ Uit de aan de leden rondgestuurde 'nieuwsbrief' van de vereniging is het huidige tijdschrift voor creatieve therapie ontstaan. Vanaf 1976 worden er door de opgezette HBO-opleidingen diploma's creatieve therapie uitgereikt, die door het ministerie van O. \& W. zijn erkend. Sinds 1986 bestaat er een 'register' als kwaliteitswaarborg voor de uitoefening van het beroep. Het proces van professionalisering wordt tegenwoordig steeds meer vanuit een beleidsvisie door de beroepsvereniging aangestuurd. Inmiddels is het door de vereniging opgestelde beroepsprofiel door werkgevers in de gezondheidszorg gevalideerd. Het daarin omschreven takenpakket van de creatief therapeut bevat naast een beschrijving van de vakinhoudelijke deskundigheid voor het directe contact met de patiënt, nu ook taken op het gebied van organisatie en beleid. Bijvoorbeeld vaardigheden wat betreft samenwerking met andere hulpverleners, het leveren van een bijdrage op patiënten- en werkoverlegmomenten, en taken ten behoeve van de ontwikkeling van een zorgvisie en beleid. Steeds meer wordt ook het belang onderkend van vaardigheden en taken op het gebied van onderzoek en onderwijs.

Tegenwoordig heerst er stagnatie op de arbeidsmarkt voor creatief therapeuten onder invloed van bezuinigingen en fusies in de gezondheidszorg. Er dreigen ontslagen voor de veelal 'part time' werkende creatief therapeuten door inkrimping van het aantal formatieplaatsen. Deze ontwikkeling betekent een tendens naar 'verharding' en 'verzakelijking' van de voormalige 'zachte' zorgsector: elke discipline moet met 'harde' outputcijfers haar bestaansrecht aantonen. Hierdoor krijgt de vraag naar een adequate ver(ant)woording van creatieve therapie niet alleen een filosofisch-theoretische relevantie maar ook een praktisch-maatschappelijke. Verdergaande professionalisering is daarom mede afhankelijk van de vraag of creatief therapeuten een goede ' $p-r$ ' voor het vak voeren binnen hun instelling. Daarnaast is het van belang dat zij als beroepsgroep ook buiten de instelling hun stem in de

45. Beroepsprofiel van de Kreatief Therapeut 1995.

46. Benneker \& v.d. Stelt: Organiseren om te overleven. Tijdschrift voor kreatieve therapie 1994/4, 134-136. 
maatschappelijk-politieke discussies laten horen met het oog op ethische en juridische regelgeving voor de (geestelijke) gezondheidszorg. De titel 'creatief therapeut' is bijvoorbeeld nog onbeschermd. Actueel in dat verband zijn initiatieven die de beroepsvereniging voornemens is te ondernemen met betrekking tot opname in de BIG-wet waarmee titels een wettelijke bescherming krijgen. Om deze reden hangt de toekomst van creatieve therapie in Nederland vooral af van de ontwikkeling van organisatorische en communicatieve vaardigheden van creatief therapeuten.

\subsection{Creatieve trajecten in training, coaching en advisering}

In deze paragraaf wordt, parallel aan de introductie van creatieve therapie, een recente ontwikkeling op de markt van organisatietrainingen, coaching en advisering geschetst. Aangezien er wat betreft de toepassing van creatieve middelen in deze andere sector (nog) niet in dezelfde mate een proces van disciplinering en professionalisering tot een beroepsgroep heeft plaatsgevonden, kan deze parallel niet geheel worden doorgetrokken. Evenmin is er op vergelijkbare wijze een grootschalig verkennend onderzoek verricht, zoals in de vorige paragraaf met betrekking tot creatieve therapie is vermeld. Het onderhavige onderzoek vormt slechts een aanzet tot beeldvorming over een vergelijkbare ontwikkeling in de sector van organisatie-advieswerk, bedrijfstrainingen en managementondersteuning. Het gepresenteerde beeld kan derhalve niet met gevalideerde empirische gegevens en cijfers worden gestaafd. In plaats daarvan staat in deze paragraaf de vraag centraal: gaat het in de beschreven 'creatieve trend' om een lucratieve hype op de modegevoelige markt van bedrijfstrainingen of vertegenwoordigt de geschetste parallel een ontwikkeling met blijvende historische waarde?

Voor dit toekomstperspectief zou de vorming van een organisatorisch-maatschappelijke inbedding voor de zich ontwikkelende nieuwe trainingsbranche tot een zelfstandige beroepsgroep behulpzaam kunnen zijn. Het belang van professionalisering is dat aspecten van dit proces mede een basis leggen voor kwaliteitsbewaking, waardoor het kaf van het koren in de wildgroei van (creatieve) trainingen kan worden gescheiden. Aanbieders van bedrijfstraininingen en opleidingen verwijzen in dit verband naar een 'kwaliteitskeurmerk' door hun training te afficheren als 'cedeo-erkend'. ${ }^{47}$ 'Cedeo' is een door de inkopers van bedrijfstrainingen en op-leidingen opgericht instituut dat in haar 20-jarige geschiedenis instrumenten heeft ontwikkeld om een kwaliteitskeurmerk te geven aan de omstreeks 3500 grotere aanbieders van het totale aanbod van ongeveer 7000 dienstverleners. Hiervan heeft $10 \%$ een 'Cedeo-erkenning' verworven. Deze erkenning is gebaseerd op klanttevredenheidsonderzoek dat aangeeft in hoeverre de gewekte verwachtingen van de aangeboden diensten daadwerkelijk worden

47. Beurscatalogus. NVwO-beurs voor opleiding en training RAI 11 dec. 1998 Kluwer bedrijfsInformatie b.v. 13, 41. Cijfer-informatie van 'Cedeo B.V. Den Haag'. 
waargemaakt. Met betrekking tot de creatieve dienstverlening bestaat er nog geen zelfstandig onderzoek dat aangeeft in hoeverre de beloofde organisatie-leerdoelen volgens de opdrachtgevers (directie, afdeling $\mathrm{pz}$ of $\mathrm{p} \mathrm{\&} \mathrm{o}$, lijnmanagers van organisaties en bedrijven) door de ingekochte training inderdaad zijn behaald. Een probleem met betrekking tot zulk onderzoek is dat de creatieve trajecten meestal zijn ingebed in een totaal trainingspakket, waardoor het specifieke creatieve onderdeel moeilijk te isoleren is uit het totaaleffect. De jaarlijkse 'NVvO'-beurs voor bedrijfsopleidingen en bedrijfstrainingen in de RAI van Amsterdam ${ }^{48}$ geeft een weerspiegeling van de 'creatieve trend'. Op basis van deze 'momentopname' blijkt dat omstreeks een achtste van de aanwezige standhouders een 'alternatieve benadering' hanteert resp. gebruik maakt van 'creatieve middelen'. ${ }^{49}$ Wanneer dit percentage mag worden toegepast op de 'Cedeo'-cijfers betekent dit dat het in de nieuwe trainingsbranche om een groep van omstreeks 875 creatieve dienstverleners gaat. De aangesneden problematiek vertegenwoordigt derhalve een vrijwel braakliggend onderzoeksveld met hoge wetenschappelijke èn maatschappelijke relevantie. De relevantie van het onderhavige beeldvormende onderzoek is gelegen in de betekenis van de onder-zoeksresultaten als opstap naar toekomstige meetinstrumenten voor kwalititeits-bewaking en maatschappelijke erkenning. Voor zover kwaliteitsbewaking een voorwaarde vormt voor het maatschappelijk verzilveren van de veronderstelde humaniserende waarde van 'creativiteit' is professionalisering van deze beroepsgroep wenselijk. Het professionaliseringsproces behelst onder meer dat de 'creatieve trajecten' tot een methodische kundigheid worden ontwikkeld zodat deze niet verloren gaat wanneer de creativiteitshausse overgaat in een volgende trend op de trainersmarkt.

In de eerste subparagraaf volgt een 'momentopname' van deze trend in de commerciële sector die wijst op een toegenomen belangstelling voor de factor creativiteit en voor alternatieve benaderingen van organisatievraagstukken. Daarna wordt de gaande zijnde ontwikkeling in de tweede subparagraaf in een historisch perspectief geplaatst, namelijk de retorische traditie van sofisten en redenaars. In de derde subparagraaf onderneem ik een poging om de aangetroffen pluriformiteit vanuit een samenhangend 'intern gezichtspunt' te beschouwen. Bij gebrek aan een bestaand 'beroepsprofiel' wordt de veronderstelde samenhang geschetst als ware zij een zich ontwikkelende 'creatieve methodiek'. Ten slotte wordt in de vierde subparagraaf de organisatorisch-maatschappelijke betekenis van de geschetste ontwikkeling door middel van de ideologie-kritische onderzoeksvraagstelling aan de orde gesteld.

48. Nederlands Tijdschrift voor Bedriffsopleidingen. 1998/12, 26-29.

49. Op basis van de Beurscatalogus. NYVO-beurs voor opleiding en training RAI 11 dec. 1998 en het aldaar beschikbare informatiemateriaal, is deze voorlopige schatting gemaakt van een aanbod van 33 'alternatieve' resp. 'creatieve trainingen' op cen totaal van 230 standhouders. 


\subsubsection{Een hype van creativiteit}

Op de markt van organisatietrainingen is er een opvallende trend te constateren om alternatieve benaderingen en creatieve middelen te gebruiken. Deze nieuwe ontwikkeling is reeds met de 'survival'-tochten vanaf de 70er jaren begonnen. Tegenwoordig is daar een divers aanbod van 'indoor'-activiteiten bijgekomen. Een voorbeeld van een ludieke trainingsvorm is de ontwikkeling van managementkwaliteiten door middel van het mennen van paarden ${ }^{\text {so }}$ :

Het mennen is een prachtige metafoor voor het managen... Bovendien blijken er vele verrassende parallellen te trekken tussen uw men- en managementstijl.

Niettegenstaande het alternatieve karakter van de 'creatieve workshops' staat er in de brochures te lezen dat ze bijdragen aan reguliere trainingsdoelstellingen zoals 'timemanagement', 'leidinggeven' en 'klantgerichtheid'. Ook worden ze in combinatie met conventionele middelen en beproefde didactische instrumenten aangeboden, bijvoorbeeld videoregistratie en directe terugkoppeling naar de werkpraktijk door middel van feedback. Vaak dienen de creatieve evenementen ter verluchtiging van zware conferentie- en trainingsprogramma's. De vorm van de aangeboden workshops kan aldus variëren van ontspanning en plezier tot een gerichte trainingsdoelstelling. Het is derhalve de vraag of de toegenomen belangstelling voor creativiteit en kunst in organisaties in het teken staat van training of van entertainment. Of gaat het om iets daar tussenin, waarvoor de term entertrainment reeds is gelanceerd? ${ }^{51}$ Achtergronden en actuele ontwikkelingen op deze markt kunnen we onder meer lezen in de tijdschriften Gids voor Personeels-management, Nederlands Tijdschrift voor Bedrijfsopleidingen en in de nieuwskrant van de Koninklijke Nederlandse Jaarbeurs Utrecht. Langs deze kanalen worden diensten uit de welzijnssector op veelbelovende en lucratieve wijze in de harde wereld van 'business, jobhunting en carrière-management' gesluisd. ${ }^{52}$ Een vraag die rijst bij het bonte aanbod is of de 'softe producten in een fancy management-jasje' een tijdelijke hype zijn of een 'creatieve dienstverlening' met blijvende waarde vertegenwoordigen.

De toepassing van creatieve middelen in training, organisatie-advisering, coaching en loopbaanbegeleiding past binnen een algemenere ontwikkeling naar een meer mensgeoriënteerde benadering van organiseren en management. De wortels hiervan zijn terug te vinden in een 'humanistische reactie' op het dominante denken over organisaties, met name het 'klassieke' management van bijvoorbeeld Taylors 'wetenschappelijke benadering' van organisatieprocessen (het 'scientific management'-model) ${ }^{53}$ Vernieuwende ideeën vinden onder meer hun oorsprong in

50. Voigens de folder Managemennen. Een training in de technieken van management en mennen.

51. Beurscatalogus. NVvO-beurs voor opleiding en training RAI 11 dec. 199833.

52. Zie Carrière Week. Studieweek 46, 1998.

53. Bovee: Management 44 e.v. 
de zogenaamde 'Hawthorne'-studies ${ }^{54}$ in de dertiger jaren, waanuit de 'functionele' rol van menselijke aandacht op organisatie-processen bleek. Vanaf de jaren '50 is daarbij op het belang van sociale en humanistische aspecten van communicatie gewezen, zoals bijvoorbeeld in de psychodynamische benaderingen van Argyris en Schön. Dergelijke vernieuwingen mondden uit in een vanaf de jaren '70 opkomende 'human resource management'-stroming. In de literatuur met betrekking tot humanistische benaderingen van management en organisatieprocessen wordt vooral verwezen naar het gedachtengoed van Maslow met zijn 'hiërarchie van menselijke behoeften en motivaties' van overlevingsdriften tot creatieve en intellectuele expressievormen. Globaal gesproken heeft er in de geschetste ontwikkeling een accentverschuiving plaatsgevonden van de overwegend mechanistische optiek op organisaties in 'het klassieke management'-model naar een meer mens-gerichte visie.

In de praktijk resulteerde deze verandering in het intellectuele klimaat onder meer in de populariteit van de uit de V.S. overwaaiende 'assertiviteitstrainingen'. Nog een andere praktische bron voor de opkomst van creatieve trainingen vormen de inmiddels populaire 'survival-tochten'. Deze zijn ontstaan uit de zogenaamde 'Outward-Bound'-trainingen ${ }^{55}$ waarin als het ware in een laboratorium-situatie een soort milde vorm van een bedreigende en gevaarlijke 'overlevings-situatie' wordt geënsceneerd. Hierdoor kan een zelfde sterke team-geest binnen korte tijd effectief ontwikkeld worden, die bijvoorbeeld zoals bekend door oorlogssituaties spontaan kunnen ontstaan.

Vanaf de tweede wereldoorlog en vooral sinds de zeventiger jaren ontstonden er ook initiatieven op Nederlandse bodem. Met name het N.P.I. - het Nederlands Pedagogisch Instituut voor het bedrijfsleven - heeft bijgedragen aan een meer mensgerichte benadering van organisatieprocessen. De oprichter van dit 'instituut voor organisatie-ontwikkeling', Lievegoed ${ }^{56}$, liet zich in zijn adviseurs- en intellectuele werk door de anthroposofie inspireren. In dat kader is er een creatieve invalshoek toegevoegd aan de psychologische begeleiding van werknemers. Dit heeft uiteindelijk geresulteerd in de ontwikkeling van beeldende trajecten in training, coaching en loopbaanbegeleiding. Het bureau Phoenix, met vestigingen door geheel Nederland, heeft hierin een voortrekkersrol gespeeld en gelegenheid geboden voor allerlei 'spin-off'-ontwikkelingen, bijvoorbeeld in de vorm van zich vrij vestigende 'creatieve trainers'.

Eind van de jaren '70 voegde het adviesbureau "Bora Consult" van Schouten en Nelissen aan de gebruikelijke 'assertiviteitstrainingen' een nieuw element toe. Zij gingen drama-middelen en theater-technieken toepassen in hun organisatie-advieswerk. De idee erachter was om organisatorische vraagstukken en doelstellingen tastbaar en ervaarbaar in beeld te brengen en vorm te geven. Dit gegeven was al

54. Management 52 e.v.

55. Bertels: Ins en Outs van Out of Door Training Magazine Opleidingen 1993/ 6.

56. Lievegoed: Organisaties in ontwikkeling. Zicht op de toekomst. 
eerder therapeutisch uitgebaat door het zogenaamde psychodrama van Moreno ${ }^{57}$ en de specialisatierichting drama binnen de HBO-opleidingen voor creatieve therapie. Ook muzische middelen werden als een creatieve annex psychologische werkvorm gebruikt binnen het personeelswerk. Bijvoorbeeld door middel van de ludieke vormgeving van een nieuw management- of organisatieconcept of ter ontspanning tussen 'serieuzere' trainingen, lezingen en workshops door op congressen, personeelsdagen en symposia.

Vanaf medio jaren ' 80 verschijnen er in Nederland steeds meer 'producten' op de trainingsmarkt, die gebaseerd zijn op de uit de V.S. afkomstige 'stroming' van het Neuro Linguïstisch Programmeren (N.L.P.). Deze eclectische invalshoek combineert inzichten uit de psycho-therapie (vooral gestalt-, gezins- en hypnose-therapie), de linguïstiek, de cybernetica en neurologisch onderzoek. ${ }^{58}$ 'NLP' biedt een methodische basis en een alternatieve invalshoek op organisatie- \& advieswerk en wordt via adviesburo's, trainingsinstituten en opleidingscentra ${ }^{59}$ op de Nederlandse markt gebracht. Deze richting kenmerkt zich onder andere door aandacht voor zintuigelijk-lichamelijke aspecten van training, coaching en advisering, in combinatie met de 'techniek' van het metaforisch herkaderen van (organisatie-)problemen.

Ook de toepassing van beeldende middelen in coaching en advisering blijkt overwegend afkomstig te zijn uit de kunstwereld en de welzijnssector. Een van oorsprong therapeutische opleiding bijvoorbeeld afficheert zich voor het bedrijfsleven als 'School voor Imaginatie'. Zij stelt in haar brochure dat het werken met imaginatie of innerlijke beelden en beeldende processen succesvol in de begeleiding van organisatieprocessen kan worden geïmplementeerd ${ }^{60}$. Uit een lezing van het foldermateriaal, de achtergrondartikelen en brochures blijkt dat traditionele meet- en trainingsinstrumenten worden gecombineerd met alternatieve middelen, zoals 'beeldenonderzoek'. Een voorbeeld hiervan is het zogenaamde enneagram $^{61}$ waarin oude, uit alchemistische en wijsheidstradities stammende 'archetypische beelden' in combinatie met gebruikelijkere typeringen van teamrollen zoals de perfectionist, de helper, de rebel, de bemiddelaar, enz. vooral worden toegepast met betrekking tot 'teambuilding'. In veel gevallen hebben de alternatieve middelen een ondersteunende rol voor reguliere trainingsdoelstellingen, zoals bijvoorbeeld voor een survivaltraining als volgt is geformuleerd:

57. Moreno: The Future of Man's World.

58. Derks \& Hollander Essenties van NLP 11-31.

59. Bijvoorbeeld het Instituut voor Eclectische Psychologie in Nijmegen

60. Brochure van Staal School voor Imaginatie trainersopleiding in Amsterdam. Nederlands Tijdschrift voor Bedriffsopleidingen. 1998/12, 6-10.

61. Nederlands Tijdschrift voor Bedriffsopleidingen. 1998/12, 40-49. Gids. Voor personeelsmanagement. 1998/ 12, 33-42. 
Tijdens de training komen de volgende onderwerpen aan de orde: praktisch leidinggeven, conflictbeheersing, teamleiderschap, teamvorming, projectmatig werken, stressbeheersing en karaktervorming. ${ }^{62}$

De aangeboden trainingen zijn onder meer gericht op het bevorderen van creativiteit als proces. Zo wordt er gesproken over 'de mobilisering van het creatieve vermogen ${ }^{, 63}$, het stimuleren van 'creativiteit in het denken ${ }^{, 64}$ en blijken er legio cursussen te zijn ontwikkeld om creativiteit in leidinggeven, presenteren, schrijven en communicatie te bevorderen. De factor 'creativiteit' is gepromoveerd van een 'vage psychologische categorie' uit de wereld van kunstenaars, welzijnswerkers en therapeuten tot een doelmatige factor die ook voor het bedrijfsleven interessant is.

Aldus hebben zich in Nederland in de jaren ' 80 en ' 90 steeds meer trainers met een alternatief aanbod van creatieve, psychologische en spirituele methoden en technieken in kleine samenwerkingsverbanden georganiseerd of zich vrij gevestigd. Een deel van hen heeft door een succesvolle praktijk een vaste plaats op de trainersmarkt veroverd en verkoopt hun diensten ook aan grote organisaties en gerenommeerde bedrijven ${ }^{65}$. Wat feitelijk succes betreft zijn deze trainingsbureau's de eerste experimentele fase ontstegen. Hoe divers en pluriform het geschetste beeld ook moge zijn, het past binnen een ontwikkeling naar een 'humanistische benadering van management en organisatieprocessen'. De specifieke aard van de gebruikte middelen en de wijze waarop ze worden toegepast spreken de 'creatieve vermogens' van de mens aan. Door het centraal stellen van de mens in de 'creatieve ondersteuning' van organisatieprocessen en de 'psychologische begeleiding' van werknemers worden de (over-)gerationaliseerde bedrijfsprocessen (ogenschijnlijk?) gehumaniseerd. Kennelijk heeft het bedrijfsleven voor deze investering in 'het menselijke kapitaal' van de onderneming veel geld over.

\subsubsection{Een oude sofistenkunst in een nieuw jasje?}

De gelaarsde kat, een kus van de kikker, houthakkers, dansende olifanten, kolibries, de geit en de slak, de koorddanser - geen beeld is zo gek of er is wel een organisatiekundige die een gelijkenis met het bedrijfsleven ziet. ${ }^{6{ }^{6}}$

De geciteerde auteur beschrijft in haar artikel op ironische toon hoe een leger beelden, vergelijkingen en metaforen in de bedrijfskundige literatuur oprukt en terrein verovert. De strekking van haar betoog is dat er uiteindelijk geen weten-

62. Carrière Week 36.

63. Brochure van Avatar

64. Bijvoorbeeld in Atelier Windekind, zie: De Bruyn \& Zegers: Paradijservaringen tegenover bedriffsbelangen. Creatieve agressie, creatieve regressie, creatieve progressie.

65. Op folders van trainingsinstituten is soms een indrukwekkende lijst met opdrachtgevers opgenomen. 66. van Bergen: Metaforen aan de macht. Elsevier 06-12-97. 
schappelijke legitimatie voor het gebruik van deze literaire middelen te geven is. Wel geeft zij een verklaring waarom het gebruik van metaforen zo populair is geworden. De door metaforen geschapen orde zou geen interne consistentie in de vorm van een 'logica van het beeld' kennen noch een empirische overeenstemming met de praktijk. Wanneer we haar kritische gedachtengang volgen is 'het metaforische genre' in laatste instantie terug te voeren op ons verlangen een beschrijving of analyse van de organisatorische werkelijkheid te geven en tegelijkertijd onze onmacht om dat daadwerkelijk te kunnen. Dit laatste hangt samen met het gegeven dat ons beperkte wetenschappelijke middelen ter beschikking staan in vergelijking met de hoge graad van complexiteit en veranderlijkheid in de wereld van organisaties. Een andere verklarende factor die de auteur aanwijst is het voortgaande rationaliseringsproces, waardoor bedrijfsprocessen steeds efficiënter worden georganiseerd. Bij gevolg zijn er steeds minder 'overtollige' en 'niet-doelgerichte' activiteiten op de werkvloer waardoor werknemers even kunnen ontsnappen aan de constante werkdruk. Zo zou er in het bedrijfsleven een toenemende behoefte annex markt voor 'speelse' activiteiten zijn ontstaan. De creatieve bedrijfstrainingen springen hierop in.

De toepassing van creatieve middelen en metaforen in bedrijfstrainingen weerspiegelt niet alleen een recente ontwikkeling in onze maatschappij. Metaforen bezitten ook een tijdloze literaire kwaliteit die eeuwenlang door kunstenaars en politici is gebruikt, door de retorica is bestudeerd en door filosofie en wetenschap als middel voor waarheidsvinding is verguisd. De overtuigingskracht en het emotionele appèl van retorische middelen op onze geest maakt het immers mogelijk dat wat krom is recht kan worden gepraat. Reeds de sofisten, die 'de openbare mening' en het 'gelijk krijgen' boven 'een objectieve waarheid' stelden, werden hierom in het klassieke Griekenland door filosofen onder kritiek gesteld. Bekend is hoe Plato tegenover deze retorische traditie een 'kritische wetenschap' inaugureerde. In zijn dialoog Gorgias karakteriseert hij de redenaarskunst als 'vleierij':

Maar zoals ik de redekunst definieer, is ze een onderdeel van iets dat helemaal niet schoon is. (...) De kwintessens van die activiteit zou ik noemen: vleierij. Vleierij $n u$, dunkt me, is een praktijk waarvan er vele onderdelen bestaan, en één daarvan is onder meer de kookkunst. Deze schijnt wel een kunst te zijn, maar is, volgens mijn opvatting, geen kunst doch empirische routine. Als onderdelen van die vleierij noem ik nog: de redekunst, ook de opsmukkunst en de sofistenkunst... ${ }^{67}$

Plato verwees vooral naar de rechtspraak en de politiek als retorische praktijken waarop zijn kritiek zich richtte. Wanneer hij nu zou hebben geleefd en bij monde van de wijze Socrates een analyse zou geven van de creativiteitshausse op de nieuwe trainersmarkt, ware zijn kritiek wellicht niet mild. De sofisten van nu

67. Plato: Verzameld werk I, 113. 
adverteren onder een andere naam, hun 'vleierij' bedient zich van andere codes, maar achter het vernieuwde imago schuilt dezelfde oude kunst van oplichterij. In essentie berust deze erop dat sofisten het pleit winnen door het woord zo te bedienen dat afgeleide en oppervlakkige aspecten, zoals de presentatie en de opsmuk van een betoog, van doorslaggevend belang worden in plaats van de zaak zelf waar het in wezen om gaat. Wanneer 'de essentie' op de voorgrond staat zoals in wetenschap en filosofie, zijn woorden, metaforen en beelden slechts bijkomstig als dragers van betekenis. Is de waarheid in het geding, dan mag men deze dienaren geen zelfstandig spel laten spelen, aldus Plato. Wat is derhalve 'de vleierij' in creatieve trainingen? De onderschikking en dienstbaarheid van het materiële woord genereert de suprematie van een hogere ideële waarheid, die blijvend is en ons een toetssteen voor de veranderlijke materiële wereld kan geven. In 'creatieve trainingen' vindt er juist een omgekeerde beweging plaats: woorden, beelden en klanken als willekeurige en aan verandering onderhevige dragers van betekenis worden op de voorgrond gesteld, terwijl de inhoud van de boodschap naar de achtergrond verdwijnt. Wat dienstig en bijkomstig is - bijvoorbeeld het hulpmiddel van de taal of zelfs maar een aspect daarvan, zoals fonetiek of beeldspraak, gaat de boventoon voeren.

Volgen we Plato dan impliceert de ontwikkeling van het creatieve trainingswerk dat de macht van het woord, de verbeelding en van andere vormen van 'mimesis' in de plaats komt van de macht van de waarheid. De aandacht verschuift van essentie naar bijzaak, van de boodschap naar de boodschapper. De inhoud van een training kan bijvoorbeeld zeer 'kinderlijk' zijn en niet direct op 'de zaak', dat wil zeggen de organisatie waarover het gaat, betrekking hebben. Bijvoorbeeld wanneer er een gezegde, dat door een van de deelnemers van een training is ingebracht zoals 'Ik moet in m'n eentje de kar trekken' - letterlijk wordt nagespeeld. ${ }^{68}$ Wanneer muziekmiddelen worden gebruikt, verdwijnt het inhoudelijke aspect vrijwel geheel en drukt 'de taal van muziek' als non-verbaal overdrachtsmiddel 'puur' haar betekenis uit. Dit creatieve uitbeeldingsproces vindt plaats op een speelse, humoristische en derhalve 'niet-serieuze' wijze. Daarom zou het, volgens een Platoonse kritiek, slechts gaan om een spel van tekens en meningen dat 'sofistisch' als kennis wordt verkocht.

In onze huidige complexe informatie-maatschappij zijn er wellicht meer maatschappelijke praktijken aan te wijzen die op eenzelfde retorische leest zijn geschoeid. In het bijzonder 'de markt van welzijn en geluk ${ }^{, 69}$ met de exhorbitante groei van psychologische en therapeutische hulpverlening. Het betreft immers een dienstverlening welke gebaseerd is op het praten over of het uiten van emoties en meningen over menselijk leed, in plaats van het doorgronden en wegnemen van de echte oorzaak ervan. De claim is weliswaar dat dit 'praten over' samen gaat met een daadwerkelijke vermindering van het leed. Een indruk van een algemeen

68. Bertels: Kernbeelden tot leven brengen. De kar-trekker leren om op de bok te zitten. Magazine Opleidingen. 1995/ 4.

69. Achterhuis: De markt van welzijn en geluk. 
gevoelde scepsis ten aanzien van deze claim kunnen we in een special van HP/De Tijd over 'het verdriet van Nederland' lezen:

Nederland is de afgelopen twintig jaar in hoog tempo gepsychologiseerd en getherapeutiseerd. Afgezien van de Verenigde Staten heeft geen land ter wereld zoveel psychiaters en psychotherapeuten en al deze hulpverleners kunnen de vraag al jaren niet meer aan. (....) Zo heeft de ideologie van de maakbaarheid zich meester gemaakt van de belang-rijkste levensterreinen: werk, kinderen en relaties. Daarmee worden hoge verwachtingen geschapen, en dus kunnen frustraties niet uitblijven.... ${ }^{70}$

Is deze gedachte juist dan zou de uitbreiding van de welzijnssector niet een vermindering maar veeleer een vermeerdering van menselijk leed tot gevolg hebben, leidend tot een 'welzijns-frustratie' groeispiraal. Ook de dienstensector van het organisatie-advieswerk kent in Nederland, zoals bekend, een hoge dichtheid. De ontwikkeling van de nieuwe creatieve dienstverlening betekent vanuit deze kritische optiek een psychologisering, esthetisering en mythologisering van werkprocessen.

\subsubsection{Naar een creatieve methodiek voor organisatievraagstukken}

Is het mogelijk om de psychologische, creatieve en spirituele middelen in organisatietraining, loopbaanbegeleiding en advisering vanuit een kritische invalshoek te beoordelen, echter zonder ze bij voorbaat als 'sofistenkunst' af te doen?

Hieronder worden enkele voorbeelden gegeven van creatieve diensten en alternatieve producten aan de hand van de in paragraaf 1.3.1 genoemde informatiekanalen. De term 'alternatief' lijkt aan te geven dat hoe uiteenlopend de gebruikte middelen ook mogen zijn, ze een alternatief bieden voor een eenzijdige rationele benadering van leerdoelen. Hiermee hangt ook het ludieke karakter van deze trainingsvormen samen. Er wordt gespeeld met bestaande organisatorische samenwerkingspatronen, leiderschapsstijlen en met 'metaforische' oplossingen voor conflicten. Bijvoorbeeld worden er workshops bedrijfsschilderen aangeboden om 'op een creatieve manier een samenwerkingsproject of een fusie vorm te geven'. Het gezamelijk kunst maken kan, volgens begeleidende teksten bij creatieve workshops, 'ontdooiend', 'ontspannend' en 'verbroederend' werken. In het kader van een 'outdoor-training' is de waarde hiervan aan het psychologische effect van 'unfreezing' opgehangen:

70. HPIDe Tijd. 27-11-1992, 38, 40. 
Pas als het vertrouwen er is kun je immers je eigen poorten openzetten, krijg je ruimte en weet je dat je nieuwe mogelijkheden krijgt.... Dat is de startmotor van organisatieverandering ${ }^{71}$

Ook spirituele middelen behoren tot de 'alternatieve toolkit' van de manager. De waarde van 'lach-meditatie' is als volgt beschreven:

Lachen is een krachtige anti-stressor, het ontspant letterlijk en figuurlijk. Lachen heeft te maken met acceptatie en loslaten. Lachen verbindt en maakt heel. Meditatie kan beschreven worden als 'bewust-zijn zonder te denken'. ${ }^{72}$

Als achtergrond bij de workshop 'management vanuit compassie' staat te lezen:

Alle problemen van onze maatschappij zijn het gevolg van een te eenzijdige nadruk leggen op het denken en het individu, vooral sinds het begin van de $17 e$ eeuw, toen Descartes met zijn 'cogito ergo sum - ik denk dus ik ben' het ontstaan van de typisch westerse cultuur markeerde. ${ }^{73}$

Uit een poëtische beschrijving van een survival-training verschijnt het 'ludieke element' in de vorm van een afwisseling van ontspanning en spanning in de context van een romantisch natuur-decor:

Terwijl de bergtoppen verkleuren in de wegkwijnende zonnestralen, verdwijnen de laatste geluiden in de koele avondlucht. Een grijze nevel zweeft boven het rimpelloze meer en valt als een deken op de verspreid staande tenten. De groep staart ontspannen en voldaan in de rood oranje vlammen van het kampvuur. De wildernis komt tot rust. De stilte is volkomen zuiver. Maar dan ergens in die onmetelijke wouden ontstaat een diep eenzaam gehuil. Er gaat een rilling door de groep, we staren elkaar aan. ${ }^{74}$

Door de toepassing van muziekmiddelen wordt een 'ervaringscontext' gegenereerd, waarvan de waarde met betrekking tot organisatorische doelstellingen aldus wordt aangegeven:

Men ervaart hoe het is om deel uit te maken van een harmonieus orkest-een creatieve organisatie- waarin iedereen als vanzelfsprekend elkaar ondersteunt, naar elkaar luistert en motiveert om boven het gangbare niveau uit te stijgen ${ }^{75}$

Volgens een andere folder ${ }^{76}$ zou het aanspreken van onbewuste processsen en de verbeelding een belangrijke rol spelen. Bijvoorbeeld bij het uitspelen van arche-

\footnotetext{
78. Magazine Opleidingen. 1995/4, 31.

79. Carrière Week Studieweek 46 1998, 26.

80. Carrière Week 28.

81. Ibid. 34.

82. Volgens de folder van Art in Rhythm.
} 
typische en spreekwoordelijke (voor)beelden van bedrijfssituaties en communicatieproblemen wordt door middel van beelden en beeldende processen gewerkt ${ }^{77}$ :

De metaforen waarmee we onze psychische of mentale processen omschrijven leveren bijna altijd ruimtelijke voorstellingen op. (...) Die beelden kunnen effectief worden gebruikt (...) als leermiddel door ze tot leven te brengen met kernbeeldoefeningen. ${ }^{78}$

Met betrekking tot deze werkwijze wordt als verklaring gegeven:

Het combineren van woorden met voorstellingen heeft als voordeel dat er twee manieren zijn om informatie terug te vinden (dual coding). ${ }^{79}$

Een belangrijk werkzaam element van het alternatieve trainingsaanbod zou aldus het in-beeld-brengen van organisatieprocessen kunnen zijn. Volgens een brochure gaat het in dit verband om het 'zichtbaar en bestuurbaar maken van taakgericht samenwerken' ${ }^{80}$ Er zou een spiegel van uw organisatie ${ }^{81}$ worden gecreëerd door middel van 'speelse' werkvormen, zoals visualisatie, het hoorspel en bedrijfstoneel. Bijvoorbeeld adverteert "Theater in Bedrijf" met 'trainingen met acteurs', 'thematisch theater', theater-improvisaties, het opzetten van een complete voorstelling, het maken van video's en met het geven van acts en workshops.

In de brochures over deze trainingen en workshops worden (vanzelfsprekend) klanten geciteerd die een positieve waardering geven over de creatieve dienst. Als succesfactoren worden onder meer genoemd: de praktijkgerichtheid, de gebruikte creatieve en ludieke middelen, de sterke teamspirit en de ontspannen sfeer waarin het ervaringsleren plaatsvindt. In een andere brochure wordt 'de verbinding tussen beide hersenhelften', 'tussen kennis en kunde' en 'tussen ratio en spiritualiteit ${ }^{82}$ als cruciale factor genoemd. De beoogde verbinding zou tot standkomen door de combinatie van een cognitieve en verbale werkwijze met creatieve en emotioneel werkende middelen. Verwezen wordt naar een dialectiek tussen spanning en ontspanning, tussen plezier en ernst als werkzaam mechanisme. Door een juiste dosering en fasering van deze factoren zou er enerzijds een sfeer worden gecreëerd die de deelnemers losmaakt van de werksituatie, maar die anderzijds juist een transfer naar de werkplek mogelijk maakt. Met de veronderstelde 'transfer' hangt het beoogde leereffect van de training samen. Welk specifieke middel als 'organisatie-metafoor' wordt ingezet lijkt daarom minder van belang dan de doelstelling om elementen zoals creativiteit, speelsheid, ontspanning, openheid en plezier

83. Brochure van Outdoor Education \& Training

84. Bertels: Kernbeelden tot leven brengen. De kar-trekker leren om op de bok te zitten. Magazine Opleidingen 1995/ 4.

72. Magazine Opleidingen 1995/ 4, 28.

73. Ibid 29.

74. Brochure van Outdoor Education \& Training.

75. Carrière Week Studieweek 46 1998, 44.

76. Folder Las Cortes. 
zodanig in leerprocessen te stimuleren dat 'de vertaalslag' naar organisatiedoelstellingen kan worden gemaakt.

In het geschetste pluriforme beeld verschijnen de contouren van een zich ontwikkelende 'creatieve benadering van organisatievraagstukken'. Niet op basis van de inhoud van de aangeboden organisatietrainingen noch van de toegepaste creatieve middelen als zodanig kan er evenwel van een 'creatieve methodiek' worden gesproken. Veeleer lijkt het kenmerkende 'creatieve aspect' zich in de wijze van toepassing te bevinden. Door de toegepaste (non-)verbale communicatiemiddelen en versterkt door het ludieke karakter van de toepassingswijze wordt de focus van de inhoudelijke boodschap naar het proces van overdracht verschoven. Methodisch kenmerkend voor de nieuwe trainingsvormen is derhalve de procesgeoriënteerde en ervaringsgerichte benadering, die een accentverschuiving teweegbrengt van de cognitieve inhoud van de training naar het proces van communicatie en interactie tussen de deelnemers. Gegeven de geschetste pluriformiteit lijkt deze overeenkomstige focus op het communicatie- en interactieproces via het creatieve medium' een gemeenschappelijke basis van de alternatieve benaderingen van organisatievraagstukken te vormen. Is deze methodische overweging juist dan is hiermee tevens het belang aangegeven van een additionele professionaliteit van de aangeboden trainingen: behalve artistieke vaardigheden op het betreffende creatieve medium zouden de trainers professionele vaardigheden in huis moeten hebben op het gebied van psychologische begeleiding en met betrekking tot de vereiste vertaalslag naar de organisatiecontext.

Hoe past het geschetste tijdsbeeld in het in de vorige subparagraaf beschreven historische perspectief van de retoriek? Voor zover de veronderstelde methodische basis betrekking heeft op het emotioneel-interactieve proces van overdracht, betekent deze ontwikkeling op de trainersmarkt inderdaad een opleving van de klassieke kunst van de retoriek. De retorische betekenisoverdracht beperkt zich hierbij evenwel niet tot de taal. Het gaat om een 'non-discursieve retoriek' met creatieve en ludieke middelen. Ze bewerkstelligt een dynamiek van betekenisgeving, die niet zozeer elementen van een bepaald kengebied naar een ander domein van kennis overdraagt, maar van een bepaald werkterrein - de wereld van organisaties met specifieke vaardigheden - naar een ander domein van 'phronèsis', van de kunst of de natuur, met analoge vaardigheden. In een beschrijving van een muzikale training wordt de analogie als volgt uitgewerkt:

Ten eerste de analyse van de persoon (...) Bij muziek kies je dan voor het werken met primitieve instrumenten. Dit zijn instrumenten die iedereen op de daarvoor bedoelde manier kan bespelen en die bovendien een zeer directe input/output-verhouding hebben. Wat jij erin stopt komt er ook uit. Een tweede stap is de analyse van de persoon, functionerend in een groep. (...) De derde 

en processen. ${ }^{83}$

Er worden bepaalde randvoorwaarden beschreven waaronder muziek als metafoor kan worden gebruikt voor het functioneren van een persoon in een groep of in een organisatie en voor processen en doelstellingen die het individuele niveau overstijgen. De wijze van samenwerking in een organisatie wordt 'overgedragen' op het creatieve middel. Bij de toepassing van muzische middelen lijkt de gepostuleerde analogie in elk geval invoelbaar. Muzikaal samenspel is qua vorm tevens samenwerking in een team. Op basis hiervan kunnen muzikale middelen als organisatie-analyse-instrument worden gebruikt. Dit zou zich bijvoorbeeld laten vertalen als 'de creatieve vormgeving van samenwerkingskwaliteiten van de deelnemers van een muziektraining tot een muzikale uitvoering'. Iets vergelijkbaars kan in het medium van de beeldende kunst plaatsvinden door de deelnemende teamleden bijvoorbeeld een gezamelijk beeld te laten maken. Materiaalhantering, kleurgebruik en groepsdynamiek bij het tot stand komen van het beeldende werkstuk genereren gezamelijk een beeld-metafoor voor de ervaren samenwerking. Ook andere organisatorische thema's, bijvoorbeeld leidinggeven of het creatief vormgeven van een fusie tussen bedrijven, kunnen muzikaal en beeldend worden uitgewerkt.

De in creatieve trainingen plaatsvindende dynamiek wordt communicatief en interactief vormgegeven in de taal van muziek, in beeldtaal of in een andere kunstof ludieke taal. Zoals beeldspraak en metaforen de discusieve betoogtrant onderbreken met een esthetisch element, zo vormen de ludieke trainingsvormen een retorische onderbreking van de overwegend verbaal en rationeel gestuurde interactieprocessen in een organisatie. Door de wijze waarop deze middelen worden toegepast, ontstaan er als het ware levende metaforen ${ }^{84}$ met betrekking tot de plaatsvindende psycho-sociale processen tussen de deelnemers van een creatieve workshop. De retorische invalshoek is bij uitstek geschikt om de verwevenheid van cognitieve, emotionele en interactieve processen van betekenisoverdracht te beschrijven. Vanuit het in dit onderzoek centraal gestelde proces van betekenisgeving is het mogelijk om 'de creatieve overdracht van vaardigheden' vanuit de retoriek als een praktische kunst of kunde te bestuderen. Hierdoor wordt enerzijds vermeden dat ze als een moderne variant van 'sofistische oplichterij' worden gedevalueerd. Anderzijds geeft deze invalshoek middelen in handen om de 'methodische meerwaarde' ten opzichte van traditionele trainingsvormen te belichten. Langs deze weg is het mogelijk een onderzoekskader te ontwerpen om de beschreven fenomenen niet alleen vanuit de uiterlijke verschijningswijze te verstaan als een modieuze toepassing van creatieve middelen, maar vooral vanuit de intern plaatsvindende dynamiek van betekenisgeving.

83. De Haas, BuMP Music Affairs: Nederlands Tijdschrift voor Bedriffopleidingen april 1998, 31.

84. Term ontleend aan Ricoeur: La métaphore vive. 
Op basis van het 'interne' retorische perspectief is de volgende methodische typering van het creatieve trainingswerk geconstrueerd:

- De retorische dynamiek in de plaatsvindende communicatie- en interactieprocessen bewerkstelligt een betekenistransgressie ten opzichte van verbale en discursieve processen van overdracht. Hierdoor worden deelnemers uit de feitelijke bedrijfscontext en arbeidsbeleving gehaald en 'metaforisch' verplaatst naar de ervaringscontext van interactie met het creatieve medium. Het aldus bewerkstelligde creatieve leerproces wordt door de trainers in verband gebracht met het (mede) aanspreken van 'niet-rationele' of 'emotionele processen' en 'de verbinding van beide hersenhelften'. Dit methodische aspect van 'betekenistransgressie' naar een kunstgerelateerd medium vereist van de trainer in elk geval artistieke kwaliteiten op het gebied van het creatieve medium.

- De 'creatieve ervaringscontext' zorgt voor een sfeer die 'ontdooiend en verbroederend' op de deelnemers werkt. Ludieke elementen zoals plezier, humor, en (ont)spanning kunnen een zodanige vertrouwensbasis en saamhorigheidsgevoel creëren, dat ook emotioneel gevoelige en taboe-onderwerpen aan de orde zullen worden gesteld. Het creëren van een vertrouwensbasis lijkt vooral samen te hangen met de 'persoonlijke integriteit' van de trainer.

- Gevoelige onderwerpen, die veelal worden verzwegen of taboe verklaard, zoals conflicten in samenwerking en spanningsmomenten in communicatie, welke normaliter impliciet en op de achtergrond blijven, komen in de retorisch vormgegeven context nadrukkelijk op de voorgrond en worden zichtbaar. Aldus worden ze bespreekbaar en veranderbaar. Of dit daadwerkelijk plaatsvindt is vooral afhankelijk van psychologische vaardigheden van de trainer.

- Door middel van het metaforisch 'voorhouden van een spiegel', waarin de onzichtbare processen van communicatie en patronen in samenwerking in beeld komen, is het mogelijk om sluimerende of impliciete problemen reeds in een vroeg stadium te diagnostiseren en een richting voor organisatieverandering uit te beelden. Hiervoor zijn aanvullende organisatiekundige vaardigheden van een 'creatieve trainer' nodig om deze 'vertaalslag' te kunnen maken.

- De creatieve werkwijze voor probleemdiagnose, organisatie-ontwikkeling en veranderingsprocessen wordt vaak in combinatie met traditionele meet- en leerinstrumenten gebruikt. Een dergelijk gecombineerd pakket wordt veelal in samenwerking met andere organisatiekundigen of trainers aangeboden.

Het veelomvattende onderzoeksveld is in deze paragraaf afgebakend aan de hand van de vraag: Biedt het geschetste 'interne perspectief' met betrekking tot de plaatsvindende retoriek een zodanige onderzoeksbasis dat wij een 'methodische 
meerwaarde' van de emotioneel-interactieve kennisoverdracht in creatieve trainingen ten opzichte van gebruikelijke verbaal-rationele overdrachtsprocessen op het spoor kunnen komen?

\subsubsection{De organisatorisch-maatschappelijke context}

In deze paragraaf wordt de veronderstelde methodische 'meerwaarde' van een creatieve benadering van organisatievraagstukken in een organisatorisch-maatschappelijke context geplaatst. Voorop gesteld dient te worden dat bovenstaande 'methodische profielschets' empirisch en methodologisch onderbouwd zou moeten worden door middel van voortgezet wetenschappelijk onderzoek naar het plaatsvindende leerproces en het daadwerkelijke effect. Onder die voorwaarde zou methodiekontwikkeling een aanzet kunnen geven voor een professionaliseringsproces van de creatieve dienstverlening.

In het geschetste beeld van de gaande zijnde ontwikkelingen op deze markt is in elk geval het belang onderstreept van het ontwikkelen van kwaliteitscriteria. Gezien het dynamische, ideologische en modegevoelige karakter van de markt van organisatietrainingen is de ontwikkeling van een kwaliteitsgarantie een precaire zaak, zoals ook is gebleken uit de geschiedenis van de professionalisering van managers tot een zelfstandige beroepsgroep en de erkenning van hun 'kunst' tot 'bedrijfskunde'. Deze ontwikkeling zou derhalve niet aan de 'grillen' en de 'onzichtbare hand' van de markteconomie mogen worden overgelaten, maar een fundamentele toets der kritiek moeten ondergaan. Het door 'Cedeo' ontwikkelde toetsinstrumentarium waarnaar in paragraaf 1.3 is gerefereerd, is behulpzaam om te kunnen onderzoeken of de aangeboden dienstverlening haar pretenties met betrekking tot organisatiedoelstellingen waar kan maken. Het onderhavige onderzoek voegt hier bovendien het belang van een kritische invalshoek ten aanzien van een eenzijdig instrumenteel gerichte managementoptiek aan toe. Door de gaande zijnde ontwikkeling in dat filosofische licht te plaatsen kan er met betrekking tot creatieve organisatietrainingen een ideologie-kritisch kader worden gegenereerd voor het genereren van meetinstrumenten en een kwaliteitsgarantie.

Voor zover de implementatie van creatieve trainingen haar weerslag heeft op communicatie- en interactieprocessen in organisaties maken ideologische- en machtsaspecten integraal deel uit van dit fenomeen. Hoe alternatief het imago van middelen als meditatie, paardenmennen, jongleren, trommelen, enz. ook moge zijn, uiteindelijk worden ze toegepast voor modieuze managementdoelstellingen, zoals 'timemanagement, teambuilding, zelfsturende teams, conflicthantering, klantgerichtheid, effectief vergaderen'. Wanneer de creatieve instrumenten als 'alternatieven' ter verhoging van efficiëntie en effectiviteit in de bedrijfsvoering worden gebruikt, is het de vraag of ze een wezenlijke verandering ten opzichte van de organisatorische en maatschappelijke status quo bieden. De ideologie-kritische onderzoeksvraag luidt derhalve of ze wellicht fungeren als een psychologisch instrument 
dat de heersende ideologie veeleer bevestigt dan dat ze haar problematiseert. Indien de 'creatieve toolkit' van de manager wordt gehanteerd als machtsmiddel om bestaande organisatiestructuren te handhaven, betekenen de ogenschijnlijk alternatieve middelen veeleer een subtiele versterking van een tot in de psyche reikende rationalisering van bedrijfsprocessen.

Er wordt evenwel ook een tegengestelde suggestie gewekt: namelijk dat de creatieve organisatietrainingen een wezenlijk alternatief bieden voor een eenzijdige, op rationalisering gerichte bedrijfsvoering. Wanneer dat inderdaad het geval is, dan kunnen ze helpen een kader te ontwikkelen voor het ter discussie stellen van bestaande machtsstructuren in organisaties en in de maatschappij. Dragen de creatieve trainingen een naïef humanisme uit dat als handlanger van de instrumentele rede opereert? Of zetten ze veeleer een tegenbeweging tegen de verzakelijking ingang, waardoor het vermogen van werknemers wordt gemobiliseerd om hun individuele autonomie ten opzichte van de organisatie en bedrijfsbelangen te vergroten? Dit heeft een democratisering van het recht en de macht om de organisatorische werkelijkheid mede te definiëren en vorm te geven tot gevolg. Vanuit een kritisch humanisme zouden creatieve organisatietrainingen de rationaliseringsprocessen in organisaties kunnen doorknisen, door bijvoorbeeld een experimenteerruimte te genereren, waarin een alternatieve sociale ordening kan worden ontworpen ten opzichte van een onwenselijke 'status quo'. Zo kan samenwerking op basis van een directe en persoonlijke bejegening in het kader van een creatieve training als alternatief ervaarbaar worden ten opzichte van onpersoonlijke communicatie op basis van hiërarchische en bureaucratische interactiestructuren. De creatieve dienstverlening zou aldus aan het creëren van een 'ideologische vrijplaats' in organisaties kunnen bijdragen, waarin een alternatieve ideologie of een nieuw, bijvoorbeeld een humanistisch 'zingevingskader' bespreekbaar en hanteerbaar wordt gemaakt. Deze ideologische betekenis van creatieve trainingen werpt een licht op 'het verborgen machtsvraagstuk' in organisaties $^{85}$.

De verkenning van het probleemveld mondt uit in een cruciale en prangende vraag, die in de volgende paragraaf wordt uitgewerkt: Betekent de implementatie van 'creatieve middelen' in organisaties en therapie een naïef humanistische dekmantel waarachter bestaande rationaliseringsprocessen worden versterkt of luidt ze veeleer een wending naar een 'kritisch humanisme' in?

\subsection{Humanisering versus rationalisering?}

Wij zijn getuigen van een unieke historische constellatie: de vermenging en kruisbestuiving van twee maatschappelijke sectoren die tot voor kort gescheiden en

85. Ramondt: Verborgen macht, de verankering van de machtsrol in hedendaagse organisaties. $M \& O$. juli/ aug. 2000, 23-38. 
soms polair tegenover elkaar gesteld werden. De humanistische aspecten van ons bestaan worden traditioneel verzorgd door de 'zachte sector', maatschappelijk ingebed in non-profit organisaties. De 'harde sector' daarentegen wordt in het algemeen gedragen door organisatie-vormen die gericht zijn op economisch overleven, winstmaken en efficiëntie. Het proces van rationalisering geeft, uit de aard der zaak, veeleer een beschrijving van de ontwikkelingen in dit tweede domein. Behalve voor het zekerstellen van de voorwaarden voor ons naakte bestaan op aarde is deze sector ook steeds meer gericht op de luxe aankleding ervan. In het rationaliseringsproces lijkt een kentering gekomen, in die zin dat naast een winstgerichte rationele bedrijfsvoering ook steeds meer aandacht ontstaat voor humanistische aspecten van werkprocessen. In de andere sector schijnt een tegenovergestelde ontwikkeling gaande te zijn, namelijk dat non-profit organisaties steeds meer op zakelijke leest geschoeid worden. Een sprekend voorbeeld is de gezondheidszorg, waarin de dienstverlening nu commercieel aan de hand van het principe 'de cliënt is koning' wordt gereorganiseerd. Hierdoor is er een situatie ontstaan waarin enerzijds het proces van rationalisering tot diep in de gezondheidszorg, de psychiatrie en het welzijnswerk is doorgedrongen, terwijl anderzijds de 'humanistische geest' nu ook voor lichamelijk en geestelijk welzijn zorgt in de 'harde wereld' van het bedrijfsleven.

Er is reeds gewezen, gegeven de toegenomen complexiteit van het bedrijfsleven, op de noodzaak van andere - humanistische - (be)sturings-mechanismen, bijvoorbeeld zulke welke afkomstig zijn uit de human resource management'-stroming. Tegelijkertijd lijkt 'de nieuwe zakelijkheid' in de gezondheidszorg een evidente oplossing te bieden voor de stijgende kosten en de beperkte (politiek toegewezen) budgets. Niettegenstaande de aannemelijkheid van zulke sociale verklaringen nodigt het geschetste maatschappelijke beeld ook uit tot een kritische en fundamentele vraagstelling:

Dragen de creatieve instrumenten in organisaties en therapie werkelijk bij tot een humanisering van communicatie- en samenwerkingspatronen? Of plaveit deze ontwikkeling juist de weg voor de instrumentele rede om steeds verder in privé- èn publieke aspecten van ons bestaan door te dringen en ze tot produceerbare en consumeerbare waar te maken?

Als eerste commentaar op deze vraag is reeds gesteld dat het bedrijfsleven feitelijk investeert in 'de menselijke factor'. Kennelijk zijn psychologische, spirituele en artistieke middelen uit de 'zachte sector' winstgevend genoeg gebleken om in het bedrijfsleven binnen te dringen. Maar genereert deze 'therapeutisering' van ons werk niet juist een humanistische façade, waarachter 'de onzichtbare hand' van het rationaliseringsproces schuilgaat? Het bestaan van het proces van rationalisering hoewel niet eenduidig en universeel te definiëren - wordt in het algemeen gezien als een cultureel-historische ontwikkeling die typerend is voor onze maat- 
schappij. ${ }^{86}$ Betekent de popularisering van creatieve middelen en het op de voorgrond stellen van de humane aspecten van ons (werk)leven in dat verband dat extreme ontwikkelingen ten gevolge van het rationaliseringsproces nu inderdaad worden omgebogen? Of schuilt daarin een humanistisch gemaskeerde vorm van de instrumentele rede die een nieuw territorium, namelijk onze psychische en geestelijke vermogens, voor haar werkzaamheid opent?

De 'creativiteitshausse' lijkt deel uit te maken van een algehele verandering in onze visie op arbeid, in het bijzonder over de existentiële betekenis van werk voor de mens. Deze ontwikkeling kan worden geillustreerd aan de hand van metaforen die aan onze opvattingen over werk en arbeid ten grondslag liggen. Het gaat om een opmerkelijke verandering in de gebruikelijke mechanistische werkopvatting die voortduurde tot aan de periode van 'wederopbouw' na de Tweede Wereldoorlog. De 'privé-sfeer' van vrije tijd en het gezin werd traditioneel gezien als de plek voor regeneratie van de werknemer om weer tot productie in staat te zijn. ${ }^{87}$ Een dergelijke notie die kenmerkend is voor het voorbije Industriële Tijdperk wordt weerspiegeld door het gebruik van mechanistische en machine-metaforen over organisaties.

\section{De zaak loopt gesmeerd.}

De lunchpauze is nauwelijks genoeg om weer bij te tanken.

We moeten de neuzen dezelfde kant op krijgen.

Tegenwoordig wordt de betekenis van werk veeleer in termen van organische en narratieve metaforen gearticuleerd. Een in het oog springend fenomeen in dit verband is de metaforisch-literaire wijze waarop organisaties en werkprocessen worden beschreven en onderzocht. Naast traditionele stappenplannen figureren Winnie de Poeh en de Tau bijvoorbeeld als kaders om organisatieprocessen te interpeteren. Ter indicatie van de omvang van dit fenomeen geeft de stijging van het aantal artikelen dat met het zoekwoord 'metafoor' in de ABI-catalogus kan worden gevonden binnen een tijdsvak van tien jaar (midden jaren ' 80 tot midden jaren '90) een verdrievoudiging te zien. Ook zit er een stijgende lijn in het aantal boeken, trainingen en congressen met betrekking tot creativiteit, vooral in relatie tot organisaties. Niettemin is het misleidend om van 'de metaforische benadering' van organisatievraagstukken of 'de creatieve trend' in het bedrijfsleven te spreken. Veeleer kenmerkend is de pluriformiteit en diversiteit in deze ontwikkelingen: van de aanprijzing van creatieve 'managementtools', methodologische reflecties over metaforen, bedrijfsethische artikelen, metaforische analyses in de organisatie-

\footnotetext{
86. Bijvoorbeeld Weber: Die protestantische Ethik und der Geist des Kapitalismus. Elias Ueber den Prozess der Zivilisation. Dijksterhuis: De mechanisering van ons wereldbeeld.

87. Bijvoorbeeld in de rechtsfilosofie van Hegel waarin de staat het algemene belang dient, in tegenstelling tot de particuliere belangen die in de maatschappij worden verwezenlijkt, Hegel: Grundlinien der Philosophie des Rechts. Zoals bekend bekritiseerde Marx de gangbare opvattingen over en de praktijk van de bestaande arbeidsverhoudingen in: Marx: Das Kapital.
} 
kunde, tot de toepassing van creatieve technieken in marketing, informatietechnologie en organisatiestrategie.

Deze ontwikkeling kan betekenen dat humanistische waarden herleven: steeds meer wordt in organisaties en bedrijven onderkend dat er voor het welzijn en de professionele ontwikkeling van werknemers meer nodig is dan 'het vrijgeven van tijd' en 'de privésfeer'. De 'hype van creativiteit' en de groei van 'de markt van welzijn en geluk' zouden we in dat verband kunnen opvatten als een subtiele manier waarop de scheidslijn tussen de privé-sfeer en de publieke sector vervaagt. Organisaties en bedrijven zijn van oudsher een maatschappelijk en publiek domein waarin zich bij uitstek het rationaliseringsproces manifesteert. Tegenwoordig wordt werk niet alleen maar gezien als een 'mechanisch' resultaat van '(im-) materiële input', zoals grondstoffen en informatie, door coördinatie-mechanismen bijeengevoegd en tot 'bedrijfsoutput' verwerkt. Werk vertegenwoordigt naast zaken als liefde, sport en vriendschap, een levensgebied waarin mensen hun existentie vormgeven. Werk is dus niet louter te vatten in termen van een beperkte 'ruil-relatie' tussen werkgever en werknemer, omdat het een proces betreft dat de gehele mens omvat. Er komt steeds meer aandacht voor de professionele ontwikkeling van werknemers, in welk verband de modieuze term employability wordt gebruikt. Een nieuw fenomeen dat deze tendens radicaliseert is de belangstelling voor de gecombineerde ontwikkeling van professionele èn persoonlijke kwaliteiten van werknemers, wat door de creatieve ondersteuning van werkprocessen haar beslag heeft gekregen. Betekent deze 'psychologisering', 'esthetisering' en 'spiritualisering' van het domein van productie en consumptie inderdaad een verbetering van de kwaliteit van ons werk-leven? Dat wil zeggen: genereert de transfer van kunst-, therapeutische en zingevingsaspecten vanuit de sectoren van herkomst naar nieuwe maatschappelijke domeinen een humanisering van ons bestaan of gaat er achter de humanistische make up een proces schuil van toenemende ontwaarding van traditionele waarden onder invloed van het rationaliseringsproces?

Op allerlei terreinen is de scheidslijn tussen privé-sfeer en publieke sector langzamerhand aan het vervagen. Op een groteske manier wordt dit door t.v.programma's als "Het spijt mij", "Jerry Springer" en "All you need is love" overgebracht, waarin privé-zaken breed uitgemeten voor het publieke oog worden uitgespeeld. De vervaging van de scheidslijn privé-sfeer en publieke sector betekent dat de 'individueelste' emoties en strevingen publiek worden gemaakt en gerationaliseerd. Vreugde, leed, liefde en geluk verschijnen net zoals materiële goederen als produceerbare en consumeerbare artikelen op de markt: maakbaar, te kijk en te koop. Het gevolg is bijvoorbeeld dat 'eugenetische ideeën' over de vervolmaking van 'ons' (Arische, Amerikaans-blanke, Zwarte, ....) ras niet langer als een publieke zaak worden uitgedragen,- zoals voorheen door (extreem) rechtse ideologische partijpolitiek waardoor ze door middel van politieke procedures ook kunnen worden ingedamd. Nu zijn ze een persoonlijke zaak geworden. In de maatschappelijke discussie hieromtrent lijkt de consument dan ook het 'recht' te 
claimen om ei- en zaadcelletjes van uitverkoren superintelligente en superschone exemplaren van ons mensenras via internet en spermabanken in te kopen.

Tegelijkertijd met de tendens van de 'rationalisering van het innerlijke domein' vindt er een 'humanisering van de publieke sfeer' plaats. Een in het oog springend symptoom in dit verband is het gegeven dat traditionele dragers van autoriteit, zoals politie, politici, medici, leerkrachten, ouders, steeds meer aan gezag inboeten en als gelijken en privé-personen worden aangesproken. Opmerkelijk hierbij is dat deze ontwikkeling niet alleen plaatsvindt doordat de groepen die zich traditioneel op een ondergeschikte positie bevinden - burgers, patiënten, leerlingen, kinderen macht naar zich toetrekken. Maar dat het om een mede door de dragers van autoriteit zelf vormgegeven trend gaat, die wordt ingezet in naam van de 'humanisering van het gezag'. Onder meer uit nieuwe fenomenen als 'oudermishandeling', verregaande intimidatie van huisartsen door patiënten en extreem geweld van jongeren tegen de politie tijdens rellen na een voetbalwedstrijd blijkt dat de machtsrelatie zich ook dialectisch omkeert. De 'humanisering' van de publieke sector kent een extreme ontwikkeling, zodanig dat steeds minder de politieke ideeẽn van leiderfiguren van belang zijn om democratisch aan politieke macht te komen. Belangrijker is de wijze waarop ze als 'gewone burgelijke privépersonen' hun politiek consumeerbaar weten te maken door middel van steeds meer showelementen en presentatietechnieken in de verkiezingscampagnes. Tegelijkertijd wordt de democratische regelgeving steeds meer gerationaliseerd. Verregaande rationalisering van democratische verkiezingsprocedures herbergt het gevaar in zich dat onderliggende waarden worden uitgehold en dialectisch opgeheven. Dit kan bijvoorbeeld resulteren in de corrumpering van democratische grondbeginselen, wat een historische les uit de Amerikaanse verkiezingen anno 2000 lijkt te zijn.

Parallel aan de klaarblijkelijke 'humanisering' van ons werkleven is er een stijgende werkdruk met daarmee gepaard gaande klachten van stress, overspannenheid en 'burn out' te constateren. ${ }^{88}$ De desastreuze gevolgen hiervan voor de werknemers zijn treffend aan de hand van de metafoor van 'de gekookte kikker' aangegeven. Deze metafoor vertelt dat een kikker in een pan met water, die geleidelijk aan steeds warmer wordt, het 'sluipende' proces van het doodgekookt worden niet opmerkt! De overtuigende suggestie van deze metafoor (ongeacht of ze 'waar' is) is dat de toegenomen lichamelijke en psychische klachten van werknemers en werkgevers een symptoom zijn van de voortgaande rationalisering van werkprocessen onder invloed van de groeispiraal van onze economie. $\mathrm{Ze}$ vormen als het ware de prijs die wij voor onze stijgende welvaart moeten betalen. Deze 'debet'-kant van onze groeiende markt lijkt evenwel te worden gecompenseerd door het 'credit' van 'humanisering'. Bijvoorbeeld door middel van de WAO- en de ARBO-wetgeving of gearticuleerd in populaire managementconcepten, zoals 'empowerment', 'employability' en 'de lerende organisatie'. In dat verband vindt

88. van Bergen: De lessen van Burn Out. 
er een verschuiving in de belangstelling plaats van materiële en meetbare facetten van het werk naar meer kwalitatieve en moeilijk kwantificeerbare aspecten, zoals het psychische welzijn en de professionele en persoonlijke ontwikkeling van werknemers. Toch kan de toename van maatschappelijke aandacht, van politieke regelgeving en geldinvesteringen met betrekking tot het (im)materiële welzijn op de werkvloer resulteren in een inhumane druk op werknemers en werkgevers, wat uiteindelijk een rationeel bedrijfsdoel dient: de verhoging van efficiëntie, effectiviteit en winst. Kortom: bieden 'humanistische' agendapunten zoals 'onthaasting', 'bezinning', 'creativiteit' en 'groene momenten' een sterk genoeg tegenwicht tegen 'de ratrace' onder invloed van de instrumentalisering van het publieke èn privédomein?

\subsection{Grondslagen van wetenschappelijke en intuitieve kennis}

In deze paragraaf zal de opgeworpen ideologie-kritische vraagstelling in relatie worden gebracht met de vraag naar de method(olog)ische 'meerwaarde' van creatieve middelen in communicatie en veranderingsprocessen. Het betoog in de vorige paragraaf verwijst naar een filosofische discussie tussen een Foucaultiaanse interpretatie versus een Habermasiaanse lezing van het verlichtingsdenken en het ideaal van humanisering. Wat uit dit filosofische debat in elk geval naar voren is gekomen is dat traditionele ideologieën, zoals het rationalisme, het christendom en het humanisme, in onze 'post-moderne tijd' hun legitimeringsrecht hebben verloren. De waarden en idealen die in deze ideologieën gearticuleerd zijn, zullen in dit onderzoek derhalve niet als een a-historische rechtvaardigingsgrond worden gehanteerd, maar als een historisch antwoord op zingevings- en rechtvaardigheidsvragen. Aldus worden verlichtings- en humaniseringsidealen beschouwd als deeluitmakend van een filosofisch en maatschappelijk debat aangaande 'rationalistische', 'christelijke', 'humanistische' en 'multiculturele' waarden en wereldbeelden. Waar de ontwikkeling van wetenschappelijke kennis in het rationalisme is geworteld, daar is de oorsprong van de onderzochte creatieve werkvormen minder duidelijk. In zekere zin lijkt hun bron een intuittieve en gevoelsmatige kenwijze te zijn, die als een 'romantische reactie' op een extreme ontwikkeling van het rationalisme is ontstaan. Vertegenwoordigen romantische idealen en waarden de 'eigenheid' en 'meerwaarde' van intuïtief-empathische praktijkkennis ten opzichte van de in het rationalisme gewortelde wetenschappelijke kennis? Zou haar grondslag misschien in een romantische tegenbeweging tegen het eenzijdige verlichtingdenken gevonden kunnen worden? Deze problematiek krijgt in de eerste subparagraaf gestalte door de mogelijkheid van een 'romantische grondslag' van creatieve praktijkkennis te onderzoeken. Een probleem dat zich hierbij voordoet is hoe wij als post-moderne wereldburgers met een 'romantische' benadering van de werkelijkheid voeling kunnen verkrijgen.

Met betrekking tot wetenschappelijke kennis heeft het grondslagendebat geleid tot een territoriumscheiding van natuurwetenschappen tegenover mens- en cultuur- 
wetenschappen.$^{89}$ Deze wetenschapsfilosofische discussie gaat onder meer terug op het zogenaamde 'Erklären - Verstehen debat' uit de vorige eeuw. De huidige herwaardering van de hermeneutiek geeft hieraan een wending door de vraag naar de betekenis van het interpretatieproces centraal te stellen. Deze herwaardering blijkt onder meer uit het uitzaaien van de hermeneutiek als een zelfstandige en specifieke methode voor allerlei takken van toegepaste wetenschap, zoals bijvoorbeeld de organisatieleer en de psychotherapie. ${ }^{90}$ Zelfs wordt in een overkoepelende zin van 'de interpretatieve benadering', gesproken, welke gecontrasteerd wordt met een meer positivistische, van oorsprong op de natuurwetenschappen georiënteerde 'verklarende benadering'. De method(olog)ische vraagstelling naar de (meer) waarde van creatieve werkvormen heeft derhalve mede betrekking op het verschil in de wijze van interpretatie die in de wetenschap resp. in intuitieve praktijkkennis uitdrukkelijk wordt. 'Interpretatie' wordt in dit verband niet als een beperkte rationele activiteit opgevat, maar als een wijze van zijn. Mogelijke verschillen in de wijze van interpreteren zullen worden gerelateerd aan een verschillende afstemming op zijn. De veronderstelling hierbij is dat een bepaalde interpretatiewijze in laatste instantie gedragen wordt door een 'grondstemming' en 'grondhouding', een emotioneel-lichamelijk verankerde afgestemdheid op de werkelijkheid. Een gevoelsmatige resp. een afstandelijke afstemming op 'zijn' is tevens een bepaalde vorm van kennen. Door zich op een specifieke wijze af te stemmen en te ver-houden tot 'de' werkelijkheid wordt zij navenant present gesteld. De rationele kenwijze van de wetenschap en de intuittieve benaderingswijze van praktijkkennis monden in die zin uit in een overeenkomstige rationalistische resp. romantische vertolking van zijn. Om als post-moderne wereldburgers toegang te verkrijgen tot een 'romantische', dat wil zeggen een meer intuittieve en gevoelsmatige 'zijnsbenadering' wordt in dit onderzoek gebruik gemaakt van fenomenologischhermeneutische interpretatiemethoden. De onderzoeksvraagstelling richt zich derhalve op een 'post-romantische' grondslag van creatieve therapie en creatieve trainingen als 'non-discursieve kennispraktijken'. In de eerste subparagraaf zal aldus in het spoor van Heidegger, Ricoeur en Gadamer naar deze 'postromantische grondslag' van intuïtieve praktijkkennis worden gezocht. In de volgende subparagraaf mondt deze dichotomiserende onderzoeksroute uit in de vraag naar een 'derde weg' tussen een rationalistische en een (post-)romantische benadering van (kennis over) de werkelijkheid. Kan deze derde funderingsroute een kritisch humanisme inluiden, waarmee het gevaar van kolonialisering van nalef gehanteerde humanistische waarden door de instrumentele rede gekeerd wordt?

89. Vergelijk de Boer: Grondslagen van een kritische psychologie. En: Hermeneutiek.

90. Morgan: Images of Organizations. En: Imaginization; the Art of Creative Management.

Lubbers: Psychotherapie door beeld en begripsvorming. Het grensoverschrijdend verstaan van de hermeneutiek.

91. Bijvoorbeeld in Arbnor \& Bjerke: Methodology for Creating Business Knowledge. 


\subsubsection{Een (post-)romantische grondslag voor intuitieve praktijkkennis?}

Zoals in de vorige paragraaf is aangegeven wordt 'de romantiek' hier beschouwd als een wereldbeeld dat zich als een reactie op een extreme ontwikkeling in het verlichtingsdenken heeft ontwikkeld. Voor zover in het verlichtingsdenken de wortels van onze wetenschap liggen, wordt 'de wetenschappelijke kenwijze' in dit onderzoek als rationalistisch bestempeld. De generatie en legitimatie van wetenschappelijke kennis is aan rationele, door onze ratio bepaalde, spelregels gebonden. Welke die precies zijn en hoe de ratio ze voorschrijft, wordt verschillend geïnterpreteerd en bediscussieerd in de wetenschapsfilosofie. Zonder verder op de verschillende wetenschapsfilosofische posities en discussies in te gaan, geef ik hieronder een schets van 'de romantische kenwijze' als zijnde het tegenbeeld van een rationalistische wijze van kennisgeneratie. Deze typering is fenomenologischhermeneutisch gericht op 'de grond' waanuit beide vormen van kennis voortkomen. De gevraagde filosofische condities, die verondersteld zijn in verschillende kennisvormen, verwijzen naar een voorwaardelijke modus voor de generatie van kennis, in het bijzonder preconceptuele resp. emotioneel-lichamelijke aspecten van kennisvergaring.

Noties zoals 'grondhouding' en 'grondstemming' benadrukken het belang van de 'totaliteit' van menszijn welke aan de vorming van wetenschappelijke en praktijkkennis noodzakelijk vooraf gaat. Deze 'totaliteit' kan conceptueel nooit totaal worden gevat. Omgekeerd is zij in zekere zin steeds voorondersteld in onze conceptuele constructies van de werkelijkheid. Hierbij kan gedacht worden aan de emotionele huishouding, de zintuiglijkheid en de lichamelijkheid, die steeds in ons denken en handelen besloten zijn. De 'totaliteit' omvat ook de psycho-sociale en ethische verhouding tot anderen. Evenals een besef van een filosofisch-spirituele verhouding tot 'het zijn', dat wil zeggen een zingevingsdimensie, die bijvoorbeeld als 'het andere" , $^{92}$ of als 'het omvattende" ${ }^{, 93}$ is benoemd. In laatste instantie betreft het een domein van het 'ongearticuleerde' of 'niet-benoembare' dat in al ons benoemen en articuleren is voorondersteld. ${ }^{94}$ Niettegenstaande dit aspect van ongearticuleerdheid zijn door filosofische stromingen - zoals de dialectiek, de fenomenologie, de hermeneutiek en het differentiedenken - begrippen, metaforen en beelden voorgesteld die dit domein aanduiden. Het onderhavige onderzoekskader heeft echter niet uitsluitend een filosofisch-speculatieve, maar ook een empirischdialogische strekking. Dat wil zeggen dat het onderzoek in dialoog met de (praktijk van) creatief therapeuten en creatieve trainers tot stand is gekomen.

Kenmerkend voor een 'rationalistische grondhouding' is dat de door de ratio voorgeschreven regels met betrekking tot de vergaring van wetenschappelijke kennis erop gericht zijn om het onderzochte objectief en neutraal te observeren en te

92. Böhme \& Böhme: Das Andere der Vermunft. Zur Entwicklung von Rationalitătsstrukturen am Beispiel Kants

93. Jaspers: Psychologie der Weltanschauungen.

94. Duintjer: Hints voor een diagnose. Naar aanleiding van Kant. 
manipuleren. Langs die weg is het mogelijk om 'het onderzoeksobject' in bestaande wetenschappelijke denkkaders in te passen. Dit oogmerk van objectiviteit en neutraliteit draagt bij aan het persoonsonafhankelijke karakter van wetenschappelijke kennis. Niettemin is deze kennis ook gebonden aan codes van een wetenschappelijke gemeenschap en is derhalve 'intersubjectief'. Enerzijds berust wetenschap dus op een afzien van 'subjectieve' aspecten in het proces van kennisgeneratie, anderzijds dienen de observaties en manipulaties (bijvoorbeeld door middel van experiment) door derden te kunnen worden nagevolgd en gecontroleerd.

Ter verduidelijking van de rationalistische kenwijze kan het volgende voorbeeld dienen. Een onderzoeker die een experiment uitvoert met proefdieren, bijvoorbeeld muizen om de werking van een bepaald medicijn te testen, dient zich eerst een 'adequate onderzoekshouding' aan te meten. Deze is nodig om de muizen zo objectief en neutraal mogelijk in hun gedrag en fysiologie te kunnen observeren en beschrijven. Wanneer dit experiment vereist dat de muizen eerst worden ingespoten met een stof die kanker veroorzaakt, zou een 'subjectieve' houding waarbij de onderzoeker met zijn gehele persoon betrokken is, de gevraagde wetenschappelijke kenhouding in de weg staan. Door persoonlijke betrokkenheid kan de onderzoeker de pijn ten gevolge van het inbrengen van de onderzoeksspuit in het muizenlijfje meevoelen. Bovendien zou $\mathrm{z}(\mathrm{h}) \mathrm{ij}$ zich bij het inspuiten van de carcinogene stof moreel bezwaard kunnen voelen om dit dier bewust ziek te maken. Een dergelijke gevoelsmatige grondhouding moet, volgens een traditionele wetenschapsopvatting, principieel worden tegengegaan. De 'rationalistische kenwijze' is derhalve te karakteriseren als een kennisstrategie, gericht op het stelselmatig uitsluiten van oncontroleerbare, emotionele en intuïtieve kenniselementen. Ze kan als zodanig worden gecontrasteerd met de systematisch uitgesloten intuittief-empathische grondhouding, die karakteristiek is voor een romantische kenwijze. De stilzwijgende vooronderstelling in beide grondhoudingen is de wijze waarop de natuur of de sociale werkelijkheid als 'onderzoeksobject' dient te worden benaderd opdat zij haar ware aard bloot geve. Door middel van emotionele en technische manipulatie en een dwingende onderzoeksopzet versus empathische betrokkenheid, intuitieve openheid en verleiding. De traditionele wetenschappelijke benadering $\mathrm{kan}$ het beste worden aangegeven door middel van een, aan Bacon ontleende metaforische typering. Deze filosofische voorvader van de moderne empirische natuurwetenschap ${ }^{95}$ heeft het onderzoeksproces beschreven als een 'in ketenen slaan van de natuur' en 'een kruisverhoor', waarbij de natuur op de pijnbank moet worden gelegd om haar ware antwoorden af te dwingen.

De rationalistische kenwijze kan nu worden samengevat als een op beheersing van het onderzoeksobject gerichte onderzoekshouding, waarbij persoonlijke betrokkenheid van de onderzoeker met het onderzochte stelselmatig dient te worden voor-

95. Bacon: Het nieuwe Atlantis 30-33. 
komen of tegengegaan. Hier tegenover staat een intuittieve benadering en een emotionele betrokkenheid van de romantische kenwijze, zoals we die bijvoorbeeld in creatieve therapie als kennispraktijk kunnen herkennen. In creatief therapeutische literatuuu ${ }^{96}$ wordt gesteld dat de therapeutische houding om een persoonlijke betrokkenheid vraagt, gekoppeld aan een gedoseerde kritische afstand. Hierbij is de vooronderstelling dat 'de juiste dosering van nabijheid en afstand' enerzijds een vertrouwensbasis legt, anderzijds voorkomt dat de therapeut te zeer in de belevingswereld van de cliënt wordt getrokken. Maar ook voor het overdragen van een toegesneden therapeutisch interventiekader blijft de persoonlijke betrokkenheid en de opgebouwde vertrouwensrelatie de dragende grond. Aldus kan de romantische kennisvorm worden getypeerd als een vorm van empathisch-intuïtieve overdracht, waarbij de totale persoon van de onderzoeker is betrokken. In termen van het hiervoor gegeven voorbeeld van de experimentele opzet om het medicijn te testen, wordt van 'de romantische onderzoeker' juist wel gevraagd dat $\mathrm{z}(\mathrm{h}) \mathrm{ij}$ de pijn van het muisje voelt wanneer de naald wordt ingebracht en dat $\mathrm{z}(\mathrm{h}) \mathrm{ij}$ zijn/haar geweten voelt knagen wanneer het carcinogene middel wordt ingespoten. Voortgaand op Bacons metafoor laat dit type onderzoeker niet 'de natuur in ketenen slaan' maar kruipt $\mathrm{z}(\mathrm{h}) \mathrm{ij}$ als het ware in de huid van hetgeen of degene die onderzocht wordt, om door middel van identificatie kennis te verkrijgen. ${ }^{97}$

Samenvattend kan de (post-)romantische kenwijze nu fenomenologisch-hermeneutisch worden getypeerd als een kennisvorm die berust op empathische samenvloeiing met het onderzochte en een intuitieve kennisoverdracht door middel van een emotioneel-lichamelijke afgestemdheid op de situatie, een overgave aan en persoonlijke betrokkenheid bij degene die resp. hetgeen onderzocht wordt. Een intuitief-gevoelsmatig verstaan op basis van identificatie met het gekende vormt de tegenhanger van de rationalistische kennisstrategie die voor de vorming van wetenschappelijke kennis een emotioneel-lichamelijke betrokkenheid bij het onderzoeksobject systematisch uitsluit. Biedt deze, langs fenomenologisch-hermeneutische weg gevonden (post-)romantische grondslag van intun̈tieve praktijkkennis voldoende houvast om de naïef ogende humanistische waarden in de onderzochte creatieve trajecten in therapie en organisatietrainingen op kritische leest te schoeien? Hiermee komt de onderzoeksvraagstelling als volgt in zicht: kan een kritisch humanisme op basis van een fenomenologisch-hermeneutische onderzoeksroute een naïef-romantische opvatting van humanisering zodanig verstevigen dat zij voldoende grond biedt om ideologische machtsaspecten met betrekking tot de creatieve dienstverlening kritisch door te lichten?

96. Bijvoorbeeld Dalley (ed.): Art as Therapy. An introduction to the use of art as a therapeutic technique, xxii.

97. Op deze wijze heeft Jane Goodall kennis over mensapen verzameld, wat een baanbrekende betekenis voor de biologie heeft gehad. Goodall: Mijn leven met chimpansees. 


\subsubsection{Een derde weg tussen een rationalistische en een romantische onderzoeksroute}

Daar waar wetenschappers geneigd zijn vanzelfsprekend een grondhouding aan te nemen van rationele afstand tot en beheersing van het onderzoeksobject, daar geloven pragmatici en professionals in het 'vanzelfzwijgende' van de intuïtie als hun kennisbron. Creatief therapeuten omschrijven deze bijvoorbeeld als een 'spontaan gevoelsmatig meebewegen' met patiënten en hun problematiek, wat hen een direct weten verschaft over hetgeen zij voor hun genezing behoeven. Een dergelijke gevoelsmatige verhouding tot het kenobject kan resulteren in een vijandige houding tegenover reflectie en verstand. Hier tegenover staat de rationalistische overwaardering van onze redelijke vermogens en een miskenning of ontkenning van de waarde van empathie, intuittie en gevoel vanuit een traditionele (positivistische) wetenschapsopvatting. Hoewel tegengesteld komen de rationalistische en de romantische grondhouding dus met elkaar overeen wat betreft de dichotomisering van verstand versus gevoel. Met de in de vorige paragraaf getypeerde (post-)romantische kenwijze, die gebaseerd is op een gevoelsmatige identificatie met het onderzochte, lijken we een belangrijk aspect op het spoor te zijn van de typerende kenhouding waarop de creatieve werkvormen gebaseerd zijn. Niettemin is het de vraag of deze vorm van praktijkkennis met het primaat van een (post-)romantische kenhouding geheel is doorgrond. Zij lijkt in deze hoedanigheid, namelijk als de van wetenschappelijke kennisvergaring systematisch uitgesloten 'gevoelsmatig intuîtieve kenwijze', ook behept met een vergelijkbare eenzijdigheid in haar benadering van de werkelijkheid. In deze paragraaf wordt derhalve de vraag gesteld of er een derde onderzoeksroute mogelijk is die niet van een dichotomie tussen verstand en gevoel uitgaat. Hoe zou er een kenhouding ingenomen kunnen worden, die tussen beide extremen door koerst van een rationalistische verabsolutering van de afstandelijke en beheersende kenwijze waarop wetenschappelijke kennis berust en een romantische verabsolutering van intuitie en emotionele identificatie? Mijn vooronderstelling is dat vanuit deze derde 'middenpositie' zowel de rationalistische grondhouding van emotionele afstand tot het onderzoeksobject als de romantische tegenhanger van persoonlijke betrokkenheid bij het gekende mogelijkheden van mens-zijn of van in-de-wereld-staan vertegenwoordigen. Ze kunnen vanuit dit derde perspectief worden opgevat als twee fundamenteel verschillende wijzen waarop 'de' werkelijkheid wordt geïnterpreteerd, resp. als twee extreme en eenzijdige vormen om zich als onderzoeker te verhouden tot het onderzochte.

Zoals reeds aangegeven impliceert de fenomenologisch-hermeneutische ontsluiting van de gezochte grondslag dat het proces van interpreteren niet alleen als kenactiviteit maar als een existentiële modus wordt opgevat. 'Interpreteren' als 'het uitleggen van zijn' is een zijnswijze die kenmerkend is voor het menselijke 
bestaan. In analogie met Watzlawicks ${ }^{98}$ axioma is het niet mogelijk om niet te interpreteren. De mogelijkheid om 'naakt' of 'volledig' te zijn en aldus samen te vallen met 'wat is' zonder een 'bemiddelende' of zich 'tussenvoegende' act van interpretatie, wordt wel vanuit religieus perspectief als een begerenswaardige maar uitzonderlijke 'mystieke eenwording' of 'staat van verlichting' voorgesteld. In mijn onderzoek vat ik haar op als een 'uiterste zijnsmodus' of een begrenzing van de menselijke bestaanswijze. In de door Husserl gegrondveste fenomenologie wordt de typisch menselijke zijnswijze gearticuleerd aan de hand van de notie 'intentionaliteit', een fundamentele 'bewustzijnsstructuur' van 'een gericht-zijnop....'. In de fenomenologische antropologie verschijnt de mens als een diersoort die niet (volledig) samenvalt met zichzelf. ${ }^{99} \mathrm{De}$ existentiefilosofie geeft met het begrippenpaar 'für sich sein' of 'etre pour soi' versus 'an sich sein' of 'etre en soi', eveneens de typisch menselijke zijnswijze weer tegenover een van de existentie 'vervreemde' bestaanswijze. ${ }^{100}$ Op vergelijkbare wijze wordt in dit onderzoek naar een 'interpreterende zijnsmodus' verwezen, als een 'zijn' waaraan 'interpretatie van zijn' inherent is. Heidegger ${ }^{101}$ onderscheidt in zijn 'existentiële fenomenologische analyse' bijvoorbeeld 'Befindlichkeit', 'Verstehen' en 'Sprache' als een drievoudig fundamentele wijze waarop het 'uitleggen van zijn' plaatsvindt: door een emotionele afstemming op, een begripsmatige en een talige articulatie van zijn. Zoals bekend kende Heidegger aan de angst als grondstemming een fundamentele betekenis toe. Het 'beheersingsdenken' van de westerse wetenschap en de taal van de metafysica zouden hiermee onlosmakelijk verbonden zijn. Heideggers 'destructie van de metafysica' richtte zich vooral op het blootleggen van de kenmerkende wijze waarop wetenschap, technologie en filosofie 'het zijn' vastleggen en in zekere zin als werkwoordelijk zijn 'miskennen'. Wetenschappelijke taal en metafysische categorieèn houden 'het zijn' in de greep. Aldus verschijnen 'de natuur', 'de mens' en 'de wereld' ons niet op 'eigen' wijze maar 'oneigenlijk' via het dominante begrippenkader en in het spoor van technologische beheersing en manipulatie.

Het fenomenologisch-hermeneutische perspectief maakt het mogelijk om 'interpretatie' als een fundamentele existentiële categorie op te vatten en als een in de grond van het menszijn geworteld proces te onderzoeken, zodat aspecten van lichamelijkheid en emotionaliteit naast de cognitie als even zo constitutief worden onderkend. In deze existentiële zin kan een kritisch humanisme de (post)romantische grondslag vertegenwoordigen die aan de intuïtieve praktijkkennis een legitimatie verschaft. De existentiële, 'niet-dichotomiserende' interpretatie van deze grondslag integreert in de 'romantische' emotioneel-lichamelijke afstemming op zijn een cognitieve component, namelijk de talige articulatie van empathischintuittieve kennis. Dit is van cruciaal belang voor de onderzoeksvraagstelling. De

98. Vgl. het axioma 'Het is onmogelijk om niet te communiceren', d.w.z ook 'niet-communiceren' is communicatie. Watzlawick (e.a.): De pragmatische aspecten van menselijke communicatie 58.

99. Zoals bijvoorbeeld Plessner, zie Cassirer: An Essay on Man, 11 e.v.

100. Sartre: Esquisse d'une théorie des émotions. en La transcendance de l'ego.

101. Heidegger: Sein und Zeit. 
beoogde integrale existentiële benadering van (kennis over) de werkelijkheid biedt de juiste bodem om een naïeve opvatting van humanisering te bekritiseren, zonder dat daarmee tevens aan de 'eigenheid' van een emotioneel-lichamelijke grondhouding geweld wordt aangedaan. Een in rationalistische richting eenzijdig ontwikkelde kritische kenhouding maakt het weliswaar mogelijk om ideologische aspecten in de 'creatieve trajecten' te problematiseren, maar daarmee wordt tevens voorbijgegaan aan hun potentieel humaniserende 'meerwaarde'. De gekozen termen 'grondhouding' en 'kenhouding' impliceren geenszins een individuele of subjectieve zijnswijze. Veeleer duidt het begrippencluster 'grondstemming, afstemming op, gehoorgeven aan, vertolking en verbeelding' van zijn op een voorwetenschappelijke kenwijze in de zin van een preconceptuele afgestemheid op het gekende, waarin van meet af aan een 'samen-zijn' verdisconteerd is. Ter illustratie zij verwezen naar lopend onderzoek gericht op het opsporen van creatieftherapeutische 'fundamentals' op basis van het categoriseren van elementaire bouwstenen van een 'scheppende lichaamstaal' ${ }^{102}$. Aan de hand van de typerende interactiewijze van kinderen met hun wereld wordt er in voornoemd onderzoek naar een taal gezocht die (meer) recht doet aan een fundamenteel 'andere' zijnswijze. De gangbare, op volwassen (en mannelijke) zelfbeleving gestoelde categorieën en woorden zijn hiervoor niet of slechts gedeeltelijk geschikt. Er worden (nieuwe) woorden gecreëerd die een zelf- en wereldervaring articuleren waarin het emotioneel-lichamelijk meebewogen worden door de ander en door 'de omgeving' centraal staat; waarin kenmerkende dichotomieën tussen 'ik en ander', 'subject en object', 'lichaam en ziel', 'ik en wereld' bij gevolg niet, veel minder of op andere wijze meespelen. Bij feministische filosofen ${ }^{103}$ staat het ontwerpen van een op vrouwelijke ervaring gestoelde werkelijkheidsconceptie hoog op de agenda. De feministisch-postmoderne kritiek op het traditionele Westerse 'subject-begrip', dat behalve 'logocentrisch' ook als 'fallocentrisch' is ge(dis)kwalificeerd, vertegenwoordigt een andere onderzoeksroute om een 'niet-rationalistische' kenwijze te rehabiliteren.

De articulatie van wetenschappelijke kennis is gebaseerd op een extreme disciplinering van de afstandelijke en bekritiserende 'rationalistische' grondhouding. Hier tegenover staat de '(post-)romantische kenwijze' die een kritische kennisinstantie ontbeert. De gedisciplineerde wetenschappelijke kenwijze vooronderstelt evenwel de buitengesloten tegenpool van intuittie, emotionaliteit en lichamelijkheid. Een 'niet-rationalistische' zijns- en kenwijze treffen we bijvoorbeeld aan in natuurlijke vaardigheden zoals lopen, zingen en dansen, in 'common sense-kennis', in kunstuitingen, in praktische kundigheden, in magische praktijken en in religieuze rituelen. Dergelijke kundigheden en 'non-discursieve kennisvormen' berusten op een intuittief-gevoelsmatige benadering van de werkelijkheid. In deze als '(post-) romantisch' gekwalificeerde grondslag van de onderzochte praktijkkennis komt de

101. Rutten-Saris: Basisboek Lichaamstaal.

102. Bijvoorbeeld Braidotti: Beelden van de Leegte. Vrouwen in de hedendaagse filosofie. Irigaray: $L$ 'étique de la difference sexuelle. Kristeva: La révolution du langage poetique. 
preconceptuele zijnswijze pregnant naar voren en is daarentegen de rationalistische kenwijze buitengesloten. Om de gezochte kritische component in het humanisme te integreren is het derhalve geboden om beide buitengesloten kennispolen uit hun extreme hoedanigheid te verlossen en in een middenpositie terug te brengen. Dit betekent dat de typerende kenwijze in beide benaderingen uit de karikaturale vorm en als positieve kwaliteit in perspectief zal worden gebracht. Hierdoor is het mogelijk het kritische kenmoment van een rationalistische benadering te koppelen aan de empathisch-intuittieve kwaliteit van een (post-)romantische kenwijze. Een kritisch humanisme kent aan de rationele pool van het proces van interpreteren een uitgebalanceerde plaats toe, zonder dat daarmee aan andere aspecten van het interpretatieproces tekort wordt gedaan. Het gevaar van een dictatoriale coupe door de rationele pool in het proces van kennisgeneratie is hiermee verijdeld. Wanneer een eenzijdige rationalistische kennisopvatting het proces van kennisgeneratie dicteert, manifesteert de getaboeïseerde tegenhanger zich als een naïef humanisme dat zich als handlanger van de instrumentele rede laat inpalmen teneinde ook de domeinen van kunst, zingeving en emotionaliteit te kolonialiseren. Hand in hand met de rehablilitatie van het empathisch-intuitieve verstaan als legitieme kennisinstantie, wordt de rationalistische kennispool ook uit zijn extreme hoedanigheid en tot een kritisch moment in het proces van kennisverwerving teruggebracht. Dan kan deze kennisinstantie zich als cognitie op een gelijkwaardige plaats manifesteren naast empathie en intuitie. Vanuit dit derde perspectief berust kennis aldus op een middenpositie, een lichamelijk-emotioneel-cognitief zijn dat tegelijkertijd een 'samen-zijn-met-anderen' is.

\subsection{De onderzoeksvraagstelling vamuit het derde perspectief}

In dit onderzoek worden uit diverse disciplines afkomstige 'vaktechnische' termen gebruikt - zoals 'preconceptuele zijnsmodus', 'authentieke betekenisgeving', 'metaforische communicatie en interactie', 'ontologische en epistemologische positie' - om het onderzoekskader vorm te geven. De (post-)romantische grondslag als een 'niet-rationele' zijns- en kenwijze is in de vorige paragraaf langs fenomenologischhermeneutische weg in de zin van een een 'middenpositie' gekarakteriseerd. De bemiddelende 'derde grondhouding' is geïntroduceerd om een dichotomisering van de rationalistische versus de romantische kenwijze te voorkomen. In de geschiedenis van de filosofie zijn diverse aanknopingspunten te vinden om praktijkkennis ten opzichte van wetenschappelijke kennis te legitimeren, bijvoorbeeld op basis van een praktische of een esthetische rationaliteit ${ }^{104}$. Kenmerkend voor de

103. In dit verband wordt verwezen naar Aristoteles' 'phronesis'-begrip, Cassirers concept van de symbolische vormen', Russels term 'knowledge by acquaintance'. Habermas onderscheidt in zijn Theorie des kommunikativen Handelns voortgaand op Kants transcendentale en kritische onderzoek een theoretische, praktische en esthetische vorm van rationaliteit. Zie Kunneman \& Keulartz: Rondom Habermas. En Widdershoven: Handelen en Rationaliteit. Met betrekking tot het graduele verschil van wetenschappelijke kennis en maatschappelijke vooroordelen: van Engeldorp Gastelaars: Lopen over water? 
hier gekozen 'derde onderzoeksroute' is dat het gezochte fundament niet de opgeroepen irrationele tegenhanger van een 'instrumentele rationaliteit' mag zijn, maar een integrale 'existentiële' vorm van rationaliteit. De gevraagde grondslag voor de onderzochte creatieve trajecten heeft aan de hand van deze probleemverkenning de contouren van een kritisch humanisme 'voorbij' de dichotomisering van rationalisme en romantiek verkregen. Tegen de geschetste maatschappelijke en historische achtergrond zal in deze paragraaf de onderzoeksvraagstelling worden geformuleerd. Met een samenvatting en een hoofdstuk-indeling wordt in de volgende twee subparagrafen het eerste hoofdstuk afgesloten.

In dit hoofdstuk is de praktijkkennis van beeldend therapeuten en creatieve organisatietrainers in een maatschappelijke context geplaatst en vanuit filosofisch perspectief belicht. De omstreden 'meerwaarde' van de onderzochte kennispraktijken is getypeerd aan de hand van het overeenkomstige wereldbeeld resp. de 'zijnsverhouding' die aan de vorming van intütieve praktijkkennis ten grondslag ligt. Hoewel een '(post-)romantische' benadering van de werkelijkheid een belangrijk aspect van dit type kennis aan het licht heeft gebracht, kan deze 'oorsprong', door haar dialectische gebondenheid aan het rationalisme, aan de gevraagde 'eigenheid' van de empathisch-intuittieve kennisvorm niet volledig recht doen. Het 'derde perspectief' voorbij rationalisme en romantiek integreert een kritisch moment in de empathisch-intuitieve benadering van de werkelijkheid. De onderzoeksvraagstelling krijgt tegen deze achtergrond reliëf door het begrip van de metafoor aan de gevraagde 'eigenheid' van de intuïtieve kennisvorm te koppelen. Aan de hand van dit begrip kunnen de onderzochte kennispraktijken als een vorm van metaforische praktijkkennis zodanig worden getypeerd dat ze niet bij voorbaat in een ideologisch (rationalistisch, humanistisch, 'new age') kader worden geplaatst. De creatieve werkvormen vertegenwoordigen in die zin een 'metaforisch' kader resp. een 'analoog' domein van creatieve vaardigheden waarnaar professionele capaciteiten en praktijkkennis als 'levende metaforen' worden verplaatst. De toepassing van creatieve middelen in communicatie- en veranderingsprocessen verwijst derhalve naar een 'metaforische kennisvorm', die berust op een kenwijze welke zich 'tussen' een rationalistisch en een romantisch interpretatiekader ten aanzien van de werkelijkheid in bevindt. Hiermee krijgt de notie interpreteren eveneens een centrale plaats in dit onderzoek.

De centrale onderzoeksvraag luidt aldus:

Is het mogelijk:

(1) om onderscheid te maken tussen verschillende manieren waarop creatieve middelen en metaforen worden gebruikt en geinterpreteerd in het kader van creatieve therapie en in creatieve trajecten in coaching, training en advisering

(2) teneinde de toepassing van creatieve middelen op waarde te schatten door middel van een 'derde weg' tussen een romantisch opgevat naïef humanisme en een rationalistische degradering van de metafoor resp. een opportunistisch gebruik van metaforen en creatieve middelen 
(3) aan de hand van een fenomenologisch-hermeneutische interpretatie van de wijze waarop de betreffende professionals creatieve middelen als metaforen in hun professionele handelen integreren en hierover reflecteren?

Om aan deze vraagstelling zoveel mogelijk recht te doen zal een onderzoekstraject worden gevolgd, waarbij het interpretatiekader aan de ene kant is gebaseerd op literatuuranalyse, aan de andere kant in dialoog met de praktijk is opgebouwd. Als belangrijke voorwaarde geldt derhalve dat het te ontwerpen kader in samenspraak met de betreffende professionals tot stand komt. De gekozen fenomenologischhermeneutische benadering maakt het aldus mogelijk om het interpretatiekader op de 'non-discursieve kennispraktijken' af te stemmen. Even belangrijk is het echter om een zekere kritische afstand tot de onderzochte praktijk te bewaren. Dit wordt bewerkstelligd door het praktische discours te plaatsen in een filosofisch perspectief waarin 'de metafoor' als trefwoord voor de eigenheid van de gevraagde kenwijze ons de 'derde onderzoeksroute' kan wijzen. Langs deze weg zal er een zodanige ver(ant)woording van intuittieve praktijkkennis worden gegeven, dat er niet 'voorbarig' gebruik wordt gemaakt van gevestigde ideologieën, waardoor aan de eigenheid van deze kennisvorm tekort wordt gedaan. In het bijzonder zullen buitengesloten elementen van een 'naïef-humanistische' en een eenzijdig rationalistische benadering vanuit de 'middenpositie' worden gerehabiliteerd. De hierlangs ingeslagen onderzoeksrichting koerst aan op een kritisch humanisme als fundament voor intuittieve praktijkkennis, waardoor kan worden voorkomen dat 'creatieve trajecten' in de greep van de instrumentele rede geraken.

\subsubsection{Samenvatting}

In dit eerste hoofdstuk is een probleemverkenning gegeven van het onderzoeksveld met betrekking tot de recentelijk toegenomen belangstelling voor creativiteit in communicatie- en veranderingsprocessen in het kader van therapie en organisatieontwikkeling. De geschetste problematiek vertoont tekenen die wijzen op een 'duivelspact' tussen een naïef humanisme en een lucratief opportunisme, zowel als op een daadwerkelijke humaniserende ontwikkeling met historische waarde. Om deze ambiguiteit te belichten is de beschreven creatieve trend in een breder historisch-filosofisch perspectief geplaatst: het verlichtingsideaal van rationalisering en een romantische tegenbeweging van humanisering. De aldus in beeld gebrachte maatschappelijke context van de onderzochte creatieve trajecten is gemarkeerd vanuit een ideologie-kritische vraag: vertegenwoordigen de (non) verbale communicatiemiddelen in therapie en organisaties, die in eerste instantie als 'humaniserende instrumenten' ten tonele verschijnen, in laatste instantie een subtiele voortzetting van het rationaliseringsproces?

Om de vraagstelling niet in een legitimeringsstrijd tussen (post-)modernistische en (post-)humanistische ideologieën uit te laten monden, is de onderzoeksroute omgebogen. Rationalistische en humanistische waarden en idealen zijn opgevat als 
deeluitmakend van een dienovereenkomstig wereldbeeld, waarin de vorming van kennis over 'de' werkelijkheid geworteld is. Terwijl de wortels van wetenschappelijke kennis in het verlichtingsdenken gevonden kunnen worden, is de oorsprong van de onderzochte intuïtieve praktijkkennis minder duidelijk. In eerste instantie lijkt zij, als een empathisch-intuitieve kenwijze, de dialectisch opgroepen tegenhanger te zijn van een rationalistische benadering van (kennis over) de werkelijkheid. In dat verband is zij getypeerd als voortkomend uit een 'romantische grondhouding'. Deze typering bleek echter niet geheel recht te doen aan de gevraagde 'grondslag' van creatieve werkvormen omdat zij hand in hand gaat met een naïeve opvatting van humanisering die een gemakkelijke prooi voor de instrumentele rede vormt. Als 'romantische kennisvorm' behelst zij bovendien ook een (tegengestelde) eenzijdigheid in haar verabsolutering van een gevoelsmatigintuitieve kennisinstantie en marginalisering van haar 'tegenhanger', het verstand.

Om uit de hierdoor opgeroepen dichotomisering van 'rationele' versus 'irrationele' kennisvormen te geraken, is de gegeven typering geduid vanuit een fenomenologisch-hermeneutische invalshoek. Hierbij is er een beroep is gedaan op noties, zoals 'afgestemdheid op zijn', 'grondstemming' en 'grondhouding'. Deze duiding mondde uit in de vraag naar de mogelijkheid van 'een derde weg' tussen rationalisme en romantiek om de gevraagde 'eigenheid' van creatieve werkvormen op een kritisch humanisme te kunnen grondvesten. Aldus is er in tweede instantie een 'grondhouding' gezocht voorbij de rationalistische verabsolutering van het verstand en het empirisch waarneembare èn de romantische verabsolutering van gevoel en intuïtie. Wanneer er langs die 'derde weg' een kritisch moment kan worden toegevoegd aan het empathische verstaan van intuittieve praktijkkennis, betekent dit dat de onderzochte creatieve trajecten in potentie een daadwerkelijke humanisering van mens en maatschappij vertegenwoordigen.

\subsubsection{Hoofdstukindeling}

De in dit hoofdstuk aangesneden problematiek zal langs de aangegeven onderzoeksroute in zes hoofdstukken worden verdeeld.

In de eerste plaats wordt er een beeld geschetst van de creatief therapeutische werkwijze, in het bijzonder van de beeldende methodiek, die gebruikt wordt om veranderingsprocessen in cliënten te bewerkstelligen. Hieraan wordt het tweede hoofdstuk gewijd door middel van een analyse van creatief therapeutische literatuur. Deze analyse resulteert in een typering van drie verschillende therapeutische veranderingsmodellen, die aan resp. de antropologische, de psychotherapeutische en de kunstgeoriënteerde benadering van creatieve therapie ten grondslag liggen. Gelet op de hierboven geformuleerde onderzoeksvraagstelling zal de analyse worden toegespitst tot de vraag welk therapeutische veranderingsmodel met betrekking tot de 'eigen-aardig-heid' van het creatieve medium het meest adequaat geacht kan worden. 
In de tweede plaats wordt er een analyse gegeven van de recente belangstelling voor de factor 'creativiteit' in organisaties. Dit wordt in hoofdstuk drie ondernomen aan de hand van een literatuurstudie met betrekking tot de populariteit van metaforen en creativiteit in het organisatie-discours. Er blijkt met betrekking tot de onderzoeksvraag een onderscheid in drie genres te moeten worden gemaakt. Er verschijnen vanuit wetenschapsfilosofische, bedrijfskundige en vanuit een toegepaste managementoptiek publicaties over de betekenis van metaforen en creativiteit voor organisaties. De literatuuranalyse krijgt haar beslag door de toepassing van metaforen en creatieve middelen in het kader van organisatie-onderzoek en veranderingstrajecten vanuit de in het eerste hoofdstuk ontwikkelde kritische vraagstelling te interpreteren. Hierdoor is het mogelijk te beoordelen of de creatieve trend een eenzijdige instrumentele optiek verraadt. De formulering van een 'dialogisch beginsel' geeft de richting aan waarin een instrumentele eenzijdigheid kan worden tegengegaan, zonder in het andere extreem te schieten van een 'romantische' verabsolutering van naïef-humanistische benaderingen van organisatieprocessen.

Daarna volgt in het vierde hoofdstuk een filosofische reconstructie van de gevraagde derde grondhouding 'tussen' een rationalistische en een romantische benadering van (kennis over) de werkelijkheid. Deze reconstructie krijgt haar beslag in 'een retorische invalshoek op communicatie' welke tot een 'hermeneutische middenpositie' uitgewerkt wordt. Met betrekking tot het type 'metaforische communicatie' dat in creatieve trajecten plaatsvindt, duidt deze middenpositie op een 'open èn betrokken gesprekshouding'. Als zodanig wordt ze in relatie gebracht met het in het derde hoofdstuk geformuleerde 'dialogische beginsel'. De 'dialogische grondhouding' van 'openheid en betrokkenheid' verschaft een fundament voor de gevraagde kritisch humanistische signatuur van creatieve organisatietrainingen. Vanuit die filosofische grondhouding kunnen er weliswaar oneindig veel interpretaties van de werkelijkheid gegeven worden, maar de dialoog wordt in een 'gesitueerde gesprekscontext' begrensd door een kritischhumanistisch opgevatte notie van 'authenticiteit' in communicatie-processen.

In het vijfde hoofdstuk wordt de dialogische grondslag in verbinding gebracht met en verrijkt door een veldstudie over de praktijk van creatieve werkvormen. Het verslag van deze veldstudie mondt uit in de vraag of de filosofisch gearticuleerde grondslag in haar huidige vorm niet een te abstracte vertaling van de praktijk heeft gegeven. Aan de hand van het onderzoeksmateriaal zijn enkele concrete metaforen in een kritisch-humanistische zin ge(her)formuleerd, in het bijzonder metaforische varianten van 'de homo ludens', een 'zijnskwaliteiten-metafoor', 'ontologische metaforen' voor de creatief therapeutische praktijk en 'organisatieveranderingsmetaforen'. Zijn deze metaforische typeringen verstaanbaar voor de betrokken professionals of behoeven ze verdere concretisering met behulp van het praktijkdiscours? 
Aan concluderende reflecties over de gevolgde onderzoeksroute - over de (meer) waarde van een filosofische invalshoek voor de onderzochte praktijk èn over de betekenis van 'de empirische wending' voor de filosofie - wordt tenslotte het zesde hoofdstuk gewijd.

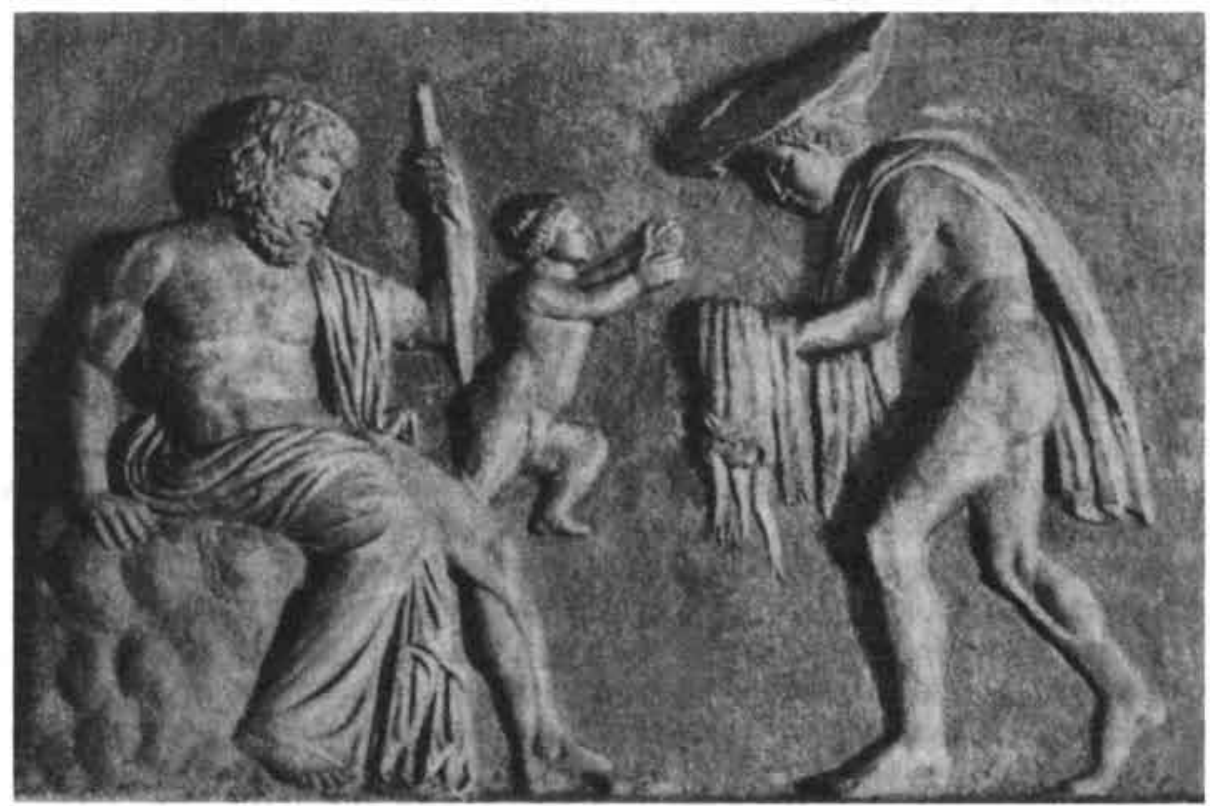

Geboorte van Dionysos: uit de dij van Zeus springt hij in de armen van Hermes. 
Hoofdstuk 2:

\section{Metaforen in de creatief-therapeutische literatuur}

\subsection{Inleiding}

In het eerste hoofdstuk is de creatief-therapeutische deskundigheid gekarakteriseerd als een vorm van intultieve praktijkkennis. Deze is in eerste instantie gecontrasteerd met wetenschappelijke kennis en als zodanig in verband gebracht met een (post)romantische kenwijze. In tweede instantie is deze kenwijze via fenomenologisch-hermeneutische noties omschreven als een preconceptuele afgestemdheid op het gekende, dat wil zeggen een ziens- èn zijnswijze. Dit hoofdstuk geeft een interpretatie van creatief therapeutische literatuur vanuit de invalshoek van de metafoor als middel tot betekenisgeving. In dat verband krijgt de preconceptuele kenwijze een centrale plaats en wordt zij opgevat als een 'metaforische ervaringsmodus'. De analyse van creatief-therapeutische literatuur is gericht op een typering van drie benaderingen van creatieve therapie. Deze typering mondt uit in een reconstructie van drie therapeutische veranderingsmodellen op basis van de daarin te traceren inherente ontwikkelingsmetaforen. De drie creatief therapeutische modellen worden vervolgens vanuit de invalshoek van metaforische betekenisgeving geïnterpreteerd als kader voor veranderingsprocessen op basis van de gegenereerde dynamiek tussen verbeelding en verwoording.

De creatief therapeutische literatuur kent een grote verscheidenheid aan invalshoeken, methodieken en schrijfstijlen. Er zijn 'praktijkhandboeken", waarin creatief therapeutische opdrachten, technieken en interventies staan beschreven. Wellicht het grootste deel wordt-gevormd door methodische handboeken, die vanuit een specifieke of eclectische therapeutische benadering geschreven zijn. ${ }^{2}$ Veelal zijn de creatief-therapeutische methodiekboeken gericht op een bepaalde behandelsetting of een cliëntenpopulatie. ${ }^{3}$ Soms ook staat een bijzondere casus of een specifieke psychische problematiek centraal. Filosofisch getinte, vanuit een uitgesproken visie geschreven verhandelingen over creatieve therapie zijn uitzon-

1. Budde: Creatieve therapie in praktijk. Opdrachten en werkwizen voor beeldende creatieve therapie Beelen (e.a.): Interactief. Kreatieve therapie met ouderen.

2. Dalley (e.a.): Images of Art Therapy. New developments in theory and practice. Wadeson: The Dynamics of Art Psychotherapie.

3. Junker \& van Rijdt: Creatieve Therapie met ouderen. Landgraten: Family Art Psychotherapy. A clinical guide and casebook. 
derlijker. ${ }^{4}$ Onderzoek naar aspecten van creatieve therapie lijken steeds meer te worden gepubliceerd. ${ }^{5} \mathrm{Om}$ deze pluriformiteit in beeld te krijgen zonder met betrekking tot de literatuuranalyse bij voorbaat een bepaald creatief-therapeutisch standpunt in te nemen, wordt de beeldende methodiek geïnterpreteerd als een vorm van metaforische betekenisgeving. De invalshoek van de metafoor maakt het mogelijk om enerzijds een verbinding te leggen met het niveau van de waarneembare, concrete interactie tussen cliënt, therapeut en creatief medium; anderzijds kan met dit perspectief het (impliciete) theoretische standpunt van de auteurs worden getypeerd.

In het eerste hoofdstuk is reeds globaal aangegeven welke psycho-therapeutische benaderingen in creatieve therapie worden toegepast. In de literatuur zijn de verschillende therapeutische referentiekaders te traceren aan de hand van vaktermen, zoals 'regressie', 'analogie', 'symbolisatie', 'fixatie', 'groei', 'weerstand', 'projectie', enzovoort. De in dit hoofdstuk uitgewerkte interpretatie van deze benaderingen richt zich vooral op de wijze waarop therapeutische veranderingen als een ontwikkelingsproces worden beschreven. Wanneer er in dat verband van 'regressie' wordt gesproken, zit hierin een metaforische suggestie dat creatieve therapie een terugwaartse beweging in de psychische ontwikkeling genereert. De tot stand gekomen creatieve werkstukken kunnen bijvoorbeeld worden beschreven als een 'typisch kinderlijke wijze van expressie'. In andere gevallen, bijvoorbeeld met de term 'symbolische realisatie', lijkt er veeleer een progressieve ontwikkelingsdynamiek naar een toekomstig volwassen stadium te worden beoogd. Welke specifieke metaforische invulling het in gang gezette ontwikkelingsproces ook krijgt, de creatief-therapeutische interventies zijn gebaseerd op een vooronderstelde wenselijke, gezonde of normale ontwikkeling. Aan dergelijke vooronderstellingen omtrent 'geestelijke gezondheid' en 'psychische ontwikkeling' wordt de norm voor het therapeutisch handelen ontleend. Deze aannames, normen en zienswijze vormen samen het therapeutische referentiekader. In overeenstemming hiermee wordt het dubbelzinnige beeldend - therapeutische proces voorgesteld als zijnde analoog, symbolisch of symptomatisch van aard. Wanneer een therapeut bijvoorbeeld vanuit een psycho-analytisch referentiekader een cliënt in therapie terug naar een kinderlijke ontwikkelingsfase verplaatst ziet, kan z(h)ij dit proces als 'symptomatisch' voor een 'fixatie' in een 'primitievere' ontwikkelingsfase duiden, terwijl 'hetzelfde' vanuit een rogeriaanse benadering verschijnt als een therapeutische vooruitgang naar een 'spontanere' wijze van expressie. De verschillende creatief-therapeutische benaderingen kenmerken zich aldus door de specifieke wijze waarop de veranderingsprocessen worden benoemd en geduid. In

4. Feder \& Feder: The Expressive Arts Therapies. Levine: Poiesis. The language of Psychology and the Speech of the Soul.

5. Van der Drift: Kindertekeningen en kindergedrag. Toetsing van de OT-index als instrument voor het meten van het gedrag van kinderen. Van der Essen-Cox: Onderzoek naar effecten van muziektherapie op communicatie bij patiênten met gevorderde dementie.

6. Sechehaye: Terug naar het nulpunt. Symbolische realisatie als geneeswijze voor de schizofreen. 
dit onderzoek zullen deze processen worden beschouwd als een metaforische dynamiek die het gehele mens-zijn betreft.

Niettegenstaande de interpretatieverschillen lijkt er sprake te zijn van een gemeenschappelijke basisaanname: namelijk dat er in creatieve therapie een oorspronkelijke manier van betekenisgeving plaatsvindt. Het 'oorspronkelijke' karakter houdt verband met het gegeven dat lichamelijkheid, zintuiglijkheid en emotionaliteit integraal bij het proces van betekenisgeving betrokken zijn. De 'oorspronkelijkheid' in betekenisgeving wordt veelal geassocieerd met spontaan handelen, authentieke expressie, en intultief-empathisch verstaan. Ze wordt gecontrasteerd met de 'normale' en 'verbale' communicatiewijze in een alledaagse context, die in het algemeen conventioneler en rationeler van aard is. De 'meerwaarde' van creatieve therapie zou met dergelijke verschillen in betekenisgeving samenhangen. De 'oorspronkelijke' zijns- resp. zienswijze wordt verondersteld in een kinderlijke of primitieve ontwikkelingsfase 'van nature' aanwezig te zijn. In latere fasen van beschaving of door het volwassen worden zou deze natuurlijke mogelijkheid worden 'bedekt' door 'rationele egostructuren', 'afweermechanismen' of 'conditioneringspatronen'. Deze 'natuurlijke' en 'oorspronkelijke' kenwijze is in het eerste hoofdstuk getypeerd als een (post)romantische benadering van de werkelijkheid.

In dit hoofdstuk worden de verschillende perspectieven op ontwikkelingsprocessen zichtbaar gemaakt aan de hand van de invalshoek van de metafoor. De therapeutische beschrijvingen van beeldende processen steunen op een (impliciete) ontwikkelingsmetafoor. Deze is te reconstrueren door de therapeutische ontwikkeling te lezen als een vorm van metaforische dynamiek die een beweging in de tijd genereert: terug in het verleden, in een 'gecondenseerd heden' of vooruit naar de toekomst. De metaforische dynamiek heeft betrekking op een interne dynamiek in ons spreken, denken, voelen en handelen, die in de creatief therapeutische dialoog tussen cliënt, therapeut en creatief medium tot expressie komt. Het betreffende therapeutische referentiekader krijgt haar beslag in de wijze waarop de metaforisch gegenereerde dynamiek als 'overstap' van het concrete handelen en de zichtbare interactie met het creatieve materiaal naar een andere, 'innerlijke' ordening wordt geïnterpreteerd. Vanuit een psycho-analytisch referentiekader bijvoorbeeld krijgt deze 'overstap' een specifieke duiding als een 'defensief mechanisme' resp. vanuit de gedragspsychologie als een 'coping-strategie' om met een onacceptabele realiteit in het reine te komen. Daarentegen beschouwt een humanistische benadering de 'primitieve' creatief-therapeutische beelden als een 'authentieke expressievorm', Dergelijke interpretatieverschillen zijn te traceren aan de hand van (impliciete) metaforen in de tekst die de schakel vormen tussen een 'letterlijke ordening' van zichtbare beelden en zintuiglijk waarneembaar handelen en een 'overdrachtelijke ordening' van 'innerlijke' beelden en processen. Met betrekking tot de wijze waarop deze metaforische betekenisoverdracht wordt geïnterpreerd behandelt dit hoofdstuk drie creatief-therapeutische veranderingsmodellen. Niettemin is er sprake van een gemeenschappelijke opvatting dat de 'oorpronkelijkheid' in het kader van creatieve therapie samenhangt met een kenmerkende 
'expressieve' en 'symbolische' wijze van tekenen resp. betekenisgeving ofwel een 'authentieke' wijze van expressie vanuit een daadwerkelijke verplaatsing naar een 'primitieve' en 'oorspronkelijkere' ervaringsmodus'. Tegen de achtergrond van deze gedeelde basisaanname wordt creatieve therapie in dit onderzoek beschouwd als een 'kader voor metaforische betekenisgeving', waarmee een transformatie kan worden bewerkstelligd in de wijze waarop men de werkelijkheid ervaart resp. waarop 'de' werkelijkheid voor ons verschijnt.

In de tweede paragraaf wordt er een karakterisering gegeven van drie creatieftherapeutische benaderingen. In de derde paragraaf zal er dan in het bijzonder worden ingegaan op de betekenis van het creatieve medium in de verschillende benaderingen. Langs deze weg worden er drie 'ontwikkelings-metaforen' met betrekking tot de creatief-therapeutische methodiek geëxpliciteerd. De vierde paragraaf beschrijft hoe in de creatief-therapeutische literatuur aanvankelijk een romantische onwikkelingsmetafoor dominant is. Deze metafoor van 'oorspronkelijkheid' ijkt therapeutische veranderingen op 'authenticiteit' in betekenisgeving resp. van 'zijn', hetgeen door middel van een regressieve ontwikkelingsdynamiek wordt bewerkstelligd. Onder invloed van reorganisaties in de (geestelijke) gezondheidszorg doet een instrumentele orientatie steeds meer haar intrede, ook met betrekking tot creatieve therapie. Hoe dit een accentverschuiving teweegbrengt in het therapeutische veranderingsmodel naar een progressieve ontwikkelingsmetafoor, wordt in de vijfde paragraaf aan de hand van citaten uitgelegd. Daarna zal er in de zesde paragraaf worden ingegaan op een niet met de stroom van 'verzakelijking' meegaande ontwikkeling binnen creatieve therapie. Deze derde kunstgeoriënteerde benadering is niet eenzijdig instrumenteel noch louter romantisch van aard. De impliciete ontwikkelingsmetafoor in de kunstgeoriënteerde richting herbergt een andere optiek op veranderingsprocessen: de therapeutische processen worden beschreven in termen van een 'betekenistransgressie binnen het medium'. Een vergelijking tussen de drie perspectieven op ontwikkeling is in de zevende paragraaf ondernomen onder de noemer van de metaforische dynamiek in betekenisgeving die in de verschillende benaderingen van creatieve therapie gegenereerd wordt. De voltrokken analyse mondt uit in een karakterisering van de drie veranderingsmodellen als een dialectiek tussen een 'letterlijk' en een 'figuurlijk niveau' van interpretatie: een dialectiek tussen verwoording en verbeelding, tussen beelddenken en denkbeelden. Een samenvatting en conclusie met betrekking tot de onderzoeksvraag welk therapeutische veranderingsmodel het meeste recht doet aan de plaatsvindende processen van betekenisgeving sluiten het hoofdstuk af.

\subsection{Drie benaderingen van creatieve therapie}

In deze paragraaf volgt een beschrijving van drie creatief-therapeutische benaderingen. Deze worden op basis van een analyse van de creatief-therapeutische literatuur getypeerd als een psychotherapeutisch annex pragmatisch, een 
antropologisch en een kunstgeoriënteerd referentiekader. De verschillen tussen deze benaderingen zullen worden besproken aan de hand van citaten, terminologie, vooronderstellingen, metaforiek en schrijfstijl.

\subsubsection{De antropologische benadering}

De antropologische benadering van creatieve therapie wordt gekenmerkt door een romantische oriëntatie op een 'oorspronkelijke wijze van betekenisgeving'. Kenmerkend voor deze benadering is een beschrijving van creatieve therapie als een vorm van beeldende expressie en rituele vormgeving vanuit een 'primitieve' werkelijkheidservaring. Ter illustratie volgt hieronder een citaat van een beeldend therapeute, die zich bezig houdt met de behandeling van incest-getraumatiseerden. Zij verwijst naar haar ervaring met rituele en magische praktijken in Ghana om een 'primitieve' omgang met de werkelijkheid te verduidelijken. De volgende punten van overeenkomst stelt ze vast tussen de creatief therapeutische en de magische ervaring:

- beide dragen een taboe-karakter

- de ervaringen zijn niet 'geverbaliseerd'

- ze worden buiten het dagelijkse bewustzijn gehouden.

In het volgende citaat worden deze punten van overeenkomst in een ruimere psycho-sociale context geplaatst:

Incest als handeling staat, net als de zwarte magie in Ghana, in het teken van het egolsme van een individu, van machtsmisbruik en het ondergraven van sociale normen .... Het incestgebeuren vindt vaak op een rituele manier plaats.

Dan beschrijft de therapeute hoe zij volgens deze interpretatie van creatieve therapie, in dialoog met haar patiënten, een symbolisch-rituele werkwijze hanteert:

Een patiēnte hakt al een tijdje th een stuk klei, dat plat voor haar op tafel ligt, terwijl ze naar het werk van anderen kijkt. Haar handen werken als vanzelf en beelden onbewust uit, wat met haar in het verleden gebeurde. De klei is te beschouwen als een symbool voor haar lichaam, het mes als een symbool voor de verkrachtingen door haar vader, opa en broer. (...) Op deze wijze komt een kandelaar tot stand, waarbij ze de steken van de onbewuste handeling als een soort versiering handhaaft. Haar agressie krijgt dus een veilige plek en wordt gedragen door de vorm waarvoor ze de verantwoording neemt.'

De antropologische visie op het vak blijkt uit de nadruk die de auteur legt op de symbolisch-rituele betekenis van de beeldende processen. $\mathrm{Zij}$ interpreteert de

7. NvKt: Symbolen in de creatieve therapie. Schwitters: In de ban. De betekenis van symbolen en symbolische rituele handelingen in de beeldende therapie met incestoverlevenden 81 . 
psychische problematiek en de genezende werking van beeldende therapie aan de hand van betekenisgevende elementen zoals 'ritueel', 'magie', 'taboe' en 'symbool', die zich tot een 'primitieve' ervaringswerkelijkheid samenvoegen. In deze casusbeschrijving zijn deze antropologische elementen niet in een overdrachtelijke zin opgevat maar als een werkelijk opgeroepen 'magisch-mythische' ordening van de realiteit. Er zou een 'diepere' ervaringswerkelijkheid in creatieve therapie worden gegenereerd, waarin zich psychosociale resp. interculturele wetmatigheden laten gelden voorbij de direct zichtbare 'letterlijke ordening' van de realiteit. Deze wetmatigheden zijn antropologisch verankerd in een 'natuur' van de mens. De antropologische interpretatie van deze casus baseert de therapeute op haar ervaring met rituele praktijken en magie in Ghana:

De symbolisch rituele handelingen en de daarmee gepaard gaande werking krijgen kracht door deze ervaring te delen met anderen die niet geïnvolveerd zijn in het familiesysteem. Het taboe rond de vroegere ervaring wordt op die manier symbolisch verbroken. Dit wordt vooral mogelijk door een andere overeenkomst met de witte magie, namelijk het non-verbale aspect van de symbolische vormgeving. Het taboe rond incest rust vooral op het verbale en hierin ligt de waarde van het werkstuk: het taboe verliest in de non-verbale uiting zijn macht. De rituele handelingen bieden de patient de kans vat te krijgen op ongewenste situaties en om gevoelens symbolisch tot uitdrukking te brengen. Tegelijkertijd ervaart hij in dit proces zijn eigen kracht en creativiteit. Dit leidt ertoe dat de patiënt zich niet langer uitgeleverd voelt aan de ban van het verleden, maar kan leren op eigen wijze vorm te geven aan zijn leven.

In deze casusbeschrijving is de 'overstap' van het 'letterlijk zichtbare' naar de 'onzichtbare psychosociale ordening' ook schatplichting aan een in het verlichtingsdenken gewortelde ontwikkelingsmetafoor. Uit het citaat blijkt dat de regressie naar een 'primitieve' expressievorm in het teken staat van een progressieve, een zich van het verleden bevrijdende vormgeving van het leven van de patiënt.

Een antropologische invalshoek op creatieve therapie wordt soms ook op meer filosofisch-speculatieve wijze geformuleerd:

The creative arts, then, can enter into psychotherapeutic work because art has an inherent capacity to heal the psyche. This fact was recognized in traditional cultures. Originally, healers were also artists; the healing process was a ritual event, and the shaman or medicine man functioned as ritual master, master of ceremonies.... It is only in the modern world-view that the healer is conceived as a detached observer working within a de-symbolized reality. ${ }^{8}$

8. Levine: Poiesis. The language of Psychology and the Speech of the Soul 3 
De antropologische benadering van creatieve therapie is verwant met die van de ethnopsychiatrie, waarin onderkend wordt dat kennis van culturen en religies essentieel is voor een adequate diagnostiek en therapie voor patiënten uit andere culturen. De ervaring leert dat zij te kampen hebben met psychische problematiek die niet in overeenstemming blijkt te zijn met traditionele westerse psychiatrische ziektebeelden.

Zo staat mij duidelijk de ziekte voor ogen van een jongen wiens ouders contact met mij hadden opgenomen, nadat hij wartaal was gaan spreken, en die zich als een bezetene gedroeg. Zijn verklaring was dat hij werd achtervolgd door een man die hij bij het station was tegengekomen en die alleen hijzelf waarnam. De behandelende psychiater schreef dit toe aan hallucinatie en het gedrag van de jongen legde hij uit als "die jongen is bezig zichzelf te ontdekken". De patiënt had regelmatig de voorgeschreven medicijnen ingenomen en ongeveer een week later ging hij zich spastisch gedragen. (...) Op mijn advies nam hij de tabletten niet meer in en ongeveer twee weken later waren de bijverschijnselen verdwenen. Hij werd uiteindelijk behandeld met ethnopsychiatrische technieken die een positieve invloed hadden op zijn ziekte.

De Zwitserse psychiater Jung heeft met behulp van een 'dieptepsychologische' duidingsmethode toegang gezocht tot een 'archaïsche' antropologische laag van de psyche, die de bron van 'primitieve' symbolen en rituelen zou zijn. De door patiënten vertelde (dag-)dromen analyseerde hij nauwgezet en bracht ze in een systematisch verband met de in diverse culturen voorkomende symbolen en rituelen. Soms liet hij deze droombeelden ook naschilderen. $\mathrm{Zijn}$ methode noemde hij 'actieve imaginatie'. Sommige betekenisvolle droombeelden - zoals het kruis, de mandala en de zon - bleken ook een bijzondere rol te spelen in religieuze tradities. Deze noemde hij 'archetypen'.

Door eigen onderzoek heb ik me ervan kunnen overtuigen dat mandala's in alle tijden en streken getekend, geschilderd, gebeeldhouwd en gebouwd werden, lang voordat mijn patiênten ze hadden ontdekt. Ik heb ook tot mijn voldoening gezien dat mandala's gedroomd en getekend werden door patiënten, die behandeld werden door psychotherapeuten die niet tot mijn leerlingen gerekend konden worden. ${ }^{10}$

Sommige creatief therapeuten hanteren een Jungiaanse methodiek. In het algemeen geldt dat bepaalde standaard-opdrachten in beeldende therapie 'staan voor' specifieke, voor de behandeling relevante aspecten van de persoon. Bijvoorbeeld het schilderen of boetseren van de eigen plek om de 'emotioneel-sociale ruimte' van de patiënt in beeld te brengen; het tekenen van 'de gevoelscirkel' - als het ware de meest simpele en kale mandalavorm, een beeld over hoe de patiënt zich 'van

9. Wooding: Geesten genezen. Ethnopsychiatrie als nieuwe richting binnen de nederlandse antropologie vii.

10. Jung: Symboliek van de Mandala. Beelden uit het onbewuste 81 . 
wording van deze bron. Het werken met ik-versterkende oefeningen heeft een zelfde functie. Wanneer het bewustzijn van die innerlijke bron sterker wordt, kunnen we steeds meer onze eigen dirigent worden. ${ }^{16}$

Het werken met symbolen zou voor dit doel zeer geschikt zijn. Met name noemt deze creatief therapeut de symbolen van de innerlijke bron, de boom en het huis, welke hij veel in zijn praktijk tegenkomt en gebruikt. Hij karakteriseert zijn invalshoek als een combinatie van psycho-synthese en kunstzinnige therapie. Beide benaderingen zijn gebaseerd op een humanistische waarde: de ontplooïng van een menselijke 'kern'.

Vaak treft men in creatief-therapeutische literatuur een zogenaamde eclectische benadering aan. Deze blijkt veelal impliciet uit de wijze waarop een casus wordt beschreven. Dan hanteert de therapeut een therapeutische taal en werkwijze, die ontleend is aan diverse benaderingen en referentiekaders. Bijvoorbeeld:

Cliënten met de diagnose borderlinestoornis hebben meestal weinig zelfvertrouwen. Zij vinden het moeilijk om aan een beeld van klei, een schildering of tekening te beginnen of weten niet goed wat ze willen schilderen of boetseren. Als therapeut reik ik cliënten voorbeelden aan of fungeer zelf als voorbeeld. Vaak werk ik dan samen met de client op hetzelfde papier of maken we een gezamelijk project. In deze fase werk ik vaak met tegenstellingen zoals: hard zacht, zwart/ wit, vrolijk/ somber, dag/ nacht, mooi/ lelijk. Ik vraag cliënten hun emoties te verbeelden in vorm en kleur. Ik probeer de cliënt op deze manier te stimuleren om hun neiging in uitersten te reageren wat meer te nuanceren. Uiteindelijk is het de bedoeling dat de cliênt meer grip krijgt op zichzelf. In deze periode is het contact tussen de client en mij als therapeut heel nauw. ${ }^{17}$

Deze 'eclectische benadering' wordt gekenmerkt door:

- Het werken door middel van de therapeutische relatie. De therapeute verwoordt dit in termen van afstand en nabijheid, bijvoorbeeld 'het herkennen en hanteren van grensoverschrijdend gedrag'.

- Het hanteren van (tegen-)overdrachtsprocessen.

- $\quad$ Thematisch werken, waarbij de keuze en vormgeving van therapeutische thema's in relatie staan tot het leven en de problematiek van de client.

- Het hanteren van de werking van het aangeboden materiaal,- in vakjargon de sensopathische appèlwaarde.

16. NvKt: Symbolen in de creatieve therapie Togt: De innerlijke bron. Integratie van Kunstzinnige therapie en Psychosynthese 83-84.

17. Vernooij: Samen en toch alleen. Cliênten met een borderlinestoornis in beeldende therapie Tijdschrift voor Creatieve Therapie 19. 
Het vormgeven van de therapie door middel van een vooronderstelde analogie tussen de wijze van beeldend werk(en) en de vormgeving van het leven door de cliënt.

Het laatstgenoemde punt is voor creatieve therapie uiterst essentieel. Het methodische uitgangspunt van een analoog verband tussen de psychische problematiek in het leven van de cliënt en de wijze van beeldende expressie, blijkt ook uit het volgende citaat. Het betreft een groepstherapiesessie. De geciteerde creatief therapeuten beschrijven de reactie van een cliënte tijdens de nabespreking van een groepswerkstuk:

Tegelijkertijd is ze teleurgesteld dat ze uiteindelijk als achtergrondkleur over gebleven is. We koppelen dit terug naar haar dagelijkse leven. Neemt ze daarin ook zo nadrukkelijk ruimte in? En wat gebeurt er als anderen ook hun aandeel opeisen? Geeft ze dan de zich toegeèigende ruimte weer op? ${ }^{18}$

Soms wordt er in een casusbeschrijving een bepaalde psycho-therapeutische techniek of methodiek heel specifiek benoemd en gerelateerd aan het therapeutische proces en de behandeldoestelling. Hoewel de methodische uitgangspunten en technieken in het algemeen niet specifiek voor creatieve therapie zijn, worden ze in dat kader wel toegesneden op beeldende processen. Uit het volgende citaat blijkt de waarde van een creatief therapeutische 'vertaling' van een gedragstherapeutische techniek in het kader van rouw-verwerking:

Een gedragstherapeutische techniek is confrontatie ('exposure') met hetgeen vermeden wordt. Door confrontatie kan geleidelijk aan gewen-ning aan het vermedene optreden. Hoe meer gewenning, hoe minder vermijdingsgedrag. Door niet te vermijden kan integratie van pro-blematische rouwemoties plaatsvinden (..) Kreatieve therapie beeldend leent zich bij uitstek voor het tot stand brengen van deze confrontaties ter realisering van de tweede rouwtaak. ${ }^{19}$

Afhankelijk van het betreffende referentiekader wordt er in de interpretatie van beeldende processen meer de nadruk gelegd op de kunstwaarde of op de psychologische waarde. In het eerste hoofdstuk is hiernaar gerefereerd met het onderscheid 'art as therapy' resp. 'art in therapy'. De hierna te beschrijven kunstgeoriënteerde benadering kan als een vorm van 'art as therapy' worden beschouwd. Tegenwoordig is er een tendens in varianten van 'art in therapy' te constateren om zich steeds meer op de wetenschap te oriënteren. Bijvoorbeeld door in praktijkbeschrijvingen de effectiviteit van creatieve therapie zoveel mogelijk aan de hand van specifieke therapeutische technieken en methodieken te benoemen en te operationaliseren, en aldus empirisch toetsbaar te maken. Dan zou de therapeu-

18. de Bruyn \& de Vilder: In de greep van het eten. Beeldende kreatieve groepstherapie voor vrouwen met eetproblemen Tijdschrift voor Creatieve Therapie 12.

19. Vos: Confronteren is beter dan vermijden. Directief- en gedragstherapeutische uitgangspunten bij gestagneerde rouw Tiidschrift voor Creatieve Therapie 118. 
tische bijdrage van creatieve therapie met betrekking tot bepaalde aspecten van de psychiatrisch gediagnostiseerde ziektebeelden in een geoperationaliseerd model kunnen worden aangegeven. Dit impliceert dat creatief therapeuten zich naar dominante referentie-kaders in de (geestelijke) gezondheidszorg gaan voegen. Een wetenschappelijke legitimatie van creatieve therapie via een medisch, psychiatrisch of psycho-therapeutisch model lijkt evenwel op gespannen voet te staan met de ontwikkeling van een 'eigen' beeldend creatief therapeutisch referentiekader. Niettemin wordt in creatief therapeutische literatuur het belang van theorievorming en wetenschappelijk onderzoek steeds meer onderkend. Een aan creatieve therapie verwante, speciaal op de behandeling van kinderen toegesneden vorm van speltherapie heeft zich op dit vlak ver ontwikkeld. Onder de naam 'beeldcommunicatie' wordt deze, aanvankelijk vanuit de fenomenologisch-antropologische psychiatrie ontwikkelde, vorm van therapie voor kinderen aan de universiteit van Leiden empirisch en theoretisch onderbouwd. ${ }^{20}$

\subsubsection{De pragmatische benadering}

Er waait in de laatste jaren in de (geestelijke) gezondheidszorg een wind uit een 'zakelijke' hoek. Een 'profit'-doelstelling en rationaliseringsideeën bepalen steeds meer de organisatie van de zorg. Bezuinigingen om de tekorten en de stijgende kosten tegen te gaan, reorganisaties in een 'pendelbeweging van centralisatie naar decentralisatie' om de zorg effectiever en efficiënter te maken, en een tendens tot verzakelijking in het denken over zorg en behandeling. De veronderstelling hierbij is dat therapie en zorg naar inzicht en believen kunnen worden vorm-gegeven door middel van organisatorische manipulaties. Bovendien dat de beoogde effectiviteit en efficiëntie ook kunnen worden gemeten en dat de meetbaarheid uiteindelijk de behandeling legitimeert. De eerdere reorganisaties hadden voor creatieve therapie een organisatorische accentverschuiving teweeggebracht van een aparte, autonome dienst naar een multi-disciplinair teamverband, waarbij creatief therapeuten steeds minder zelfstandig opereerden als (mede-)behandelaar en steeds meer een ondersteunende rol toebedeeld kregen. De nieuwste golf van fusies in de (geestelijke) gezondheidszorg heeft deze organisatie-structuur weer op losse schroeven gezet, onder geleide van een beleidsverandering naar het zogenaamde 'protocollair werken ${ }^{21}$. Hiermee streeft men naar standaardisatie van de behandeling per discipline, toegesneden op ziektebeelden volgens het zogenaamde DSM-IVmodel. $^{22}$ In de praktijk betekent dit dat creatief therapeuten hun zorgtaken in

20. Hellendoom (e.a.): Beeldcommunicatie. Een vorm van kinderpsychotherapie.

21. Hutschemaekers \& Neymeijer Beroepen in beweging. Professionalisering en grenzen van een multi-disciplinaire G.G.Z.

22. Door de vereniging voor creatieve therapie en die voor psychomotorische therapie is in samenwerking met het Trimbosinstituut over dit onderwerp een symposium georganiseerd op vrijdag 3 november met als titel Producten van vaktherapeuten in de GGZ. De publicatie vakwerk producttyperingen van vaktherapeuten voor het programma stemmingsstoornissen is op deze dag uitgereikt. 
vastgelegde 'behandelprogramma's' dienen in te passen en dat er aan de gestandaardiseerde creatieve dienstverlening een prijskaartje wordt gehangen. De beleidsverandering wordt organisatorisch onderstreept door creatief therapeuten bij een nieuw te vormen dienst 'vak-therapieën' of de 'adjunctieve dienst' in te delen. De professionele identiteit van de creatief therapeut is onder invloed van deze ontwikkelingen verandert van een op 'communicatief handelen' gerichte therapeutische behandelaar naar een 'producent en verkoper van een creatieve dienst'. De nieuwe spil in deze op marktdenken gebaseerde organisatie van de zorg is de zogenaamde 'zorgmanager' die voor patiënten 'op maat' behandelpakketten samenstelt en inkoopt. Om haar dienst te legitimeren moet de creatief therapeut derhalve zoveel mogelijk klanten werven en haar 'patiëntenload' opvoeren. $Z(h) i j$ moet productie leveren om voldoende winstgevend te zijn.

De beleidsverandering naar kort durende behandelvormen, naar groepsbehandelsettings met steeds minder individuele behandelmogelijkheden en de voorgestelde protocollaire aanpak impliceert voor creatieve therapie ook een vakinhoudelijke verandering. Hieraan lijkt de zogenaamde pragmatische benadering tegemoet te komen. In deze benadering staat niet zozeer het interpretatieproces centraal, maar het zichtbare therapeutische effect van de beeldende processen. Er wordt niet 'gespeculeerd' over de 'intermediaire ruimte' (de black box) met onzichtbare innerlijke processen. Creatieve therapie verschijnt door de bril van wat empirisch waarneembaar is als een concrete (be)handelvorm, als een zintuiglijk waarneembaar beeldend proces of product en als een meetbaar psychologisch effect. Vanuit deze invalshoek worden er instrumentele beschrijvingen gegeven van creatief-therapeutische casussen, technieken, opdrachten en werkvormen. Aangezien er geen corresponderende psychodynamische processen worden benoemd en geïnterpreteerd, lijkt er van een soort 'psycho-techniek' sprake te zijn. Voorbeelden van deze benadering zijn te vinden in handboeken met een praktische oriëntatie. Ter illustratie het volgende citaat:

Het uitgangspunt van dit boek wordt gevormd door meer dan 100 opdrachten voor beeldend werken. (...) Beeldende creatieve therapie is een vorm van psycho-therapie waarbij gebruik gemaakt wordt van beeldend werken als middel. (...)

De opdrachten zijn toegespitst op een bepaalde deelnemer en zullen daarom onderling variëren van techniek, thema, werkduur en complexiteit. Uitzondering hierop vormen de opdrachten die aangeboden worden in de introductieperiode van de creatieve therapie. (...) In deel 4 van dit boek is een lijst opgenomen met opdrachten die geschikt zijn om in een introductieperiode aan de deelnemer aan te bieden. ${ }^{23}$

Het is waarschijnlijk dat onder invloed van de gaande zijnde verzakelijking van de (geestelijke) gezondheidszorg de pragmatische benadering in betekenis groeit.

23. Budde: Creatieve Therapie in Praktijk. 11, 25. 
De geschetste 'rationalisering van de zorg' past binnen het terreinwinnende 'marktdenken' dat zich minder op humanistische waarden oriënteert en steeds meer op 'strategisch handelen' met het oog op efficiëntie en meetbaarheid. Dit houdt in dat de creatief therapeut professionele organisatorische capaciteiten bij de gebruikelijke vakinhoudelijke en communicatieve vaardigheden moet ontwikkelen, zoals 'p.r'- en presentatietechnieken, teneinde de 'meerwaarde' van deze therapievorm te kunnen ver(ant)woorden en verkopen. Tegen deze achtergrond is het de vraag of creatieve therapie in haar huidige vorm zal blijven bestaan. Zeker is dat er in deze arbeidssector een stagnatie heeft plaatsgevonden wat betreft 'employment' en 'employability' van creatief therapeuten. Het gevolg van de gaande zijnde bezuinigingen en beleidsveranderingen is dat er aan de aanvankelijke groei van arbeidsplaatsen en werkvelden in de zestiger en zeventiger jaren een einde is gekomen. Tijd en geld voor meer scholingsmogelijkheden en een carrièreperspectief is er voor creatief therapeuten door deze ontwikkeling doorgaans niet bij. Zelfs voor de gebruikelijke werkoverlegvormen en patiëntenvergaderingen blijft er steeds minder tijd over door de relatieve toename van patiëntencontacturen. Creatieve therapie - van oorsprong op humanistische en esthetische ${ }^{24}$ waarden gericht - moet net zoals andere romantische restanten uit de zorg- en welzijnssector nu haar waarde 'doel-rationeel' door middel van meetbaar effect en winstgevendheid bewijzen.

\subsubsection{De kunstgeoriënteerde benadering}

Aangezien creatieve therapie veelal door praktizerende kunstenaars is ontwikkeld neemt de 'kunstgeoriënteerde benadering' eveneens een belangrijke plaats in. De eerste kunstenaars die als therapeuten werden aangesteld, lieten zich inspireren door stromingen in de kunst $^{25}$, vooral het expressionisme en het surrealisme. Naast de dominante romantische en instrumentele oriëntaties is er in de vakliteratuur derhalve nog een derde interpretatie van creatief therapeutische ontwikkelingsprocessen te onderscheiden. In kunstgeoriënteerde benaderingen van creatieve therapie worden de communicatie- en veranderingsprocessen zoveel mogelijk beschreven in artistiek-beeldende termen. Voorstanders van deze benadering reflecteren op de zichtbare beeldend-therapeutische en kunstprocessen teneinde een 'beeldtaal' en op beeldende processen toegesneden referentiekader te ontwikkelen waarmee het vak onderbouwd kan worden. Deze derde benadering lijkt wat betreft het vermijden van sterk theoretisch geladen terminologie op 'de pragmatische benadering'. Overeenkomstig is aldus het aspect dat de therapie wordt beschreven en uitgelegd aan de hand van het waarneembare beeldende product en de zichtbare

24. Ten aanzien van deze terminologie moet een voorbehoud worden gemaakt: creatief therapeuten benadrukken dat de beeldende expressie en vormgeving in het kader van creatieve therapie wezenlijk verschilt van een 'zuiver' artistieke en esthetische wijze van expressie en aldus meer gericht zijn op therapeutische waarden.

25. Zie bijvoorbeeld Gilroy \& Dalley: Pictures at an exhibition. Smeijsters: Handboek 88 e.v. 
beeldende processen. Ook de therapeutische relatie, interactie- en persoonskenmerken van de cliënt worden zoveel mogelijk beeldend beschreven. Een belangrijk verschil met 'de pragmatische benadering' is echter dat vanuit deze 'kunstinvalshoek' juist wel het 'innerlijke' proces van betekenisgeving centraal komt te staan. Wanneer deze wijze van beschrijving wordt uitgebouwd tot een zelfstandig referentiekader, wordt ze hier tot 'de kunstgeoriënteerde benade-ring' gerekend. Een voorbeeld hiervan is de zogenaamde 'kunstanaloge benade-ring', van waaruit creatieve therapie wordt beschreven aan de hand van aan de kunst ontleende concepten, die op de beeldende processen in therapie worden toegesneden. Ook de op antroposofische grondslag ontwikkelde 'kunstzinnige therapie' kan tot deze benadering worden gerekend.

Het volgende citaat is afkomstig uit een studie over creatieve therapie, waarin naast de kunstinvalshoek nog twee andere perspectieven worden gehanteerd. De auteur beschrijft een casus in termen van beeldende aspecten van het therapeutische proces en voegt hieraan een theoretische onderbouwing toe; daarnaast reflecteert zij op haar therapeutische handelen in de vorm van een persoonlijke verslag:

I immediately felt empathy and compassion for Farah; my metaphor of the fragile flower was a powerful determinant in my connection to her. This metaphor often led me to want to protect her and to provise a nourishing emotional atmosphere for Farah which would be a counter-experience or corrective experience for her. (...) Much of what I did with Farah in individual sessions was to create an artistic environment, to establish a quiet, aesthetic oasis where Farah could feel safe and free. ${ }^{26}$

De geciteerde creatief therapeute integreert een psycho-analytische benadering van de verwerking van een verstoorde ontwikkeling door middel van een 'correctief emotionele ervaring' met een humanistische oriëntatie op gezonde aspecten van de cliënte. De 'esthetische oase' uit het citaat is een operationalisering van deze humanistische gerichtheid, waarin de cliënte tot esthetische zelf-expressie wordt uitgenodigd. Hoewel de auteur elders in het boek expliciet verwijst naar ideeèn van Winnicott en Klein, is deze casus niet in uitgesproken psychologische terminologie beschreven. Veelal hanteert zij concrete, op beeldende processen gerichte waarnemingstermen. Waar zij toch naar een psychologische ordening verwijst die het direct waarneembare overstijgt, duikt de term 'metafoor' op. De auteur bedient zich van de metafoor van de kwetsbare bloem om de parallellie tussen de concrete zintuiglijke gewaarwording en de opgeroepen innerlijke gevoelens en beelden aan te geven. Naar deze parallellie wordt in psychotherapeutische zin verwezen in termen van het fenomeen van (tegen-)overdrachtsprocessen: 'de therapeute voelt de neiging om het kwetsbare meisje te beschermen'.

26. Levine: Tending the fire. Studies in Art Therapy and Creativity 90-91. 
Ook een andere Amerikaanse creatief therapeute (art therapist) gebruikt metaforen om de therapeutische functie van kunst en creativiteit aan te geven. Bijvoorbeeld de metafoor van het vuur:

I am using the metaphor of fire to understand, in a theoretical sense, the importance of creativity in firing up the self and the connection between the maintenance of the fire of creativity and the maintenance of the aliveness of self. I want to understand the way in which creativity emerges from the earliest experiences of the infant and the mother and is sustained or not sustained throughout our lives. Like a fire, imagination and creativity must first be built up and then ignited. ${ }^{27}$

De kunstgeoriënteerde invalshoek staat aan de basis van een zich ontwikkelende 'beeltaal', een 'eigen' referentiekader, dat vooral geènt is op wetmatigheden van de kunst. Veelal wordt 'fenomenologisch' beschreven wat 'op analoge wijze' zichtbaar is 'in' de beeldende processen op papier, 'in' het klei of 'in' ander beeldmateriaal. Hierbij worden de veranderingsprocessen niet zozeer geïnterpreteerd tegen de achtergrond van een progressieve of een regressieve psychologische ontwikkeling. Veeleer wordt de creatief-therapeutische verandering begrepen als een transgressieve dynamiek die in een 'gecondenseerd heden', in de actualiteit van het beeldend werken, plaatsvindt. Deze betekenistransgressie wordt beschreven als een, aan het zichtbare beeldende proces parallelle of analoge, ordening van 'innerlijke kleuren, vormen en dynamiek'. Hieronder volgt als voorbeeld een casusbeschrijving waarin concepten als 'metafoor' en 'symbool' worden gebruikt om de betekenisoverdracht te bewerkstelligen van de 'letterlijk waarneembare ordening' van zichtbare beeldende processen naar een 'onzichtbare ordening' van innerlijke processen:

Voor Ahna had het ei nog geen betekenis evenals haar tekening. Het zou zijn betekenis pas krijgen door de relatie die ze ermee aan zou gaan. Toch is er ergens wel een relatie tussen Alina en het ei, daarvoor past het te goed op haar leven en spiegelt ze ook later in het proces hierin de metafoor van haar levensverhaal. ${ }^{28}$

Uit de verdere beschrijving van de casus blijkt dat de symbolische betekenis van het beeldend werk in het licht van een Jungiaanse visie wordt geduid. Het citaat vertegenwoordigt een mengvorm, waarin de symbolische betekenis van beelden enerzijds vanuit (on-)zichtbare beeldende processen wordt begrepen en anderzijds vanuit een psychotherapeutisch referentiekader.

De 'kunstgeoriënteerde benadering' komt het meest pregnant naar voren bij therapeuten die de psychologische betekenis van de gemaakte beelden interpre-

27. Tending the fire. Studies in Art Therapy and Creativity 50.

28. Vugt: Het gouden ei. Werken met Symbolen in de behandeling van psychotici en zeer vroeg ontwikkelingsgestoorde patiênten. In: NvKt: Symbolen in de creatieve therapie. 68-69. 
teren als integraal deeluitmakend van het beeldende proces. Vanuit die invalshoek is de innerlijke psychische problematiek af te lezen aan het parallel verlopende creatieve proces, als de wijze waarop cliënten vormgeven aan het beeldende werk en aan hun relatie met de therapeut. Het belang van deze benadering met betrekking tot de onderzoeksvraag is dat deze diagnostische 'leeskunst' een in de praktijk ontwikkelde vorm van hermeneutiek lijkt te zijn.

\subsection{Drie perspectieven op metaforische betekenisgeving}

Deze paragraaf is gewijd aan de vraag welke betekenis het creatieve medium toekomt in de drie benaderingen van creatieve therapie. Het kunstmedium fungeert in alle benaderingen als middel tot betekenisgeving maar krijgt erin een verschillende plaats: als middel naar een 'oorspronkelijke bron van betekenisgeving', als 'instrument om grip op psychische problemen te krijgen', als 'creatieve speelruimte voor verbeelding en verwoording'. Vanuit het kader van dit onderzoek is er niettegenstaande de verschillen een overeenkomstige basis gereconstrueerd: namelijk de door de interactie met het medium gegenereerde 'metaforische dynamiek', die resp. een regressieve, progressieve of transgressieve beweging in 'het innerlijk' van cliënten bewerkstelligt. Aldus verwijst 'metaforiek' zowel naar een dynamiek in de 'belevingsorganisatie,29 als naar een 'metaforische dynamiek' in de beschrijving van creatief therapeutische processen. Metaforiek duidt derhalve op betekeniseffecten voorbij de 'letterlijke' (beschrijving van) creatief therapeutische processen. De metaforisch opgeroepen 'andere ordening' bestaat zowel uit innerlijke en uterlijk vormgegeven beelden als uit psychosociale processen tussen therapeut en cliënt. Deze 'andere ordening' is hiervoor globaal aangeduid als cen 'metaforische ervaringsmodus' op grond waarvan 'de werkelijkheid' op andere wijze wordt ervaren, resp. in het kader van creatieve therapie verschijnt. Hieronder ga ik in op de verschillende interpretaties die in de drie creatief-therapeutische benaderingen aan deze dubbelzinnige verandering in werkelijkheidservaring wordt gegeven.

Dominant in de creatief-therapeutische literatuur is de romantische interpretatie van de betekenis van het creatieve medium als een middel dat een regressie instelt naar een 'oorspronkelijker' stadium in de ontwikkeling. Aan de hand van de hiervoor besproken 'antropologische benadering' van creatieve therapie kunnen we ons een beeld vormen van een 'primitieve' werkelijkheids-ervaring, die gedragen wordt door symbolisch-rituele praktijken, metaforisch denken en een mythischmagische beleving. Veelal treft men in de creatief therapeutische literatuur publicaties aan waarin dit romantische perspectief gecombineerd wordt met een instrumentele interpretatie van 'de metaforische ervaringsmodus', namelijk als een noodzakelijke 'tussenstap' naar een 'hoger' of 'verder' stadium in de ontwikkeling.

29. Hellendoorn: Beeldcommunicatie. Een vorm van kinderpsychotherapie 37 e.v. 
De instrumentele benadering van creatieve therapie berust op een vooruitgangsgeloof, op grond waarvan 'primitieve' of 'pathologische' vormen van beeldende expressie in het teken staan van (herstel van) de ontwikkeling naar 'volwassen' en 'geciviliseerde' vormen van betekenisgeving. In de kunstgeoriënteerde benadering wordt er een derde interpretatie gegeven aan de creatief-therapeutische veranderingsprocessen. Vanuit deze invalshoek worden ontwikkelingsprocessen niet als een 'civilisatieproces' noch als een 'terugkeer naar een natuurlijke zijnswijze' geduid, maar als een creatief veranderingsproces dat in de beeldende processen zichtbaar en uitdrukkelijk wordt. Deze derde interpretatie is niet zozeer romantisch of instrumenteel van aard, noch een combinatie van beide. Het creatieve medium wordt opgevat als 'de plaats' waarin in een gecondenseerde vorm ontwikkelingsdynamiek plaatsvindt, als een parallel verlopend beeldend en innerlijk vormgevingsproces. De wijze waarop ontwikkelingsprocessen vanuit deze optiek worden geïnterpreteerd kan derhalve het beste gekarakteriseerd worden als een 'analoge', aan de mediumactiviteit gekoppelde 'psychische' betekenistransgressie. Volgens het kunstgeoriënteerde interpretatiekader is 'ontwikkeling' derhalve geen 'vooruitgang' noch 'terugkeer' in de tijd maar een verandering in de ontsloten 'psychische ruimte' via de interactie met het medium. De therapeutische veranderingen zijn te traceren 'in' de beeldende processen: in en door de interactie met het creatieve medium en met de therapeut. Creatieve therapie is volgens dit derde model een betekenisgevend kader, waarin door middel van creatieve vormgeving en kleurenspel, psychosociale processen worden gekatalyseerd en gekanalyseerd. Deze therapeutisch afgebakende 'tijdspeelruimte' waarin aldus 'metaforische betekenisgeving' plaatsvindt, staat volgens deze optiek aan de basis voor de genezing van de cliënt.

De interpretatie van de betekenis van het creatieve medium voor het bereiken van therapeutische veranderingen kan samenvattend worden getypeerd als 'de ruimte' waar resp. een regressieve, progressieve of transgressieve ontwikkelingsdynamiek plaatsvindt. Aldus wordt de cliënt op verschillende wijze via het creatieve medium 'uitgenodigd' om zich innerlijk en in interactie met het materiaal naar de primitieve en authentieke oorsprong of de metaforische speelruimte van ons spreken, denken, voelen en handelen te bewegen. Wellicht hangt de keuze tussen deze therapeutische veranderingsmodellen samen met 'de organisatie-cultuur' van de betreffende instelling waarin creatieve therapie wordt gegeven. Wanneer deze een humanistische inslag heeft, kan de creatief therapeut zich een oriëntatie op sociale, morele en esthetische waarden veroorloven. In de mate dat creatief therapeuten hun handelen moeten verantwoorden aan de hand van stappenplannen, toegepaste technieken, eenduidig geformuleerde therapie-doelstellingen en bereikte resultaten, kan men zich minder een 'waarde-gestuurde' therapeutische werkwijze permitteren. Ten gevolge van deze ontwikkeling winnen instrumentele benaderingen en vooral de pragmatische werkwijze steeds meer terrein. In de pragmatische benadering is de instrumentele oriëntatie op de spits gedreven. Theoretische onderbouwing en filosofische reflectie op het vak vertegenwoordigen geen waarde op zichzelf meer, maar alleen voor zover ze 'nuttig' zijn of 'functioneel' voor de 
praktijk. Bij gevolg verliest creatieve therapie haar 'romantisch' en 'humanistisch' karakter en wordt ze een gedisciplineerde vorm van dienstverlening. Tegen de achtergrond van deze ontwikkeling draagt de antropologische benadering een oud stempel van de romantische pioniersgeest toen creatieve therapie minder instrumenteel gericht was en als het ware een 'creatieve vrijplaats' binnen de psychiatrie vertegenwoordigde. In een gerationaliseerde maatschappij lijkt hiervoor steeds minder geld en ruimte te zijn. Het is de vraag of de kunstgeoriënteerde benadering aan gene zijde van een romantische en een instrumentele oriëntatie, een interpretatie van creatief therapeutische veranderingen kan uitdragen, die aansluit op resp. tegenwicht biedt aan de verzakelijking van de gezondheidszorg. De huidige 'organisatorische inkadering' van creatieve therapie stelt immers strenge eisen aan de wijze waarop het professionele handelen moet worden ver(ant)woord, overeenkomstig de dominante instrumentele invalshoek.

Wat kan filosofische reflectie op de grondslag van het creatief-therapeutische handelen in dit opzicht betekenen? Een filosofische invalshoek maakt inzichtelijk op welke uitgesproken en verzwegen vooronderstellingen de verschillende benaderingen berusten. Wat op basis van de pragmatische benadering ogenschijnlijk 'ideologieneutraal' als een 'psycho-techniek' wordt benoemd, verschijnt vanuit de antropologische invalshoek als een 'symbolisch-rituele handeling'. Creatief-therapeutische interventies worden in het licht van een psycho-therapeutische oriëntatie zoveel mogelijk empirisch benoemd en onderbouwd, terwijl de kunstgeoriënteerde werkwijze het professionele handelen in het kader van beeldende processen verankert. Door de gekozen invalshoek van de metafoor kan het ideologisch gehalte van de verschillende benaderingen worden benadrukt en onderzocht. Bij gevolg worden de creatief-therapeutische beschrijvingen niet opgevat als (on-)juiste of (on-)zinnige uitspraken over wat er 'feitelijk' plaatsvindt in therapie. Ze worden verstaan als een verbale expressie van het ideologisch gekleurd interpretatiekader van een creatief therapeut. Wanneer beschrijvingen van creatieve therapie aldus niet 'empirisch' maar filosofisch worden geïnterpreteerd, komt het perspectief op ontwikkelingsprocessen van waaruit de beschrijving is gegeven, als zodanig op de voorgrond te staan. Voor creatief therapeuten kan dit betekenen dat ze inzicht verkrijgen in de theorie-geladenheid van hun professionele handelen. In de spiegel van de metafoor is het mogelijk de specifieke 'ideologische kleur' van de verschillende therapeutische referentiekaders te identificeren.

De filosofische onderzoeksinsteek heeft voor creatieve therapie een gemeenschappelijke basisaanname geïdentificeerd met behulp van de invalshoek van de metafoor. Vanuit die optiek genereert creatieve therapie een metaforische ervaring van de werkelijkheid door middel van tonen, beelden, dans en drama. In dit onderzoek staat deze transformatie in werkelijkheidsbeleving door middel van creatieve media centraal. In de metaforische ziens- en zijnswijze zou (nog) geen sprake zijn van een 'subject-object'-dualisme, maar vindt het proces van betekenisgeving via het creatieve medium tegelijkertijd als beleving en als zijnsordening plaats. Deze 'dubbele enscenering' van de 'ervaringswerkelijkheid', 
krijgt in de verschillende creatief therapeutische referentiekaders een andere interpretatie. Het (verschillend) duiden van de 'metaforische lading' ten gevolge van de interactie met het creatieve medium gaat gepaard met een (impliciete) epistemologische en ontologische claim. In het verlengde daarvan wordt het werkzame koppelingsmechanisme tussen de metaforische ervaringsmodus en de bewerkstelligde therapeutische veranderingen als een 'psychologisch' resp. een 'functioneel', een 'creatief' of een 'magisch' verband geduid. Deze verschillende interpretaties van de dubbelzinnige dynamiek in de 'metaforische' ervaringswerkelijkheid belicht dit onderzoek aan de hand van de funderende ontwikkelingsmetaforen.

In de volgende drie paragrafen staat de vraag centraal hoe er in de verschillende benaderingen van creatieve therapie op basis van een (impliciete) ontwikkelingsmetafoor een epistemologisch-ontologische interpretatie van de therapeutische werkzaamheid van beeldende processen wordt voltrokken. (Hoe) geven de gehanteerde referentiekaders zicht op een 'oorspronkelijke' of een 'ultieme' betekenisgevende ordening, die door beeldende expressie ontsloten wordt? In de zevende paragraaf van dit hoofdstuk wordt deze 'grondslagen'-problematiek verbonden met de vraag of de invalshoek van de metafoor uitzicht biedt op een onderbouwde keuze voor het meest adequate therapeutische veranderingsmodel.

\subsection{Een romantische ontwikkelingsmetafoor}

Hoe wordt de oorspronkelijkheid van de 'metaforische werkelijkheidservaring' in de creatief therapeutische literatuur op verschillende wijze opgevat? Een romantische interpretatie geeft aan 'oorspronkelijk' de betekenis van 'dichter bij de oorsprong'. Deze interpretatie keert het ontwikkelingsperspectief in het vooruitgangsdenken van een 'natuurstaat' naar een 'geciviliseerde' staat van zijn als het ware om. De 'primitieve' werkelijkheidservaring bevindt zich 'dichter' bij het 'authentieke' mens-zijn in een natuurlijke staat. Derhalve is de 'oorspronkelijke' wijze van betekenisgeving in creatieve therapie niet een 'ideologie-neutrale' benaming maar vertegenwoordigt zij een wenselijke zijnsmodus. De romantische ontwikkelingsmetafoor illustreer ik in de volgende twee subparagrafen aan de hand van voornamelijk Engelstalige creatief therapeutische literatuur. De angelsaksische literatuur is reflectiever van karakter dan de Nederlandstalige, overeenkomstig de meer voortgeschreden ontwikkeling van creatieve therapie in Engeland en de V. S. wat betreft haar theoretische onderbouwing.

\subsubsection{Betekenisgeving vamuit een oorspronkelijke zijnsordening}

Opvallend is dat in veel 'antropologisch georiënteerde' literatuur de therapeutische waarde van creatieve processen in haar algemeenheid wordt aangegeven, niet gespecialiseerd naar een specifiek medium. Bijvoorbeeld de opvatting dat het therapeutische gebruik van kunst in therapie dichter bij de 'oorspronkelijke' 
inbedding van kunst in 'de primitieve samenleving' ligt dan bij de hedendaagse 'functie' van kunst. Tegenwoordig is kunst als een 'esthetisch domein' losgemaakt van het dagelijkse leven en hoegenaamd niet meer functioneel voor andere levensgebieden van de mens. In tegenstelling hiermee zou kunst oorspronkelijk integraal deel uitmaken van religieuze en therapeutische praktijken:

(...) early dance was more than mere self-enjoyment. Among primitive peoples today, dance is religious, self-expressive, and communicative (...) according to psychologist-anthropologist Richard Katz, for in healing, the IKung (the tribesmen of the Kalahari Desert, H.M.) make no distinction among their physical, emotional and spiritual needs'. The healing energy comes from the gods, and the dances and songs heat up the energy to facilitate the healing process. $^{30}$

Behalve op antropologische literatuur baseren de auteurs hun visie op een analogieredenering. Tegen de achtergrond van de romantische ontwikkelingsmetafoor correspondeert de ontwikkelingsfase van hedendaagse 'primitieve volken' met onze zijnswijze in de prehistorie:

Inferences about the use of music as therapy during prehistoric times are strengthened by the knowledge that it is used today for that purpose by primitive peoples. In some parts of Africa, the medicine man still uses a magic drum and an Ouombi harp to play over the stomach of a patient, and in the Indian tribes of Ontario, magicians and shamans are also music teachers . (...) A good deal is known about the use of music, dance and art among the Indians of North America, from which we may reasonably infer the widespread use of such therapies among other preliterate peoples. The Navajo, for example, in their well known 'curing' sings, use combinations of song, dance and sandpainting, in which specific patterns are used for specific illnesses. ${ }^{31}$

De auteurs schetsen drie hoofdrichtingen in de psychologie - de psycho-analyse, de gedragstherapie en humanistische benaderingen van psychotherapie - die, conform een Westerse benadering, een rationalistische, wetenschappelijk gelegitimeerde grondslag aan creatieve therapie geven. Kenmerkend voor de antropologische invalshoek op creatieve therapie is evenwel dat wetenschappelijke theorieenn voor de creatief therapeutische processen slechts een 'rationele verklaring achteraf bieden. De antropologische zienswijze wijst in plaats daarvan op een gemeenschappelijke 'primitieve' prerationele beleving van de werkelijkheid, die de grond legt voor de 'rationele werkelijkheidsbeleving' van de geciviliseerde, westerse, volwassen (mannelijke) mens.

30. Feder \& Feder: The Expressive Arts Therapies 2.

31. The Expressive Arts Therapies 3. 
In de literatuur zijn ook 'funderingsstrategieën' te vinden die langs een andere route uitkomen bij een 'prerationele zijnswijze'. In plaats van antropologisch een authentieke werkelijkheidsbeleving van de 'primitieve mens' te beschrijven, wordt er filosofisch gereflecteerd op verschillende soorten benaderingen van de werkelijkheid. Deze verschillen hoeven niet noodzakelijkerwijs op een authentieke expressievorm te berusten, maar worden in verband gebracht met de verschillende context waarbinnen 'de werkelijkheid' wordt geïnterpreteerd bijvoorbeeld een wetenschappelijke context tegenover een kunstinvalshoek, een religieuze benadering tegenover een 'common sense'-opvatting. Een wetenschappelijke optiek op de werkelijkheid maakt het dynamische en meerduidige 'zijn' statisch, verklaarbaar en manipuleerbaar. De gezochte prerationele notie van zijn zou naar een werkelijkheidservaring verwijzen, die aan de wetenschappelijke 'vooraf' gaat en veeleer in de kunst gearticuleerd is. Aldus wordt er een prerationele grondslag voor creatieve therapie op speculatieve wijze gevonden.

Dergelijke reflecties op creatieve therapie vertonen overeenkomst met metafysicakritiek, bijvoorbeeld een 'postmoderne' kritiek op het 'westerse project van de Verlichting'. Er wordt in creatief therapeutische literatuur ${ }^{32}$ echter de suggestie gewekt dat er een mogelijkheid bestaat om op exclusieve wijze toegang tot 'het zijn' te verkrijgen. Waar postmoderne auteurs op dit punt een relativisme en pluralisme huldigen, daar wordt in de creatief therapeutische literatuur onder meer gewezen op een op overgave, intuittie en verbeelding gebaseerde zijnsmodus welke superieur aan de rationele, verbale en verklarende benadering van de wetenschap wordt geacht. Door middel van een empathische en authentieke zijnswijze zou het mogelijk zijn om de werkelijkheid direct, buiten conceptuele kaders om, te kennen. Deze empathische ervaringsmodus is ook in verband gebracht met Nietzsche's esthetica, vooral de aan de god Dionysos gewijde dynamische opvatting van zijn. Een 'vloeiende en vurige zijnswijze' wordt tegenover een aan Apollo toegeschreven statische, in beelden tot stilstand gebrachte zijnsconceptie geplaatst. Creatieve therapie zou op een dionysische, op overgave en lichamelijkheid gebaseerde werkelijkheidsbeleving berusten. $\mathrm{Zij}$ staat derhalve op gespannen voet met een appolinische zijns- en zienswijze, die in de wetenschappelijke en de technisch-instrumentele omgang met de werkelijkheid tot expressie komt. Hierin is eveneens de invloed van Heideggers zijnsfilosofie bespeurbaar. In zijn vroege werk beoogde deze filosoof de metafysische 'beheersing van het zijn' bloot te leggen om een 'andere' zijnsgeoriënteerde verwoording van de werkelijkheid mogelijk te maken. In een creatief therapeutische studie is bijvoorbeeld in het bijzonder naar Heideggers interpretatie van het Griekse 'poièsis'-begrip verwezen. Vooral in onderscheid met een technische omgang en verwoording van 'zijn' duidt dit begrip op een typisch menselijke en artistieke zijnswijze:

32. Bijvoorbeeld: The Expressive Arts Therapies. Levine \& Levine: Foundations of Expressive Arts Therapy. Levine: Poiesis. The Language Psychology and the Speech of the Soul. 
This means also that poiesis opens us the possibility of healing. The suffering which lies in the human condition and which strikes each one of us in the form of our fate can only be met by a surrender to Being which makes it possible to receive a blessing adequate to our pain. The therapeutic power of art rests not in its elimination of suffering but rather in its capacity to hold us in the midsts of that suffering so that we can bear the chaos without denial or flight . (...) There is joy in this path; but it is, as Nietzsche saw, a tragic joy which arms existence in the face of suffering. The only foundation is our capacity to admit that there is no foundation, to play among the ruins and find the gift which lies in wait for us there. ${ }^{33}$

Hieronder volgt een Nederlandstalig voorbeeld van een filosofische en psychotherapeutische fundering van creatieve therapie. Er wordt een beroep gedaan op Gadamers hermeneutiek om de typisch creatief-therapeutische beeld- en begripsvorming te omschrijven.

Senso-pathische ervaringen die hun kader in de 'Verständigungsgemeinschaft' vinden herken je gemakkelijk en kun je ook plaatsen. Alleen het niet gekende en verkeerd verwerkte heeft de macht mensen van hun troon te stoten en in het ongewisse van een puur gevoelsisolement te voeren. Er zijn verschillende reacties op zo'n beklemming mogelijk: ontkenning, bezwering, projectie (...) Hermeneutische methodes zijn bedoeld om mensen op hun verhaal te brengen. Niet op mijn of ons verhaal, maar op hun verhaal dat hen kennis, zekerheid en vertrouwen geeft. Daartoe moeten verhalen levensecht, niet verbergend, niet leugenachtig zijn. ${ }^{34}$

Deze hermeneutische fundering van de creatief-therapeutische praktijk vertegenwoordigt een vruchtbare richting waarin het mogelijk zou kunnen worden dat creatieve therapie zich van haar eenzijdige 'romantische' gerichtheid op een oorspronkelijke wijze van betekenisgeving bevrijdt zonder in het andere extreem van een instrumentele oriëntatie te vervallen. In het algemeen lijkt de 'prerationele grondslag' in dit speculatieve type literatuur echter 'romantisch' te worden opgevat als een 'oorspronkelijke' vorm van betekenisgeving, die op 'natuurlijke' wijze plaatsvindt vóór de conceptualisering van 'zijn' tot een rationeel bouwwerk. Hier wordt niet verder ingegaan op de vraag of er in de besproken creatief therapeutische literatuur voldoende recht wordt gedaan aan de gebruikte filosofische auteurs en noties. Dit vertegenwoordigt een mogelijke zwakke kant van dit genre: namelijk dat de gezochte grondslag van 'alternatieve benaderingen' aan de kapstok van grote namen in de filosofie (een metonymische strategie) wordt opgehangen. ${ }^{35}$ Wanneer er in dat bestek te weining ruimte is om daadwerkelijk tot

33. Foundations of Expressive Arts Therapy 31.

34. Lubbers: Psychotheranie door beeld en begripsvorming 61, 65 .

35. Dit gevaar dreigt bijvoorbeeld in Olthof \& Vermetten: De mens als verhaal. Narratieve strategieẽn in psychotherapie voor kinderen en volwassenen. 
de filosofische grond door te dringen kunnen de filosofische uitspraken en reflecties als het ware van buitenaf op de creatief-therapeutische praktijk worden geplakt. Wat betreft de zoekrichting komt dit genre overeen met de antropologische benadering. Beide opvattingen over de 'oorspronkelijke' vorm van betekenisgeving geven een romantische interpretatie aan de grondslag van creatieve therapie. Deze notie van 'oorspronkelijkheid' suggereert immers het daadwerkelijke verankerd zijn van creatief therapeutische betekenisgeving in een fundamentele betekenisgevende ordening in onze 'natuur', voor zover ze door civilisatie nog ongerept is.

Behalve langs antropologische en filosofische weg is er ook op psychologische wijze onderzocht hoe creatieve therapie in een 'oorspronkelijke zijnsmodus' berust. Humanistische en psycho-analytische stromingen in de psychologie interpreteren een 'preconceptuele zijnsmodus' als een bepaalde psychische constellatie of dynamiek bijvoorbeeld aan de hand van het concept van 'het onbewuste' dat aan de rationele bewustzijnsstructuur ten grondslag zou liggen. De klassieke freudiaanse interpretatie met de psycho-analytische regressietechniek draagt een stempel van het verlichtingsideaal om, overeenkomstig Freuds woord 'was Es war soll Ich werden' de onbewuste irrationele krachten uiteindelijk in de greep van het 'ego' te krijgen met het oog op een rationele omgang met de werkelijkheid. In de verdere ontwikkeling van de psycho-analyse, bijvoorbeeld door Freuds leerling Jung, is er een andere interpretatie aan 'prerationele' ervaringen gegeven. Ze wordt niet negatief ten opzichte van de rationele wijze van ervaren gedefinieerd, maar als een positief fenomeen uitgelegd. In dat verband heeft Jung de regressietechniek verder ontwikkeld door 'het vrije associeren' niet slechts verbaal maar ook in beeldtaal te laten plaatsvinden. Dit resulteerde in de toepassing van het visualiseren en het naschilderen van de (dag)dromen als een therapeutische methodiek. In de creatief therapeutische literatuur wordt vaak op een jungiaanse wijze naar beelden in het onbewuste en (droom)beelden verwezen. Vooral archetypische beelden zouden een dusdanig uitzonderlijke kracht hebben, dat ze zich aan rationele controle onttrekken en zich manifesteren in dromen, symbolen, mythen en rituelen. Hier zal verder niet worden ingegaan op de complexe psychologische en filosofische problematiek van het bestaan van 'het individuele en collectieve onbewuste'. Ze is slechts als illustratie geschetst van de derde, psychologische variant waarop creatieve therapie aan de hand van een romantische ontwikkelingsmetafoor op een 'oorspronkelijke' wijze van betekenisgeving wordt gefundeerd.

\subsubsection{Een symbolisch-rituele ordening}

Deze paragraaf gaat meer in detail in op de wijze waarop in de antropologische benadering van creatieve therapie een 'oorspronkelijke betekenisgevende ordening' als grondslag wordt gearticuleerd. Aan de hand van een casusbeschrijving kan licht geworpen worden op een 'emotionele' en een 'interatieve' 
resp. 'narratieve lading' van beelden die in creatieve therapie op basis van 'de metaforische ervaringsmodus' tot stand komen. Centraal staat het begrip 'overdracht', waarbij een verbinding wordt gelegd tussen therapeutische en antropologische aspecten van overdrachtsverschijnselen.

Het psycho-analytische begrip 'overdracht' heeft ook in de creatief-therapeutische literatuur een centrale betekenis gekregen om de genezende werking van de therapeutische relatie te verklaren. Echter is het verschijnsel van overdracht in de context van creatieve therapie complexer geworden door het bestaan van het medium als 'derde gesprekspartner' in de dialoog tussen cliënt en therapeut. De beelden die in therapie gemaakt worden, vormen mede een 'object' waarop de overdracht kan worden gericht. De therapie biedt een kader om de geprojecteerde emotionele lading te uiten, te ervaren en in relatie te brengen met de problematiek en het leven van de cliënt. Op emotionele en inzichtgevende wijze spreken de beelden mee in de creatief therapeutische dialoog. Een auteur ${ }^{36}$ heeft de soort overdrachtsprocessen die hierbij meespelen als 'magisch' benoemd. In het bijzonder verwijst zij naar antropologische literatuur van o.m. Cassirer en Frazer waarin het fenomeen van 'de zondebok' staat beschreven. De 'projectie' van een emotionele betekenis op de beelden die in creatieve therapie tot stand zijn gekomen is vergelijkbaar, aldus de auteur, met de rituele overdracht van 'zonden' die in een gemeenschap hebben plaatsgevonden op een 'uitverkoren' dier, de zondebok. Zoals bekend is uit de antropologische literatuur zou er door deze rituele slachting een magisch-religieuze transformatie van het kwaad plaatsvinden. Nadat de zondebok de zonde van de gemeenschap 'letterlijk' op zich heeft genomen, kan de gemeenschap zich van het kwaad bevrijden door het offeren van het dier. In therapie worden beelden gemaakt die 'staan voor' een emotionele gebeurtenis uit het leven van de cliënt. De emotionele lading die de cliënt onder invloed van het creatief therapeutische proces op de beelden overbrengt kan een vergelijkbare 'symbolische betekenis' verkrijgen. Dat wil zeggen dat de beelden 'letterlijk' staan voor de ervaren pijn of frustratie, voor het leed of het trauma waarvoor de cliënt hulp heeft gezocht. De 'magische overdracht' is aldus te begrijpen als een 'empowerment' van het beeldende object door middel van een emotionele lading. De in therapie tot stand gekomen beelden 'representeren' volgens de auteur niet alleen een 'emotionele betekenis' maar zijn 'letterlijk' dragers van emotionele kracht geworden en verkrijgen aldus de betekenis van zondebok, fetisj of talisman:

Louise, a young woman in her mid-twenties, (...) had a dream which was so real that she awoke with a clear and vivid image of a corpse in the room with her. The next day she was haunted by this image and in an attempt to come to terms with it, (...) she made a picture of it. She told me about the dream and the picture, but she did not initially show me the picture. Her fear of the image was so great that she was convinced that it would affect me similarly (....) This

36. Schaverien: The scapegoat and the talisman: transference in art therapy in: Dalley (e.a.): Images of Art Therapy 74-109. 
image was no mere description of her dream. The image itself was experienced as powerful and fearsome. ${ }^{37}$

Vanzelfsprekend geldt een dergelijke uitzonderlijke 'magische' betekenis niet voor elk beeld dat in creatieve therapie is gemaakt. Om in dit opzicht beelden van elkaar te onderscheiden introduceert Schaverien, de geciteerde auteur, de term 'diagrammatisch' naast 'magisch' om beelden aan te duiden die geen emotionele lading dragen maar toch op bepaalde wijze 'overdragen'. In tegenstelling tot beelden met een 'talisman'-kwaliteit kunnen diagrammatische beelden emoties van de cliënt slechts 'representeren'. Een voorbeeld van een diagrammatische 'beeldwaarde' uit een andere context is het gebruik van de symbolen (i) en (a) in elektronische communicatie. Hiermee wordt een representatie van emoties van vreugde en verdriet gegeven, zonder dat in de symbolen een voelbare emotionele lading is geprojecteerd. Terwijl 'talisman'-beelden emoties aldus belichamen kunnen 'diagrammatische' beelden een emotionele betekenis weerspiegelen. Het verschil is vergelijkbaar met de informatieve mededeling 'ik voel me goed' of 'ik voel me rot' tegenover een emotionele uitbarsting van lachen of huilen. In het kader van therapie verkrijgen beelden aldus een 'emotionele meerwaarde' wanneer patiënten hun emoties overdragen op de verschijningswijze van beelden. In dat geval stellen deze beelden emoties present. Schaverien introduceert hiervoor de term 'belichaamd beeld'.

In het verlengde hiervan maakt zij nog een ander relevant onderscheid. De creatief therapeutische overdracht van een emotionele lading op een beeld verleent aan het beeld tevens een 'narratieve meerwaarde', waarvoor Schaverien de dramatherapeutische termen enactment versus acting out gebruikt. 'Enactment' wil zeggen dat er een 'rituele' (constructieve) voltrekking van de geprojecteerde emotionele betekenis van het beeld tot stand komt, terwijl 'acting out' de ongerichte (destructieve) expressie van deze emotionele lading beschrijft. De 'narratieve lading' hangt samen met het gegeven dat de therapeutische en beeldende overdrachtsprocessen in een handelingscontext plaatsvinden. De cliënt heeft de beelden gecreëerd in interactie met de therapeut, in dialoog met het eigen verleden en met het aangereikte beeldende materiaal. Zoals het overdragen van 'de zonde' op een uitgekozen dier overeenkomstig het 'zondebokprincipe' door een rituele slachting van het dier wordt gevolgd, zo kan de magische overdracht van emoties op een beeld in creatieve therapie ook een ritueel vervolg krijgen. Op analoge wijze kunnen, ter afronding van de therapie, bepaalde beelden met een bijzondere betekenis voor de cliënt, ritueel worden vernietigd, bijvoorbeeld verscheurd of verbrand. Maar ook in een minder uitgesproken vorm dragen beelden een 'rituele' of 'scriptwaarde' in zich. De beelden 'vertellen' het levensverhaal van de cliënt op 'dramatische wijze': door bepaalde aspecten ervan te

37. The scapegoat and the talisman: transference in art therapy 91.

38. Zie ook Gadamers notie van 'present stellen' en Goodman: Languages of Art. An approach to a theory of symbols. 
benadrukken, andere juist weg te laten of ze eruit te lichten, door ze uit hun oorspronkelijke verband te halen en ze nu weer anders te belichten. Het creëren van een 'beeld-narratief' is een complexe 'retorische strategie' van het weglaten, vervormen, relativeren en benadrukken van betekeniselementen. Door de creatief therapeutische doelstelling wordt er aan de retoriek nog een belangrijk biografisch element toegevoegd, zodat de betekeniselementen opnieuw in 'het levensscript' kunnen worden ingevoegd aan de hand van 'de rode draad' van het verhaal van de cliënt. Deze narratieve 'script' of 'interactieve' waarde (enactment) van creatief therapeutische beelden vertegenwoordigt ten opzichte van de tegenhanger van 'het afreageren' (acting out) in deze antropologische zin een potentieel genezende werking. Dezelfde handeling, bijvoorbeeld het verscheuren van werkstukken in therapie, kan aldus een tegengestelde creatief-therapeutische 'handelingswaarde' hebben. Al naar gelang de context waarin de cliënt deze handeling voltrekt is het verscheuren een symbolisch ritueel of een uitbarsting van agressie.

De 'emotionele' en 'interactieve' waarden van creatief-therapeutische beelden geven aan wat 'authentieke expressie' betekent in een antropologische, existentiële zin. Dat creatieve therapie een handelingscontext voor een magische praktijk van verbeelding en ritualisering genereert, berust als het ware op een 'oorspronkelijke wezenskern' van de mens. De genezende werking van creatief therapeutische processen bestaat aldus uit een integratie van de symboliserende en de ritualiserende kracht van beelden. Door middel van dubbelzinnige metaforische en therapeutische overdrachtsprocessen kan er in createve therapie een 'diepere' symbolisch-rituele ordening worden ontsloten, op grond waarvan een 'magische transformatie' van de werkelijkheid plaatsvindt.

\subsection{Een instrumentele optiek op ontwikkeling}

In de vorige paragraaf is beschreven hoe creatieve therapie in een antroplogisch geduide 'metaforische zijnsmodus' van symbolisch-rituele wetmatigheden verankerd wordt. De daarmee voltrokken 'epistemologisch-ontologische beweging' verraadt een romantische interpretatie van ontwikkelings-processen die kenmerkend is voor de pioniersfase van creatieve therapie. Dit romantische perspectief op ontwikkeling is niet alleen op een antropologische manier maar ook op filosofische en diepte-psychologische wijze gearticuleerd. Ook is geschetst hoe er in de loop van de tijd een accentverschuiving naar een instrumentele oriëntatie van creatieve therapie is ontstaan. In de vakliteratuur wordt in plaats van een antropologische betekenis steeds meer de functionele waarde van creatief therapeutische technieken benadrukt. Daarbij is aangegeven hoe deze verandering in optiek samenhangt met de sterker wordende verzakelijking van de gezondheidszorg. Creatief therapeuten zoeken derhalve aansluiting bij dominante psychotherapeutische referentiekaders om als jonge, 'alternatieve' disicpline serieus genomen te worden. Tegen deze maatschappelijke achtergrond krijgen de verschillende benaderingen van creatieve therapie een gesitueerde historische betekenis. In 
de creatief-therapeutische literatuur kunnen ze echter niet altijd zo scherp van elkaar worden onderscheiden. Wanneer er een romantische oriëntatie overheerst zal er aan de 'primitievere werkelijkheidsbeleving' en het 'metaforische denken' van cliënten een humaniserende waarde worden toegekend en niet slechts een functionele betekenis voor de genezing. Creatief-therapeutische interpretaties van de rol van de verbeelding kunnen aldus variëren van het primair stellen van een symbolisch-rituele omgang met de werkelijkheid als zodanig tot een instrumentele (onder)waardering ervan. Een humanistische visie geeft een positievere duiding van de rol van de verbeelding in vergelijking met een freudiaanse interpretatie als 'defensief mechanisme' of als 'sublimatie' van overlevingsinstinkten (libido). Zowel vanuit een romantische als vanuit een instrumentele oriëntatie wordt de verwoording van creatief thera-peutische processen als secundair ervaren, niet als waarde in zichzelf. De taal wordt als een (rationaliserend) instrument beschouwd waarmee men zich kan verstaan met collega-therapeuten, psychologen, verpleegkundigen en psychiaters. In het verlengde van de bestaande professionele hiërarchie tussen de verschillende disciplines in de (geestelijke) gezondheidszorg verkrijgen dominante psycho-therapeutische referentiekaders bij gevolg een hogere status dan het zich moeizaam ontwikkelende 'beeldende' referentiekader. Deze tendens wordt natuurlijk versterkt wanneer creatief therapeuten de bestaande hiërarchische ordening tussen de professies en de daaruit voortvloeiende onderwaardering van creatieve therapie overnemen. In de vakliteratuur is deze ambiguiteit bijvoorbeeld te herkennen als een spanningsverhouding tussen een humanistische orientatie op 'authentieke betekenisgeving' en een instrumentele gerichtheid op meetbare doelstellingen, protocollen, onderzoek en evalutaties. Bij gevolg is het mogelijk dat psycho-analytische termen als 'regressie', 'overdracht', 'orale fase', 'oedipus complex', 'katharsis', 'ego-versterking', 'symptoomformatie' samen met termen uit latere onwikkelingen van de psycho-analyse, de gedragspsychologie en 'humanistische stromingen' worden gebruikt, zoals 'bewustzijnsgroei', 'individuatieproces', 'gezonde delen van de psyche', 'agressieregulatie', 'het uiten en benoemen van gevoelens', 'het verminderen van fobische klachten', 'het leren omgaan met stress', enzovoort, eventueel gecombineerd met antropologische termen zoals 'magische verbeelding', 'talismanfunctie', 'rituele handeling', 'symbolisering' en poëtisch beeldende beschrijvingen van het therapeutische proces.

Hieronder zal deze pluriformiteit en ambiguitteit in de verwoording van creatieve therapie in verband worden gebracht met de accentverschuiving van een romantische naar een instrumentele optiek op ontwikkelingsprocessen. Aan de hand van citaten wordt dit geilllustreerd. Eerst een citaat afkomstig uit een antropologische benadering van creatieve therapie:

There are ritualized forms of giving which have more archaic significance. There is, for example, the offering of the first fruit of the harvest, as thanksgiving, and in order to ensure the abundance of future harvests. This gift has magical significance. There is an investment in performing the act of giving 
which is propitiatory. The gift is an appeasement of the powerful spirits or god. Embodied within this positive act is an acknowledgement of the dangerous implications of not giving. (..) The pictures made by Alex demonstrated both these forms of giving. (...)His initial method of disposal of his empowered images was as gifts. This was a way of pleasing others. (...) If'a part can stand for the whole' (...) Alex could be seen to have been giving parts of himself away. My early intervention asking him to keep his pictures together for the duration of his treatment, was based on a feeling that Alex was dispersing his power. ${ }^{38}$

Dit citaat is van een 'antropoloog' die 'participerend' een 'primitieve gemeenschap' observeert, met dit verschil dat de therapeut op basis van de observaties en participaties ook intervenieert met het oog op de therapie-doelstelling. De creatief therapeute heeft enerzijds empathisch gevoel en begrip voor het 'primitieve' handelen van de besproken patiënt Alex, maar anderzijds houdt zij afstand om waar gewenst het gedrag van de patiënt aan de orde te stellen en bij te sturen. Dit element van 'distantie' in de professionele attitude creëert ruimte voor een vorm van instrumentele rationaliteit. In dit voorbeeld past de instrumentele gerichtheid binnen de overkoepelende romantische oriëntatie op een 'primitieve wijze van betekenisgeving'. De therapeutische interventie is er derhalve niet op gericht om de 'primitieve ervaringsmodus' op een 'hoger' ontwikkelingsplan te brengen. Dit blijkt uit het volgende citaat waarmee zij de casus afsluit:

Alex's pictures were talismans, in that they were embodied images of his inner world. He was engaged in them from the beginning, as if he knew intuitively what he had to do. It was in the process of disposal that significance of the talisman changed. From an offering to appease and please others, they became containers of his own power, so that when he left hospital he took them with him and was able to value them.

Volgens de geciteerde therapeute schuilt in de symbolisch-rituele transformatie van het beeldende werk de genezende kracht van creatieve therapie. De verandering in betekenis van het beeldende werk voor Alex van 'zoenoffer' naar 'krachtcontainer' is, volgens de auteur, de dragende grond voor zijn genezing geweest.

Een dergelijke antropologische interpretatie van creatieve therapie staat op gespannen voet met een positivistisch-wetenschappelijke fundering voor 'dezelfde' creatief-therapeutische processen, die dan in empirisch meetbare en gedragspsychologische termen worden gearticuleerd. Vanuit een instrumentele benadering interpreteert men 'regressie naar een primitievere ervaringswijze' als een noodzakelijke 'terugval', een 'tussenstation' in het therapeutische veranderingstraject naar een 'hoger ontwikkelingsniveau'. Ter illustratie het volgende citaat uit een andere casus. Het is afkomstig uit de tijd dat creatieve therapie ontstond als experimenteel hulpmiddel binnen een psychiatrische setting, zo omstreeks het

38. The scapegoat and the talisman: transference in art therapy 105. 
midden van deze eeuw. Hier gaat het om een psycho-analytische behandeling van de als 'schizofreen' gediagnostiseerde patiënte Renee. De symbolisch ervaren 'omgeving' en haar dubbelzinnige tekeningen vormen het aangrijpingspunt voor het therapeutische veranderingsproces:

Ik moest met Renee tot het laatste stadium teruggaan, de regressie tot in het autisme en haar op die manier symbolisch toestaan in de moederrschoot te vluchten, wanneer ze het niet meer aankon. (...) Bij de medicijnen kwamen compressen en hete kruidenthee als symbool voor de vlucht in de moeder. Maar er bleef nog een moeilijkheid voor de psychische therapie: door de warme dranken werden Renee's aanvallen van misselijkheid erger en de dokter schreef ijs voor. Maar ijs is kou, het tegendeel van het symbool van de moederlijke warmte. (..) I $k$ wees Renee erop dat het warme slecht voor haar was en het koude waar ze zo bang voor was, juist gunstig. Zoals ook de eieren, voor haar symbool van het voedsel van de moeder, ongezond konden zijn, want het bekwam haar slecht als ze die at. Zo begon ze een magische causaliteit te vervangen door een werkelijke causaliteit. ${ }^{39}$

In dit citaat heet het gebruik van beeldende technieken en middelen geen 'creatieve therapie' maar 'symbolische realisatie'. De in therapie tot stand gekomen tekeningen en ervaringen interpreteert de psychiater vanuit een psychoanalytisch veranderingsmodel. Hun betekenis wordt aldus in termen van de ontwikkeling van een autistische, orale en oedipale fase naar een volwassen stadium geformuleerd. Achter het psycho-analytische ontwikkelingsperspectief gaat het vooruitgangsdenken schuil. Vanuit dat perspectief wordt de symbolischmagische werkelijkheid van de patiënte als een symptoom van een 'primitief' stadium in de ontwikkeling opgevat. De werkelijkheid zou 'in werkelijkheid' immers niet 'symbolisch-magisch' geordend zijn, maar 'rationeel-causaal', zo kunnen we uit de laatste zin van het citaat concluderen.

In het volgende citaat schrijft een creatief therapeute (speltherapeute) over de rol van rituelen en beelden voor rouwverwerking bij kinderen. $\mathrm{Zij}$ baseert haar beschouwing vooral op theoretische noties van Winnicott en Klein:

What play is doing is to be a medium both culturally and psychologically for the child. 'It makes the bridge between the child's consciousness and his emotional experience, and so fulfills the roles that conversation, introspection, philosophy and religion fill for the adult' (...) Winnicott sees the role of the creative impulse being a prerequisite for human development. This starts in a small way, through the use of objects between the mother and child. As we develop into adults, the ability to use objects to communicate with the world, to make space and belongings personal, becomes the basic mechanism by which

39. Sechehaye: Terug naar het mulpunt. Symbolische realisatie als geneeswijze voor de schizofreen 62-63. 
we attempt to maintain degrees of health over ill-health on personal environmental and cultural levels. (...) This potential space is an illusionary area between the inner world of the baby and his actual reality. ${ }^{40}$

De verbeelding, creatieve activiteiten, spel en rituelen worden beschouwd als een 'transitionele ruimte'. Deze 'tussenruimte' is uitermate belangrijk als 'overgangsfase' in de ontwikkeling, omdat ze een brug slaat tussen de binnenwereld en de eisen van de realiteit in de volwassenwording van het kind. Verbeelding en beelden hebben in de eerste plaats in de vorm van magisch denken en van sprookjes een kinderlijke hoedanigheid. Maar in de tweede plaats kunnen ze ook een volwassen stadium bereiken, bijvoorbeeld in culturele uitingen zoals in kunst, filosofie en religie. Opvallend in de laatste omschrijving van creatieve therapie is de ambiguë vermenging van een romantische en een instrumentele opvatting over de rol van verbeelding, symbolen, rituelen en magie. Vanuit een instrumentele optiek vertegenwoordigen symbolisering en ritualisering van de werkelijkheid een reële want feitelijk in een bepaald ontwikkelingsstadium voorkomende ken- en zijnswijze. Echter wordt de 'symbolisch-magische ervaring' niet direct met de realiteit verbonden. Deze ervaringsmodus die in creatieve therapie gereactiveerd wordt, zou naar een wereld van verbeelding tussen zinsbegoocheling en werkelijk-heid verwijzen.

In het algemeen zijn creatief-therapeutische casusbeschrijvingen niet exclusief op een romantische of een instrumentele ontwikkelingsmetafoor gebaseerd, maar is er een gecombineerd perspectief op ontwikkelingsprocessen 'eclectisch' tot stand gekomen. Wanneer creatieve therapie vanuit humanistisch perspectief wordt beschreven zal de realiteitswaarde van de 'symbolisch-magische' ervaringsmodus van cliënten minder categorisch worden ontkend dan in het citaat over de patiënte Renee. Niettemin overheerst er in psycho-therapeutische en pragmatische benaderingen van creatieve therapie een instrumentele oriëntatie. Deze blijkt onder meer uit de toegenomen belangstelling om beeldend-therapeutische processen wetenschappelijk te onderzoeken en te toetsen. In extremo mondt een instrumentele wetenschappelijke optiek uit in een identificering van 'de werkelijkheid' met wat empirisch-rationeel meetbaar is. Dit kan bijvoorbeeld resulteren in het geloof in een 'werkelijke causaliteit' tegenover een illusoire 'magische causaliteit' of in het uitgangspunt dat de betekenis van creatieve therapie samenvalt met het gemeten effect in termen van de behaalde 'patienten-load'.

\subsection{Naar een hermeneutische ontwikkelingsmetafoor}

Volgens de kunstgeoriënteerde benadering wordt beeldende expressie niet 'romantisch' als een 'terugkeer' naar een 'authentieke zijnswijze' opgevat en evenmin als 'primitieve uiting' in het licht van het vooruitgangsdenken. Deze derde benadering

40. Dalley: Images of Art Therapy 68-69. 
gaat niet uit van een traditioneel ontwikkelingsperspectief dat op een ruimtelijke tijdsmetafoor is gebaseerd, zoals de ontwikkelingstrap met traptreden van 'laag' naar 'hoog', resp. van 'primitief naar geciviliseerd'. De verhouding van de verbeelding en metaforen ten opzichte van de verwoording en (wetenschappelijke) concepten lijkt gedemocratiseerd. Welke andere ontwikkelingsmetafoor staat aan de basis van dit kunstgecentreerde veranderingsmodel? Doordat het proces van betekenisgeving via het creatieve medium aan de hand van narratieve en dialogische metaforen, zoals spel en kunst, wordt geinterpreteerd, lijkt zich in deze derde benadering een hermeneutisch perspectief ${ }^{41}$ op ontwikkelingsprocessen af te tekenen. De 'transgressieve' dynamiek in betekenisgeving volgens dit derde perspectief verschilt radicaal van de instrumentalisering van 'primitieve expressie' èn van het 'romantiseren' van de verborgen 'authentieke kunstenaar' in iedere mens. In plaats daarvan biedt creatieve therapie een metaforisch ontsloten 'speelruimte', een 'plaats' waarin men kan experimenteren om het leven op 'eigen' wijze vorm te geven. De 'oorspronkelijke' eigen ervaringswijze verschijnt in deze derde optiek als een gelijkwaardige zijnswijze ten opzichte van een wetenschappelijke, een religieuze of een alledaagse zijnsbenadering. Als zodanig vertegenwoordigt creatieve therapie een interactiekader waarin men als het ware een eigen definitie beeldend ontwerpt van een voor de genezing bevorderlijke 'authentieke' werkelijkheidservaring.

De kinderlijke beleving kan vanuit dit perspectief als een 'metaforisering' of een 'ritualisering' van 'de' werkelijkheid worden getypeerd zonder dat daarmee geïmpliceerd wordt dat ze 'primitiever' is dan de volwassen werkelijkheidsbeleving. Ze verschillen evenwel wezenlijk van elkaar en in zekere zin komt de volwassen ervaringswijze uit de kinderlijke voort. Niettemin wordt de kinderlijke werkelijkheidservaring als een zelfstandige en in zichzelf waardevolle zijnsmodus opgevat. Het volgende citaat illustreert hoe een creatief therapeute een adequate taal zoekt om de (andere) zelf- en wereldervaring van de baby, de peuter, enz. te articuleren.

Baby's zijn druk bezig, daardoor vormen zij zelf actief het Gewaar-zijn van een Ontluikend zelf. (..) Ze doen dat door uitlokken, volhouden, ophouden en vermijden van Ontmoeting. (..) Het Gewaar-zijn van een Ontluikend-zelf is een bron vol mogelijkheden tot het scheppen van een wereld, is het uiteindelijke reservoir waaruit ze kunnen putten voor alle scheppende activiteiten. De kreatieve ervaring zelf. Alle kreatieve activiteit en daarmee al het vormgeven en leren, begint in het gebied van ontluikende verbanden, begint in het-gebiedvan-het-aan-het-ontstaan-zijn. Alleen dit gebied is bezig met het bezig-zijnmet-het-verkrijgen-van-ordening, het is het hart van scheppen en leren. ${ }^{42}$

41. Widdershoven: Ethiek in de kliniek Hedendaagse benaderingen in de gezondheidszorg 79 e.v. Psychotherapie als praktische wetenschap Tijdschrift voor Psvchotherapie (26) 6, 395-404.

42. Rutten-Saris: Basisboek Lichaamstaal 47. 
De kinderlijke beleving van de werkelijkheid verschilt van de volwassen ervaring vooral wat betreft het aanbrengen van scheidingen tussen 'ik en jij', 'ik en wereld', 'geest en lichaam', enzovoort. De geciteerde creatief therapeute suggereert niet dat de kinderlijke werkelijkheidsbeleving een 'exclusieve' zijnsmodus vertegenwoordigt die ons dichterbij het werkelijke 'zijn' brengt. Ze kan worden gekarakteriseerd als een mogelijke werkelijkheidservaring, met een kenmerkende vloeiende en dynamische hoedanigheid, die in beelden, verhalen en 'metaforisch denken' tot expressie komt. In die zin is ze als 'metaforisch' en 'narratief' te typeren en legt ze de basis voor vergelijkbare ervaringswijzen, bijvoorbeeld een kunstervaring of een 'creatief' (therapeutisch) proces.

Een andere creatief therapeut ${ }^{43}$ laat vanuit $^{44}$ zijn eigen artistieke creaties een parallel verlopend proces van metaforische verwoording en reflectie ontstaan. Organisch en dialogisch ten opzichte van het beeldende proces van 'zichtbaar maken' vindt er een analoog proces van 'tot inzicht komen' plaats:

Gericht kerf ik. Vanuit de beweging met materiaal, kleur en de vormen die beklijven, ben ik op zoek. Een handvol lijnolie wrijf ik door de ecoline; gebrande sienna druipt tussen mijn vingers. Ik stop in het grensgebied van vorm en vormeloosheid. En kijk. Dicht op de huid zie ik het begin van stolling en ben verwonderd over de drijfveer van beweging. Ik blaas hoopjes goudpoeder in het natte oppervlak. (.)

IN SPELONKEN EN ZOMPIGE LAGEN VAN MIJN DIEP-RODE ZIJN, / VER VOORBIJ WAAR HUID HET OOG FASCINEERT; / DAAR WORDEN DE KEUZES BEKLONKEN / IN AMORFE BEWEGING EN PEILLOZE ROOD / VALLEN ZIN EN ZIJN TEZAMEN . I LIEF EN ZEER WENTELEN DAAR VERTEREND / RITMISCH IN EEN STRIJD OP LEVEN OF STILSTAAN. ${ }^{45}$

De auteur beschrijft met kleingedrukte letters het artistieke proces waaruit beelden voortkomen. Deze tekst is gedrukt op kleurcopieën van zijn beeldend werk en vormt als het ware 'een verwoording van de verbeelding'. Het beeldende proces is aldus 'letterlijk' verbonden met zijn reflectie hierover (in kleingedrukte letters) en met een poëtische interpretatie (het grootgedrukte gedicht). Deze laatste verwoording vindt plaats vanuit de verbeelding of in samenspraak met de beelden. De poëtische woorden vertolken zijn ervaringswerkelijkheid tijdens het artistieke proces. Reflectie en verwoording zijn aldus geworteld in 'diepere' lagen van een existentiële werkelijkheid. Het 'innerlijke beeldende' proces beschijft hij evocatief als een 'rood-zijn waarin zich 'spelonken' en 'zompige lagen' bevinden en waarin 'zin' en 'zijn' samenvallen." Uit deze beschrijving blijkt dat het existentiële niveau van leven en dood tegelijkertijd emotioneel-lichamelijk en reflectief-zingevend

43. Marissing: Huid en Ziel. Studies in zichtbaar maken.

44. Hiervoor gebruikt hij de term 'talking with', die van 'talking aboutr' en van 'talking to' onderscheiden wordt: dialogische kwalificaties ontleend aan Shaun McNiff.

45. Huid en Ziel. Studies in zichtbaar maken 5-7, 21. 
ervaren wordt. Het rood-zijn bijvoorbeeld is tegelijkertijd 'letterlijk' zichtbaar op het doek, op de huid, in het bloed en 'metaforisch' ervaarbaar in de diepten der menselijke ziel. In tegenstelling tot een romantische duiding presen-teert de auteur de beelden niet als 'authentieker' dan de verwoording van het beeldende proces van betekenisgeving. Terwijl een instrumentele interpretatie een psychologische functie van 'de metaforische beelden' zou benadrukken, wordt er in dit citaat een interpretatie gegeven, die in dialoog met van het artistieke proces zelf is ontstaan. Aan de beschreven kunstervaring geeft de auteur geen waardering in termen van een ontwikkelingsperspectief, bijvoorbeeld als ware zij een 'primitie-vere' werkelijkheidsbeleving. Hij maakt het proces van betekenisgeving dat aan de beelden ten grondslag ligt zichtbaar en verstaanbaar als een artistiek en existentieel verhaal, als een meerduidig en ambiguë proces.

\subsection{Grondslaggevende dialectiek tussen verbeelding en verwoording}

Op grond van een analyse van de vakliteratuur zijn er drie benaderingen van creatieve therapie getypeerd aan de hand van het door de therapeut ingenomen perspectief op ontwikkelingsprocessen. Op basis hiervan verchijnt het beeldendtherapeutische veranderingstraject als een regressieve, progressieve of transgressieve beweging in de ontwikkeling, overeenkomstig de (impliciete) romantische, instrumentele of hermeneutische 'ontwikkelingsmetafoor'. Deze paragraaf voert de interpretatie van de verschillende benaderingen van creatieve therapie tot een einde door de drie ontwikkelingsmetaforen in verband te brengen met een wisselwerking tussen een 'letterlijk' en een 'figuurlijk niveau' van betekenisgeving en een dialectiek tussen beeld en woord resp. tussen verbeelding en verwoording.

De voltrokken literatuuranalyse heeft zicht gegeven op drie verschillende wijzen waarop er een grondslag van creatief-therapeutische processen wordt voorondersteld. Dat wil zeggen dat er een 'fundamentele betekenisgevende ordening' in de 'metaforische dialectiek van verbeelding en verwoording' wordt gepostuleerd, die zelf aan deze 'metaforiek' zou ontsnappen. In de antropologische benadering vertegenwoordigen processen van symbolisering en ritualisering dit fundament. De instrumentele invalshoek stelt een psychologisch mechanisme als funderend principe primair. De psychologie definieert derhalve het interpretatiekader om de beeldend-therapeutische processen te vertalen en om aan te geven wat de beelden therapeutisch gezien betekenen. Dit interpretatiekader is geminimaliseerd tot een 'functionalistisch' perspectief in de pragmatische benadering: 'dat wat werkt' vormt de dragende grond voor (de interpretatie) van creatief-therapeutische processen. Volgens de kunstgeoriënteerde benadering vertegen-woordigt de 'zichtbare metaforiek in het medium' het organisatieprincipe voor het therapeutische veranderingsproces. In onderscheid met de andere benaderingen wordt hier geen fundamentele ordening verondersteld, die buiten deze metaforiek is gesitueerd. De 
interne dialectiek tussen verbeelding en verwoording fungeert zelf als metaforische basis om de beeldende processen en producten te interpreteren.

Zowel in de romantische als in de instrumentele ontwikkelingsmetafoor is de dialectische wisselwerking tussen verbeelding en verwoording en tussen beelddenken en denkbeelden tot een 'absolute grond' gereduceerd. Op grond van een verabsolutering van het 'metaforische' onderscheid tussen de 'letterlijke' ordening van zichtbare processen en de 'overdrachtelijke' van innerlijke processen kan er een sprong in de ontwikkeling, voorgesteld als een 'daadwerkelijk' afgelegd tijdspad naar een 'primitief' of een 'volwassen' stadium, worden bewerkstelligd. Beide metaforen vooronderstellen dus een vorm van vooruitgangsdenken resp. een 'romantisch verlangen naar oorspronkelijkheid'. De romantische en de rationalistische interpretatie van onze existentiële historiciteit kunnen samengenomen worden in een vorm van dialectisch denken over ontwikkeling, waarbij in de eerste fasen reeds de zaadjes van latere stadia te herkennen zijn en andersom, dat de oorspronkelijke gestalten in latere vormen worden meegenomen. Ook in antropologische benaderingen van creatieve therapie wordt er een 'letterlijke' culturele betekenis van symbolische rituelen voor 'primitieve' volken, zoals bijvoorbeeld het zondebokverschijnsel, 'overgedragen' op een psycho-therapeutisch interpretatieniveau. Deze duidingswijze resulteert in een 'figuurlijk' verstaan van de creatief therapeutische werkstukken als 'wat deze beelden met een zondebokfunctie in het levensscript van de cliënt te zeggen hebben'. In tegenstelling tot romantische en instrumentele ontwikkelingsmetaforen relateert de kunstgeoriënteerde interpretatie de werkzame therapeutische dynamiek aan de zichtbare metaforiek in het medium. Dit derde perspectief op creatief therapeutische processen berust dus niet op een 'dialectische opheffing' van de plaatsvindende processen naar een 'hoger' of 'lager' zijns- en ontwikkelingsniveau. Het therapeutische 'veranderingsproces' genereert geen 'ontwikkeling' maar een betekenistransgressie 'in' de 'metaforische tijd-speelruimte' die door de medium-activiteit geopend wordt.

Met het oog op de onderzoeksvraagstelling zal ik aangeven hoe volgens deze derde kunstgeoriënteerde interpretatie van 'ontwikkelingsprocessen' creatieve therapie op een fundamenteel andere wijze wordt gefundeerd dan volgens beide andere benaderingen. Antropologische, psycho-therapeutische en pragmatische richtingen van creatieve therapie komen ondanks de besproken verschillen overeen wat betreft een instrumentele optiek op taal, die resulteert in een 'functionele' verwoording van creatief therapeutische processen. Hoe verhouden de creatieftherapeutische processen zich tot 'het zijn' volgens de kunstgeoriënteerde benadering? De verwoording van het proces hoeft, volgens deze derde optiek, niet op 'externe' wijze en 'secundair' plaats te vinden, maar kan analoog aan de gecreëerde beelden, geschieden vanuit een 'interne', 'dialogische' of 'organische' zijnsverhouding. Deze dialogisch-organische verhouding van verwoording en verbeelding tot 'het zijn' vormt de basis voor een ontwikkelingsdynamiek, die aan deze metaforiek inherent is en 'in' de interactie met de therapeut en het medium uitdrukkelijk wordt. Deze 'ontwikkelingsmetaforiek' heeft een parallel verloop in 
het innerlijk van de cliënt, in de interactie met de therapeut, in het beeldende medium en in de taal. De metaforiek in 'het innerlijk' van de cliënt is hetgeen zichtbaar wordt in de 'tijd-speelruimte' van het medium. Ze wordt aldus niet gefundeerd in een 'letterlijk' opgevatte ontwikkelingsmetafoor, als een 'tijdruimtelijk uitgestrekte dimensie', bijvoorbeeld een parallelle psychologische, historische en interculturele ontwikkelingsgang die de mensheid aflegt van 'primitief' naar 'geciviliseerd'. De ontwikkelingsdynamiek is in de mediumactiviteit verdicht tot 'dezelfde tijd en plaats'. De 'letterlijk' verschijnende beelden en beeldende processen zijn tevens de ontvouwing van een 'innerlijke ordening' van gevoels- en gewaarwordingsprocessen. De kunstinvalshoek biedt aldus een radicaal verschillende interpretatie van de grondslag van creatieve therapie.

$\mathrm{Nu}$ kan de literatuuranalyse op de onderzoeksvraag worden betrokken aan de hand van de geschetste verschillen in interpretatie van de grondslaggevende metaforiek en dialectiek. Zoals hierboven aangegeven impliceren de meeste modellen een 'verabsoluterende' opvatting ten aanzien van de wisselwerking tussen de 'zichtbare' en de 'onzichtbare' ordening van beeldende processen. Deze verabsolutering wordt uitdrukkelijk in de vorm van een 'letterlijk' opgevatte ontwikkelingsmetafoor, als een daadwerkelijk in de tijd plaatsvindende ontwikkelingsterug- of vooruitgang. Essentieel voor het verschil tussen de hermeneutische ontwikkelingsmetafoor en de twee andere funderende metaforen is dus een interne versus een externe verhouding van de 'zijnsgrond' tot de verwoording en verbeelding van creatief-therapeutische processen. Deze verhouding wordt vanuit de kunstgecentreerde invalshoek organisch en dialogisch gearticuleerd: de beelden ontvouwen zich in het gesprek van de cliënt met therapeut en beeldend medium. Processen van verbeelding en verwoording worden, conform deze drie interpretaties, in een typerende verhouding tot 'de werkelijkheid' gesteld. Een instrumentele interpretatie plaatst verbeelding en verwoording in een externe verhouding tot de realiteit. Hier tegenover staat de romantische interpretatie van creatieve therapie, volgens welke de taal zich weliswaar extern ten opzichte van de (ervaren) werkelijkheid bevindt, maar die de verbeelding bevoorrecht en in een symbiotische verhouding daartoe stelt. Het derde kunstgecentreerde perspectief kent zowel aan de verwoording als aan de verbeelding de mogelijkheid toe van een interne zijnsverhouding, wat zij door middel van organische en dialogische metaforen articuleert.

Vanuit deze laatste optiek verkrijgen noties als 'letterlijk' en 'figuurlijk', 'verwoording' en 'verbeelding' een relatieve betekenis tegen de achtergrond van de grondslaggevende metaforiek. Romantische en instrumentele perspectieven op creatieve therapie berusten derhalve op een verabsoluterende interpretatie van deze begrippen. Hierdoor wordt er aan het onderscheid tussen een 'letterlijke' en een 'overdrachtelijke' ordening van metaforische processen, aan processen van verwoording en verbeelding een 'gereificeerde' ${ }^{46}$ betekenis gegeven, als zou het gaan

46. 'Reificeren' staat voor het proces van verdinglijken, zie ook paragraaf 5.2 van het volgende hoofdstuk. 
om statische niveau's in de taal, in onze kenprocessen en in de werkelijkheid. De antropologische, psycho-therapeutische en pragmatische benaderingen van creatieve therapie berusten derhalve op een 'metafysische' interpretatie ${ }^{47}$ van de dialectiek tussen beelddenken en denkbeelden, tussen verbeelding en verwoording. De romantische en instrumentele ontwikkelingsmetaforen waarop deze benaderingen zijn gebaseerd, articuleren een absoluut opgevatte zijnsordening resp. betekenisgevende ordening, die zelf aan de funderende metaforiek en dialectiek zou ontsnappen. De 'letterlijke interpretatie' van een ontwikkelings-metafoor als een ontwikkeling vooruit of achteruit in de tijd gaat hand in hand met een 'metafysische interpretatie' van de grondslaggevende metaforische dynamiek. De derde kunstgeoriënteerde benadering lijkt op deze filosofische kritiek te anticiperen in de wijze waarop zij juist de inherente metaforiek als spil van therapeutische veranderingsprocessen onderkent en hiermee een hermeneutische grondslag aan creatieve therapie geeft.

\subsection{Samenvatting en conclusie}

In dit hoofdstuk is een analyse van creatief-therapeutische literatuur gegeven vanuit de invalshoek van de metafoor. Langs die weg zijn de impliciet of expliciet ingenomen creatief-therapeutische posities in de vakliteratuur getypeerd als de antropologische, de psycho-therapeutische annex pragmatische en de kunstgeoriënteerde benadering van creatieve therapie. Vervolgens zijn deze drie benaderingen geïnterpreteerd vanuit de vraag welke ontwikkelingsmetaforen er impliciet aan de verschillende therapeutische referentiekaders ten grondslag liggen. Het therapeutische veranderingsmodel dat in de antropologische benadering is voorondersteld is getypeerd als een vorm van 'romantische regressie': vanuit dit model wordt een dynamiek terugwaarts in de ontwikkeling gegenereerd naar een 'primitievere ervaringsmodus'. De psycho-therapeutische en pragmatische veranderingsmodellen zijn instrumenteel gericht op een progressieve ontwikkelingsdynamiek, voor- of opwaarts, waarbij de 'primitievere ervaringsmodus' als middel daartoe wordt gebruikt. Het kunstgecentreerde veranderingsmodel condenseert de ruimtelijke ontwikkelingsmetafoor tot een 'metaforische tijdspeelruimte' via de interactie met het medium.

De analyse van creatief-therapeutische literatuur is in verbinding gebracht met haar onstaansgeschiedenis. Aanvankelijk overheerste er een eenzijdige romantische interpretatie van creatieve therapie volgens welke de therapeutische processen gefundeerd zijn op een 'authentieke' wijze van betekenisgeving. Aan de hand van de antroplogische benadering is meer in detail onderzocht hoe de romantische oriëntatie op een 'oorspronkelijke' en 'authentieke' wijze van betekenisgeving als

47. Dat wil zeggen: een verabsoluterende opvatting van de dialectiek tussen het letterlijke en figuurlijke interpretatieniveau dat resulteert in een gereificeerd/ statisch beeld van de 'domeinen' waarop de woorden betrekking hebben. Zie voor verdere uitleg van deze term hoofdstuk 4 paragraaf 2.3 . 
fundament voor creatieve therapie haar beslag heeft gekregen. Vervolgens is met citaten aangegeven hoe de aanvankelijk overheersende humanistische waarden steeds meer worden vervangen door een instrumentele optiek. In de feitelijke ontwikkeling van creatieve therapie tot een zelfstandige discipline binnen de (geestelijke) gezondheidszorg is de romantische oriëntatie aldus aangevuld met een ander eenzijdig perspectief. Onder invloed van de verzakelijkte gezondheidszorg en vanuit een instrumentele verhouding tot processen van verwoording en verbeelding, worden dominante psycho-therapeutische referentiekaders op de voorgrond gesteld om de beeldende processen te interpreteren en de therapeutische interventies te rechtvaardigen.

Ten slotte zijn de verschillende benaderingen van creatieve therapie nog verder geanalyseerd in termen van een 'dialectiek tussen verbeelding en verwoording' en een metaforiek tussen een 'figuurlijk' en een 'letterlijk niveau' van betekenisgeving. De metaforiek tussen een 'letterlijke ordening' van zichtbare beeldende processen en een 'figuurlijke ordening' van onzichtbare, innerlijke processen wordt in de vakliteratuur veelal 'metafysisch' dat wil zeggen statisch en gereïficeerd beschreven, vanuit een 'letterlijk' opgevatte ontwikkelingsmetafoor als een trap of een ladder van 'primitief' naar 'geciviliseerd'. In vergelijking hiermee berust het kunstgecentreerde veranderingsmodel niet op een 'metafysische' interpretatie van ontwikkelingsprocessen, maar op de fundamenteel gestelde inherente metaforiek in het medium. De therapeutische verandering vind $t$ plaats in de 'letterlijk' plaatsvindende interactieprocessen tussen cliënt en therapeut en als wisselwerking tussen verbeelding en verwoording. De verhouding tussen woord en beeld, tussen een 'figuurlijke' en een 'letterlijke' zijnsordening, verschijnt vanuit de kunstinvalshoek als gelijkwaardig en niet-hiërarchisch. Het hiermee corresponderende hermeneutische veranderingsmodel lijkt daarom het meeste recht te doen aan de 'eigenheid' van de beeldend-therapeutische processen.

De antropologische, de psycho-therapeutische en pragmatische benaderingen gaan alle drie uit van een eenzijdige optiek op creatieve therapie. Uit de analyse volgt derhalve als conclusie dat deze eenzijdige oriëntaties tekort schieten om de inherente metaforiek in creatief-therapeutische processen adequaat te kunnen beschrijven. De derde kunstgeoriënteerde benadering geeft een gelijkwaardige plaats aan de ordening van het beeld en de verbeelding ten opzichte van de ordening van het woord en de verwoording. Dit genereert een adequater perspectief op metaforische communicatie- en veranderingsprocessen op basis van een gedemocratiseerde verhouding tussen verwoording en verbeelding in relatie tot 'het zijn'. Hiermee correspondeert een niet-metafysisch perspectief op 'ontwikkeling' als een in de actualiteit van het heden voortgaand veranderingsproces. Of deze kunstgecentreerde interpretatie van de grondslag van creatieve therapie filosofisch kan worden onderbouwd zonder een nieuwe metafysica te ontwerpen, $\mathrm{zal}$ in het vierde hoofdstuk worden uitgewerkt aan de hand van de hermeneutiek. 


\section{HOOFDSTUK 3:}

\section{Metaforen in het organisatie-discours}

\subsection{Inleiding}

In dit hoofdstuk wordt het organisatie-discours geanalyseerd vanuit de invalshoek van de metafoor als middel tot betekenisgeving. In onderscheid met de Nederlandstalige vakliteratuur over creatieve therapie kent het vakgebied van de bedrijfskunde ook een wetenschappelijke traditie naast het toegepaste genre met betrekking tot management-vraagstukken. Terwijl in het populaire genre van de managementliteratuur de belangstelling voor de metafoor als analyse- en interventiemiddel toeneemt, wordt er in wetenschappelijke kringen met scepsis op deze ontwikkeling gereageerd. Deze scepsis houdt verband met een epistemologische invalshoek van waaruit de rol van de metafoor methodologisch wordt afgemeten aan de hand van de wijze waarop concepten en modellen worden gebruikt om de organisatorische werkelijkheid te beschrijven. Hier tegenover staat dat er in de managementcontext weinig aandacht wordt besteed aan het method(olog)isch verantwoorde gebruik van metaforen, resp. dat dit gelijk wordt gesteld aan het behaalde succes. In dit onderzoek ga ik ervan uit dat beide invalshoeken te kort schieten om de 'meerwaarde' van de metafoor te kunnen onderbouwen. Het gevaar van een wetenschappelijke evaluatie van de metafoor in het kader van organisatie-vraagstukken is dat aan haar kracht en eigenheid te kort wordt gedaan. Hier tegenover staat dat het opportunistische metafoorgebruik in een context van toepassing ruim baan geeft voor ideologisch (machts)misbruik. Tegen deze achtergrond is de centrale vraag in dit hoofdstuk of er 'tussen' beide eenzijdige invalshoeken een 'derde benadering' mogelijk is die recht doet aan 'de toegevoegde' waarde van de metafoor als methodisch instrument voor organisatie-onderzoek en veranderingstrajecten. Om deze vraag te kunnen beantwoorden zal er eerst een overzicht worden gegeven van de wijze waarop metaforen en creatieve middelen in het wetenschappelijke organisatie-discours functioneren. Daarna laat ik een licht schijnen op de manier waarop deze middelen in het populaire managementgenre worden ingezet. De literatuuranalyse mondt uit in de formulering van een richtlijn om metaforen en creativiteit in de context van organisaties methodisch en ideologisch verantwoord te gebruiken.

De tweede paragraaf beschrijft de pluriformiteit met betrekking tot de rol van metaforen en concepten in het organisatie-discours. De rol van metaforen is een verschillende, al naar gelang de context een bedrijfskundige, een wetenschapsfilosofische of een toegepaste is met betrekking tot managementinterventies. In de derde paragraaf wordt bijzondere aandacht geschonken aan Morgans werk over 
metaforen in organisatieonderzoek. In het verlengde van een pragmatische wending in zijn werk, ga ik in op de populariteit van metaforen als communicatieen interventiemiddel voor managers en adviseurs. De vierde paragraaf geeft een kritische analyse van een specifieke sportmetafoor - de basketbal-organisatie - die staat voor organiseren in het postmoderne tijdperk. Daarna wordt, in de vijfde paragraaf, de vraag behandeld of metaforen minder opportunistisch kunnen worden toegepast vanuit een communicatieve benaderingswijze van organisatieprocessen. De basis hiervoor staat in de zesde paragraaf als een zich ontwikkelende 'rationaliteit van communicatie, emotionaliteit en verbeelding', welke geschetst wordt aan de hand van enkele richtinggevende ideeën en modellen, zoals het door Argyris en Schön ontworpen communicatiemodel, Habermas' idee van een 'machtsvrije dialoog' en de methode van 'het Socratische gesprek'. Deze ingrediënten worden samengevoegd tot de richtlijn van een dialogisch principe als grondslag voor 'een metaforische benadering' van organisatievraagstukken. Ten slotte volgen in de zevende paragraaf een samenvatting en conclusies.

\section{2 Drie genres in het organisatie-discours}

Het organisatie-discours kenmerkt zich ten minste door drie verschillende genres, overeenkomstig een filosofisch-wetenschappelijke, een bedrijfskundige en een management-perspectief op organisaties. Deze genres worden in de eerste subparagraaf gekarakteriseerd met betrekking tot de rol van metaforen in de opbouw van conceptuele kennis. In de tweede subparagraaf volgt een discussie tussen vooren tegenstanders van een wetenschappelijke rol van de metafoor.

\subsubsection{Metaforen, concepten en hybriden}

Het wetenschappelijke genre van het organisatie-discours is gericht op een academisch publiek en heeft zich op basis van fundamentele wetenschappen zoals de sociologie, de economie, de psychologie en de filosofie ontwikkeld. Dit genre kenmerkt zich door het verzamelen en wetenschappelijk toetsen van veelal in de praktijk geboren modellen en concepten over uiteenlopende organisatievraagstukken. Gezien haar recente entrée in de wetenschap ${ }^{1}$ treft men in de literatuur daarnaast ook wetenschapsfilosofische publicaties aan met vragen over het ideologische gehalte van de bedrijfskunde, met betrekking tot haar wetenschappelijke statuut en over de incommensurabiliteit van verschillende paradigmata ${ }^{2}$. Dat de bedrijfskundige kennis niet 'zuiver' wetenschappelijk is maar mede gestuurd wordt door bedrijfsbelangen wordt onomwonden gearticuleerd in de populaire management-literatuur. Dit genre is uitgesproken retorisch en pragmatisch van toon. Men treft er minder vaak methodologisch onderbouwde analyses

1. van Baalen: Management en hoger onderwijs:De geschiedenis van het academisch managementonderwijs in Nederland.

2. Zie: Essers: Naar een kritiek van de organisatorische rede. 
aan, veeleer gaat het om het succesvol verkopen van nieuwe managementconcepten, marketing-technieken, leiderschapsstijlen, analyse- en implementatie-instrumenten. In dit verband wordt het gebruik van stijlfiguren zoals de metafoor als een uiterst effectief middel gepropageerd. Daarentegen wordt haar theoretische rol in het wetenschappelijke genre geproblematiseerd en gemarginaliseerd. Dit is niet verwonderlijk, aangezien kennisoverdracht door beeldspraak niet berust op logische principes en empirische correspondentie, de twee grondpijlers van de wetenschap volgens een traditionele kennistheoretische opvatting. De metafoor werkt op grond van haar retorische kracht, waardoor ook onjuiste opvattingen overtuigend kunnen worden overgebracht. Bij gevolg wordt aan de metafoor in het kader van wetenschappelijk kennis veelal geen zelfstandige epistemologische functie toegekend. Niettemin is er vaak op gewezen dat organisatiekundige taal doorspekt is met versleten, vooral militaire metaforen ${ }^{3}$, zoals evident is in uitdrukkingen als:

"We moeten onze concurrenten verslaan".

"De nieuwe koers is om meer marktaandeel te veroveren".

"Het is goed om op ontwikkelingen in de markt te anticiperen en nieuwe strategieën uit te zetten".

Bovendien dringen er regelmatig nieuwe metaforen en neologismen in het organisatiediscours door, zoals 'adhocratie', of wordt de stijl van argumentatie 'metaforisch' van toon.

Het organisatie-discours is aldus zeer pluriform door de gerichtheid op een uiteenlopend publiek. Een notoir gebrek aan traditie en historisch bewustzijn geeft dit genre evenwel een uitermate tijdgebonden en modieus karakter. Dit hangt mogelijk mede samen met de veranderlijkheid en vluchtigheid die de wereld van organisaties eigen is. Bij gevolg lijken termen even snel te verdwijnen als dat er nieuwe worden gelanceerd. Ronduit 'stoffig' ten opzichte van het hedendaagse vlugge managementjargon komt bijvoorbeeld de volgende passage over uit een 'openbare les' op 10 oktober 1933 aan de Nederlandsche Handelshoogeschool te Rotterdam:

Toch meen ik, dat de zielkunde op menig punt handel en bedrijfsleven van voorlichting kan dienen. Welke wetenschap zou het beter toevertrouwd zijn om ons inzicht te geven in wat innerlijk omgaat bij producent en consument, bij bedrijfsleider, bankier, handelsman, en deze allen beweegt tot hun daden. ${ }^{4}$

Het 'achterhaalde' karakter van deze tekst betreft niet alleen woordkeuze en schrijfstijl, maar vooral ook het feit dat het betoog wordt opgehangen aan de klassieke mythe over Hermes en Psyche! Deze Griekse mythe presenteert de privaatdocent bij aanvang van zijn les om symbolisch op 'de innige betrekking' tussen handel en zielkunde te wijzen. In tegenstelling hiermee figureert de veel-

3. Weick: The Social Psychology of Organizing. Van Dongen e.a.: Een kwestie van verschil. Conflicthantering en onderhandeling in een configuratieve integratietheorie 59.

4. van der Spek: Hermes en Psyche 5. 
zijdige god Hermes in het huidige organisatie-discours veeleer in zijn hoedanigheid als 'beschermheilige van handelaren en dieven' en dreigt men zijn psychologische en literaire kwaliteiten als mythologische grondlegger van de hermeneutiek te vergeten. Karakteristiek voor het organisatie-discours is een overmatig aandeel van angelsaksische terminologie en het gebruik van veelbelovende concepten zoals 'de flexibele organisatie', 'virtueel netwerken', 'postmodern organiseren', en 'the learning organisation'. De 'zielkundige' aspecten van organisatieprocessen worden in het algemeen niet meer als fundamenteel onderkend en onderzocht. Flexibilisering en ad hoc inspringen op contingentie en chaos om continue te innoveren, zo luidt de nieuwe les voor organisaties in 'het postmoderne tijdperk. Ter illustratie een passage uit een inaugurele rede van een Hoogleraar Bedrijfskunde aan de Erasmus Universiteit Rotterdam, anno 1998:

Veranderende concurrentieomgevingen dwingen ondernemingen in vrijwel alle sectoren om hun strategie en organisatievorm kritisch onder de loep te houden. Er lijkt een groeiende consensus te bestaan tussen managers dat de weg naar toekomstig succes afwijkt van traditionele strategievoorschriften die top-down controle, formele planning en diepgaande industrieanalyse aanprijzen als de waarborg voor excellentie.

Of de steeds vernieuwde succesformules tot daadwerkelijke vernieuwing hebben geleid blijft te bezien, zeker gezien de vraag wat 'excelleren' precies inhoudt en hoe dat 'gemeten' zou moeten worden anders dan door dezelfde aangeprezen 'standaards van succes'. Wel staat vast dat de bedrijfskundige lessen over hoe te innoveren aan blijvende vernieuwing onderhevig zijn. Tegenwoordig wordt aan een 'pro-actieve doelstelling' zoals het creëren van 'excellente' ondernemingen de voorkeur gegeven boven 'klassiekere' oorlogzuchtige bedrijfsinstrumenten die gericht zijn op het verslaan van concurrenten.

Wanneer managementconcepten en succesformules uit de context van toegepassing in het wetenschappelijke discours worden geïntroduceerd ondergaan ze een gedaantewisseling. Uit de vluchtige ideeën en praktische instrumenten worden ogenschijnlijk 'letterlijke' beschrijvingen van organisatieprocessen, 'harde' managementconrepten en bedrijfskundige 'stappenplannen' gemaakt. Veelal blijkt het toch om 'metaforen' te gaan die, buiten de 'oorspronkelijke' context verplaatst en geabstraheerd, tot een organisatiecategorie worden uitgebouwd. Een voorbeeld is de metaforisch-conceptuele wijze waarop een aantal 'strategische stijlen' worden gecategoriseerd in een standaardboek over management. De derde categorie van 'defensieve strategieën' is onderverdeeld in een 'turnaround', een 'harvest', een 'divesture', een 'bankruptcy' en een 'liquidation'-strategy. Voor elk van deze wellicht in de praktijk geboren metaforische aanduidingen wordt een 'wetenschappelijke definitie' gegeven. Zoals:

5. Volberda: Blijvend Strategisch Vernieuwen: concurreren in de 21e eeuw 7-8. 
'Bankruptcy' is a retrenchment strategy in which an organization unable to meet its obligations seeks court protection to gain time and opportunity to attempt a turnaround. ${ }^{6}$

Dat een faillissement hier wordt voorgespiegeld als een (escape) strategie geeft een fraai voorbeeld van de organisatorische instrumentele rede die zelfs een uitzichtsloze 'status quo' ('an organization unable to meet its obligations') 'metaforisch' weet te keren in een ethisch twijfelachtige optie tot strategisch handelen, die niet minder paradoxaal klinkt als 'De koning is dood, leve de koning!' Een ander voorbeeld van een organisatiekundige categorie met een 'metaforische lading' is de term 'post-modern'. Dit woord, met een 'duistere filosofische oorsprong', is gebruikt om een periode in de architectuur en de kunstgeschiedenis aan te duiden en later voor een filosofische wijze van reflecteren over de verleden epoche van de moderniteit. Het is vervolgens toegepast in een bedrijfskundige context om een verandering in de wijze van denken over organisaties en organiseren aan te geven. Hierbij is echter een omgekeerde beweging te constateren als die van de 'quasiverwetenschappelijking' van metaforische management-concepten uit het vorige voorbeeld. Veeleer lijkt er sprake te zijn van een 'metaforisering' van een wetenschappelijke term met een duidelijke verwijzing naar een kunsthistorische periode. Haar beschrijvende betekenis is 'overgedragen' naar een 'innerlijke ordening' van 'het' Westerse denken en beduidt een omstreden 'keerpunt' in de filosofie. In de praktische context van management krijgt het woord een nog verder strekkende metaforisch-magische betekenis. Met het postmoderne organiseren wordt gedoeld op een futuristisch-fictieve organisatievorm, waarbij middelen voor flexibilisering en virtualisering worden aanbevolen tot aan de grens van het 'fysieke bestaan' van 'de organisatie',- bijvoorbeeld 'virtual banking', strategisch 'netwerken' als organisatievorm, de 'chaos' als organisatieprincipe of als een 'oscilerende traject' tussen andere organisatievormen ${ }^{8}$. In het kielzog van dergelijke denkbeelden is er een metaforische managementles voor het huidige informatietijdperk gelanceerd in de vorm van een 'basketbalstrategie', wat in de vierde paragraaf zal worden besproken.

Nog andere voorbeelden van hybride termen die zich 'tussen' concepten en metaforen in bevinden, zijn te vinden in het standaardboek over organisatiekunde van Mintzberg'. Daarin wordt 'de adhocratie' als vijfde organisatiestructuur na 'de machinebureaucratie', 'de professionele bureaucratie' en 'de divisistructuur' behandeld. In zekere zin zijn alle vijf aanduidingen metaforisch: ze zijn ooit uit een 'oorspronkelijke' context naar deze nieuwe context verplaatst en verdicht tot organisatiecategorie. Echter hebben ze hun metaforische karakter in de loop van de tijd verloren en verborgen achter een conceptueel uiterlijk. Ze zijn tot een 'werkelijk bestaand ding' gereïficeerd en als 'theoretisch concept' door de wetenschap-

6. Bovee e.a.: Management 249.

7. de Mul: Het romantische verlangen in (post)moderne kunst en filosofie 15.

8. Zie Blijvend Strategisch Vernieuwen: concurreren in de 21 e eeuw 72 e.v.

9. Mintzberg: Organisatiestructuren. 
pelijke gemeenschap erkend. Deze 'reificerende beweging' is bijvoorbeeld getraceerd aan de hand van het woord 'organisatie' zelf, dat als biologische metafoor voor het eerst door Herbert Spencer in $1873^{10}$ in een overdrachtelijke betekenis voor de 'niet-biologische' organisatie-context is gebruikt. Eenzelfde metaforische geboorte en metamorfose tot een wetenschap-pelijk concept zou gereconstrueerd kunnen worden met betrekking tot het woord 'bureaucratie'. Deze term, waarin de metaforische oorsprong van 'bureau' duidelijk herkenbaar is, heeft vooral door Weber een academische status gekregen ${ }^{11}$. Bij het neologisme 'adhocratie' is de semantische vernieuwing op basis van een tegenstrijdige samenvoeging van 'ad hoc' en het gebruikelijke stramien van '....-cratie' nog steeds hoorbaar. Naarmate het nieuwe woord met zijn paradoxale betekenis van 'ongevormd op de situatie inspringend' èn 'een beheersingsvorm waarnaar de situatie zich dient te voegen' ingeburgerd raakt in het organisatie-discours, zal het zijn onconventionele karakter kwijtraken. Met het verbleken van de literaire glans, kan het beter als een beschrijvende term gaan functioneren. Indien het niet wordt getroffen door het grillige lot om 'uit de managementmode' te geraken, is het mogelijk dat het de status van wetenschappelijk concept verkrijgt. Epistemo-logisch gesproken is het de vraag of met deze statusverhoging ook een daadwerkelijke methodologische vooruitgang is geboekt of dat er achter de conceptuele 'face lift' het oorspronkelijke 'beeld' blijft opspelen. Woorden zoals 'adhocratie', 'de oscilerende onderneming' en 'bank-ruptcy strategy' opereren als een soort tussencategorie tussen beeldspraak en concepten, en geven aldus een tweeslachtig metaforisch-conceptueel karakter aan het organisatie-discours.

Behalve dat de oorsprong van veel vaktermen metaforisch is, is het organisatievertoog niet altijd rechtlijnig. Soms wordt de redeneertrant metaforisch van toon:

Het getal 'vijf' duikt telkens weer op in onze bespreking. Eerst waren er vijf coördinatiemechanismen, toen vijf basisonderdelen van de organisatie, later vijf soorten decentralisatie. Vijf is natuurlijk geen gewoon getal. "Het is het symbool van de eenheid, van het huwelijk volgens de aanhangers van Pythagoras; ook het getal van het centrum, van harmonie en evenwicht." (...) Het is natuurlijk geen toeval dat het getal 'vijf' in onze discussie zo vaak opduikt; het blijkt dat alle verschillende elementen in groepen van vijf bij elkaar horen. Bij elke configuratie speelt een ander coördinatiemechanisme de belangrijkste rol, neemt een ander onderdeel van de organisatie de voornaamste plaats in en wordt een andere vorm van decentralisatie gebruikt. ${ }^{12}$

Hoewel dit voorbeeld van 'metaforisch-magisch denken' wellicht een didactisch doel dient - om de bedrijfskundige les via een effectieve speelse zijsprong over te dragen - schuilt er achter dit gegeven een fundamentele wetenschaps-filosofische vraag. Wat betekent het metaforische karakter van het organisatie-discours voor de

10. Grant \& Oswick: Metaphor and Organizations 2.

11. Goddijn: Max Weber. Zijn leven, werk en betekenis 176 e.v.

12. Organisatiestructuren 161. 
wetenschappelijke pretentie van de bedrijfskunde? Nog een voorbeeld uit het reeds aangehaalde organisatiekundige boek van Mintzberg om het verborgen metaforische karakter aan te geven van ogenschijnlijk eenduidige wetenschap-pelijke termen, namelijk de titel van hoofdstuk zeven, Ontwerp als configuratie. Daarin zijn de woorden '(ont-)werpen' en 'figuur' als versleten of slapende metaforen herkenbaar. Wat is de betekenis van de 'letterlijke' interpretatie van deze woorden voor de organisatiekunde? Zijn organisatiekundigen, zoals architecten huizen volgens hun plan laten bouwen, experts om organisatietypen op vraag en op maat in figuurlijke zin te ontwerpen, op te bouwen en te verkopen? Creēert de 'letterlijke' oorsprong van organisatiekundige grondconcepten een esthetische illusie die een metaforisch-magische glans geeft aan het abstracte karakter van een wetenschappelijk betoog? Is de metaforische lading van bedrijfskundige begrippen 'slechts opsmuk', waardoor het organisatie-discours beter verteerbaar wordt voor 'professionals' en pragmatici? Of is de radicale consequentie uit dit gegeven dat de 'rock bottom' van onze kennis over organisaties een metaforisch moeras van wensdromen, intüties, ideologische vooroordelen en gissingen blijkt te zijn?

\subsubsection{Pro en contra de metafoor}

De radicale vraagstelling waartoe de vorige paragraaf heeft geleid, nodigt uit tot een 'pro' of 'contra-stellingname' met betrekking tot het wetenschappelijk statuut van de metafoor. Vertegenwoordigt het literaire karakter van het organisatie-discours een marginale schijnbeweging in het overigens empirisch-conceptuele verband van een wetenschappelijke tekst of is de bedrijfskundige grondstructuur uiteindelijk metaforisch van aard? ${ }^{13}$ Een extreme consequentie van deze laatse optie zou zijn om de wetenschappelijkheid van de bedrijfskunde algeheel te ontkrachten in het spoor van Nietzsche's boude bewering over waarheid als een 'verdichtsel', waarin men dogmatisch is gaan geloven, een 'illusie', waarvan men het illusoir karakter is vergeten, een 'metafoor', wier beeldkarakter is verbleekt zoals het embleem op een oud muntstuk is versleten:

Was ist also Wahrheit? Ein bewegliches Heer von Metaphern, Metonymien, Anthropomorphismen, kurz eine Summe von menschlichen Relationen, die, poetisch und rhetorisch gesteigert, aberttragen, geschmückt wurden und die nach langem Gebrauch einem Volke fest, kanonisch und verbindlich dünken: die Wahrheiten sind Illusionen, von denen man vergessen hat, dass sie welche sind, Metaphern, die abgenutzt und sinnlich kraftlos geworden sind, Munzen, die ihr Bild verloren haben und nun als Metall, nicht mehr als Münzen, in Betracht kommen.. ${ }^{14}$

13. Deze vraag is geīnspireerd door Derrida's denken over de metafoor (in: Marges de la Philosophie). 14. Nietzsche: Ueber Wahrheit und Lige im aussermoralischen Sinn in: Werke II 1022. 
De radicaliteit van Nietzsche's standpunt heeft aanleiding gegeven tot fundamentele discussies in de filosofie over de vraag naar een universele grondslag voor (onze kennis over) de werkelijkheid. Vanuit een nietzscheaans perspectivisme ${ }^{15}$ schuilt achter de geclaimde wetenschappelijkheid de alomtegenwoordigheid van de 'organisatorische' wil tot macht. Grond voor een 'post-modern perspectief' om de academische schijn-(heiligheid) te ontsluieren en om de bedrijfskunde op narratieve leest te schoeien ${ }^{16}$ ?

Een gebruikelijke reactie op een dergelijke radicale vraagstelling is de degradering van de status van metaforen tot in de marge van een wetenschappelijke tekst. De metafoor wordt verwelkomd als een heuristisch instrument. Net zoals een microscoop of een questionaire wordt gebruikt voor het verzamelen van natuur- resp. sociaal-wetenschappelijke kennis, zo wordt de legitieme rol van de metafoor beperkt tot het aanleveren van bouwstenen voor bedrijfskundige kennis. Organisatiemetaforen fungeren als zoeklicht en kunnen diagnostisch worden gebruikt om bijvoorbeeld taboe-onderwerpen op het spoor te komen. In deze zin heeft Morgan metaforen voor de bedrijfskunde wetenschappelijk gerehabiliteerd, waarover meer in de volgende paragraaf. Daarnaast dienen ze dankbaar als kapstok voor allerlei 'intuities' en 'vage noties' over organisatievraagstukken, totdat er een 'wetenschappelijke' verklaring of beschrijving is ontworpen. Een voorbeeld is de matrix die de Boston Consulting Group als 'managementtool' heeft ontwikkeld om de relatieve waarde en de verhouding tussen het marktaandeel en de groeikansen van organisaties te bepalen. ${ }^{17}$ Een metaforisch raster van sterren, koeien, vraagtekens en honden biedt een instrument om deze verhouding in te schatten. Aan de hand van dit metaforische raster zijn organisaties te verdelen in 'sterren' (hoog aandeel en sterke groei), 'koeien' (hoog aandeel en zwakke groei), 'vraagtekens' (laag aandeel, sterke groei) en 'honden' (laag aandeel en zwakke groei). Wat betreft de algemene toepasbaarheid en geldigheid is dit analyse-instrument echter vanuit bedrijfskundige hoek onder kritiek gesteld. Niettemin heeft de metaforische categorisering kennelijk heuristisch gewerkt voor een verdere bedrijfskundige verfijning van analysetechnieken en wordt het nog steeds als een 'didactische metafoor' in het aangehaalde managementleerboek uitgebeeld.

De heuristische functie van metaforen geldt echter niet specifiek voor de bedrijfskunde. Een veel aangehaald voorbeeld in een natuurkundige context is de metafoor van de vallende appel die voor Galileï model stond voor het formuleren van de

15. Zie paragraaf 5.3. van het volgende hoofdstuk.

16. Kilduff \& Mehra: Postmodernism and Organizational Research Academy of Management Review. 22 (2) 453-481. Barry \& Elmes: Strategy retold: Toward a narrative view of strategic discourse Academy of Management Review. 22 (2) 429-452. Hamilton: Rhetorical Discourse of Local Pay Organization 4 (2) 229-254. Boyce: Collective Centring and Collective Sense-making in the Stories and Storytelling of One Organization Organization Studies 16 (1) 107-137. Boje: Stories of the storytelling organization: a postmodern analysis of Disney as 'Tamara-land Academy of Management Journal. 38 (4) 997-1035.

17. Management 250-251. 
valwetten met betrekking tot de fenomenen versnelling en zwaartekracht. Ook het didactische gebruik van retorische aspecten van de metafoor voor de praktische 'vertaling' van theoretische concepten en modellen wordt algemeen geaccepteerd. Zo kan het verband tussen elektrische stroom, weerstand en kracht uitgelegd worden aan de hand van de metafoor van een waterstroom. Om de wetmatigheid van elektrische verschijnselen te begrijpen helpt deze metafoor het abstracte verband tussen voornoemde natuurkundige grootheden aanschouwelijk te maken aan de hand van het beeld van een 'waterstroom die in een stroomversmalling een stroomversnelling te zien geeft'.

Een opvatting over het gelimiteerde legitieme wetenschappelijk gebruik van metaforen, wordt in de organisatiekundige literatuur aangeduid met een gematigd 'nonconstructivistisch' standpunt. Volgens een dergelijke 'rekkelijke' visie cre-eren metaforen geen realiteit, ze laten ons 'de' realiteit slechts op bepaalde wijze zien. Taal heeft geen generatieve maar een beschrijvende en afbeeldende functie. Toch kunnen metaforen ons op het spoor zetten om 'werkelijk' bestaande struc-turen, fenomenen en wetmatigheden te ontdekken. Wetenschap heet 'de queeste' om de realiteit zoals zij naar haar ware aard buiten onze beschrijving om bestaat, te ontdekken, volgens de 'non-constructivisten'. Een 'gematigde' non-constructivistische positie kan aldus goed samengaan met het exploiteren van de heuristische waarde van metaforen. Er zijn evenwel ook 'non-constructivisten' die het gebruik van metaforen en beeldspraak voor wetenschappelijke doeleinden categorisch afwijzen. Een bekende protagonist van deze 'precieze' visie is Ortony:

Metaphors characterize rhetoric, not scientific discourse. They are vague, inessential frills, appropriate for the purpose of politicians and poets, but not for those of scientists because the goal of science is to furnish an accurate description of reality. ${ }^{18}$

In de wetenschapsfilosofie hebben veel 'tegenstanders' van retoriek in de wetenschap een uitgesproken negatieve waardering van de metafoor geventileerd. Voor hen lijkt de rehabilitering van de metafoor ${ }^{19}$ model te staan voor de ondergraving van de wetenschappelijke fundamenten van het Westerse project om een rationele verklaring van de werkelijkheid te geven. Aanhangers van deze opvatting worden in de organisatiekundige literatuur ook wel 'modernisten' genoemd' en tegenover 'post-modernisten' en 'constructivisten' gesteld. Vanzelfsprekend huldigen 'constructivisten', die ervan uitgaan dat de werkelijkheid (in elk geval mede) geconstrueerd is door onze taal en concepten, een andere, veelal positieve opvatting over de generatieve kracht van metaforen. Daarnaast bestaan er 'nonconstructivisten' die niettemin 'voorstanders' zijn van het gebruik van metaforen, echter op zodanige wijze dat zij aan rationele banden wordt gelegd. De metafoor

18. Ortony in Metaphor and Organizations 5.

19. Bijvoorbeeld door Max Black en Mary Hesse, zie Ankersmit \& Mooij: Knowledge and Metaphor. Ankersmit: History and Tropology. The Rise and Fall of Metaphor University of California Press, Berkeley, 1994. 
als dienstmaagd van de wetenschap. Een voorbeeld is Tsoukas, die een methodologisch model heeft ontworpen om in drie stappen de impliciete vergelijking die in een metafoor verstopt zit, tot een letterlijke en wetenschappelijk gefundeerde beschrijving uit te werken. ${ }^{20}$ Bijvoorbeeld het metaforische gebruik van biologische noties in een bedrijfskundige context: de idee van 'survival of the fittest' uit de evolutietheorie is in een organisatietheorie, de zogenaamde 'contingency theory', als biologische metafoor gebruikt om het belang van het aanpassingsvermogen van de organisatie aan de omgeving aan te geven. Aan de hand van dit model kan de metaforische verplaatsing van de idee van 'natuurlijke selectie' naar de bedrijfskunde als 'factor voor concurrentievoordeel' methodologisch onderbouwd worden. Volgens Tsoukas moet de vergelijkbaarheid dus getoetst worden door het biologische gedrag van organismen systematisch te vergelijken met de wetmatigheden die in de wereld van organisaties gelden. Wanneer er voldoende zichtbare eigenschappen en onderliggende principes met elkaar overeenkomen, is de metaforische vergelijking wetenschappelijk gewettigd.

In deze paragraaf is getoond hoe metaforen op verschillende wijze worden gebruikt en gewaardeerd, al naar gelang de context een wetenschappelijke is of een toegepaste. Tegenover de theoretische blik van de wetenschapper staat de pragmatische optiek van de manager. Is er voorbij beide extreme opvattingen, in de discussie tussen 'voorstanders en tegenstanders' van de metafoor, tussen 'constructivisten en nonconstructivisten', tussen 'postmodernisten en modernisten', nog een andere visie mogelijk ten aanzien van de (meer)waarde van metaforen?

\subsection{Metaforen in organisatie-onderzoek}

Met betrekking tot de in de vorige paragraaf ontwikkelde vraagstelling neem ik het interne perspectief en de inherente waarde van 'metaforische kennis' van betrokkenen tot uitgangspunt. Een kritische analyse van de ideologische lading van metaforen en metaforische betekeniseffecten wordt daar tegenover geplaatst, teneinde een toegevoegde waarde van het 'interne metaforische perspectief' op het spoor te komen zonder monologisch en willekeurig van 'het eigen gelijk' van metaforen uit te gaan. Daartoe zal in de eerste subparagraaf het werk van Morgan worden besproken. Hij heeft als een der eersten een lans gebroken voor de introductie van de metafoor als diagnose-instrument voor organisatic-onderzoek. Volgens hem bestaat 'de meerwaarde' van metaforen uit hun kracht om 'democratisch' een nieuw perspectief op organiseren te creëren dat gebaseerd is op 'bottom up' ontwikkelde beelden van betrokkenen met het oog op organisatieontwikkeling. In de daarop volgende subparagrafen wordt verder ingegaan op het ideologische perspectief van waaruit metaforen in een managementcontext worden toegepast.

20. Tsoukas: The missing link: a transitional view of metaphors in organizational science in: Academy of Management Review. 18 (3) 566-585. 


\subsubsection{Morgans onderzoek}

De belangstelling voor metaforen is vooral door Morgan $^{21}$ onder de bedrijfskundige aandacht gebracht. In zijn werk zijn drie fasen te onderscheiden waarin hij op verschillende wijze de functie van metaforen voor de bedrijfskunde beschrijft. Dit zal ik hieronder toelichten met behulp van drie belangrijke boeken uit zijn oeuvre.

Samen met Burrell heeft Morgan in 1979 een 'opus magnum' uitgegeven waarin zij een systematisch en historisch overzicht geven van de grondslagen van de sociale wetenschappen. Daarin figureert de metafoor op een meta-theoretisch niveau, vergelijkbaar met het paradigma-begrip zoals dat vooral door Kuhn tot een centraal wetenschapsfilosofisch concept is uitgewerkt. Hun studie resulteert in een raster met vier ramen, waarin het geheel van sociaal-wetenschappelijke literatuur geplaatst kan worden. Het 'raster' is opgebouwd aan de hand van twee meest relevant geachte 'dimensies' van sociale kennis. De eerste dimensie heeft betrekking op de aard van de kennis die gegenereerd wordt, geplaatst op een schaal van 'subjectief' naar 'objectief'. De tweede dimensie heeft betrekking op de aard van de maatschappelijke verandering. Deze aard wordt gesitueerd op het spectrum van 'evolutionair' tot 'revolutionair'. Aan de hand van deze twee fundamentele dimensies kan elk 'raam' van het raster worden gedefinieerd. Aldus hebben Morgan en Burrell een ontwerp gemaakt voor vier 'paradigmata' van de organisatiekunde:

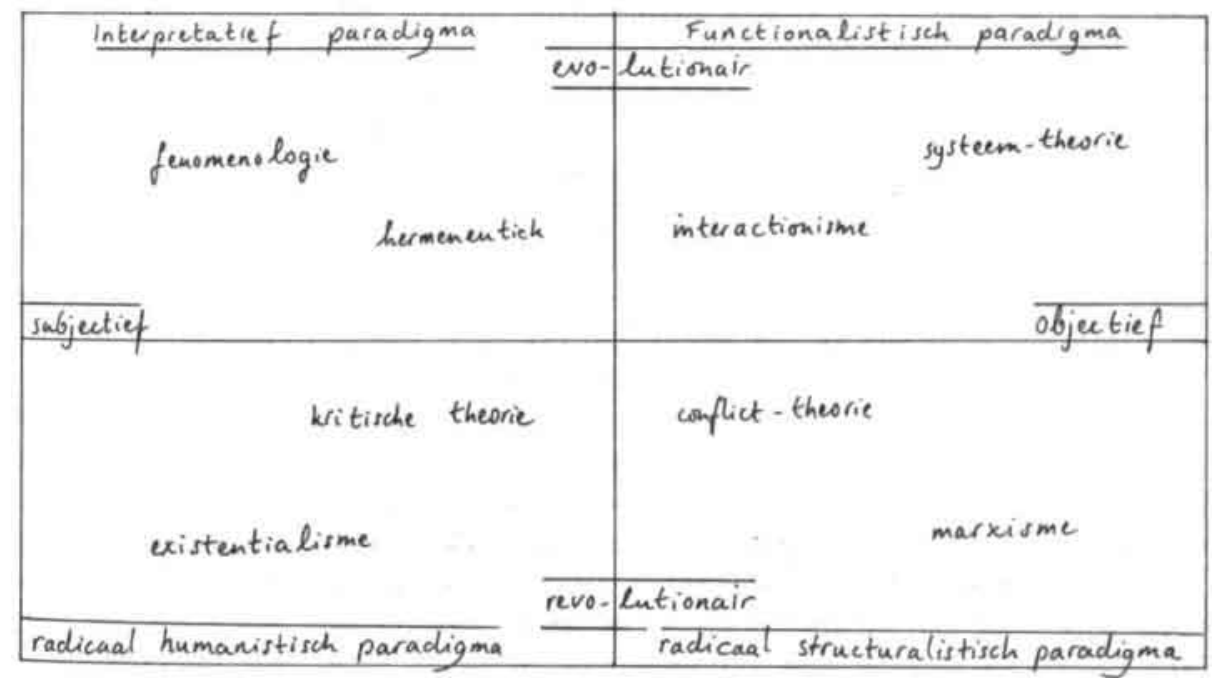

21. In het bijzonder is gebruik gemaakt van Morgan \& Burrell: Sociological Paradigms and Organizational Analysis. Morgan (ed.): Beyond Method: Strategies for Social Research. Morgan: Images of Organization. En: Imaginization: The Art of Creative Management. 
Ter karakterisering van de vier paradigmata hebben zij de volgende namen gekozen: interpretatief (subjectief, evolutionair), functionalistisch (objectief, evolutionair), radicaal humanistisch (subjectief, revolutionair) en radicaal structuralistisch (objectief, revolutionair). Hoewel deze namen niet uitgesproken metaforisch klinken, is de wijze waarop zij worden gebruikt dat wel. Het indelen van sociaal-wetenschappelijke literatuur aan de hand van een raster is een overkoepelende, samenvattende en typologiserende 'kennisstrategie'. Door het positioneren van de literatuur in deze vier 'ramen' wordt er een verplaatsend en verdichtend dus metaforiserend betekeniseffect gegenereerd. De organisatiekunde wordt erdoor op een meta-niveau gebracht, van de 'letterlijke' lectuur naar een uitspraak over haar in 'overdrachtelijke zin'. Het 'overdrachtelijke' betreft de aard van de wetenschappelijke kennis en van de beschreven maatschappelijke veranderingsprocessen. Door het aldus ontworpen interpretatiekader wordt de betekenis van de sociaal-wetenschappelijke literatuur naar deze 'innerlijke' ordening verplaatst en verdicht. Dat wil zeggen dat het 'raster' fungeert als een samenvattende uitspraak die het pluriforme geheel tot de betreffende typering condenseert.

Het boek Beelden van Organisaties is Morgans bekendste werk. Daarin maakt hij expliciet melding van het belang van metaforen voor de organisatiekunde. Zijn belangstelling betreft hier minder de grondslag van sociale kennis, alswel de functionaliteit en toepasbaarheid van metaforen voor de bedrijfskunde. In plaats van de vier 'metaforische paradigmata' verschijnen er acht concrete metaforen die de functie hebben om organisaties diagnostisch te lezen en de organisatorische complexiteit kritisch te evalueren. Hieruit blijkt dat deze 'tweede Morgan' zelf zowel in het 'interpretatieve' als in het 'humanistische' paradigma van zijn eerdere schema is te plaatsen. De acht organisatiemetaforen hebben een heuristische functie om een concrete organisatie te conceptualiseren, veeleer dan om een theorie over 'de organisatie' op te stellen. De metaforen zijn op basis van 'action research' in de praktijk ontstaan met betrekking tot een specifiek probleem in de betreffende organisatie. Bij gevolg is hun theoretische status en empirische referentie beperkt: 'Laten we deze organisatie eens conceptualiseren als machine, ... als organisme,... als culturen, ... als hersenen, ... als flux, ... als een geestelijke gevangenis, ... als instrumenten van overheersing, ... als politiek systeem..... Niettemin hebben de metaforen een verderstrekkende geldigheid gekregen, omdat ze algemeen herkenbaar zijn en wellicht op veel organisaties toepasbaar. Als zodanig vertegenwoordigen de acht organisatie-metaforen typerende wijzen van kijken. Ze vervullen derhalve eenzelfde soort 'paradigmatische' functie op kleinere schaal en in toegepaste zin als het schematische raster uit zijn vorige werk. Andersom kunnen we deze metaforen ook gebruiken om de vier paradigmata van sociaalwetenschappelijke kennis metaforisch te typeren. De 'machine-metafoor' is paradigmatisch voor een functionalistische optiek op organisaties. Het begrijpen van organisaties in termen van 'culturen' is typerend voor een interpretatieve benadering. De organisatie opvatten als een 'politiek systeem' is kenmerkend voor een radicaal structuralistische zienswijze, terwijl de organisatie als 'geestelijke gevangenis' een radicaal humanistische visie verraadt. 
Uit het latere werk van Morgan spreekt een nog sterkere pragmatische wending. De titel van het boek dat hiervoor model staat is Imaginization en verwijst naar het creëren van metaforen als vaardigheid, wat beantwoordt aan de kernopgave waarvoor hij het huidige management als het ware gesteld ziet. Zijn benadering kan als een combinatie van een functionalistische en een interpretatieve invalshoek worden gekenschetst, hoewel hij bij wijze van theoretische onderbouwing ${ }^{22}$ aangeeft nog steeds een interpretatief-hermeneutische werkwijze te volgen. Het werk is in dialoog met de praktijk bij wijze van 'action learning' ontstaan en heeft niet de pretentie een metaforische beschrijving van organisaties te geven met een algemenere strekking. De algemene geldigheid betreft de vaardigheid van het metaforiseren of imaginiseren, wat het 'interpretatieve' karakter van zijn benadering onderstreept. Een 'functionalistische' insteek blijkt echter uit zijn doelstelling om de 'manageability' van organisaties in ons huidige 'complexe, fluctuerende, innoverende, onzekere' tijdsbestek zeker te stellen. Op een speelse en pragmatische wijze zet hij uiteen hoe het imaginiseren functioneel is voor gebruikelijke managementtaken en organisatiedoelstellingen, zoals teambuilding, strategieën uitzetten, organisatie-ontwikkeling, innovatie-processen bevorderen en begeleiden, enzovoort. Ter illustratie een metafoor uit dit werk waarmee een nieuw organisatieconcept wordt verbeeld: de organisatie als een plant, een chlorophytum. Met behulp van deze zich door de lucht naar alle kanten toe wortelschietende moederplant worden de interne verhoudingen tussen 'hoofdkantoor en business units' op een andere dan de gebruikelijke hiërarchische manier voorgesteld. Hij illustreert (letterlijk en figuurlijk) hoe metaforen voortkomen uit een wijze van organiseren en leidinggeven waarbij niet alleen het 'logische verstand' met redelijke analyses maar ook 'de verbeelding' het woord krijgt.

\subsubsection{Metaforen, creativiteit en andere management hypes}

Morgans derde 'metaforische benaderingswijze' kan model staan voor veel pragmatische en speelse literatuur over organisaties en management. ${ }^{23}$ In termen van Morgan en Burrell's raster lijkt er een accentverschuiving in de organisatie- en managementliteratuur aan de gang te zijn van een 'functionalistisch' naar een 'interpretatief' paradigma. Metaforisch gesproken verschuift het bedrijfskundige perspectief 'van tellen naar vertellen' hetgeen gepaard gaat met een verandering in

\footnotetext{
22. In cen appendix bij dit werk.
}

23. Bijvoorbeeld: Boozer: Using metaphor to create more effective sales messages The Journal of Business and Industrial Marketing. 7 (1). Mattimore: Breakthroughs Creatively Destroying the Barriers to Business Innovation Success. nov. 1988, 44-50. Goodman: Creative Management. Grunwald: Creativiteit in Organisaties. Effectief managen in een minder lineaire wereld. Clegg \& Birch: DisOrganization. The handbook of creative organizational change. Robinson \& Stern: Corporate Creativity. How Innovation and Improvement Achually Happen. de Bruyn \& Zegers: Paradijs-ervaringen tegenover bedriffsbelangen. Creatieve Agressie, Creatieve Regressie, Creatieve Progressie. 
managementstijl en wijze van leidinggeven. ${ }^{24}$ Wat houdt deze verandering in de praktijk in? Tegenwoordig winnen humanistisch ogende instrumenten, zoals de bedrijfscultuur, de huisstijl met het bedrijfslogo, de 'mission-statement', een 'bottom up' managementstijl gericht op 'enabling' en 'empowerment' steeds meer terrein van traditionele bakens voor het besturen van organisaties, zoals controle van bovenaf en 'top down' opgelegde beheersingssystemen. De nieuwe koers wordt uitgezet aan de hand van gouden bergen belovende managementconcepten: 'globalisering', 'flexibilisering', 'employability', 'continuous innovation' enzovoort. Hoewel het vaak onduidelijk is wat ze precies betekenen bezitten deze sleutelwoorden een symbolische kracht en stralen ze 'credebility' uit. Ze positioneren zich op een hoge plaats op de agenda in organisaties en mobiliseren politieke middelen in het sociaal-economische krachtenveld. Omdat ze het vertrouwen bij voorbaat winnen, lijkt een gedegen argumentatie overbodig. Ze verkrijgen, kortom, de status van een toverformule, talisman of fetisj en de dubbelzinnigheid van een metafoor. Maar uiterlijk verschijnen ze meer als 'harde concepten' en succesvolle wetenschappelijke modellen.

Over het retorische effect van metaforische concepten in de wetenschappelijke context van de bedrijfskunde en over de mogelijke wetenschapsfilosofische betekenis van deze hybriden is in de tweede paragraaf gesproken. Nu zal worden ingegaan op hun betekenis voor de managementpraktijk. Hiervoor is ook gewezen op het tijdgebonden karakter van het organisatiediscours. Uit een studie ${ }^{25}$ naar de opkomst, de populariteit en de devaluatie van managementconcepten blijkt dat succesvolle trends zoals de 'matrix organisatie', 'management by objectives', 'total quality management', 'decentralisatie', 'the learning organization', 'employability', enzovoort niet alleen een sterk retorische werking hebben, maar dat het feitelijke verloop van hun succes vergelijkbaar is met modetrends. Wanneer managementconcepten inderdaad veeleer een retorische dan een wetenschappelijke betekenis hebben, waarop berust hun succes? De auteurs beschrijven vier soorten verklaringen voor de opkomst en het verval van de succesformules. ${ }^{26} \mathrm{De}$ concepten kunnen worden beschouwd als 'gebakken lucht': managementconcepten voegen niets wezenlijks toe aan de praktijk, als 'oude wijn in nieuwe zakken': de ontwikkeling van managementconcepten verloopt niet anders dan andere maatschappelijke trends waarin modes te bespeuren zijn, als een 'pendelbeweging': het management van vandaag creëert de problemen van morgen, waardoor we per saldo geen stap verder komen, en de meest positieve optie beschouwt de ontwikkeling van managementconcepten als een collectief leerproces.

Vanuit de laatste optimistische zienswijze kan voor het klaarblijkelijke trage en moeizame verloop van dit leerproces als verklaring worden gegeven dat het

24. Zie bijvoorbeeld: Covey: De zeven eigenschappen van effectief leiderschap. Brenters: De organisatie als netwerk. Hoe mensen organisaties veranderen en organisaties mensen Bernstein: Company image and reality. A critique of corporate communications.

25. Karsten \& van Veen: Managementconcepten in beweging: tussen feit en vluchtigheid.

26. Managementconcepten in beweging: tussen feit en vluchtigheid 52. 
verschijnsel 'organiseren' een complex gebeuren is. De drie andere verklaringen benadrukken vooral sociaal-retorische aspecten van de beschreven ontwikkeling. Er zijn immers tenminste drie soorten sociale gemeenschappen bij het 'leerproces' betrokken, elk met hun eigen cultuur, taal en belangen: de wetenschappelijke gemeenschap van bedrijfskundigen, de groep consultants en organisatietrainers, en de managers. Vanuit een sociaal-retorische optiek neemt de complexiteit van het verschijnsel nog meer toe. Ze roept ook andere vragen op, bijvoorbeeld: hoe slaagt de groep consultants en organisatiekundigen erin om bepaalde metaforische termen als harde concepten te verkopen, zowel aan het management, aan de politiek, als aan de wetenschap? Ter illustratie dient het concept 'employability'. Zoals zoveel managementconcepten is ook deze snelle 'rijzende ster' afkomstig van de Amerikaanse markt. Schijnbaar probleemloos is het concept in Nederland tot in de politiek en de cao-onderhandelingen doorgedrongen. ${ }^{27}$ Door Wim Kok bijvoorbeeld wordt de vage belofte met harde sociaal-economische munt verkocht: 'Door scholing kan de moderne werknemer baanzekerheid vervangen door werkzekerheid ${ }^{28} \mathrm{Om}$ de bittere politieke pil van het 'verlies van baanzekerheid' te slikken zijn er smaak-verbeteraars aan toegevoegd, bijvoorbeeld het morele goed van de 'individuele verantwoordelijkheid' van werknemers, bedrijfsdoelstellingen zoals 'flexiblisering' en sociale doelen van de vakbeweging, zoals 'werk voor iedereen'.

Gezien het retorische karakter van de ontwikkeling van managementconcepten lijkt een sociaal-psychologische verklaring en een (wetenschaps)filosofische problematisering meer op zijn plaats, dan een bedrijfskundige legitimering. Hoe genereren de flexibele managementconcepten dat effect van betrouwbaarheid en eenduidigheid, wat resulteert in de overtuiging dat er 'echt' iets in de werkelijkheid is, waarmee 'employability' correspondeert? Bezitten deze termen een empirische inhoud die verder strekt dan de praktijk van consultants en organisatiekundigen waarin ze worden gegenereerd en gereproduceerd? Het kan bijvoorbeeld zijn dat we door de utopische kracht van deze hybriden in een ontvankelijke gemoedstoestand worden gebracht. Mogelijk gaat er een mythologiserend appèl van de verborgen metafoor uit waardoor we een kinderlijk geloof en naïef vertrouwen in de managementboodschap verkrijgen. Terwijl tegelijkertijd dit gegeven zelf, van het mythologisch aangesproken worden, bedekt wordt door de harde wetenschappelijke uitstraling van de woorden. De impliciete utopie die bijvoorbeeld in 'employability' verstopt zit is de mythe van 'een flexibele arbeidsmarkt met voor eeuwig en iedereen beschikbaar werk'. Managementconcepten/metaforen bevatten aldus in gecomprimeerde vorm een ideologische optiek op organisaties en sociale verhoudingen, die in de plaats komt van een wetenschappelijke en politieke legitimering van de gewenste organisatorische en sociale veranderingen. Deze invalshoek maakt het opmerkelijke gegeven invoelbaar dat de hybride toverformules veelal geruisloos aan de organisatietheorie worden toegevoegd, terwijl metaforen als 'de organisatie als jazzband' (een beeld voor 'de postmoderne organisatie'), 'de manager als dolfijn' (een beeld voor de nieuwe stijl van leidinggeven)

\section{Ibid. $49-50$}

28. Wim Kok, geciteerd door Meijer: Employability-vraagstuk zorgt voor onnust. 'Flexabiliteit gaat ten koste van zekerheid in: Erasmus Magazine 1999 (6). 
en 'de werknemer als gekookte kikker' (een beeld voor fatale stress in organisaties) met scepsis worden ontvangen. Zij komen er immers open en bloot voor uit dat ze thuishoren in een mythologische, sprookjesachtige wereld.

Al biedt de retoriek een verklaring voor het succes van managementconcepten, dan dient alsnog de vraag gesteld te worden of dit een algehele scepsis ten aanzien van een 'metaforische benadering' van organisaties rechtvaardigt. Er kan immers een 'logica van de metafoor' of een 'rationaliteit van de verbeelding' werkzaam zijn, die een gelijkwaardige plaats toekomt ten opzichte van traditionele 'empirischrationele' pijlers van wetenschappelijke kennis. De retorische invalshoek wijst evenwel op nog een ander belangrijk aspect dat met de legitimeringsvraag van 'metaforische kennis' samenhangt. De scepsis betreft namelijk niet alleen een tekort aan conceptuele inhoud en empirische referentie, maar ook het onkritische ideologische gebruik van metaforen en beelden. Laten we ervan uitgaan dat in de scepsis en het cynisme een terechte kritiek schuilt, dan zouden de naïef gehanteerde en ongelegitimeerde metaforen, indien ze aan de macht komen, vergelijkbaar zijn met politieke leidersfiguren zoals Hitler en Mussulini. In beide gevallen gaat het immers om een onwenselijke situatie van machtsmisbruik, waarin 'de irrationaliteit', gepersonifieerd in een dictator of in een dictatoriale metafoor, het stuur heeft overgenomen en de sociale werkelijkheid van een gemeenschap manipuleert. Dictator en dictatoriale metafoor vertegenwoordigen een politiek meesterspel in het aanwakkeren en bespelen van emoties en de verbeelding. Als zodanig zouden we het verschil tussen opportunistisch metafoorgebruik en het kritisch hanteren van beeldspraak kunnen vergelijken met het verschil tussen 'dictatoriaal' en 'democratisch' gedragen politiek leiderschap,- namelijk het verschil tussen voornoemde dictators en figuren als Gandhi, Mandela en Martin Luther King. Martin Luther King's woorden "I have a dream..." hebben nog steeds retorische kracht, maar net zoals de politieke ideeën van Gandhi en Mandela, worden ze daarnaast gedragen door een visie, die openstaat voor reflectie en discussie. Een cruciaal gebrek aan kritische distantie, dialoog en ethische reflectie markeert de scheidslijn tussen beide soorten metaforen en leidersfiguren.

Aan de hand van deze paragraaf, waarin een schets is gegeven van het 'hype'karakter van metaforen en managementconcepten in de context van adviseurs, trainers en managers, is een belangrijk aspect van de onderzoeksvraagstelling naar voren gekomen. Een methodologisch onderzoek naar de grondslag voor een 'metaforische benadering van organisaties' voorbij een opportunistische insteek en een positivistische degradering en marginaliserig van de metafoor, kan niet woren losgemaakt van ideologische en machtsvraagstukken. ${ }^{29}$ Het methodische aspect van 'de meerwaarde' van de metafoor is aldus onlosmakelijk verbonden met sociaal-ethische problematiek en met de 'politiek van organisaties'. In de volgende paragraaf wordt een kritische interpretatie gegeven van de manier waarop meta-

29. Ramondt: Verborgen Macht. De verankering van de machtsrol in hedendaagse organisaties $M \& O$. juli/aug. 2000, 23-38. 
foren en creatieve middelen in de populaire managementliteratuur figureren, vooral met betrekking tot impliciete vooronderstellingen van ideologische aard. Deze analyse zal in de vierde paragraaf worden toegespitst tot een 'deconstructie ${ }^{30}$ van de metafoor van het succesvolle basketbal-team voor 'de postmoderne organisatie'.

\subsubsection{Het metaforische masker van de instrumentele rede}

Hieronder wordt ingegaan op sport- en spel-metaforen in de managementliteratuur, in het bijzonder op ideologische aspecten. De beschrijving van het 'hype'-karakter van 'de metaforische trend' in de vorige paragraaf heeft ons een hint gegeven waarom metaforen in de wereld van organisatiekundigen en managers zo aanslaat: ze besparen ons immers tijdrovende en vanuit pragmatisch oogpunt overbodige inspanningen om onze acties en overtuigingen te onderbouwen en politiek te verantwoorden. In plaats van een legitimatie wordt bijvoorbeeld pakkend, elegant en doeltreffend gesteld:

\section{To make your workers winners, first you have to make them players ${ }^{\text {mII }}$}

De organisatorische instrumentele rede heeft zich kennelijk een sportief confectiepak aangemeten. De manager opereert hierin niet anders dan de arts, wanneer $\mathrm{z} / \mathrm{hij}$ zich beroept op het feit dat een medicijn 'klinisch' werkt. Hoe deze effectiviteit wetenschappelijk te verklaren, laat staan ethisch en politiek te verantwoorden is, komt voor de pragmaticus op de tweede plaats. Metaforen staan aan de wieg van effectieve therapiee ${ }^{32}$ en zijn daarom onmisbare (semi)wetenschappelijke instrumenten voor arts en manager. De metafoor is de kroon op het succesvolle regime van de instrumentele rede. $\mathrm{Zij}$ bedient zich van dit elegante instrumentarium om haar doelen nog efficiënter te bewerkstelligen. Metaforen van sport en spel spelen dit goed klaar.

Sportmetaforen in de managementliteratuur lijken minder een perspectief van 'fair play' en veeleer een competitieretoriek te mobiliseren. Dat blijkt wanneer een 'managerial' vooringenomenheid en de op winstmaximalisatie gerichte bedrijfsdoelen niet op het spel worden gezet. Wanneer de wereld van organisaties met sport en spel wordt vergeleken gaat het in het algemeen om een accentverschuiving in de wijze van organiseren, gegeven het niet ter discussie staande doel van 'winnen' of 'winst maken'. De impliciete redenering in de metafoor is: Als we nog beter en sneller willen winnen en winst maken, dan moeten we het organisatiespel nog beter leren spelen. Als sporten spelmetaforen deze boodschap overbrengen, vervullen ze alleen ogenschijnlijk een

30. Een neologisme door een koppeling van de begrippen 'constructie en destructie' van de 'postmoderne' filosoof Derrida, dat inmiddels modieus wordt gebruikt en dus aan betekenis inboet. Hier gebruik ik het als een filosofische vakterm die aangeeft dat betekenisgeving berust op een semantisch spel van woorden die naar elkaar verwijzen hetgeen resulteert in het afbreken van oude en het opbouwen van nieuwe betekenissen door de steeds wisselende 'inter-tekstuele' context. Met het oog op de probleemstelling van dit onderzoek heb ik deze 'retorische analyse' van het proces van betekenisgeving geplaatst in een psycho-sociale context van communicatie en interactie.

31. Case: The great Game Across the Board nov./dec, 95.

32. Hulspas: Genezende beelden Intermediair 31 jan. 1997, 33. 
ideologie-kritische functie ten opzichte van de versleten militaire metaforen, die het organisatiediscours traditioneel organiseren. Uiteindelijk getuigen ze van eenzelfde ideologische geest wanneer de sport of het spel gericht is op het uitzetten van 'strategieën' en 'tactische zetten' om doeltreffend 'te winnen'. Binnen het overkoepelende metaforische kader van competitie en concurrentie-strijd zou er wellicht sprake kunnen zijn van een vervanging van 'oorlog' door 'sport' (maar de grens tussen beide is niet altijd duidelijk te trekken! $!^{33}$ ) of van 'winnen door openlijke strijd' naar 'winnen in vredestijd. ${ }^{34}$ Daarbij wordt de gebruikelijke 'oorlogs-mentaliteit' carnavalesk gecamoufleerd achter een kleurrijk en sportief ogend pak. De verslindende blik van niet te stillen winsthonger is verscholen achter een masker met een 'softe new age'-grimas. De welzijnsboodschappen van weleer worden opportunistisch met 'repressieve tolerantie' in de harde concurrentiestrijd geworpen. In de literatuur zijn wat betreft ideologische aspecten van organiseren min of meer kritische geluiden te beluisteren. Bijvoorbeeld is er tegen het 'misleidende aspect' van de metafoor gewaarschuwd $^{35}$ : een organisatie zal zichzelf uiteindelijk in de vingers snijden wanneer zij eenzijdig focust op het verslaan van concurrenten door het vergroten van haar marktaandeel. Op grond van economische en management-argumenten wordt aangeraden dat een organisatie zich beter kan concentreren op het verbeteren van de eigen organisatie en het vergroten van de winst, dan op 'het verslaan van de tegenstander'. Dit laatste heet 'de concurrentie-valkuil'. In het kader van de gezondheidszorg in de V.S. is gesteld dat sportmetaforen veeleer bijdragen aan de crises in die sector, dan dat ze er een oplossing voor bieden, omdat ze een destructieve competitiementaliteit genereren danwel in stand houden. ${ }^{36}$

Fundamenteler dan de introductie van 'humanistisch' ogende metaforen in het organisatiediscours is het ter discussie stellen van de overwegend agressieve optiek op 'winnen', die door de sport- en militaire metaforen wordt gearticuleerd. Een daadwerkelijke humanisering van organisatieprocessen en van de bedrijfscultuur verloopt niet simpel en lineair door 'een blik alternatieve metaforen' open te trekken, maar impliceert een meerlagig, dynamisch en complex transformatieproces. Het gaat immers om (onbewust verankerde) waarden en beelden in onszelf en in de sociale instituties en interactiepatronen van onze cultuur. Om een 'paradigmaverschuiving' in het denken over en handelen in organisaties bespreekbaar te maken, hebben sport- en spelmetaforen overigens niet het monopolie. Veelal introduceert men juist andere, met het traditionele discours divergerende metaforen om de gewenste verandering in beeld te brengen. Zo wordt gesproken van 'stop de klok' en een lans gebroken voor een oriëntatie op 'het kompas', als symbool voor effectiviteit versus efficiëntie, voor

33. Dit wordt niet alleen feitelijk bedoeld, zoals uit de exhorbitante agressie bij voetbalwedstrijden blijkt, maar doelt ook op een mogelijke 'innerlijke verwantschap' tussen '(wed)strijd' en 'spel', waarop Huizinga in De Homo ludens aannemelijk heeft gewezen.

34. Bookman: Ignite Team Spirit in Tired Lions Hrmagazine June 1990, 106-108.

35. Scott Armstrong: The profitability of winning Chief Executive. jun. 1994, 61-63.

36. Adams: False Metaphors. Sports, competition and the new leadership paradigm in health care Hospitals Health Care Networks 5 nov, 1995, 42-44. 
empowerment van werknemers in plaats van 'controle van bovenaf. ${ }^{37}$ De oproep om 'soft ware design' meer aan de hand van organische in plaats van mechanische metaforen te organiseren genereert een vergelijkbare perspectiefwisseling in een geheel andere context, bijvoorbeeld door zich meer op verjaardagen dan op deadlines te richten. $^{38}$

Er valt dus geen eenduidige rekening over sport- en spelmetaforen op te maken, wel een kritisch-meerduidige. Metaforen van sport en spel organiseren het discours over organisaties, op meerdere niveau's en op verschillende wijzen. In het proces van betekenisgeving constitueren slapende militaire metaforen op impliciete wijze de overheersende ideologie van winstbejag, dat wil zeggen winnen ten koste van de vijand ofwel de concurrent. Daarnaast gebeurt dit door bijvoorbeeld beelden uit de wereld van sport in het organisatiediscours in te lassen. Dan leent men in het algemeen de aantrekkelijke connotatie van een sport om een betere manier van winnen te expliciteren. Maar soms stelt deze metafoor de heersende mentaliteit van 'winnen of verliezen' als zodanig aan de kaak. Het retorische effect van sportmetaforen is aldus ambivalent.

Deze evaluatie van metaforen in de managementliteratuur geeft aan dat er sprake is van een onmiskenbaar eenzijdige trek in 'de metaforische benadering van organisatievraagstukken'. De eenzijdigheid vormt als het ware de tegenhanger van 'het kind met het badwater weggooien'. Vaak lijken sportmetaforen niet meer te zijn dan het overgebleven schuimende badwater, een 'lege huls', of de 'glamour and glory' van een videoclip, waarvan je als kijker geniet maar tegelijkertijd weet dat het een technologisch vernuftige montage van geluidseffecten en afgevuurde beelden is. Er is evenwel ook een andere interpretatie van sport- en spelmetaforen mogelijk, een duiding die de nadruk legt op de fundamentele inspiratie die met dergelijke metaforen wordt opgeroepen. Vanuit deze optiek zou het kunnen gaan om een verandering in basisoriëntatie, welke in dit onderzoek in verband is gebracht met 'de humanisering van ons (werk-)leven'. In de literatuur ${ }^{39}$ worden in dit verband ook andere concepten gebruikt, bijvoorbeeld 'interdependentie'. Deze term verwijst, volgens de hieronder geciteerde natuurkundige David Bohm, naar een 'basisoriëntatie' die een fundamentele wijziging aanbrengt in de gangbare oriẻntatie. Gebruikelijk is een 'grondhouding' die uitgaat van een grondslaggevende dichotomie tussen 'ik en ander' of tussen 'de organisatie en de omgeving'. De 'interdependente oriëntatie' doorkruist dergelijke opsplitsingen. In dat verband worden modieuze termen in de huidige 'creativiteitshausse', zoals 'de reactieve' versus de 'creatieve' of de 'pro-actieve' houding, met een kritische kanttekening voorzien:

37. Covey: Stop the Clock. Incentive sept. 1994, 45.

38. lay Arthur: Birthdays, not deadlines. Software Magazine april 1992, 98-99.

39. Bijvoorbeeld in Senge (c.a.) The fifth discipline fieldbook. 
Perhaps that explains why, despite its worthwhile qualities, the creative orientation often leads to vicious rivalry and extraordinarily, self-centered behavior in organizations. It seems to breed a fast-paced, exhausting way of life, where you are always expected to do, to create, and to shape the world in your image. ${ }^{40}$

Met betrekking tot 'het dictatoriale gebruik' van metaforen in de managementliteratuur heb ik met deze paragraaf gewezen op het belang van een ideologiekritisch moment dat in de organisatorische instrumentele rede zou moeten worden geïntegreerd. In de praktijk kan dit gestalte krijgen door bezinning en reflectie systematisch in te lassen in de opportunistische, op direct en meetbaar nut gerichte communicatie en interactie. In een context van democratische managementstijlen en creatieve trainingsvormen is het mogelijk om 'bottom up' ontwikkelde, sociaal gedragen en politiek gerechtvaardigde metaforen voor organisatie-ontwikkeling te ontwerpen. Er zijn in de literatuur aanzetten te vinden om de 'creatieve trend' uit te tillen boven het stadium van een 'managementmode'. De vraag of deze ontwikkeling op een 'alternatieve grondslag van rationaliteit' kan worden gefundeerd, wordt in de vijfde paragraaf uitgewerkt.

\subsection{Een gemaskeerde retoriek van agressie en competitie}

Het artikel ${ }^{41}$ waarin de basketbal-metafoor figureert maakt deel uit van de populaire (Amerikaanse) managementliteratuur, waarin diverse (voor)beelden worden gebruikt om een nieuwe optiek op organisaties te propageren. In de vorige paragraaf is aangegeven hoe sportmetaforen het organisatiediscours op een ambivalente wijze organiseren: achter het vernieuwde imago schuilt vaak een oude geest van competitie. De in deze paragraaf centraal gestelde metafoor is ontleend aan een in de V.S. populaire sport, basketbal. De auteur pleit met zijn artikel voor een verandering van leiderschapsstijl, van een controlerende naar een 'enabling' wijze van leidinggeven. Hij stelt zich voor als een consulent van een organisatie-adviesbureau dat zich vooral richt op het ontwikkelen van 'championship organizations'. Ook genereert hij een retorisch betekeniseffect van geloofwaardigheid door zich voor te stellen als een academisch geschoolde maar 'gewone' Amerikaanse 'family man', met vrouw en twee kinderen. Hoewel de auteur dit niet expliciet maakt, is de organisatie-ontwikkelingsdoelstelling van een championship organization reeds een metafoor. Deze leiderschapsmetafoor is niet willekeurig uit de kast getrokken, maar 'existentieel gefundeerd': je proeft een kennis van en liefde voor de sport uit elke zin. Aldus genereert de auteur een nieuw perspectief op basketbal als sport die past in 'de post-moderne werkelijkheid'. Tevens ontstaat er een andere invalshoek op 'het postmoderne organiseren' als een sportief en strategisch samenspel.

41. Geciteerd in The fifth discipline fieldbook 229.

42. Daniels: Leadership lessons from championship basketball. Journal for Quality and Participation June 1996. 


\subsubsection{Over het succes van de 'basketbal-organisatie'}

The industrial age, with its rigid division of labor, management and tasks, is linked metaphorically to the sports of football. The information age has created the need for a leaner, quicker, more responsive organization - one that resembles a championship basketball team. ${ }^{42}$

Dit citaat geeft de inhoudelijke boodschap van de leiderschapsles aan. De metafoor schetst een ideaal beeld waarin we ons kunnen spiegelen met klemmende vragen over organiseren in het huidige tijdsbestek. 'Basketbal' staat metaforisch voor een maatschappij en markt, die door continuë verandering worden gekenmerkt. Dit vergt van ons andere eigenschappen en capaciteiten dan die we hebben ontwikkeld in het voorbije industriële tijdperk. De uitdaging van de nieuwe tijd is om op een wereld van voortdurende verandering in te spelen, individueel en met de organisatie als geheel. Daartoe zijn basketbalspelers-kwaliteiten behulpzaam, zoals moed om je als individu te profileren, maar ook sociale capaciteiten en vertrouwen in het team waarvan je deeluitmaakt. Daarnaast wordt er gevraagd om een aanpassingsvermogen aan veranderende omstandigheden te combineren met een alertheid om je kansen te grijpen, juist ook als de veranderingen tot een crisis kunnen leiden. Bovendien om naast een scherp observatie- en analytisch vermogen je intuittie te ontwikkelen, omdat de veranderingen te snel gaan en zo radicaal zijn dat een antwoord op grond van een systematische doorlichting van de situatie niet adequaat is. Vanuit het perspectief van de auteur is het (Amerikaanse) voetbal een sport, die meer op vaste samenwerkingspatronen is gericht. Daarom past ze metaforisch gesproken beter bij het 'moderne' tijdsbestek, terwijl basketbal als metafoor een appèl doet om flexibel te opereren en voornoemde kwaliteiten in ons aan te boren. Als zodanig hoort ze bij de 'postmoderne' situatie van het Informatie-tijdperk. Een staaltje van metaforisch denken is de suggestie van de auteur dat het niet slechts toevallig is dat deze sport in Amerika in populariteit enorm is gestegen...

De analogieredenering luidt: Of het $\mathrm{nu}$ om een sportteam of een team in een organisatie gaat, uiteindelijk berust succes op een aantal basisprincipes die tot 'de overwinning' leiden indien ze succesvol worden toegepast. Succes is aldus gebaseerd op een zevental sociale principes die op analoge wijze werken voor een sportteam en een organisatieteam. De principes van succes zijn:

1. Poneer jezelf als winnaar.

2. Er zal niets gebeuren tenzij je zelf actie onderneemt.

3. Bekommer je om het systeem en er zal ook voor jou gezorgd worden.

4. Profileer jezelf op jouw gebied, maar leer ook op andere plaatsen te functioneren.

5. Bloei op in perioden van turbulentie om (de gewenste) veranderingen te creëren.

6. Speel niet zomaar een spelletje, maar leer en implementeer spelpatronen.

43. Leadership lessons from championship 36. 


\section{Verdediging is de beste aanval.}

De metafoor autoriseert allerlei vooronderstellingen, uitgangspunten, associaties en connotaties in de 'belevingsorganisatie' van de lezer. De retoriek in de tekst kan de inhoudelijke boodschap bekrachtigen, tegenspreken of relativeren. ${ }^{43}$ Het 'wat' van de metafoor is onlosmakelijk verbonden met het 'hoe', de inhoud wordt gedragen door het medium waarmee de boodschap wordt overgebracht. De semantiek opereert aldus hand in hand met de retoriek, de wijze waarop het weefsel van een tekst is gestructureerd tot een tekstueel verband, een patroon van kleuren en vormen, van connotaties, interne en verwijzende betekeniseffecten. Afhankelijk van dit samenspel van retoriek en semantiek werkt de metaforische leiderschapsles min of meer overtuigend. De basketbalmetafoor zou dus zelf de opgesomde zeven kwaliteiten in het betoog over 'succesvolle teams en leiderschap' moeten organiseren om de boodschap congruent over te brengen, om inderdaad succesvol te zijn. Om een indruk van de (in-)congruentie te verkrijgen ga ik na hoe in het proces van betekenisgeving een soort 'mimetische verdubbeling' plaatsvindt die een versterking resp. een verzwakking van de inhoudelijke boodschap bewerkstelligt. Hoe wordt de inhoud van de leiderschapsles teruggespeeld door de retoriek in de tekst?

\subsubsection{Over het succes van de basketbal-metafoor}

"Follow the leader...leader...leader...."

Met retorische kracht onderstreept de auteur zijn intuïtie over leidinggeven in het postmoderne tijdsbestek. Dat er zeven grondbeginselen van succes zijn appelleert aan onze overtuiging dat we hier met een kern van 'heilige' principes te doen hebben: god schiep de wereld in zeven dagen, onze week telt zeven dagen en in het klassieke (archimedische) wereldbeeld cirkelden er om de aarde zeven planeten. De vanzelfsprekenheid waarmee de auteur de basketbalmetafoor introduceert is een toonbeeld van het eerste principe: poneer jezelf als winnaar, wees van je eigen succes overtuigd! Door de magische kracht van de leiderschapsmetafoor kan deze 'American dream' werkelijkheid worden. Het is geen kwestie van genialiteit op geestelijk of fysiek nivean, maar het simpelweg toepassen van een succesformule. We hoeven geen Ford, Albert Heyn of Walt Disney te heten om de magie van de metafoor te begrijpen. De zeven grondbeginselen van succes vormen met de geciteerde uitspraken van coaches schering en inslag van de tekst. Ik word als lezer langs dit vlechtwerk van succesprincipes en succesverhalen heengeleid. Met elke regel bekruipt mij meer het gevoel ingewijde te worden in een simpele maar krachtige missie voor leidinggeven in het informatietijdperk. De metaforische kennis is evenwel ook

43. Deze 'retorische analyse' van de wijze van overdracht van de inhoudelijke boodschap is gebaseerd op Watzlawick's onderscheid tussen inhouds- en betrekkingsniveau, in: De pragmatische aspecten van de menselijke communicatie 42 e.v.

44. Populaire song van de groep Cross \& Fyah. 
'hermetisch': ze blijft besloten binnen de metafoor tot we haar gaan toepassen op ons eigen team. Dit wordt door het tweede principe bekrachtigd: Er zal niets gebeuren tenzij je zelf actie onderneemt. Het tweede principe poneert de mentale switch die we moeten maken als sleutel tot succes. Speel jezelf als overwinnaar is niet zomaar een spelletje maar een voorwaarde om jezelf als individu en als deel van de organisatie het succes toe te eigenen, om je identiteit als winnaar te constitueren. Om aan deze positieve variant van het principe van 'selffulfilling prophecy' gehoor te geven, moeten we natuurlijk van het eerste principe heilig overtuigd zijn. De auteur roept bij mij als lezer een gemengd gevoel op, een zekerheid door de bevestiging van bekende noties en een fascinatie door nieuwe inzichten, grenzend aan (on)geloof aangezien ze wonderschoon kloppen.

Bekommer je om het systeem en er zal ook voor jou gezorgd worden. Het diepverankerde oerbesef van deze sociale wet heeft eveneens een retorische tegenhanger in de tekst. Analoog aan dit derde beginsel van sociale wederkerigheid is de correspondentie tussen de mate waarin de metafoor succesvol de tekst als geheel organiseert met de kracht van haar toegespitste betekenis. De metafoor profileert zich niet alleen op haar eigen gebied van sport en spel maar ook op de 'topos' van organisaties. Elke particuliere 'match' van een organisatorische functie met een spelersrol overtuigt de lezer van de werkzaamheid van de metafoor als geheel, en andersom, de 'adequatio' van de metafoor in het algemeen bevestigt het 'kloppen' van de basketbalmetafoor tot in detail. Zo word ik als lezer primair emotioneel geraakt door de verrassende herkenning van het analoge verband, waarna ik cognitief in de inhoud van de boodschap ga geloven. De verschillende rollen van de basketbalspelers corresponderen wonderlijk genoeg één op één met de kernwaarden van een organisatie-cultuur van winnen: innovatie, integratie, productie, motivatie, balans, groei, hulpbronnen en ondersteuning. Door een prettig, harmonieus gevoel dat we ervaren wanneer we in de werkelijkheid geen chaos aantreffen, maar verbanden die precies in elkaar grijpen, zijn we rijp voor de les van 'gedeelde verantwoordelijkheid' en 'teamspirit'! Deze les leert het vierde beginsel: Profileer jezelf op jouw gebied, maar leer ook op andere plaatsen te functioneren. Ook de auteur is geen solist, hij getuigt van 'teamspel': de leiderschapsles heeft hij samen met topsporters, coaches van succesvolle basketbalteams en 'zwaargewichten' uit de auto-industrie opgesteld. Deze metaforische uitleg maakt de samenhang tussen 'multifunctionaliteit' en 'stressbestendigheid' begrijpelijk. Een championship-team weet in tijden van 'transitie' en 'crises' de dreigende chaos te keren in kansen voor groei en innovatie. De basketbal-metafoor concretiseert abstracte managementconcepten tot tastbare en zichtbare beelden. De auteur beweegt zich met hinkstapsprongen van de wereld van organisaties naar het sportveld en realiseert hiermee het vierde succesprincipe.

De auteur blijkt ook een meester te zijn van het zesde leiderschapsprincipe: speel niet zomaar een spelletje, maar leer en implementeer spelpatronen. Tussen zijn eigen reflecties door laat hij andere kenners van sport en organisaties aan het woord. De wijze waarop hij hun bevindingen citeert en parafraseert gaat volgens 
een patroon van 'elkaar de bal toespelen'. Dit is de manier waarop topspelers direct, intuittief en effectief 'intunen' op 'turbulentie' tijdens een topwedstrijd, zonder zich af te vragen hoe hun de bal is toegespeeld en hoe zij deze verder zullen spelen. Ook de auteur bekommert zich minder om nauwgezette argumentatie en onderbouwing, maar formuleert doeltreffend de zaak waarover het gaat. Zie hier, lezer, de basisprincipes, hoe ze werken en waarom, ik speel ze u toe, als balletjes die direct en zeker zullen scoren.

Rest de vraag: Hoe wordt de gemiddelde werknemer een topbasketbalspeler die zowel functioneel uitmunt op een specifieke positie als multifunctioneel inzetbaar is, stressbestendig en juist creatief in tijden van crises? Dit vormt de "quintessence', de boodschap van het vijfde succesprincipe. Volgens de auteur berust "championship performance" op een "shared vision and mission". Maar onder het gras van het 'softe harmoniemodel' schuilt het addertje van een heftige concurrentiestrijd. Met de verplaatsing van het basketbal-organisatieprincipe van de 'zachte' naar de 'harde sector' gaat een betekenisverschuiving gepaard, die succes in verband brengt met strijd en vijandigheid. Dit wordt door het zevende principe geformuleerd: verdediging is de beste aanval.

The championship basketball system relies on a team-oriented, pressure defense that rotates towards the opponent with the ball and moves aggressively in an attacking and relentless fashion. ${ }^{45}$

Uiteindelijk blijkt oorlog toch de vader van alle dingen te zijn: het echte leiderschap ademt een geest van 'onverzoenlijke agressie'. Sleutelconcepten uit de leiderschapsles bevatten versleten militaire metaforen zoals 'aanval', 'verdediging', 'tegenstander' en slapende mechanistische metaforen zoals 'kracht', 'energie' en 'druk'. Achter de uiterlijke humanistische glans van organisatorische kernwaarden van 'het algemene belang', 'cohesie', 'creativiteit en 'innovatie' blijkt een gedragsmatig beloningssysteem het 'zelf-actualiseren' pavloviaans te bekrachtigen. Eufemistisch wordt van 'educatie' gesproken, maar in de dagelijkse praktijk van organisaties zal het neerkomen op sociale en economische druk op iedere werknemer om even goed, snel en effectief uit te munten in leiderschapskwaliteiten. Gij zult een leider worden en Gij zult zich ten eeuwigen dage blijven ontwikkelen, doorleren en groeien zijn de geboden van deze managementovertuiging.

\subsubsection{De dubbele boodschap van succes}

"Als ik een woord gebruik, zei Humpty Dumpty op nogal smalende toon, dan betekent het precies wat ik wil dat het betekent - niks meer en niks minder".

"De vraag is," zei Alice, "of je wel kunt maken dat woorden zoveel verschillende dingen betekenen".

45. Leadership lessons from championship 42. 
"De vraag is," zei Humpty Dumpty, "wie de baas zal zijn - dat is alles. "46

De basketbalmetafoor is niet alleen ambivalent omdat een metafoor per definitie een 'overdrachtelijke betekenis' aan de 'conventionele inhoud' toevoegt. Onder de cognitieve oppervlakte van de metaforische leiderschapsles zit een paradoxale boodschap verscholen, die lijkt op een 'dubbele binding ${ }^{47}$. Om het succes deelachtig te worden moet aan onvervulbare voorwaarden worden voldaan. Zelfs een professioneel topteam speelt immers niet uitsluitend succesvolle wedstrijden waarin crises en chaotische spelsituaties tot kansen om te scoren worden gekeerd. 'Succes' krijgt in de metaforische uiteenzetting de surrealistische betekenis van het aaneenrijgen van de ene glansrijke overwinning na de andere. In deze wereld van 'glamour and glory' lijkt er geen tegenslag, faalangst, gemiste kansen of domme fouten te bestaan, evenmin de minder leuke kant van het moeizame trainen met momenten van wanhoop om toch vol te houden, laat staan dagelijkse beslommeringen, onzekerheid of sleur. Dit wordt ook onomwonden zo gesteld: "On the championship basketbalteam everyone is a leader". Hierbij wordt verwezen naar Weicks concept van 'enactment', hetgeen deze managementvariant van de Maslowiaanse welzijnsboodschap uit de jaren ' 60 en '70 een wetenschappelijk cachet geeft. De leiderschapsmissie is een stralende zon in het zenit die geen schaduw werpt, zoals de 'zelf- geactualiseerde mens' uit de humanistische psychologie geen schaduwkanten meer kent. Deze zon in het betoog is zo sterk dat elk opkomend kiempje van twijfel door een verzengende hitte verschroeid wordt. De missie wordt uitgedragen door een monoloog van zelfverzekerdheid. Er is geen meerstemmigheid in de melodie te beluisteren, laat staan dissonanten of valse noten, tegenmelodie noch tegenritme,- wel spreekt de stilte van het ontbreken van deze geluiden.

Deze stilte onderstreept de messcherpe retoriek waarmee de nieuwe stijl van leidinggeven wordt verkocht. Door de zachte disciplinerende macht van de humaniora worden ook de werknemers, die zich voor het leiderschap niet geschikt achten - zich te oud of niet in staat voelen dan wel geen zin hebben in te stappen in de carrousel van de 'education permanente' - met harde hand sociaal gedemoveerd, gedegradeerd of uitgerangeerd. De blijde boodschap van de nieuwe kerstening creëert haar eigen ketters. Door een subtiele sociale technologie wordt er een groep gemarginaliseerden aan de zelfkant van de samenleving toegevoegd: na de goddelozen, de criminelen, de daklozen en de redelozen zijn er nu ook de 'zelflozen' die hun 'innerlijke leider' weigeren te actualiseren. Gij zult zich transformeren tot een flexibel, stressbestendig en multifunctioneel Zelf! Dat het om een blijde boodschap met religieuze kracht gaat is gemaskeerd achter het wereldlijke karakter van de basketbalmetafoor. Deze spreekt ons allen aan en verpakt een 'tricky' (in de dubbelzinnige betekenis van het woord) managementmodel in een simpel beeld. De lessen uit de metafoor worden 'straight' gebracht en ogen ondogmatisch, want met 'redenen' omkleed. De argumentatie ademt echter een dictatoriale geest van evidentie. De 'grondbeginselen' die de leiderschapsles zouden

46. De pragmatische aspecten van de menselijke communicatie 67.

47. Ibidem. 171 e.v. 
moeten onderbouwen, komen als zelf-evidente 'redenen' uit de lucht vallen. $\mathrm{Nu}$ eens worden het 'sleutelfactoren' genoemd, dan weer zou het om 'essentiële ingrediënten' of 'elementen' van succes gaan. Wat de uiteindelijke drijvende kracht achter het succesverhaal is, komt als aap uit de mouw aan het einde van de leiderschapsles. Ter verheldering van het zesde basisprincipe wordt met zoveel woorden gesteld dat de blijde boodschap 'pays off. Een organisatie die de paradigmawisseling van een voetbal- naar een basketbalmentaliteit genereert zal dat dubbel en dwars terugverdienen, want

They tend to attract, retain the best employees. They tend to develop the best technology, the best new product, the most effective process. They tend to satisfy more customers more consistently. They tend to have more fun. ${ }^{48}$

Wie zou deze verleiding kunnen weerstaan? Maar ook: welke organisatie kan de mooie belofte ooit waarmaken? Ten slotte: hoe kunnen we aan de verleiding van dit 'heilige moeten' ontsnappen, want de dubbelzinnige, agressieve maar vreedzaam ogende boodschap dat 'verdediging de beste aanval is', wordt met gespierde taal onderstreept:

The most important thing is to start, because once others in your industry start demonstrating championship capabilities, you may never catch up ${ }^{49}$

Met dit laatste schot schiet je als lezer vanzelf in de verdediging. Wanneer ons de bedoelde economische straf ten deel valt is het immers onze eigen schuld door het overtreden van het nieuwe gebod?

Voor degegen die zich laten inspireren resp. manipuleren door de metafoor blijt het evenwel de vraag hoe de organisatie-ontwikkelingsdoelstelling concreet voor de praktijk te vertalen. Last de auteur op dit punt een retorische stilte in, als ware zijn metafoor een verkapte reclameboodschap om de succesformule door zijn consultancybureau te laten implementeren? De basketbalboodschap draagt evidente doch hermetisch gesloten kennis over. We kennen de boodschapper van dit soort kennis als de slang uit het paradijsverhaal. Het succesvol toepassen van de basisprincipes vraagt om een manoeuvre, vergelijkbaar met de beweging van een slang die in haar eigen staart bijt. Het 'succesvolle basketbalteam' vooronderstelt immers dat de switch tot een 'basketbalmentaliteit' reeds gemaakt is. Dan pas is het slotakkoord van de tekst geen cirkelredenering maar zo klaar als een klontje, zoals de auteur het ook brengt: het belangrijkste is om gewoon te beginnen!

48. Leadership lessons from championship 46.

49. Ibid. 48 . 
Eine neu Gattung Philosophen kommt herauf: ich wage es, sie auf einen nicht.......ungefauhrlichen Namen zu taufen....mochten diese Philosophen der Zukunft als Versucher bezeichnet werden. (...) Brauche ich nach alledem noch eigens zu sagen, dass auch sie freie, sehr freie Geister sein werden, diese Philosophen der Zukunft... ${ }^{\text {so }}$

Met dreigende taal leren we hoe het geluk deelachtig te worden. De metaforische les forceert ons in het goede nieuws te gaan geloven. De sportmetafoor organiseert in de tekst een 'competitieretoriek' die de boventoon voert ten opzichte van de gepropageerde 'teamspirit'. Het perspectief van 'fair play' staat uiteindelijk in de schaduw van een vijandige concurrentiementaliteit. 'Fair play' verwijst naar een ethische invalshoek, die kan voorkómen dat de gronddynamiek van sportiviteit en samenspel uit balans raakt. Metaforisch gesproken wordt er vanuit een competitiementaliteit eenzijdig voor 'de knikkers' ten koste van 'het spel' en 'de spelers' gekozen. Spelen om het spel articuleert als het ware een ethische basishouding van spelers die het spelen als kunst en het plezier in het spel primair stellen ten opzichte van het einddoel om te winnen. Het principe van 'fair play' creëert een 'ludieke norm voor rechtvaardigheid' tussen de spelers, waardoor de instrumentele doelstelling van concurrentiestrijd en winnen wordt gerelativeerd. Niettemin blijft het grondgegeven bestaan dat het spel winnaars en verliezers kent. Uit het 'ludieke rechtvaardigheidsbeginsel' volgt dat een team omwille van het spelen van het spel zich inzet om te winnen maar niet andersom dat het spel om de winst wordt gespeeld. Deze laatste omdraaing is het addertje onder het gras van de basketbalmetafoor. Door die perspectiefwisseling wordt de sportmetaforiek op onkritische wijze gebonden aan eisen van de organisatorische instrumentele rede om te winnen koste wat het kost. Deze gebondenheid heeft het karakter van een 'dubbele binding' omdat er tegelijkertijd de 'worst van bevrijding' voor de neus wordt gehouden.

Wellicht zal een doorsnee-reactie op het nieuwe geloof in 'flexbanen', 'championship organizations', 'high performing teams' en 'employability' onzekerheid, onrust en weerstand zijn. Wanneer het succesverhaal niet wordt belichaamd door cen levend geloof van werknemers en organisatie in zichzelf en in elkaar, wordt het een 'geestelijke dwangbuis van succes'. Daarbij is het de vraag of er geen belangen of fundamentele rechten van personen of groepen worden geschaad, zoals 'het recht op arbeid' van werknemers die geen leiderschapsambities koesteren. Wanneer dergelijke psychologische en ethische vragen overgeslagen worden, komt 'het misleidende aspect' van de metafoor naar voren. We zouden de basketbalmetafoor kunnen herformuleren door de invalshoek van 'fair play' juist op de voorgrond te stellen. In overeenstemming met die alternatieve interpretatie kunnen we in organisatiekundige literatuur aanknopingspunten vinden hoe dit perspectief concreet te vertalen voor een

50. Nietzsche: Jenseits von Gut und Böse in: Werke III 53-54. 
organisatiecontext. ${ }^{51}$ Dit zou onder meer betekenen dat de organisatie-(veranderings-) kundige veeleer een facilitator en procesbegeleider wordt dan een expert. Deze bewaakt het proces en bewaart een kritische afstand tot de sociale dynamiek en de metaforische retoriek. Een capabel organisatie-(veranderings)kundige munt niet zozeer uit in het voorschotelen van modieuze, exotische en succesvolle veranderingsmetaforen, maar in het genereren van een bepaald emotioneel klimaat. Er is immers vertrouwen en betrokkenheid van werknemers nodig om te achterhalen welke organisatiebeelden er leven, en welke beweegredenen er zijn om voor sommige metaforen warm te lopen en zich tegen andere te verzetten. Het daadwerkelijk vormgeven van de invalshoek van 'fair play' vraagt van de 'veranderingskundige' om aan te sluiten bij de belevingswereld van alle betrokkenen in een organisatie. Dit 'aansluiten' betekent onder meer dat z(h)ij hun (beelden)taal leert verstaan en de voorwaarden voor communicatie schept zodat zij zelf de metaforen creëren die passen bij 'de organisatorische werkelijkheid' waarin ze (niet/ wensen te) leven.

Onder deze randvoorwaarden kan een leiderschapsmonoloog worden omgebogen tot een dialoog, waarin de door het topmanagement gewenste veranderingsrichting met een metafoor ter discussie aan alle betrokkenen wordt voorgelegd. De consequentie hiervan is dat vraagstukken van 'flexibiliteit', 'employability' en 'de lerende organisatie' complexer worden dan het simpelweg toepassen van een succesformule. Uiteindelijk wil iedereen, ook een 'doorsnee-werknemer met een voetbalmentaliteit van het industriële tijdperk' gehoord en serieus genomen worden. Het is aannemelijk dat als gevolg van een gelijkwaardige verdeling van (materiële en immateriële) winst en verantwoordelijkheid commitment voor de organisatie op grond van de dialectiek van 'betrokken-worden' en 'betrokken-raken' op een natuurlijke wijze voortvloeit. Het proces van organisatie-ontwikkeling wordt dan een waagstuk om de pluriformiteit van levende metaforen te laten spreken in een 'organisatorische multiloog'. Laten we dus niet alleen maar een les leren uit 'het succesvolle basketbalteam', maar vooral uit de 'succesvolle basketbalmetafoor'. Op deze manier kunnen we haar metaforische boodschap herinterpreteren. Niet zozeer relevant is het zoeken naar 'succesfactoren' van de basketbalorganisatie, maar het reflecteren over de wijze waarop de basketbalmetafoor als een krachtig retorisch instrument fungeert voor (het denken over) veranderings- en ontwikkelingsprocessen in organisaties. Deze perspectiefverandering zorgt ervoor dat het metaforische proces van betekenisgeving als zodanig centraal gesteld wordt, in plaats van de specifieke metafoor die op grond van haar retorisch vermogen gereificeerd en instrumenteel in het organisatiediscours opduikt. Deze 'linguistic turn' genereert een beslissings- en (onder)handelingsruimte waarin waardegestuurde bezinningsmomenten ten aanzien van het strategische handelen en instrumentele denken in organisaties worden bewaakt en bewaard. Wanneer zulks gerealiseerd wordt, is het resultaat ten opzichte van de basketbalmetafoor een minder 'flexibele' leiderschapsles. Als voorbeeld van een waardegestuurde visie op leiderschap citeer ik Gandhi's 'oproep tot burgerlijke ongehoorzaamheid' ten tijde

51. Bijvoorbeeld: Brenters: De organisatie als netwerk. Hoe mensen organisaties veranderen en organisaties mensen. Schön: The Reflective Practioner. How professionals think in action. 
van de Britse overheersing van India. Het komt mij voor dat beide 'leiderschapslessen' vanuit een vergelijkbare humanistische inspiratie spreken: om als individu in een positie van 'innerlijk leiderschap' te gaan staan. De laatste heeft evenwel niet alleen een sterk retorisch effect maar behelst tevens een sociaal gedragen 'spelmetafoor' die een aanzet geeft tot reflectie, bezinning en politieke moed om niet langer een speelbal van politieke krachten te zijn:

We are all puppets in their hands. But it would be wrong and foolish to blame the authority. That authority does not compel us to be puppets. We voluntarily run into their camp. It is therefore open to any and every one of us to refuse to play the British game. ${ }^{52}$

\subsection{Een metaforische benadering van organisaties}

Er verschijnen in de (Amerikaanse) managementliteratuur aan de lopende band nieuwe metaforen die als 'de sleutel tot succes' worden aangeprezen. In dit populaire genre lijkt het erop dat de instrumentele rede zich maskeert achter een alternatieve look. Is dus de conclusie dat in het organisatie-discours alleen ogenschijnlijk een 'humanistische organisatorische rationaliteit' wordt gearticuleerd, die uiteindelijk een ludieke verschijningsvorm van 'de instrumentele rede' blijkt te zijn? Dat er massaal creatieve middelen, succesverhalen uit de consultancypraktijk, innovatieve managementideeën, vernieuwde stappenplannen en succesformules worden aangeboden en ingekocht is uiteindelijk immers ter verhoging van de organisatorische winst, effectiviteit en efficiëncy? Niettemin zijn er in het organistiediscours ook teksten aan te treffen ${ }^{53}$ die in aanzet een alternatieve vorm van rationaliteit vertegenwoordigen. Zou het zo kunnen zijn dat daarin een 'communicatieve rationaliteit' tot expressie wordt gebracht, met speciale aandacht voor de rol van verbeelding, intuitie en emotionaliteit voor de generatie van (praktijk)kennis? Op welke wijze zijn deze elementen van belang met betrekking tot een ijkpunt voor 'metaforische communicatie en interactie', teneinde metaforen esthetisch, psycho-sociaal en ideologisch te toetsen? De veronderstelling van dit onderzoek is dat op basis van een dergelijke alternatieve vorm van rationaliteit er een richtsnoer kan worden geformuleerd voor 'een

52. Gandhi, geciteerd in Parekh: Gandhi's Political Philosophy. A Critical Examination 124.

53. Bijvoorbeeld: Goia \& Chittipeddi: Sensemaking and sensegiving in strategic change initiation Strategic Management Journal. (12) 433-448; Palmer \& Dunford: Conflicting uses of Metaphors: reconceptualizing their use in the field of organizational change Academy of Management Review (21) 691-717. Weick: Theory Construction as Disciplined Imagination Academy of Management Review (14) 4, 516-531.Yanow: Supermarkets and Culture Clash: The Epistemological Role of Metaphors in Administrative Practice American Review of Public Administration (22) 2, 89-109. Tsoukas: Analogical Reasoning and Knowledge Generation in Organization Theory Organisation Studies (14) 3, 323-346. Hirschman: Ideology in Consumer Research, 1980 and 1990: A Marxist and Feminist Critique. Journal of Consumer Research (19) 537-555. Behn: Management and the Neutrino: The Search for Meaningful Metaphors Public Administration Review. (52) 5, 409-419. 
metaforische benadering van organisatievraagstukken'. Op grond daarvan zullen er metaforen worden gegenereerd die zowel effectief zijn als sociaal gedragen en principieel kritisch (kunnen) staan ten op zichte van de heersende ideologie. Zonder die grondslag kan 'de trend van creatieve benaderingen van organiseren' niet worden onderscheiden van een tijdelijke lucratieve hype die even snel weer plaats zal maken voor een nieuwe mode.

Inmiddels is er een serieuze discussie ontstaan over de (vrij)blijvendheid van de metafoor en over de noodzaak om een methodologisch kader voor haar wetenschappelijke toepassing te ontwikkelen ${ }^{54}$ De vraag of er een 'organisatorische meetlat' voor metaforen bestaat vormt de aanleiding voor een aantal symposia en publicaties over het onderwerp metaforen en organisaties. ${ }^{55}$ Daarin zijn verschillende posities ten aanzien van het gebruik van metaforen in de organisatieliteratuur in kaart gebracht en vertegenwoordigers van standpunten aan het woord gelaten. In de tweede paragraaf van dit hoofdstuk is aan de vraag naar een 'maat' voor metaforen aandacht geschonken, onder meer tegen de achtergrond van een 'constructivistisch' versus een 'non-constructivistisch' standpunt, van 'voorstanders' en 'tegenstanders' van het gebruik van metaforen in de organisatiekunde. Het uitgangspunt in voornoemde reeks publicaties is echter niet om een bepaald 'pro-' of 'contra'-standpunt ten aanzien van de metafoor in te nemen maar om bestaande discussies te inventariseren en nieuwe concepten, metaforen en toepassingen te ontwikkelen. Centraal hierbij staat de vraag hoe metaforen toegesneden kunnen worden ten behoeve van organisatieonderzoek en organisatieontwikkeling. Zijdelings wordt aandacht besteed aan de epistemologische problematiek die hierbij meespeelt. Welke theoretische status heeft de metafoor in de organisatiekunde? Wat is de consequentie van het gegeven dat er geen funderingsroute kan worden bewandeld buiten de metafoor om $^{56}$ ? Wat betekent de onderkenning dat er alleen een relatieve grondslag kan worden gegeven, dat wil zeggen een herleiding tot een 'intern standpunt' dat zelf ook principieel metaforisch van aard is? Mogelijk wordt nu in het spoor van een 'post-modern' fin de siecle definitief afscheid genomen van het zoeken naar een 'onafhankelijk en absoluut ijkpunt', waaraan metaforen ontologisch en epistemologisch kunnen worden afgemeten. De consequentie van een dergelijk relativisme is de onderkenning dat het slechts mogelijk is om hun relatieve waarde ten opzichte van

54. Bijvoorbeeld tussen Morgan, die als een 'radicaal constructivist' te boek staat en meer 'gematigde constructivisten' die op het gevaar van het gebruik van metaforen in een wetenschappelijke context wijzen: Pinder \& Bourgeois: Controlling Tropes in Administrative Science in: Administartive Science Quarterly. Dec. 1982. Morgan: More on Metaphor: Why We Cannot Control Tropes in Administrative Science Administartive Science Quarterly (28) 601-607.

55. In de negentiger jaren van de vorige eeuw aan het King's College in Londen met publicaties onder redactie van David Grant \& Cliff Oswick.

56. De redacteuren lijken Derrida's standpunt (in: Marges de la Philosophie) te onderschrijven, dat er voor een sluitende theorie over metaforen altijd een metafoor 'te weinig is' om de impliciete metaforen in de theoretische grondbegrippen te definiêren, zodat het onmogelijk is een 'metaforologie' op te stellen (een theorie die zelf niet behept is met metaforische betekeniseffecten) of 'een metafoor teveel' door de onvermijdelijke 'metaforiek' in teksten. 
elkaar en ten opzichte van een externe waarde of doelstelling aan te geven,bijvoorbeeld het oogmerk om wetenschappelijke kennis te genereren of het doel 'om organisaties diagnostisch te lezen'. Dat het onmogelijk is om de metafoor tot een 'niet-metaforische grondslag' te herleiden trekt een wissel op een fundamenteel filosofische invalshoek om haar verschillende verschijningsvormen en haar praktische werking te beschrijven. Daarmee is de organisatiekundige weg geopend, die ook in voornoemde publicaties wordt bewandeld, om metaforen te groeperen en te typeren met betrekking tot de doelstellingen waarvoor ze worden gebruikt. Tegenover de fundamentele vraagstelling naar 'de grondslag van metaforische communicatie' worden dergelijke 'regionale routes' veeleer gekenmerkt door een instrumentele en functionele optiek.

Ook in het onderhavige onderzoek wordt het radicale uitgangspunt van 'de onontkoombaarheid en de onherleidbaarheid van de metafoor' onderschreven. De conclusie die ik hieraan verbind is om de mogelijkheid te onderzoeken of er een metaforische grondslag dan wel een grondslag op metaforische wijze kan worden gearticuleerd. Dit heeft consequenties voor de gezochte 'derde grondhouding tussen rationalisme en romantiek', namelijk dat zij zelf de metaforische aard van hetgeen $\mathrm{zij}$ fundeert vooronderstelt. Dit 'circulaire gegeven' nodigt uit tot een hermententisch gezichtspunt. Daarbij is vooral van belang dat de 'eigen vooringenomeıneic, het 'subjectieve' en het 'ideologische' karakter van het ingenomen standpunt, niet kan worden 'bewezen' noch 'ontkracht' op grond van een 'neutrale' of 'objectieve' positie. Volgens de hermeneutiek dienen 'vooringenomen' ideeën, associaties en veronderstellingen niet als 'bias' te worden buitengesloten maar als onderzoeksmateriaal in de reflectie meegenomen. Ze worden als 'bron' voor het proces van betekenisgeving positief gewaardeeerd. De eerste subparagraaf geeft een indruk van enkele 'regionale routes' die bewandeld zijn om het (wetenschappelijke) gebruik van metaforen method(olog)isch in te kaderen. In de volgende subparagraaf worden enkele voorbeelden uit de literatuur behandeld waaruit een 'dialogisch principe' wordt gedestilleerd teneinde de praktijk van 'metaforische communicatie' kritisch-humanistisch te onderbouwen.

\subsubsection{Metaforen en rationaliteit}

Aan de hand van Morgans werk zijn er 'drie niveau's' onderscheiden waarop de metafoor figureert: in meta-theoretische reflecties, op het niveau van de wetenschappelijke theorievorming, en op het toepassingsniveau van management. Op het eerstgenoemde 'hoogste' of 'diepste' niveau (afhankelijk van welke metafoor men als indelingscriterium voor kennis kiest) werken metaforen op paradigmatische wijze in het proces van betekenisgeving door. Een 'paradigmatische metafoor' blijkt uit de wijze waarop 'de (organisatorische) werkelijkheid' wordt geconceptualiseerd en beschreven. Dit niveau van metafoorgebruik komt overeen met Burrell en Morgans' 'raster' van 'metaforische paradigmata': 'functionalistisch', 'interpretatief, (radicaal) humanistisch' en 'structuralistisch'. Derrida spreekt in 
dit verband van 'meta-metaforen'. Op analoge wijze worden termen gebruikt als 'macro-metaforen', 'verhaalmetaforen' en 'moeder-metaforen,57. Vergelijkbare indelingen berusten op een verondersteld fundamenteel 'metaforisch niveau' ten opzichte van afgeleide niveau's: 'diepte-metaforen' en 'generatieve metaforen',58, 'wortel-metaforen' 59 , 'sterke' metaforen ${ }^{60}$, 'geslaagde metaforen' ${ }^{61}$ en 'metaforische velden' ${ }^{62}$ zouden aan de basis staan van onze 'standaard' metaforen en cliché-beelden. Met betrekking tot de bedrijfskunde kan ter illustratie op de metafoor van de 'mens-machine' en de oorlogsmetafoor worden gewezen die een grondslaggevende rol vervullen.

Anderssoortige indelingen berusten niet zozeer op 'niveau-verschillen' in metafoorgebruik, maar geven een andere taalfilosofische typering aan. Een bekende is die van 'dode' en 'slapende' tegenover 'levende metaforen ${ }^{36}$, van 'nieuwe' tegenover 'versleten' metaforen ${ }^{64}$, of het verschil tussen 'structural' en 'orientational' metaforen ${ }^{65}$. Een andere wijze van systematisering wordt verkregen wanneer de metafoor als stijlfiguur ten opzichte van andere 'tropen' wordt gesitueerd, zoals de metonymie, de synecdoche, de simile en de personificatie ${ }^{66}$. Vanuit een taalpsychologische invalshoek is een onderscheid gemaakt tussen visuele, auditieve, kinesthetische metaforen en kunnen typologieën worden opgesteld aan de hand van de psychologische functie van metaforen, bijvoorbeeld defensieve, ondersteunende en start-metaforen. ${ }^{67}$ In dit onderzoek is naast de filosofische insteek ook een psychologisch indelingscriterium gehanteerd om te kunnen onderscheiden tussen 'emotionele', 'cognitieve' en 'interactieve' (waarde van) metaforen. Dit onderscheid is gebaseerd op de analyse van creatief therapeutische literatuur uit het vorige hoofdstuk, in het bijzonder de gekarakteriseerde 'antropologische invalhoek' op de psychologische functie annex symbolische betekenis van beelden. Voor de 'deconstructie' van de basketbalmetafoor heb ik van deze psychologische optiek op metaforen gebruik gemaakt om te onderzoeken hoe de inhoudelijke boodschap door het betrekkingsniveau van communicatie wordt bekrachtigd of gerelativeerd.

57. Buys: Metaforiseren. Naar een procesgerichte visie op metaforen 51.

58. Schőn: Generative metaphor: A perspective on problem setting in social policy in: Ortony: Metaphor and Thought.

59. Grant \& Oswick (ed.) Organisation Development 193-204.

60. Black: More on Metaphor. In: Ortony: Metaphor and Thought 27.

61. Bulhof: Darwins Origins of Species: Betoverende wetenschap

62. Marshak: Metaphors, Metaphoric Fields and Organizational Change. in Grant \& Oswick (ed.) Metaphor and organisations 147-166.

63. Bijvoorbeeld: Ricoeur: La métaphore vive. Zie voor een verdere uitleg van deze termen hoofdstuk 4, paragraaf 3.2

64. Nietzsche: Ueber Wahrheit und Linge im aussermoralischen Sinn 6.

65. Lakoff \& Johnson: Metaphors We Live By

66. Gibbs: Process and products in making sense of tropes. in Ortony: Metaphor and Thought. 252-

276. Zie voor de betekenis van deze terminologie hoofdstuk 4 paragraaf 1.

67. Derks \& Hollander: Essenties van NLP. Sleutels tot persoonlijke verandering 426. 


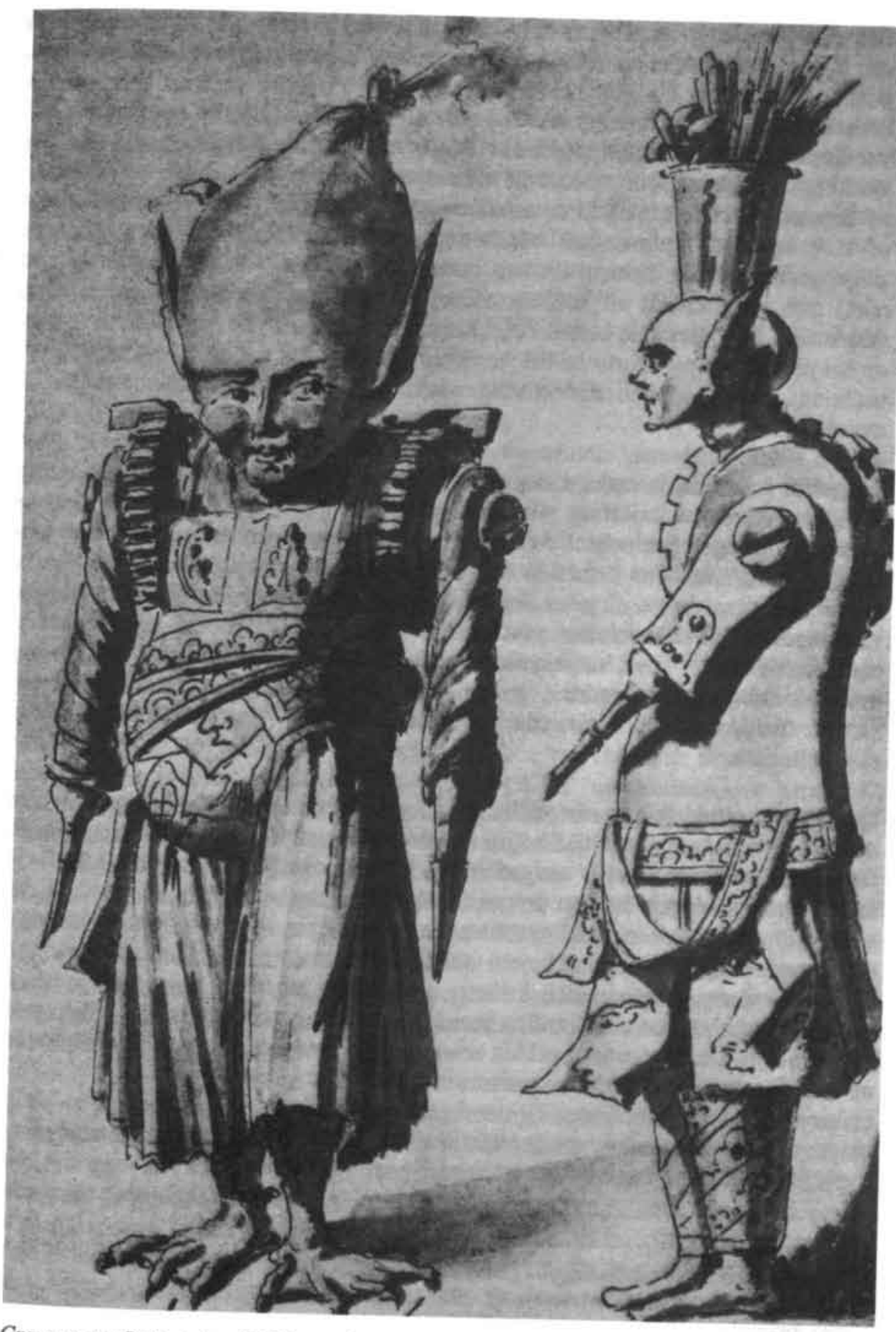

Gravure van Peticot (ca. 1771) van de mens-machine 
In vergelijking met een linguïstische categorisering in soorten stijlfiguren, verlegt een taalpsychologische en taalfilosofische benadering de aandacht van het linguïstische product naar het proces van 'metaforiseren', waarbij vaak op een innerlijk verband van taalstructuren met het ken- of denkproces wordt gewezen ${ }^{68} \mathrm{Bij}$ voorbeeld vanuit een taalfilosofische invalshoek verklaart men de semantische werking van de metafoor meestal in termen van een 'vergelijkings-', 'substitutie-" of 'interactiebenadering' ${ }^{69}$ In de eerste twee benaderingen wordt de metafoor min of meer als het eindresultaat beschouwd van het proces van vergelijken of substitueren van een element uit het 'onderwerpdomein' (waar het eigenlijk over gaat) met een element uit het 'metafoordomein' (waarnaar de betekenis wordt verplaatst). De 'interactie-benadering' kenmerkt zich door een dynamischer optiek op het proces van metaforische betekenisgeving: namelijk dat de 'overdrachtelijke' betekenis berust op een dialectische wisselwerking tussen beide betekenisdomeinen.

De meest bewandelde onderzoekspaden in de organisatieliteratuur komen uit op een algemene karakterisering van de functionaliteit van metaforen voor organisatie- en managementdoelstellingen dan wel op een meer toegespitste 'metaforische typering' van een bepaalde organisatie of managementstijl. Zo worden er vooral biologische en ecologische metaforen aangeprezen om, ten opzichte van een traditionelere 'mechanistische' manier, een eigentijdse wijze van organiseren te conceptualiseren. ${ }^{70}$ Een 'metaforische benadering' kan bijvoorbeeld vanuit een bedrijfskundige optiek worden geoperationaliseerd tot het aangeven van 'de sterke' en 'de zwakke kanten' van een specifieke metafoor wat betreft organisatiedoelstellingen.

Uit deze bespreking van verschillende mogelijkheden om een systematiek van metaforen te ontwerpen, blijkt het in de vorige paragraaf besproken fundamentele filosofische probleem dat is aangeduid als 'de onmogelijkheid van een metaforologie'. Dat wil zeggen: hoe het proces van metaforische betekenisgeving ook wordt ingedeeld, het gekozen indelingscriterium van 'diepte, 'wortel', 'moederschap', etc. berust zelf ook op een impliciete metafoor. Daarnaast zal er nooit een volledige of een consistente systematiek kunnen worden aangebracht, aangezien er altijd metaforen zijn of gecreèerd zullen worden die niet (eenduidig) in de indeling te plaatsen zijn. Deze bezwaren gelden zowel voor het aanbrengen van een hiërarchie tussen verschillende soorten metaforen als voor andere taalfilosofische en taalpsychologische indelingen. Bijvoorbeeld de in dit onderzoek gebruikte indeling in cognitieve, emotionele en interactieve metaforen gaat uit van een psychologische betekenis van 'de meerwaarde' van metaforen met het oog op een

68. Ankersmit \& Mooij: Knowledge and Language. Metaphor and Knowledge (vol III).

69. Mooij: A Study of Metaphor: On the Nature of Metaphorical Expressions, with Special Reference to their Reference.

70. Bijvoorbeeld: Broekstra: The Triune-Brain Metaphor: The Evolution of the Living Organism. in: Organisation Development 53-73. 
communicatie-, interventie- of veranderingsdoelstelling in het kader van therapie of organisatietrainingen.

Met betrekking tot dergelijke analytische onderscheidingen is in deze paragraaf gewezen op een fundamenteel filosofisch probleem bij het ontwerpen van een 'maat voor metafoorgebruik'. De gesignaleerde problematiek hangt samen met een traditioneel begrip van rationaliteit dat een universeel criterium voor de legitimatie van kennis proclameert. In volgende subparagraaf zal worden ingegaan op voorbeelden in de organisatieliteratuur waarin aandacht wordt geschonken voor de ontwikkeling van een alternatief rationaliteitsconcept.

\subsubsection{Naar een communicatieve rationaliteit}

Voor een verbreding van de vernauwde instrumentele managementblik is aansluiting gezocht bij Habermas' concept van een praktische rationaliteit ${ }^{71}$. Kennelijk gaat er van Habermas' idee van de machtsvrije dialoog en van het 'waardegestuurde handelen' dat een eigen maatschappelijk domein beheert (de zogenaamde leefwereld) naast het 'doel-rationele' handelen in sociaal-economische systemen, een inspirerende en richtinggevende kracht uit. Habermas' visie houdt onder meer in dat onze 'leefwereld' met het 'communictieve handelen' tegenover kolonialiserende tendenzen van het maatschappelijke bestel beschermd moet worden, wil het menselijke bestaan niet volledig gedomineerd gaan worden door de 'systeem-rationaliteit' met haar strategisch-instrumentele optiek. De vooronderstelling dat er een strikte scheiding te maken valt tussen de maatschappelijke domeinen waarop het 'strategische handelen' en het 'communicatieve handelen' betrekking hebben, is door dit onderzoek geproblematiseerd. Juist de wederzijdse doordringing van wat traditioneel van elkaar is gescheiden als 'de publieke sector' met haar kenmerkende instrumentele optiek en de 'privé-sector', waarin overwegend communicatieve waarden zouden heersen, lijkt kenmerkend te zijn voor onze tijd en de huidige maatschappelijke ontwikkelingen. Niettemin is er zowel in de privé- als in de publieke sector, zo heb ik in het eerste hoodstuk aan deze problematisering toegevoegd, een tegengestelde tendens te constateren van rationaliserings- en humaniseringsprocessen die zich in ons (werk-)leven tegelijkertijd manifesteren.

In dit verband wordt de toenemende belangstelling voor de factor creativiteit op de markt van organisatietrainingen nog eens in herinnering geroepen die in het eerste hoofdstuk is beschreven. Over deze ontwikkeling is gesteld hoe de innovatieve 'creatieve producten' ogenschijnlijk in het teken van een humanisering van werkprocessen staan. In de V.S. heeft bijvoorbeeld een aantal bedrijven het gezamelijk trommelen als een creatief samenwerkingsconcept in organisationeel verband vormgegeven, door een speciale ruimte met faciliteiten, de zogenaamde 'drum-

71. Gustavson: Dialogie and Development. Naschold (e.a.): Constructing the new industrial Society. 
de hand van theoretisch èn empirisch onderzoek in de vorm van action research. Met behulp van sociologische en psychologische kennis hebben zij groepsgesprekken gevoerd om de kundigheid van adviseurs en managers te onderzoeken en te onderbouwen. Op die wijze hebben zij een praktische vorm van theorie- èn praktijkgestuurde kunde ontwikkeld. Deze zogenaamde 'reflectieve praktijkkennis' hebben zij geoperationaliseerd tot een alternatief communicatiemodel voor interventies en procesbegeleiding met het oogmerk om leerprocessen in organisaties te stimuleren ${ }^{9}$ De contextgebondenheid achten zij voor deze kennisvorm karakteristiek. Het situationele en unieke aspect van deze kunde brengen zij tevens in verband met een 'metaforische kenwijze', dat wil zeggen een kennisstructuur waarin het gaat om: "iets zien in termen van iets anders" ${ }^{80}$ Ten opzichte van een traditionele wetenschappelijke kennisstructuur kan het metaforische praktijkoordeel als een opzettelijke 'categorie-fout' worden betiteld. ${ }^{81}$ Wat dit betreft komt deze kenwijze bijvoorbeeld veeleer overeen met de 'case study' dan met een 'representatieve steekproef'. Het intuiltieve, communicatieve en innovatieve karakter van Schön en Argyris' communicatiemodel onderscheidt zich zowel van een gebruikelijke managerial strategisch-opportunistische optiek als van een wetenschappelijke abstraherende en algemeniserende kenwijze.

Een communicatietheorie die steeds meer erkenning geniet, waarin de veelal eenzijdige cognitieve optiek op organisatieprocessen een psycho-dynamische aanvulling heeft gekregen, is Weicks sociaal-psychologische theorie over betekenisgeving ${ }^{82}$. Een 'paradigma-verschuiving' in de organisatiekunde naar een 'interpretatieve' en 'constructivistische' wetenschapsopvatting geeft hij aan met behulp van de metafoor 'teksten lezen'. Zijn optiek plaatst de auteur nadrukkelijk in een context van psycho-sociale processen. Het concept van 'enactment' heeft in deze context een centrale plaats gekregen om het belang, de dynamiek en de complexiteit van sociale interacties ten aanzien van het proces van betekenisgeving aan te geven. Organisatieonderzoek dat zich baseert op de 'grounded theory ${ }^{83}$ biedt eveneens een 'alternatieve invalshoek' ten opzichte van een positivistisch georiënteerde wetenschaps-methodologie. Op basis hiervan heeft zich een Rotterdamse School van de 'sociale configuratie-theorie' ontwikkeld. De term 'configureren' wordt gebruikt om het bijzondere belang van het betrekkings-aspect van communicatie ten opzichte van het inhoudsaspect te benadrukken ${ }^{84}$ In deze theorie wordt ook speciale aandacht geschonken aan de rol van metaforen in het kader van onderhandelen en conflicthantering. Een metafoor kan immers verrassend op de 'belevingsorganisatie' inwerken en bondig een ander perspectief op een door gefixeerde concepten vastgelopen onderhandelingssituatie genereren,

79. Schön: The Reflective Practioner. How professionals think in action.

80. The Reflective Practioner. How professionals think in action. 138 e.v.

81. Ibid. 181.

82. Weick: Sensemaking in Organizations.

83. Glaser \& Strauss: The Discovery of Grounded Theory: Strategies for Qualitative Research.

84. van Dongen e.a: Een kwestie van verschil.Conflicthantering en onderhandeling in een configuratieve integratietheorie. 
waardoor er weer zicht komt op alternatieve opties. Als 'toegevoegde' waarde van de metafoor wordt het losmaken van vastgeroeste betekenissen en het bieden van een spiegel of een aanknopingspunt voor reflectie genoemd. Om dit dynamische aspect van de metafoor te typeren hebben de auteurs teruggegrepen naar klassieke filosofische terminologie. De dynamiek van de metafoor in het proces van betekenisgeving omschrijven zij als een proces van (de-)reificatie, ${ }^{85}$ waarbij 'reifficeren' staat voor 'verdinglijking' en 'de-reificeren' voor 'ontdinglijking'. 'Metaforiseren' noemen zij de 'techniek van het systematisch inlassen van alternatieve beelden ${ }^{, 86}$ om te voorkomen dat communicatieprocessen vastlopen. Het proces van het vastleggen, institutionaliseren en bevriezen van betekenissen tot 'gereïficeerde' gedachtenconstructies wordt door de auteurs als een grondgegeven van menselijke communicatie beschouwd. Deze visie gaat als het ware uit van 'het natuurlijke verloop' van de stroom van communicatie, zoals water in de regel van een hoger niveau naar een lager gelegen niveau stroomt. Voor het creëren van een nieuwe zienswijze of een alternatief perspectief op een organisatieprobleem moet iets worden ondernomen dat tegen het 'normale verloop' ingaat, net zoals er een bijzondere ingreep in de fysieke constellatie van de natuur moet worden aangebracht om water naar boven te laten stromen,- bijvoorbeeld door de druk te verhogen. Om zo'n bijzondere interventie in communicatieprocessen te bewerkstelligen is de metafoor een aangewezen instrument.

Voor de ontwikkeling van een 'communicatief rationaliteitsconcept', waarin emotionaliteit en verbeelding als constitutieve momenten dialogisch zijn opgenomen, zijn deze in de literatuur aangetroffen dialoogvormen van belang. Daarnaast kan geput worden uit een groeiende hoeveelheid literatuur met metho(dolog)ische reflecties ten aanzien van metaforen, creatieve middelen en praktische kennis met betrekking tot organisatieprocessen. Aan de hand van case study's, ethnografische, fenomenologische en hermeneutische onderzoeksmethoden, en met behulp van aan de kunst ontleende middelen worden voorstellen gedaan hoe communicatie- en interactieprocessen (in organisaties) op een niet-instrumentele wijze onderzocht en aangestuurd kunnen worden. ${ }^{87}$ Opmerkelijk in deze ontwikkeling is dat 'onderzoek' minder de betekenis heeft van een wetenschappelijke verklaring of beschrijving maar dat er aansluiting wordt gezocht bij actie-gerichte en beleidsmatige evaluatie-methoden ${ }^{88}$ Als sleutelwoord voor een praktijkgeoriënteerde sociale onderzoeksmethodiek die veel navolging heeft gevonden, fungeert het concept onderhandelen. De onderhandelende vorm van interactie van de onderzoeker met de onderzochte 'sociale werkelijkheid' betitelen zij als 'de vierde generatie' na de wetenschappelijke gerichtheid op 'meten', 'beschrijven' en 'oordelen' ${ }^{89}$ In een Nederlandse variant op het gebied van de beleidsweten-

85. Een kwestie van verschil. Conflicthantering en onderhandeling in een configuratieve integratietheorie 60-61.

86. Ibid 58.

87. Denzin \& Lincoln: Handbook of Qualitative Research.

88. Guba \& Lincoln: Fourth Generation Evaluation. Abma: Responsief evalueren.

89. Fourth Generation Evaluation 8. 
schappen is responsief evalueren als een alternatieve onderzoeksmethode ontwikkeld op basis van democratisch verzamelde en door respondenten gecheckte ervaringskennis over een sociale werkelijkheid die gericht is op 'empowerment' 90 van betrokkenen.

\subsubsection{Een dialogisch principe}

In de vorige paragraaf is er zicht gekomen op een 'dialogisch principe' dat, vertaald in een empirische vorm, een communicatieve onderbouwing geeft aan humaniseringsprocessen in organisaties. In vergelijking met Habermas' 'ideaaltypische dialoogvorm' wordt in het communicatiemodel van Argyris en Schön 'communicatieve symmetrie' niet zozeer in termen van machtsgelijkheid 'ideaaltypisch' voorondersteld, maar door een aantal realiseerbare randvoorwaarden mogelijk gemaakt. Namelijk in de mate dat deelnemers betrokken zijn, over betrouwbare informatie beschikken en op basis hiervan een geinformeerde en vrije keuze kunnen maken inzake te nemen beslissingen of te voeren onderhandelingen. Dit model wordt geëffectueerd door een 'facilitator' of 'proces-begeleider' die het groepsproces en de naleving van de communicatieregels bewaakt. Om dit type dialoog te karakteriseren hebben zij het afgezet tegen een gebruikelijke wijze om in organisaties te interveniëren, onder leiding van een expert of deskundige. Aangezien een expert over meer of relevantere informatie beschikt krijgt $\mathrm{z}(\mathrm{h}) \mathrm{ij}$ in de regel meer beslissingsbevoegdheid en verantwoordelijkheid, dus (meer) macht in handen.

Vanuit een instrumentele optiek wordt de gespreks- en onderhandelingspartner in het kader van strategisch handelen, als middel tot het te bereiken doel gezien. Dit type handelen is erop gericht om voordeel uit een onderhandelingssituatie te halen, zo nodig ten koste van de positie van de ander die als 'tegenpartij' wordt bejegend. De gebruikelijke communicatie- en onderhandelingsvorm in organisaties staat derhalve op gespannen voet met een 'humanistische' of een 'ethische invalshoek', bijvoorbeeld met Kants categorische imperatief, om 'de ander nooit als middel doch altijd als doel in zichzelf te beschouwen', of in de zin van de 'gulden regel': Wat gij niet wilt dat $u$ geschiedt doet dat ook een ander niet. Een kritischhumanistisch communicatie-model vooronderstelt een rationaliteitsconcept dat ruimte laat voor een dergelijke ethische invalshoek. De dialoog als model kan worden getypeerd als een vorm van 'democratische communicatie', waarbij de onderhandelingen worden gevoerd op basis van een (stilzwijgend) contract tussen gelijkwaardige maar van elkaar afhankelijke gesprekspartners, die op basis van vrijheid en betrokkenheid, onder voorwaarde van 'informatieve symmetrie' een gesprek aangaan. In zo een dialogische context wordt 'de (re-)organisatie' op basis van de feitelijke uitkomst uit het groepsgesprek, dus als compromis, dissensus of consensus tussen de gesprekspartners, steeds opnieuw ter discussie gesteld en

90. Responsief evalueren 101. 
ge(her)definieerd. Aldus worden vanuit een 'dialogische grondhouding' op democratische basis beslissingen genomen ten aanzien van de organisatie en eventuele veranderingen in 'de organisatorische status quo'. De organisatie-(veranderings) kundige is geen expert maar een 'gesprekspartner en gespreksleider', die betrokken is bij èn reflectieve afstand houdt tot het proces van verandering. Onder deze voorwaarden kan er langs kritisch-humanistische weg een veranderingsproces worden aangestuurd, dat gedragen wordt door alle betrokkenen.

Aan de hand van de literatuuranalyse die in dit hoofdstuk is gegeven, is het mogelijk geworden om ten aanzien van de onderzoeksvraag een onderscheid te maken tussen het technisch-instrumentele gebruik van metaforen in communicatieprocessen en de ontwikkeling van een 'metaforische methodiek' voor organisatieveranderingsprocessen. Met deze tweede optie wordt gedoeld op de ontwikkeling van een methodisch onderbouwde en (ideologie-)kritisch doorgelichte wijze van 'metaforische communicatie en interactie'. Met de literatuurvoorbeelden in deze paragraaf is aangegeven hoe langs theoretische èn praktische weg een eigen domein en rationaliteitsvorm voor praktische ervaringskennis ten opzichte van wetenschappelijke kennis afgebakend kan worden. Hiermee wordt voorkomen dat 'de metaforische benadering van organisatievraagstukken' door het heersende opportunisme in de greep van de instrumentele rede geraakt. Het 'dialogische principe' definieert een 'communicatieve rationaliteit' en biedt daarmee een kritisch èn humanistisch ijkpunt om de metaforische kennisvorm niet eenzijdig vanuit een wetenschappelijke rationaliteitsnorm af te meten.

Welke elementen zijn nu essentieel voor deze 'derde weg' tussen rationalisme en romantiek, tussen opportunistisch en mythologiserend metafoorgebruik? In het bijzonder aan de hand van het onderzoek van Argyris en Schön is op het belang van een geoperationaliseerde vorm voor dialogische communicatie gewezen, die mij vooral relevant toeschijnt met betrekking tot emotionele en ideologische aspecten van organisatieprocessen. Het 'dialogische principe' doelt aldus op een 'ethisch beginsel' dat 'de ander' gehoord dient te worden, hetgeen op nog fundamenteler niveau een confrontatie met onszelf en met 'de ander in onszelf inhoudt. Dat wil zeggen dat wij ook onze eigen overtuigingen, waarden en normen aan een kritisch onderzoek dienen te onderwerpen om ze eventueel in te ruilen voor anderen die in de dialoog naar voren zijn gekomen. Hiervoor is een bepaalde innerlijke houding en gemoedsgesteldheid nodig die (aristotelisch) het midden houdt tussen beheersing van het communicatie- en onderhandelingsproces vanuit een kritische distantie en een overgave aan dit proces door een empathische betrokkenheid bij de ander en bij de zaak waarover gesproken wordt. Dit vooronderstelt hetgeen Krishnamurti heeft beschreven als de mogelijkheid van een angstvrije 'staat van zijn':

Onze vraag is of de geest en ons gehele wezen ooit volledig vrij van angst kunnen zijn. De opvoeding, de maatschappij, de regeringen en de godsdiensten hebben deze angst aangemoedigd; godsdiensten zijn gebaseerd op angst. En angst wordt 
ook gecultiveerd door de aanbidding van autoriteit - het gezag van een boek, het gezag van een priester, het gezag van diegenen die weten enzovoort. We worden zorgvuldig in angst grootgebracht. En wij vragen of het mogelijk is om er totaal vrij van te zijn. ${ }^{\prime \prime 9}$

De literatuuranalyse heeft geresulteerd, overeenkomstig de 'dialogische grondhouding van reflectieve afstand en empathische betrokkenheid', in de articulatie van een 'dialogisch principe'. Hiermee is een een sociaal communicatie-model te ontwerpen, dat een empirische basis verschaft aan humaniseringsprocessen in organisaties. In het tweede hoofdstuk is op grond van de analyse van creatief therapeutische literatuur op het belang van het creatieve medium als gelijkwaardige gesprekspartner in de dialoog gewezen. Deze bevinding uit het onderzoek geldt eveneens met betrekking tot de toepassing van creatieve middelen en metaforen in het kader van organisatievraagstukken. De gevraagde 'derde grondhouding tussen rationalisme en romantiek' impliceert derhalve ook een openheid voor het medium van de kunst als 'derde gesprekspartner' in de organisatorische dialoog. Deze openheid is de basis voor de ontwikkeling van communicatieve, ideologische en esthetische waarden met betrekking tot 'de metafoor' in het kader van organisatievraagstukken. In het volgende hoofdstuk zal de dialogische grondslag filosofisch worden uitgewerkt vanuit de hermeneutiek.

\subsection{Samenvatting en conclusie}

In dit hoofdstuk is een analyse van het organisatie-discours gegeven vanuit de vraag naar de rol van de metafoor als middel tot betekenisgeving. Uit deze analyse blijkt dat er een onderscheid gemaakt dient te worden al naar gelang de context waarin de metafoor figureert.

In het wetenschappelijke genre wordt het gebruik van metaforen afgemeten aan een traditionele wetenschapsmethodologie. In dat kader klinken er kritische geluiden ten opzichte van het wetenschappelijke gebruik van literaire stijlfiguren zoals de metafoor. In tegenstelling hiermee staat de (meer)waarde van de metafoor in de praktische context van management gelijk aan haar exploitatie. In het discours van organisatie(des)kundigen worden methodologische reflecties op alternatieve kennispraktijken van professionals afgewisseld met instrumentele beschrijvingen met betrekking tot creativiteit en metaforen. Dit type literatuur kenmerkt zich door een tussenvorm tussen het zakelijk-letterlijke en het retorischfiguurlijke taalgebruik en krijgt derhalve een hybride karakter. De verschillende rol van de metafoor in de onderscheiden genres is aan de hand van Morgans werk verduidelijkt. Op 'meta-theoretisch' niveau werkt de metafoor paradigmatisch als een raster of bril waarmee we de (organisatorische) werkelijkheid waarnemen en conceptualiseren. Op bedrijfskundig niveau wordt ze als heuristiek voor een diag-

91. Krishnamurti: Waarheid en Werkelijkheid 69. 
nostische lezing en kritische evaluatie van concrete organisaties gebruikt. Op toegepast niveau gaat het om een metaforische vaardigheid, waarbij organisatiebeelden en metaforen voor organisatievraagstukken voortkomen uit het verbeelden als proces.

In de populaire managementliteratuur worden metaforen als een nieuwe 'techniek' naast de bestaande managementtools opportunistisch verwelkomd. Ze worden aangeprezen als een effectief analyse- en interventiemiddel om organisatiekundige inzichten voor de managementpraktijk te vertalen. Inzake dit punt is er een wetenschapsfilosofische tweedeling te maken tussen voorstanders en tegenstanders van het gebruik van metaforen. Voorstanders worden in de organisatie- en managementliteratuur als 'post-modernisten' en 'constructivisten' bestempeld en tegenover 'modernisten' en 'non-constructivisten' gesteld. De eerstgenoemde groep kent aan taal en metaforen in het bijzonder een constructieve rol toe. (Metaforische) beschrijvingen hebben een generatieve waarde om organisatorische processen op unieke wijze te beschrijven. Non-constructivisten gaan er daarentegen van uit dat er een van het waarnemende subject onafhankelijke realiteit bestaat, waarvan de wetenschap een objectieve afbeelding geeft. Derhalve houden zij vast aan het primaat van de letterlijke taal ten opzichte van beeldspraak, zij het dat aan de metafoor, mits onder het regime van Logos gesteld, een ondersteunende rol wordt toegekend. De promotie van de metafoor in de bedrijfskunde lijkt zo door een manoeuvre van 'repressieve tolerantie' uiteindelijk toch onder het ultieme gezag van de 'organisatorische instrumentele rede' te vallen.

De pragmatische invalshoek op de metafoor in het management-discours is geillustreerd met enkele voorbeelden van populaire sportmetaforen. Aan de hand van een ideologie-kritische analyse van de basketbal-metafoor is aangegeven hoe zij retorische betekeniseffecten sorteert in de vorm van een succesformule van een consultancybureau voor een nieuwe manier van leidinggeven in het informatietijdperk. In dat verband is het belang onderstreept van een 'reflectief moment' in het proces van metaforische betekenisgeving. Hierdoor kan aan de voor dit genre kenmerkende kolonialiserende beweging van de instrumentele rede, die nu ook de verbeelding in dienst heeft genomen, een halt toegeroepen worden. Een reflectief moment biedt tegenspel aan potentieel machtsmisbruik door 'dictatoriale metaforen'. Het opportunistische metafoorgebruik is dus te beschouwen als een vorm van onverschillige tolerantie op grond waarvan willekeurig welke metaforen en beelden eclectisch in het bedrijfskundige discours worden verwelkomd. Hier tegenover staat een verschillige tolerantie, waarbij verschillen in optiek en (tegenstrijdige) belangen tussen betrokkenen er juist toe doen en communicatief in het veranderingsproces worden ingebracht. Dit vooronderstelt echter een andere 'grondhouding' dan de opportunistische en instrumentele. Ten aanzien van de 'competitie-retoriek' die door sportmetaforen gegenereerd wordt, is er gewezen op het belang van een alternatieve interpretatie van de sportieve grondhouding in termen van 'fair play'. Deze staat metaforisch voor een ethische invalshoek, die geconcretiseerd is met de idee van een 'organisatorische dialoog' of 'multiloog'. 
Op basis van bestaande dialoogvormen, zoals het Socratisch gesprek, Habermas' idee van de machtsvrije dialoog en het door Argyris en Schön ontwikkelde communicatie-model van een 'gesitueerde dialoog tussen gelijkwaardige, betrokken, vrije en geinformeerde gesprekspartners', zijn de contouren van een kritischhumanistische dialoogvorm aangescherpt. Dit perspectief verschaft het gevraagde 'communicatieve' rationaliteitsconcept voor de afbakening en onderbouwing van een metaforische benadering van organisatievraagstukken.

Resumerend is het volgende resultaat uit de analyse van het organisatie-discours bereikt. Ten opzichte van een traditioneel rationaliteitsconcept dat voor iedereen en te allen tijde zou gelden is het primaat van een gesitueerde organisatorische dialoog aangegeven, waarin communicatieve, ideologische en esthetische waarden en normen van alle betrokkenen ter discussie worden gesteld en geconcretiseerd. Een 'dialogische grondhouding tussen rationalisme en romantiek' impliceert ook een communicatieve openheid voor 'de derde gesprekspartner' van het creatieve medium. Een aldus vormgegeven dialogische context is voorwaardelijk voor de invulling van het kritisch-humanistisch ijkpunt voor metaforische communicatie. De communicatieve invalshoek op organisatieprocessen resulteert in een onderscheid tussen het technische gebruik van metaforen als alternatief middel in een instrumentele context van strategisch handelen en het methodisch hanteren van metaforische communicatie- en interventiemiddelen in een dialogische context. In deze laatste benaderingswijze is een 'reflectief en communicatief moment' ten aanzien van metafoorgebruik voorondersteld, onder de noemer van een 'dialogische grondhouding'. Deze filosofische grondslag dient in een sociale context tot een bepaalde procedureel bewaakte dialoogvorm concreet te worden uitgewerkt, conform het in dit hoofdstuk ontwikkelde 'dialogische principe':

Een methodisch gestuurd (bijvoorbeeld socratisch) groepsgesprek, waarin beslissingen worden genomen ten aanzien van gemeenschappelijke zaken of tegenstrijdige belangen op een dusdanige wijze dat alle partijen als gelijkwaardige, betrokken, goed geinformeerde en (in sociaal en ethisch opzicht) vrije gesprekspartners aan de dialoog en de beslissingsprocedure participeren.

Als conclusie uit dit hoofdstuk volgt het fundamentele belang van het 'dialogische principe' als richtlijn om een metaforische benadering van organisatievraagstukken te verantwoorden en te operationaliseren. In het volgende hoofdstuk zal dit principe als 'derde weg tussen rationalisme en romantiek' vanuit de hermeneutiek worden betrokken op 'de metaforische communicatievorm' van de onderzochte creatieve trajecten. 
HOOFDSTUK 4:

Een hermeneutische interpretatie van metaforische

communicatie

\subsection{Inleiding}

In dit hoofdstuk staat de vraag centraal hoe een grondslag van creatieve trajecten in therapie en organisatietrainingen vanuit de hermeneutiek gestalte krijgt. In de voorgaande hoofdstukken is er een analyse gegeven van de creatief-therapeutische literatuur en van het organisatie-discours met het oog op de interpretatie van 'creatieve trajecten' in training en therapie als een vorm van 'metaforische praktijkkennis'. Hierbij is de onderzoeksroute aangegeven als een 'derde weg' voorbij een instrumenteel-rationalistische en een metafysisch-romantische benadering van (kennis over) de werkelijkheid. In verband met deze 'derde weg voorbij' is er een post-romantische omkadering van de 'meerwaarde' van creatieve communicatiemiddelen gegeven en op het primaat van een middenpositie gewezen. De middenpositie zou zich 'tussen' beide extremen in bevinden van een beheersende en reflecterende kenhouding versus een empathische houding die tot identificatie met het gekende leidt. Dit hoofdstuk is gecentreerd rond een hermeneutische duiding van de middenpositie die als grondslag voor de 'metaforische kennisvorm' in plaats van een naïve metafysisch opgevatte romantische grondhouding wordt voorgesteld. Vanuit een 'retorische invalshoek op communicatie', in het bijzonder met betrekking tot de rol van 'de metafoor' in de onderzochte kennispraktijken, kan er toegang verschaft worden tot de gevraagde 'derde' middenweg tussen rationalisme en romantiek. In het verlengde van de literatuur-analyse uit de vorige hoofdstukken staat 'de metafoor' voor de 'eigenheid' van het onderzochte type praktijkkennis. In dat verband wordt ze opgevat als middel tot betekenisgeving, waarmee een dynamiek en dialectiek tussen een 'figuurlijk' en een 'letterlijk' betekenis- resp. zijnsniveau ingesteld wordt. De communicatie en interactie tussen cliënt en therapeut of trainer via het creatieve medium wordt in deze zin geïnterpreteerd als een metaforisch proces van betekenisgeving.

Volgens een rationalistische kennisopvatting staan logische argumentatiemiddelen tegenover retorische stijlfiguren. Vanuit die optiek is de metafoor een literair middel, net zoals andere vormen van beeldspraak, de metonymie, de synecdoche, de simile, of de ironie. ${ }^{1}$ Haar wordt derhalve een vergelijkbare wetenschappelijke

1. Stijlfiguren die niet zoals de metafoor op een gelijkenis berusten, maar op een andersoortige 'retorische' betrekking, resp. een biologische verwantschap, op cen 'pars pro toto', op een vergelijking. en op een tegenstelling. 
functie ontzegd, die logische instrumenten, zoals de implicatie, de reductio ad absurdum en het syllogisme, voor de opbouw van wetenschappelijke kennis vervullen. Die opvatting impliceert dat beeldspraak niet effectief (en mogelijk zelfs contra-productief) is ten aanzien van de onderbouwing en verantwoording van betrouwbare kennis over de werkelijkheid. Vanuit de hermeneutiek staat de metafoor niet in oppositie met logische middelen, als een stijlfiguur die misleidend werkt en de wetenschappelijkheid van kennis ondermijnt. De metafoor mag een retorisch middel zijn maar retoriek omvat meer dan het sorteren van een psychologisch effect op een publiek. De traditionele devaluerende opvatting ten aanzien van de metafoor heeft een lange filosofische geschiedenis die teruggaat tot Plato en Aristoteles. De laatstgenoemde filosoof en wetenschapper heeft als eerste in de geschiedenis een systematische verhandeling over de metafoor geschreven. ${ }^{2}$ Hij heeft hiermee de toon gezet voor haar inkadering als retorisch instrument. Toch beoordeelde hij beeldspraak, ook met betrekking tot de kenvraag, niet uitsluitend negatief. Hij beschouwde het creëren van een treffende metafoor als een gave, als een geniale intuittie om het gelijkende in of ondanks waargenomen verschillen te zien. Hierin verschilt hij van zijn leermeester Plato die retoriek in het algemeen als een 'sofistenkunst' categorisch veroordeelde bij monde van Socrates,- waarbij overigens is opgemerkt hoe paradoxaal diens veroordeling is in het licht van zijn retorische 'dialogen'. ${ }^{3}$ Ten opzichte van de concurrerende scholen ${ }^{4}$ van retoren en sofisten heeft Plato's oordeel over de metafoor het pleit op dit punt gewonnen. Zijn veroordeling van de retoriek is in de West-Europese wijsgerige traditie gemeengoed geworden. Eerst in onze eeuw is daarin een zodanige verandering te constateren dat er van een 'rehabilitatie van de metafoor's wordt gesproken.

De hermeneutische invalshoek maakt het mogelijk om buiten de strijd te blijven tussen voor- en tegenstanders van de metafoor als wetenschappelijk instrument. In plaats van een dichotomisering van logische en retorische instrumenten worden ze in dit onderzoek gelijkelijk opgevat als 'middelen tot betekenisgeving'. Overeenkomstig een retorisch uitgangspunt staat niet de beschrijvende en afbeeldende functie van (wetenschappelijke) taal voorop maar veeleer haar generatieve kracht om een werkelijkheid te construeren en present te stellen. Vanuit deze invalshoek staat wetenschap op één lijn met bijvoorbeeld literatuur, beeldende kunst en religie. Hoe verschillend zij ook onderling mogen zijn, als 'kennispraktijken' genereren en reproduceren zij (aspecten van) 'de' werkelijkheid. Vanuit het 'interne perspectief' van de onderzochte praktijk en de betrokken professionals, is kennis niet zozeer een 'afspiegeling van' maar veeleer een bepaalde 'omgang met' de werkelijkheid. Zoals wetenschappelijke kennis voortkomt uit een zakelijke, van de concrete situatie en persoon abstraherende kenwijze, zo wordt praktijkkennis gekenmerkt

2. In zijn Poetica en Rhetorica.

3. Usseling: Retoriek en Filosofie. Wat gebeurt er wanneer er gesproken wordt?

4. Scholten: Retoren en demokratie.

5. Ricoeur: La metaphore vive. Ankersmit \& Mooij: Knowledge and Language, (vol III) Metaphor. and Knowledge. Ankersmit: History and Tropology. The Rise and Fall of Metaphor. 
door een meer persoonlijke en pragmatische benadering. Dat wil zeggen dat de auteur als persoon in beeld komt en er een appèl wordt gedaan op algemene meningen, natuurlijke waarneming en 'common sense'-argumentatie veeleer dan op logica en andere analyse-technieken, technisch ondersteunde waarneming, verificatie- en falsificatieprocedures. In dit hoofdstuk zal er vanuit een hermeneutische onderzoeksbenadering een typering worden ontwikkeld van de metaforische vorm van praktijkkennis op basis van de gepostuleerde middenpositie tussen beheersing van en identificatie met het onderzoeksobject.

De tweede paragraaf geeft een toelichting op een aantal relevante uitgangspunten van een retorische invalshoek op communicatie. Hiertoe wordt het grondbegrip van de metafoor als 'middel tot betekenisgeving' buiten de gebruikelijke dichotomie tussen retorica en logica gebracht. Deze relativering maakt het mogelijk om in de derde paragraaf drie vormen van 'metaforische communicatie' te onderscheiden. De relativerende optiek vertegenwoordigt de middenpositie, van waaruit communicatie verschijnt als een proces van betekenisgeving op basis van de gegenereerde dialectiek tussen metaforisering en conceptualisering. De primair gestelde dialectische wisselwerking tussen een conceptuele en een metaforische wijze van betekenisgeving staat centraal in de vierde paragraaf. Eerst wordt dit thema geplaatst in de context van ontwikkelingsprocessen, regressieverschijnselen en creatieve processen. Daarna volgt er een methodologische toespitsing met het oog op het in het vijfde hoofdstuk beschreven veldonderzoek. De vijfde paragraaf belicht het verband tussen de 'derde weg' voorbij rationalisme en romantiek en de middenpositie die zich tussen een reflectieve en een empathische grondhouding in bevindt. Deze samenhang wordt uitgelegd aan de hand van een hermeneutische dialectiek tussen denkbeelden en beelddenken, als twee fundamenteel verschillende ervaringswijzen. De dialectische wisselwerking tussen beide wijzen van ervaren vertegenwoordigt de 'derde', hermeneutische middenpositie. Vanuit deze hermeneutische visie wordt er een interpretatie van ontwikkelingsprocessen in therapie en training gegeven die wezenlijk verschilt van een rationalistische of een romantische optiek op ontwikkeling, namelijk als een onophoudelijk proces van betekenisgeving ten aanzien van onze zelfbeelden, organisatiebeelden, maatschappijbeelden en wereldbeelden. Geconfronteerd met de 'post-moderne' idee van de esthetisering van ons bestaan is het de vraag of deze visie niet evenzeer een metafysische illusie is. Is het mogelijk het proces van betekenisgeving te funderen op een vorm van 'authentieke communicatie' vanuit de middenpositie? Deze vraag wordt ten slotte in verband gebracht met het dialogische beginsel dat in het derde hoofdstuk is geformuleerd. In de zesde paragraaf volgt een hermeneutische interpretatie van de onderzochte creatieve trajecten als 'levende metaforen' in een dialogische context. De zevende paragraaf sluit het hoofdstuk af met een samenvatting en conclusie. 


\subsection{Retorische aspecten van communicatie}

Deze paragraaf introduceert een retorische invalshoek op communicatie. In de eerste subparagraaf worden eerst enkele uitgangspunten en elementen van de retorische traditie beschreven, met als doel om eenzijdigheden, vooronderstellingen en verzwegen uitgangspunten van een rationalistische kennisopvatting te corrigeren en aan te vullen. De tweede subparagraaf spitst dit gezichtspunt toe tot de metafoor als betekenisgenererend middel met een eigen 'logica'.

\subsubsection{De retorische traditie}

Een fundamenteel uitgangspunt van een retorische invalshoek op communicatie is dat een betoog gericht is op het aanspreken van een bepaald publiek: om het te overtuigen, te misleiden, in verwarring te brengen, te onderwijzen of te vermaken. ${ }^{6}$ In een strikt logisch-wetenschappelijke context heeft een betoog een monologische en universele strekking. De logische redeneervormen en argumen-tatieregels zouden voor iedereen en te allen tijde gelden. ${ }^{7}$ Hier tegenover stelt de retorica een dialogische context met gesitueerde communicatie. ${ }^{8}$ De retorische geschriften gaan niet over een tijd- en lichaamloos spreken, dat zuiver, persoons-onafhankelijk en logisch deugdelijk behoort te zijn. Het retorische onderwijs behandelt concrete communicatievormen, bedoeld voor levende sprekers om een specifiek onderwerp aan de orde te stellen: in het kader van de rechtspraak, de politiek, een wetenschappelijk of een maatschappelijk probleem. ${ }^{9}$ Deze 'schone kunst' leert regels over hoe je te richten op een bepaald gehoor om overtuigend een boodschap over te brengen. Van fundamenteel belang voor een retorische insteek is derhalve kennis van de betreffende sociale context met de geldende communicatieregels, bijvoorbeeld het socratische vraag- en antwoord-spel, het rechtsprincipe van hoor en wederhoor, de regels van een kruisverhoor, de beginselen van een wetenschappelijk dispuut, enz.

Een retorisch uitgangspunt krijgt nu expliciet de aandacht, dat mij met betrekking tot het onderzoeksonderwerp van bijzonder belang toeschijnt: namelijk het gegeven dat een spreker langs verschillende wegen een gehoor kan overtuigen. ${ }^{10}$ Door Aristoteles zijn wat dit betreft drie aspecten van communicatie onderscheiden die met de tussen haakjes geplaatste termen worden aangeduid. Een logische invalshoek op communicatie is beperkt tot de rationele weg van steekhoudende argumentatie en deugdelijk redeneren (Logos). Het rationele aspect van communicatie is gericht op het overtuigend overbrengen van de inhoudelijke boodschap op

6. Retoriek en Filosofie.

7. Naess: Elementaire argumentatieleer.

8. Perelman: Retorica en argumentatie 99.

9. Peters: Retoriek van de communicatie. Communicatiemiddelen, communicatievormen, communicatietechnieken.

10. Richards: The Philosophy of Rhetoric. 
basis van empirische overeenstemming en logisch geldige argumentatievormen. In 'levende' communicatie is dit aspect evenwel verbonden met 'a-logische' menselijke overwegingen. Door de persoonlijke wijze van communicatie creëert een spreker een bepaald (moreel en psychologisch) beeld bij het publiek (Ethos). Dit wordt bijvoorbeeld in de rechtsspraak gebruikt om getuige-verklaringen (on-) geloofwaardig te laten overkomen, door de getuige psychologisch in een kwaad of gunstig daglicht te stellen en dit vervolgens te koppelen aan een twijfelachtige of juist onbesproken juridische voorgeschiedenis. Zaken die in een bepaalde communicatieve context uitgesproken relevant zijn, zijn dat vanuit logisch oogpunt beschouwd niet: een dergelijke 'bewijsvoering' geldt als een drogreden ad personam. Ten slotte kan een spreker emotioneel inspelen op de gevoelens van het publiek (Pathos). In hedendaagse terminologie overheerst soms een logische optiek op een context van 'levende' communicatie als er van emotionele en sociale aspecten is geabstraheerd. Bijvoorbeeld wanneer er gesproken wordt over 'informatieoverdracht', 'informatie-technologie', 'kennis-management in organisaties' en 'de digitalisering van kennis' tot 'bits of information'. In dit onderzoek zijn, in navolging van Aristoteles, drie 'niveau's' in het communicatieproces onderscheiden om de retorische betekeniseffecten van de metafoor te benoemen. Naast de inhoudelijke boodschap van de metafoor (het cognitieve niveau) is voor de onderzoeksvraagstelling vooral haar appèl op emoties en lichamelijkheid van belang. Dat betekent dat emotionele en interactieve aspecten van 'metaforische communicatie en interactie' het primaat krijgen om 'de eigen(aard-ig)heid' van creatieve trajecten tot begrip te brengen.

Kennis over deze 'communicatie-niveau's' en hun onderlinge samenhang in de retorisch-narratieve zeggingskracht van communicatieve boodschappen is derhalve relevant voor (dit onderzoek naar) deze metaforische vorm van intultieve praktijkkennis. Behalve uit retorische geschriften kunnen we inzicht in deze kennisvorm verkrijgen door lezing van psychologische en therapeutische literatuur. De analyse van creatief therapeutische publicaties in het tweede hoofdstuk, met name ten aanzien van 'de symboliserende en ritualiserende kracht' van beelden, is bijvoorbeeld in dit opzicht van belang. In dat verband is er gewezen op de wijze hoe beelden emoties soms op meer belichaamde en dan weer op meer diagrammatische wijze overbrengen. ${ }^{11}$ Daarnaast is aangegeven hoe een beeld impliciet een verhalende kracht behelst, die een handelingscontext overdraagt. De metafoor is vanuit dat gezichtspunt getypeerd als een verhaal in een gecondenseerde vorm, een 'beeldnarratief'. Met dergelijke onderscheidingen kan de werking van (impliciete) beelden en metaforen in het communicatieproces worden getypeerd. Steeds meer wordt immers onderkend hoe non- en para-verbale aspecten van communicatie een hoofdrol spelen in het proces van betekenisgeving. Van doorslaggevend belang voor het genereren van betekenis in 'levende' communicatie is de wijze van spreken, de invloed van lichaamshouding, gevoelsladingen en betekenisconnotaties die een spreker bedoeld èn onbedoeld overbrengt en waarmee $z(h) i j$ de

11. Zie paragraaf 2.4 .2 . 
gemoederen van een gehoor beroert. Toehoorders nemen niet alleen kennis van de cognitieve boodschap maar vooral van de 'begeleidende' emoties van vreugde, verbazing, verdriet, herinneringen, dromen en associaties, die 'het betekenisveld' structureren en kleuren. Een gebrek hieraan betekent een verlies van haar retorischnarratieve zeggingskracht en maakt dat men een betoog als 'saai', 'vlak' of 'abstract' ervaart. Het klasieke niveau van ethos is hier vertaald in het morele en psychologische 'beeld als persoon' dat een spreker oproept, wat in het bijzonder betrekking heeft op het handelingsaspect van de metafoor. De geloofwaardigheid van een spreker hangt immers nauw samen met de vraag of de inhoud van een boodschap gedragen dan wel ontkracht wordt door een analoge of tegengestelde lichamelijke boodschap. Het is evident dat de mededeling 'Heel interessant wat $u$ daar zegt' ontkracht wordt door de 'begeleidende lichaamstaal' van gapen en op het horloge kijken. De 'handelingsmetaforen' uit dit voorbeeld zullen een sterker effect hebben dan de tegengestelde boodschap in 'discursieve taal'. De communicatieleer spreekt in dit geval van een discongruentie tussen inhouds- en betrekkingsniveau. ${ }^{12}$ Het bundelen van retorische en psychologische kennis omtrent (beeld)communicatie tot methodische en theoretische modellen met betrekking tot creatieve trajecten, heeft tot gevolg dat de 'intuitieve praktijkkennis' onderbouwd en overdraagbaar wordt.

Op grond van deze schets van de retorische traditie kunnen er nu, wat betreft de professionele vormgeving van creatieve trajecten in therapie, training en advisering, drie essentiële elementen worden benoemd: de gesitueerdheid, de dialogische context en het regelgeleide aspect van communicatie, dat wil zeggen de methodische ondersteuning en sturing van communicatieprocessen. In deze specifieke toepassingscontext is het dialogische uitgangspunt verfijnd tot een trialoog. De 'derde gesprekspartner' in de dialoog verwijst, zoals in het vorige hoofdstuk is gesteld, niet alleen naar het creatieve medium, maar tevens naar een dimensie van openheid. Hiermee is het principiële uitgangspunt bedoeld dat in een dialoog 'de ander' nooit volledig begrepen kan worden, waarbij dit 'on-begrip' niet negatief geldt als een gebrek aan begrip, maar als een positief (ethisch) uitgangspunt dat aan de dialoog en de rechtspraak als het ware een grondslag geeft. Namelijk het beginsel dat een gesprekspartner in een dialoog het recht heeft om haar/zijn mening te (her)formuleren, aan te vullen, anders te verwoorden of te herzien, resp. het rechtsbeginsel dat een beklaagde altijd gehoord dient te worden. Een retorische invalshoek op communicatie leert ons dus dat wat 'de ander' zegt principieel een voorlopig en partieel karakter heeft, als een persoonlijke respons in een specifieke situatie. Geplaatst in een dialogische context dient een creatieftherapeutische of een trainingsdoelstelling derhalve met behulp van methodische communicatie-regels dusdanig te worden vertaald dat 'de cliënt' zo volledig mogelijk als persoon met een eigen voorgeschiedenis en een specifieke hulpvraag tot zijn of haar recht komt.

12. Watzlawick: De pragmatische aspecten van de menselijke communicatie 51 e.v. over de betrekking tussen het analoge en het digitale communicatie-niveau. 


\subsubsection{Logica van de metafoor}

In deze paragraaf wordt de hiervoor geschetste aanvulling van retorische elementen op een logische visie op communicatie toegespitst tot de metafoor als middel tot betekenisgeving. Vanuit logisch gezichtspunt beschouwd creëert de metafoor een 'category mistake'. Dit is gemakkelijk te illustreren aan de hand van het voorbeeld van 'coachend leiderschap'. Deze 'metaforische omschrijving' berust evident op een logische fout omdat een eigenschap van een bepaalde entiteit uit de werkelijkheid naar een andere categorie wordt verplaatst zonder een bemiddelende middenterm ${ }^{13}$ die de klasse van sportcoaches eenduidig met de klasse van managers verbindt. Een logische of dialectische schakel wordt weliswaar gesuggereerd door de analogie van de relationele term van het 'coachen' of 'leiding-geven', maar de 'metaforische overdracht' wordt logisch gesproken niet onderbouwd. Ze blijft in zekere zin impliciet, wat juist aan haar retorische kracht bijdraagt. Echter, wanneer een strikt empirische of logische waarheidsclaim wordt losgelaten kan de retorische invalshoek een ander licht werpen op 'ontologische aspecten $^{14}$ van de metafoor. Hierbij is het van belang op te merken dat de metafoor weliswaar niet in een beschrijvende zin een 'waarheidsaanspraak' maakt, maar mogeljk wel generatief door middel van een 'andere structurerering' van de werkelijkheid ten opzichte van een 'letterlijke beschrijving'. De metafoor onderscheidt zich met andere vormen van beeldspraak van concepten, modellen en logische argumentatie-middelen, doordat zij op 'overdrachtelijke' wijze via een 'vergelijkbaar' domein in de werkelijkheid betekenis genereert. 'Letterlijke' taal is op een andere wijze 'generatief' ten aanzien van (aspecten van) 'de' werkelijkheid, namelijk juist door haar claim om de werkelijkheid 'direct' af te beelden. Door de 'directe verwijzing' naar de realiteit zou zij zelf als betekenisdrager 'onzichtbaar' blijven. Zonder de retorische werkzaamheid van een derde 'middenterm', lijkt taal als een zuivere 'spiegel' te werken en de 'subjectieve' of 'talige' vervorming van metaforische betekenisgeving te ontberen. In tegenstelling tot het concept dat aldus 'letterlijk' betekent, abstraheert de metafoor niet van haar hoedanigheid als drager van betekenis. De focus wordt hierdoor niet alleen op de inhoud van de boodschap gericht, maar ook op haar eigen specifieke wijze van zijn als 'betekenisdrager'. Haar zijnswijze als vorm van beeldspraak is zichtbaar, haar beeldende wijze van overdracht komt nadrukkelijk op de voorgrond en is constitutief voor de betekenis van het betoog waarin zij figureert. Voor dit generatieve aspect van taal dat in metaforische betekenisgeving pregnant te voorschijn treedt, is een retorische invalshoek op communicatie uiterst relevant.

13. Zoals bijvoorbeeld het 'tertium datur' van het syllogisme.

14. Zie Ricoeur: La métaphore vive, waarin hij een 'ontologie van de metafoor' ontwerpt. 
Door de wijze waarop de metafoor in een tekst verschijnt, bewerkstelligt zij zowel in 'economische"15 als in 'ecologische' richting een betekeniseffect. Enerzijds werkt ze 'economisch', door een uitgebreide empirische beschrijving of een lange argumentatie tot een beeld te verdichten. Deze metaforische dynamiek verhoogt de retorische zeggingskracht van een betoog, vergelijkbaar met het vergroten van de druk in een gas wanneer dit wordt samengeperst. Aldus versterkt het beeld van het lichaam als kerker van de ziel de retorische kracht van een theologische uiteenzetting over de mindere ('gedevalueerde') waarde van lichamelijke zaken ten opzichte van geestelijke goederen. Het 'economische' betekeniseffect speelt bijvoorbeeld ook een rol in Morgans metaforische benadering van organisaties wanneer hij een bepaalde casus uit zijn consultancy-praktijk kritisch beschrijft in metaforische termen: Deze organisatie is een geestelijke gevangenis. Zijn metaforische omschrijving van een (bepaald type) organisatie is eigenlijk een moderne 'vertaling' van Plato's grotmythe. In het bijzonder verwijst Morgans metafoor naar de wijze waarop de Amerikaanse auto-industrie reageerde op het naoorlogse succes van haar Japanse concurrenten teneinde mogelijkheden te creëren om uit 'de geestelijke gevangenis' van een bepaalde vastgeroeste wijze van organiseren te breken en de economische werkelijkheid op andere wijze te bezien en tegemoet te treden. (Morgans toepassing van) Plato's grotmythe geeft ons ook een voorbeeld van de 'ecologische werking' van metaforische betekenisgeving: er wordt een extra betekenis in de vorm van een allegorie aan de constaterende uitspraak over onze (geestelijke gevangen) staat van zijn toegevoegd. Een allegorische vertelling spreekt behalve de cognitie vooral onze verbeelding en emotionaliteit aan. Door de retoriek van Morgans betoog wordt er een beroep gedaan op meerdere communicatiekanalen tegelijk. De retorische werking van dit 'ecologische principe' is derhalve vergelijkbaar met de vergroting van de natuurlijke rijkdom en evolutionaire kracht door het ecologische beginsel van 'bio-diversiteit'.

Een 'retorische verrijking' van een betoog is vanuit een strikt logische invalshoek op communicatie niet relevant. Logisch gesproken kan 'de organisatie als geestelijke gevangenis' alleen indirect betekenis hebben: namelijk in 'overdrachtelijke' zin als uitdrukking van iets fictiefs of subjectiefs. 'De geestelijke gevangenis' zou aldus niet direct of objectief naar 'de organisatie' verwijzen, maar mogelijk wel als een subjectieve expressie van de werknemers. Volgens een positivistische wetenschapsopvatting bestaat 'de organisatie' feitelijk en objectief waarneembaar, los van dergelijke 'subjectieve factoren'. De subjectieve 'vervorming' of 'beeldvorming' kan wel, aan de hand van een enquete bijvoorbeeld, worden geobjectiveerd. De metaforische typering van 'de geestelijke gevangenis' verkrijgt daarnaast nog een andere betekenis. Plato's grotmythe verwijst naar een zuivere ideeënwereld die aan de zintuiglijk waarneembare werkelijkheid ten

15. De toepassing van deze term op semantische dyamiek in teksten is geinspired door Derrida: Le retrait de la metaphore Poesie. No 7, 1977-1978, 112-113, waarin hij de generatieve kracht van de metafoor 'economisch' behandelt, dat wil zeggen vanuit een gezichtspunt van (metaforische) 'waardegeneratie' ten gevolge van een teveel of een schaarste aan (betekenis)dragers. 
grondslag ligt. Een metafoor kan aldus een 'metafysische werkelijkheid' achter of boven de 'letterlijk' waarneembare werkelijkheid aanduiden, die niet door wetenschap te kennen of met taal direct te beschrijven valt. Wanneer het zo is dat de aanduidende wijze van beschrijven typerend is voor metaforisch woordgebruik, zou het zo kunnen zijn dat het 'metaforische treffen' van een zaak een 'innerlijke' of 'metafysische' werkelijkheid beduidt, zoals het afbeeldende woordgebruik van de wetenschap naar 'de' empirisch waarneembare werkelijkheid verwijst en karakteristiek is voor een 'conceptuele overeenstemming'? Het beeldend aanduiden van een 'metafysische grondslag' die niet direct te beschrijven valt is een subtieler 'epistemologisch gebaar' dan een 'directe' afbeelding. In plaats van een empirischrationele verwijzing is er een emotioneel-beeldende afstemming op een onuitsprekelijke grond, die tot beweging en vertolking aanzet. Bijvoorbeeld in de vorm van Plato's grotmythe, waarbij het vastgeketend-zijn van mensen in de grot onze psychisch-mentale staat van gevangenschap verbeeldt. Is het zo dat juist de metaforische wijze van spreken resp. het creëren van een beeldenwerkelijkheid', in zekere zin adequater is om een 'diepere' ordening in de werkelijkheid aan te duiden - bijvoorbeeld een bovenzinnelijke of een dieptepsychologische realiteit dan de directe verwijzing naar 'de feiten' door middel van een 'representerende' wetenschappelijke beschrijving? Maar mijn metaforische suggestie van een diepere' ontologische orde opent de deur naar een metafysische interpretatie van het hier bedoelde. Is het mogelijk om met behulp van een kritisch-humanistisch perspectief een 'niet-metafysische grondslag' te formuleren? Misschien vertegenwoordigt 'de metaforische wijze van betekenisgeving' niet zozeer een 'fundamentelere' zijnsorde, maar veeleer een 'diepere' zijnsordening, dat wil zeggen een in ons mens-zijn 'diep' gewortelde wijze van ordenen van 'het zijn'. Mogelijk geeft dit onderzoek naar metaforische communicatie langs die weg zicht op een kritischhumanistische benaderingswijze van de werkelijkheid: 'humanistisch' omdat aan 'diepe' aspecten van mens-zijn (zoals verbeelding, zingeving en emotionalitiet) recht wordt gedaan, waaraan een kritische evaluatie ten aanzien van ontologische claims en ideologische betekeniseffecten van de metafoor is toegevoegd.

Vanuit logisch oogpunt beschouwd geeft de 'ecologische' werking van retoriek niet alleen een overbodige toevoeging van beelden en verhalen aan een 'letterlijke beschrijving', maar ook roept het inlassen van een allegorie in een filosofisch tekst epistemologische en ontologische vragen op. Hoe beoordelen we of de 'metaforische omweg' ons niet op een dwaalspoor voert? Hoe bepalen we of het beeld van 'de grot' of van 'de geestelijke gevangenis' adequaat is om de werkelijkheid waarover het gaat te typeren? Waarom is er eigenlijk een indirecte zegswijze nodig via een tweede werkelijkheid van beelden? Hoe verhoudt die 'metaforische wereld' zich tot de 'letterlijk' beschreven empirisch waarneembare werkelijkheid? De gestelde kentheoretische en metafysische vragen komen in een ander licht te staan vanuit de hier ontwikkelde retorische invalshoek op communicatie. Zonder een logische of empirische 'waarheidsclaim' krijgt ook de vraag naar 'de adequaatheid' van metaforische beelden een andere betekenis. In plaats van direct empirisch verwijzend en logisch deugdelijk naar 'de werkelijkheid' te verwijzen, treffen 
metaforen op een andere wijze 'de zaak' waarover gesproken wordt. Welke wijze is dat? Wellicht heeft de 'meerwaarde' van de indirecte spreekvorm te maken met de hierboven aangegeven versterking van retorische zeggingskracht door middel van een (metaforisch) verdichte communicatievorm, waarbij diverse zintuiglijke, emotionele en lichamelijke communicatiekanalen tegelijkertijd en nadrukkelijk worden beroerd. Dit zou betekenen dat het 'metaforische treffen' niet zozeer een cognitieve 'afspiegeling' van 'de werkelijkheid' geeft, maar meer een emotionele en interactieve afstemming op zijn genereert, wat in het eerste hoofdstuk met de term 'grondhouding' is aangegeven. Wellicht wordt door deze 'grond'-overeenstemming' in het metaforische 'treffen' de mens als compleet wezen met hoofd, hart èn lichaam overeenkomstig een kritisch-humanistisch perspectief meer recht gedaan, dan door een logisch-empirische overeenstemming alleen.

De retorische nadruk op emotionele en handelingsaspecten van metaforische betekenisgeving wil echter niet zeggen dat het 'slechts' om psychologische en niet om (onto-)logische aspecten van de metafoor zou gaan. Waar deze retorische invalshoek op communicatie ons aldus op wijst is het primaat van een fundamenteel 'dialogisch' principe: dat een uitspraak over de werkelijkheid nooit om de bemiddelende 'derde' van de taal en van het sprekende subject heen kan gaan, zoals wij geneigd zijn te geloven door de ontologiserende claim van een 'wetenschappelijke kenwijze'. Het 'letterlijke' taalgebruik van de wetenschap suggereert het bestaan van een directe link tussen concept en ding. Waar de 'onontkoombaarheid' van de 'bemiddelende derde instantie' in metaforische communicatie door de retorische wijze van overdracht evident is, geldt dit uiteindelijk ook voor 'letterlijke' beschrijvingen. Dit betekent dat uiteindelijk achter elke directe en letterlijke beschrijving een metaforische aanduidende overeenstemming schuilgaat. Dat wil zeggen dat ook een betoog dat in eerste instantie 'letterlijk' oog, in laatste instantie 'overdrachtelijk' is. Vanuit die optiek verwijst de 'letterlijke' zegswijze veeleer naar conventionaliteit of overeenstemming binnen een bepaalde taalgemeenschap, dan dat er een directe verwijzende relatie tussen woord en ding buiten de sociale context om zou bestaan. De (breuk met) conventionaliteit van (metaforische) betekenisgeving brengt ook het ideologische aspect van de metafoor in het vizier als de door de betreffende gemeenschap gedragen dan wel getaboeïseerde overtuigingen ten aanzien van 'het zijn'. Dit betekent tevens dat ook een natuur-wetenschappelijke beschrijving van 'de werkelijkheid' uiteindelijk niet berust op een directe en letterlijke verhouding tot de natuur, maar op een grondslaggevende 'verscholen' metafoor. ${ }^{16}$ Darwins evolutieleer kun je bijvoorbeeld beschouwen als een empirisch-conceptuele uitwerking van de oorlogsmetafoor dat organismen voor hun voortbestaan en ontwikkeling moeten strijden: met elkaar, tegen de veranderende eisen van de omgeving en onder druk van de tijd. Het is evenwel heel goed mogelijk om vanuit een andere basismetafoor de natuur te bestuderen en te beschrijven. Uitgaande van een funderende metafoor van de natuur als een 'harmonieuze eenheid' (bij-

16. Zie bijvoorbeeld Bulhof: Betoverende wetenschap. 
voorbeeld vanuit de Griekse Gaia-mythe of vanuit een Indiaanse visie op de natuur als een 'bezield wezen') voegen de verschillende organismen zich naar de omvattendere gemeenschap waarvan ze deel uit maken. Op basis van deze andere natuurmetafoor werken organismen, bijvoorbeeld mieren die plantenluizen 'melken', veeleer met elkaar samen dan dat ze elkaar uitbuiten of bestrijden. ${ }^{17}$ Vooronderstelt derhalve elke wetenschappelijk onderzochte 'empirisch-logische ordening' van 'de werkelijkheid' niet een 'metafysica' of een ideologische grondovertuiging ten aanzien van 'het zijn? Is dus de conclusie onvermijdelijk waartoe 'de logica van de metafoor' ons (ver)leidt: dat elke metaforische èn wetenschappelijke beschrijving uiteindelijk berust op een metaforische geloofsovertuiging over de 'grond van het zijn'?

Vragenderwijs is er een hermeneutische interpretatie-ruimte geopend om te onderzoeken hoe 'de grondslag' van metaforische praktijkkennis omschreven kan worden. Met het postulaat van de middenpositie komt aan de logische en de retorische invalshoek op communicatie een relatieve geldigheid toe. Dit betekent dat er niet naar een bevoorrecht 'archimedisch' standpunt gezocht wordt om 'de werkelijkheid' te beschouwen. Evenmin leidt de retorische invalshoek tot de conclusie dat elke wijze van beschrijving om het even is ('anything goes'). Een beschrijving van 'de werkelijkheid' verschijnt vanuit de hermeneutische middenpositie als een beeld dat aangeeft hoe degene die de beschrijving geeft zich verhoudt tot het beschrevene. Een metaforische beschrijving van een organisatie bijvoorbeeld verwijst in dat verband naar de grondhouding die tot juist deze beschrijving heeft geleid. Retorisch gesproken wordt er met die uitspraak een 'voorstel' gedaan of een 'uitnodiging' gegeven om dezelfde grondhouding in te nemen of 'de organisatie' vanuit het perspectief van de gesprekspartner te bezien. Maar 'het innemen van een perspectief' is niet een willekeurige keuze. Het is een voorstel met gevolgen. In die zin bevat een organisatiemetafoor een 'voorschrift' of een 'oproep' om een bepaalde sociaal-economische en spiritueel-psychologische ordening te creëren, zoals uit de analyse van 'de basketbal-organisatie' in het vorige hoofdstuk ook is gebleken. Een metafoor 'treft' weliswaar 'de zaak' op unieke wijze maar ze kan geen aanspraak maken op exclusiviteit. De openheid voor alternatieve metaforische beschrijvingen is derhalve geen 'subjectivering' van wetenschappelijke kennis over organisaties, maar een principieel kritischhumanistisch uitgangspunt om de sociale werkelijkheid van organiseren toegankelijk en bespreekbaar te maken voor een ieder die bij de organisatie betrokken is. Ook vanuit 'esthetisch' oogpunt is het 'metaforische treffen' geen willekeurige zaak. Om een 'vaag gevoel' of een 'diepere motivatie' metaforisch vorm te geven, is niet elk beeld 'even logisch'. Een metaforische beschrijving berust wellicht op een dialogisch èn een esthetisch principe. Een 'treffende metafoor' is door een 'logica van het beeld' en een 'logica van het gevoel' gemotiveerd en kan kritisch-

17. Empirisch-rationeel valt noch de 'eenheidsmetafoor' noch de 'strijdmetafoor' te bewijzen, waarop Kant reeds wees in zijn Kritiek der reinen Vermunft met betrekking tot de regulatieve ideeên van de 'rede'. Het kritisch-humanistisch uitgangspunt van dit onderzoek wijst in dit verband op het primaat van het 'sprekende subject' in (metaforische) betekenisgeving. 
humanistisch worden gelegitimeerd wanneer zij dialogisch door een sociale gemeenschap wordt geaccepteerd. Deze retorisch-pragmatische invalshoek op communicatie wijst op het primaat van een dialogisch beginsel, waaruit een criterium voor 'metaforische adequaatheid' volgt, dat primair een emotioneelesthetisch aspect heeft. Op grond hiervan kunnen beelden de toehoorder (aan)spreken en toehoorders geraakt worden. Bovendien wijst het kritischhumanistische uitgangspunt op het belang van het be-antwoorden en het verantwoorden van het aangesproken en geraakt-zijn in metaforische communicatie. De derde 'middenterm' in (metaforische) communicatie of de derde 'gesprekspartner' in de dialoog via een creatief medium vertegenwoordigt in zekere zin het kritisch-humanistische uitgangspunt. Namelijk voor zover deze 'derde' staat voor de openheid en betrokkenheid in de dialoog: openheid van gesprekspartners jegens elkaar en voor het medium van de kunst, gekoppeld aan de betrokkenheid van het 'sprekende subject' bij 'de zaak waarover gesproken wordt' en bij het 'creatieve beeld'. Voor Plato's behandeling van metafysische en kennis-theoretische vragen diende zich juist de grot als beeld aan. Aan de hand van dit beeld kon Plato een epistemologisch-ontologische analyse van onze 'staat van zijn' geven, waarbij hij de filosofische vraagstelling koppelde aan spirituele en psychologische betekenissen van onze onvolmaakte ken- en zijnswijze. In het algemeen zal metaforische communicatie in dit onderzoek derhalve worden opgevat als een uitnodiging aan de betreffende sociale gemeenschap om de werkelijkheid op juist die metaforisch gesuggereerde wijze te zien, te conceptualiseren en tegemoet te treden, teneinde een gewenste sociaal-economische en spiritueel-psychologische ordening te creëren.

Uit het voorgaande volgt dat elke (metaforische) beschrijving van 'de' werkelijkheid een dialogische kwaliteit in zich herbergt, dat wil zeggen principieel voorlopig en 'intersubjectief' is: onderwerp van verbeelding, van dialogische communicatie en onderhandeling in een sociale gemeenschap. Nu is het de vraag of dit dialogische uitgangspunt 'niet-metafysisch'18 begrepen kan worden. Deze interpretatie krijgt haar beslag door de onderzochte metaforische communicatie langs 'een derde weg' voorbij rationalisme en romantiek dialogisch te grondvesten. Zowel de 'rationalistische' als de 'romantische' grondhouding geven een 'metafysische' interpretatie van 'de grond' voor kennisvergaring. De 'rationalistische grond' bestaat uit eeuwig en overal geldige regels van onze Ratio terwijl de 'romantisch grond' een 'intuittieve' kennisinstantie is die op een directe wijze kennis verschaft door middel van empathische identificatie. In plaats van dergelijke 'metafysische' interpretaties van de ken- en zijnsgrond introduceert dit onderzoek een dialogische context waarin praktijkkennis verantwoord dient te worden. Vanuit het primaat van de dialoog is aan de 'empirisch-rationele' en de 'gevoelsmatig-intuitieve' kenwijze een relatieve waarde toegekend. De hermeneutische 'middenpositie' maakt geen exclusieve keuze voor een logische ò een retorische invalshoek op communicatie, maar nodigt uit tot een 'dialogisch

18. Zie voor de relevantie van een 'niet-metafysische' grondslag met betrekking tot creatieve therapie de zevende paragraaf van het tweede hoofdstuk. 
verstaan', dat hermeneutisch tussen een eenzijdige empathische of reflexieve verhouding tot 'de werkelijkheid' heen laveert.

\subsection{De metafoor als middel tot betekenisgeving}

Deze paragraaf spitst de retorische invalshoek toe tot de metafoor als communicatiemiddel. De eerste subparagraaf geeft als achtergrond een algemene schets van taalfilosofische literatuur over de metafoor. In de volgende subparagraaf figureert 'de metafoor' als een retorische kracht in het tekstuele verband van een betoog. $\mathrm{Zij}$ wordt als 'het gezag van Metaphora' ten tonele gevoerd, met een polaire werking ten opzichte van de empirisch-logische ordening van een tekst. In de daarop volgende subparagraaf komen een aantal specifieke taalfilosofische begrippen voor het voetlicht, als bouwstenen voor een conceptueel kader om betekenisgevende aspecten van 'de metafoor' te kunnen belichten. De vierde subparagraaf bevat een uiteenzetting van drie verschillende vormen van 'metaforische communicatie'.

\subsubsection{Dialectiek van metaforisering en conceptualisering}

Omdat deze beschouwing in dialoog met de bestaande literatuur over 'de metafoor' is ontstaan, wordt er gebruik gemaakt van conventionele onderscheidingen, zoals het onderscheid tussen 'letterlijke' en 'figuurlijke' betekenissen, de metafoor als een vorm van 'beeldspraak' en 'metaforische betekenisgeving' als een vorm van (emotionele) 'kennisoverdracht'. Evenwel worden de conventionele onderscheidingen niet absoluut opgevat, maar in een relatieve zin gehanteerd, vanuit de fundamenteel gestelde dialectiek tussen metaforisering en conceptualisering. In het verlengde hiervan zijn de verschillende taalfilosofische benaderingen van de metafoor niet als elkaar uitsluitende theorieën opgevat, maar als 'relatief geldige' perspectieven, die inzicht verschaffen in de wijze waarop de metafoor betekenis genereert. De gebruikelijke 'vergelijkings'-, 'vervangings-' en 'interactie'-theorieën ${ }^{19}$ verkrijgen daarmee een relatieve geldigheid, als een mogelijk gezichtspunt om de retoriek van de metafoor te begrijpen. De verschillende benaderingen werpen een specifiek licht op de wijze waarop de metafoor in diverse toepassingscontexten betekenis genereert.

In het voorbeeld van 'De manager coacht zijn team' worden twee soorten leidersfiguren uit de wereld van sport en uit het domein van organisaties met elkaar vergeleken. In het vorige hoofdstuk is in de vierde paragraaf aan de hand van de basketbalmetafoor het retorische effect van een metaforische 'vergelijkings-strategie' gedemonstreerd. Dit neemt niet weg dat deze metafoor ook kan worden opgevat als een uitnodiging voor een 'semantische vervanging' van de gebruikelijke term 'manager'. Ten slotte kan het zo zijn dat in een

19. Mooij: A Study of Metaphor: On the Nature of Metaphorical Expressions, with Special Reference to their Reference. 
specifieke gebruikscontext de metaforische betekenis ook 'terugslaat' op de 'letterlijke' betekenis van het woord 'coach', zodat meer uitgesproken dan voorheen 'managementkwaliteiten' integraal deeluitmaken van de betekenis van het woord 'sportscoach'.

Metaforen genereren ten opzichte van de conventies van een taalgemeenschap een betekenistransgressie, een onconventioneel semantisch effect, waardoor het gebruikelijke conceptuele kader wordt overschreden. Ook in taalpsychologisch opzicht genereert de metafoor een 'betekenistransgressie', waarop vooral in het tweede hoofdstuk is gewezen met betrekking tot het beeldend-therapeutische proces van betekenisgeving. 'Metaforische communicatie' verschuift de aandacht van cognitieve 'informatie-overdracht' naar de fysiek-zintuiglijk-emotionele basis van het kenproces. De metaforische wijze van emotionele kennisoverdracht berust in vergelijking met andere vormen van beeldspraak (bijvoorbeeld de analogie, de synecdoche, enz.) op de verbinding van twee voorheen gescheiden maar op een bepaalde zintuigelijk-associatieve manier gelijkende (betekenis- resp. zijns-) domeinen. Taalfilosofisch gezien creëert de metafoor een 'paradoxale' waarheidsclaim, in die zin dat het metaforisch gestelde zo is en niet zo is. De metaforische dynamiek werkt aldus 'de-reëficerend '20 op een (rationele) werkelijkheidsconstructie zodat er filosofisch èn psychologisch gesproken ruimte ontstaat voor alternatieve perspectieven en een andere werkelijkheidsbeleving. 'Metaforische communicatie' maakt duidelijk hoe door de dialectiek tussen conceptualisering en metaforisering 'werkelijkheden' worden ge(de)construeerd. In het proces van betekenisgeving, opgevat als een voortdurende keten van (de)reificaties van werkelijkheid-constructies, schept 'metaforische communicatie' een interpretatieruimte voor alternatieve percepties op de organisatorische en therapeutische realiteit.

Een retorische invalshoek op (metaforische) communicatie relativeert het belang van de inhoudelijke boodschap van woorden ten opzichte van het relatie-aspect van de taal als medium of boodschapper. De metafoor verbindt niet alleen twee domeinen van de werkelijkheid met elkaar ${ }^{21}$ zodat onze theoretische kennis over de betreffende gebieden wordt uitgebreid. Maar de generatieve kracht van de metafoor bewerkstelligt ook een transgressie uit dit cognitieve aspect van kennisgeneratie: de metafoor genereert een verbinding van beide werelden wat betreft hun medium-zijn, wat betreft de vormgeving in het medium. De vaardigheid van het coachen levert uiteindelijk de gevraagde andere betekenis van managementkwaliteiten op, niet (zozeer) de theoretische kennis hieromtrent. In 'creatieve trajecten' vindt de (metaforische) overdracht via het creatieve medium plaats, waardoor het inhoudsaspect van communicatie wordt geminimaliseerd en het betrekkingsniveau in de vorm van de psycho-sociale dynamiek tussen de deel-

20. Zie voor het gebruik van deze term in een context van 'organisatieverandering' hoofdstuk 3 paragraaf 5.2 .

21. Deze betekenis van de metafoor wordt in cognitieve benaderingen benadrukt, zie bijvoorbeeld het methodologische model van Tsoukas dat in hoofdstuk drie paragraaf 2.1 is beschreven. 
nemers van het traject, een retorisch accent krijgt. De therapeutische en trainingsdoelstellingen zijn metaforisch gearticuleerd in de taal van het creatieve medium. De psycho-sociale aspecten van communicatie vormen de (impliciete) 'middenterm' in de metaforische vergelijking of in de analogie-redenering. Langs deze weg is bijvoorbeeld het trainingsdoel 'inspirerend leidinggeven' in een muziekmetafoor vertaald op een seminar over dit thema. Daar werd een dirigent uitgenodigd om interactief met beeld en geluid 'het inspirerend dirigeren van een orkest' te vergelijken met 'het inspirerend leiden van een organisatie ${ }^{, 22}$.

De met dit onderzoek bewandelde 'middenweg' maakt het mogelijk dat de semantische dynamiek van de metafoor als een (psycho-)logica van communicatie kan worden nagetrokken in velerlei kennisdomeinen en allerlei 'cultuursectoren': van rituele religieuze praktijken tot Informatie-Technologie, van managementbenaderingen tot creatieve therapie. Het stelt ons in staat om de creatieve trajecten in het kader van organisatietraining, advisering en therapie enerzijds als een eenheid te conceptualiseren (namelijk als een 'metaforische kennisvorm'), anderzijds om recht te doen aan evidente verschillen en pluriformiteit die deze praktijken eigen zijn. In deze zin staat 'de metafoor' voor de 'eigenheid' van deze vorm van praktijkkennis en wordt ze als zodanig opgevat als 'de integrale structuur' van onze cognitieve, emotionele en interactieve betrokkenheid op de werkelijkheid. Hoe deze integrale wijze van betekenisgeving als een 'logica van de metafoor' aan de onderzochte intuïtieve praktijkkennis een 'grondslag' verschaft, zal in de volgende paragrafen worden toegelicht en uitgewerkt.

\subsubsection{Het gezag van Metaphora en de macht van Logos}

Het creëren van metaforen is ouder dan ons denken over de metafoor. Deze open deur verwijst naar een principieel filosofisch uitgangspunt. Elke studie over de metafoor vooronderstelt haar eigen onderwerp en wordt erdoor ingehaald. Hiermee zij aangegeven dat de metafoor op bepaalde wijze aan ons onderzoek en aan elke wetenschappelijke benadering ontsnapt. Vanuit een rationele kennisopvatting is dit een zwakte of een theoretische deficiëntie die zoveel mogelijk moet worden vermeden, tegengegaan en verholpen. Bijvoorbeeld door middel van het ontwerpen van een verfijnd theoretisch kader om de metafoor conceptueel eenduidig en uitputtend vast te leggen. Deze wetenschapsbenadering gaat uit van de veronderstelling dat het mogelijk is om een sluitende definitie van de metafoor en een duidelijke afbakening van haar domein en werkwijze te geven, zodat haar geldigheid en reikwijdte kan worden aangegeven met behulp van toepassings- en vertaalregels. Postmoderne kritiek stelt hier tegenover dat zelfs in de meest doortimmerde theoretische onderbouwing en afbakening van haar domein er ongemerkt metaforen meespelen die niet door het conceptuele kader worden

22. Op 27 juni 2000 aan de Erasmus Universiteit Rotterdam, onder meer bedoeld voor 'alumni van de bedrijfskunde faculteit'. 
gerechtvaardigd. Dat de metafoor zich aldus aan een conceptuele omkadering onttrekt ${ }^{23}$ wordt hier, in navolging van Derrida, niet als een praktisch of theoretisch tekort beschouwd, maar als een principieel, positief en onontkoombaar gegeven. Het is een onvermijdelijke 'co-incidentie' die met de act van het definiëren en conceptualiseren zelf wordt ingezet. Het woord 'coïncidentie' ironiseert de 'noodzakelijke' semantische 'wet' dat er tegelijkertijd met de conceptualiserende beweging van het denken die de metafoor beoogt vast te leggen een impliciete metafoor is gecreëerd die buiten deze definitie treedt. Deze fundamentele metaforische dynamiek is inherent aan ons spreken, voelen, handelen en denken. In navolging van Derrida is hiervoor de term metaforiek gebruikt, die meer dan het zelfstandige naamwoord en statische begrip van de metafoor, naar dynamische aspecten van betekenisgeving verwijst. Ook waar gemakshalve van 'metafoor', 'metaforen' of 'metaforische betekenisgeving' wordt gesproken is deze inherente dynamiek voorondersteld. Zoals reeds aangegeven is de metaforische dynamiek in het onderwerp van onderzoek uitgebreid van een tot de taal beperkte semantiek naar een metaforiek in onze zintuiglijke, emotionele en interactieve betrokkenheid op 'de werkelijkheid'. Voor de articulatie van deze integrale, metaforische, betrokkenheid op de wereld lijkt 'de taal van een creatief medium' bij uitstek geschikt te zijn.

De 'meerwaarde' van creatieve trajecten hangt mogelijk samen met het gegeven dat deze werkvorm spoort met onze fundamentele metaforische betrokkenheid op de wereld. In dit onderzoek is deze 'integrale betrokkenheid' aangeduid met de omschrijving van 'creatieve trajecten' als een metaforische vertolking van 'zijn' door 'levende metaforen'. 'Vertolking' verwijst naar het uitgangspunt dat ook een wetenschappelijke beschrijving geen 'zuivere' afspieging van 'de' werkelijkheid geeft, maar dat de typerende 'objectieve' kennisvorm voortkomt uit een 'beheersende en afstandelijke grondhouding' tot 'het zijn'. Het kritisch-humanistische perspectief van dit onderzoek vestigt de aandacht op de verwevenheid van het type ('metaforische' of 'conceptuele') kennis met een overeenkomstige grondhouding en bijbehorende psycho-dynamiek van de betreffende kennisgemeenschap ten opzichte van het kenobject. Karakteristiek voor creatieve trainingen en therapievormen is de typerende wijze waarop de psycho-sociale dynamiek van de kennisgemeenschap via het creatieve medium nadrukkelijk meespreekt. De primair gestelde dialectische wisselwerking tussen een metaforische en een conceptuele benadering van de werkelijkheid komt met Ricoeurs ${ }^{24}$ opvatting overeen. Om de typerende 'narrativiteit' in (beeldende) kunstexpressies te belichten, benadrukt dit onderzoek dat beeldelementen op ludieke wijze in de dialoog met het creatieve medium 'spelend-beeldend meespreken'. Dit wordt aangeduid met de term 'dialectische speelruimte', die mede door Gadamers notie van spel is geïnspireerd. ${ }^{25}$ Het

23. Derrida: Le retraite de la metaphore 125-126.

24. Ricoeur: La mètaphore vive. Tiemersma: Ricoeur's hermeneutics of action and schematheory. Phenomenological Inquiry 9 (1985) 58-71.

25. Gadamer: Wahrheit und Methode. 
spelbegrip onderstreept de open maar begrensde ruimte van 'de dialoog' via de (non-)verbale taal van het creatieve medium. In de vierde paragraaf zal de verbinding van het spelbegrip met de dialogische grondhouding verder worden uitgewerkt tot een 'speelse' gesprekshouding en een dialogische onderzoeksbenadering.

\subsubsection{Een conceptuele omkadering van de metafoor}

De hiervoor gegeven typering van 'creatieve trajecten' als levende metaforen vestigt de aandacht op de functie van de metafoor als 'katalysator' voor een herstructurerering van 'het existentiële veld' resp. van 'de belevings-organisatie ${ }^{26}$ van deelnemers aan creatieve trajecten. In deze paragraaf wordt een begrippenkader ontwikkeld om deze metaforisch-conceptuele dynamiek in het proces van betekenisgeving aan te duiden en conceptueel te omkaderen.

In de aan Ricoeur ontleende typering van 'levende metaforen' staat de 'levende' tegenover de 'dode' metafoor, met dien verstande dat in alle vormen van taalgebruik afgestorven èn nieuwe metaforen te herkennen zijn. Een voorbeeld van een dode metafoor vinden we in de zinsnede 'een conceptuele be-nadering van de metafoor'. Daarin is te horen dat een concept een metafoor (letterlijk en figuurlijk) 'be-nadert'. Bij eerste lezing valt de metaforische betekenis van dit woord niet op. Een 'oorspronkelijke' letterlijke betekenis kan gaan meeklinken wanneer de tekst opnieuw wordt gelezen en gehoord.

Heidegger ${ }^{27}$ bijvoorbeeld kwam tot een herinterpretatie van Leibniz' formulering van het rationaliteitsbeginsel - 'Nihil est sine ratione' - doordat hij na jaren 'hetzelfde' op een andere manier hoorde. Hierdoor gingen de woorden voor 'zijnsvervoeging' (is) en voor 'zijnsgrond' (ratione) anders samenklinken. In plaats van de nadruk op de dubbele ontkenning ('nihil' en 'sine') te leggen verschoof Heidegger het accent naar een 'samenklank', een 'positieve herformulering' van het beginsel tot "Jegliches was ist, hat einen Grund".

Op grond van het hermeneutisch herinterpreteren van de betekenis van woorden het mogelijk dat 'dode metaforen' weer tot leven worden gewekt. Een ander voorbeeld is de wijze waarop ik het woord 'coïncidentie' in de vorige paragraaf, 'zin-spelend' met de conventionele betekenis van 'toeval' en de letterlijke connotatie van 'samen-gebeuren', heb gebruikt om het 'noodzakelijke' samen-spel van Logos en Metaphora onder de aandacht te brengen. Wanneer een versleten metaforische betekenis 'meeresoneert' wordt dit veelal bijkomstig opgevat als een

26. Deze aan de theorie van beeldcommunicatie ontleende term (zie hoofdstuk 2, paragraaf 2.2.1) suggereert een 'psychologische' en dus 'subjectivistische' duiding van het proces van metaforische betekenisgeving. Omdat in dit hoofdstuk juist de ontologische aspecten hiervan worden benadrukt voeg ik de term 'existentieel veld' hieraan toc.

27. Heidegger: Der Satz vom Grund. 
associatie die alleen psychologisch relevant is. In dit onderzoek naar de metaforische kennisvorm wordt ze beschouwd als een wezenlijk moment van het hermeneutische verstaan. Het laten meeklinken van 'metaforische (bij)betekenissen' komt voort uit de dialectiek tussen een metaforische en een conceptuele ervaringsmodus. Volgens deze interpretatie van 'levende metaforen' wordt duidelijk hoe in creatieve trajecten juist dit retorische samenspel van metaforische en conceptuele effecten op de voorgrond treedt via de taal van het creatieve medium'.

Binnen het domein van versleten metaforen kan nu een nuancering worden aangebracht: namelijk tussen slapende en dode metaforen. Het hiervoor gegeven voorbeeld van een 'conceptuele benadering' is bij nader inzien veeleer een slapende dan een dode metafoor. Het 'naderen' kon immers als slapende metafoor weer tot leven worden gewekt. Echter is het soms niet zonder meer mogelijk om in woorden een verstopte letterlijke betekenis te ontdekken. Bijvoorbeeld de woorden 'slapend', 'levend' en 'dood' zelf verstaat men als zodanig letterlijk. Pas in en door de context van een studie over de metafoor worden ze op overdrachtelijke wijze op de metafoor toegepast. De metaforische betekenis van het woord 'levend' is door Ricoeur in de aangehaalde studie over de metafoor bewust naar voren gehaald. Door de speciale toepassingscontext wordt het bestaan gesuggereerd van een letterlijk opgevat 'biologisch leven' en een figuurlijk 'semantisch leven'. Een begrippenpaar dat op vergelijkbare wijze het onderscheid tussen een conventioneel en een metaforisch betekeniseffect benoemt, is de onderscheiding 'eigenlijke' versus 'oneigenlijke' betekenis. 'Eigenlijk' verwijst naar 'taal-eigen', dus 'lexicaal' of 'conventioneel' taalgebruik. Een metaforische verdraaiing van de conventionele betekenis merkt men derhalve als een 'oneigenlijke' spreekwijze aan. Niettemin kan het oneigenlijke metaforische spreken 'romantisch' worden omgeduid, zodat de in woorden verstopte 'letterlijke' betekenis juist als de eigenlijke wordt geherinterpreteerd. Vanuit een romantische visie 'behelst' een metafoor een letterlijke betekenis die als 'oorsprong' in het 'eigenlijke' verstaan van woorden doorklinkt, ten opzichte waarvan een 'vervreemding' optreedt onder invloed van het 'conventionele verstaan'. Etymologisch onderzoek kan de 'verborgen oorspronkelijke betekenis', die in conventioneel taalgebruik niet meer wordt gehoord, opnieuw aan het licht brengen. Heideggers werk ademt een zekere romantische geest doordat hij prachtige voorbeelden geeft van een metaforischetymologische interpretatie van filosofische concepten. Bijvoorbeeld lezen we in zijn 'hoofdwerk' Sein und Zeit niets over 'de mens', maar gebruikt hij 'Da-sein' als een 'oorspronkelijkere' betekenis voor 'het menselijke existeren'; 'Lichtung' en 'Er-eignis' fungeren als metaforen voor 'het existentiële zijns-verstaan' in zijn latere werk.

Een voorbeeld uit de natuurlijke spreektaal is het woord 'lichaam'. Dit is een samenstelling van het Germaanse 'lika' of 'vlees' dat in ons woord 'lijk' nog doorklinkt en het woord 'haman' dat 'omhulsel' betekent. Oorspronkelijk was de aanduiding 'vleselijk omhulsel' dus een metaforische omschrijving als ware 
ons lichaam een 'mantel van de ziel'. Nu is deze metafoor versleten en vervormd tot het letterlijk opgevatte 'lichaam'.

Overigens geeft deze classificatie van metaforen, door middel van het metaforische gebruik van de woorden 'levend', 'dood' en 'slapend', een voorbeeld van de inherente metaforische dynamiek van ons spreken en denken. Zoals reeds aangegeven berust een conceptuele omlijning van de metafoor zelf ook weer op metaforen. In de uitleg van metaforisch geleende termen verschijnen opnieuw versleten metaforen. Bijvoorbeeld verwijst de kwalificering van betekenissen in 'letterlijk' en 'oorspronkelijk' naar letter(tekens) en oorsprong. Vanuit een rationalistische kennisopvatting wordt het in deze paragraaf gevormde conceptuele kader door de bedoelde dynamiek metaforisch ondermijnd. Hermeneutisch gesproken is de metaforische dynamiek onvermijdelijk, ook in een 'abstracte' karakterisering van 'hetzelfde'. Bijvoorbeeld de 'abstracte' classificatie van 'actuele' versus 'gewezen' metaforen. Impliciet bevatten deze classificerende termen ook weer metaforische betekeniselementen: de metafoor als act in 'actueel' en de zinspeling met haar werkwoordelijke en substantiële 'wezen'. Een poging om deze metaforische elementen eveneens in een conceptuele omschrijving onder te brengen kan de termen 'impliciet' en 'expliciet' lenen. Echter zullen we ook deze begrippen weer moeten definiëren, waarbij er metaforisch een beroep wordt gedaan op het invouwen en ontvouwen van een semantische ordening. Aldus komen we bij het rationalistische project van een 'metaforologie', dat wil zeggen een eenduidige conceptuele omkadering van de metafoor, onherroepelijk in een oneindige regressie terecht. Derrida heeft dit semantische grondgegeven uitgewerkt en benoemt als 'de wet van de metafoor'. Met betrekking tot dit onderzoek wordt het belang van dit inzicht voor 'creatieve trajecten' onderstreept door 'het gezag van Metaphora' op te vatten als een fundamentele metaforiserende beweging die een logische ordening van begrippen in een conceptuele benadering van de werkelijkheid - 'de wet van Logos' - doorkruist. De conclusie waartoe deze paragraaf leidt is derhalve dat elk betoog berust op een samenspel van conceptualisering en metaforisering.

Dit fundamentele gezichtspunt dat een betoog aldus dialectisch op metaforischconceptuele wijze betekenis genereert, impliceert dat de metafoor ook buiten de bewuste intenties van een auteur om een semantische werking in een tekst heeft. Met betrekking tot de onderzoeksvraagstelling geeft het primaat van de krachtenmeting tussen Logos en Metaphora aanleiding tot een methodische vraag met betrekking tot 'de meerwaarde' van deze kennispraktijk: Hoe spelen (niet) bewust geïntenteerde metaforische betekeniseffecten mee 'in' en 'door' de 'letterlijke' vormgeving van 'levende metaforen' in het creatieve medium? Zoals 'verbale metaforen' in een tekst associatieve en zintuigelijke connotaties oproepen, zo bewerkstelligen 'levende metaforen' in creatieve trajecten dat in een nog verderstrekkende zin. Hierbij zijn in principe alle aspecten van lichaamstaal betrokken zodat er een conglomeraat van emotionele, verbeeldende en lichamelijke bijbetekenissen wordt gegenereerd. Het is de kundigheid van de creatieve trainer of 
therapeut om dit integrale proces van metaforische betekenisgeving in de 'creatieve trajecten' met het oog op de trainings- of behandeldoelstelling te begeleiden en bij te sturen. Derhalve is er een samenspel tussen 'kennis van het hoofd' en 'kunst van het hart' nodig om het creatieve medium op dusdanige wijze te laten meespreken dat er een balans ontstaat tussen 'spontane creatieve expressie' en 'instrumenteel handelen' met betrekking tot de individuele hulpvraag, resp. de organisatiedoelstelling.

Op grond van dit dialectische samenspel of deze hermeneutische 'balanceerkunst' vindt er door middel van de creatieve werkvorm een herstructurering van 'de belevingsorganisatie' en 'het existentiële betekenisveld' van de deelnemende cliènten plaats. In de context van dialogische communicatie tussen therapeut of trainer en cliënten spreken emotionaliteit, verbeelding en lichamelijkheid van aanwezigen op nadrukkelijke, stilzwijgende en uitgesproken wijze via de taal van kunst mee. Hoewel deze aspecten in alle taalhandelingen meespelen, stelt de metaforische handelingscontext van 'creatieve trajecten' ze op integrale wijze op de voorgrond. Dit betekent dat ze door de deelnemers niet omzeild kunnen worden, zoals dat veelal in alledaagse verbaal gerichte communicatie wel gebeurt. Vanuit de onderzoeksvraagstelling naar de grondslag van 'creatieve trajecten' is de dialogische context, waarin de psycho-dynamiek van communicatie op metaforische en conceptuele wijze aan de orde wordt gesteld, van fundamenteel belang. Hierdoor krijgen deze algemeen menselijke aspecten van communicatie een 'eigen' vorm van verantwoording, wat beantwoordt aan het met dit onderzoek ter discussie gestelde (kritisch versus naïef) humanistische gezichtspunt ten aanzien van de toepassing van metaforen in therapie en organisaties.

\subsubsection{Metaforische communicatie}

De retorische invalshoek krijgt in deze paragraaf een toespitsing tot communicatie waarin metaforen een meer of minder uitgesproken rol spelen. Het minst prominent is de rol van de metafoor wanneer zij als een vorm van beeldspraak tussen 'letterlijke' omschrijvingen door wordt ingelast om een betoog te verlevendigen. Sterker wordt het retorische effect als metaforen niet alleen een zakelijke beschijving opsmukken, maar wanneer de vorm van communicatie metaforisch is. Een spreker kan in een verhalende vorm - bijvoorbeeld met een sprookje - een beschrijving geven van een werkelijke of een wenselijke situatie. Op die wijze is het sprookje van Andersen Het lelijke eendje gebruikt om een psychologisch-spiritueel ontwikkelingsperspectief te schesten, waarbij de ontwikkeling van een 'sociaal alledaags zelf' (als jong 'lelijk eendje') naar een 'oorspronkelijk en authentiek zelf' (de zwaan) metaforisch uitgelegd wordt. ${ }^{28}$ Wanneer een sprookje of een verhaal gecondenseerd is tot een levende metafoor, een 'beeldnarratief' dat het gehoor als

28. Knibbe: lezing Studium Generale, Erasmus Universiteit Rotterdam, 17 oct. 2000. Zie zijn boek $\mathrm{De}$ niet-herkende Boeddha. hoofdstuk 2: Neurose als niet-herkende Boeddhakwaliteit. 
zodanig herkent, worden beide vormen van 'metaforische communicatie' tegelijkertijd gebruikt. Bijvoorbeeld zinspelend op Andersens sprookje kan iemand metaforisch verzuchten "Ik voel me onder de nieuwe chef net het lelijke kleine eendje".

De eerstgenoemde vorm van 'metaforische communicatie' - de doorbreking van de zakelijke directe betoogtrant door middel van metaforen - grenst aan de ene kant aan de introductie van nieuwe beelden in onze woordenschat, aan de andere kant aan het gebruiken van cliché's, zoals: 'Zij blijft mijn roosje' en 'Alle neuzen staan dezelfde kant op'. Het risico bij het creëren van nieuwe metaforen is dat deze te ideosyncratisch kunnen zijn en als zodanig niet worden verstaan. Hier tegenover staat het gebruik van cliché's op gespannen voet met de levendigheid en authenticiteit van een betoog. Niettemin bewerkstelligen ook versleten metaforen en cliché's een retorisch betekeniseffect. Wanneer aan het einde van een lange theologische verhandeling over het belang van een ascetische levenswijze wordt geconcludeerd dat 'het lichaam de kerker van de ziel is', versterkt deze metafoor het beroep op de toehoorders om allerlei lichamelijke verleidingen links te laten liggen. Een voorbeeld van een metaforische vormgeving van een filosofischspirituele boodschap is Plato's beroemde grotmythe. Daarin geeft hij door middel van een verhaal - over 'de geketende mensen in een grot die slechts kennis van de wereld achter hen hebben door middel van schaduwbeelden die op de wand voor hen zijn geprojecteerd' - een beschrijving van de gevangen en onvolmaakte staat van zijn op aarde met 'schaduwkennis' in plaats van 'ware' en 'heldere' kennis uit de volmaakte ideeënwereld.

Boeddhistische taal is zeer bloemrijk: zo worden er twee historische varianten van het boeddhisme als 'het kleine voertuig' en 'het grote voertuig' van elkaar onderscheiden. Daarnaast is er het wereldlijke 'pad van de krijger' als 'weg' om de 'verlichting' te bereiken. In (zen-)boeddhistische tradities wordt vaak de tweede sterkere vorm van 'metaforische communicatie' aangewend als didactisch middel om tot (hoger) inzicht te komen. Zo is het gebruikelijk dat de leerling van zijn leermeester (guru) een koan of raadsel krijgt, waarop hij mediteert tot hem de oplossing in een verlossend moment van inzicht voor zijn geestesoog verschijnt. Een bekend voorbeeld luidt:"Hoe was je gezicht van voor de geboorte?" of "Wat is het geluid van éen klappende hand"? Een ander voorbeeld is een anekdote waarin een professor bij een guru komt om over de verlichting te filosoferen. Terwijl de professor nog midden in zijn relaas zit schenkt de spirituele leermeester hem thee in. Voor het oog van de professor blijft hij doorschenken totdat deze de thee over de rand van het kopje ziet stromen. Nadat hij de guru waarschuwt voor wat er gebeurt zegt deze: "Maar wat wilt u eigenlijk van mij? Uw hoofd zit net zo vol als dit theekopje!" 29

29. Watts: Zen-Boeddhisme. Jansen: Het Boeddha-boek Boeddha's, godheden en rituele symbolen. Kahn: De Tau van het Gesprek. De kunst van het luisteren. de Wit: (1998) De lotus en de roos. Boeddhisme in dialoog met psychologie, godsdienst en ethiek. 
Deze laatste anekdote bevat een vorm van 'metaforische communicatie', die met betrekking tot de onderzoeksvraag van bijzonder belang is. In dit voorbeeld van deze derde vorm is de wijze van communicatie en de betrekking tussen de gesprekspartners 'op metaforische wijze' present gesteld. De 'indirecte boodschap' van de 'analoge communicatie' komt door de metaforische vorm van het theeschenken pregnant naar voren. Vergelijkbaar met dit voorbeeld kan het analoge aspect van communicatie via de taal van de kunst worden vormgegeven. De betekenis van de 'indirecte boodschap' wordt beschreven in termen van 'iets anders', namelijk in de taal van 'het theeschenken', met dans of door muzikaal samenspel, in beeldtaal, door bewegingstaal of in verhaalvorm door middel van een sprookje. Hierbij wordt het betrekkingsniveau van communicatie op nadrukkelijke wijze op de voorgrond gesteld. Via de dialoog met het kunstmedium verschijnt dit aspect van de onderlinge betrekking in communicatie als een metafoor op de voorgrond. De discursieve inhoud van wat gecommuniceerd wordt, verschuift hierdoor naar de achtergrond. Door de interactie tussen de deelnemers van een creatieve workshop via het creatieve medium van muziek, beelden, drama, dans, enz., wordt het betrekkingsaspect in een metaforische vorm via klanken, kleuren, vormen en verhalen vertolkt. De levende metafoor 'staat voor' de wijze waarop er met elkaar wordt gecommuniceerd, welke in een 'normale' context op de werkvloer of in de persoonlijke levenssfeer als zodanig impliciet blijft. In het bovenstaande voorbeeld: de woordenstroom van de professor die over de verlichting wil discussiëren en de nonverbale taal van de guru die voor de neus van de professor het kopje thee laat overstromen en hieraan een 'metaforische uitleg' geeft. De psycho-sociale overdrachtsprocessen die normaal gesproken in de communicatie op het werk of in het gezin onuitbesproken blijven, krijgen als 'beelden van communicatie' of 'handelingsmetaforen' een expliciete vorm. In het kader van een creatieve organisatietraining of in creatieve therapie worden professionele en existentiele onderwerpen in een metaforische vorm, bijvoorbeeld aan de hand van een sprookje of een dramatisch thema, aan de orde gesteld. Op weer andere wijze kan een biografisch of professioneel thema muzikaal of in een beeld(verhaal) door de deelnemers aan een 'creatief traject' worden geënsceneerd. Door de 'levend' metaforische vormgeving van creatieve trajecten gaan overdrachtsprocessen via het creatieve medium de hoofdrol in communicatie spelen.

Er kan een verbinding worden gelegd tussen deze drie vormen van 'metaforische communicatie' - het inlassen van een metafoor in een betoog, een metaforische verhaalvorm en metaforische communicatie via een 'nonverbaal' medium - met de in de tweede paragraaf aangegeven driedeling in 'communicatie-kanalen': de cognitieve, emotionele en interactieve 'wijze van overdracht'. In dat verband zouden we kunnen spreken van het creëren van een 'handelingsmetafoor' of een 'bewegingsbeeld' wanneer vooral het interactieve overdrachtsniveau op de voorgrond staat. Een voorbeeld is de enscenering van een thema, bijvoorbeeld leidinggeven, tot een 'dramatisch' of 'psycho-motorisch' gegeven, zoals een oefening in 'dansend leiden en volgen'. Primair hierbij is de narratieve vorm van communi- 
catie: in en door de gedramatiseerde handelingen in de dansante oefening wordt de onderlinge betrekking van 'leidinggevende en volgende' metaforisch verbeeld en vormgegeven. Wanneer vooral het emotionele niveau van communicatie wordt present gesteld zou je metaforisch kunnen spreken van het genereren van een 'belevingsbeeld' of van een 'emotionele metafoor'. Dit kan bij uitstek worden bewerkstelligd door middel van een muziekmetafoor, waarbij het inhoudsaspect van communicatie is geminimaliseerd. De klanken en het samenspel genereren een 'emotionele taal', waardoor deelnemers aan een muziektraining onmiddelijk worden aangesproken. De cognitieve afronding van een creatief traject in therapie of training tot het gewonnen inzicht in het uiteindelijke 'leereffect', zou je kunnen beschouwen als een 'cognitieve metafoor' ofwel de constructie van een 'denkbeeld' uit 'de levende metafoor'.

Overigens zijn dit analytische onderscheidingen die aan het 'totaaleffect' en de 'dialectiek' van 'metaforische communicatie' eigenlijk onrecht doen: het samenspel van zintuigmodaliteiten met elk een eigen taal, om niet te spreken van transmodale effecten, is principieel onvertaalbaar. De hier gemaakte onderscheiding in denk-, belevings- en bewegingsbeelden verraadt bovendien een 'visuele bias'. Het gezichtszintuig wordt in de beschrijving bevoorrecht ook daar waar het eigenlijk om andere zintuigmodaliteiten gaat. Met de aanduiding van een beeldnarratief wordt dit enigszins gerelativeerd door de betekenis van een beeld als een verhaal in verdichte vorm. De 'bias' hangt enerzijds samen met het feit dat in het bijzonder de beeldende creatieve therapie is onderzocht, anderzijds met het algemene gegeven dat onze wetenschappelijk taal met betrekking tot het theoretische verstaan van verschijnselen het oog veelal bevooroordeelt.

Met betrekking tot de derde vorm van 'metaforische communcatie' - de 'vertolking door levende metaforen' - is er nog een ander belangrijk aspect van de retorische invalshoek op communicatie van belang. Retorisch gesproken hoeven niet alle stappen in een betoog te worden gerechtvaardigd, terwijl dat voor een logische analyse wel geldt. Sterker nog: een retorisch verhaal wint aan overtuigingskracht door bijvoorbeeld sprekende stiltes in te lassen. Op weer andere wijze wordt de rechtlijnigheid van een betoog onderbroken door het stellen van een retorische vraag. Terwijl hier vanuit logisch oogpunt iets overbodigs aan het betoog wordt toegevoegd, wordt daar, in een retorische context, met opzet een schakel weggelaten of een sprong in de betoogopbouw gemaakt. Er klinkt een suggestie zonder het direct te zeggen of er wordt een vraag gesteld waarop het antwoord bekend verondersteld wordt, etc. Ook het vertellen van moppen berust vaak op het verzwijgen van elementen, op de wijze van presentatie van verhaalelementen, op het overdrijven van de stand van zaken,- kortom op het volgen van een retorische en juist geen logische strategie. Ook de reeds genoemde raadsels of koans die een leerling in een (zen)boedhistische traditie van zijn guru krijgt, worden gekenmerkt door deze kryptische, dat wil zeggen betekenisweglatende en daardoor tot betekenisgeving aanzettende communicatievorm. Daarin speelt nog een ander retorisch element een rol: namelijk de paradoxale vorm van communicatie. In de ironie 
speelt deze vorm ook op eigen wijze mee, namelijk door juist dat te zeggen wat je niet bedoeld.

De kryptische en de paradoxale vorm is duidelijk in het gegeven voorbeeld van de koan 'Wat is het geluid van één klappende hand?' In een gebruikelijke context van communicatie of door middel van een empirisch-logische benadering van de vraag, leidt de koan tot een evidente absurditeit of een onmogelijkheid. Teneinde een oplossing voor het raadsel te vinden is het noodzakelijk van de absurditeit of de tegenspraak een paradox te maken, waarmee de 'normale' grenzen van ons verstaan die ons door verstand en zintuigen zijn gesteld, worden overschreden.

In het algemeen kunnen we derhalve stellen dat voor een logische betoogopbouw het expliciet maken van alle argumenten en denkstappen karakteristiek is, terwijl een narratieve betoogtrant juist gebruik maakt van het retorische effect wanneer argumenten of denkstrappen impliciet blijven of als ze op indirecte of vervormde wijze worden geëxpliciteerd. Met betrekking tot ons onderzoek naar de creatieve werkvorm betekent dit dat de derde 'metaforische communicatievorm' zeer uitgesproken en pregnant in vergelijking met 'gewone' communicatie, van retorische elementen gebruik maakt. Er wordt gespeeld met retorische dynamiek van het weglaten, toevoegen, overdrijven, verkleinen en afwegen van betekenis-gevende elementen.

De werkzame retoriek in 'creatieve trajecten' berust aldus op een samenspel van 'economische' en 'ecologische' krachten in het proces van betekenisgeving. Aan de ene kant is er in communicatie een tendens naar overvloed van betekenis onder invloed van het creëren van nieuwe woorden en metaforen. Bijvoorbeeld door de introductie van reeds bestaande termen in een nieuwe context waardoor er meerduidigheid en ambiguë betekenissen ontstaan. Net zoals de natuur een overvloed aan levensvormen creëert, werkt er in de natuurlijke context van communicatie een ecologisch beginsel dat een betekenissurplus genereert. Aan de andere kant is er een semantisch principe werkzaam in de richting van zuinigheid en beperking van woordbetekenissen. Onder invloed van het 'economisch' rouleren van de semantische munteenheid van het woord, verslijt de metaforische betekenis langzamerhand tot 'letterlijke taal'. Dit is bijvoorbeeld duidelijk in de semantische ontwikkeling van de woorden 'stokpaardje' of 'kerfstok', die aanvankelijk 'letterlijk' naar fysieke objecten verwezen en nu een overdrachtelijke betekenis hebben gekregen.

'Een goede manager coacht zijn team.' Dit voorbeeld uit de context van management illustreert het inflatieproces waaraan een metafoor onderhevig is. In het aanvankelijke metaforische gebruik van de term 'coach' bewerkstelligde de verbinding van de wereld van sport met die van organisaties een nieuwe betekenis van dit woord. Met 'coachen' wordt een specifieke leidinggevende kwaliteit van de manager aangegeven die in de gebruikelijke betekenis van 
'managen' ontbrak of onderbelicht bleef. Wanneer er een symposium over 'coachend leiderschap' wordt georganiseerd, betekent dit dat de nieuwe betekenis door de gemeenschap van managers en organisatiekundigen is geaccepteerd. Hiermee heeft het begrip echter aan innovatieve kracht ingeboet. Ook het expliciteren van de impliciete vergelijking in een metafoor of het uitleggen van een mop verzwakt het retorische effect. In de management-literatuur is er een algemene tendens van 'het verslijten' van deze metafoor van 'coachend leiderschap' merkbaar, tot zij nu nagenoeg 'letterlijk' wordt opgevat. ${ }^{30}$

Ook al is in deze derde paragraaf een 'logische' en een 'retorische' invalshoek op communicatie tegenover elkaar gesteld, duidelijk is dat in elke betoogvorm beide typen van betekenisgeving altijd meespelen. Aldus kan zowel een logische analyse als een literair verhaal worden beschouwd als het resultaat van een hermeneutisch spel van retorische en logische betekenisgevende elementen. Een tekst berust op de krachtenmeting tussen Logos en Metaphora, waarbij de balans kan uitslaan naar het impliciet laten of het expliciteren van vooronderstellingen, argumenten en denkstappen. Afhankelijk van het gecreëerde machtsevenwicht tussen Logos en Metaphora is het betoog gericht op het overdrijven of het ironiseren van betekenissen dan wel het nauwgezet afmeten van de zaak waar het om gaat. Waar metaforische communicatie vooral gebruik maakt van retoriek om betekenissen impliciet te laten of om ze op overdreven, vervormde en gekleurde wijze te presenteren, daar begeeft een logische analyse of een wetenschappelijke presentatie zich naar de andere extreme pool van explicitering en het getrouw weergeven van elke noodzakelijke stap in de betoogopbouw. Betekenis ontstaat aldus door een samenspel van het economisch rouleren, wat inflatie van zeggingskracht genereert; èn het ecologisch uitzaaien van woorden in een andere context, als zaadjes in nieuwe bodem, waaruit neologismen en alternatieve betekenissen groeien. Ook deze filosofische verhandeling over de metafoor is aan semantische inflatie onderhevig: door de onderzoeksmatige benadering is de inherente retorische dynamiek van het onderzochte afgezwakt. Tegelijkertijd is ook de omgekeerde ecologische dynamiek werkzaam omdat de onderzochte praktijk in een andere, filosofische context verschijnt en daarmee een nieuwe betekenis verkrijgt

\subsection{Regressieve, progressieve en transgressieve dynamiek}

De in de derde parargraaf gegeven metaforisch-conceptuele omkadering van de metafoor grenst aan velerlei filosofische vraagstukken ${ }^{31}$ en psychologische onderwerpen, zoals processen van creativiteit en regressie, verbeelding als waan, als fictie en als voorschouw, bewustzijnsverlagende en bewustzijnsverhogende dynamiek. Deze veelomvattende thema's worden hier niet uitputtend behandeld. Voor

30. Seminar "Coachend Leiderschap", georganiseerd door FOCUS te Amsterdam op 8 juni 2000, waarop onder ander Johan Cruyff als gastspreker sprak.

31. Zie bijvoorbeeld: Haak: Metafoor en Filosofie. 
zover relevant met betrekking tot het onderwerp van onderzoek snijd ik ze als de filosofisch-psychologische horizon in de eerste subparagraaf aan. In de tweede subparagraaf wordt dit perspectief betrokken op een profielschets van een hermeneutische onderzoekshouding. Deze is gekarakteriseerd vanuit de dialogische middenpositie en krijgt in de derde subparagraaf methodologisch toespitsing. Welke consequenties dit heeft voor het (onderzoeks-)proces van interpretatie zal in de vierde subparagraaf worden besproken.

\subsection{De metafoor als katalysator van ontwikkelingsprocessen}

In de vorige paragraaf is de metafoor als een oudere vorm van betekenisgeving in vergelijking met het conceptuele denken (over de metafoor) gekarakteriseerd. Hiermee hangt de problematiek van een 'primitieve' denkvorm samen. Dit type denken zou zich vooral door de bevoorrechte rol van metaforen onderscheiden van meer ontwikkelde abstract-logische denkvormen. De filosoof Cassirer onderscheidt in deze zin bijvoorbeeld het 'metaforische denken' van 'primitieve volken' van het meer ontwikkelde denken waarop de wiskunde, de filosofie en de wetenschap berusten. ${ }^{32}$ Een dergelijke antropologisch-historische optiek ${ }^{33}$ beschouwt de metafoor als een symptoom van een regressieve beweging van ons 'bewustzijn' naar een primitiever stadium. In het tweede hoofdstuk is gebleken hoe in de antropologische benadering van creatieve therapie deze regressieve ontwikkelingsdynamiek een hoofdrol speelt in het therapeutische proces van metaforische betekenisgeving. In creatieve therapie zou gebruik worden gemaakt van een 'oude' vorm van 'metaforisch denken' die in zekere zin overeenkomt met 'magisch denken' van kinderen en symbolisch-rituele handelingen van 'primitieve volken'. In dat verband is ook benadrukt dat de metaforische betekenisoverdracht in het kader van creatieve trajecten in therapie en training niet een tot de taal en de cognitie beperkte semantische dynamiek genereert, maar dat er tevens een handelingscontext met een emotionele geladenheid in de vorm van een existentieel betekenisveld wordt geconstitueerd.

Wanneer 'primitief denken' in de huidige, westerse en 'geciviliseerde' mens optreedt, interpreteert men dit in de regel als een regressieverschijnsel wat, als een 'symptoom' of een deviantie ten opzichte van 'normale' gedachtepatronen, een negatieve bijklank heeft. Deze deviantie krijgt een positieve duiding wanneer er een sublimatie tot kunstwerken plaatsvindt. Dit negatieve aspect van 'metaforisch-

32. De metafoor zou bijvoorbeeld een rol spelen in het magische geloof dat een deel van een persoon (zoals het haar, de nagels of een foto) de persoon als geheel re-presenteert in de letterlijke zin van het woord (volgens het principe pars pro toto), zodat de magische handeling die op het 'afgesneden' deel wordt uitgevoerd tegelijkertijd en in dezelfde letterlijke zin betrekking heeft op de persoon zelf. Op deze manier kan de betreffende persoon heil dan wel schade worden toegebracht. Zie Frazer: De gouden tak en deel II van Cassirer: Philosophie der symbolischen Formen.

33. Zie bijvoorbeeld ook Langer: Philosophy in a New Key. A study in the Symbolism of Reason, Rite and Art. 
magisch denken' als een 'pathologisering van het bewustzijn' overheerst evenwel. Kennelijk worden 'primitieve volken' geassocieerd met hypnotische en tranceachtige bewustzijnstoestanden, sjamanistische praktijken, genezingsrituelen, uittredings-verschijnselen, paranormale waarneming. In het kader van een 'geciviliseerde cultuur' worden 'dezelfde' verschijnselen geïnterpreteerd als 'hallucinatoir' of het 'stemmen horen door een schizofreen', als een 'psychotische aanval' of een 'manische periode van een depressief persoon'. Het 'metaforischmagische denken' van een volwassen westerling - dat zich bijvoorbeeld uit in het nauwkeurig betreden van stoeptegels zonder de tussenruimtes aan te raken teneinde onheil te voorkomen - geldt als een dwang-handeling. Een vergelijkbaar 'ritueel gedragspatroon' bij een Europees kind heet een onschuldig fantasiespel te zijn, terwijl 'hetzelfde gedrag' in de context van niet-westerse volken veeleer als een 'bezweringsritueel' zou overkomen. Slechts onder bepaalde omstandigheden krijgen symptomen van een 'niet-rationeel' bewustzijn bij de westerling de classificatie 'geniaal' of 'creatief'. In de literatuur worden 'gevallen' beschreven van personen waarin beide uitingsvormen tegelijkertijd of gefaseerd zijn voorgekomen. Bijvoorbeeld Van Gogh's beruchte laatste levensfase van waanzin, waarbij hij zowel een sterke creatieve periode had als een stuk van zijn oor afsneed. Kunst als 'sublimatie van de primitieve libidinale drift' is typerend voor een Freudiaanse visie, die bijvoorbeeld is uitgewerkt in diens psycho-analytische interpretatie van de kunstenaar Leonardo da Vinci. ${ }^{34}$ Anton Heyboer is een voorbeeld van een hedendaagse kunstenaar die kunst gebruikt om zijn waanzin in leefbare en artistieke vormen tot uitdrukking te brengen, volgens de kunsthistoricus Locher. $^{35}$

Jung beschrijft vanuit zijn psycho-analytische invalshoek een wezenlijke samenhang tussen verschijnselen van pathologie, creativiteit en spiritualiteit in het kader van een bewustzijnsontwikkeling, onder de noemer van een 'individuatie-proces'. Hij gebruikt het begrip archetype om een bijzondere 'dieptepsychologische' werking van beelden in het onbewuste te verklaren. De archetypische beelden met hun uitzonderlijke zeggingskracht hebben tegelijkertijd een 'primitieve', een 'creatieve' en een 'spirituele' betekenis.

Een voorbeeld van de archetypische betekenis van beelden is de symboliek van de mandala. Dit ogenschijnlijk alledaagse beeld komt in diverse vormen voor: meer figuratief als 'aangeklede wielen' met bloem- en diermotieven of meer geometrisch als een 'kwadratuur in een cirkel'. De mandala manifesteert zich in mythologische en rituele beelden uit de Indiase en de Indiaanse cultuur, in het Tibetaans boeddhisme, en in de Europese alchemistische en mystieke literatuur. Naast het 'collectieve' voorkomen van dit archetype heeft Jung ook 'individuele' varianten beschreven, namelijk in de vorm van droombeelden die hij zijn patiënten heeft laten vertellen en natekenen. Op grond van zijn

34. Freud: Leonardo da vinci. A memory of his childhood. Ark Paperbacks, London, 1984.

35. Locher: cursusmateriaal Metafoor en Beeldtaal. 
cultureel-historische kennis en klinische ervaring interpreteert Jung de mandala als symbool voor het individuatie-proces. Dit beeld zou staan voor een proces van eenwording of heelwording van de persoon met niet-geaccepteerde delen van zichzelf (de zogenaamde 'schaduw'-kanten) en met een groter geheel (de kosmos, God,...).

Het 'metaforische denken' lijkt aldus twee extreme vormen aan te nemen: een 'creatieve' variant van genialiteit tegenover een 'magische' in de vorm van bezetenheid door waanbeelden. In tegenstelling tot het 'primitieve denken' wordt het innovatieve 'metaforische denken' juist als een jonger denken opgevat. Dit denken staat aan de geboorte van vernieuwende concepten in de wetenschap, alternatieve inzichten in de organisatorische praktijk en doorbraken in het therapeutische proces. De rebelse variant van 'metaforisch denken' verwijst aldus naar velerlei vormen van betekenisvernieuwing op emotioneel, artistiek en intellectueel gebied. $^{36}$ In een wetenschappelijke of filosofische beschouwing werpen innovatieve metaforen een nieuw licht op bestaande verschijnselen of vestigen de aandacht op nieuwe verschijnselen. Een voorbeeld is een bekende voorstelling van de atoomstructuur van de kleinste eenheid van materie, die analoog aan het beeld van 'cirkelende planeten rond de zon' is ontworpen. Maar ook poëtische taal kan als een vorm van 'metaforisch denken' worden opgevat. Dichters verstaan bij uitstek de kunst om zodanig met woorden te spelen dat er een zintuigelijk voelbare betekenis wordt opgeroepen. De zogenaamde Haiku-gedichten uit de zenboeddhistische traditie zijn erop gericht om een basale emotie of 'grondstemming' in woorden te schilderen:

De avondlijke bries;

't water kabbelt

tegen 's reigers poten. $^{37}$

Met weinig woorden, poëtisch gerangschikt, wordt er een kalme gemoedsstemming metaforisch opgeroepen. Een evocatief geschilderd natuurbeeld treft direct doel, waar een wetenschapper of filosoof via de (om)weg van verklaring uitleggend op de zaak ingaat.

Het 'metaforische denken' kent aldus verschillende verschijningsvormen, wat zich in ons denken, voelen, handelen en spreken uit via een dubbelzinnige semantische dynamiek die enerzijds innoverend progressief en anderzijds conserverend regrèssief werkt. Met betrekking tot processen van artistieke en wetenschappelijke vernieuwing is veelal een fasering in (vier) stadia aangebracht, van voorbereiding tot doorbraak en uitwerking van het vernieuwende inzicht, waarbij het beruchte 'eureka'-moment het culminatiepunt vormt. ${ }^{38}$ Dit moment van doorbrekend inzicht

36. Goosen: Breaking out of the Box. The Logic and Art of Creativity and Business.

37. Watts: Zen-Boeddhisme 138.

38. Ulmann: Kreativität. Neue amerikanische Ansatze zur Erweiterung des Intelligenzkonzeptes 20-33. 
wordt geschraagd door een euforiegevoel. In deze verhoogde bewustzijnstoestand zouden alle vroegere stadia van kennisvergaring en inspanning die tot de vernieuwing hebben geleid, op een integrale manier voor de geest verschijnen in de vorm van het 'aha-Erlebnis'. Ten aanzien van dergelijke beschrijvingen van de creatieve ontdekking is overigens gewezen op het kunstmatige of cliché-karakter dat meer naar de mythe rondom genialiteit lijkt te verwijzen dan naar het feitelijke creatieve proces. $^{39}$

Een voorbeeld van de dubbelzinnigheid in het samenspel van 'regressieve conserverende' en 'progressieve innoverende' dynamiek in denkprocessen wordt in de literatuur over creativiteit genoemd $d^{40}$. Het betreft een gevalsbeschrijving van de natuurkundige Pauli die als patiënt van Jung niet alleen therapeutisch baat had bij het analyseren van zijn droombeelden, maar ook voor het oplossen van een natuurkundig vraagstuk waarmee hij worstelde, hetgeen geleid heeft tot de formulering van het 'coincidentie'-beginsel als tegenhanger van het causaliteitsprincipe.

Met betrekking tot de onderzoeksvraag is het van belang na te gaan of het mogelijk is bovenstaande verabsoluterende interpretaties van 'metaforische denken' tot een uiting van 'het creatieve proces', van 'de pathologisering van de geest' of van 'het primitieve bewustzijn' op niet-metafysische wijze wijze te herinterpreteren. Hiertoe heb ik de notie 'metaforische ervaringsmodus' als tegenhanger van de rationalistische kenwijze geïntroduceerd. Langs de middenweg 'tussen' rationalisme en romantiek, zou deze kenvorm 'ideologie-neutraal' getypeerd kunnen worden, weliswaar in relatie tot het betreffende cultureel-historische referentiekader waarin zij plaatsvindt, echter zonder haar in een 'absolute' zin als 'primitief' 'creatief', 'geniaal' of pathologisch' aan te merken. Een dergelijke absolutistische, metafysische interpretatie van deze ervaringsmodus berust, zo heb ik aan het slot van hoofdstuk twee geconcludeerd, op een 'letterlijk' opgevatte ontwikkelingsmetafoor. Die wijze van voorstellen is in in dat kader in verband gebracht met rationalistische en romantische perspectieven op ontwikkeling. Een veelvoorkomende voorstelling van zo een 'letterlijk opgevatte ontwikkelingsmetafoor' is een ontwikkelingstrap omhoog of omlaag. Het rationalisme ziet op de hoogste traptrede van de menselijke ontwikkeling een volledig gerationaliseerde beschaving. Civilisering, rationalisering en humanisering betekenen parallelle schreden in de ontwikkelingsgang voorwaarts en omhoog, onder geleide van een progressieve beweging van ons bewustzijn. Hier tegenover staat een romantisch omgekeerde ontwikkelingstrap, met als einddoel een ontwikkelings-teruggang naar een 'Goede Oerstaat', naar een natuurlijke vorm van 'samenleving' en een 'kinderlijk' of 'primitief bewustzijn'. De-civilisering, humanisering en naturalisering zijn volgens het romantische perspectief analoge momenten van een regres-

39. Boden: The Creative Mind. Myths \& Mechanisms.

40. Boden: Dimensions of Creativity. 
sieve ontwikkelingsdynamiek van de mens(heid) om uit de vervreemding van het beschavingsproces naar een oorspronkelijke 'natuurstaat' terug te keren.

Vanuit de hermeneutiek worden rationalisme en romantiek relatief opgevat als twee extreme perspectieven, die uit een dialectisch proces van betekenisgeving tot een overeenkomstig wereldbeeld zijn gereïficeerd. In plaats van een dergelijke verabsolutering van een rationalistische of romantische kenwijze annex 'interpretatiekader', stelt de hermeneutiek de 'dialectiek van grondhoudingen' primair, die gedragen wordt door de middenpositie 'tussen' een beheersende en vervloeiende verhouding tot 'de' werkelijkheid. In deze hermeneutische 'tussenruimte' vindt er primair een dialectisch spel met grondhoudingen plaats, dat in tweede instantie tot een 'wereldbeeld' kan worden gereificeerd. Grondslaggevend voor een kritisch-humanistische vormgeving van de creatieve werkvormen zou veeleer deze 'hermeneutische interpretatieruimte' zijn dan een specifiek 'wereldbeeld'. In deze dialectische speelruimte vindt de dialoog tussen cliënt en therapeut of trainer via het creatieve medium plaats.

\subsubsection{Hermes tussen hoofd en hart}

Deze paragraaf geeft een interpretatie van de hermeneutische middenpositie. Allereerst een metaforische typering van de mythische figuur aan wie de hermeneutiek wordt toegeschreven.

Volgens de Griekse mythologie is Hermes de grondlegger van de hermeneutiek en de literatuur. Dat hij eveneens de uitvinder van getallen, maten en gewichten is, bewijst dat hij geen eenzijdige geest heeft. In verband met het toepassingsgebied van de bedrijfskunde is het bovendien interessant op te merken dat hij de god van kooplieden, reizigers en dieven is. Bovendien heeft hij een eerbiedwaardige 'staat van dienst': als buitenechtelijk kind van Zeus en met een crimineel verleden, is hij begonnen als god van herders en kudden, en opgeklommen tot gezant van de goden. Zijn herautenstaf is het symbool voor zijn hoedanigheid als bemiddelaar tussen goden en mensen, maar ook als geleider van gestorven zielen naar de onderwereld.

Hermes' veelzijdigheid helpt ons metaforisch om de onderzoeksroute uit te stippelen tussen de eeuwige, onveranderlijke en universele kennis van de goden, de Wet van Logos, en de veranderlijke en tijdelijke kennis van het ondermaanse, die onder het gezag van Metaphora valt. Hermes is als bemiddelaar tussen beide werelden ons voorbeeld hoe in de (onderzoeks-)praktijk te balanceren tussen een rationalistische en een romantische benadering van (kennis over) de werkelijkheid. Hermes' balanceerkunst kan goed met een uitspraak van Gandhi worden getypeerd: 
I have come to the fundamental conclusion that if you want something really important to be done, you must not merely satisfy the reason, you must move the heart also. ${ }^{41}$

Deze uitspraak verwijst naar een 'middenpositie' van waaruit zowel hoofd als hart gemobiliseerd kunnen worden. Ik gebruik haar om 'het samenspel tussen metaforisering en conceptualisering' in de 'hermeneutische speelruimte' aan te duiden. Concepten, modellen en theorieèn zijn producten van onze wetenschappelijke hersenen; metaforen dragen we met ons hart uit. Hermes bewaakt de bemiddeling tussen hoofd en hart, tussen een rationalistische en een romantische grondhouding. Het gaat om de kunst de bemiddelingsruimte te begrenzen èn open te houden. De grens ligt bij het 'verabsoluteringspunt' wanneer men de kennis van het hoofd of van het hart tot alleenzaligmakend uitroept. Dan wordt vanuit een van beide extreme posities het andere extreem verworpen. Een romantisch standpunt omarmt de levende kennis van het hart en ziet de abstracte kennis van het hoofd als een dwaalweg. Vanuit een rationalistisch standpunt bekeken betekent de metafoor een gevaar voor de universaliteit van theoretische kennis. Hierbij past een positivistische degradering van de metafoor tot dienstmaagd van de wetenschap. Een metafoor kan worden uitgesponnen tot een concept of model; in een (wetenschappelijk) concept of model schuilt een (slapende of dode) metafoor. De dienstbaarheid van de metafoor geschiedt veelal vanuit een ontwikkelingsperspectief, waarin er een metaforische fase aan het 'eigenlijke' proces van theorievorming vooraf gaat of erna komt in de praktijkcontext van heuristiek, toepassing en didactiek. Waar een rationalistische kennisstrategie erop gericht is om in het proces van betekenisgeving van metaforische kwaliteiten te abstraheren, daar is volgens een romantische kenwijze het bewaren en benadrukken van de metaforische oorsprong van conceptuele kennis de aangewezen weg om tot werkelijk inzicht te komen. Waar een romantische benadering uiteindelijk uitkomt op een omkering van het statusverschil tussen concept en metafoor, daar resulteert een postmoderne nivellering ${ }^{42}$ van dit statusverschil in de consequentie dat een metafoische beschrijving van de kunst van het management aan de hand van verhalen van Winnie-de-Poeh, de Tao of de kunst van het paarden-mennen in laatste instantie epistemologisch op gelijke voet staat met organogrammen, sterkte/zwakte analyses en een ondernemingsplan. Ook de hermeneutiek relativeert het traditionele epistemologische verschil tussen metaforen en concepten. Niettemin richt dit onderzoek zich juist op de 'eigen-(aardig)heid' van metaforische praktijkkennis ten opzichte van conceptuele kennis, zonder één van beide a priori te bevoorrechten noch de verschillen te verwaarlozen.

Een hermeneutische benadering is niet vooringenomen ten aanzien van oorsprong of eindpunt van het proces van kennisgeneratie, zoals rationalisme en romantiek

41. Gandhi, geciteerd in: Parekh: Gandhi's Political Philosophy. A critical Examination 146.

42. De term 'postmoderne nivellering' duidt enerzijds op een 'degradering van het concept' in het verlengde van 'het onvoltooide' van de rede, zie bijvoorbeeld Reijen van: De onvoltooide rede. Modern en Postmodern; anderzijds op de 'rehabilitering van de metafoor' in het spoor van de dialoog tussen kunst en filosofie, zie bijvoorbeeld: Oosterling \& Prins (red): Filosofie en Kunst I en II. 
dat wel zijn. Maar ze stelt het proces van betekenisgeving als zodanig centraal, waarbij aandacht voor de ontstaansgeschiedenis, de focus op de actualiteit en een gerichtheid op de toekomst samenkomen. $\mathrm{Zij}$ bakenen als constitutieve momenten van het proces van betekenisgeving de dialectische interpretatieruimte af. De hermeneutiek spreekt liever van 'context van interpretatie' dan van 'oorsprong van betekenissen', omdat dit laatste woord een romantische bevoorrechting suggereert van de emotionele, zintuiglijke en lichamelijke aspecten van betekenisgeving als zijnde 'de oorsprong' van de betekenis van een metafoor. Geen dichotomisering van aspecten van maar evenmin een samenvloeiing met 'de totaliteit'. De dialectische wisselwerking staat centraal, tussen verleden, heden en toekomst, tussen theorie en praktijk, tussen concretisering en abstrahering. Deze onderscheidingen hebben een relatieve geldigheid tegen de achtergrond van het totale en ondeelbare proces van betekenisgeving. Net zoals Hermes tussen goden en mensen bemiddelt, zo fundeert 'de bemiddelende grondhouding' een kundigheid die het midden houdt tussen 'kennis van het hoofd' en 'kunst van het hart'. De 'hermeneutische middenpositie' balanceert tussen rationele controle over en empathische overgave aan 'het zijn'.

Wanneer we de hermeneutische middenpositie in een dialogische context plaatsen manifesteert zij zich als een meanderende beweging tussen een angstvallige beheersing van de communicatie en een symbiotisch samenvallen met het toevallige verloop van het gesprek. De middenpositie kan nu in verband worden gebracht met het aan het einde van hoofdstuk drie geformuleerde 'dialogische principe':

Een methodisch gestuurd (bijvoorbeeld socratisch) groepsgesprek, waarin beslissingen worden genomen ten aanzien van gemeenschappelijke zaken of tegenstrijdige belangen op een dusdanige wijze dat alle partijen als gelijkwaardige, betrokken, goed geïformeerde en (in sociaal en ethisch opzicht) vrije gesprekspartners aan de dialoog en de beslissingsprocedure participeren.

Wanneer we de hermeneutische interpretatieruimte als een communicatieve onderhandelingsruimte opvatten, kan het onbegrensde, oneindige proces van betekenisgeving worden begrensd door het hier geformuleerde dialogische principe. De openheid van het hermeneutische spel van grondhoudingen is daarmee verankerd in de dialogische middenpositie. Deze verankering vindt in de dialoog plaats door een afstemming op 'zijn', dat wil zeggen een afgestemde betrokkenheid op de gesprekspartners, op het besprokene en op het verloop van het gesprek. Hermes als bemiddelaar laat zich niet door vaste communicatieregels beheersen maar speelt met de dominante door de cultuur voorgeschreven rationalistische en romantische varianten van gespreksvoering. In het volgende citaat uit een studie over de dialogische kunst van luisteren en spreken wordt er een dilemma geschetst dat de auteur typerend acht voor onze cultuur, een dilemma tussen een 'oppervlakkige conversatiestijl' en 'de vijandigheid van discussies en twistgesprekken': 
Je kunt roddelen of over koetjes en kalfjes praten. Je kunt verhalen vertellen of ernaar luisteren. Je kunt om de beurt een mening ventileren, die weinig of niets te maken heeft met wat de vorige spreker heeft gezegd. Maar als je je mengt in een gesprek over een onderwerp waar je echt bij betrokken voelt, dan betekent dat strijd. (...) Het zal echter niemand verbazen dat discussies in onze samenleving een dergelijk beeld oproepen, omdat dit beeld kenmerkend is voor onze cultuur, die steeds meer verandert in een vechtcultuur. (...) Is het dan vreemd dat we worden grootgebracht met de gedachte dat je ruzie moet vermijden en dat je je maar beter op de vlakte kunt houden? ${ }^{43}$

De twee in dit citaat geschetste 'gesprekshoudingen' lijken varainten te zijn van de rationalistische en de romantische grondhouding. Enerzijds is er de 'angst voor het onbekende' als drijfveer, die leidt tot 'controle willen houden', tot instrumentele willekeur en een rationaliserende, vijandige houding tegenover gevoelens en 'het irrationele'. Anderzijds is er een houding van kritiekloze overgave, samenklonterende empathie en een romantische willekeur van intuïties en verbeeldingen door gebrek aan onderscheidingsvermogen. De 'oppervlakkigheid' in gespreksvoering kan zowel wijzen op een (romantische) kritiekloze instemming met de geventileerde gevoelens en meningen van andere gesprekspartners, als op een (rationalistische) angstreactie om een eigen stellingname te vermijden. De speelse middenpositie creëert een 'open onderhandelingsruimte' in de plaats van het 'switchen' tussen beide cultureel dominante oriëntaties. Als bemiddelaar hoef je je niet te identificeren met een rationaliserende of een romantische houding ten aanzien van onze emoties en de omgang met anderen, maar kun je er een dialoog mee aangaan. De hermeneutische bemiddelingskunst vooronderstelt een 'dialogische grondhouding' èn maakt haar tevens mogelijk. Voor de middenpositie is een 'spelhouding' karakteristiek, een 'vrije en gebonden' (ver)houding van spelers tot een spel. Vanuit Hermes' bemiddelaarspositie is het mogelijk te balanceren tussen een beheersing van het spel als strategisch project enerzijds - een doelgerichte attitude waardoor de spelregels direct met het oog op winnen in een concrete situatie worden toegepast - en anderzijds een attitude van overgave aan emotionele en lichamelijke aspecten van het spel als een plezierige en (ont)spannende activiteit. Een speelse verhouding tot anderen in de dialoog integreert een kritische houding ten aanzien van ver(ant)woording van het besprokene met overgave aan, afstemming op en betrokkenheid bij het gesprek en het besprokene. De speelse houding is zowel relativerend, met humor doorspekt en door vreugde gedragen als serieus en betrokken bij de zaak. Door deze middenpositie wordt de dialoog niet alleen opengehouden maar ook beperkt. Hermes' bemiddeling in deze context van communicatie bestaat aldus uit het openen en begrenzen van een interactioneel en situationeel 'midden', door juist niet exclusief voor één van beide extreme posities in het dialogische proces van betekenisgeving te opteren.

43. Kahn: De Tao van het gesprek. De kunst van het luisteren 17-18. 
Kan Hermes' ons ook bij een onderzoeksproces begeleiden, dat volgens hermeneutische spelregels gespeeld wordt? Van spelregels hebben spelers al spelend weet, terwijl er soms ook nieuwe ontstaan in en door het spelen zelf. Analoog zou een hermeneutische benadering van kennis over en onderzoek van 'de werkelijkheid' berusten op een dialogisch verstaan van de wereld, van waaruit methodische regels gearticuleerd worden. Dat houdt in dat algemeen geldige onderzoeksregels ingebed zijn in een funderende emotionele betrokkenheid op en omgang met het onderzochte. Een hermeneutische interpreterende verhouding tot de werkelijkheid heeft aan de basis van dit onderzoek gestaan en de methodische vormgeving gestuurd. Achteraf zijn ze in dit proefschrift als 'methodologie' gereconstrueerd. In onderscheid met een rationalistische onderzoeksbenadering is er geen 'methodologische blauwdruk' vooraf gehanteerd. Dat er nochtans 'regels der kunst' hermeneutisch te reconstrueren zijn vormt het belangrijkste onderscheid met een romantische kenwijze, waarin het primaat wordt gegeven aan een niet verder te onderbouwen intuittief gevoel.

\subsubsection{Een hermeneutische interpretatie van de middenpositie}

In deze paragraaf volgt een hermeneutische reconstructie van de middenpositie als onderzoekshouding. Met het oog op het in het volgende hoofdstuk beschreven veldonderzoek, wordt hier filosofisch gereflecteerd op de vraag hoe de hermeneutiek tot een onderzoeksvorm kan worden uitgewerkt. Een hermeneutische uitwerking van ethische gezondheidsvraagstukken met betrekking tot medische en psychologische dienstverlening in de zorgsector is reeds tot een vruchtbare (onderzoeks-)praktijk ontwikkeld. ${ }^{44}$ Een rationalistische onderzoeksbenadering doet onrecht aan de onderzochte verschijnselen wanneer ze in een theoretisch gestuurd conceptueel kader worden geperst. In tegenstelling hiermee staat een romantische benadering te dicht bij de te onderzoeken praktijk, hetgeen wel een empathische betrokkenheid en intuîtief verstaan, echter geen interpretatie mogelijk maakt. Een hermeneutische onderzoeksroute kan op basis van een dialectiek tussen beide extreme onderzoekshoudingen worden ontworpen. Doet men aan deze dialectiek onvoldoende recht dan bestaat het gevaar dat de methodologische onderbouwing geheel ontbreekt danwel dat ze teveel in instrumentele zin, bijvoorbeeld in de vorm van uitgewerkte methoden en technieken als het ware extern, aan het onderzoek wordt toegevoegd in plaats van dat ze intern en dialogisch uit het onderzoeksproces voortkomen.

In de literatuur worden naast 'de hermeneutiek' nog andere methodologische concepten genoemd om vergelijkbare 'dialectische' en 'dialogische' vormen van onderzoek aan te duiden. ${ }^{45} \mathrm{Z}$ o worden bijvoorbeeld ethnografie, de biografiestudie,

44. Widdershoven: Principe of praktijk. Een hermeneutische visie op gezondheid en zorg En:

Ethiek in de kliniek. Hedendaagse benaderingen in de gezondheidsethiek. 79-107.

45. Uit: Denzin \& Lincoln: (ed) Handbook of Qualitative Research. Schwandt: Constructivist, Interpretivist Approaches to Human Inquiry 118-137. 
de case study, participerende observatie, fenomenologie, action research gepresenteerd als deeluitmakend van een 'constructivistische', 'kwalitatieve', 'interpretatieve' of 'post-moderne' benadering van wetenschap. Elementen uit deze benaderingen zijn eveneens voor het veldonderzoek gebruikt en als 'spelregel' ingebracht in de dialectiek tussen 'afstandelijke observatie en theoretisering' en 'empathische afgestemdheid en intuïtief verstaan'. Een treffende metaforische aanduiding voor deze dialectiek in het onderzoeksproces is de dans. ${ }^{46}$ Zoals een choreografie van een dans in dialoog met waargenomen lichaamsbewegingen ontstaat, zo 'beweegt' het onderzoeksontwerp 'dialogisch mee' met de verschillende stappen van het daadwerkelijke onderzoek. Een theoretisch opgestelde onderzoeksopzet die als 'ideale blauwdruk' aan het praktische onderzoeksproces wordt opgelegd, komt in deze optiek juist als gekunsteld over en als te ver van de praktijk afstaand, waardoor aan de verschijnselen onrecht wordt gedaan. Een rationalistische benadering zou in termen van de dans-metafoor overeenkomen met een op de tekentafel geschetste choreografie, zonder dat er met de dansbewegingen en danspatronen daadwerkelijk op de dansvloer is geëxperimenteerd. Hier tegenover staat een romantische interpretatie van deze metafoor als 'het dansend opgaan in de muziek' zonder dat er ook beschouwend en op afstand naar de dans als vorm van betekenisgeving wordt gekeken. In overeenstemming met deze metafoor zijn gebruikelijke methodologische principes op een andere manier ingevuld. Vaak wordt met 'interpretatieve methoden' geen algemeengeldigheid maar juist het in kaart brengen van het unieke karakter van het onderzochte verschijnsel beoogd, zoals bijvoorbeeld in de biografie en de case study. Derhalve zijn methodologische regels zoals interne en externe validiteit, betrouwbaarheid en generaliseerbaarheid niet zo eenduidig aan de hand van het manipuleren en statistisch bewerken van 'omgevingsvariabelen' te controleren, maar gaat het er veeleer om de 'contextafhankelijkheid ${ }^{47}$ in beeld en tot begrip te brengen. Hoe past het onderzochte verschijnsel juist in die specifieke situatie, met dat tijdsbeeld, in die cultuur, op deze plaats en bij het handelen van deze personen?

Methodologisch gesproken kan er aan de ene kant op de 'wetenschappelijkheid' van (natuur- en) sociaalwetenschappelijke kennis worden afgedongen, zoals bijvoorbeeld Van Engeldorp Gastelaars ${ }^{48}$ heeft gedaan. In een grondige systematische en historische studie relativeert hij het veronderstelde principiële onderscheid tussen wetenschappelijke oordelen en maatschappelijke (voor-)oordelen. Aan de andere kant kan metaforische kennis als een specifieke vorm van praktijkkennis met een 'eigenstandige vorm van rationaliteit' worden onderbouwd. Hiervoor kunnen inzichten aan allerlei filosofische stromingen zoals het pragmatisme, de dialectiek, de kritische filosofie, de hermeneutiek, de fenomenologie, de taalfilosofie en 'het post-modernisme' worden ontleend. In deze zin heeft Widders-

46. Janesick: The Dance of Qualitative Research Design. Metaphor, Methodolatry and Meaning. 199. 209 in: Handbook of Qualitative Research.

47. de Leede \& van Engeldorp Gastelaars: Naar een methodologie van de kunde in: Reemsdijk (red.) Dilemma's in de bedrijfskundige wetenschap 141-163.

48. van Engeldorp Gastelaars: Lopen over Water 30. 
hoven ${ }^{49}$ bijvoorbeeld op basis van Aristoteles' phronèsis-begrip een 'handelingsrationaliteit' onderzocht en in verband gebracht met relevante aspecten uit de filosofie van Wittgenstein, Merleau-Ponty, Gadamer en Habermas. Nog andere studies, bijvoorbeeld die van Pott en die van Jonhson en Lakoff ${ }^{50}$ zijn van belang met betrekking tot het funderen van rationaliteit, cognitie en wetenschappelijke kennis in de lichamelijk-zintuigelijke ervaring en haar 'voorstadia' van onbewuste verschijnselen en kinderlijke ontwikkeling. In de lijn van deze studies is ook hier gezocht naar een ervaringsgerichte filosofische basis voor de metaforische kennisvorm, op grond waarvan een cognitieve benadering van kennis kan worden verbonden met aspecten van lichamelijkheid en emotionaliteit.

\subsubsection{Een hermeneutisch interpretatiekader voor intuitieve praktijkkennis}

Het kernbegrip van een hermeneutische onderzoeksmethodologie is 'interpretatie': tot welk type behoort het interpretatieproces wanneer er voor het onderzoek naar 'metaforische kennispraktijken' dialectisch het midden wordt gehouden tussen een empirisch-conceptuele constructie en een empathisch-intuïtief verstaan van de praktijk?

Weber heeft 'het ideaaltype' als een sociaal-wetenschappelijke tegenhanger van natuur-wetenschappelijke categorieën geïntroduceerd. Hiermee doelt hij op een 'ideèle constructie' (dus geen empirisch begrip) die door Steigerung ${ }^{31}$ van kenmerkende aspecten van het fenomeen is ontworpen. Als zodanig is het een 'grensbegrip' en moet het als een de methodische gedachtenconstructie worden opgevat. Wel dient men deze constructie te baseren op een (sociologische of historische) studie over het betreffende fenomeen en verschaft het ideaaltype aldus een wetenschappelijke basis voor een empirische beschrijving. Een voorbeeld is Webers ideaaltypische beschrijving van 'charismatisch', 'traditioneel' en 'rationeel' leiderschap dat gebaseerd is op een typologie van gezagsuitoefening op basis van traditioneel, affectief, ideeel en doel-rationeel handelen. Het bureaucratiebegrip is een ideaaltypisch geconstrueerd begrip voor de meest 'zuivere' vorm van 'doel-rationeel' bestuur. Dat de bureaucratische gezagsvorm niet alleen in een bepaald type staatsinrichting haar beslag heeft gekregen, maar ook in allerlei kleinere organisatievormen, beschouwt Weber als een 'symptoom' van een algemener rationaliseringsproces in Westerse maatschappijen ${ }^{52}$ Op vergelijkbare

49. Widdershoven: Handelen en Rationaliteit.

50. Pott: De liefde van Alcibiades. Over de rationaliteit van emoties. Lakoff: Women, Fire and Dangerous Things. What Categories Reveal about the Mind. Johnson: The Body in the Mind. Lakoff \& Johnson: Metaphors we live by.

Ortony (e.a.): The cognitive structure of emotions.

51. Hempel: Typologische Methoden in den Sozialwissenschaften in: Topisch (red): Logik der Sozialwissenschaften 85-101. Albert: Probleme der Wissenschaftslehre in der Sozialforschung in: König: (red): Handbuch der empirischen Sozialforschung 57-59.

52. Goddijn: Max Weber. Zijn leven, werk en betekenis 185-202. 
wijze kan 'de metafoor' als bouwsteen voor methodische modellen en praktijkgerichte theorieên of als een narratieve basis voor een soort typologie-vorming worden opgevat. Een verschilpunt met Webers typologie-begrip is dat 'de metaforische benadering' een sociaal-wetenschappelijk fundament lijkt te ontberen. Uit de literatuuranalyse in hoofdstuk drie is immers gebleken dat metaforische diagnoses en analyses van de organisatorische praktijk veelal 'ad hoc' zijn geconstrueerd met een minimale theoretische verantwoording. Het is dus de vraag of er voor de onderzochte intuittieve praktijkkennis een op de 'metaforische kennisvorm' toegesneden 'empirische toetsing' en 'theoretische onderbouwing' kan worden ontworpen.

In deze paragraaf vindt een verkenning van deze vraagstelling plaats op basis van de 'dialogische middenpositie' en de 'hermeneutische interpretatie-ruimte'. In het verlengde hiervan is de specifieke aard van het interpretatieproces dat tot (kennis over) 'metaforische kennispraktijken' leidt te verstaan als een 'bemiddelingsproces' tussen een 'ervaringsvreemde' theorie-gestuurde methodologie en een intui-tief-gevoelsmatig begrip van de praktijk. De metaforische kennisvorm berust op een interpretatie van 'intuitieve ervaringskennis'. Als zodanig is ze het resultaat van een dialectische wisselwerking tussen begripsvorming en denkbeelden enerzijds en anderzijds gevoelsmatig intuittieve afstemming en beelddenken. In de praktijk van deze kennisvorm is de balans naar deze laatstgenoemde pool verschoven, terwijl in het onderzoek naar deze kennispraktijk het accent juist meer naar de eerstgenoemde pool wordt verlegd. 'Metaforische kennis' is aldus de vrucht van een hermeneutisch interpretatie-proces van de toegepaste praktijkkennis van professionals. Kenmerkend voor dit proces van interpretatie is dat er, door middel van een 'systematisering van praktische intuïties' wordt voortgebouwd op de ervaringskennis van professionals, bijvoorbeeld zoals Morgan zijn 'metaforische typeringen' van organisaties heeft ontworpen. Hier tegenover staat een kenhouding van stelselmatige twijfel, die kenmerkend is voor de opbouw van wetenschappelijke kennis. ${ }^{53}$ De met dit onderzoek beoogde kritisch-humanistische vorm van ver(ant)woording van intuitieve praktijkkennis berust overeenkomstig de 'middenweg' in een dialectiek tussen methodologische afstand tot en een empathische identificatie met het kenobject. Het met de dialogische middenpositie overeenkomende hermeneutische interpretatiekader voor creatieve trajecten biedt de mogelijkheid om de handelingsintuities uit de praktijk method(olog)isch te verrijken.

In zekere zin is in elke vorm van waarneming en verstaan, dus ook in de 'romantische intuïtieve afstemming', reeds een interpretatie besloten: namelijk een onuitgesproken denkbeeld, dat de waarneming van een verschijnsel juist mogelijk makt en stuurt. Over de 'theorie-geladenheid' van zintuigelijke waarneming is

53. Descartes' 'cogito ergo sum' is een bekend voorbeeld van een filosofisch uitgewerkte fundamentele twijfel als fundament voor wetenschappelijke kennis, in zijn Discours de la méthode. (1637) 
veel psychologische en kennis-theoretische literatuur geschreven. ${ }^{54}$ Een verankering in de empirie kan tegen de achtergrond van dergelijke inzichten in laatste instantie nooit methodologisch gerechtvaardigd worden door middel van een beroep op 'harde feiten' of 'ruwe sense data', zoals bijvoorbeeld het logisch positivisme van de Wiener Kreis heeft geprobeerd. Een positivistische methodologie vooronderstelt een 'theorie-neutrale' realiteit als universele toetssteen voor de vergaring en legitimering van objectieve kennis. Vanuit deze wetenschapsopvatting mag een persoonlijke en gevoelsmatige betrokkenheid bij het onderzochte in methodologisch opzicht geen rol spelen. Dergelijke 'subjectieve factoren' dienen zoveel mogelijk uit een 'wetenschappelijke' onderzoekshouding te worden geëlimineerd. Een romantische kenhouding daarentegen berust in zekere zin juist op het impliciet blijven dan wel uitblijven van methodologische sturing van metaforische intuitties. Ter illustratie hiervan kan gedacht worden aan de praktische kennis die besloten is in het kunnen lopen, dansen en zingen. Reflectie over deze processen werkt blokkerend op het directe en spontane verloop van de handelingen. Niettemin ligt in de uitvoering van een dans of een lied ook een interpretatie besloten. Deze kan echter niet worden losgekoppeld van de persoonlijke betrokkenheid van de uitvoerende kunstenaar bij het muziekstuk of de dansuitvoering. Een romantische 'interpretatie' is op vergelijkbare wijze verweven met het intuïtieve verstaan van het onderzochte. Hierdoor wordt het onderzoeksproces in een fundamentele zin afhankelijk van de psychologische 'make up' van de onderzoeker. In plaats van de rationalistische persoonsonafhankelijke ruimte van methodologische kenniscriteria wordt de (post)romantische toetssteen voor kennisverwerving gesitueerd in een intermediaire ruimte van persoonlijk gekleurde communicatie en interactie.

Het positivistische kennisideaal is door revolutionaire wetenschapsfilosofische inzichten van Kuhn, Lakatos en Feyerabend ondermijnd. Derhalve lijkt het onvermijdelijk om uit te gaan van een fundamenteel constructief element in wetenschappelijke theorievorming. Onder invloed van een linguïstische en pragmatische wending in de filosofie worden methodologische criteria steeds meer gezien als het resultaat van een proces van reflectie, afweging, discussie en acceptatie binnen een wetenschappelijke gemeenschap. Als zodanig zijn ze niet 'ahistorisch, onveranderlijk en universeel' maar geworteld in een culturele, maatschappelijke en historische dialoog en staan ze principieel open voor amendementen. Dit dialogische proces gaat vooraf aan de eenmaal gekozen methodologische criteria. Bezien vanuit dit dialogisch-hermeneutische perspectief bakenen methodologische regels een procedurele interactieruimte af waarin het onderzoeksobject en de onderzoekers zich op de aldus gedefinieerde wijze tot elkaar dienen te verhouden. Een rationalistische methodologie vertegenwoordigt aldus een uiterste disciplinering van de dialogische context van onderzoek. Andersom plaatst de dialogisch-hermeneutische invalshoek de rationalistische onderzoeksbenadering in

54. Zie bijvoorbeeld Koningsveld: Het verschijnsel wetenschap. Geurts: Feit en Theorie. Kernproblemen in de wetenschapsleer, van Peursen: De Opbouw van de Wetenschap. Een inleiding in de wetenschapsleer. 
een ruimer perspectief. Op polair tegengestelde wijze vermag zij dit ook te doen ten aanzien van de (post)romantische onderzoekshouding. Voor zover deze rond een intuittief-gevoelsmatige afstemming op het onderzochte is gecentreerd, kan er in de praktijk een negatieve waardering ontstaan ten aanzien van reflectie en theoretische onderbouwing. Hiervoor is immers afstandelijkheid en een 'rationele vertaling' van de gevoelsmatige intuities nodig, hetgeen tegengesteld is aan de empathische grondhouding. Een bemiddelende stap hiertoe biedt de dialogische context, die een interpretatieruimte afbakent waarmee de intuitieve praktijkkennis een op de metaforische kenwijze toegesneden vorm van ver(ant)woording verkrijgt. Deze dialogische context biedt de randvoorwaarde om de intuïtieve, in het directe professionele handelen verdisconteerde, interpretatie van metaforische praktijkkennis te expliciteren.

De dialogische grondhouding geeft een grondslag om de handelingsintuities hermeneutisch te reconstrueren en de metaforische vorm van praktijkkennis aldus te onderbouwen. Analoog aan de functie van een choreografie voor een dansuitvoering zou deze hermeneutische reconstructie als een methodologische richtlijn aan de pragmatische invalshoek kunnen worden toegevoegd. De dialogische grondhouding plaatst beide extreme onderzoekshoudingen in een ruimer perspectief en biedt daarmee een verrijking aan de eenzijdige romantische en rationalistische benadering van de werkelijkheid. Als leidraad voor de reconstructie van de impliciete methodologie van dit onderzoek naar praktijkkennis fungeert aldus de vraag:

Welke aard van interpretatie is in de uitvoering van het onderzoeksproces besloten die zoals de choreografie van een dans expliciet gemaakt zou kunnen worden?

Voor wetenschappelijke kennis geldt dat de praktische toepassing of bruikbaarheid en de maatschappelijke relevantie van het onderzoek veelal ter discussie staan. Daarentegen wordt juist de wetenschappelijke verantwoording en theoretische onderbouwing van praktijkkennis vaak als problematisch ervaren. Cruciaal voor een hermeneutische benadering is de balans tussen theoretische en praktische sturing van het onderzoeksproces. Hiertoe is in dit onderzoek een 'dialogische onderhandelingsruimte' voorgesteld, waarin er een dialectische wisselwerking tot stand komt tussen een rationalistische en een romantische benadering van het onderzoeksonderwerp op basis van de dialoog tussen onderzoekster en onderzochte praktijk. In het vijfde hoofdstuk volgt een beschrijving van het dialogische onderhandelingsproces dat het praktijkonderzoek naar creatieve trajecten heeft vormgegeven. 


\subsection{Rationalisme en romantiek als wereldbeelden}

Hoe verhoudt de hierboven toegelichte dialogisch-hermeneutische onderzoeksbenadering zich tot rationalistische en romantische opvattingen over ontwikkelingsprocessen in het kader van therapie en organisatie-trainingen? Deze vraag zal in deze paragraaf in een filosofisch-historische zin worden uitgewerkt. Uit de eerste subparargraaf blijkt dat de ontwikkelingsmetafoor van 'de moderniteit' een inherente dubbelzinnigheid met betrekking tot rationalisering en humanisering bevat. In de tweede subparagraaf zal deze dubbelzinnigheid ten aanzien van ontwikkelings-processen worden geïnterpreteerd als een dialectische wisselwerking tussen denkbeelden en beelddenken. Hoe deze dubbelzinnigheid en dialectiek vanuit de hermeneutiek kan worden verstaan, behandelt de derde subparagraaf in relatie tot een post-moderne opvatting over 'de reproductie van denkbeelden' en 'de esthetisering van ons bestaan'.

\subsubsection{Rationalisering èn humanisering}

De filosofische grondslag van het rationaliseringsproces is op pregnante wijze door Kant als 'verlichtingsideaal' geformuleerd in zijn opstel Was ist Aufklärung? Individueel roept hij de mens op tot autonomie, "Wordt mondig en bevrijd je uit ketenen van zelfverkozen voogdij.", maar ook in de vorm van een "cultureel manifest':

Der Mensch ist durch seine Vermunft bestimmt, in einer Gesellschaft mit Menschen zu sein, und in ihr sich durch Kunst und Wissenschaft zu kultivieren, zu zivilisieren und zu moralisieren... 55

Rationalisering betekent volgens Kant dus dat mensen, wat voor hem neerkomt op mannen ${ }^{56}$, moeten leren om zelfstandig van hun redelijke vermogens gebruik te maken, opdat men vrij worde en niet van anderen afhankelijk blijve. Verlichting op het niveau van het individu duidt op het ontsteken van 'het licht der rede' teneinde deze autonomie en mondigheid te bereiken. Hoewel Kant dus een voorbehoud maakt ten aanzien van de 'vrouwelijke irrationele constitutie', roept hij met zijn ideaal mensen op om zelf de verantwoordelijkheid over hun bestaan te dragen en deze niet aan anderen of hogere instanties over te dragen. In maatschappelijke zin resulteert rationalisering in de ontwikkeling van de 'proefondervindelijke wijsbegeerte', de wetenschappen en de techniek. Volgens een andere woordvoerder van de Verlichting: "Waarheid moet door het licht der natuur ontdekt worden en niet in de duisternis van het verleden." ${ }^{57}$ Het doel van deze maatschappelijke ontwikkeling is de kwaliteitsverbetering van het (im)materiële bestaan op aarde.

55. Kant geciteerd in Böhme: Philosophieren mit Kant 217.

56. Zie Böhme \& Böhme: Das Andere der Vermunft. Zur Entwicklung von Rationalitätsstrukturen am Beispiel Kants 119.

57. Bacon: The Refutation of Philosophies in: Farrington: The Philosophie of Francis Bacon 121. 
Het rationalisme berust op een geloof in de ratio opdat de mens het lot in eigen hand neme en zo het individuele bestaan zowel als de samenleving kan verbeteren. De hoogmoed in dit geloof ten aanzien van de menselijke rede was oorspronkelijk gekoppeld aan religieuze deemoed: het ultieme mysterie van het bestaan zou nooit volledig door onze wetenschappelijke kennis kunnen worden ontraadseld. Hiervoor blijft de mens, volgens Kant, aangewezen op het christelijke geloof, op religieuze deskundigheid en in laatste instantie op een Goddelijke voorzienigheid.

Deze summiere schets over de oorsprong van ons verlichtingsdenken brengt een opmerkelijk verschil ten opzichte van recentere opvattingen over rationalisering in beeld. Rationaliseringsprocessen verwijzen tegenwoordig in het bijzonder naar het efficiënter maken van denk- en handelingsprocessen op de werkvloer, waardoor vooral ons materiële bestaan op aarde wordt verbeterd. Het aanvankelijke primaire gegeven van de ontwikkeling van geestelijke zaken, zoals het streven naar zieleheil, geluk en levenswijsheid, de ontwikkeling van ethische vermogens en artistieke expressie hebben de betekenis van een 'existentieel surplus' gekregen. Als zodanig sporen de oorspronkelijke existentiële en humanistische waarden niet meer met de recentere vernauwde opvatting over rationalisering,- kunnen ze zelfs als hieraan tegengesteld worden beschouwd. Voor zover het verlichtingsideaal is uitgemond in een extreem maakbaarheidsgeloof dat zover strekt dat ook 'de goede samenleving' en 'het menselijk geluk' binnen het bereik van onze rationele vermogens zijn getrokken, komt het rationalisme op gespannen voet te staan met zingevingsvragen en met het geloof. Bij gevolg kan het 'oorspronkelijke' religieuze besef van een aangewezen zijn op een hogere goddelijke instantie uit ons bestaan worden 'weggerationaliseerd'. In het eerste hoofdstuk is er reeds op gewezen dat juist deze in extremo doorgevoerde rationalisering kan hebben bijgedragen aan de sterke populariteit van creativiteit en aandacht voor 'de menselijke factor' in organisaties.

Niettegenstaande de geschetste metamorfose in het verlichtingsdenken met betrekking tot onze denkbeelden over rationalisering is in het eerste hoofdstuk ook 'metaforisch' een 'overkoepelende' grondhouding getypeerd, die mij dunkt karakteristiek te zijn voor 'het verlichtingsproject'. Fundamenteel zou een grondhouding zijn die tot expressie komt als 'het zoeken naar zekerheid'. Het 'verlichtingsproject' is gebaseerd op een onbetwijfelbaar geloof in de Ratio om de (im)materiële aspecten van ons bestaan te kunnen zekerstellen. Haar 'dialectische' tegenpool wordt gevormd door de angst om de rede en daarmee onze grip op de werkelijkheid te verliezen. Deze dubbelzinnigheid lijkt inherent aan het verlichtings-project te zijn en geeft aanleiding tot fundamentele vragen. Kunnen we (de verantwoordelijkheid over) ons bestaan wel ten volle aanvaarden zonder een God of een andere (filosofische) Zekerheid? Vallen we niet in de greep van 'het Irrationele' wanneer we onze traditionele christelijke of metafysische bestaansbasis laten varen? Nietzsche heeft een existentiële angst voor 'het redeloze', wanneer onze Logos ontgoddelijkt en onze Ratio onttroond is, poëtisch en filosofisch verwoord: 
Der tolle Mensch:- Habt ihr nicht von jenem tollen Menschen gehört, der am hellen Vormittage eine Laterne anzündete, auf den Markt lief und unaufhörlich schrie: "Ich suche Gott! Ich suche Gott!"- Da dort gerade viele von denen zusammenstanden, welche nicht an Gott glaubten, so erregte er ein grosses Gelächter. Ist er denn verlorengegangen? Sagte der eine. Hat er sich verlaufen wie ein Kind? Sagte der andere. Oder halt er sich versteckt? Fürchtet er sich vor uns? Ist er zu Schiff gegangen? ausgewandert? - so schrien und lachten sie durcheinander. Der tolle Mensch sprang mitten unter sie und durchbohrte sie mit seinen Blicken. "Wohin ist Gott?" rief er, "ich will es euch sagen! Wir haben ihn getötet - ihr und ich! Wir alle sind seine Mörder ? $^{58}$

De 'romantische omduiding' van het rationalistische vooruitgangsgeloof keert de ontwikkelingsmetafoor in het verlichtingsdenken om. 'Ontwikkeling' in romantische zin komt overeen met een 'letterlijke' af- of ont-wikkeling van beschavingslagen tot aan een natuurlijke kern of een oorspronkelijke bestaanswijze van de mens. Deze kan verschillend worden ingevuld als een mythisch eenheidsbewustzijn met de natuur of een oorspronkelijke eenheid met God. In tegenstelling hiermee constitueert de rationalistische grondhouding juist een methodologische afstand tussen mens en wereld in de hoedanigheid van onderzoeker tot onderzoeksobject voor de vorming van wetenschappelijke kennis. De romantische kenhouding gaat uit van een tegengesteld ideaal en beoogt in dat verband de opheffing van de (methodologische) kloof tussen subject en object die ons van eenheid met de werkelijkheid gescheiden houdt. De dialectische tegenhanger van het rationalistische maakbaarheidsgeloof, resp. het geloof in de heilsbrengers van wetenschap en techniek, bestaat uit de bevoorrechting van 'niet-rationeel beheersbare' maatschappelijke domeinen, bijvoorbeeld kunst en religie, om het culturele voortouw te nemen. Een romantisch 'bevrijdingsideaal' om een hernieuwde eenheid met 'de natuur' of met 'het zijn' te bereiken, lijkt bijvoorbeeld aan de basis te staan van bepaalde stromingen in de schilderkunst, zoals het surrealisme.

Deze absolute surrealiteit wordt door de surrealisten niet opgevat als een transcendente wereld, maar als een volstrekte immanente werkelijkheid, die hier en nu bereikt kan worden. De surrealistische hoop is niet gericht op een representatie van deze eenheid, maar op haar onmiddelijke present(at)ie. ${ }^{59}$

Een Romantische interpretatie van de ontwikkelingsmetafoor brengt aldus in beeld wat door het verlichtingsproces in de schaduw is gesteld: een 'oorspronkelijk' besef van 'het ultieme mysterie' en een hierin gelegen direct contact met 'de grond van het zijn'. 'Bevrijding' of 'verlichting' vereist volgens deze invalshoek juist geen toename van onze rationele vermogens, maar een relativering ervan door het vrij maken van een 'humanistische' kern van menszijn, die door de Ratio

58. Nietzsche: Die fröhliche Wissenschaft in: Werke II 400-401.

59. de Mul: Het romantische verlangen in (post)moderne kanst en filosofie 89. 
overheerst wordt. 'Naturalisering' en 'humanisering' vertegenwoordigen derhalve parallelle schreden op het romantische pad naar Verlichting. De bevrijding uit de greep van de Ratio gaat hand in hand met de ontwikkeling van artistieke en humanistische vermogens. De ontwikkelingsmetafoor van 'de moderniteit' herbergt aldus een inherente dubbelzinnigheid in zich van rationalisering èn humanisering, van (de-)civilisering èn (de-)naturalisering. Achter het vaandel van de 'vernieuwingsbeweging' van de moderne wetenschap wordt een 'tegenbeweging' dialectisch opgeroepen: om onze onderdrukte 'irrationele kant' uit de schaduw van 'het licht der rede' te voorschijn te laten treden door de mobilisering van 'irrationele', creatieve en religieuze vermogens.

\subsubsection{De dialectiek tussen beelddenken en denkbeelden}

In de vorige paragraaf is beschreven hoe de filosofisch gereconstrueerde wereldbeelden van het rationalisme en de romantiek in relatie staan tot een overeenkomstig perspectief op ontwikkelingsprocessen. Het concept 'wereldbeeld' is evenwel problematisch in die zin dat het de zaak die het beoogt te verhelderen zelf veronderstelt. Het schetsen van een beeld van een bepaalde wereldoriëntatie is een vorm van 'metaforische kennis', die juist op grond van de geschetste beelden verhelderd moest worden. De vraag is hoe we vanuit deze hermeneutische cirkel tot 'de grond' van 'intuittief-metaforische ervaringskennis' kunnen doordringen. Niet door een 'sprong uit' deze cirkel, maar juist door de dialectische spanning tussen beide polen constructief te betrekken in het onderzoeksproces. In de vierde paragraaf is de 'hermeneutische denkbeweging' getypeerd aan de hand van de metafoor van 'Hermes' als bemiddelaar tussen kennis van het hoofd en kunst van het hart. Hermes' bemiddelingskunde brengt een accentverschuiving aan ten opzichte van het romantisch verabsoluteerde 'oorspronkelijke beelddenken' als een zintuiglijk-gevoelsmatige-intuïtief proces, zonder in het rationalistische extreem van een conceptuele reductie tot denkbeelden te schieten. Hoe wordt de verhouding van de rationalistische en de romantische benadering van de werkelijkheid tot beide overeenkomstige wereldbeelden vanuit de hermeneutiek geïnterpreteerd?

In overeenstemming met (postmoderne) metafysica-kritiek is mijn uitgangspunt dat het onmogelijk is kennis over 'de werkelijkheid' te verkrijgen buiten onze werelden zelfbeelden om door een eenwording met de 'grond van het zijn' of met ons 'authentieke zelf'. De mogelijkheid van een mystieke eenwording, een verlichtingservaring of een zijnservaring sluit ik evenwel niet uit. Echter: zelfs met het bestaan van deze zijnsmodus stuiten we op hetzelfde probleem, namelijk dat kennis van een dergelijke eenwording toch weer verwoord of verbeeld moet worden. Inzicht in het fundamentele omsloten zijn door onze wereld- en zelfbeelden betekent echter in zekere zin ook een bevrijding hieruit. Dat wil zeggen dat het zicht op onze gevangenschap alleen mogelijk is vanuit een besef van 'een wijdere ruimte' daarbuiten. Er zijn als het ware ramen in de gevangeniscel gekomen. Maar is het niet mogelijk om uit het raam van de gevangeniscel te ontsnappen en 
daadwerkelijk de vrije ruimte te betreden? Dat zou pas een waarlijke bevrijding uit onze fysieke, psychische en geestelijke gevangenis zijn. De ultieme eenheidservaring heet de realisering van deze 'uiterste zijnsmodus' te zijn. Maar is deze aantrekkelijke ontsnappingsroute uit onze existentiële gevangenis niet een dwaalweg in een doolhof van metafysische verlangens en speculaties? Dit is het geval wanneer de dichterlijke metafoor van verlichting 'te letterlijk' wordt genomen. Niettemin bestaan er getuigenissen over de mystieke ervaring en bestaat zij derhalve als een poëtische expressie van een 'eenheidservaring'. In die hoedanigheid behelst zij ook 'kennis omtrent het (zelf)zijn'. Een 'letterlijke' interpretatie van de poëtische metaforen voor deze ervaring maakt evenwel een ontologische claim die niet 'waar' gemaakt kan worden. We bezitten immers, teruggekeerd in onze 'aardse kerker' niets anders dan ons uitzicht uit het gevangenisraam en kennen 'de vrije ruimte' daarbuiten niet (meer) onafhankelijk van onze momentane waarneming. De 'aardse kerker' is een treffende metafoor voor ons fundamentele omsloten-zijn door conceptuele en metaforische interpretatiekaders. In een 'absolute zin' past er geen kennissleutel ${ }^{60}$ op het slot van onze gevangeniscel, maar onze cel kan enigszins worden verhelderd door het licht van filosofische, religieuze en poëtische kennis. We zijn gevangenen van metafysische illusies wanneer we ons bevrijd wanen en pretenderen 'absolute kennis' te hebben van 'de ware werkelijkheid', onafhankelijk van onze culturele en historische referentiekaders, los van onze beperkte waarneming en beschrijving. Bevrijd zijn we daarentegen wanneer we als gevangenen het uitzicht uit onze cel beschrijven. Het geloof in een permanente staat van bevrijding uit onze lichamelijke, psychische en geestelijke kluistering wordt hier als een vorm van 'metafysica' gezien. De mogelijkheid om definitief buiten onze referentiekaders te treden lijkt mij een 'escape-route' uit de fundamentele eindigheid van ons bestaan. Een 'niet-metafyische' interpretatie van verlichting geeft de begrenzing aan van onze menselijke mogelijkheid om inzicht in de aard van onze gevangenschap te verkrijgen.

In deze beschrijving van onze '(on)verlichte staat van zijn' is van metaforische en conceptuele kennisvormen gebruik gemaakt. Juist door de wisselwerking tussen beide in het proces van beeld- en begripsvorming is het mogelijk om een empathische eenwording met 'het zijn' als 'grenservaring' en 'grondslag' van intuittieve ervaringskennis 'niet-metafysisch' aan te duiden. Zonder de gevangenismetafoor zou 'hetzelfde' in een abstracte taal zijn gegoten, wat suggereert dat het mogelijk is om op directe wijze een 'letterlijke' beschrijving te geven van de 'zijnsgrond'. In een abstracte beschrijving blijft de funderende zijnsmetafoor impliciet en wordt haar betekenis wellicht in een gereïficeerde zin opgevat door de suggestie van het 'objectieve' bestaan van 'het zijn'. Er vindt als het ware een letterlijke interpretatie van haar metaforische zin plaats. Juist door het inlassen van beelden en metaforen, zoals mijn aan Plato's beroemde grotmythe ontleende gevangenis-metafoor, wordt een interpretatieruimte geopend waarin het mogelijk is de grondslag aanduidenderwijs te bevatten. Beelden en metaforen leggen de grond

60. Deze 'kennissleutel' wordt veelal exclusief door fundamentalistische stromingen van religieuze tradities geclaimed. 
immers niet eenduidig en direct-beschrijvend vast, maar nodigen uit om de 'bedoelde betekenis' door middel van een dialectiek tussen denkbeelden en beelddenken te achterhalen. Het beeldend in de voorstelling waarnemen van hetgeen de metafoor bij ons oproept heeft een betoverend betekeniseffect. Het bedoelde verschijnt voor het geestesoog door de presentie van een metaforisch beeld. Tegelijkertijd wordt de lezer weer op reflexieve afstand tot dit beeld gesteld door een conceptuele interpretatie van de 'levende metafoor'. De metaforische wijze van beschrijving heeft aldus 'op meta-niveau' gecommuniceerd dat de geschetste grondslag bestaat èn niet bestaat. Ze bestaat niet in een absolute zin, maar haar geldigheid is metaforisch, 'bij wijze van spreken'. We leggen haar niet metafysisch vast, maar haar betekenis is voorlopig en gerelateerd aan een dialogische context. We duiden haar in beeldtaal en metaforisch aan en geven een conceptuele interpretatie van de beelden. In dialoog met beelden en metaforen vertolken we zijn, geven we betekenis aan hetgeen aan onze concepten ontsnapt.

Een hermeneutische interpretatie van de 'dialectiek tussen beelddenken en denkbeelden' impliceert een verrijking ten opzichte van de rationele reductie van beelden en metaforen tot letterlijke en abstracte taal èn ten opzichte van de romantische vertaling van metaforen en concepten tot intuitieve gevoelens en beelden. Deze 'verrijking' betekent overeenkomstig het 'gestalt'-beginsel dat 'het metaforische geheel van beelden en concepten' meer is dan de som der delen. De 'dialectiek tussen denkbeelden en beelddenken' is meer dan een analytische opeenstapeling van beelden, metaforen en begrippen, die vervolgens tot een conceptuele 'abstractie' vertaald wordt. De hermeneutische middenpositie neemt een zinspeling met 'letterlijke' betekenissen in 'de dialectiek van beelddenken en denkbeelden' ernstig, zonder op een absoluut gestelde 'funderende metafoor' uit te komen. Het hermeneutische perspectief laat zien hoe het proces van betekenisgeving principieel onvoltooid blijft. Op grond van de wisselwerking tussen verbeelden en conceptualiseren creëren wij zelfbeelden, organisatiebeelden, maatschappijbeelden en wereldbeelden. Aldus reconstrueren wij onze 'ervaringswerkelijkheid'. Een bevrijdingsroute uit dit proces van metaforische betekenisgeving, uit onze seriële en gefragmenteerde werkelijkheidservaringen naar een 'metafysisch' geconstrueerde 'grond van het zijn' is hiermee hermeneutisch afgesloten. In plaats daarvan is er een toegang tot de dialogische middenpositie met een vrije interpretatieruimte ontsloten. Het proces van betekenisgeving is op grond van deze eindigheid opnieuw oneindig geworden en principieel onafgesloten.

\subsubsection{Wereldbeelden en de esthetisering van ons bestaan}

In de vorige paragraaf is de dialogische middenpositie aanschouwelijk gemaakt door te laten zien hoe onze 'ervaringswerkelijkheid' zich ontrold aan een fundamentele dialectiek tussen 'beelddenken en denkbeelden'. In deze paragraaf zal 
deze hermeneutische visie worden geconfronteerd met een relativerende gedachte uit het 'postmoderne discours' die met 'esthetisering' ${ }^{61}$ is aangegeven.

Als conclusie uit de voorgaande analyse volgt dat de grondslaggevende dialectiek tussen metaforisering en conceptualisering statisch wordt gemaakt vanuit een eenzijdige 'grondhouding' die een rationalistisch of romantisch wereldbeeld reificeert. Rationalisme en romantiek wortelen in die zin in een verabsolutering van de 'conceptuele' resp. de 'metaforische ervaringsmodus'. Wanneer we hermeneutisch van de relatieve waarde van de verschillende wereldbeelden uitgaan, is tevens de mogelijkheid geopend om hun verworteling in verschillende 'wijzen van in de wereld staan' te onderzoeken. De hermeneutiek erkent de principiële waarde van verschillende ervaringsmodi: juist een wisselwerking van metaforisering en conceptualisering verschaft ons een 'vollediger' verstaan van de wereld. Rationalisme en romantiek hebben een extreme ervaringsmodus verabsoluteert in het totale palet van mogelijkheden van in-de-wereld-staan. Aldus maakt een hermeneutische visie een perspectiefverschuiving mogelijk waardoor de verschillende benaderingswijzen binnen de grenzen van hun ervaringsdomein tot hun recht kunnen komen. Het totale hermeneutische palet schildert tegen de achtergrond van de 'dialectische speelruimte' wisselende configuraties van reflexieve afstand en emotionele nabijheid tot het onderzochte, welke een onderzoeker ter beschikking staan. In het verlengde hiervan zijn verschillende epistemologische uitwerkingen mogelijk tussen een meer dwingende voorafgegeven empirisch-rationele methodologie en een meer intuittieve gevoelsmatige benadering.

$\mathrm{Nu}$ is het de vraag of deze hermeneutische interpretatie weliswaar aan het Scylla van een metafysisch-romantische interpretatie van 'de grond' van 'metaforische intuittieve ervaringskennis' ontsnapt is, maar daarna onherroepelijk terecht komt in het Charybdis van een 'post-modern' nihilisme. Is dit de implicatie van het relativistische uitgangspunt dat wij niet buiten onze taalkaders om 'de werkelijkheid' kunnen bereiken op grond van een absoluut geldig of 'archimedisch' ijkpunt? Is dus de conclusie gewettigd dat in laatste instantie elke vorm van kennis even relatief waar of onwaar is? Een epistemologisch relativisme is bijvoorbeeld als een 'perspectivisme' treffend verwoord door Nietzsche:

Wir können nicht um unsre Ecke sehn: es ist eine hoffmungslose Neugierde, wissen zu wollen, was es noch für andre Arten Intellekt und Perspektive geben könnte (...) Aber ich denke, wir sind heute zum mindesten ferne von der lacherlichen Unbescheidenheit, von unsrer Ecke aus zu dekretieren, dass man nur von dieser Ecke aus Perspektiven haben dürfe. Die Welt ist uns vielmehr noch einmal 'unendlich' geworden: insofern wir die Möglichkeit nicht abweisen können dass sie unendliche Interpretationen in sich schliesst. Noch einmal fasst uns der grosse Schauder - aber wer hätte wohl Lust, dieses

61. Zie bijvoorbeeld: Het romantische verlangen in (post)moderne kunst en filosofie 31. 
Misschien is er een andersoortig epistemologisch criterium te formuleren tegen de achtergrond van het besef dat wij via (creatieve) taal toegang tot de werkelijkheid verkrijgen, bijvoorbeeld Nietzsche's criterium van vitaliserende kennis of van een 'vrolijke wetenschap'? Een dergelijk 'a-rationeel' kenniscriterium stelt in plaats van een absolute toetssteen een in de mens besloten 'humaniserend' criterium voor. Dit zou in het licht van 'post-moderne' relativeringen en 'metafysica-kritiek' een vruchtbaar alternatief voor dogmatische opvattingen hieromtrent vertegenwoordigen. Niettemin blijft onze kennis van zo'n criterium opnieuw afhankelijk van onze verwoording en verbeelding.

Met de post-moderne idee van 'de esthetisering van ons bestaan' is een radicaal relativistisch uitgangspunt verwoord. 'Esthetisering' betekent in dat verband dat elk wereldbeeld epistempologisch en ontologisch gesproken even geldig is. Aldus worden epistemologie en ontologie tussen haakjes geplaatst en krijgt de gestelde vraag veeleer een 'pragmatische', 'politieke' en 'ethische' strekking: wat is het effect van kennis op mens en maatschappij? Alweer zijn we voor de beantwoording van deze vraag aangewezen op 'kennispraktijken'. Wetenschap, kunst, religie, reclame en politiek geven weliswaar zeer verschillende maar in het licht van de 'esthetiseringsgedachte' even 'geldige' beschrijvingen en beelden van 'de' werkelijkheid. Een voorbeeld van de idee van 'esthetisering' vinden we in Baudrillards ${ }^{63}$ radicaal relativistische concept van 'de hyperrealiteit'. Onze woorden, metaforen, concepten en theorieën zijn 'verleidende tekens', die oneindig gereproduceerd worden zonder dat er een van deze betekenisgevende kaders onafhankelijke 'code' is gegeven hoe die tekens met 'de realiteit' verbonden zijn. In die zin worden wij omringd door een onzinnige tekenproductie, die ons niettemin verleidt in hun waarheid te geloven. Op fatale en ironische wijze wordt ons een werkelijkheid voorgespiegeld die niet anders bestaat dan op de wijze van deze voorspiegeling, wat Baudrillard met de term 'hyperrealiteit' uitdrukt. 'Fataal' omdat door deze tekenproductie een illusoir geloof in het 'echte' bestaan van 'de werkelijkheid' wordt gewekt,- een illusie die niettemin werkelijke effecten heeft. Wij leven derhalve in een simulatie van de werkelijkheid zonder dat we ooit weet kunnen hebben van een echte realiteit die hieraan ten grondslag ligt. 'Esthetisering' wil in die zin zeggen dat onze taalkaders niet 'slechts bemiddeling' zijn, waardoor wij toegang tot 'de werkelijkheid' verkrijgen, maar dat onze werkelijkheid precies uit de voorgespiegelde of verbeelde 'werelden van taal en tekens' bestaat. De ironie wil dat wij de tekens van kunst, politiek, reclame en wetenschap niet anders kunnen lezen dan door de schijn van het bestaan van een buitentalige 'echte' werkelijkheid. Evenwel zijn er geen betrouwbare kenniscriteria van 'betrouwbaarheid' te geven anders dan door opnieuw een talig kader te creëren dat dezelfde

62. Nietzsche: Die fröhliche Wissenschaft 524.

63. Baudrillard: De fatale strategieên. Gils van: Realiteit en illusie als schijnvertoning. Over het werk van Jean Baudrillard. 
teken-status heeft en ten aanzien waarvan dus dezelfde vraag met betrekking tot 'betrouwbaarheid' en 'werkelijkheidswaarde' gesteld dient te worden. Dit gegeven impliceert een oneindige regressie. We zijn figuranten op het beroemde ouderwetse cacaudoosje geworden en er is geen enkele mogelijkheid om buiten het 'drosteeffect' dat onze werkelijkheid definieert, te treden.

Is dus de uiterste consequentie van de post-moderne idee van 'esthetisering' dat ons 'ware' kennis op basis van een 'éénwording van subject en object' definitief is ontzegd? Dat de mogelijkheid van 'verlossing' door een unificatie van de mens met zich 'Zelf', met 'God', met 'de Natuur' of met 'het zijn' ons weliswaar door kunst, wetenschap, magie en religie wordt voorgespiegeld maar niet kan worden waargemaakt? Voert deze gedachtegang onherroepelijk tot de conclusie van een principiële onmogelijkheid van 'authentiek contact' met de werkelijkheid en met ons zelf? Of kan een hermeneutische interpretatie van 'de dialogische middenpositie' ons een uitweg uit het geschetste dilemma tussen metafysica of nihilisme wijzen? De idee van 'esthetisering' waarschuwt ons dat er voor deze uitweg geen exclusief referentiekader bestaat. De vraag is echter of er een mogelijkheid van 'authentiek contact' met de werkelijkheid blijft bestaan, gegeven de onmogelijkheid om buiten een dialogische context te treden, om onafhankelijk van teken- en taalkaders 'het zijn' te doorgronden. ${ }^{64}$ Wanneer de mogelijkheid van 'authentiek contact' binnen een dialogische context bestaat, is hiermee tevens 'de grond' gegeven voor een kritisch-humanistisch perspectief op creatieve trajecten. Is er in het proces van betekenis-geving, in de oneindige reproductie van zelf-, maatschappij-, organisatie- en wereldbeelden, een historische en gesitueerde 'grond' aan te geven waarop deze beelden op 'authentieke wijze' in relatie tot het verbeelde en de verbeelder kunnen worden gebracht? De vraag is dus: op grond waarvan kunnen we beslissen of een metaforisch of conceptueel geconstrueerde werkelijkheidservaring 'authentiek' is? Alleen wanneer we buiten onszelf kunnen treden om vanuit 'Gods troon' te beoordelen of de beelden van onze geest overeenstemmen met de verbeelde werkelijkheid is er van 'authentieke eenheid' sprake in een absolute zin. Als 'gevangenen in onze aardse kerker' moeten we nagaan of er een 'relatieve vorm' van 'eenwording' bestaat in de mogelijkheid om overeenstemming 'daadwerkelijk' te ervaren en 'authentiek' te beschrijven. Een mogelijk voorbeeld van 'het aangeraakt worden door een zijnsgrond' is te vinden in de vorm van een 'dichterlijke expressie van het numineuze ${ }^{65}$ :

Het ogenblik komt

Niet ver weg misschien

Dat de mens zelfs verliest

Wat hij niet bezit.

64. Door de (zen-)boeddhistische meditatiepraktijk, bijvoorbeeld, wordt er wel een kader geschapen om losser van onze conventionele referentiekaders te geraken.

65. Leopold: Vervoeging van zijn 29. 
De glans van een steen

In de zandwoestijn

Is dan nergens meer

Zonder weg erheen.

\section{Ik ga onteigend}

Ik weet niet door wie

Een weg die niet zijn kan

Die mij gaat misschien.

De geciteerde dichter Leopold lijkt in zijn dichtbundel Vervoeging van zijn mystieke thema's te articuleren met betrekking tot 'een eeuwig ogenblik', 'egoloosheid' en 'de niet-weg' naar bevrijding. Andere voorbeelden van een 'eenheids-' of een 'zijnservaring' lezen we in het latere werk van Heidegger ${ }^{66}$, vertolkt door een 'grondstemming' van gelatenheid of als openheid voor 'het horen van de roep van zijn'. In dit verband breng ik Nietzsche's notie van een muzikale overeensteming in herinnering:

Mit Tönen kann man die Menschen zu jedem Irrtume und jede Wahrheit verführen: wer vermöchte einen Ton zu widerlegen ${ }^{67}$ ?

Vermag misschien Nietzsche's 'a-rationele waarheidscriterium' ons een humanistisch houvast bieden voor het proces van betekenisgeving, dat kritisch genoeg is om ons voor metafysische valkuilen te behoeden? Maar ontzegt Nietzsche's muzikale metafoor ons niet juist het vermogen om waarheid van leugens te onderscheiden? Nietzsche relativeeert ons rationele onderscheidingsvermogen door van waarheid te spreken 'voorbij goed en kwaad'. Welke 'andere' vorm van 'waarheidsspreken' vindt er door 'muzikale overeenstemming' plaats? Een 'muzikale waarheid' voorbij goed en kwaad is een levende metafoor: ze is 'raak' zonder dat ze zich bewijst. Kunnen we in de lijn van Nietzsche een kritischhumanistisch criterium voor 'authenticiteit' formuleren als een vorm van creatieve expressie in het kader van 'dialogische communicatie', als een muzikale afstemming op elkaar en op het gespreksthema in en door de dialoog? Een dergelijk criterium is voor groepsgesprekken verduidelijkt aan de hand van een andere muziekmetafoor:

Een echte jamsessie gaat als volgt. Je begint met je in het nummer in te leven en je komt tot een interpretatie. Tegelijkertijd hoor je hoe je buurvrouw met een andere interpretatie komt. Terwijl je speelt, luister je goed en dat doet zij ook. Geleidelijk of plotseling hoor je waar ze heen wil en je begint jouw interpretatie op de hare te richten. Op hetzelfde moment hoort zij wat jouw bedoeling is en neemt jouw interpretatie op in die van haar. Vanaf dat moment

66. Bijvoorbeeld Heidegger: Was heisst Denken? Vortrage und Aufsätze. Zur Sache des Denkens. 67. Nietzsche: Die frohliche Wissenschaft 386. 
is het niet meer de interpretatie van een persoon, maar van de hele groep. (...) Op deze manier kun je ook over gesprekken denken. Niemand zal zeggen dat de interpretatie van een van de muzikanten de juiste was. Wat hierbij onze aandacht verdient, is niet dat er goede en foute interpetaties zijn, maar juist dat elke interpretatie de anderen inspireert en een vonk doet overslaan, zodat er een compositie ontstaat die geen van de muzikanten in zijn eentje had kunnen bedenken. ${ }^{68}$

De auteur heeft dit type gespreksvoering nog op andere wijze gekarakteriseerd aan de hand van de metafoor van 'het schuren bouwen'. Zoals in de tijd van de pioniers van de Verenigde Staten er gemeenschappelijk met buren schuren werden gebouwd om het individuele tekort door geld- en tijdgebrek op te heffen, zo is er een type gespreksvoering mogelijk waarbij individuele deelnemers op elkaars bijdragen aan de dialoog voortbouwen en deze niet 'cynisch' afbreken, zoals bij (wetenschappelijke) discussies gebruikelijk is. De in onze cultuur dominante vormen van gespreksvoering typeert de auteur aan de hand van de volgende metaforen: het vrije gevecht, de missverkiezing en de momumentendag. ${ }^{69}$ In deze gespreksvormen is de gesprekshouding van deelnemers ten opzichte van elkaar ofwel afbrekend (in 'het vrije gevecht') ofwel elkaar beconcurrerend (in 'de missverkiezing') ofwel onverschillig (in 'de monumentendag'). De 'grondhouding' die bij deelnemers aan een dialoog verondersteld is, stemt niet overeen met deze drie dominante gesprekshoudingen in onze cultuur: vijandigheid, onverschilligheid en strijd. De 'dialogische communicatievorm' is te vergelijken met een 'jamsessie' waarin een 'gestaltprincipe' werkzaam is. De transponering van dit principe naar een dialogische context fundeert de open en betrokken gesprekshouding als een vorm van 'authentieke communicatie', analoog aan het constructieve 'interpretatieproces' in een jamsessie. Hierbij ontstaat door middel van authentieke expressie een empathische wederzijdse afstemming op elkaar en op het muzikale/ gespreksthema. Dit 'dialectisch' opbouwende proces resulteert in een muzikaal samenspel, resp. in dialogische gespreksvoering. Het gestaltbeginsel in een muzikale context van samenspel is in het kader van dit onderzoek vertaald als een kritischhumanistisch perspectief op dialogische communicatie. Dat wil zeggen dat iedere deelnemer aan het dialectische proces van groepsgespreksvoering bijdraagt èn andersom dat de dialoog aan ieders individuele bijdrage 'iets' toevoegt. Het kritisch humanisme koppelt aan het gestaltprincipe, in de zin van een dialectische verrijking tot een 'dialogisch geheel' op basis van de constitutieve elementen van 'beelddenken' en 'denkbeelden', een communicatief evaluatief moment.

De dialogische grondhouding is aldus niet 'letterlijk' gedefinieerd maar metaforisch getypeerd. Aan de hand van de metafoor van een jamsessie is het mogelijk de dialogische context van creatieve trajecten op te vatten als een 'communicatieve inbedding' voor 'authentiek contact' vanuit een kritisch-humanistisch perspectief.

68. Kahn: De tao van het gesprek 26-27.

69. De tao van het gesprek 32-36. 
De mogelijkheid van een waarlijk contact met de werkelijkheid bestaat vanuit dit perspectief niet naïef-romantisch als een kritiekloze overgave aan 'het zijn' maar uit een mogelijke ervaring van 'authenticiteit', in de zin van een Niezscheaans muzikaal geraakt worden in en door de dialoog. Zoals een choreografie zich tot een dans verhoudt, een muziekcompositie tot een muzikale uitvoering en de spelregels tot het gespeelde spel, zo definieert 'de dialoog' de mogelijkheid van het aangesproken-worden en het ver-ant-woorden door een wederzijdse afstemming op elkaar en op het gesprek.

\subsection{Levende metaforen en de dialogische grondhouding}

In deze paragraaf zal meer concreet worden aangegeven hoe de dialogische grondslag van creatieve trajecten in relatie kan worden gebracht met 'de levende metaforen' in therapie en organisatietrainingen. In de vorige paragraaf is aan de hand van Nietzsche's muziekmetafoor, de metafoor van 'de jamsessie' en van 'het collectieve schuren bouwen' de dialogische wijze van communicatie getypeerd. De opbouwende aard van het interpretatieproces in de dialoog kan men als een ontwikkelingsproces opvatten. Op grond van het opbouwende communicatieproces tussen cliënt, therapeut of trainer en creatief medium wordt er een ontwikkelingsproces gegenereerd met het oog op de gewenste therapeutische verandering of de trainingsdoelstelling. De dialogische visie op ontwikkelingsprocessen is niet eenzijdig gericht op een rationalistisch maakbaarheidsgeloof noch op een naïefromantisch idee van humanisering en authenticiteit. Welke kritisch-humanistische bouwstenen volgen er uit deze hermeneutische invalshoek voor het veldonderzoek naar de praktijk van de metaforische kennisvorm?

Vermag de hermeneutiek een perspectief op 'levende metaforen' te articuleren waar-door ze anders verschijnen dan als een subjectieve vervorming van een 'objectief' veranderingsproces resp. als een articulatie van een 'authentieke' zijnsof zelfervaring welke een romantisch-naïeve geest ademt. Vanuit kritisch-humanistisch perspectief is het mogelijk om een andere duiding te geven van het overdrijven of het ironiseren, het weglaten of het verdubbelen, het vergroten of het verkleinen van ervaringen en denkbeelden. Het zintuiglijk-gevoelsmatig-lichamelijk 'inkleuren' van de ervaring representeert een retorische ervaringsbasis voor een dialogisch vormgegeven ontwikkelingsproces. Het metaforische leermateriaal geeft een direct toegankelijke speelse èn methodische basis die in wisselwerking met verbale en traditionele leer-instrumenten een narratief kader vormen om de beoogde veranderingsprocessen aan te sturen. Door de dialogische context is het mogelijk om 'van binnen uit', dat wil zeggen vanuit de directe ervaring, een andere betekenis te geven aan 'bekende' en 'ingesleten' communicatie- en gedragspatronen. Wanneer deze hermeneutische interpretatie met de praktijk overeenstemt zouden de creatieve trajecten een 'narratieve leeromgeving in therapie en organisaties' vertegenwoordigen, waarin de condities worden gegenereerd dat cliënten een nieuw perspectief op een oude vertrouwde werkelijkheid 
van biografie of werksituatie genereren resp. een nieuwe, tot verandering aanzettende 'werkelijkheids- of zelfervaring' opdoen. In vergelijking met een eenzijdige instrumentele benadering aan de hand van een 'rationalistische leerstrategie' die overwegend cognitief op mensen inwerkt, wordt er door middel van de creatieve taal van muziek, beeldende kunst, drama, dans, enz, vooral een emotioneel en interactief appèl gedaan op de deelnemers. De multi-modale insteek van 'het narratieve ervaringsleren' behelst derhalve in potentie een 'methodische meerwaarde' ofwel een surplus aan mogelijkheden met betrekking tot communicatie- en veranderingsprocessen.

De veronderstelde 'meerwaarde' van creatieve trajecten is hiervoor gekarakteriseerd aan de hand van het voorbeeld van 'het coachen' als vaardigheid met het oog op de ontwikkeling van leidinggevende kwaliteiten. Met betrekking tot het gezamelijk muziek maken als creatieve spelvorm biedt 'het dirigeren' een vergelijkbare metafoor en laten zich nog andere muzikale metaforen afleiden met het oog op bijvoorbeeld samenwerking of teambuilding ('samenspel' en 'harmonie'), ondersteuning ('muzikale begeleiding') en initiatief nemen ('soleren'). Het muzikaal vormgeven van thema's met betrekking tot communicatie en samenwerking vertegenwoordigt een ervaringsdomein en niet slechts een kennisdomein, stelt een 'existentieel betekenisveld' present en niet slechts een 'subjectieve beleving'. Het gezamelijk muziek maken genereert aldus een existentiële ervaringsbasis annex betekenisgevend kader, waarin met betrekking tot de gewenste persoonlijke of professionele kwaliteiten analoge vaardigheden worden voorondersteld èn bewerkstelligd. Aldus dicteert deze werkvorm op dialectische en dialogische wijze een 'narratieve leeromgeving', waarin er een appèl wordt gedaan op rationele èn creatieve vermogens van cliënten door middel van een gefaseerde balans tussen 'empathische betrokkenheid' en 'reflexieve distantie', meanderend tussen een speelse en een instrumentele vormgeving van leerdoelen. Het lijkt derhalve wenselijk dat de 'creatieve leertrajecten' voor persoonlijke en professionele ontwikkeling dialectisch-dialogisch worden vormgegeven tot een op het leerdoel toegesneden methodisch afgewogen combinatie van intuittieve èn cognitieve didactische instrumenten en van rationele en romantische leerstrategieën. Aldus kan er bij cliënten een veranderingsproces op gang worden gebracht dat niet vanuit een bepert en beperkend ontwikkelingsperspectief is gegenereerd. Vanuit een rationalistisch idee over ontwikkeling zou het therapeutische leerdoel 'resocialisatie' wellicht eenzijdig worden opgevat als 'een gedragsreparatie om zo snel mogelijk weer te functioneren in het maatschappelijke systeem'. Een polair tegengestelde eenzijdigheid vanuit een romantisch ontwikkelingsperspectief zou een leerdoelstelling van 'persoonlijke groei' kunnen zijn, welke door het leven zelf als therapeutische leerschool plaatsvindt. Het idealistische streven van 'de anti-psychiatrie' om patiënten voor hun genezing terug naar de maatschappij te sturen, ademt een dergelijke 'naïef humanistische' geest. Vanuit het hier geschetste kritisch-humanistische perspectief op 'creatieve leertrajecten' volgt de conclusie dat er met beide eenzijdige en beperkte oriëntaties 
aan de cliënt als een gelijkwaardige deelnemer aan een dialogisch aangestuurd ontwikkelingsproces onrecht wordt gedaan.

De literatuuranalyse tot dusver wijst op een potentiële 'meerwaarde' van 'het narratieve ervaringsleren' voor zover de creatieve leertrajecten vanuit een kritischhumanistisch perspectief op dialogische wijze worden vormgegeven. Of deze hermeneutisch gereconstrueerde meerwaarde en grondslag met de praktijk spoort, komt in het volgende hoofdstuk aan bod. Bieden de creatieve leertrajecten een dialogisch vormgegeven kader voor ontwikkelingsprocessen op basis van 'authentieke communicatie', waarbij een 'muzikale' afstemming op elkaar en op het leerdoel geïntegreerd is met een toegesneden vorm van verantwoording? Is deze vorm van 'authentieke communicatie' via het creatieve medium kenmerkend voor de ludieke organisatie-leervorm van 'entertrainment', die zich tussen entertainment en training in bevindt? Biedt het hermeneutische perspectief op ontwikkelingsprocessen een dialogisch richtsnoer om de veranderingsdoelstellingen niet naïefromantisch humaniserend op te vatten noch eenzijdig instrumenteel vorm te geven? Mijn veronderstelling is dat een kritisch humanisme als geconcretiseerd dialogisch richtsnoer voor de creatieve leertrajecten ertoe kan bijdragen dat de toepassing van (non)verbale communicatiemiddelen in therapie en organisaties niet alleen een modieuze trend hoeft te zijn maar een narratieve methodiek met blijvende historische en culturele waarde vertegenwoordigt.

\subsection{Samenvatting en conclusie}

In dit hoofdstuk is langs hermeneutische weg een grondslag ontworpen voor creatieve trajecten in therapie, organisatietraining, coaching en advisering. Hiertoe zijn enkele begrippen met betrekking tot de metafoor geïntroduceerd waarmee de onderzochte verschijnselen tot begrip gebracht kunnen worden. Het conceptuele kader is vanuit een zodanige retorische invalshoek op communicatie ontwikkeld dat de metafoor, buiten de gebruikelijke dichotomie tussen logica en retorica gebracht, als een middel tot betekenisgeving is opgevat. Tegen deze achtergrond is het proces van betekenisgeving geïnterpreteerd als een voortdurend en meerlagig interactieproces dat voortgestuwd wordt door een dialectische spanning in het semantische krachtenveld. Deze is voorgesteld als een krachtenmeting tussen 'de macht van Logos' - de logisch consistente ordening en de empirische referentie van een tekst - en 'het gezag van Metaphora' - de retorisch-metaforische doorkruising van de empirisch-rationele ordening. De metafoor bewerkstelligt in het semantische spanningsveld in twee richtingen een betekeniseffect. Enerzijds als een 'ecologisch' principe dat in communicatie een teveel aan betekenis creëert. Anderzijds in de zin van een 'economisch' beginsel, op grond waarvan er efficiënt wordt omgesprongen met betekeniselementen. Vanuit de retorische invalshoek is er gewezen op het belang van de gesitueerdheid, het regelgeleide-methodische aspect en de emotioneel-interactieve kant van communicatie. Met betrekking tot de metaforische communicatievorm betekent dit dat niet zozeer het inhoudsniveau, 
maar vooral het betrekkingsniveau van communicatie het accent krijgt. De metaforische overdracht via het creatieve medium genereert een 'levende metafoor' met betrekking tot analoge apecten van het communicatieproces.

De hermeneutische reconstructie van 'de derde weg' voorbij rationalisme en romantiek is in verband gebracht met de dialogische 'middenpositie'. De 'hermeneutische bemiddeling' is aan de hand van de metafoor van 'Hermes' balanceerkunst' getypeerd. Vervolgens is ze geïnterpreteerd als 'een dialectische speelruimte' tussen een theoriegestuurde, ervaringsvreemde en een empathische, bij de ervaring blijvende onderzoeks- resp. gesprekshouding. De dialectiek van 'reflexieve afstand en empathische betrokkenheid' is ook in verband gebracht met Gadamers spel-begrip. Aan de hand van de metafoor van het spel is deze dialectiek in onderzoek en gespreksvoering getypeerd als de speelse verhouding van spelers tot elkaar en tot het spel. De speelse houding houdt het midden tussen beheersend en regelgeleid handelen èn een zich aan de situatie overgevende, op het plezier en de lichamelijkheid van het spel gerichte activiteit. De hermeneutische onderzoeksbenadering is ook aan de hand van de metafoor van de dans uitgelegd: een hermeneutisch vormgegeven methodologie komt analoog tot stand als een choreografie die ontstaat door de wisselwerking tussen het emotioneel-lichamelijke opgaan in het dansen en een beschouwende distantie tot de dans als een configuratie van bewegingspatronen.

Daarna zijn beide extreme onderzoekshoudingen in verband gebracht met de historisch-filosofische wortels van 'rationalisering' en 'humanisering' in het Verlichtingsdenken en in de dialectisch opgeroepen 'romantische tegenbeweging'. Vervolgens zijn rationalisme en romantiek als wereldbeelden tegen de achtergrond van de 'hermeneutische cirkel' geïnterpreteerd als een reïficatie van de fundamentele 'dialectiek tussen denkbeelden en beelddenken'. Vanuit de hermeneutiek is deze dialectiek voorgesteld als een meander waarlangs het oneindige proces van betekenisgeving zich voltrekt als een spiraalbeweging tussen conceptualisering en metaforisering. In het proces van betekenisgeving vindt een onophoudelijke reconstructie van zelfbeelden en wereldbeelden plaats. In en door de dialoog wordt dit interpretatieproces tot een voorlopig einde gebracht maar staan de beelden principieel open voor verandering.

Geconfronteerd met de postmoderne idee van de 'esthetisering van ons bestaan' is de vraag gesteld of er een 'niet-metafysische' interpretatie van het dialectische proces van beeld- en begripsvorming kan worden gegeven. Afgezet tegen een relativistische interpretatie van deze idee, bijvoorbeeld van 'een onzinnige reproductie van denkbeelden' in Baudrillards concept van 'hyperrealiteit', is de mogelijkheid onderzocht om haar als een 'authentieke' vorm van betekenisgeving op te vatten. Hiertoe is 'de dialoog' als een een constructief groepsgesprek getypeerd, aan de hand van een aantal metaforen: Nietzsche's 'a-rationele waarheidscriterium', de metafoor van de 'jamsessie' en van het 'collectieve schuren bouwen'. Op basis van die dialogische 'grond' krijgen zelf-, organisatie-, maat- 
schappij- en wereldbeelden een op het creatieve medium toegesneden vorm van ver(ant)woording. Er kan inderdaad geen absoluut ijkpunt ten aanzien van onze werkelijkheidsconstructies worden gegeven buiten onze interpretatiekaders om. Niettemin hoeft de conclusie uit een dergelijk relativisme geen 'nihilisme' te zijn. De toetssteen voor 'authenticiteit' is de 'open en betrokken grondhouding' waarmee men maatschappij-, organisatie- en zelfbeelden dialogisch (re)contrueert. De conclusie waartoe de hermeneutische interpretatie heeft geleid is dat deze kritisch-humanistische vorm van 'authentieke communicatie' de gezochte grondslag voor creatieve trajecten in therapie en organisatietrainingen vertegenwoordigt.

Met het oog op het veldonderzoek is het de vraag of de gevonden grondslag spoort met de praktijk van creatieve therapie en creatieve trainingen. Overeenkomstig het hermeneutische uitgangspunt dat de 'toepassing' van kennis niet een toegevoegd 'extern' moment is ten opzichte van het 'eigenlijke' wetenschapelijke onderzoeksproces, maar er integraal deel vanuitmaakt, zullen de hier gewonnen filosofische bevindingen in het volgende hoofdstuk in verbinding worden gebracht met een beschrijving van de praktijk.

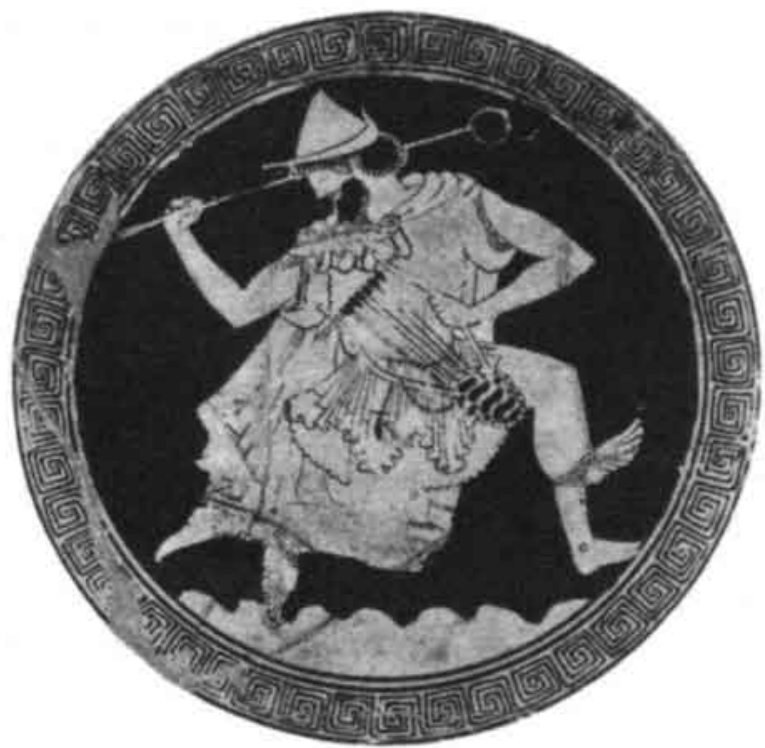

Hermes ruilt zijn lier voor een gouden staf van Apollo 


\section{Hoofdstuk 5:}

\section{Een veldstudie naar metaforische communicatie}

\subsection{Inleiding}

In dit hoofdstuk staat een veldstudie centraal over de toepassing van creatieve trajecten in therapie, training, loopbaanbegeleiding en coaching. De doelstelling van deze studie is om de hermeneutische interpretatie van creatieve trajecten in therapie en organisaties in dialoog te brengen met de praktijk van deze kundigheid. Bij het veldonderzoek zijn twee groepen professionals betrokken geweest: creatief therapeuten beeldend en 'creatieve organisatietrainers'. Het is vormgegeven als een 'action research'-project, gericht op de 'verbetering van de status quo' van hun werksituatie door middel van uitwisseling van professionele ervaring en deskundigheid. Aan het uitwisselingsproject zijn twee kleinere projecten en literatuurstudies vooraf gegaan.

In het eerste hoofdstuk is geschetst hoe de maatschappelijke context van beide groepen professionals traditioneel een tegenstelling vertoont. Tegenover de commerciële sector van organisatietrainers, loopbaanbegeleiders en adviseurs is de dienstverlening in de (geestelijke) gezondheidszorg van oudsher op 'non-profit'basis georganiseerd. In beide sectoren lijkt er momenteel een tegengestelde ontwikkeling aan de gang te zijn. In de (geestelijke) gezondheidszorg worden de praktische consequenties van het nieuwe 'markt-georiënteerde denken' steeds meer merkbaar in de vorm van reoganisaties en bezuinigingen. Onder invloed van de verzakelijking van de zorg dreigt creatieve therapie haar 'oorspronkelijke' humanistische oriëntatie en 'autonome' plaats te verliezen en als een 'vaktherapie' te worden ingelijfd onder het regime van 'sterkere' disciplines, zoals de psychiatrie, de psychologie en de psychotherapie. In de bedrijfscontext van organisatietrainers, loopbaanbegeleiders en adviseurs is een tegengestelde ontwikkeling te constateren. De oude mechanistische optiek op organisatieprocessen lijkt plaats te maken voor een humanistische geest. Creatieve, psychologische en spirituele middelen komen uit 'de zachte sector' overwaaien en vinden steeds meer toepassing bij de ondersteuning van organisatieprocessen. Hoewel organisatietrainers hun 'creatieve workshops' en 'ludieke evenementen' in de regel op projectbasis aanbieden en derhalve, in vergelijking met creatief therapeuten, ten opzichte van de organisatie een autonomere positie innemen, dienen de 'creatieve trajecten' uiteindelijk binnen de organisatiedoelstellingen en bedrijfsbelangen te passen. 
Het uitwisselingsproject is mede vormgegeven tegen de achtergrond van deze verschillen tussen en de veranderingen binnen beide contexten. In dat kader is de method(olog)ische onderzoeksvraag naar de contextspecifieke toepassing van creatieve middelen in relatie gebracht met de ideologie-kritische vraagstelling van dit onderzoek: Hoe verhoudt de creatieve ondersteuning van communicatie- en veranderingsprocessen zich tot dominante ideeën over ontwikkelingsprocessen in termen van rationalisering en humanisering? Een beperking van de gehanteerde onderzoeksopzet is dat deze vragen aan de hand van de uitgesproken visie van de bij het onderzoek betrokken professionals in de vorm van een 'hermeneutische onderzoeksdialoog' is uitgewerkt. Op basis van de onderhavige resultaten zou een vervolgonderzoek aan te bevelen zijn, dat de ervaring van cliënten en van de opdrachtgevende organisatie hierbij betrekt vanuit een interpretatief opgezet en/of een empirisch effectonderzoek.

Een methodologische verantwoording van de veldstudie die voortbouwt op de in het vorige hoofdstuk uitgewerkte hermeneutische 'derde weg voorbij rationalisme en romantiek' is in de volgende paragraaf te vinden. In de derde paragraaf zijn de verschillende stappen van het praktijkstudie beschreven. Vervolgens staat in de vierde paragraaf de 'context van uitwisseling van de onderzoeksdialoog' centraal, zoals die door de gemaakte methodologische keuzes is gedefinieerd. Een beeld van de dialectische aard en de methodologische opbouw van het onderzoeksproces wordt in de vijfde paragraaf geschetst. In de zesde paragraaf volgt een duiding van de onderzoeksresultaten van het uitwisselingsproject. Wat de dialoog tussen onderzoek(ster) en praktijk voor de betrokken partijen heeft opgeleverd komt in de zevende paragraaf aan bod. Ten slotte volgen samenvatting en conclusie in de laatste paragraaf.

\subsection{Een hermeneutische methodologie van de middenpositie}

Deze paragraaf schetst het methodologische kader dat aan de opzet en de verantwoording van het veldonderzoek ten grondslag ligt. In het vierde hoofdstuk is met betrekking tot een hermeneutische onderzoeksbenadering gewezen op het belang van reflectie op de typerende aard van het interpretatieproces dat in de metaforische kennisvorm vervat zit. ${ }^{1}$ Hiertoe diende de volgende vraag als leidraad:

Welke aard van interpretatie is in de uitvoering van het onderzoeksproces besloten die zoals de choreografie van een dans expliciet gemaakt zou kunnen worden?

De metafoor van de dans typeert de intuïtief-metaforische vorm van praktijkkennis die aan creatieve trajecten ten grondslag ligt. $\mathrm{Ze}$ drukt in dit verband uit dat impliciet in het creatief therapeutische handelen een interpretatie besloten ligt, 
vergelijkbaar met een in de dans verscholen 'choreografie'. De impliciete interpretatie in handelingsintuities kan, zoals deze dansmetafoor aangeeft, worden ver(ant)woord vanuit de dialogische middenpositie. Het spel is een vergelijkbare metafoor om de aard van dit inter-pretatieproces te belichten. De speelse houding van spelers tot elkaar en tot het spel is exemplarisch voor de dialogische grondhouding 'tussen' een houding van beheersing en reflectie enerzijds en anderzijds een attitude van overgave en empathie. In het bijzonder is de middenpositie met betrekking tot de dialoog uitgewerkt als een open en betrokken gesprekshouding. Op basis hiervan blijft de dialoog open door de principiële mogelijkheid tot herinterpretatie èn begrensd, door de bereidheid de eenmaal gekozen interpretatie in een gesprek uit te dragen en te verantwoorden. In dit verband constitueert een reflectief-communicatief moment een buffer tegen strategisch opportunisme èn een drempel tegen romantisering van het onderzochte.

De reconstructie en interpretatie van het onderzoeksproces vindt plaats tegen de geschetste hermeneutische achtergrond. De dialogische benadering van het uitwisselingsproject zal nu in de vorm van onderzoeksspelregels worden beschreven. Analoog aan een choreografie die de bewegingspatronen van een dans expliciet maakt. Zoals in een choreografie 'de vierde dimensie' van tijd, intensiteit en dynamiek verloren gaat, ontbeert deze reconstructie van het veldonderzoek de dionysische aspecten van het onderzoeksproces en van het onderzochte. Hermeneutische kenniscriteria verschillen van een gebruikelijke persoonsonafhankelijke wetenschappelijke methodologie, in die zin dat een dialogisch onderzoeksproces op fundamentele wijze van de uitvoerende en deelnemende personen afhankelijk blijft. De spelmetafoor geeft aan dat de 'speelse onderzoekshouding' zich ten opzichte van een wetenschappelijke houding wèl engageert met het onderwerp van onderzoek. Het romantische extreem van empathische identificatie met het onderzochte wordt anderzijds eveneens door de speelse grondhouding in balans gebracht door het relativerende èn de geldingsdrang van het spel als (ont)spannende activiteit.

Met betrekking tot de interpretatie van het onderzoeksmateriaal betekent het voorgaande dat er geen generalisaties naar algemeen geldende uitspraken over 'creativiteit', 'therapie' en 'training' gemaakt zijn. Het onderzochte ligt niet als een 'gegeven realiteit', onafhankelijk van de 'ingrijpende' onderzoekshandeling vast, om door middel van 'neutrale' onderzoeksprocedures 'ontdekt' te worden. Het onderzoeksproces laat 'het zijn' niet onberoerd, maar plaatst de onderzochte verschijnselen in een andere context, waardoor ze een nieuwe betekenis verkrijgen. De betekenis van het onderzochte is de interpretatie die uit het onderzoeksproces tevoorschijnkomt. Dit houdt onder meer in dat er steeds tussenrapportages over het uitwisselingsproject zijn gemaakt, waarop feedback gevraagd is, teneinde de respondenten ook bij de interpretatie van de onderzoeksgegevens te betrekken. 
Uiteindelijk is in de vorm van twee in vaktijdschriften gepubliceerde artikelen ${ }^{2}$ een voorlopige terugkoppeling naar achterliggende thema's met betrekking tot de onderzoeksvraagstelling gemaakt. De daarin beschreven resultaten worden in dit hoofdstuk tegen de achtergrond van de literatuuranalyse uit de voorgaande hoofdstukken geplaatst.

Aan het interpretatieproces is weliswaar geen universele waarheidsaanspraak verbonden maar wel worden er andere criteria ${ }^{3}$ gesteld met betrekking tot verstaanbaarheid, geloofwaardigheid en zeggingskracht van het onderzoeksverslag. Uiteindelijk blijkt de waarde van het onderzoek dialogisch uit de praktijk door herkenning, vergroting van het (zelf)inzicht in en aanknopingspunten voor (verandering van) het professionele handelen van betrokkenen, belanghebbenden en geînteresseerden. Voor de explicitering van de gevolgde onderzoeksroute is er gebruik gemaakt van geldigheidsprocedures zoals die voor de zogenaamde 'responsieve' en 'onderhandelende' onderzoeksmethode ${ }^{4}$ zijn uitgewerkt: de member check, triangulatie, langdurige betrokkenheid, volhardende observatie, referentiële adequaatheid, peer-debriefing, het bijhouden van een reflexief logboek, het hermeneutisch-dialectische onderzoeksproces, de evaluatie van de onderzoeksprocedures door middel van een audit-rapport. Voor een heldere beschrijving en boeiende toepassing van deze procedurele criteria zij naar $\mathrm{Abma}^{5}$ verwezen. In deze paragraaf is globaal aangegeven hoe ze in de dialogische context van het onderhavige onderzoek passen. In de volgende beschrijving van het onderzoekstraject zal er soms meer toegespitst naar worden gerefereerd. Het bijhouden van een 'reflexief logboek' met onderzoeksaantekeningen en tussenverslagen, een proces van 'peer-debriefing', in de vorm van begeleidingsgesprekken met mijn (co-)promotores, alsmede een evaluatieve fase van terugrapportage aan en feedback van de respondenten bij wijze van 'member check' vormen belangrijke methodologische steunpunten. De dialogische wijze waarop het veldonderzoek gefaseerd over een lange periode is vormgegeven heeft de basis gelegd voor een 'langdurige betrokkenheid' van de onderzoekster bij het onderzochte. In veel 'constructivistische' literatuur over kwalitatieve onderzoeksmethoden krijgt het begrip triangulatie een centrale plaats. Dit principe grondvest een procedureel criterium voor de geldigheid van kwalitatief onderzoek: namelijk het systematisch

2. Muijen: Creatief buitenskamers! De appèlwaarde van de verzakelijkte zorg NVKT (1999) nr. 4 en: Managing Creativity?! De 'hype van creativiteit' in filosofisch perspectief Filosofie in Bedriff. ter perse. 3. Vergelijk van Eeden, die in haar proefschrift Waarnemen als besturingsopdracht. Governance, hermeneutiek en het vraagstuk van levensbeëindigend handelen. een 'model voor beeldvorming van maatschappelijk-politieke problemen' ontwikkelt en test; in welk verband de auteur de volgende methodologische criteria benoemt die kenmerkend zouden zijn voor het hermeneutische verstaan: de vorming van een 'kennishorizon', de dialoog, een proces van betekenisvernieuwing, de hermeneutische cirkel en historiciteit. Erasmus Universiteit Rotterdam, 2000.

4. Deze paragraaf bouwt voort op hoofdstuk 3 paragraaf 5.2. waarin op het belang van een 'communicatieve rationaliteit' voor organisatieonderzoek wordt ingegaan. In dat kader (in noot 89) wordt behalve naar Guba \& Lincoln ook naar Abma verwezen, die deze onderzoeksmethode in verband met 'beleidsevaluaties' heeft uitgewerkt.

5. Abma: Responsief evalueren 94-97. 
gebruik maken van meerdere perspectieven, onderzoekers, kennisbronnen, methoden en technieken, en theorieën ${ }^{6}$. Dit kwalitatieve onderzoeksprincipe dat een alternatief geeft voor het nastreven van 'algemeengeldigheid' is in dit onderzoek vormgegeven als het zo getrouw mogelijk in beeld brengen van een persoonlijke werksituatie. Op basis van een 'democratisch principe' om de stemmen van betrokkenen te horen, is zoveel mogelijk aan 'de pluriforme werkelijkheid' recht gedaan. Het oogmerk van 'gezamelijk gewin' van het uitwisselingsproject komt overeen met de empowerment-doelstelling van de responsieve onderzoeksmethode.

Het voorgaande impliceert dat de onderzochte situatiemet haar pluriformiteit zo rijk mogelijk in beeld is gebracht. Dit komt onder meer tot uitdrukking in de keuze voor beeldend therapeuten die werkzaam zijn in uiteenlopende werkvelden en door de variëteit van de door organisatietrainers en adviseurs gebruikte creatieve middelen te laten weerspiegelen in de uitgekozen groep respondenten. De onderzoeksvragen waren gecentreerd rond de professionele visie op het vak en de maatschappelijke en organisationele context waarin beide beroepsgroepen opereren. De vragen waren open geformuleerd en nodigden uit tot een persoonlijk antwoord in verbale en/of beeldende vorm met het oog op de unieke situatie van de betreffende respondent. Toegepast werden onderzoeksmethoden zoals participerende observatie, individuele diepte- en groepsinterviews en het gebruik van beeldende hulpmiddelen bij de interviews en groepsbijeenkomsten. Het hieruit voortgekomen onderzoeksmateriaal is verzameld door middel van onderzoeksaantekeningen, geluidscassettes en in beeld gebrachte antwoorden; vastgelegd in tussenverslagen van de (indiviuele en groeps)interviews, in de vorm van schriftelijke en mondelinge reacties van respondenten op de terugrapportage en samenvattende artikelen. Aldus was de onderzoeksopzet erop gericht om de respondenten in staat te stellen hun 'ervaringswerkelijkheid' in woord en beeld present te stellen?

\subsection{Reconstructie van het onderzoekstraject}

In overeenstemming met de hermeneutische onderzoeksbenadering is de opzet van het uitwisselingsproject in wisselwerking met literatuuronderzoek en met een tweetal kleinschaliger praktijkstudies tot stand gekomen.

De eerste onderzoeksstap besloeg de periode 1993 - 1996 en behelsde een voorbe-

6. Valerie Janesick (zie hoofdstuk 4 paragraaf 4.2 noot 37) aan wie ik de dansmetafoor voor onderzoek heb ontleend, voegt interdisciplinariteit als een vijfde vorm van triangulatie toe aan de gebruikelijke die in de literatuur worden genoemd: data, onderzoeker, theorie en methode.

7. Zie voor het gebruik van beeldende hulpmiddelen in interviews en organisatieonderzoek: Abma: Stakeholder conflict: a case study Pergamon. Evaluation and Program Planning Nr. 23 (2000), 203 en Chia: Metaphors and metaphorization in organizational analysis: thinking beyond the thinkable. In: Grant \& Oswick (ed): Metaphor and Organization 127-146. 
reidende literatuur- en praktijkstudie voor een 'experimentele opzet' van beeldende creatieve therapie in een specifieke sector van de gezondheidszorg, namelijk een verpleeghuis, waarin zij (nog) niet tot het gebruikelijke aanbod van zorg behoort. ${ }^{8}$ Uit het praktijk-onderzoek kwam het belang naar voren van het creëren van een 'sociaal en politiek' draagvlak binnen de instelling om belanghebbenden, in het bijzonder het management, te kunnen overtuigen van de waarde van creatieve therapie voor de cliëntenpopulatie van dementerende ouderen. ${ }^{9}$ Uit deze eerste stap in het onderzoekstraject is gebleken dat 'p.r.'-kwaliteiten van een creatief therapeut en het kunnen uitdragen van een professionele visie op het vak minstens zo belangrijk zijn voor de implementatie van deze discipline in een nieuw werkveld als vakinhoudelijke capaciteiten. In de gevoerde onderhandelingen over de te creëren formatieplaats creatieve therapie overheerste de invloed van organisatorische, financiële en beleidsvoorwaarden. Dit kwam tot uitdrukking in de door het management gestelde prioriteit van het kunnen aantonen van 'meetbaar nut' van creatieve therapie voor deze cliëntengroep. In die context waren er uiteindelijk onvoldoende gekwantificeerde argumenten die het management konden overtuigen dat er aan creatieve therapie ten opzichte van de bestaande 'activiteitenbegeleiding' een 'meerwaarde' is verbonden, welke de extra investering rechtvaardigt. Op basis van deze studie zijn een aantal relevante thema's met betrekking tot de organisatorische inkadering en de profilering van creatieve therapie geformuleerd. Deze zijn aangescherpt door middel van vier interviews met beeldend therapeuten. Aan de hand van literatuurstudie is het concept van de metafoor geïntroduceerd als $\operatorname{kader}^{10}$ om beeldend therapeutische processen te kunnen interpreteren met betrekking tot haar 'meerwaarde', zonder van een bepaald therapeutisch referentiekader uit te hoeven gaan.

Een tweede stap in het onderzoeksproces besloeg de periode 1995 - 1999 en was gericht op het gebruik van creatieve middelen voor communicatie- en veranderingsprocessen in het kader van managementdoelstellingen. Er is in concept een vraagstelling geformuleerd ten aanzien van de toenemende populariteit van de metafoor als onderzoeks- en interventiemiddel met het oog op bijvoorbeeld organisatiediagnose, organisatieontwikkeling en de typering van managementstijlen. Hiertoe is, naast het baanbrekende werk van Morgan, de populaire, vooral uit de V.S. afkomstige managementliteratuur uit de periode 1985-1995 bestudeerd, waar-

8. Resultaten zijn vastgelegd in een 'Onderzoeksverslag' en gevalideerd door de 'post-HBO-praktijkopleiding' Creatieve Therapie (Dinklage/Meyer) in Amersfoort. Deze studie was erop gericht de mogelijkheidsvoorwaarden voor de opzet van creatieve therapie te onderzoeken wat betreft de specifieke problematiek van de betreffende cliêntenpopulatie, dementerende ouderen, binnen het vigerende behandelbeleid van een dagbehandeling, gegeven de organisatorische randvoorwaarden van een verpleegtehuis.

9. In dit verband is Abma's beschrijving van de 'onderhandelende' onderzoeksmethode (in: Responsief evalueren 217 e.v.) verhelderend, die veeleer gericht is op 'voortgaande interacties' en op de waarde van verschillende interpretaties van betrokkenen en belanghebbenden dan op het creêren van consensus, wat Guba \& Lincoln centraal stellen.

10. Muijen: Metaforen, creativiteit en therapie in filosofisch perspectief Management report series No 5 (13), Erasmus Universiteit Rotterdam, 1997. Muijen: Metaforiek en metaforen Tijdschrift voor Creatieve Therapie (1997) 2, 10-18. 
in de metafoor naast andere innovatieve middelen en creativiteitsbevorderende technieken wordt gepropageerd. ${ }^{11}$ De onderzoeksvraagstelling is bijgesteld aan de hand van twee interviews met 'creatieve organisatietrainers' en op basis van een experimentele opzet voor een onderwijsmodule 'metaforische onderzoeksmethode' binnen het bestaande methodologiecurriculum van bedrijfskundestuden$\operatorname{ten}^{12}$ Deze studie leverde een tweeslachtig beeld op wat betreft de vooronderstelde 'meerwaarde' van de metafoor als onderzoeks- en communicatiemiddel: van een 'positief en klinisch' geloof in haar kracht in de praktische context van het organisatie- en advieswerk versus een 'sceptische en cynische' reactie in de academische context van theoretisering vanuit een overwegend positivistische benadering van organisatievraagstukken.

Op basis van de evaluatie van de hieruit voortgekomen aantekeningen en onderzoeksverslagen en aan de hand van feedback van begeleiders en betrokkenen bij het onderzoek is de definitieve opzet van het uitwisselingsproject tot stand gekomen. Deze derde stap van de veldstudie besloeg de periode 1998 - 1999 en bestond uit voorbereiding, uitvoering en evaluatie van dit project. Het praktijkonderzoek was opgebouwd uit vier fasen, gericht op uitwisseling van ervaring en deskundigheid tussen de twee deelnemende beroepsgroepen. De creatief therapeuten waren afkomstig uit diverse werkvelden van de (geestelijke) gezondheidszorg. De organisatietrainers, adviseurs en loopbaanbegeleiders werkten met uiteenlopende creatieve middelen voor diverse organisaties en bedrijven. Het gefaseerde uitwisselingsproject had behalve verheldering van de onderzoeksvraag door middel van 'kennisgeneratie' de doelstelling van 'gezamelijk gewin' voor beide groepen professionals. Dat wil zeggen dat de deelnemers als 'participanten' en niet slechts als 'informanten' bij het project waren betrokken. ${ }^{13}$ Tegen deze achtergrond was het uitwisselingsproject gericht op verheldering en herschikking van de oorspronkelijke tegenstelling tussen en de recente 'tegenbeweging' binnen de maatschappelijke sectoren van beide groepen professionals.

De eerste fase van het uitwisselingsproject bestond uit een serie interviews met 18 respondenten uit iedere groep. In tegenstelling tot de groep creatief therapeuten bleek de groep 'creatieve organisatietrainers' minder goed in 'disciplines' in te delen. Deze groep respondenten werkte met uiteenlopende creatieve middelen, zoals muziek, drama, beelden, multimedia, jongleerballen en gespreksvoering. De geïnterviewde beeldend therapeuten en 'creatieve trainers' werden vervolgens uitgenodigd voor een tweede fase om tijdens een bijeenkomst met vakgenoten als een 'klankboord-groep' de thema's en 'voorlopige resultaten' uit de interviews te

11. Muijen: Pit and Pitfalls of Metaphors in Organization (theory) in: Combes, Grant, Keenoy, Oswick (ed.): proceedings of the conference Organizational Discours:Pretexts, Subtexts and Contexts 29-31 july 1998, King's College, University of London. En: Sportmetaforen: De retoriek van competitic of de imperatief van 'fair play' Filosofie in Bedrijf (10) 36, 20-37.

12. In de periode 1996-1998 aan de Erasmus Universiteit Rotterdam.

13. Zie Abma: Responding to ambiguity, responding to change the value of a responsive approach to evaluation Pergamon. Evaluation and Program Plannin. (2000) 23, 463. 
evalueren en te verdiepen. Deze thema's hadden betrekking op de visie en de maatschappelijke context van de professionals ten aanzien van het gebruik van creatieve middelen in het kader van therapie, training en loopbaanbegeleiding. In een derde fase waren de aldus verrijkte en gevalideerde onderzoeksgegevens tot uitgangspunt genomen voor een heterogene groepsbijeenkomst, gericht op interdisciplinaire uitwisseling. De onderzoeksbevindingen zijn ten slotte in een vierde fase naar de respondenten teruggekoppeld in de vorm van een toegestuurd onderzoeksverslag waarop een telefonische evaluatie is gehouden.

De eerste fase bestond uit een serie individuele, semi-gestructureerde diepteinterviews van ongeveer $1 \frac{1}{2}$ uur. De interviews zijn opgenomen en vonden zo mogelijk plaats op de werkplek van therapeut of trainer en anders thuis of op de universiteit. Er waren een aantal gespreksthema's benoemd, gericht op de gehanteerde methodiek, knelpunten in het werk en op de 'meerwaarde' van het gebruik van creatieve middelen voor communicatie- en veranderingsprocessen. De interviews waren op basis van voornoemde gespreksthema's 'semi-gestructureerd' met de mogelijkheid om op bepaalde punten door te vragen. Gerelateerd aan de verschillende context waarin beide groepen professionals opereren, kreeg de vraagstelling een ander accent. Met de beeldend therapeuten werd vooral gesproken over de thema's 'professionalisering' en 'rationalisering van de zorg', over organisatorische problemen binnen de instelling, over de profilering en de 'meerwaarde' van creatieve therapie ten opzichte van andere disciplines. De aan trainers, consulenten en adviseurs gestelde vragen hadden vooral betrekking op de 'meerwaarde' van de nieuwe creatieve werkvorm in de context van organisatietrainingen, bedrijfsadvisering en loopbaanbegeleiding, op haar specifieke wijze van toepassing in deze context en haar maatschappelijke betekenis, alsmede op een antal populaire managementconcepten en metaforen, zoals de 'lerende organisatie', 'de zieke organisatie' en 'organiseren als sport of spel'.

Een bijzonderheid in de wijze van interviewen was de mogelijkheid om ook een beeldend antwoord te geven op sommige vragen. De achterliggende idee hierbij was om de veronderstelde 'meerwaarde' van dit middel in het dialogische onderzoeksproces zo mogelijk ook zelf te gebruiken. Bijvoorbeeld bij thema's die nog onvoldoende bereflecteerd en geverbaliseerd zijn, zoals de omstreden 'meerwaarde' van het creatieve middel zelf. Of met betrekking tot gevoelige onderwerpen zoals de ervaren samenwerking met collega's en leidinggevenden. Voor deze laatste vraag werd een 'beeldende code' voorgesteld om met behulp van kleuren en vormen de werkbeleving te symboliseren. Ook ten aanzien van de vraag naar de 'organisatorische posititionering' en de 'meerwaarde' van creatieve therapie werd de mogelijkheid geopperd om een beeldend antwoord te geven of een metafoor te bedenken. Voor de beeldende en metaforische antwoorden was materiaal (wascokrijt en blanco papier) ter beschikking gesteld. Methodologisch cruciaal hierbij is hoe de beelden en metaforen geïnterpreteerd worden. Vanuit mijn hermeneutische onderzoeksbenadering ben ik niet a priori uitgegaan van een fundamenteel verschil voor de interpretatie van verbale ten opzichte van beeldende 
antwoorden. Waar antwoorden in taal ogenschijnlijk onproblematisch langs geijkte methodologische procedures tot 'onderzoeksmateriaal' verwerkt kunnen worden, daar wijzen metaforen en beelden ons direct op het proces van interpretatie in een dialogische context. Deze onderzoekscontext vormt aldus de voorwaarde voor de interpretatie van (beeldende) antwoorden, zodat dat de onderzoekster de duiding als 'betekenis' van het beeld resp. van de metafoor aan de respondenten ter toetsing voorlegt. Tijdens de interviews zijn de gecreëerde beelden en metaforen in dialoog met de respondenten op deze wijze geïnterpreteerd.

In de interviews met beeldend therapeuten werd vooral de vraagstelling naar de organisatorische inkadering van creatieve therapie in de betreffende instelling geaccentueerd. De respondenten waren werkzaam in uiteenlopende werkvelden van de (geestelijke) gezondheidszorg, zoals een Riagg, een instituut voor verstandelijk gehandicapten, een L.O.M-school, een eigen praktijk, een opleidingsinstituut, een P.A.A.Z., een psychiatrische kliniek, een psychiatrische dagbehandeling, een verpleegtehuis, een T.B.S.-kliniek, een psychiatrisch centrum gespecialiseerd in (oorlogs- en vluchtelingen-) getraumatiseerden. Dit betekent dat zij met zeer verschillende cliëntengroepen werkten, onder diverse behandelvoorwaarden, in een specifieke organisatorische setting en met uiteenlopende psychische problematiek: van kinderen met ontwikkelingsstoornissen tot dementerende ouderen; van gedwongen behandeling van psychiatrisch gediagnostiseerde delinquenten totzelfverkozen en zelfgefinancierde behandeling van psychische klachten via een particuliere praktijk. Problematische aspecten met betrekking tot de organisatorische randvoorwaarden en de multi-disciplinaire samenwerking kwamen aan de orde. Daarnaast werd gevraagd naar ideeën over een mogelijke verbetering van de organisatorische inkadering. Beide aspecten keerden terug in de uitnodiging om een veranderingsmetafoor te ontwerpen met het oog op 'de profilering van creatieve therapie' binnen de instelling. Als voorbereiding voor het ontwerpen van deze metafoor werd gesproken over 'organisatorische knelpunten', zoals taakafbakening, bevoegdheden en verantwoordelijkheden, inschaling en functieomschrijving, samenwerking met en waardering van collega's, werkdruk. Ten slotte werd de respondenten gevraagd de 'meerwaarde' van het vak te verwoorden en/of te verbeelden, zoals zij dat in contacten met cliënten en collega's (zouden) doen. Voor deze vraag was de mogelijkheid open gelaten om zelf een metafoor te ontwerpen en/of een interpretatie te geven aan drie voorgestelde metaforen: spel, spelen; gereedschap; voedsel, voeding. Bij de bespreking van de onderzoeksgegevens in de zesde paragraaf zal worden ingegaan op de keuze voor juist deze drie metaforen.

In de interviews met organisatietrainers stond de vraagstelling centraal hoe zij hun 'creatieve methodiek' op eigen wijze hebben ontwikkeld, aangezien hiervoor geen gerichte opleiding bestaat. In dat verband kwam de vraag aan de orde naar hun visie op de creatieve methodiek in relatie tot organisatievraagstukken. Hoe zien organisatietrainers de specifieke kracht en waarde van de creatieve werkvorm door middel van trommelen, zingen, tekenen, schilderen, boetseren, imaginatie, 
lichaamswerk, drama en theatertechnieken, enz. in relatie tot de professionele vorming van werknemers, tot managementdoelstellingen en tot organisatieontwikkeling? Kleven er bezwaren of zwakke kanten aan deze methode? Hoe positioneren zij de creatieve training ten opzichte van bedrijfsbelangen? Dragen zij een visie uit met betrekking tot een wenselijke verandering in organisaties? Daarnaast is hun mening gevraagd over de huidige populariteit van metaforen en creativiteit en hun commentaar op enkele populaire metaforen en managementconcepten, zoals 'de lerende organisatie', 'de zieke organisatie', 'sportmetaforen', en 'employability'. Net zoals bij de interviews met beeldend therapeuten kon er zonodig op punten worden doorgevraagd en werden de respondenten ten aanzien van de vraag over populaire organisatiemetaforen uitgenodigd het antwoord metaforisch in beeld te brengen.

De beschrijving van het veldonderzoek is toegespitst tot deze derde stap van de veldstudie, namelijk het uitwisselingsproject, waarvan de verslaglegging in de volgende paragrafen is te vinden. Na een (methodologische) schets van de context van het uitwisselingsproject, staat in de vijfde paragraaf een procesbeschrijving van de onderzoeksdialoog, ook met betrekking tot de twee voorafgaande studies. Hierbij wordt vooral ingegaan op de houding en de rol van de onderzoekster in het dialectische spanningsveld van 'afstand en betrokkenheid' tot het onderzochte. Daarna wordt er een 'model voor metaforische communicatie en interactie' gepresenteerd dat als resultaat uit de twee aan het uitwisselingsproject voorafgaande onderzoeksstappen is voortgekomen. In de tweede fase van het uitwisselingsproject is dit model ter discussie gesteld. De aanpassing van het 'model' aan de feedback van respondenten is illustratief voor de dialogische wijze waarop de onderzoekster haar interpretatiekader heeft gevormd. In de zesde paragraaf volgt een interpretatie van de resultaten van het uitwisselingsproject.

\subsection{De context van het uitwisselingsproject}

De 'context van uitwisseling' waarin het onderzoek als een dialoog tussen drie gesprekspartners, de beeldend therapeuten, de creatieve trainers en de onderzoekster, plaatsvond wordt in onderstaande vierde paragraaf geschetst. Tegen de achtergrond van de gaande zijnde maatschappelijke en organisatorische ontwikkelingen met betrekking tot de beroepsuitoefening van beide groepen respondenten wordt eerst de doelstelling van gezamelijk gewin geformuleerd. Daarna volgt een beschrijving van de door de onderzoekster gemaakte methodologische keuzes die aan de vormgeving van het 'uitwisselingsproject' ten grondslag liggen.

\subsubsection{Uitwisseling van kennis en ervaring voor gezamelijk gewin}

Eerder is beschreven hoe de maatschappelijke ontwikkelingen in beide werkvelden van de twee beroepsgroepen een dialectische tegengestelling vertoont: tegenover de tendens tot 'verzakelijking van de (geestelijke) gezondheidszorg' lijkt er in de 
harde sector een 'humanisering van werkprocessen' gaande. Nu zal er eengecomprimeerde samenvatting van deze ontwikkeling worden gegeven, waaruit een drietal onderzoeksvragen worden gedestilleerd.

De oorspronkelijke humanistische waarden en romantische idealen van creatieve therapie lijken hun legitimeringskracht te hebben verloren. Op basis van een efficiënte bedrijfsvoering en een 'no-nonsense'-ideologie dienen creatief therapeuten hun praktijk opnieuw te rechtvaardigen. In tegenstelling hiermee worden er in het bedrijfsleven juist extra middelen gereserveerd om een 'humanistische vrijplaats' in te ruimen binnen het op nut en winst(maximalisatie) gerichte organisatiekader. Ook zonder dat de functionaliteit van creatieve middelen in coaching, advisering en organisatietrainingen (wetenschappelijk) is bewezen investeren organisaties en bedrijfven in de menselijke factor en in kunst. Terwijl in de 'harde sector' van de productie van goederen en diensten de zorg om de producerende mens steeds meer centraal komt te staan, wordt in de 'softe sector' de zorg en het welzijn van de zieke mens zoveel mogelijk gerationaliseerd door een zakelijke aanpak, meetbaar nut en winstgevendheid van de dienstverlening voorop te stellen. Tegen de achtergrond van deze opmerkelijke inherente dialectiek in beide werkvelden tussen de ideologische wortels en de opgeroepen 'tegenbeweging' heeft de 'win-win-doelstelling' in de vorm van uitwisseling van ervaring en deskundigheid gestalte gekregen. Deze is geconcretiseerd als mogelijkheid dat creatief therapeuten van creatieve organisatietrainers zouden kunnen leren om 'commerciëler' met 'de creatieve dienstverlening' om te gaan, zonder de humanistische basis te verliezen. Andersom zouden 'humanistische waarden' door creatief therapeuten als tegenwicht kunnen worden ingebracht tegen de instrumentele optiek en het opportunisme in de context van organisatietraining, advisering en managementdoelstellingen. De veronderstelde 'leermomenten' hebben aan de vormgeving van het uitwisselingsproject bijgedragen aan de hand van drie onderzoeksvragen:

Hoe kunnen creatief therapeuten hun dienst binnen de verzakelijkte gezondheidszorg, vergelijkbaar met de markt voor creatieve organisatietrainingen, op commerciëlere wijze organisatorisch inkaderen, zonder dat de 'oorspronkelijke' humanistische waarden verloren gaan?

Hoe kan de creatieve werkvorm in de context van managementdoelstellingen op professionele leest worden geschoeid, vergelijkbaar met de ontwikkeling van creatief therapeutische methodieken en modellen, maar toegesneden op organisatieprocessen en niet strijdig met bedrijfsbelangen?

Hoe kan aan de 'humanistische communicatieruimte' die de creatieve werkvorm in beide contexten vertegenwoordigt een ideologie-kritisch moment worden toegevoegd zonder dat zij gekolonialiseerd wordt door de instrumentele rede en het strategische handelen? 
De vormgeving, beschrijving en evaluatie van het interdisciplinaire uitwisselingsproject is op basis van deze drievoudige onderzoeksvraagstelling tot stand gekomen

\subsubsection{Een choreografie van methodologische keuzes}

$\mathrm{Er}$ is op tweevoudige wijze contact gelegd met de deelnemers aan het uitwisselingsproject. Er is een uitnodigingsbrief voor deelname opgesteld, waarin achtergrond en doelstelling van het onderzoek zijn uitgelegd en de keuze is opengelaten om alleen aan de eerste fase van het interview of ook aan een of twee volgende fases mee te doen. De deelnemers zijn niet op grond van een a-selecte steekproef uitgekozen maar 'voortrollend' door gebruik te maken van het professionele netwerk van de eerste 'per toeval' aangezochte personen. Dit resulteerde in twee groepen aan het project deelnemende professionals, met in iedere groep 18 respondenten, waarbij zoveel mogelijk getracht is om aan de pluriformiteit van de werkvelden recht te doen. Voor of na het sturen van de uitnodigingsbrief is telefonisch de motivatie voor eventuele deelname nagevraagd en is een mondelinge toelichting en uitleg over het onderzoek aan de schriftelijke uitnodiging toegevoegd. Op deze wijze waren de benaderde personen in het algemeen voldoende geïnformeerd om een gemotiveerde keuze te maken voor of tegen deelname aan het project. Hieruit bleken grote individuele verschillen wat betreft de persoonlijke inschatting over de zinvolheid van het onderzoek. Ook kwam een interessant groepsverschil naar voren. Wat betreft de groep creatieve trainers leek de keuze vooral te worden bepaald door de factor 'tijdsdruk en werkagenda', terwijl voor de groep beeldend therapeuten veeleer de 'adequaatheid van het gekozen filosofische perspectief' en een 'mogelijke politieke gevoeligheid' bij de eigen instelling als keuzebepalende factoren werkten. Met dit verschil spoort een analoog verschil in reactie ten aanzien van verslaglegging en publicatie van de onderzoeksresultaten. Waar creatieve trainers onderzoek over hun professionele praktijk in het algemeen als een vorm van p.r. zagen, van netwerken en het creëren van een situatie van gezamelijk gewin, daar benadrukten creatief therapeuten veeleer belang te hechten aan het 'onzichtbaar maken' en het buiten een herkenbare context plaatsen van hun deelname aan het onderzoek. Deze verschillende verhouding van beide groepen professionals tot het onderzoek herstelde de balans tussen het verschil in affiniteit met beide professies van de onderzoekster. Door mijn bekendheid met de wereld van creatieve therapie herkende ik een dergelijke kritische houding ten aanzien van theorievorming en filosofische reflectie. De veelal coöperatieve houding en getoonde interesse voor het onderzoek van een aantal creatieve trainers hielp mij om mijn onbekendheid en scepsis ten aanzien van het organisatie-advieswerk te compenseren.

Creatieve therapie in Nederland is inmiddels sterk geïnstitutionaliseerd van een aanvankelijk in de praktijk gegroeide kundigheid tot een erkend HBO-opleidingsverband met vijf subdisciplines en een organisationele koppeling met een aantal 
werkvelden in de (geestelijke) gezondheidszorg, het bijzondere onderwijs en de zwakzinnigenzorg. Binnen de HBO-opleidingen vormen 'beeldend', 'muziek', 'dama', 'dans' (en 'tuin') ${ }^{14}$ de vijf specialisatierichtingen. Bewust is er gekozen voor de inperking van de te interviewen groep creatief therapeuten tot de specialisatie beeldende creatieve therapie. Deze keuze hangt enerzijds samen met een inhoudelijke motivatie vanuit de onderzoeksvraagstelling: om de wisselwerking tussen verbeelding en verwoording en de inherente samenhang tussen beeld- en begripsvorming tot uitgangspunt te nemen. Anderzijds is de keuze gemotiveerd door mijn persoonlijke affiniteit met deze richting. Om zoveel mogelijk aan de pluriformiteit van deze beroepsgroep recht te doen zijn er beeldend therapeuten uit verschillende werkvelden voor de interviews aangezocht.

Met betrekking tot de groep 'creatieve organisatietrainers' gold een andere uitgangssituatie. Er is (nog) niet of nauwelijks sprake van disciplinering en professionalisering tot een beroepsgroep. Derhalve is de ontwikkeling van het creatieve begeleidings- en trainingswerk direct gekoppeld aan de professsionele 'voorgeschiedenis' van de individuele organisatietrainer, adviseur of loopbaanbegeleider. Deze bleek zeer verschillend te zijn. Een aantal van de ondervraagde trainers heeft zich vanuit een therapeutische achtergrond (resp. begeleidings- of agogisch werk) bij- of omgeschoold, anderen hebben vanuit een kunstzinnige vorming de overstap naar de trainersmarkt genomen, weer anderen hebben hun reguliere organisatie-adviespraktijk door middel van 'creatieve bijscholing' in deze specialistische richting verder ontwikkeld. Navenant geeft de beroepsgroep wat betreft de soorten gebruikte creatieve middelen en de wijze waarop ze worden ingezet een uitgesproken divers beeld te zien. Om deze reden is er geen keuze gemaakt voor één bepaald creatief medium maar is deze diversiteit tot uitgangspunt genomen om haar zoveel mogelijk te laten terugkeren in de uitgekozen groep respondenten. De helft van de geïnterviewde groep gebruikt (parallel aan 'creatieve therapie) beeldende, muzische en drama-middelen, de andere helft is moeilijker in deze categorieën in te delen en/of maakt gebruik van combinaties. Zo laat het 'creatieve palet' naast herkenbare methoden en technieken uit therapeutische, artistieke en didactische disciplines allerlei nieuw vormgegeven varianten zien van lichaamswerk, bewustwordingsmethoden, toepassing van multimedia, creatieve denktechnieken, filosofische gespreksvoering, jongleerkunst, biografische werk- en imaginatie-methoden.

In de tweede fase van de homogene groepsbijeenkomsten verliep het proces wat betreft aanmelding parallel: ongeveer de helft van de groep uit de eerste fase van de serie individuele interviews had zich voor deelname aan de tweede fase opgegeven. Door ziekte en andere afmeldingen 'door overmacht' viel de groep organisatietrainers uiteindelijk iets kleiner uit dan de groep therapeuten. De eerste disciplinaire bijeenkomst bestond uit een groep met zeven trainers, terwijl de tweede parallelle groepsbijeenkomst tien beeldend therapeuten telde. De aan-

14. Over de richting 'tuin' heeft altijd discussie bestaan of zij inderdaad een creatief medium vormt. Ook in kwantitatief opzicht verkeert zij in een ondergeschikte positie. 
melding voor de derde fase van de interdisciplinaire uitwisselingsbijeenkomst besloeg met elf deelnemers ongeveer tweederde van alle deelnemers aan de tweede fase. Vooral door onvoorziene afmeldingen bleek op de interdisciplinaire bijeenkomst dat de organisatietrainers opnieuw in de minderheid waren: namelijk vier trainers tegenover zeven therapeuten. Wat inhoud en wijze van uitwisseling betreft was er een interessant verschil tussen beide groepsbijeenkomsten in de tweede fase. De bijeenkomst met beeldend therapeuten had een meer praktisch, op uitwisseling van concrete professionele ervaring en op een verbetering van de werksituatie gericht karakter. De trainersbijeenkomst was meer reflectief en 'netwerkend' van aard. Dit verschil in insteek van de twee professionele groepen heb ik in de opzet van de interdisciplinaire uitwisselingsbijeenkomst laten terugkeren. Enerzijds door de groepsdiscussie over het thema van de eigen professionele identiteit ten opzichte van de andere beroepsgroep aan de hand van een verbeeldingsopdracht te faciliteren. Anderzijds door middel van een uitwisseling in subgroepjes over een gemeenschappelijk thema - namelijk 'de communicatiekloof tussen management en werkvloer' - waarbij de bijdrage van de verschillende professionele rollen van therapeut en trainer en de mogelijke 'win-winbetekenis van beide groepen voor elkaar vooraf werd gestructureerd. In iedere subgroep van vier personen werd een therapeut uitgenodigd om een casus met betrekking tot deze problematiek in te brengen en kon één trainer het probleem vanuit 'managementperspectief' belichten. Ten slotte zou een persoon uit iedere subgroep het resultaat van deze uitwisseling in de vorm van een 'veranderingsmetafoor' met betrekking tot de besproken casus terugrapporteren naar de afsluitende plenaire groepssessie.

Aangezien er voor het laatste thema van de interdisciplinaire uitwisselingsbijeenkomst onvoldoende tijd bleek te zijn, is er een telefonische interviewronde aan de vierde evaluatieve fase van het project toegevoegd.

\subsection{De veldstudie als onderzoeksdialoog}

Deze paragraaf geeft een indruk van de dialogische aard van het onderzoeksproces. Een reconstructie van deze dialoog wordt in de eerste subparagraaf beschreven in termen van een dialectische afwisseling en wisselwerking van 'afstand en betrokkenheid' van onderzoekster tot de onderzochte praktijk. De onderzoeksresultaten zijn evaluatief-onderhandelend uit dit dialectische proces voortgekomen. Hoe er in deze context een 'model van metaforische communicatie en interactie' is ontwikkeld wordt in de tweede subparagraaf uiteengezet.

\subsubsection{Dialectiek van afstand en betrokkenheid}

Het uitwisselingsproject heeft totaal, van voorbereiding tot evaluatie, een periode van twee jaar in beslag genomen. Dit project is, zoals hiervoor aangegeven, gegroeid in dialoog met de resultaten uit de eerdere literatuur- en praktijkstudies. 
Op basis van een 'reflexief logboek' en de evaluatie van de aldus verkregen gegevens door middel van 'peer-debriefing' met de begeleiders van dit onderzoek heeft het project gestalte gekregen. Deze vormgeving van de onderzoeksdialoog verliep als een 'dialectiek van afstand en betrokkenheid' tussen onderzoekster en het onderzochte.

Met betrekking tot creatieve therapie lag er door mijn affiniteit met dit werkgebied een voorsprong in het onderzoeksproces. De praktijkervaring tijdens een stagejaar op een klinisch geïntegreerde dagbehandeling van een psychiatrische kliniek en de experimentele opzet van beeldende therapie met dementerende ouderen in een verpleeghuis gedurende anderhalf jaar stonden in het teken van een liefdevolle toewijding aan de behandelde mensen, geduld en uithoudingsvermogen, de spreekwoordelijke inertie van een bureaucratische organisatie, inspirerende èn ontmoedigende samenwerking met collega's. Via contact met patiënten, collegiale samenwerking, overleg en onderhandelingen met 'het management' heb ik het onderzoeksveld 'van binnenuit' leren kennen. Dit had niet alleen een waarde in zichzelf en voor mijn professionele ontwikkeling, maar vormde ook een belangrijke ervaringsbasis voor dit onderzoek. Om hieruit een onderzoeksvraagstelling te destilleren moest ik meer reflexieve afstand tot de opgedane praktijkervaring creëren. Langs deze weg van wisselwerking en afwisseling tussen beide attitudes van 'intuïtief handelen in de praktijk' en van 'beschouwend onderzoeken' kristalliseerden de aanvankelijk vage ideeën over de onderzoeksthema's zich uit tot bruikbare concepten en onderzoeksvragen.

Op het gebied van management en organisatiekunde leverden de voorafgaande literatuur- en praktijkstudies genoeg informatie en ervaring op om de 'relatieve achterstand' ten opzichte van het beroepsveld van creatieve therapie te compenseren ten behoeve van de definitieve opzet van het uitwisselingsproject. Door mijn onbekendheid met en reserves ten aanzien van het organisatie- en advieswerk was er een extra basis nodig om deze praktijk beter in mijn ervaringswereld in te passen. Behalve literatuurstudie waren hiervoor de eerste interviews met organisatietrainers behulpzaam, alsmede het verzorgen van enkele onderwijsmodules voor bedrijfskundestudenten. Ik werd geraakt door de inspiratie en het idealisme van de geinterviewde 'creatieve organisatietrainers' en door het accent dat zij legden op het aspect van 'mensenwerk'. Uit de wijze waarop zij over hun ervaring en deskundigheid spraken haalde ik de vooronderstelling dat het 'in de kern der zaak' weinig uitmaakt of je als trainer of als therapeut mensen begeleidt door middel van een creatief medium. Het onderwijs aan bedrijfskundestudenten betekende enerzijds een extra mogelijkheid om meer affiniteit met de (belevings) wereld van (aankomende) managers te verkrijgen, anderzijds confronteerde het mij met de 'onpersoonlijke aspecten' van het modulaire, vluchtige en instrumenteel gerichte onderwijssysteem van de bedrijfskundefaculteit, waar standaardisatie, bureaucratisering en vercommercialisering steeds meer terrein veroveren op de 'oude academische cultuur' van 'zuiver' wetenschapsbeoefening. Een organisatiecultuur, waarin langzamerhand een norm wordt gevestigd om je hiërarchische 
machtspositie, de regels van de onderwijsbureaucratie en je professionele rol voorop te stellen in het contact met studenten en collega's, is in mijn beleving niet bevordelijk voor een inspirerend werkklimaat. Als een soort aanhoudende achtergrondruis pleegden dergelijke 'systeem-rationele en instrumentele' aspecten van dit beroep een forse aanslag op het vakinhoudelijke plezier en de didactische voldoening die ik ken uit het volwassenenonderwijs. Mijn sympathie voor deze andere onderwijscontext en voor de rol als 'procesbegeleider' in creatief therapeutische trajecten werd door deze ervaring onderstreept.

Langs de dubbele weg van praktijkervaring en literatuurstudie heeft zich het onderzoekskader voor het gefaseerde uitwisselingsproject ontwikkeld. Het hermeneutische proces van onderzoek articuleerde zich als deze dialectiek van afstand naar betrokkenheid (en vice versa) tot beide onderzoeksvelden en de wisselwerking tussen theoretische kennis en praktijkervaring. Op basis van de methodologische pijlers van een 'reflexief logboek' over een 'vijfjarige betrokkenheid' met de praktijk zorgde de 'A.O.I.-onderzoeksinbedding'15 bovendien voor structurele momenten van 'peer-debriefing'. De uiteindelijke onderzoeksopzet heeft via drie dialectische fasen vormgekregen: vanuit een eerste fase van persoonlijke betrokkenheid bij de praktijkstudies, naar een tweede fase van meer afstand tot deze praktijk door literatuurstudie en evaluatie van de onderzoeksresultaten. Beide onderzoekshoudingen integreerde ik tot een houding van 'afstand èn betrokkenheid' die in het bijzonder voor de derde fase van het uitwisselingsproject geboden bleek. Als interviewer streefde ik naar de in dit onderzoek gekarakteriseerde 'middenpositie', vergelijkbaar met de 'participerende observator-rol' van een antropologisch onderzoeker. Het 'empirische materiaal' uit de interviews werd op die basis, vanuit het perspectief van de geïnterviewden, zo getrouw mogelijk weergegeven in de vorm van onderzoeksaantekeningen.

De verzamelde onderzoeksgegevens uit de serie interviews en de 'tussenverslagen' vormden de basis voor de tweede stap in het 'uitwisselingsproject': de twee groepsbijeenkomsten met vakgenoten van steeds drie uur. Door een integratie en afwisseling van de beschouwende en de betrokken rol stuurde ik op een groepsproces aan dat tot uitwisseling van kennis en ervaring leidde. Hierdoor kon het gewonnen empirische materiaal worden gecorrigeerd, verdiept en aangevuld. Deze (aan)sturende en ondersteundende rol werd mede mogelijk gemaakt doordat er een dagvoorzitter en twee deskundige gastsprekers waren uitgenodigd. Hun bijdrage op de groepsbijeenkomsten gaf bovendien een vakinhoudelijke verdieping van de besproken thema's. Bij gevolg werd er voor mij als onderzoekster meer ruimte gecreëerd voor de observator-rol. Daarnaast werd ik weer voor een deel ontzien in mijn onderzoekstaak door de hulp van een student-assistente die voor het notuleren van de groepsgesprekken zorg droeg, waadoor ik beter kon participeren en interveniëren in het groepsproces. De rol- en perspectiefwisselingen in

15. 'A.I.O.' staat voor 'Assistant in Opleiding'. In een vierjarig welhaast schools traject wordt een onderzoeks- en onderwijsstrucuur gecreěerd, waarin opzet, uitvoering en verslaglegging van een promotie-onderzoek onder deskundig toezicht geschiedt. 
de verschillende fasen van het uitwisselingsproject, de voorbereiding en de begeleiding van de drie groepsbijeenkomsten vormden een waardevolle ervaring en een oefening in flexibiliteit, improvisatievermogen en faciliteren van groeps-processen vanuit 'de middenpositie'. Door deze oefening in 'Hermes' balanceerkunst' voelde ik mij soms een circusartiest op de trapeze, om na het balanceren als het ware op een stoel in het publiek te gaan zitten om 'de voorstelling' nog eens de revue te laten passeren.

De neerslag van deze dialectische onderzoeksdialoog verscheen in de vorm van 'tussenrapportages', 'werkboeken' en een operationalisering van drie centrale thema's voor de interdisciplinaire uitwisselingssessie, waarvoor beide groepen samen waren uitgenodigd. Deze finale van het project leverde een rijke verzameling van onderzoeksmateriaal op, waarin door het hermeneutische onderzoekspad natuurlijk ook mijn persoonlijke inkleuring en begeleiding van het proces verdisconteerd was. Voor de interpretatie van het onderzoeksmateriaal moest ik mij derhalve over beide aspecten in hun onderlinge verhouding buigen om over de wisselwerking tussen mij als onderzoekster met de onderzochte praktijk rekenschap af te leggen. Op welke momenten was ik (teveel) in de afstandelijke onderzoekersrol? Op welke momenten heb ik me (teveel) geïdentificeerd met betrokkenen in de praktijk? Op welke momenten heb ik een balans gerealiseerd en beide rollen evenwichtig geïntegreerd? Door het geduldig bekijken, beluisteren en (her)lezen van het onderzoeksmateriaal is deze rekening opgemaakt en aan respondenten en onderzoeksbegeleiders voorgelegd. De methodologische vraag hierbij was nietzozeer of de wijze waarop de resultaten uit de individuele interviews zijn verbonden met de thema's voor de groepsgesprekken en de onderzoeksvraagstelling 'juist' was maar veeleer of ze 'verantwoordbaar' is. Overeenkomstig een responsieve benadering stond de vraag centraal of mijn specifieke wijze van interpretatie, inkleuring en sturing van het onderzoeksproces door middel van methodologische keuzes in de dialoog met de respondenten voldoende gelegitimeerd zijn: in mijn ogen als onderzoekster, ten aanzien van de respondenten en voor 'de wetenschappelijke gemeenschap', vertegenwoordigd door mijn begeleiders en de promotiecommissie.

Dit meanderende proces tussen zelfreflectie op mijn onderzoekersrol, reflectie over de onderzoeksopzet en over het gewonnen empirische materiaal leverde een kleurrijk en veelvormig beeld op. Hoe dit te vertalen in een verstaanbare interpretatie voor derden? Welke 'middenweg' voert er aan gene zijde van het positivistische geweld ten aanzien van de gevoerde multiloog door een analytische 'reductiestrategie' enerzijds en anderzijds van het nauwkeurig weergeven van alle losse verhalen, fragmenten en persoonlijke ervaringen van de respondenten? Beide extremen schenen mij zo niet onmogelijk dan toch onwenselijk toe. De hermeneutische sleutel voor de interpretatie van de veelheid tot een pluriforme eenheid bestond uit een evaluatieproces van het afgelegde traject zelf, middels mijn logboek, de 'peer debriefing'-overlegmomenten met mijn onderzoeksbegeleiders en de 'member checks' door middel van de groepsbijeenkomsten en de tot 'ver- 
slagen' gereconstrueerde, toegestuurde en telefonisch geëvalueerde onderzoeksgegevens. Hieruit volgde behalve de in paragraaf zes beschreven onderzoeksresultaten een overwegend positieve reactie van repondenten op het uitwisselingsproject. Het zou hebben bijgedragen aan ideëenvorming over het beroepsveld met betrekking tot verdere professionalisering. Het was ervaren als een vruchtbare vorm van 'netwerken' en uitwisseling van ervaringen. Het werkte als aansporing om te reflecteren op de zinvolheid om de nieuwe trainingsvormen van een professionele basis en een organisatorische inbedding te voorzien. Het had gediend als platvorm om een strategische visie op creatieve therapie en haar toekomst te ontwikkelen. Wat als een gemis bleek te zijn ervaren was dat de visie van de onderzoekster over de aangeboorde thema's aan het begin van de uitwisselingsbijeenkomst niet duidelijker naar voren is gebracht. Dit heb ik opgevat als een teken dat de gewenste integratie van de onderzoekers- en participatorrol tijdens deze bijeenkomst niet geheel uit de verf is gekomen. Door de begeleidende 'werkboeken' met betrekking tot het uitwisselingsproject, de onderzoeksverslagen, de extra telefonische evaluatie en twee gepubliceerde artikelen iser ten dele aan deze behoefte van de deelnemers aan het project tegemoet gekomen.

Het evaluatieproces heeft geresulteerd in voornoemde artikelen. ${ }^{16}$ Nog meer reflexieve afstand tot de daarin gepresenteerde 'voorlopige onderzoeksresultaten' heb ik door het schrijven van dit hoofdstuk genomen. Hiermee is deze eerste interpretatie van het onderzoeksmateriaal verbonden met de filosofische analyse uit de vorige hoofdstukken.

\subsubsection{Naar een 'model van metaforische communicatie en interactie'?}

In deze paragraaf staat beschreven hoe de eerste twee onderzoeksstappen van de veldstudie hebben geleid tot een interpretatiekader voor creatieve trajecten in therapie en organisatietrainingen in de vorm van een 'model voor metaforische communicatie en interactie'. Op basis van de literatuur- en praktijkstudies die aan het uitwisselingsproject zijn vooraf gegaan heb ik de methodische kracht van creatieve trajecten gemodelleerd tot een metaforische kennisvorm. In het model zijn enkele filosofische, creatief-therapeutische en organisatiekundige concepten uit de vakliteratuur met elkaar in verband gebracht teneinde de creatieve trajecten in therapie en training te kunnen beschrijven en interpreteren. Dit 'conceptmodel' is in de context van het uitwisselingsproject in de onderzoeksdialoog ter evaluatie ingebracht. De wijze waarop het model door middel van feedback van de respondenten is aangepast, is illustratief voor het dialogische onderzoeksproces als een vorm van onderhandelen en evalueren.

Het 'conceptmodel' is in de tweede fase van het 'uitwisselingsproject' aan de op de groepsbijeenkomst aanwezige organisatietrainers voorgelegd. Aan deze respon-

\section{Zie noot 2 .}


denten is het model van metaforische communicatie en interactie gepresenteerd met behulp van een grafische voorstelling (zie verder) en beelden van de Griekse goden $^{17}$ Apollo, Dionysos en Hermes. De onderzoekster gaf als toelichting dat deze godenfiguren 'staan voor' een bepaalde benaderingswijze van de werkelijkheid, die correspondeert met resp. een wetenschappelijke (rationalistische), een intuïtieve (romantische) en een 'betrokken-reflexieve' benadering vanuit 'de middenpositie'. De praktijk van de creatieve werkvormen berust vooral op een 'Dionysische grondhouding', terwijl voor een (hermeneutisch) onderzoek hiernaar de middenpositie gewenst is. Dit uitgangspunt staat aan de basis van een opvatting over creatieve trajecten als een betekenisgevend kader ofwel een interpretatieruimte, waarin een spel van implicatie en explicatie van betekenisgevende elementen plaatsvindt via (lichaams)taal en de taal van het creatieve medium. De creatieve werkvorm creëert op speelse wijze betekenis over het betrekkingsniveau van communicatie tussen de deelnemers in de vorm van een 'levende metafoor'. De psycho-sociale dynamiek wordt aldus via de dialoog met het creatieve medium langs drie kanalen of 'communicatieniveau's' present gesteld. Om een bepaald leereffect met een creatief traject te bewerkstelligen, bijvoorbeeld 'inzicht in de 'eigen'-wijze van communicatie en samenwerking', creëert de 'levende metafoor' uiteindelijk een cognitieve betekenis, een denkbeeld ten aanzien van de eigen communicatieve vaardigheden. De methodische voorwaarden voor het bereiken van dit effect bevinden zich evenwel in de leerervaring en aldus op de twee andere 'niveau's' van communicatie: levende metaforen als dragers van emotionele en interactieve betekenis. Juist omdat levende metaforen niet louter cognitief werken maar op 'het existentiële veld' en de 'belevingsorganisatie ${ }^{18}$ van deelnemers inwerken kunnen ze hun ludieke betekenisspel spelen. Een creatief traject kan inzichtgevend voor een cliënt werken door de dialoog met de therapeut of trainer via het creatieve medium, op basis waarvan er een 'emotionele kennis-overdracht' in een dialogische handelingscontext plaatsvindt.

Ter illustratie van dit model van metaforische communicatie dient nog eens de muziekmetafoor als voorbeeld. Het muzikale samenspel staat voor 'samenwerking' binnen een team. Het gezamelijk trommelen genereert een situatie die in sterke mate inspeelt op de emotionele beleving van de deelnemers. Zo kan het zitten in een kring en het gezamelijk trommelen van een ritme een sterk gevoel van saamhorigheid oproepen of juist een reeds bestaande, onderhuidse conflictsituatie laten opspelen.De muzikale expressie en het samenspel vertegenwoordigen metaforisch gesproken een 'configuratie' van emotionele reacties en interacties. Om het totaal aan mogelijkheden van communicatieve effecten van de muziekmetafoor samen te vatten, kunnen we spreken van het pre- en configureren van een belevingsbeeld in een handelingscontext resp. een muzikaal bewegingsbeeld. Het zitten in de kring, het trommelen van het ritme en de opgeroepen emoties en interacties in de groep zijn volgens deze invalshoek te interpreteren als de

17. De gepresenteerde visie is schatplichtig aan Nietzsche's esthetica, zie hoofdstuk 2 pragraaf 4.1, p. 88.

18. Zie voor een uitleg van deze termen hoofdstuk 4, paragraaf 3.3 , p. 165. 
'metaforische vormgeving' van emotioneel geladen handelingen en beelden tot een muzikaal samenspel. Tenslotte wordt er na deelname aan de muziekworkshop ook een denkbeeld over het onderwerp 'samenwerking binnen ons team' geconstrueerd. Bijvoorbeeld is het volgende concept over samenwerking geformuleerd: 'samenwerking wil zeggen 'goed naar elkaar kunnen luisteren'.19

Het aldus gepresenteerde model is door de onderzoeksdialoog met de respondenten aangepast. De eerste schets geeft een grafische vertaling van het model dat aan de groep creatieve trainers in de tweede fase van het uitwisselingsproject is voorgelegd. Aan de hand van de ontvangen feedback heb ik deze eerste voorstelling gewijzigd in de volgende twee schetsten. Het eerste statische tweedimensionale model is als het ware gedynamiseerd door middel van lijnen die beweging suggeren, als een grafische weergave van emotionele bewogenheid en handelingspatronen. Op die manier is 'de vierde dimensie' van tijd en ontwikkelingsdynamiek aangeduid, die in de communicatie- en interactieprocessen plaatsvindt, welke in een tweedimensionele voorstelling verloren gaat. De twee aangepaste schetsen geven aan hoe 'achter' of 'in' het eerdere schema een voorstelling van de lichamelijke verschijningsvorm van de mens geprojecteerd kan worden; en hoe dit mensbeeld gedynamiseerd raakt door een voortgaande spiraalbeweging die de psychodynamiek van de mens representeert. De geschetste lichamelijke verschijningsvorm van de mens is als het ware een 'metafoor' voor de emotioneel-interactieve betrokkenheid van de mens op 'het zijn'.

Schetsen I, II, III: 'Model van metaforische communicatie en interactie'

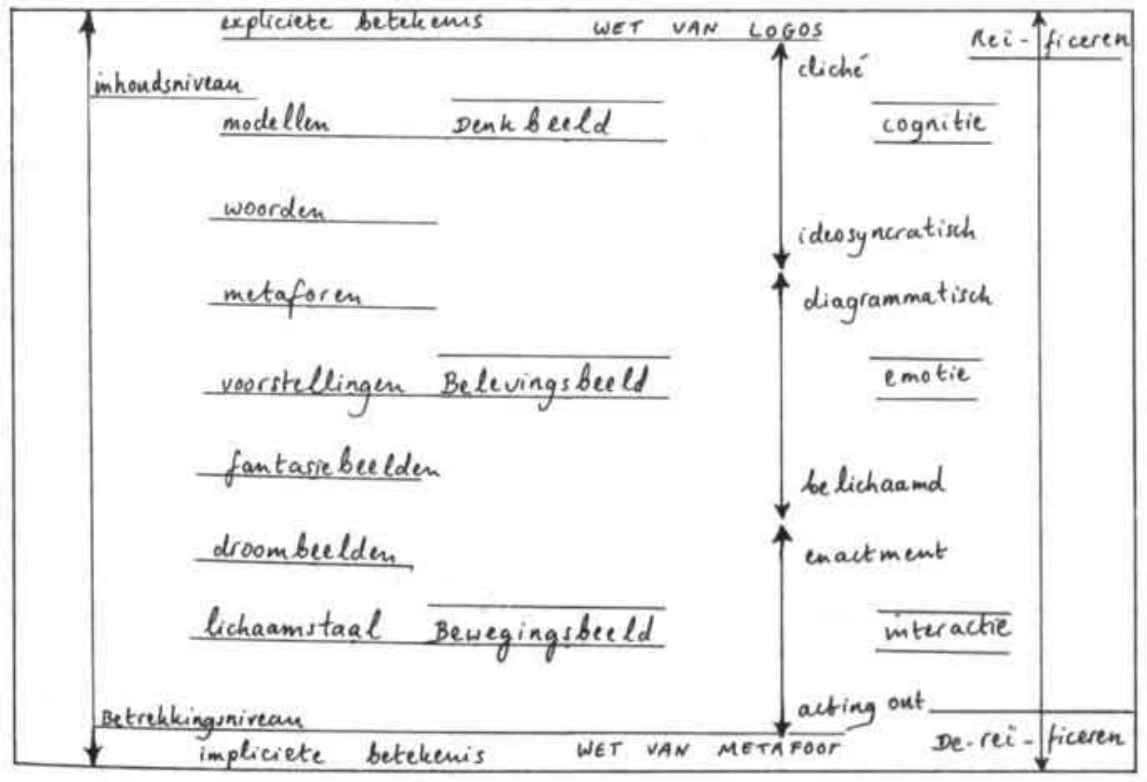

19. Onderzoeksmateriaal van de 'veldstudie'. 


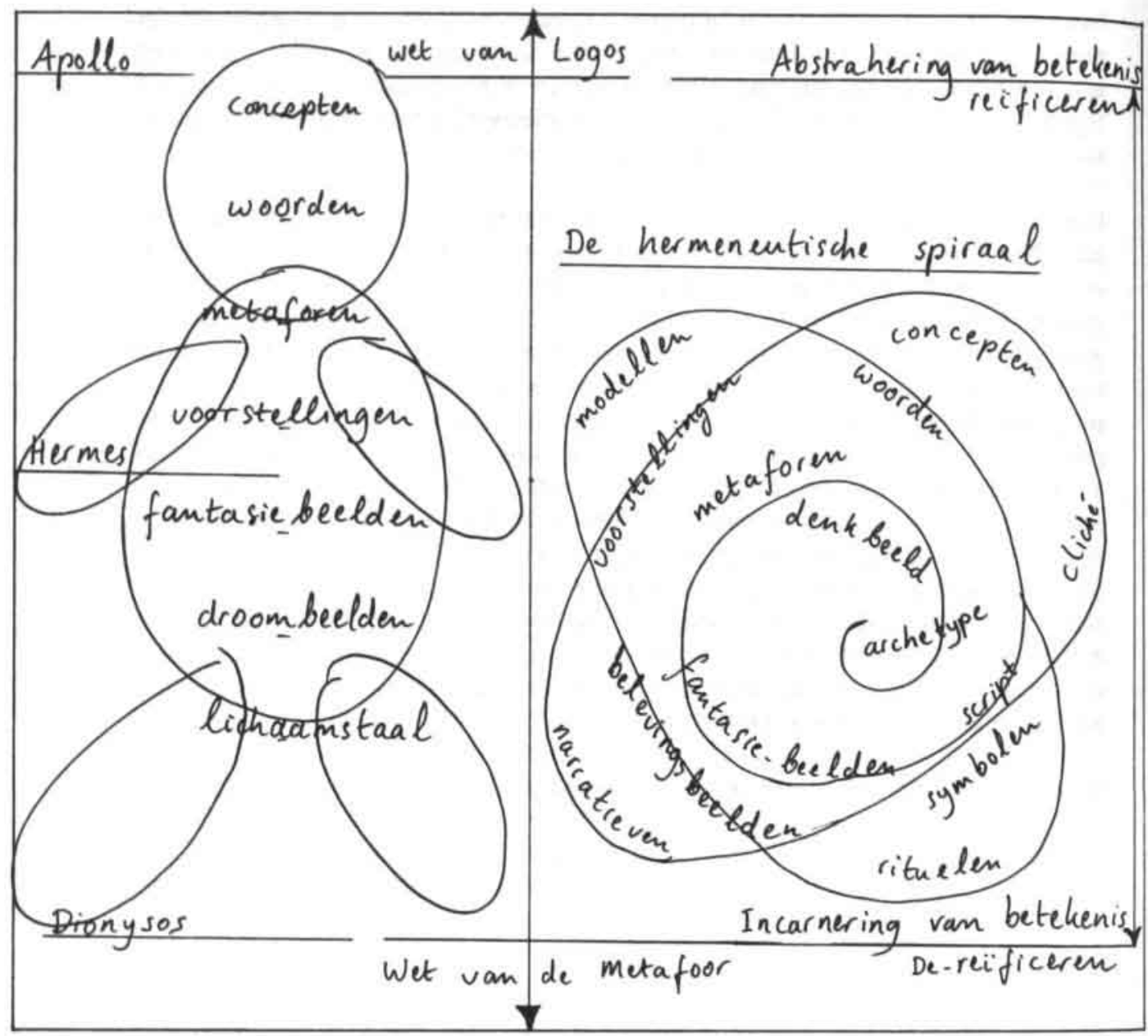

Tussen de onderscheiden niveau's vindt 'analoge communicatie ' plaats op grond van 'vormovereenkomsten' tussen mentale, emotionele en lichamelijke dynamiek: tegelijkertijd en gelijkvormig vinden er mentale 'denkbewegingen', 'psychische bewogenheid' en 'lichamelijke expressie ' plaats. Het verband tussen de niveau's is aldus 'isomorf' of 'analoog' en krijgt in begrippen en taal een 'metaforische uitdrukking'. Er vindt in 'metaforische communicatie en interactie' als het ware 'simultane vertaling' plaats tussen de niveau's door een dynamiek van verdichting en verplaatsing van betekeniselementen. Het proces van metaforische betekenisgeving is in die zin te beschouwen als een proces van 'ontvouwing' of 'explicatie' van wat lichamelijk in ons verankerd is tot psychische beelden en denkbeelden; en andersom, als een proces van 'implicatie' of 'verankering' van 'de beweging' van onze geest in emotionaliteit en lichamelijkheid. 
In het eerste model zijn de drie 'communicatie-niveau's' benoemd met behulp van vaktermen ${ }^{20}$, ontleend aan mijn analyse van creatief therapeutische literatuur. Zoals in het tweede hoofdstuk is uitgelegd, geven de 'beeldwaarden' diagrammatisch versus belichaamd aan dat beelden kunnen worden opgevat als dragers van een emotionele betekenis. In dialoog met het medium wordt er op metaforische wijze een emotionele betekenis op een beeld overdragen. Een schets die mijn organisatorische positie binnen een bepaald samenwerkingsverband ruimtelijk weergeeft, heeft een 'diagrammatische' beeldwaarde ten opzichte van een zelfbeeld dat aangeeft hoe ik mijzelf in deze werksituatie emotioneel voel. Wanneer ik in het tot stand komen van dit laatste beeld mijn emoties laat meespreken zijn ze door de wijze van presentatie daadwerkelijk 'belichaamd' in het beeld. In de interviews heb ik van deze beeldwaarden gebruik gemaakt, bijvoorbeeld door creatief therapeuten uit te nodigen om een beeldende weergave van hun werksituatie te maken. De cognitieve component van het metaforische proces van betekenisgeving opereert tussen de extremen van een 'conventioneel beeld' (of een 'cliché') en een 'ideosyncratisch beeld'. Het cliché-beeld van de roos als symbool voor liefde heeft een conventionelere en daardoor een minder meerduidige betekenis in vergelijking met spontane beelden in een met passie geschreven liefdesgedicht. In het kader van creatieve therapie geldt in het algemeen dat hoe onconventioneler de beelden zijn, hoe meer emotionele, interactieve èn cognitieve beeldwaarde ze vertegenwoordigen. Het 'interactieve' niveau van 'de levende metafoor' representeert een dimensie van beeldcommunicatie die in verband met de antropologische benadering van creatieve therapie in hoofdstuk twee als 'beeldnarratief' is geïnterpreteerd. In dat verband stelt de metafoor een handelingscontext present, waarin de interactieve betekenis van dit beeld in een rituele handeling of door middel van een emotioneel geladen beweging kan worden gearticuleerd. Deze handelings- of 'script-waarde' van de metafoor bevindt zich tussen de pool van een ongerichte emotionele ontlading 'acting out', zoals bijvoorbeeld in een agressieve of destructieve handeling, en de pool van 'enactment', de gerichte en rituele vormgeving van de impliciete emotionele betekenis van een beeld. In het eerste hoofdstuk zijn de populaire 'survivaltochten' in de Ardennen als een voorloper van de 'creatieve trainingen' gekarakteriseerd. Vanuit dit model worden ze geinterpreteerd als een 'natuurlijke situatie' die dient als metaforisch kader, waarin op nondirectieve en spontane wijze samenwerkingsverbanden ontstaan. Hier tegenover staat het gegeven voorbeeld van de muzikale bedrijfsworkshop waarbij er 'gericht' aan een trainingsdoelstelling wordt gewerkt, aan de hand van een 'script'en door middel van muzikaal samenspel, dirigeren en soleren, zodat de deelnemers als het ware aan den lijve 'leidingeven en samenwerking binnen een team' kunnen ervaren. ${ }^{21}$

20. Vooral ontleend aan: Dalley (ed.): Images of Art Therapy. New Developments in Theory and Practice En: Art as Therapy. Introduction To the Use of Art as a Therapeutic Technique. Zie hoofdstuk 2 paragraaf 4.2

21. Materiaal uit de veldstudie, bijvoorbeeld een afstudeeropdracht van HBO-studenten muziektherapie die in vergelijkbare zin een muziek-trainingsconcept hebben ontwikkeld. 
De waarde van dit model ligt in de mogelijkheid om het metaforische proces van betekenisgeving in therapie en training te kunnen benoemen en interpreteren. Echter bleek uit de reacties op de groepsbijeenkomst dat deze waarde niet eenduidig is overgekomen. Een belangrijk resultaat uit het ontvangen commentaar is dat het model het concrete, levende en ondeelbare proces van betekenisgeving, statisch en abstract zou maken en dichotomiseren. De 'levende metaforen' in therapie en training zouden als het ware 'op de anatomische snijtafel' van een modelbouwer versterven. Ik acht deze kritiek in zekere zin terecht, namelijk in die zin dat een modelmatige reconstructie van 'de' werkelijkheid, waarop het model betrekking heeft, de dynamiek en het proceskarakter van zijn reîficeert. Als zodanig is dit bezwaar evenwel van toepassing op elk model. Bovendien spreekt uit de kritiek een vooronderstelling dat er, bijvoorbeeld op 'empathisch-intütieve wijze', er een adequatere representatie van 'zijn' zou kunnen worden gegeven. Vanuit mijn hermeneutische stellingname is dat een romantische illusie en gaat het hierbij om verschillende wijzen van (re-)presenteren. Elke (re)presentatie betekent een 'ingreep in de zijnsstroom', die daarmee iets toevoegt of ontneemt aan hetgeen ge(re)presenteerd wordt en aldus 'het zijn' niet ongerept laat. In antwoord op deze kritiek heb ik, in het aan de respondenten toegestuurde verslag van deze groepsbijeenkomst, voorgesteld het model als een 'notatie-systeem' te beschouwen, zoals dat bijvoorbeeld ook voor het ongrijpbare fenomeen van muziek is ontwikkeld. Hiermee kan het principieel 'dynamische en dionysische proces' niettemin door een 'apollinische kunst' in kaart worden gebracht. De professionele begeleiding van communicatieprocessen met 'vloeiende' betekenissen en metaforische dynamiek vereist van een trainer of therapeut een dionysische kwaliteit van 'overgave, empathie en intütief handelen'. De interpretatie van dit proces vraagt daarbij evenwel om een apollinische kwaliteit van afstandnemen, reflecteren en beeldend in de voorstelling reconstrueren van de vervloeiende en stromende wijze van betekenisgeving via creatieve expressie en langs de keten van sociale interacties.

Het gepresenteerde model is als het ware een voorstel om een bepaalde samenhang tussen een aantal relevante vaktermen aan te brengen teneinde de psycho-dynamiek in communicatie en betekenisgeving in het kader van creatieve trajecten te beschrijven en interpreteren. Vanuit de hermeneutische invalshoek is het mogelijk om bijvoorbeeld een muziekworkshop te beschouwen als een samenspel van impliciet, op de achtergrond blijvende betekeniselementen (lees: de communicatieen samenwerkingspatronen op de werkvloer) en de expliciete, op de voorgrond gestelde muzikale vormgeving hiervan. Aldus kan met het model worden aangegeven hoe een creatieve trainer of therapeut, analoog aan de 'deconstructie van de basketbalmetafoor' in het derde hoofdstuk, aan deelnemers of cliënten overbrengt op welke wijze inhouds- en betrekkingsniveau van communicatie via analoge boodschappen met elkaar samenhangen. Wanneer de groepsleider uit het hiervoor gegeven voorbeeld van de muziekmetafoor, zich bijvoorbeeld met angstzweet en beven in het midden van de kring begeeft, is het evident dat inhouds- en betrekkingsniveau op incongruente wijze met elkaar samenhangen. 
Het 'model' is aldus in dialoog met de deelnemende professionals geëvalueerd. Er is kennelijk meer concretisering nodig om de verbinding van het 'meta-niveau' van het model met de praktijk te kunnen leggen. Misschien, zoals een van de respondenten suggereerde, door 'menselijkere' concrete metaforen te gebruiken om de verschillende communicatieniveau's en de met vakjargon benoemde beeldwaarden te typeren.De in het kader van het uitwisselingsproject tot stand gekomen en hierna weeggegeven 'zijnsmetafoor' is illustratief hiervoor. Bovendien zouden de drie communicatieniveau's als een 'metaforische psycho-dynamiek' in hun onderlinge samenhang aanschouwelijk kunnen worden gemaakt op grond van praktijkverhalen en casussen. Voor zover het model als middel kan dienen om reflectie op de professionele praktijkervaring te structureren en methodische concepten te systematiseren draagt het bij aan methodiekontwikkeling en professionalisering. De feedback heb ik opgevat als een amendement op mijn concept-voorstel hoe een 'model van metaforische communicatie en interactie' te ontwerpen. Om aan het dynamische karakter van 'levende metaforen' meer recht te doen is de onderscheiding 'reïficeren -dereïficeren' ${ }^{22}$ in het model extra benadrukt en vertaald als een 'proces van verdichting en vervluchtiging' van betekeniselementen, resp. als een proces van verankering in ons lichaam en 'incarnering in de belevingsorganisatie' versus een proces van 'abstrahering' of vervluchtiging van de metafoor tot een inzicht of concept dat 'het existentiële veld' (her)structureert. Deze dialectiek van (incarnering tot) beelddenken en (abstrahering tot) denkbeelden zou methodisch kunnen worden uitgewerkt, bijvoorbeeld aan de hand van het in de literatuur veel aangehaalde 'vier fasen model' ${ }^{23}$ waarmee processen van ontdekking en momenten van intellectuele en emotionele doorbraak worden getypeerd. Deze 'methodische aanvulling' van 'het model' is in de terugrapportage verwerkt en aan de respondenten voorgelegd. Op basis van de telefonische 'nainterviewronde' heb ik geconcludeerd dat een dergelijke concretisering van het model meer herkenning oplevert dan de gepresenteerde 'filosofische' conceptversie. De gegenereerde onderzoeksdialoog heeft hiermee tevens bijgedragen aan de onderkenning van de waarde van reflectie op en systematisering van intuïtieve praktijkkennis voor de professionalisering van creatieve werkvormen in therapie en training.

Deze reconstructie van een gedeelte van de onderzoeksdialoog onderstreept tevens het fundamentele gegeven dat ik als onderzoekster door de handeling van het benoemen en interpreteren op dialectisch-hermeneutische wijze ingrijp in het

\footnotetext{
22. 'Reificeren' is een uit het Latijn afkomstige filosofische term die 'het verdinglijken' aanduidt, eent proces van het verkrijgen of toekennen van een 'dingmatig karakter' aan 'zijn'. Bij filosofische auteurs van het dialectisch idealisme en materialisme (zoals Hegel en Marx) speelt het concept bijvoorbeeld een rol als het materialiseren van een idečel ding, in de zin van 'objectivering van de geest' of als 'fetisjisme van de waar'.

In de organisatie-literatuur is deze terminologie overgenomen in het kader van conflict-hantering, namelijk in het reeds aangehaalde boek van Van Dongen e.a.: Een kwestie van verschil. Conflicthantering en onderhandeling in een configuratieve integratietheorie. Zie hoofdstuk 3 paragraaf 5.2

23. Zie hoofdstuk 4 paragraaf 3.3, met literatuurverwijzing in noten 39 en 40 .
} 
onderzochte. De ongrijpbare dynamiek van het proces van metaforische betekenisgeving heb ik op juist deze wijze vastgelegd (een door de onderzoekster aangebrachte inkleuring en reificatie van het onderzochte) en niet op een andere, waaruit de fundamentele afhankelijkheid van de onderzoeksresultaten van de persoon van de onderzoekster blijkt. Tegelijkertijd is hiermee het belang en de waarde van het dialogische principe naar voren gekomen. Op basis van de dialoog met de respondenten is het model zodanig aangepast dat het meer recht doet aan 'dionysische aspecten' van de creatieve kennispraktijk in vergelijking met de eerste filosofische vertaling tot een 'metaforische kennisvorm'. De dialoog biedt derhalve de basis om deze 'apollinische' reconstructie van 'metaforische communicatie en interactie' zodanig te operationaliseren dat ze voor de praktijk bruikbaar wordt. Dit onderstreept tevens het fundamentele uitgangspunt dat het bij de vraag naar een 'metaforische adequaatheid' niet zozeer om een 'empirische' overeenstemming gaat maar veeleer om een 'interne logica van de metafoor', zoals in het vierde hoofdstuk is uiteengezet.

Het model van metaforische communicatie en interactie zou ook als een versie van 'de hermeneutische cirkel'24 geïnterpreteerd kunnen worden. Door het metaforische samenspel van impliciete en expliciete betekenisgevende elementen vindt er als het ware nog een extra vorm van 'triangulatie' plaats, aangezien er van meerdere zintuigelijke, lichamelijke, emotionele en verstandelijke 'informatiekanalen' gebruik wordt gemaakt bij het verzamelen van organisatie- en therapieverhalen. Hiervoor is reeds op het verband gewezen met de in het vierde hoofdstuk beschreven 'dialectische wisselwerking tussen beelddenken en denkbeelden'. Daar werd het belang van deze dialectiek onderstreept met het oog op een 'nietmetafysische' interpretatie van de grondslag voor creatieve trajecten. Hier is bovendien haar betekenis voor een begrip van haar methodische 'meerwaarde' aangegeven. Illustratief is het reeds gegeven voorbeeld van 'de muziekmetafoor' als 'samenwerkingsconcept'. In deze paragraaf is benadrukt dat door de creatieve trainingsvorm dit 'concept' niet alleen langs cognitieve weg als denkbeeld wordt overgebracht maar vooral als vaardigheid door middel van emotionele en interactieve overdrachtsprocessen. In het gegeven voorbeeld van de muziekworkshop wordt van meerdere communicatiekanalen tegelijkertijd gebruik gemaakt, inclusief transmodale en synergie-effecten. Het beoogde leereffect zou aldus op een wisselwerking tussen de 'metaforische' en de 'conceptuele ervaringsmodus' berusten. Het lijkt waarschijnlijk dat hierdoor een diepere verankering in de 'belevingsorganisatie' en het 'existentiële veld' met betrekking tot feitelijke communicatieen handelingspatronen plaatsvindt dan anderszins het geval zou zijn. Empirisch onderzoek naar de veronderstelde leereffecten zou dit kunnen bevestigen of ontkrachten.

24. Zie Guba \& Lincoln: Fourth Generation Evaluation 152. 


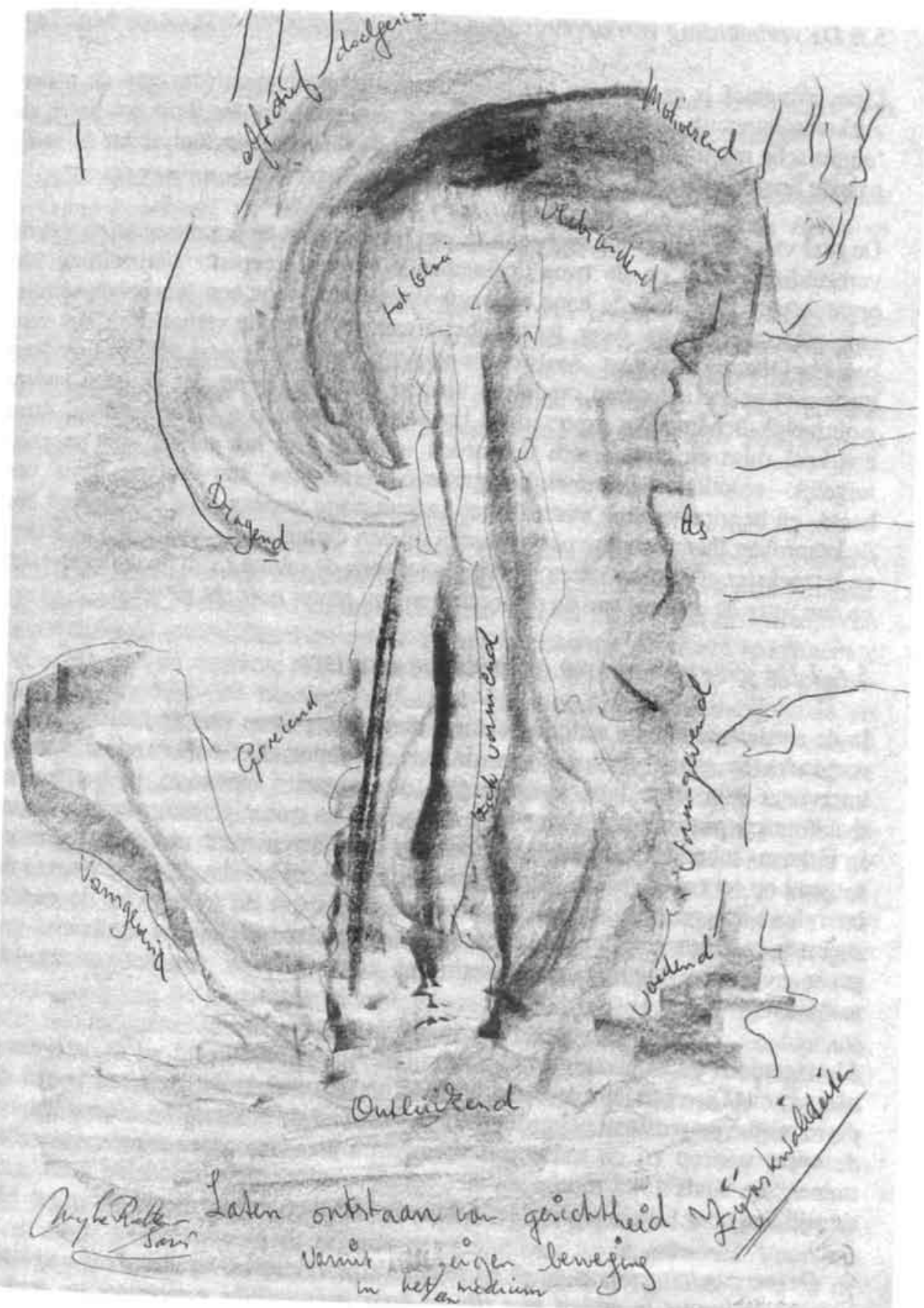


Deze paragraaf is gewijd aan het interpretatie- en evaluatieproces van de onderzoeksresultaten uit de praktijk. In de zevende paragraaf worden deze resultaten als 'empirische winst' in verbinding gebracht met de theoretische analyse uit de voorgaande hoofdstukken.

De titel van het project 'de verbeelding van organisaties en het organiseren van de verbeelding' duidt op de twee deelnemende beroepsgroepen. 'Verbeelding van organisaties' geeft aan de hand van een visuele metafoor een 'kerncompetentie' van 'creatieve trainers' weer, terwijl 'het organiseren van de verbeelding' dat voor beeldend therapeuten doet. Zoals reeds eerder opgemerkt is deze titel wel treffend maar niet geheel adequaat omdat de visuele bias suggereert dat er geen andere zintuigelijk-lichamelijke aspecten bij betrokken zouden zijn. 'Verbeelding' dient dus heel ruim en metaforisch te worden verstaan als 'het geheel van onzezintuigelijk- emotioneel-lichamelijk-cognitieve vermogens' dat aan de basis van beeld- en begripsvorming staat. In het onderstaande verslag staat beschreven hoe de besproken thema's zijn voortgekomen uit een dialogisch evaluatieproces tussen onderzoekster en respondenten. Hierbij is nu eens de inbreng van de onderzoekster en dan weer de respons van de respondenten van groter gewicht geweest.

\subsubsection{De groep creatieve organisatie-trainers}

In de eerste fase van de serie individuele diepte-interviews was de inbreng van de respondenten groter dan die van de onderzoekster. De onderwerpen van de interviews zijn door haar aangedragen, de suggestie om soms in beelden of metaforen te antwoorden, alsmede de keuze om op sommige onderwerpen dieper in te gaan. Inhoudelijk komen de hieronder beschreven resultaten derhalve overwegend op rekening van de geïnterviewde trainers, zij het dat de wijze waarop de interviews en groepsbijeenkomsten zijn verslagen uit de koker van de onderzoekster is gekomen. Er wordtnamelijk geen 'transcript' van de interviews gegeven maar een 'citering, parafrasering en comprimering' van het onderzoeksmateriaal.

Als algemeen beeld kwam 'de pluriformiteit' van het werkveld uit de interviews naar voren. Dit veelkleurige beeld heeft te maken met de variëteit wat betreft de persoonlijke en professionele voorgeschiedenis van de trainers, die 'doorstraalt' in de wijze waarop zij de trainingen vormgeven en verwoorden. Een organisatietrainer, die sinds 1985 trainingen met behulp van creatieve middelen geeft, omschrijft een door hem ontwikkelde 'percussieworkshop' bijvoorbeeld als volgt:

De percussieworkshop geeft de cliënt de gelegenheid, op een heel originele manier kennis te maken met zijn of haar persoonlijke gewoontes in: leider- 
schap, communicatie, persoonlijk functioneren. ${ }^{25}$

Tegenover deze functionele beschrijving karakteriseert een andere trainer zijn 'jongleer-workshop' op ludieke wijze als 'management in een handomdraai':

The Modern Manager's Guide To The Ancient Art Of Juggling: Complexiteit vereenvoudigen, De kunst van het loslaten, Barrières doorbreken, Falen en opstaan, Flexibiliteit aanleren, Creativiteit stimuleren. ${ }^{26}$

Aldus laat het beeld van deze eerste fase van het project, overeenkomstig de eerdere werkveldoriëntatie ${ }^{27}$, een grote variëteit zien van de aangeboden 'creatieve diensten', van 'training' tot 'entertainment'. De pluriformiteit komt tot uitdrukking in de diversiteit van gebruikte middelen, de wijze waarop ze tot een 'levende metafoor' zijn vormgegeven en de uiteenlopende doelstellingen waarvoor ze worden gebruikt.

\section{De groepsbijeenkomst met creatieve trainers}

In de tweede fase van homogene groepsbijeenkomsten is de dialogische balans wat betreft de inbreng van de onderzoekster ten opzichte van de respondenten hersteld. Op basis van het beluisteren en het herkaderen van het interviewmateriaal zijn een aantal thema's gedestilleerd en op de groepsbijeenkomst gepresenteerd teneinde het werkveld van creatieve organisatietrainers in beeld te brengen. Met de presentatie van het hiervoor beschreven 'model van metaforische communicatie en interactie' beoogde de onderzoekster een veronderstelde 'onderliggende' eenheid niettegenstaande de evidente pluriformiteit ter discussie te stellen. Zoals in de vorige paragraaf is aangegeven volgt uit de onderzoeksdialoog dat de 'abstracte' vorm van dit model voor de professionals met betrekking tot toepassing in de praktijk een concretisering behoeft. Na de presentatie van de resultaten uit de interviews stond de evaluatie van dit model als tweede onderdeel van de groepsbijeenkomst op het programma. Met het thema 'professionele motto's' expliciteerde de onderzoekster haar veronderstelling van een gemeenschappelijke humanistisch thema met betrekking tot het creatieve trainingswerk tegen de achtergrond van de klaarblijkelijke pluriforme verschijningsvormen. Er bleek in deze fase inderdaad sprake te zijn van onderlinge herkenning van de uiteenlopende 'professionele motto's'. Aan de veronderstelde gemeenschappelijke humanistische basis was het derde onderdeel van de groepsbijeenkomst gewijd aan de hand van voorgelegde stellingen, die onder leiding van een uitgenodigde gastspreeksterdoor de trainers werden bediscussieerd.

Het thema 'professionele motto's' was als belangrijk ijkpunt voor het trainingswerk uit de interviews met de organisatietrainers naar voren gekomen. Voor een goed begrip van dit thema schetste de onderzoekster eerst een globaal beeld uit de

25. Fred Cohen, folder muziekworkshops voor bedrijven.

26. Gids bij de jongleerballen van More Balls Than Most.

27. Zie het eerste hoofdstuk paragraaf 3 . 
interviews met betrekking tot de aangetroffen verschillen in gebruikte middelen, wat betreft de methodische vormgeving van de creatieve trajecten en de verschillende managementdoelstellingen waarvoor trainers worden ingehuurd. De veelkleurigheid van dit beeld leek gecentreerd rond de spil van een 'persoonlijke missie' voor het creatieve trainingswerk. De missie van een trainer bleek soms uit een handelsmerk maar meestal was het in een algemenere zin als een professioneel motto in de interviews hoorbaar. Van een 'handelsmerk' wordt gesproken wanneer de trainer het motto in die vorm extern communiceert, wat bijvoorbeeld het geval is met 'Why worry' voor muziekworkshops in bedrijven en voor dejongleerworkshop 'De kunst van het loslaten, management in een handomdraai'. Wanneer dit niet zo (uitgesproken) het geval was, parafraseerde de onderzoekster het op dit thema betrekking hebbende gedeelte van het interview tot een 'professioneel motto'. Enkele voorbeelden hiervan zijn:

Beelden bieden letterlijk een aangrijpingspunt om te veranderen.

Ik werk aan het openen van alle communicatiekanalen.

Ik help mensen op weg naar het meest vitaliserende beroepsperspectief.

Kunst en beelden bieden tegenwicht tegen de vervreemding.

Het gaat om de morele vragen en dilemma's achter de beelden en metaforen.

Ik nodig mensen uit tot openheid, plezier en contact maken.

Met muziek speel je wie je bent.

De kunst van het omdraaien: door pardoxen, vooroordelen en provoceren.

De kracht van vitaliserende beelden uit het onbewuste.

Deze 'humanistische' motto's geven als het ware kernachtig weer wat de 'authentieke', met de persoonlijke voorgeschiedenis samenhangende professionele overtuiging van een trainer is. Aan het begin van de groepsbijeenkomst verzocht de onderzoekster de respondenten om een (geanonymiseerd) motto, dat op een A4papier was opgeschreven, als 'eigen' uitspraak uit te kiezen. Uit deze opdracht bleek dat de motto's een zodanige herkenning opriepen dat het uitgekozen motto soms uit een interview met een andere respondent afkomstig was in plaats van uit het eigen interview. Niettemin werd de 'geleende' uitspraak als een eigen keuze of een 'authentieke' weergave van 'de professionele kern' van het trainingswerk onderkend. Zo kon door de onderzoekster worden nagegaan in hoeverre de motto's inderdaad een gemeenschappelijke basis voor het creatieve trainingswerk vertegenwoordigen. De volgende reeks motto's zijn door de op de groepsbijeen- 
komst aanwezige trainers verkozen als zijnde 'representatief' voor hun persoonlijke missie in het trainingswerk:

Het gaat erom via de verbeelding de authenticiteit van de mens te bewaren.

Als consulent moet je zijn wat je zegt.

Metaforen geven steun en structuur aan informatie.

De homo ludens wil gehoord en gezien worden.

Het gaat om de vormgeving van je leven: hoe je van je huis een thuis maakt.

Mijn leren is spelen, mijn spelen is leren.

\section{Bezieling en kwaliteit in organisaties.}

De onderlinge herkenning bleek niet alleen in die zin dat sommige trainers het motto van een andere trainer als het eigene hadden uitgekozen, maar ook in de groepsdiscussie over dit onderwerp. De motto's lijken derhalve zowel uitdrukking van een 'persoonlijke missie' te zijn als een inwisselbaar 'retorisch concept' om een creatieve training van een 'handelsmerk' te (kunnen) voorzien. Hoe zou deze ambivalentie van 'retoriek' en 'authenticiteit' in de professionele motto's geduid kunnen worden?

De onderzoekster lichtte op de bijeenkomst haar interpretatie van de motto's toe. Een motto verwijst met 'retorische' kracht naar 'authentieke communicatie' als 'humanistische grondslag' voor het trainingswerk. Dit aspect van 'authenticiteit' in communicatieprocessen werd in het algemeen door de geïnterviewde trainers als een fundamenteel 'existentiëel niveau' opgevat, dat zij via het creatieve medium bij de deelnemers beogen te beroeren. Zij 'vertalen' het creatieve medium op een zodanige 'authentieke' wijze in het eigen vormgevingskader, dat daarin de persoonlijke resp. professionele ontwikkeling van de trainer tot uitdrukking komt. Deze 'authentieke' expressie van de persoonlijke missie die aan het creatieve trainingswerk ten grondslag ligt, wordt met het professionele motto (metaforisch) aangeduid. Deze interpretatie van de onderzoekster werd in de groepsdiscussie besproken en in relatie tot de organisationele context van het trainingswerk gebracht. Ten opzichte van het 'existentiële niveau' van 'authentieke communicatie' komen de managementdoelstellingen, waarbinnen een creatieve training of workshop moet passen, over als van een geheel andere orde. De volgende reeks managementdoelstellingen was uit het interviewmateriaal naar voren gekomen:

stressmanagement,

employability,

flexibilisering, 


\author{
klantgerichtheid, \\ teambuilding. \\ een fusie vormgeven, \\ iets creatiefs, \\ managing change, \\ managing the future, \\ managing uncertainty, \\ managing diversity, \\ zelfmanagement,...
}

De op de groepsbijeenkomst aanwezige trainers stemden in grote lijnen in met de 'ideologie-kritische' interpretatie dat dergelijke managementdoelstellingen van secundair belang zijn ten opzichte van het 'existentiële niveau' dat met 'de levende metafoor' in een creatief traject wordt geënsceneerd. In het algemeen gaven trainers aan de managementconcepten en organisatiedoelstellingen de betekenis van een 'taal' die je moet leren verstaan om een opdracht te kunnen aannemen en te vertalen in de 'existentiële taal' van het creatieve medium.

Het 'niveauverschil' tussen 'de existentiële vormgeving' en het 'retorisch-ideologische niveau' van managementconcepten en organisatiedoelstellingen, is door de onderzoekster in verband gebracht met een 'kritische' invalshoek op het humanistische aspect van het trainingswerk resp. de omstreden 'meerwaarde' van creatieve communicatiemiddelen voor veranderingsprocessen. De kracht van 'levende metaforen' zou in de eerste plaats verband houden met dit 'diepere', existentiële niveau van communicatie. Niettegenstaande de pluriforme wijze waarop dit niveau in de diverse trainingen wordt beroerd, vertegenwoordigt het gemeenschappelijke humanistische aspect in de professionele motto's de basis van het trainingswerk. In een van de bediscussieerde stellingen is deze grondslag aangeduid als de authentieke en persoonlijke bejegening in communicatie via het creatieve medium. Dit humanistische fundament wordt geschraagd, zo heeft de onderzoekster op basis van de interviews geconcludeerd, door een creatieve en ludieke vorm van 'authentieke' communicatie, waardoor er een krachtig retorisch appèl wordt gedaan op de homo ludens. Dat wil zeggen dat er in een creatieve training de gehele mens en niet alleen het hoofd wordt aangesproken met het appel om 'creatief' en 'spelend' te communiceren, los van de professionele of de sociale rol.

Zoals reeds aangegeven blijkt uit het onderzoeksmateriaal dat de trainers de individuele leerdoelstelling van de deelnemers aan een creatieve training primair stellen ten opzichte van de aangereikte managementdoelstellingen. Toch raakt het organisationele aspect ondanks het in de trainingen gelegde accent op 'de individuele autonomie en authenticiteit' niet geheel uit beeld. In een creatieve training wordt met het raakvlak van individuele en organisatiedoelstellingen gespeeld. De veronderstelling hierbij zou kunnen zijn dat tegelijkertijd met een persoonlijke resp. professionele trainingsdoelstelling aan organisatie-ontwikkeling 
zal worden bijgedragen. Dit betekent dat een individuele trainingsdoelstelling, zoals 'de verbetering van de persoonlijke effectiviteit', een gunstig effect heeft op bestaande samenwerkings-verbanden en communicatiepatronen op de werkvloer en langs die schakel tevens een bijdrage levert aan het creëren van een 'lerende', 'vitaliserende', 'bezielende', 'inspirerende', ... organisatie. Deze onderlinge verwevenheid en interdependentie van persoonlijke èn organisatieleerdoelen stelde de onderzoekster in haar interpretatie van het creatieve trainingswerk op de voorgrond. Aangezien de aanwezige trainers in het algemeen met deze duiding instemden, is deze onder de noemer van de 'zijnskwaliteiten'-metafoor als thema uitgekozen voor de interdisciplinaire uitwisselingsbijeenkomst.

Als derde programma-onderdeel van de groepsbijeenkomst met organisatietrainers werd een aantal stellingen bediscussieerd met het oog op verdere aanscherping, aanvulling en wijziging van het geschetste beeld uit de interviews. Dit gebeurde onder leiding van een uitgenodigde gastspreekster, die met een loopbaanstart als creatief therapeute nu in samenwerking met een trainingsbureau beeldende trainingen ontwikkelt. Een van de stellingen heeft betrekking op de waarde van de metaforische invalshoek voor creatieve trainingen. Een andere stelling onderstreept de centrale plaats van de mens ten opzichte van organisatorische belangen. Weer een andere breekt een lans voor de vorming van een organisatorisch verband voor belangenbehartiging, netwerken en kwaliteitsbewaking. Er ontstond discussie over de wenselijkheid van een opleiding en over de vraag naar het meest geschikte referentiekader voor theorievorming met betrekking tot 'de eigen aard' van het creatieve medium. In deze discussie gingen stemmen op voor een te vormen organisationeel kader om 'te netwerken' met het oog op professionele samenwerking en belangenbehartiging en op de zich vormende professionele identiteit. Uit deze discussie volgde geen eenduidige stellingname als groep ten aanzien van de voorgelegde stellingen. Wel kreeg één van de stellingen de voorkeur van drie van de zeven aanwezige trainers en algemene bijval tijdens de groepsdiscussie:

De beoogde verdieping van metaforische communicatie en interactie is alleen mogelijk vanuit een persoonlijk geinspireerde mensvisie: een geloof in de individuele autonomie en authenticiteit van de mens.

Nog twee andere uitgekozen stellingen ${ }^{28}$ stelden het belang centraal van 'fundamentelere processen van (metaforische) communicatie' ten opzichte van 'oppervlakkigere' vormen' van creativiteit zoals 'entertainment' en de 'metaforen-hype'. De voorkeur voor deze stellingen wijst op de onderkenning van het belang van een fundamenteel 'humanistisch' communicatieniveau dat op de groepsbijeenkomst was gekarakteriseerd als het existentiële niveau van 'persoonlijke bejegening' en het aanspreken van de 'individuele autonomie en authenticiteit' bij deelnemers aan

28. Deze twee uitgekozen stellingen hadden betrekking op het belang van een organisationele inbedding als beroepsgroep (stelling 1) en op de aanbeveling om de rol van 'trainer' en 'entertainer' niet in een persoon te verenigen (stelling 3 ). 
een creatieve training. Deze door de onderzoekster voorgelegde duiding van het creatieve trainingswerk spoort met hetgeen in het voorafgaande literatuuronderzoek is gearticuleerd als de gevraagde kritisch humanistische grondslag. De op de groepsbijeenkomst gepresenteerde professionele motto's kunnen derhalve gelezen worden als voorbeelden van een persoonlijke interpretatie van de gemeenschappelijke humanistische grond, waarin in meer of mindere mate een 'ideologie-kritisch' moment verdisconteerd is. Ter illustratie een citaat van een trainer die zijn keuze voor een motto toelicht:

Het gaat om de vormgeving van je leven: 'hoe je van je huis je thuis maakt'. Anders gezegd: Hoe geef je je leven vorm en hoe geef je vorm aan je leven? Door te reflecteren op vormgeving is het mogelijk om zowel flexibele als inflexibele signalen (bottlenecks) op te pakken en te kijken waar sprake is van stagnatie dan wel beweging.

Uit dit citaat blijkt hoe juist door dit persoonlijk gekleurde stempelvan 'vormgeving' de kritisch-humanistische grondslag concreet en werkzaam wordt. De authentieke zijnswijze van de trainer komt tot expressie in de wijze waarop z(h)ij een 'creatief traject' tot een 'levende metafoor' vormgeeft, waardoor 'het geloof in de individuele authenticiteit en autonomie' van de deelnemers wordt overgebracht. De geciteerde trainer operationaliseert zijn 'motto' in een 'metaforische taal' met betrekking tot 'huiselijke vormgeving', wat zowel een existentiêle als een esthetische component heeft. Als zodanig kan 'authenticiteit' worden opgevat als een door de trainer belichaamde zijnswijze, een 'zijnskwaliteit' die op de deelnemende groep humaniserend werkt. 'Zijnskwaliteiten', die onder de noemer van een professioneel motto gestalte krijgen, zijn bijvoorbeeld: humor, openheid, creativiteit, liefde, speelsheid, kracht... De onderzoekster had deze interpretatie van de grondslag van het trainingswerk in termen van de zijnskwaliteiten-metafoor op de groepsbijeenkomst aan de trainers voorgelegd. In dat verband had zij betoogd dat er een samenhang lijkt te bestaan tussen het bevorderen van individuele auto-nomie en authenticiteit en een doelstelling op een 'hoger agregatieniveau', zoals 'organisatie-ontwikkeling'. Vanuit het kritischhumanistische perspectief kan dit verband worden verklaard. De verbindende schakel zou bestaan uit het stimuleren van 'menselijke' vormen van communicatie en samenwerking in organisationeel verband zodat mensen ook individueel tot hun recht komen in de organisatie en vice versa. Hoewel in zekere zin elk 'maatschappelijk patroon' dat op mensen inwerkt hen per definitie van een 'authentieke zijn' vervreemdt, lijken veel organisatiestructuren dusdanig vervreemdend te werken dat mensen aangeven het contact met deze 'kern' te verliezen. De 'creatieve trainingen' dragen bij aan persoonlijke èn organistieontwikkeling door deze opnieuw te herstellen. Wanneer creatieve trajecten op die wijze 'menselijkheid' in communicatie- en samenwerkingspatronen bekrachtigen, wordt dit aspect daardoor tegelijkertijd in 'organisationeel verband' èn in ieders persoonlijke authenticiteit en autonomie ten opzichte van de organisatie versterkt. In dit verband gaf de onderzoekster op basis van het interviewmateriaal een 
metaforische typering van twee extreme vormen van 'vervreemdende' en 'nietvervreemdende' ofwel 'humaniserende' organisationele verbanden: 'de zieke organisatie' versus 'de lerende organisatie'. Deze op de trainersbijeenkomst besproken typering was vervolgens op de hierna te beschrijven groepsbijeenkomst met beeldend therapeuten:

\section{Bij een zieke organisatie}

* is de lijm tussen mensen angst, verborgen verdriet en haat, jaloezie, schuld, ressentiment en wantrouwen

* is de verbinding met buiten en met de kern verbroken

* werken mensen samen op basis van concurrentie en ontkenning

* zijn er muren van rigide en hiërarchische structuren tussen mensen opgetrokken

* denken mensen in hokjes en kijken allen dezelfde kant op

\section{Bij een lerende organisatie}

* is de lijm tussen mensen: openheid, plezier, bezieling en humor

* is er genoeg ruimte voor pluriformiteit en voor het eigen verhaal van mensen

* is er een voedingsbodem voor vitaliserende energie, voor de natuurlijke creativiteit van mensen

* wordt moed gevraagd van mensen om vraagtekens te plaatsen en in de spiegel naar jezelf te kijken

* wordt een appèl gedaan op je verantwoordelijkheidsbesef

\subsection{2 de groep beeldend therapeuten}

De serie interviews met beeldend therapeuten had ten opzichte van de interviews met creatieve trainers een parallel verloop wat betreft de relatief grotere inbreng van respondenten in deze eerste fase van het project in vergelijking met de onderzoekster. Ook inhoudelijk bleek er een (vorm)overeenkomst ten aanzien van de pluriformiteit van 'de context' waarbinnen beide groepen professionals hun werk verrichten. Terwijl met betrekking tot het werkveld van creatieve trainingen de pluriformiteit wellicht verwijst naar verschillen in persoonlijke en professionele achtergrond van de organisatietrainers, lijkt er wat betreft creatieve therapie veeleer een verband te bestaan met haar (on-)duidelijke 'organisatorische inkadering'.

Uit de interviews kwam in de eerste plaats naar voren dat de naamgeving van creatieve therapie zeer verschillend kan zijn. Per instelling blijkt er (in-)formeel een andere naam te worden gegeven aan 'het therapeutisch werken met beeldende middelen': 
creatief of crea,

creatieve activering, activiteiten therapie, activiteiten begeleiding, creatieve therapie, beeldende therapie, creatieve therapie beeldend, speltherapie, nonverbale therapie, adjunctieve therapie, vaktherapie, creatieve vereniging, hobbyvorming, ...

Hetzelfde geldt voor het imago, dat wil zeggen het beeld van collega's, cliënten en 'de instelling' ten aanzien van het vak in de ogen van de geïnterviewde creatief therapeuten. Dit variëert van 'een zeer leuk maar vaag gebeuren' tot een 'uitgesproken duidelijk en effectief therapeutisch middel'. Ook de organisatorische positionering geeft een zeer uiteenlopend beeld te zien: soms bevindt creatieve therapie zich 'ergens zwevend' tussen de verschillende (para)therapeutische disciplines. Soms wordt ze 'geannexeerd' door of is ze 'gelieerd' met een andere discipline, zoals de activiteitenbegeleiding, de sociotherapie, de arbeidstherapie, de speltherapie of de verpleging. Een vaag imago en organisatorische plek gaat vaak samen met een onduidelijk pakket verantwoorde-lijkheden, bevoegdheden en taken. Bij gevolg beslist de creatief therapeut op overlegmomenten niet altijd mee als (mede-)behandelaar over de behandeling van cliënten. Soms heeft de creatief therapeut evenwel een duidelijke plaats in de organisatie en participeert $\mathrm{z}(\mathrm{h}) \mathrm{ij}$ in overleg- en beslissingsvormen.

Dit resultaat uit de eerste fase van het uitwisselingsproject hangt samen met een opmerkelijk verschil tussen beide groepen dat ook met betrekking tot andere thema's naar voren is gekomen en aan de basis staat van het uitgangspunt van gezamelijk gewin. Waar de groep creatieve trainers het 'retorisch-ideologische niveau' van managementconcepten van secundair belang achtten ten opzichte van fundamentele humanistische waarden in de creatieve werkvormen, daar gaven creatief therapeuten aan dat de organisatorische context van 'het medisch model', het dominante psychotherapeutische referentiekader en de beleidsplannen juist een cruciale invloed op hun functioneren binnen de instelling hebben. Terwijl de modieuze managementconcepten door de creatieve trainers op 'eigen' wijze in een existentieel annex creatief thema bij wijze van trainingsdoelstelling worden vertaald, vertegenwoordigt de organisatorische inkadering van creatieve therapie met betrekking tot functiewaardering, inschaling en naamgeving een noodzakelijke randvoorwaarde waarbinnen creatief therapeuten de oorspronkelijke humanistische oriëntatie 'hard' moeten maken.

\section{De groepsbijeenkomst met beeldend therapeuten}

Parallel aan de groepsbijeenkomst met creatieve organisatietrainers was tijdens de presentatie van de resultaten van de interviews aan de groep beeldend therapeuten de balans met betrekking tot de relatieve inbreng van respondenten en onderzoekster in de onderzoeksdialoog weer hersteld. Om meer zicht te verkrijgen op de pluriformiteit wat betreft het werk van creatief therapeuten, stond de volgende vraag voor deze tweede fase van het project centraal: Welke factoren 
spelen een rol bij de aangetroffen pluriformiteit binnen het werkveld? Om mogelijk relevante factoren 'in beeld' en 'tot begrip' te brengen had de onderzoekster voor deze groepsbijeenkomst een 'werkboek' samengesteld. Nadat zij een toelichting op het werkboek had gegeven, werkten de aanwezige therapeuten een aantal vragen en opdrachten uit en vond er een groepsgesprek hierover plaats. De resterende tijd van de bijeenkomst werd besteed aan een groepsdiscussie naar aanleiding van een radicale stellingname ten aanzien van deze problematiek door een uitgenodigde gastspreker. De doelstelling van het aangeboden programma was "het verkrijgen van inzicht in het organisatorische krachtenveld' in de eigen instelling, teneinde bewuster te worden van de mogelijkheid van een 'op instellingsmaat te ontwerpen strategie' voor de profilering van creatieve therapie. Deze doelstelling werd door de gastspreker geplaatst in het lange termijn perspectief om 'de crisis in de geestelijke gezondheidszorg tot een kans voor de professionalisering van creatieve therapie' te keren. Er vond een gedachtenuitwisseling plaats over de aangekaarte thema's, waarbij er geen consensus werd nagestreefd noch bereikt. Wel zijn een aantal belangrijke aandachtspunten voor de profilering en profesionalisering van creatieve therapie in het verslag van deze bijeenkomst geformuleerd, die hieronder worden aangegeven.

De teksten, vragen en opdrachten in het werkboek waren zodanig bijeengebracht dat van 'de kracht van het beeldende medium' zelf gebruik is gemaakt om een 'diagnose' van de organisatorische positionering van creatieve therapie te kunnen stellen. Voorbeelden hiervan zijn: 'teken van je werksituatie de energiebalans tussen zorg (voor anderen) en zelf(ontplooiing)', 'verbeeld je rol in het team', 'typeer de organisatiecultuur van je instelling', 'ontwerp een persoonlijk gekleurd professioneel motto en logo'. De teksten waren bedoeld als achtergrondinformatie bij deze opdrachten en hadden betrekking op 'zelf-management', 'leidinggevende kwaliteiten' en 'organisatiecultuur'. Deze opdrachten waren zodanig samengesteld dat hiermee het relatieve belang van drie clusters van factoren in kaart kon worden gebracht, waarvan de onderzoekster veronderstelde dat ze een rol spelen bij de organisatorische positionering van creatieve therapie:

* de organisatie(cultuur) en de ontstaansgeschiedenis van creatieve therapie

${ }^{*}$ de specifieke cliëntenpopulatie met haar psychische problematiek

${ }^{*}$ persoonlijke en professionele capaciteiten van de creatief therapeut

Uit de groepsdiscussie bleek dat er verschillend wordt gedacht over welke factor in dit cluster van overwegend belang is voor de organisatorische plaats die creatieve therapie in een instelling inneemt. De meeste reacties kwamen neer op een relatieve waardetoekenning in het samenspel van deze factoren. Ter illustratie volgt hieronder een uitgesproken mening van een beeldend therapeute, werkzaam is in een psychiatrisch dagcentrum, over het samenspel van de eerste en de derde factor. 
Uiteindelijk hangt het af van de persoon die aan de top staat of de setting daadwerkelijk wordt veranderd. Je kunt je dan ook afuragen wat de organisatie dan werkelijk is? Maar de creatief therapeut zelf zal deze 'persoon aan de top' moeten informeren en enthousiasmeren. Je moet een 'nieuw persoon' dan ook zorgvuldig bewerken en kennis laten maken met de gehele organisatie.

Hier tegenover staat een ander type reactie van therapeuten om een van de drie factoren als de belangrijkste naar voren te schuiven:

Het is niet de verantwoordelijkheid van de therapeut maar van de instelling. De instelling moet non-verbale therapie belangrijk vinden en de faciliteiten bieden. Het moet dus ook door de gehele organisatie gedragen worden. De organisatie staat overal boven, dus de enige manier waarop het kan is op instellingsniveau.

Aldus een beeldend therapeut in een TBS-kliniek. Een andere therapeut die op een centrum voor (oorlogs- en vluchtelingen-)getraumatiseerden werkt stelt hier tegenover:

Het zwaartepunt moet bij jezelf liggen. Een setting verandert, dus daar moet niet alle energie naar toe gaan omdat er kans op vervreemding aanwezig is. Je moet vanuit je vak de instelling beinvloeden.

Nog twee andere beeldend therapeuten spraken zich voor het overwegende belang van 'de persoonlijke factor' uit, waarbij een therapeute die werkzaam is op een medisch centrum wel in het belang en de mogelijkheid zei te geloven om met het multidiscipliaire team gezamelijk één vuist te maken tegenover de (organisatorische) buitenwereld, terwijl de hierboven geciteerde therapeute van het psychiatrisch dagcentrum deze mogelijkheid juist relativeerde.

Hoewel er in de groepsdiscussie onduidelijkheid bleef bestaan over (de zinvolheid van) de scheidslijn tussen 'zorg' en 'therapie' werd wel algemeen onderschreven dat de verwatering van de grens tussen 'creatieve activiteiten' als 'dagbesteding' en als 'therapie' of 'behandeling' onwenselijk is. In dit verband refereerde de onderzoekster naar een mogelijk gaande zijnde ontwikkeling binnen het werkveld van creatieve therapie, die met de verzakelijking en reorganisatie van de zorg parallel loopt. Hangt de (on-)duidelijke organisatorische positionering van creatieve therapie in een instelling samen met de (on-)mondigheid van de betreffende cliënten-populatie? Is er er een trend gaande dat creatieve therapie voor onmondige patiënten, zoals 'verstandelijk gehandicapten', 'kinderen' en 'dementerende ouderen' van 'therapie' naar 'begeleiding' tot 'zorg' degradeert, terwijl voor mondige cliënten in de psychiatrie er een duidelijke therapeutische settting blijft bestaan? Achter de 'organisatorische innovatie' waardoor de patiënt een klant van gezondheids-'producten' wordt, kan een minder fraaie werkelijkheid schuilgaan. Pakt de opwaardering van de lijdzame 'patiënt' tot een consumerende 'klant' ook 
inderdaad voor alle partijen gunstig uit? Wat betekent de machtige en strategische positie van de nieuwe 'zorgmanager' als spil in deze reorganisatie van de zorg voor de andere disciplines? Voor creatief therapeuten lijkt een 'ondersteunende rol' in de zorg voor (onmondige) patiënten samen te gaan met een onduidelijke plaats in de organisatie en het niet structureel aanwezig (mogen) zijn op overlegmomenten. Bijvoorbeeld volgde uit de opdracht over 'de energie-balans' dat de meeste therapeuten last hebben van 'een organisatorisch overgewicht' wat dit betreft door 'extra' of 'onduidelijke' nevenactiviteiten die de organisatie verlangt maar niet (genoeg) honoreert. Volgens de eerder geciteerde beeldend therapeut van de TBSkliniek:

Heel veel organisatorische taken komen bij mij terecht. Daarin zou ik graag een andere balans willen vinden ten opzichte van mijn andere werk.

Hier tegenover stelt een beeldend therapeute met leidinggevende taken binnen een verpleeghuis:

Door je bezig te houden met nevenactiviteiten kun je nieuwe contacten leggen en kan ik tevens reclame maken voor mijn dienst. Daardoor levert het mij in verhouding genoeg op.

Een beeldend therapeut in de gehandicaptenzorg omschrijft het dilemma dat deze problematiek voor een creatief therapeut met zich mee kan brengen, als volgt:

Het maken van de keuze, wat wel en wat niet te doen is heel moeilijk. Ik zie mij keer op keer genoodzaakt om veel dingen buiten werktijd te doen. Alles wordt door elkaar heen gepland. Overleg is er wel maar komt slechts sporadisch voor. Als ik serieuzer zou worden genomen, dan zouden mijn werkuren ook toenemen.

Ook het 'vage' imago door de naamgeving 'creatief' werd in de groepsdiscussie algemeen als 'negatief' bestempeld en in relatie gebracht met de onduidelijke organisatorische positionering. Velen gaven de voorkeur aan een naam welke aan het specifieke medium gerelateerd is, zoals 'beeldende therapie', analoog aan de term 'muziektherapie' die inmiddels is ingeburgerd.

De volgende algemene aandachtspunten, die op instellingsmaat toegesneden moeten worden, werden door de aanwezige therapeuten in de groepsdiscussie naar voren gebracht en onderschreven:

- Het belang van een sterke lobby

- Geen gaten laten vallen in de (ontstaans)geschiedenis van creatieve therapie in een instelling

- Een door de instelling gedragen 'zorgvisie' die de negatieve kanten van de verzakelijking van de zorg kan voorkomen of tegengaan 
In het werkboek was de werkbeleving van creatief therapeuten in verband gebracht met een 'organisatie-thema' uit de interviews met trainers in de vorm van de vraag: Hoe ziek is de geestelijke gezondheidszorg? De op de trainersbijeenkomst besproken metaforische typering van 'de zieke' versus 'de lerende organisatie' werd in dit verband aan de aanwezige beeldend therapeuten voorgelegd. Uit het groepsgesprek hierover bleek dat het beeld van 'de zieke organisatie' algemeen herkenbaar was. Het stemde overeen met de ervaring van veel therapeuten in de vorm van 'verziekte arbeidsomstandigheden', vooral wat betreft organisatorische aspecten van het werk. Kennelijk doen dienstverlenende organisaties met disciplines die gespecialiseerd zijn in psycho-sociale problematiek om 'pathogene communicatieen interactiepatronen' van klanten weer gezonder te maken, zelf niet onder wat betreft ziekmakende factoren in samenwerkingsverbanden, communicatie en werkdruk, - leidend tot stress, ziekteverzuim en overspannenheid. Dit opmerkelijk resultaat onderstreept het belang van een door de instelling uitgedragen zorgvisie, die tegenwicht kan bieden aan de verzakelijking van de zorg, welke gepaard gaat met toenemende strijd en concurrentie tussen de verschillende disciplines. De gepropageerde heilzame ingrediënten van 'concurrentie' en 'marktdenken' doen steeds sterker hun intrede binnen instellingen, terwijl ze tegelijkertijd nagenoeg niet meer als een 'kapitalistische' ideologie worden onderkend, maar zich als de 'onbetwistbare status quo' laten gelden.

In het werkboek was een opdracht opgenomen met betrekking tot een veel voorkomend probleem dat hiermee verband houdt, namelijk de 'communicatiekloof' tussen management en werkvloer. Dit leidde tot een uitwisseling van algemeen herkenbare werksituaties en ervaringen in verband met dit probleem. Creatief therapeuten hadden hun ervaring op dit punt in de interviews veelal in termen van politieke en antropologische metaforen verwoord:

\section{Er heerst hier een soort strafcultuur.}

We werken hier in een heel gesloten systeem met taboe's.

Er wordt veel op de persoon gespeeld.

Met het management is er gebrekkige communicatie.

Er worden verborgen agenda's gehanteerd.

Er lijkt een soort koude oorlog gaande.

De 'metaforische' beelden over deze 'communicatiekloof' die in het werkboek waren ontworpen, werden na de groepsbijeenkomst aan de onderzoekster gegeven of later opgestuurd. Op grond van een evaluatie van de groepsdiscussie en de toegestuurde beelden was de keuze gemaakt om een veranderingsmetafoor met 
betrekking tot de 'communicatiekloof' als gemeenschappelijk onderwerp voor de interdisicplinaire uitwisselingsbijeenkomst uit te werken.

Na deze groespdiscussie over onderwerpen uit 'het werkboek' was het thema 'de toekomst van creatieve therapie' aan de orde gesteld met het oog op de alom gaande zijnde bezuinigingen, reorganisaties en fusies en de beleidsverandering naar protocollair werken. Aan de hand van een provocerende stellingname door een gastspreker, een muziektherapeut met een leidinggevende functie, werd het algemeen heersende 'doemdenken' onder creatief therapeuten aan de kaak gesteld. In zijn verhaal relativeerde deze therapeuten coördinator de betekenis van het 'negatieve rapport' van de visitatiecommissie over de HBO-opleidingen door te benadrukken dat het door mensen is opgesteld die niet ter zake kundig zijn wat creatieve therapie betreft. Aan de andere kant wees hij op een zwakke kant van creatief therapeuten, namelijk de 'angstige houding' met betrekking tot organisatieaspecten zoals macht en hiërarchie. Hier tegenover stelde hij 'de feitelijke successen' die creatieve therapie in haar relatief jonge geschiedenis toch reeds heeft geboekt, wereldwijd en binnen Nederland. Gezien deze potentieel gunstige constellatie pleitte hij voor een 'cultuur-verandering' wat betreft de (ver)houding van creatief therapeuten tot de instelling en een 'mentaliteitsswitch' van een 'doemscenario' naar een 'successcenario' voor de toekomst van creatieve therapie. Dit werd in de groep algemeen herkend en de 'gewenste verandering naar het succesdenken' werd concreet vertaald als

- Het investeren in dwarsverbanden

- Het profileren van creatieve therapie door middel van workshops

- Een gewenste en noodzakelijke verandering van de organisatiecultuur van 'solist' naar 'orkestlid' leidend tot 'overleg' en 'samenwerking' met collega's èn andere disciplines

- Werken aan meer beslissingsbevoegdheid en gelijkwaardigheid met andere disciplines

- een goede timing van te zetten stappen

Het door de gastspreker gelanceerde thema duidt op de correspondentie en interdependentie van 'individuele professionele ontwikkeling' en 'organisatieontwikkeling'. Dit heeft de onderzoekster in haar verslag van de bijeenkomst geformuleerd als een gewenste verandering in de professionele attitude van 'Wat betekent de(reorganisatie voor mijn plaats als creatief therapeut?' tot 'Wat kan ik als creatief therapeut voor de (re)organisatie betekenen?' Met betrekking tot de generatie van ideeën voor deze 'attitudeverandering' zou de uitwisselingsbijeenkomst een kader bieden. 


\subsubsection{De interdisicplinaire uitwisselingsbijeenkomst}

Bij de opzet van de laatste, interdisciplinaire groepsbijeenkomst is een integratie nagestreefd van beide voorgaande bijeenkomsten, zowel wat betreft de inhoudelijke thema's als de groepsverschillen die in de onderzoeksdialoog naar voren zijn gekomen. De zijnskwaliteiten-metafoor, veranderingsmetaforen en het model van metaforische communicatie en interactie waren de drie thema's welke de onderzoekster op basis van de twee voorgaande fasen van het project had uitgekozen en geoperationaliseerd met het oog op de doelstelling van gezamelijk gewin. In deze paragraaf wordt de respons van de aanwezige respondenten op deze onderzoeksthema's beschreven.

Het eerste thema, de zijnskwaliteiten-metafoor, geeft een concretisering van het kritisch humanisme in de creatieve trajecten in therapie en organisatie-trainingen. Deze metafoor werd door de aanwezige respondenten door middel van een verbeeldingsopdracht uitgewerkt. De onderzoekster introduceerde het themazijnskwaliteiten als een metafoor voor de professionele en persoonlijke kwaliteiten van een therapeut of trainer die $\mathrm{z}(\mathrm{h}) \mathrm{ij}$ door middel van een creatieve werkvorm uitdraagt. De 'creatieve leertrajecten' zijn op zodange wijze georganiseerd dat persoonlijke èn professionele aspecten van het handelen integraal worden aangesproken en in hun samenhang in de (creatieve) dialoog aan bod komen. Dit aspect was door trainers en therapeuten in de interviews veelal aan de hand van de spelmetafoor verwoord. De 'als-of'-situatie van het spel biedt een kader om op een 'verdekte'en veilige manier te experimenteren met de professionele of sociale identiteit van deelnemers. Tegelijkertijd laat de spel-situatie ruimte voor expressie van andere aspecten van de persoon dan alleen de professionele of de sociale rol. Door een muziektrainer was dit als volgt verwoord:

In de training speel je wie je bent.

De spelmetafoor verwijst naar het fundamentele gegeven dat de creatieve werkvorm behalve 'entertainment' en plezier een ludieke leervorm vertegenwoordigt, resp. een vorm van creatief 'ervaringsgestuurd leren' bewerkstelligt. Uit het interviewmateriaal bleek dat de integratie van het spelplezier van de 'homo ludens' met de ernst van een leerdoelstelling wordt gedragen door de persoonlijke betrokkenheid en integriteit van therapeut of trainer. De volgende uitspraken van twee met imaginatiemethoden resp. dramamiddelen werkende trainers, verwijzen hiernaar:

Als consulent moet je zijn wat je zegt.

Ik zet een ander nooit voor wat ik zelf niet zou willen eten.

Wanneer een organisatietraining vanuit dit fundament van persoonlijke betrokkenheid en integriteit is opgezet, zou dit de toon zetten voor een overeenkomstige 
groepsdynamiek, die vervolgens weer een appèl doen op ieders persoonlijke betrokkenheid en integriteit, wat leidt tot 'authentieke communicatie'. In de volgende citaten van twee, met beeldende middelen werkende, organisatietrainers is deze 'grondtoon van authenticiteit' en de navenant bewerkstelligde groepsdynamiek als volgt verwoord:

Bij ons hoeft niemand precies met de anderen in de maat te slaan. Nee... wat je ook maar voor geks/ eigens/ authentieks verzint, wij gaan ervan uit dat je serieus bezig bent en ieders bijdrage is gelijkwaardig aan die van anderen.

Heerlijk als mensen vooroordelen hebben, hoe meer hoe beterl Het roddelcircuit is vaak nog het enige plezier dat mensen uit hun werksituatie halen. ${ }^{29}$

\section{Samen kunst maken werkt ontdooiend en verbroedert.}

De trainer uit het eerste citaat gebruikt de 'negatieve' inbreng van cliënten, zoals roddels op het werk, als werkmateriaal voor haar beeldende trainingen. Deze in de training geuite 'negativiteit' en 'weerstand' vormt zij door middel van de retorische 'kunst van het omdraaien en provoceren' om tot een 'positieve' ervaringsbasis. Een trainer dient hiervoor echter eerst een vertrouwensrelatie met de cliënten aan te gaan door middel van persoonlijke betrokkenheid en integriteit. Pas dan zullen deelnemers 'de luikjes' naar verborgen kamers van taboe's en geheimen op de werkvloer openen. Het emotionele trainingsmateriaal kan, zonder deze vertrouwensbasis, gemakkelijk een afbrekende lading van cynisme en 'acting out' verkrijgen, in plaats van de constructieve geladenheid van ironie en paradoxen die in 'rituele vormen van enactment' tot uitdrukking komt. De 'zijnskwaliteitenmetafoor' verwijst naar deze kritische maar constructieve omgang met de humanistische waarden die in de creatieve dialoog gestalte krijgen. Namelijk op grond van de fundamentele samenhang tussen de persoonlijke zijnswijze van trainer of therapeut en de professionele vormgeving van de creatieve training, wat resulteert in een ludieke vorm van 'authentieke communicatie' met de deelnemers.

$\mathrm{Na}$ een gecomprimeerde ${ }^{30}$ introductie van dit thema stelde de onderzoekster dat uit het interviewmateriaal naar voren kwam dat organisatietrainers deze 'kracht' van het creatieve trainingswerk in de vorm van een 'professioneel motto' resp. een 'handelsmerk' in vergelijking met creatief therapeuten beter weten uit te baten. Dit zou ook kunnen samenhangen met de 'autonome positie' die zij innemen ten opzichte van de organisatie die hen inhuurt. Hier tegenover reageren therapeuten als het ware 'defensief' op de bedreigende bezuinigingen en reorganisaties binnen hun instelling. Zij moeten de oorspronkelijke humanistische oriëntatie van crea-

29. Informatiemateriaal van 'Art catering'.

30. Op de bijeenkomst zelf heeft de onderzoekster een verkorte versie van deze toelichting gegeven, op grond van haar inschatting dat dit thema bij de deelnemers op basis van de interviews en de voorgaande bijeenkomsten reeds voldoende in beeld zou zijn. Zoals aangegeven in paragraaf 5.1 bleek uit de evaluatie van deze bijeenkomst echter dat dit (ten dele) een inschattingsfout is geweest en zouden sommige deelnemers aan deze uitgebreidere versie behoefte hebben gehad. 
tieve therapie vertalen in harde 'stappenplannen', 'meetbaar effect' en behaalde 'patiëntenload'. De kritisch-humanistische grond van betrokkenheid, authenticiteit en integriteit zei de onderzoekster evenwel cruciaal te achten voor beide beroepsgroepen. Deze 'grond' krijgt een verschillende kleur door de individuele 'zijnskwaliteit' van therapeut of trainer, zoals: humor, bezieling, openheid, liefde, speelsheid, kracht, mildheid. Na deze toelichting gaf de onderzoekster aan hoe zijnskwaliteiten in beeld gebracht kunnen worden door middel van kleursymboliek, meegebrachte objecten die de vier natuurelementen representeren en zelf te tekenen symbolen met wascokleuren op papier. De aanwezige respondenten werden vervolgens uitgenodigd om met behulp van deze middelen de eigen 'zijnskwaliteit' metaforisch in beeld te brengen. Veel respondenten verkozen 'de steen' als symbolisch object voor het natuurelement aarde, soms ook 'vuur', waaraan zij als 'zijnskwaliteit' een persoonlijke invulling gaven. Deze opdracht leidde onder andere tot de volgende metaforen:

Een met beeldende middelen werkende trainer had het kaarsje als symbolisch object voor het element 'vuur' gekozen en tekende het symbool van een vuurbal: dat staat voor "Rood, kracht, vuur, energie, licht, vonken".

Keuze voor de elementen 'aarde' en 'vuur': Het getekende symbool van de verworteling in de aarde met een stralend vuur daarboven was afkomstig van een muziektrainer met de betekenis: "Vanuit kern - confrontatie: veiligheid naar binnen en weer uitstralen naar buiten. Vanuit je wortels, nieuwe paden bewandelen, oude paden onderhouden".

Het getekende symbool van 'de boom die uit een laars groeit' door een beeldend therapeute, werkzaam in een 'multi functionele eenheid' binnen de volwassenenpsychiatrie, zou staan voor "Stevige stappers, grond onder m'n voeten, basaal, duidelijkheid. Daarin groeit een boom, krijgt een boom de kans te groeien."

Een beeldend therapeute van een psychiatrisch centrum tekende het symbool van zonovergoten aarde met een stralende zon erboven, en gaf hieraan de betekenis: Degelijk, betrouwbaar praktisch, houdt zich aan afspraken, concreet, zorgend, invoelend, voorwaardescheppend (aarde-element) groepsmens, humor, gezelligheid en warmte (vuur-element).

Als opstap voor de groepsdiscussie gaf de onderzoekster aan dat de 'zijnskwaliteitenmetafoor' een waarde vertegenwoordigt voor de professionalisering van creatieve trajecten in therapie en organisatietrainingen. Deze metafoor benadrukt dat de creatieve werkvorm een kader genereert voor 'ervaringsgestuurd leren' dat op fundamentelere wijze in de 'belevingsorganisatie' van de mens ingrijpt in vergelijking met cognitief gerichte leertrajecten. Door de creatieve werkvorm wordt immers niet alleen het hoofd maar vooral het identiteitsniveau van deelnemers aangesproken. Het leereffect berust derhalve niet zozeer op verbale 
informatie-overdracht als wel op emotioneel-interactieve overdracht van betekeniselementen met betrekking tot (de ontwikkeling van) professionele en persoonlijke vaardigheden. Wat dit'fundamentele' niveau betreft zou de vraag gesteld kunnen worden of er een wezenlijk verschil bestaat tussen 'creatieve therapie' en 'creatief trainingswerk'. Op dit punt nam de onderzoekster een radicale stelling in, namelijk dat de therapeutische en de trainings-trajecten eigenlijk twee varianten vertegenwoordigen van 'eenzelfde' creatief ervaringsgestuurd leerproces. Verschillen tussen beide professies hebben als zodanig meer te maken met pluriformiteit wat betreft de maatschappelijke, ideologische en organisationele context en met methodiekverschillen ten aanzien van de (specifieke psychische problematiek van de) betreffende doelgroep. Tegenover deze 'vormgevings-" of 'contextuele' verschillen verwijst de humaniserende dialoog in creatieve trajecten naar het gemeeschappelijke fundament van 'persoonlijke betrokkenheid en integriteit' van trainer of therapeut welke als 'zijnswijze' doorstraalt in de retorisch-methodische vormgeving van het creatieve medium en als 'authentieke communicatie' met de deelnemers. De 'zijnskwaliteiten-metafoor' vertegenwoordigt aldus de onderliggende fundamentele kritisch-humanistische 'eenheid' tegenover de contextuele verscheidenheid.

In de hierop volgende groepsdiscussie onderstreepten de aanwezige respondenten weliswaar het belang van dit fundamentele 'existentiële' niveau van communicatie, maar overwegend hielden zij toch vast aan een 'absolute' grens tussen beide professies. Deze zou samenhangen met een fundamenteel verschil in autonoom tegenover afhankelijk 'zijn' van deelnemers aan een training versus psychiatrische patiënten, resp. met een verschil wat betreft de geïntegreerde tegenover gebroken 'identiteit' van 'patiënten' tegenover 'cliënten'. De zijnskwaliteiten-metafoor heeft ten opzichte van deze 'conventionele' opvattingmet betrekking tot(professionele) identiteiten een 'grensoverschrijdende' betekenis. De metafoor verwijst naar het trainings- en therapeutische werk als een vorm van creatief 'ervaringsgestuurd leren' dat inhaakt op algemeen menselijke aspecten van communicatie en interactie, waarmee er een radicale betekenisverschuiving in de conventionele professionele scheidslijnen teweeg wordt gebracht. De onderzoekster gaf aan dat creatief therapeuten mogelijk hiermee hun voordeel kunnen doen. Op basis van deze humanistische samenhang zouden zij hun 'zijnskwaliteiten-metafoor' tot een persoonlijk gekleurd 'motto' of 'handelsmerk' kunnen ontwikkelen, naar het voorbeeld van de markt voor creatieve trainingen, inspelend op èn als tegenwicht tegen de verzakelijking van de zorg.

Het tweede thema, de communicatiekloof tussen management en werkvloer. is vormgegeven aan de hand van vier door therapeuten ingebrachte casussen. Deze werden in kleinere groepen besproken, leidend tot een 'metaforische oplossing' voor het betreffende communicatieprobleem. In iedere subgroep was één trainer aanwezig die het probleem vanuit 'management-perspectief' belichtte. De aldus gezamelijk geconstrueerde veranderingsmetafoor werd door iemand uit de subgroep weer teruggerapporteerd in een afsluitende plenaire bespreking. Deze opzet 
had de onderzoekster vooraf aangegeven om een uitwisseling van ervaring en ideeên over deze problematiek tussen beide groepen te laten ontstaan. De volgende vier veranderingsmetaforen waren het resultaat en werden als volgt omschreven:

De Havenmeester (leidinggevende van creatieve therapie in een TBS-kliniek) die het bootje (creatieve therapie) dat een haven zoekt (de nieuwe positie na de reorganisatie) maar laat ronddobberen.

In het beeld van 'de bergen en de dalen' werden mogelijkheden geschetst over hoe de 'bergmensen' (management van een psychiatrisch centrum) met de 'dalmensen' (creatief therapeuten en andere disicplines op de werkvloer) in contact gebracht kunnen worden: bijvoorbeeld door middel van helicopters of door bergwandelingen.

Het beeld van een 'forens' was uitgewerkt om aan te geven hoe een creatief therapeut (werkzaam, in een TBS-kliniek voor zedendelinquenten) met de attitude van een forens gezond kan blijven door een 'gezonde' (reis)afstand en autonomie ten opzichte van een 'zieke organisatie' te bewaren.

De beelden van 'kunstmest', 'vraagzaad' en 'communicerende vaten' duiden in beeldtaal een oplossing aan voor het communicatieprobleem in een instituut voor verstandelijk gehandicapten: door de 'communicatieve kracht' van 'kunst' als 'mest' te gebruiken om de communicatie met het management weer te herstellen en te versterken. 'Vraagzaad' zou de geblokkeerde communicatiekanalen kunnen openen. Door het instellen van 'communicerende vaten' kunnen ze ook open blijven.

Deze in kleine heterogene groepen ontworpen veranderingsmetaforen hebben als een kapstok gewerkt om het ervaren probleem te verwoorden en erover met collega's uit te wisselen. In geval van de 'havenmetafoor' heeft ze bovendien als ijsbreker gefungeerd - zo bleek uit de telefonische evaluatie - om het probleem met de leidinggevende daadwerkelijk aan te kaarten. Het beeld van de dal- en bergmensen was (nog) te weinig uitgewerkt om deze meerwaarde te verkrijgen (bijvoorbeeld wat betekenen 'de helicoptervluchten' en 'de bergwandelingen' vertaald naar de praktijksituatie van de betreffende instelling?). Ook de andere beelden waren nog onvoldoende geconcretiseerd tot waar zij in de praktijk voor kunnen staan. Niettemin duiden ze in de taal van het medium op een overbrugging van de communicatiekloof door de 'metaforisch verpakte' mogelijkheid om het directe persoonlijke contact met leidinggevenden te herstellen en open te houden.

Het derde thema, het 'model van de metafoor', had tot doel om aan te geven hoe de feedback van respondenten in het model is verwerkt door de dynamiek van veranderingsprocessen meer op de voorgrond te stellen en in concretere termen te benadrukken. Hiervoor bleek op de uitwisselingsbijeenkomst te weinig tijd te zijn. Derhalve is er een extra telefonische interviewronde aan de vierde evaluatiefase 
van het project toegevoegd. Deze 'evaluatieve fase' van het uitwisselingsproject leverde verschillende reacties op. Globaal kwam naar voren dat het concept van de metafoor als invalshoek om creatieve trajecten 'methodisch' en 'ideologisch' te interpreteren voor de respondenten in het algemeen en voor creatief therapeuten in het bijzonder een te hoog abstractieniveau heeft om direct op de praktische werksituatie en de eigen deskundigheid toepasbaar te zijn.

Een reactie van een 'creativiteitstrainer' verwoordt in dit verband de inherente ambivalentie van de metafoor:

De metafoor schept vrijheid maar ook vrijblijvendheid. Metaforen kunnen als een vrijbrief voor opportunisme werken: we plukken uit de metafoor wat ons goed uitkomt.

In andere reacties werd het contrast benadrukt tussen het abstracte en statische karakter van het metafoor-model en de concrete en dynamische wijze waarop trainers en therapeuten over ontwikkelings- en veranderingsprocessen spreken. De volgende negatieve reacties van creatief therapeuten op het voorgestelde 'model van de metafoor' zijn vanuit de ervaring van dit contrast te begrijpen:

Ik denk niet zo in beelden en metaforen.

Metaforen duiden een 'alsof-situatie' aan en kunnen daarom te weinig doelgericht de zaak waar het om gaat omschrijven.

Metaforen zijn te a-specifiek om de essentie te raken.

Een filosofische verwoording versterkt eerder het vage imago van creatieve therapie dan dat het verduidelijkt wat creatieve therapie eigenlijk is.

Een positievere reactie gaven respondenten wanneer zij werden uitgenodigd het concept concreet te maken aan de hand van een aan de praktijk ontleend beeld, dat het dynamische karakter van communicatie- en veranderingsprocessen in therapie en training vermag aan te duiden. Een met beeldende middelen werkendetherapeute annex trainer gaf de volgende twee concrete metaforen over 'de meerwaarde' van het creatieve medium, 'de zicht na het optrekken van de mist' en 'het zien van de eigen bouwconstructies':

Creatieve werkvormen kunnen de mistige situatie laten zien waarin iemand zich bevindt, en leren zien hoe de mist kan optrekken.

Het biedt een werkvorm om het bouwwerk van iemands leven te bekijken en de verschillende bouwconstructies na te gaan waarmee iemand zijn leven vormgeeft. 
Een muziektrainer zei in zijn trainingen met de metafoor van 'de onbewaakte spoorwegovergang' te werken:

De muziekworkshop creëert een onbewaakte spoorwegovergang naar lagen in de persoon 'voorbij' de censuur van het denken.

Een creatief therapeute die een bureau voor loopbaanbegeleiding met beeldende middelen is begonnen omschrijft 'de kracht' van haar werk met de 'trechtermetafoor':

Ik ben een trechter en leer mijn cliënten trechteren, zodat zij zelf het essentiële kunnen halen uit wat er boven komt in de beeldende sessies.

Deze 'evaluatieve fase' van het uitwisselingsproject onderstreept de in de vijfde paragraaf beschreven uitkomst uit de onderzoeksdialoog dat het 'model van de metafoor' in haar gepresenteerde abstracte en statische vorm niet in overeenstemming is met de taal van creatief therapeuten en creatieve trainers. Een dynamische uitwerking op basis van concrete metaforen uit de praktijk, zoals hierboven aangegeven, kan aan deze kritiek tegemoet komen.

Een hiermee samenhangende conclusie uit het voorgaande sluit aan op wat in het derde hoofdstuk is benoemd als het verschil tussen het 'wetenschappelijke discours van de organisatiekunde' en de 'praktische managementtaal' ${ }^{31}$ Er blijkt een niet te negeren onderscheid in soorten kennis en discoursen te bestaan. Tegenover de concrete metaforen, ontleend aan de taal van het creatieve medium, waarmee professionals communicatie- en veranderingsprocessen verwoorden, staan de filosofische metaforen die 'spelen' met het medium van de taal. Er blijven onophefbare verschillen opspelen tussen het praktische discours van de kunde, de abstracte wetenschappelijke taal en de filosofische stijl van dit onderzoek. Vanuit een bemiddelaarspositie, van waaruit de interviews en de groepsbijeenkomsten zijn opgezet, waren de verschillen te overbruggen. Echter wanneer de uitkomsten van de onderzoeksdialoog in één van beide discoursen verwoord worden, treden de verschillen weer aan het daglicht. Deze conclusie wordt onderstreept door een andere bevinding uit het uitwisselingsproject, namelijk het groepsverschil tussen beide groepen professionals, waarnaar hiervoor reeds is gerefereerd. De 'taal' van creatief therapeuten is minder reflectief en verbaal, meer praktisch van aard, op het doen en de verbeelding gericht in vergelijking met die van de organisatietrainers. Dit verschil bleek op de interdisciplinaire bijeenkomst zowel een hindernis in de groepsdiscussie over de betekenis van de zijnskwaliteiten-metafoor, als een hulp voor de uitwisseling in vier subgroepjes door middel van de verschillende perspectieven van betrokkenen op de ingebrachte casus over een communicatieprobleem, hetgeen in de constructie van veranderingsmetaforen resulteerde.

31. Hoofdstuk 3, paragraaf 2.1, p. 106 e.v. 
Vooral in het kader van dit laatste thema over de herkenbare 'communicatiekloof tussen management en werkvloer' was, op grond van de verbinding van het therapeuten- en het trainers-perspectief, de beoogde 'win-win-doelstelling' van het uitwisselingsproject verzilverd. De hierdoor gegenereerde uitwisseling van ervaring en kennis is in het algemeen als zinvol beoordeeld. Het project bleek voor beide beroepsgroepen waardevol met het oog op inzicht in de professionele identiteit en in de organisatonele en maatschappelijke positionering. Een kritische kanttekening wat dit betreft heeft betrekking op de (on-)gelijkwaardigheid tussen beide groepen respondenten. Hoewel de 'win-win-doelstelling' in theorie een balans tussen creatief therapeuten en creatieve trainers zou creëren is dit mogelijk in de praktijk niet helemaal het geval geweest. De 'winst' voor de creatieve trainers, werkzaam in de instrumenteel gerichte, opportunistische context van management en organisaties, in de vorm van 'transfer' van analoge praktijkkennis en een dialogische invalshoek bleek door de uitgekozen groep respondenten overwegend reeds zelf te zijn behaald. Een 'winst' door netwerken en uitwisseling van praktijkervaring dat tot een plan tot samenwerking heeft geleid, komt wel als 'spin off' op rekening van het uitwisselingsproject. Het betreft een samenwerkingsproject van twee respondenten om hun trainers- resp. creatief therapeutische kennis en ervaring te bundelen voor het nieuwe werkveld van creatieve organisatietrainingen. Het volgende commentaar van een van beide respondenten geeft een belangrijk aandachtspunt aan voor het laten slagen van dit project:

Het is belangrijk om je eerst oriënterend in het nieuwe werkveld te begeven en je 'low profile' op te stellen om niet in dezelfde strijd terecht te komen als met de professionalisering van creatieve therapie is gebeurd. Om hier iets te kunnen betekenen moet je niet in de eerste plaats je 'artistieke' $k$ waliteiten als trainer benadrukken, maar eerst met resultaat 'effectief' laten zien wat je te bieden hebt. Daarna kun je aangeven dat 'het creatieve' je methode is. Anders manoeuvreer je je al gauw in een verdedigende positie of kom je terecht in de hoek van 'entertainer'.

De doelstelling van gezamelijk gewin vooronderstelt en bouwt voort op de dialogische middenpositie met de open gesprekshouding, die op hermeneutische wijze in het vierde hoofdstuk is uitgewerkt. De 'winst' uit dit filosofische perspectief voor de praktijk is door de onderzoekster geconcretiseerd met de formulering van een ander gezichtspunt op het professionaliseringsthema dan algemeen gebruikelijk is onder creatief therapeuten. De professionalisering van creatieve therapie is gebaat bij de ontwikkeling van een professionele attitude, die vanuit de 'middenpositie' een romantische benadering van praktijkkennis aanvult met een moment van verantwoording, zonder in het rationalistische extreem te vervallen van een eenzijdig instrumentele optiek. Het 'model van de metafoor' was in de onderzoeksdialoog voorgesteld als hulpmiddel om een op de intuïtieve praktijk (-kennis) toegesneden vorm van verantwoording te ontwerpen. Hiermee kan de naïefromantische opvatting van de humanistische basis van het creatieve 'ervaringsgestuurde leren' met een kritisch-communicatief moment worden verrijkt ten 
behoeve van de professionalisering van het vak. ${ }^{32}$ In de volgende paragraaf wordt de richting aangegeven, waarin de (te) abstract geformuleerde 'grondslag' een aanvulling krijgt met behulp van empirisch materiaal uit dit project.

\section{7 De empirische winst uit het veldonderzoek}

Deze paragraaf is gecentreerd rond de volgende vragen: Wat heeft de dialoog met de praktijk opgeleverd? Is de 'metafoor' als grondconcept adequaat om de specifieke vorm van communicatie en interactie via het creatieve medium te interpreteren? De onderzoeksdialoog heeft geleid tot de articulatie van enkele centrale thema's: de waarde van concrete metaforen en 'beeldnarratieven' ten opzichte van het filosofische begrip van de metafoor, bijvoorbeeld de 'zijnskwaliteitenmetafoor' en de metafoor van de 'homo ludens', om de 'meerwaarde' van creatieve trajecten in therapie en training te verwoorden. Vier concrete 'ontologische metaforen' (de zenleraar, de journalist, de wetenschapper en de dichter) worden hierna beschreven, welke, op basis van het evaluatieproces, met het oog op de profilering van creatieve therapie zijn ontworpen. Narrativiteit als 'grondstructuur' van de dialogisch vormgegeven therapie- en organisatie-verhalen, geeft de wijze aan waarop het filosofische 'model' van metaforische betekenisgeving kan worden geconcretiseerd.

Op grond van de hermeneutische literatuuranalyse zijn 'creatieve trajecten' opgevat als een gesitueerde, aan het medium gerelateerde en persoonsgebonden dialoogvorm. Een 'open en betrokken gesprekshouding' is de filosofische 'grond', die de dialoog tussen trainer/therapeut, cliënt en creatief medium draagt. Het empirische materiaal blijkt elementen te bevatten die de 'blauwdruk' van 'dialogische communicatie' concretiseert. De 'dialogische grondhouding' wordt als het ware aangekleed met concrete beelden en verhalen uit de praktijk. In het vorige hoofdstuk is het spelbegrip hermeneutisch uitgewerkt en in verband gebracht met de 'metaforische kennisvorm' in de zin van een dialogische middenpositie, 'tussen' een controlerend-beheersende en een empathisch-betrokken kenhouding. Het creatieve 'ervaringsgestuurde leren' zou aldus verwijzen naar een speelse dialoog via de taal van het medium. Door het veldonderzoek krijgt het speelse element een extra accent en een concrete invulling door middel van een empirische interpretatie van de metafoor van 'de homo ludens'. Op basis van het uitwisselingsproject betekent 'speels' vooral de lichtvoetige èn serieuze wijze waarop emotionele, zintuiglijke en lichamelijke betekeniselementen in 'creatieve leertrajecten' meespelen en meespreken. Deze 'ludieke dialoog' blijken therapeuten en trainers niet anders te kunnen verwoorden dan in concrete metaforen, zoals die uit de vorige paragraaf: 'de onbewaakte spoorwegovergang', 'de trechter' en 'het optrekken van de mist'. Deze concretisering van de 'open en betrokken gesprekshouding' door middel van een kritisch-humanistische duiding van de dialoog geeft een ade-

32. Zie ook het interview in Tijdschrift voor Creatieve Therapie (2000) 4, 27-28. 
quatere, want met de stemmen van betrokkenen uit de praktijk mede gevormde, interpretatie van de creatieve werkvorm, dan op basis van de hermeneutische literatuuranalyse alleen gegeven is. In de volgende paragrafen staat te lezen hoe het veldonderzoek heeft geleid tot een concretisering van het filosofische onderzoekskader.

\subsubsection{Professionele motto's en profilering}

In de eerste fase van het uitwisselingsproject was 'de spelmetafoor' door de onderzoekster ingebracht als een typering voor de 'eigenheid' van 'creatieve trajecten'. Aan de hand van de respons van creatieve trainers heeft het filosofische 'naakte gelaat' van 'de homo ludens' persoonlijke gelaatstrekken gekregen. Twee muziektrainers gaven de volgende toelichting op hun 'speelse werkvorm':

De homo ludens wil gehoord en gezien worden. Het speelse element is onmisbaar in elke situatie, hoe serieus je ook bezig bent.

Met muziek speel je wie je bent.

Uit de volgende twee citaten blijkt dat het ludieke element niet (alleen) een 'prettige bijkomstigheid' is, maar een leervorm die typerend is voor het creatieve 'ervaringsgestuurde leren':

Mijn leren is spelen, mijn spelen is leren.

Ik nodig mensen uit tot openheid, plezier en contact maken.

De empirische aankleding van 'de homo ludens' was op basis van de groepsbijeenkomst met trainers onder de noemer van 'professionele motto's' als 'potentiêle winst' voor creatief therapeuten met betrekking tot hun bedreigde organisatorische positie in het uitwisselingsproject ingebracht.

Aan creatief therapeuten was de spelmetafoor in de eerste fase van het project voorgelegd naast twee andere metaforen om 'de meerwaarde' van creatieve therapie te verwoorden. In het algemeen vonden beeldend therapeuten deze metafoor weliswaar treffend om de interactie binnenskamers tussen therapeut en cliënt via het creatieve materiaal aan te duiden. Echter achtten zij deze beeldspraak niet adequaat om haar 'naar buiten toe', voor collega's en cliënten, te gebruiken. Het speelse element zou teveel de connotatie van 'kinderlijk' en 'niet serieus te nemen' krijgen, waardoor het 'vage imago' van het vak wordt versterkt. Vanuit dat bezwaar werd soms aan de organische metafoor van voedsel/ voeding of aan de instrumentele metafoor van 'gereedschap' de voorkeur gegeven. Hieronder volgen enkele voorbeelden van metaforische aanduidingen van 'de meerwaarde' van 
creatieve therapie op basis van deze drie metaforen. Twee beeldend therapeuten verkozen de voedsel/ voedingsmetafoor:

Het proeven van de verschillende ingredienten als basis om een maaltijd te koken in tegenstelling tot het koken op basis van een recept.

Vast voedsel als 'een stevige hap' waar je flink op moet kouwen tegenover vloeibaar voedsel, dat makkelijker naar binnen glijdt maar ook minder beklijf.

Andere therapeuten gebruikten de gereedschapsmetafoor:

Met creatieve therapie geefje mensen letterlijk gereedschap in handen.

Als de therapie geslaagd is komt er hanteerbaar gereedschap uit voort.

Je laat mensen eigen gereedschap maken.

Je zou bijvoorbeeld mensen kunnen leren met gereedschap minder grof te werken, van een hamer naar een fijn penseeltje.

De geciteerde creatief therapeuten vonden de gereedschapsmetafoor geschikt omdat deze het handelingsaspect en de instrumentele waarde van creatieve expressie met betrekking tot de behandeldoelstelling aan kan geven. Voor anderen was dit juist aanleiding om deze metafoor als te functioneel af te wijzen. Daarmee zou in hun ogen aan het creatieve en speelse karakter van beeldende therapie tekort worden gedaan. Om deze reden werd soms weer de voorkeur gegeven aan de organische metafoor van voedsel/ voeding of aan de spelmetafoor.

Veel respondenten vonden geen van de aangedragen metaforen adequaat om 'de meerwaarde' van creatieve therapie te omschrijven. $\mathrm{Zij}$ gaven een aanduiding op basis van een eigen metafoor:

\section{Creatieve therapie is een ontdekkingsreis.}

Creatieve therapie zijn de vruchten van een boom die iemand kleur geven.

Creatieve therapie is een plek om iemand tot zijn recht te laten komen.

De onderzoekster plaatste deze metaforische antwoorden van respondenten terug in haar hermeneutische onderzoekskader. Richtinggevend was de vraag of de metaforische typeringen een bepaalde opvatting ten aanzien van de verhouding taal beelden - ervaringswerkelijkheid impliceren. Welke impliciete ontologische vooronderstelling spreekt uit de metaforische antwoorden? Waar de gereedschapsmetafoor een instrumentele visie vertegenwoordigt, daar drukt de voedings/ voedselmetafoor een organische verhouding uit, terwijl de spelmetafoor het meest 
geschikt is om een dialogische verhouding aan te geven. Wanneer deze interpretatie hout snijdt, geven de metaforen aan hoe de geïnterviewde creatief therapeuten ten aanzien van hun professionele handelen impliciet een opvatting over de verhouding 'verwoording - verbeelding - vertolking van de werkelijkheid' hanteren. De onderzoekster heeft deze interpretatie aan de respondenten met de uitnodiging tot feedback voorgelegd teneinde zich van de 'naïef' ingenomen ontologische positie bewust te worden. Haar veronderstelling hierbij was dat dit filosofische thema ideeën zou opleveren om 'de meerwaarde' van creatieve therapie zodanig (metaforisch) te verwoorden dat 'derden' inzicht kunnen verkrijgen in de waarde van het creatieve middel, zonder van vakjargon gebruik te maken of zich op een (in de instelling dominant) psycho-therapeutisch referentiekader te beroepen. Dit zou aan 'de profilering van creatieve therapie' en aan een 'autonomere positie' van creatief therapeuten ten opzichte van de instelling ten goede kunnen komen.

Op basis van de hermeneutische interpretatie van de reacties van creatief therapeuten zijn er vier 'ontologische posities' onderscheiden. Deze heeft de onderzoekster door middel van concrete metaforen getypeerd en aan de respondenten voorgelegd in het toegestuurde onderzoeksverslag. Creatief therapeuten nemen een houding aan ten opzichte van de taal (van het creatieve medium) die vergelijkbaar is met de manier waarop de zenleraar, de dichter, de journalist en de wetenschapper 'de werkelijkheid' tegemoet treden. De zenleraar-opvatting vooronderstelt dat 'de werkelijkheid' in essentie pré- of postverbaal is: verwoording houdt een misleidende verdubbeling in. Getransponeerd naar de context van creatieve therapie betekent dit dat de gemaakte beelden meer tot deze 'nonverbale' pure werkelijkheid behoren, terwijl de verwoording van de 'betekenende beelden' veeleer tot 'maya' of de versluiering ervan bijdragen. Het standpunt van de dichter brengt hierin een accentverschuiving aan: niet alleen de 'letterlijk' gecreëerde beelden, maar ook beeldspraak en poëtische beelden, vermogen de werkelijkheid essentialiter over te brengen. Het 'journalistenstandpunt' beroept zich op een 'common-sense'-instantie om de betekenis van creatief-therapeutische beelden te verwoorden. De 'wetenschapspositie' schuift hiervoor een deskundigen-oordeel in de plaats: voor een 'adequate interpretatie' van de gemaakte beelden moeten we ons beroepen op kennis van ter zake kundigen, zoals de psycholoog, de pedagoog en de kunsthistoricus.

Deze vier metaforen typeren de (on)bewust ingenomen 'ontologische posities' van creatief therapeuten. Als zodanig kunnen ze in verband worden gebracht met een rationalistische, een romantische en een hermeneutische benadering van de werkelijkheid. De gereedschapsmetafoor stemt wat betreft de impliciete instrumentele visie op de verhouding taal - werkelijkheid overeen met een rationalistische grondhouding. Hier tegenover staat de organische metafoor van 'voedsel, voeding', die juist correspondeert met een romantische benadering, waarbij er van een 'symbiotische verwevenheid' van de ervaringswerkelijkheid van cliënten met hun creatief-therapeutische verbeelding wordt uitgegaan. Zowel het 'journalistenstand- 
punt' als de 'wetenschapspositie' gaan uit van een instrumentele en externe verhouding van taal - werkelijkheid. Op dit punt staan ze tegenover de 'dichterpositie' die veeleer in overeenstemming is met een organisch of dialogisch opgevatte interne verhouding tussen beide. De 'dichtermetafoor' kan zowel uitdrukking zijn van een romantische als van een hermeneutische grondhouding. Het 'zenleraarstandpunt' is hierin eenduidiger en vertegenwoordigt als het ware de negatieve tegenhanger van de instrumentele visie, van waaruit taal als dysfunctioneel wordt opgevat voor de generatie van werkelijk inzicht in depsychische werkelijkheid. De instrumentele metafoor onderkent weliswaar het belang van een rechtvaardiging maar vat deze op een eenzijdig rationalistische manier op, in termen van wat 'zichtbaar en manipuleerbaar' is. De derde metafoor van het 'spel' is in overeenstemming met de dialogische relatie tussen de gesprekspartners, tussen cliënt - therapeut en creatief medium. Zij zijn de spelers van de 'creatief therapeutische dialoog' die elkaar verstaan via de voor de therapeutische relatie geldende spelregels. Nog een ander wezenlijk aspect van deze metafoor is het plezier in het spel, hetgeen wijst op de emotionele betrokkenheid van de gesprekspartners met elkaar en ten aanzien van het besprokene. In de organische metafoor ontbreekt het dialogische moment van verantwoording afleggen door de romantisch opgevatte symbiotische verhouding tussen zijn en taal, welke de voedsel/ voedingsrelatie suggereert. Deze laatste opvatting komt het dichtste in de buurt van de romantische pioniersgeest van creatieve therapie. De instrumentele visie van het 'wetenschaps-' en het 'journalistenstandpunt' weerspiegelt veeleer de huidige tendens naar verzakelijking van de gezondheidszorg.

Hoewel deze vier 'ontologische metaforen' niet verder in het uitwisselingsproject zijn uitgewerkt, zijn zij toch als 'nevenspoor' in de onderzoeksdialoog ter sprake gebracht door middel van een toegestuurd onderzoeksverslag en een in het vaktijdschrift van creatief therapeuten gepubliceerd artikel. Vanuit de beroepsvereniging en via dit vaktijdschrift is een postieve reactie ontvangen wat betreft de potentielle waarde van dit onderzoek voor de 'profilering' van creatieve therapie in een breder maatschappelijk verband. Heeft de aangesneden ontologische problematiek ook een concete waarde voor de profilering van creatieve therapie resp. voor de praktijk van creatief therapeuten?

Wat betreft het gewonnen inzicht in het eigen impliciet ingenomen 'ontologische' resp. 'ideologische' standpunt valt er winst te boeken met het oog op interdisciplinair overleg over de behandeling van patiënten. Wanneer deze problematiek in verband wordt gebracht met de hermeneutische analyse van creatief therapeutische literatuur uit het tweede hoofdstuk verkrijgt de daarin getrokken conclusie ook praktische relevantie. Daar is gesteld dat zowel de instrumentele als de romantisch (resp. organisch) opgevatte verhouding taal - beeld - werkelijkheid minder adequaat is met betrekking tot de omschrijving van 'de meerwaarde' van creatieve therapie in vergelijking met de 'derde positie' die door de spel- (resp. dichter-) metafoor wordt gearticuleerd Het taalspel van de dichter voegt aan de interne organische verhouding tot 'zijn' een dialogisch moment toe. De dichter 
vertolkt het zijn, speelt met tekens van taal, waardoor 'de werkelijkheid' voor ons ontsloten wordt. De poëtische taal geeft geen 'zuivere weerspiegeling' van de realiteit, maar zij evoceert een ervaringswerkelijkheid. Het dichterlijke woord en beeld roepen een realiteit op paradoxale wijze tevoorschijn: ze versluieren èn openbaren de dingen juist op die toon, in die kleur en met die geur. De beeldspraak van de dichter laat door een onthullend-verhullend spel 'het zijn' zien in een kleed van symbolen dat de goede verstaander ontraadselt. Het poëtische discours is evenals de creatief-therapeutische dialoog een 'open en betrokken' gesprek tussen dichter - (beeld)spraak - zijn en toehoorder. In het dichterlijke gesprek vindt ook een speelse verbeelding en verwoording van 'zijn' plaats, echter is de relatie tussen de gesprekspartners een andere. De dichter vertolkt het zijn op unieke wijze, als 'expert' èn 'getuige' van een ervaringswerkelijkheid. Een creatief-therapeutische relatie heeft een minder 'vrijblijvend' karakter en de 'expert'- en 'getuige'-rol zijn niet in een persoon verenigd, maar geeft de rolverdeling tussen hulpvrager en hulpbieder tijdens de therapie aan. Door de hulpvraag van de cliënt wordt de 'machtspositie' van de therapeut als deskundige 'hulpverlener' gelegitimeerd. Hiermee wordt een hijkel en gevoelig onderwerp, zeker ook voor therapeuten zelf, aangesneden ${ }^{33}$.

Wanneer de filosofische conclusie uit de literatuuranalyse met de empirische herinterpretatie van de spelmetafoor aan de hand van de ontologische metafoor van 'de dichter' wordt verrijkt, betekent dit 'winst' voor de praktijk van creatieve therapie. Dat wil zeggen dat haar 'meerwaarde' zodanig metaforisch kan worden getypeerd dat er recht wordt gedaan aan de eigen-aard(igheid) van het creatieve medium zodat bovendien de 'authentieke communicatievorm' tussen therapeut en cliënt wordt benadrukt. Daarbij heeft het veldonderzoek erop gewezen hoe belangrijk het is dat de metaforische typering in 'externe' communicatie daadwerkelijk aanspreekt. De volgende poëtische karakterisering van 'de meerwaarde' van creatieve therapie door een respondente:

\section{Creatieve therapie is een spel met kleuren en vormen.}

zou als uitgangspunt kunnen dienen om de 'toegevoegde waarde' en het 'ludieke' element van het creatieve medium in verbinding te brengen met het dialogische aspect van de communicatie tussen cliënt en therapeut binnen het instrumentele kader van de (geestelijke) gezondheidszorg. Op de (inter)disciplinairegroepsbijeenkomsten is voor de aanwezige respondenten een handvat aangereikt hoe metaforen tot een 'handelsmerk' of 'professioneel motto' uit te bouwen. Hierdoor behoudt de creatieve dienstverlening niet alleen haar 'humanistische' signatuur maar verkrijgt zij ook een 'commerciëel' stempel waarin deze grondslag doorwerkt als een 'kritisch' moment ten aanzien van de heersende ideologie, met name de verzakelijking van de zorg. Langs deze weg kan de 'crisis van de gezondheids-

33. Hoewel dit onderwerp niet in de onderzoeksdialoog is uitgewerkt, bleek uit individuele reacties van respondenten dat zij het wel relevant achten. 

betekenen.

In het verlengde van de vraag naar 'de meerwaarde' van creatieve therapie ligt de waarde van het ontwikkelen van een 'eigen' beeldend therapeutisch referentiekader. Immers een groep onderscheidt zich niet alleen van anderen door middel van een eigen territorium, maar ook door het hebben van een eigen naam en taal. Dit onderwerp is in het kader van het uitwisselingsproject naar voren gebracht als de vraag naar de meest adequate taal waarin beeldend-therapeutische processen verwoord kunnen worden. Vanuit een wetenschapspositie is men geneigd te kiezen voor bestaande psychotherapeutische, psychologische of pedagogische kaders. Hier tegenover wordt op grond van een 'zenleraar-standpunt' elke verwoording en theorievorming uiteindelijk inadequaat geacht. Een 'journalisten-opvatting' geeft de voorkeur aan een zo 'letterlijk' mogelijke formulering in de 'natuurlijke omgangstaal' (voor cliënten) of in een 'algemene hulpverleningstaal' (voor collega's). Met betrekking tot de profilering van creatieve therapie in de (geestelijke) gezondheidszorg, lijkt mij het 'zenleraar-standpunt' het minst adequaat. Een creatief therapeut die een dergelijke opvatting huldigt beperkt de communicatie met derden tot nonverbale middelen, die principieel meerduidig zijn ten aanzien van de vraag naar 'het effect' van de therapie. Bijvoorbeeld door het tonen van beeldend werk van cliënten (aan de hand van werkstukken, dia's of een casus), waarop de therapeutische veranderingen zichtbaar zijn en als zodanig 'voor zichzelf zouden spreken'. Hoewel natuurlijk ook de verwoording van beeldendtherapeutische processen meerduidig is, geeft de therapeut daarmee de additionele mogelijkheid uit handen om door middel van taal invloed uit te oefenen op de interpretatie van de (waarde van) beelden en beeldende expressie binnen de instelling. De getoonde 'nonverbale' middelen zouden een aanvullende waarde in dit verband kunnen verkrijgen wanneer de 'beeldtaal' van de werkstukken en casussen een verbale toelichting niet vervangt maar onderstreept. Vanuit de twee andere posities wordt de waarde van een 'adequaat referentiekader' weliswaar onderkend,- echter dreigt met de keuze voor bestaande psychotherapeutische kaders of een algemene hulpverleningstaal de 'eigenheid' van creatieve therapie uit het $00 \mathrm{~g}$ te worden verloren. Dit gegeven vormt de inzet van de vierde positie van creatief therapeuten, die een op de beeldend-therapeutische processen toegesneden 'beeldtaal' willen ontwikkelen. Met betrekking tot het profileringsthema lijkt het 'dichtersstandpunt' resp. de keuze voor een 'beeldend' referentiekader derhalve te verkiezen. 


\subsubsection{Professionalisering en organisatiecultuur-verandering}

In de vorige paragraaf is de relevantie van een hermeneutische benadering voor de praktijk $^{34}$ van creatief therapeuten aangegeven, waarbij een analogie met het werkveld van creatieve organisatietrainers is getrokken. Dat de profilering van creatieve therapie gediend is met de ontwikkeling van een 'beeldend' referentiekader neemt niet weg dat het voor creatief therapeuten in organisaties van de (geestelijke) gezondheidszorg ook van belang is zich verstaanbaar te kunnen maken via dominante therapeutische en medische referentiekaders. Ook wat dit betreft kan er een analogie worden getrokken met een agendapunt van de groepsbijeenkomst met creatieve trainers, namelijk dat uit de interviews is gebleken dat de geïnterviewde organisatietrainers in het algemeen de managementtaal verstaan als een 'hulpmiddel' om de organisatiedoelstelling door middel van een intake-gesprek te vertalen naar een op de 'creatieve werkvorm' afgestemde operationalisering. Tegenover het conventionele managementkader met modieuze concepten zoals 'stressmanagement', 'coaching', 'flexibilisering', enz. plaatsen zij hun eigen 'creatieve' resp. 'existentiële' interpretatiekader. Het ijkpunt voor deze 'vertaalslag' ligt in de kritisch-humanistische grondslag van het creatieve trainingswerk, die in het uitwisselingsproject getypeerd is als het geloof in de individuele authenticiteit en autonomie van de mens'.

Terwijl de 'externe', door bedrijven ingehuurde trainers zich een dergelijk autonoom standpunt ten aanzien van het dominante managementkader kunnen veroorloven, bevinden creatief therapeuten binnen een instelling van de (geestelijke) gezondheidszorg zich in een lastiger parket. $\mathrm{Zij}$ moeten hun vak immers verdedigen ten opzichte van concurrerende (therapeutische) disciplines en onder toenemende druk van bovenaf in de vorm van de door het management uitgedragen beleidsveranderingen. Op de groepsbijeenkomst met creatief therapeuten bleken beelden en metaforen als stammenstrijd, pikorde en teritoriumgevecht zeer herkenbaar en geschikt om hun ervaringwerkelijkheid op dit punt te typeren. Ze werden in verband gebracht met 'de ontstaansgeschiedenis' van beeldende therapie en met de 'organisatiecultuur' in de betreffende instelling. Wanneer creatieve therapie in samenspraak met psycho-therapeuten, psychologen en psychiaters is ontstaan, heeft ze in de instelling meer aanzien verworven dan wanneer ze vanuit activiteitenbegeleiding, arbeidstherapie of sociotherapie zelfstandig is geworden. Dergelijke 'standsverschillen' spelen door in de naamgeving (therapie of niet?) de functieomschrijving (hoeveel taken en verantwoordelijkheid?), salariëring en status! Op basis van het uitwisselingsproject lijkt de hamvraag te zijn: Gaat het om een vorm van therapie en dus behandeling of biedt creatieve therapie 'alleen' ondersteuning en begeleiding door middel van creatieve activiteiten? In de groepsdiscussie over deze vraag was 'de communicatiekloof' tussen management en werkvloer als een algemeen herkenbaar beeld naar voren gekomen. Mede door

34. Zie hiervoor ook Widdershoven: Ethiek in de Kliniek 79-107. En: Psychotherapie als praktische wetenschap in: Tijdschrift voor Psychotherapie (6) 26, 395-402. 
de stellingname van de uitgenodigde muziektherapeut die deze problematiek in een breder maatschappelijk en historisch kader plaatste is een bewustwording van een gewenste organisatie-cultuurverandering annex een verandering in professionele attitude bij creatief therapeuten aan de orde gesteld.

Deze resultaten uit het uitwisselingsproject resumerend blijkt het belang van een overkoepelende visie of een ruimere dimensie van zingeving ${ }^{35}$ teneinde de conventionele, management- en creatief therapeutische, referentiekaders te kunnen relativeren. Tegen de achtergrond van de hermeneutiek is in dit verband op de doeltreffendheid gewezen van 'metaforische taal' in het algemeen en van narratieve metaforen in het bijzonder, zoals de spel- en dichtermetafoor. Echter zouden de metaforen vanuit 'de middenpositie' van Hermes in de ervaringsgerichte aankleding van de 'homo ludens' gearticuleerd moeten worden. Dit standpunt bevindt zich 'tussen' de rationalistische koers van Apollo, die ertoe neigt om metaforen opportunistisch en dictatoriaal te lanceren teneinde aan de werkzame metaforiek te ontsnappen en het romantische manoeuvre van Dionysos, die een 'onaantastbare' metafoor proclameert om zich zelf aan het proces van ver(ant)woorden te onttrekken

De conclusie luidt aldus dat de voor verdere professionalisering van creatieve therapie gewenste verandering van professionele attitude alleen vanuit 'de middenpositie' kan worden voltrokken. Dit was reeds geillustreerd aan de hand van het ervaringsgegeven dat creatief therapeuten in het algemeen geneigd zijn de verhouding tussen verstand en gevoel in termen van een 'conflictmodel' te zien. Vanuit dat perspectief wordt voor de rechtvaardiging van therapeutische interventies geen additioneel beroep gedaan op reflectie en de optie van dialogische verantwoording blijft onbenut. Deze extra mogelijkheid en verantwoordelijkheid van creatief therapeuten wordt veelal door het exclusieve beroep op een 'praktische intuïtie' als overbodig of zelfs 'averechts werkend' afgedaan. Op grond van de gebruikelijke opvatting dat creatieve therapie in wezen een gevoelsmatige en intuitieve kundigheid is, staan reflectie, systematisering en theoretisering op gespannen voet met deze 'kerncompetentie' van creatief therapeuten. Hier tegenover propageert dit onderzoek de hermeneutische 'bemiddelingskunst' waarmee een brug wordt geslagen tussen 'kennis van het hoofd' en 'kunst van het hart'. De verandering van professionele attitude in combinatie met de organisatiecultuurverandering onder geleide van Hermes kan in de praktijk resulteren in het toelaten van meer reflectie op het eigen professionele handelen en het inbrengen van creatieve communicatie en intuitieve momenten op vergaderingen en (in-)formeel overleg met collega's. De integratie van beide veranderingsprocessen zal - gegeven de fundamentele interdependentie van mens en 'omgeving' - zowel de positie van creatief therapeuten als de (re)organisatie ten goede komen. Uit het veldonder-zoek is gebleken dat dit hermeneutische inzicht door de filosofische verwoording beeldend therapeuten niet motiveert en derhalve in de vorm van 'actiepunten' en

35. Zie Duintjer: Rondom metafysica. Jaspers: Psychologie der Weltanschauangen. 
concrete metaforen geoperationaliseerd moet worden, waarmee in de vorige paragrafen een begin is gemaakt.

\subsubsection{Van 'metaforische communicatie' naar 'narrativiteit vanuit een kritisch humanisme'}

Deze paragraaf voert de 'evaluatieve fase' van het uitwisselingsproject tot een (voorlopig) einde met de vraag: Wat betekent de 'empirische winst' uit het veldonderzoek voor het hermeneutische onderzoekskader?

Uit de veldstudie is naar voren gekomen dat de filosofische grondslag een narratieve concretisering behoeft aan de hand van organisatie- en therapieverhalen om voor trainers en therapeuten toegankelijk te zijn. Het begrip 'narrativiteit' wordt in steeds meer domeinen als een grondslaggevende categorie gearticuleerd. ${ }^{35}$ In die hoedanigheid zou een verhalende structuur aan de basis staan van ons zelfverstaan, van de (artistieke) expressie hiervan via de dialoog met het creatieve medium en van de interpretatie van deze expressieve uitingen in de vorm van 'metaforische kennis'. Analoog aan de dansmetafoor geldt met betrekking tot een verhaal: in haar 'uitvoering' of 'vertelling' ligt een interpretatie besloten als de unieke vertolking van het verhaal door de schrijver of verhalenverteller. Ook ontstaan er andere duidingen door het gesitueerde verstaan van de toehoorders. Daarnaast staat het eenmaal vertelde open voor steeds nieuwe vertolkingen. De interpretatie van een verhaal of tekst is derhalve niet beperkt tot haar ontstaan en de 'oorspronkelijke' betekenis die de auteur eraan geeft. Derrida brengt dit fundamentele gegeven in verband met de 'materialiteit' van een tekst of 'de tekstualiteit', waarbij de betekenis van 'tekst' anders dan in de natuurlijke omgangstaal een fundamenteel-filosofische, een op de 'grondstructuur van ons denken' betrekking hebbende strekking krijgt. ${ }^{36}$ Wat in dit onderzoek als 'dialogisch grondbeginsel' is verwoord spoort met deze 'tekstuele grondslag'. Dat wil zeggen: processen van communicatie en interpretatie worden geschraagd door 'de open en betrokken gesprekshouding' als de bereidheid de eigen definities met betrekking tot het gespreksonderwerp uit te dragen en te verantwoorden. Het veldonderzoek concretiseert dit filosofische fundament tot een narratieve vorm: de explicatie van ons existentiële (zelf)verstaan vindt plaats door middel van concrete metaforen, de therapie- en organisatieverhalen hebben een narratieve gestalte. Tot welke resultaten heeft dit geleid?

\footnotetext{
35. Onder meer op het gebied van de literatuur door Ricoeur: Temps et Recit. In het Engels vertaald als Time and Narrative Op gebied van psychologie en psychotherapie bijvoorbeeld door Vroon \& Draaisma: De mens als metafoor. Oltman \& Vermetten: De mens als verhaal. Narratieve strategieên in psychotherapie voor kinderen en volwassenen. Op religieus-wijsgerig gebied zie Moerland: De sleutels der kennis. Een inleiding tot de gnostiek. Op het gebied van de bedrijfskunde zie noot 16 van hoofdstuk 3. Paragraaf 2.2.

36. Derrida: Grammatologie. Berns: Jacques Derrida en de taalfilosofie in Berns e.a.: Denken in Parijs. 139-169. Kimmerle: Derrida. Zur Einfilhrung.
} 
De creatieve trajecten in therapie en training zijn in eerste instantie omschreven als een vorm van metaforische communicatie. Het praktijkmateriaal werpt een nieuw licht op deze omschrijving. Het in de voorgaande paragrafen geformuleerde primaat van 'de individuele authenticiteit en autonomie' en van de 'integriteit' van therapeut of trainer wijst op het belang van een zingevingsdimensie, die zowel conventionele referentiekaders van bijvoorbeeld de psychotherapie, als het filosofische niveau van 'metaforische betekenisgeving' transcendeert. Hierbij moet evenwel, op basis van de evaluatie van het uitwisselingsproject, worden benadrukt dat dit 'overstijgen' niet zozeer tot abstracte denkbeelden voert, maar veeleer tot een concretiserend beelddenken. Veel van de geïnterviewde trainers zeiden op 'identiteitsniveau' te werken, waardoor de samenhang van persoonlijke en professionele vaardigheden van de deelnemers aan een organisatietraining wordt aangesproken en de congruentie van individuele en organisatorische belangen in perspectief wordt gebracht. Deze invalshoek kan nu worden geïnterpreteerd als een perspectief dat 'voorbij' conventionele referentiekaders naar een 'dimensie van zingeving' verwijst die niettemin in de concrete ervaring geworteld blijft.

De 'dimensie van zingeving' transcendeert èn relativeert de gebruikelijke wijze waarop bijvoorbeeld communicatie- en samenwerkingsproblemen 'op de werkvloer' worden besproken en opgelost, namelijk vanuit modieuze managementconcepten, 'succesvolle stappenplannen' en (therapeutische) communicatietechnieken. De gebruikelijke interpretaties van een 'probleem' worden 'gedereificeerd' en krijgen vanuit dat ruimere perspectief via het creatieve medium een menselijke vorm. Het 'probleem' verschijnt dan als een (inter-)menselijk, psychodynamisch aspect van waarneembare creatieve processen, van communicatie en gedrag. Het 'probleem' wordt van zijn conventionele hoedanigheid en beladen geschiedenis losgekoppeld en in een aan het creatieve medium gerelateerde betekenis door therapeut of trainer aan de orde gesteld. Doordat dit proces van betekenisgeving vanuit de directe ervaring van de deelnemers via de dialoog met het creatieve medium vormgegeven wordt, krijgt het een narratieve en metaforische gestalte. Door middel van concrete metaforen en verhalen worden hulpvragen voor een organisatie of een individuele cliënt herkaderd, waarmee een richting aangewezen is waarin de organisatie of de cliënt zelf een oplossing kan vinden. De 'dimensie van zingeving' plaatst de dominante instrumentele invalshoek op communicatie binnen het ruimere, existentiële perspectief van het 'vertellen van een verhaal'. Vanuit dit ruimere perspectief van het 'existentielle (zelf-)verstaan' verkrijgen therapeutische en trainingsdoelstellingen een narratieve vorm en een kritisch-humanistisch fundament. De 'zingevingsdimensie' vertegenwoordigt de ruimte waarin het kritisch humanisme een bodem biedt voor existentiële narratieven. Hiermee kan het rationalistische makbaarheidsgeloof worden begrensd. Vanuit die dimensie van zingeving worden we geconfronteerd met 'de grens van ons organisatievermogen' en ons uiteindelijke aangewezen zijn op 'anderen', op 'toeval', op 'contingentie' en op 'externe factoren' die niet manipuleerbaar zijn. Vanuit die ruimere context komt de betekenis in zicht van een 
fundamentele verbondenheid van mens en organisatie. Dit ruimere perspectief werd door sommige trainers benoemd als een 'existentiële', 'humanistische' of 'spirituele' dimensie van menselijke communicatie en (onder)handelen, op grond waarvan organisatorische en persoonlijke belangen niet in hun strijdig-zijn verschijnen, maar in hun wederzijdse verwevenheid en afhankelijkheid. Een kritisch humanisme verankert aldus op narratieve en democratische wijze 'de dialoog', aan gene zijde van mystificerend-abstraherende èn opportunistischstrategische communicatie- en onderhandelingspatronen.

Vooral uit de interviews met creatieve organisatietrainers is het fundamentele belang van een omvattend 'zingevingskader' naar voren gekomen, dat het existentiële 'middenniveau' van 'authentieke communicatie' vermag te articuleren, waarin psychologische 'interne' en organisatorische 'externe' aspecten van interactie samenkomen. Maar ook door een creatief therapeut is dit fundamentele gegeven bijvoorbeeld als volgt verwoord:

\section{Je bent als creatief therapeut geen solist meer maar een orkestlid.}

Ten opzichte van conventionele betekenisgevende kaders, die ofwel de persoon ofwel de organisatie centraal stellen, berust dit 'zingevingskader' op een 'meta'- of 'trans'-perspectief dat tot een standpunt uitnodigt voorbij het beperkte en dichotomiserende gezichtspunt van 'de organisatie' tegenover 'het individu', van een 'subjectieve' versus een 'empirisch waarneembare' werkelijkheid. De voorvoegsels 'meta' en 'trans' suggereren een esoterische lading en lijken een metafysische betekenis aan de gevonden grondslag te geven. Om deze metafysische vluchtroute af te sluiten is in het vierde hoofdstuk een nietmetafysische interpretatie van 'dialogische communicatie' uitgewerkt. Het gevaar bestaat immers dat de humanistische grondslag van creatieve trajecten in therapie en training een romantisch-metafysische versluiering van menselijke communicatie en interactie geeft die in de plaats komt van de dominante instrumenteelstrategische optiek. Het uitwisselingsproject heeft de dialogische grondslag geconcretiseerd tot een specifieke, mediumgerelateerde vorm van 'authentieke communicatie'. Als zodanig verwijst 'authenticiteit' naar de wijze waarop persoonlijke en professionele zijnskwaliteiten in een intermenselijke context gestalte krijgen. De 'existentiële' herinterpretatie snijdt tevens de andere extreme interpretatie van creatieve trajecten de pas af vanuit een 'opportunistisch-strategische' optiek, bijvoorbeeld op basis van de opvatting dat kwaliteiten zoals humor, vreugde, inspiratie, bezieling, vertrouwen 'slechts' functioneel zijn om bij werknemers nog betere werkprestaties uit te lokken. Aldus is er een 'ideologiekritische' invalshoek aan de humanistische grondslag toegevoegd om te voorkomen dat creatieve trajecten in therapie en training subtiele vormen van 'disciplinerende macht' of van 'romantisch zelfbedrog' vertegenwoordigen. Het kritisch-humanisme biedt een existentieel perspectief op menselijke communicatie waarbij 'authenticiteit', in de zin van de bereidheid om in een dialogische proces ver(ant)woording (uit) te dragen, als ijkpunt geldt. 
Samenvattend kan de creatieve werkvorm worden opgevat als het creëren van een 'zingevingskader', waarin de cliēnt wordt uitgenodigd om op existentieelnarratieve wijze delen van zijn/ haar levensverhaal metaforisch te herschrijven teneinde vanuit kritisch-humanistisch perspectief weer 'op verhaal te komen'. Bijvoorbeeld door de verwerking van een traumatische - of een verlieservaring, door het (her-)vinden van ontbrekende stukken in het vertelde verhaal, door het centreren van fragmentarische ervaring en incidenten rond een 'rode draad' van het levensverhaal, door het verbinden van aspecten van de persoon, resp. subpersoonlijkheden rond een centrum van zelfervaring, enz. Wij interpreteren ons zijn-in-dewereld als een verhaal dat wij vertellen aan onszelf, over onszelf aan anderen, over anderen aan onszelf en anderen, enz. om zin te geven aan het gefragmenteerde, het pijnlijke, het toevallige, het onbenullige, het vreugdevolle, het absurde en het tragische van ons leven. Het in creatieve leertrajecten aangeboden 'zingevingskader' is een uitnodiging om de gebrokenheid en het tragische van ons bestaan op metaforische en narratieve wijze te vertolken en hieraan een existentiële interpretatie te geven. Hierdoor wordt er een samenhangend, zinvol geheel gereconstrueerd, in de vorm van een levensverhaal met een ontstaan, een plot, een verloop en een afloop. Over de 'noodlottige' gebeurtenissen die ons treffen kunnen we bijvoorbeeld een dramatische tragedie schrijven. Met behulp van dezelfde 'noodlottige elementen' is het evengoed mogelijk een epos of een komedie te vertellen. We kunnen met andere woorden over hetgeen ons treft de verantwoording aanvaarden wanneer we bijvoorbeeld een omkering van een 'slachtofferoptiek' naar een 'handelingsperspectief' aanbrengen binnen onze levensloop. Vanuit kritisch humanistisch perspectief hangt welzijn en levensgeluk samen met het gelukken om van hetgeen ons in het leven overkomt als een ogenschijnilik zinloos of onzinnig, noodlottig of toevallig, voorbestemd of onbegrijpelijk gebeuren als een narratief-existentiële samenhang te interpreteren die in onze zelfervaring is gecentreerd. Dit perspectief maakt het mogelijk dat wij op 'authentieke' wijze onze (kleine) verhalen ${ }^{36}$ vertellen aan onszelf en aan anderen. Met deze accentveschuiving van 'metaforische betekenisgeving' naar 'narrativiteit' vanuit een kritisch humanisme, heb ik de richting aangegeven waarin de in dit onderzoek filosofisch gearticuleerde thema's ten aanzien van de 'meerwaarde' van het creatieve medium een op de praktijk toegesneden concretisering en in de ogen van betrokken professionals relevantie kunnen verkrijgen.

De conclusie is dus dat de narratief-existentiële vormgeving van levens- en organisatieverhalen een kritisch humanistisch 'zingevingskader' vooronderstelt èn mogelijk maakt. Teneinde de humanistische elementen 'integriteit, 'authenticiteit' en 'autonomie', die deze grondslag definiëren, niet 'metafysisch' of 'absoluut' maar 'ideologie-kritisch' te interpreteren, zijn ze in dit onderzoek 'metaforisch' opgevat. Aanvankelijk is de funderende dialogische communicatievorm en gesprekshouding aan de hand van een filosofisch referentiekader benoemd. Ook aan

36. Lyotard: Het postmoderne weten. 
andere taalkaders, bijvoorbeeld de ethiek of de rechtspraak, kan voor een begrip van dit fundament betekenis ontleend worden. In het 'autonomie'-begrip spelen elementen van 'eigenmachtigheid' en 'eigengerechtigheid' mee op basis van de 'oorspronkelijke' letterlijke betekenis van het zichzelf de wet te stellen. Met 'authenticiteit' wordt een betekeniskader van ambachtelijke of kunstzinnige expressie geactiveerd, het eigenhandig en eigenzinnig tot stand brengen van iets. De verplaatsing van deze humanistische waarden naarweer een 'ander' referentiekader, geeft opnieuw een (impliciete) metaforische betekenis aan 'authenticiteit' en 'autonomie'. De hermeneutische analyse uit de theoretische hoofdstukken heeft tot de conclusie geleid dat het beroep op een (impliciete) metafoor een noodzakelijke, met het denken, spreken en handelen samenhangende semantische dynamiek is. De onvermijdelijke metaforiek die met de act van het benoemen wordt ingesteld, brengt het gevaar met zich mee dat de 'open en betrokken gesprekshouding' gesloten wordt. Dit gebeurt wanneer het beperkte betekenisgevende kader, waaraan gerefereerd is om betekenis aan 'authenticiteit' en 'autonomie' te verlenen (zoals ethiek, rechtspraak of de wereld van ambachten en kunsten), wordt verabsoluteerd. Waar een naïef humanisme hiertoe machteloos staat vermag het kritisch-humanistische perspectief dit risico voorkomen.

Het onderzoek heeft aannemelijk gemaakt dat er geen boven alle beperkte en conventionele referentiekaders staand 'absoluut' betekenisgevend kader bestaat, waarop een beroep kan worden gedaan om de metaforische betekenis van 'authenticiteit' te ijken. Het verlangen naar een 'absoluut referentiepunt' vertegenwoordigt de valkuil van een naïef opgevat romantisch humanisme. Bij het vermijden van deze valkuil, bijvoorbeeld door middel van metafysica-kritiek, is het gevaar groot dat men in het andere extreem doorschiet van een strategischopportunistische optiek. Zodra een bepaald referentiekader omtrent ons handelen dominant wordt, is de deur geopend naar 'metafysische' (absolutistische) èn 'strategische' (opportunistische) dwaal-routes. In het vorige hoofstuk heb ik laten zien hoe de 'dialogische grondhouding' in filosofische zin een tegenwicht tegen dit gevaar biedt. Met het veldonderzoek is bovendien concreet gemaakt hoe deze grondhouding van 'openheid en betrokkenheid' in de praktijk vormgegeven kan worden door middel van een omvattende (want de beperkte conventionele referentiekaders principieel relativerende) maar concrete (want 'gesitueerde', aan de directe ervaring en het creatieve medium gekoppelde) 'dimensie van zingeving'. Deze ruimere dialogische dimensie staat aan de basis van onze zelf-, maatschappijen wereldbeelden, aan onze organisatie- en levensverhalen. Het kritisch humanisme vermag aan de dialoog een menselijke gezicht te geven die in creatieve leertrajecten op narratief-existentiële wijze gestalte krijgt. Hiermee heeft 'Hermes' bemiddelingskunst' niet alleen een filosofisch fundamentele maar ook een methodisch-toegepaste betekenis met betrekking tot de creatieve werkvorm gekregen. 


\subsection{Samenvatting en conclusie}

In dit hoofdstuk is de theoretische analyse ten aanzien van creatieve trajecten uit de voorgaande hoofdstukken met de praktijk in verbinding gebracht door middel van een 'uitwisselingsproject' tussen creatief therapeuten en creatieve organisatietrainers.

$\mathrm{Er}$ is een methodologische uitwerking van de hermeneutische onderzoeksbenadering gegeven aan de hand van twee metaforen. De verhouding van de gereconstrueerde methodologie en het daadwerkelijke onderzoeksproces is gekarakteriseerd als de impliciete betrekking tussen 'choreografie en dans' en tussen 'spelregels en spel'. Vervolgens is het onderzoekskader geoperationaliseerd aan de hand van methodologische criteria, ontleend aan 'responsieve' en 'onderhandelende' onderzoeksmethoden. De voorbereidende onderzoeksstappen voor het 'uitwisselingsproject' zijn weergegeven, waaraan een procesbeschrijving in termen van een 'dialectiek van afstand en betrokkenheid' van de onderzoekster tot het onderzochte is toegevoegd. Hoe 'de resultaten' uit het dialogische onderzoeksproces zijn voortgekomen is in het bijzonder getoond aan de hand van de ontwikkeling van een 'model van metaforische communicatie en interactie', dat in de context van de onderzoeksdialoog 'onderhandelend' met de respondenten tot stand is gekomen.

Tegen de achtergrond van deze context van onderzoek is aangegeven hoe de hermeneutische analyse van 'de dialogische grondhouding' meteen onderzoek naar de praktijk van de 'creatieve werkvormen' is verrijkt. In dit verband is op de waarde van concrete metaforen gewezen, zoals de 'zijnkwaliteitenmetafoor' en 'de homo ludens', die het abstracte 'model van metaforische betekenisgeving' dusdanig aanschouwelijk kunnen maken, dat het mensen uit de praktijk aanspreekt. In het bijzonder is een empirische herinterpretatie gegeven van de spel- resp. de dichtermetafoor, waardoor de filosofische conclusie uit de analyse van vaklliteratuur een concrete betekenis heeft verkregen met betrekking tot het articuleren van 'de meerwaarde' van creatieve therapie. De wisselwerking van hermeneutiek met de praktijk heeft duidelijk gemaakt hoe creatieve leertrajecten als een narratieve vormgeving van existentiële en organisatorische thema's op kritisch humanistische leest kunnen worden geschoeid. De in training en therapie geconstrueerde levensverhalen en organisatieverhalen verschijnen als 'beeldnarratieven', waarin op speelse en dialogische wijze een perspectief op ontwikkelingsprocessen wordt gearticuleerd dat niet (noodzakelijk) spoort met dominante en eenzijdig opgevatte ideeën over rationalisering of humanisering. Creatieve trajecten genereren een narratief communicatiekader, waarin zelfbeelden, organisatiebeelden en wereldbeelden worden ontworpen. Bovendien vermogen ze een zingevingskader met een kritisch humanistische invalshoek op veranderings- en ontwikkelingsprocessen te activeren. 
Met deze 'empirische winst' uit het veldonderzoek is aan de filosofisch gereconstrueerde dialogische grondhouding een menselijk gelaat gegeven. Een eerste bevinding uit het veldonderzoek wijst aldus op het belang van concrete metaforen en verhalen, wat hier met de term 'narrativiteit' is aangeduid. Het praktijkmateriaal laat zien hoe narrativiteit een toegevoegde waarde vertegenwoordigt ten opzichte van de filosofische blauwdruk van de dialoog. De veldstudie heeft getoond hoe de filosofische grond bestaat uit het vertellen van verhalen als 'narratieve structuur' van ons existentiële zelfverstaan, van de creatieve expressie hiervan tot 'levende metaforen' èn van de interpretatie van deze metaforische articulaties. Een tweede bevinding is vervat in de interpretatie van creatieve trajecten als dialoogvormen, waarmee een 'zingevingskader' wordt gegenereerd dat de conventionele referentiekaders in therapie en organisaties transcendeert. Deze 'dimensie van zingeving' ontwikkelt zich vanuit de directe ervaring en via de taal van het creatieve medium tot een vorm van kritisch humanisme. Deze tweede bevinding maakt duidelijk dat vanuit dit ruimere perspectief aan beperktere betekenisgevende kaders, zoals de invalshoek van 'het management' en het 'therapeuten-perspectief', een relatieve plaats en betekenis toekomt. Ook blijkt hoe de bepertere referentiekaders, vanuit die ruimere zingevingsdimensie, met elkaar in verband kunnen worden gebracht. De conclusie waartoe dit leidt is dat een dualistische zienswijze op de mens tegenover organisaties of vice versa moet worden bekritiseerd. Het bleek juist een'non-dualistische' optiek te zijn die de doelstelling van gezamelijk gewin van het uitwisselingsproject mogelijk heeft gemaakt, opdat de bevindingen uit dit project aan inzicht in en verbetering van de organisationele en maatschappelijke posi-tionering van creatief therapeuten en creatieve organisatietrainers ten goede komen. Een 'dualistische optiek' leidt tot de aangegeven dichotomisering van perspectieven en in het verlengde hiervan de veronderstelde tegenstelling tussen absoluut opgevatte processen van rationalisering versus humanisering. De creatieve werkvormen geven aldus op narratief-existentiële wijze vorm aan een kritisch humanisme. Andersom zijn creatieve trajecten in therapie en training op te vatten als maatschappelijk-historisch ontwikkelde dialoogvormen waarin veranderingsmetaforen en ontwikkelingsperspectieven op democratische wijze worden gegenereerd.

De onderzoeksresultaten wijzen ook op een 'filosofische winst' uit het uitwisselingsproject voor de praktijk van de deelnemende professionals. Het onderzoek heeft bijgedragen aan 'bewustwording' van de veelal onbewust ingenomen theoretische positionering van trainers en therapeuten en de vaak onduidelijke organisatorische plaats van creatief therapeuten. De filosofische winst is verzilverd in de vorm van de explicitering van vier ontologische metaforen en vier veranderingsmetaforen met betrekking tot 'de communicatiekloof tussen management en werkvloer', alsmede door een uitleg van de waarde van narratieve metaforen - in het bijzonder de spel- en dichtermetafoor - met betrekking tot 'de meerwaarde' van creatieve therapie. Mede door de dialoog met organisatietrainers hebben creatief therapeuten ideeën kunnen ontwikkelen hoe 'de crisis in de gezondheidszorg tot een kans om te buigen'. Bijvoorbeeld door aan de hand van de 
zijnskwaliteiten-metafoor een (metaforisch) 'handelmerk' of 'professioneel motto' voor de eigen praktijk te ontwerpen. Op basis van de onderzoeksdialoog is een kritisch perspectief ontwikkeld om in de context van de verzakelijkte zorg op een meer 'commerciële manier' met het vak om te gaan, zonder aan de humanistische grondslag van creatieve therapie geweld te hoeven doen. De groep creatieve organisatietrainers bleek grotendeels zelf de gewenste professionele kundigheid als tegenwicht tegen de eenzijdige instrumentele optiek in organisaties reeds in huis te hebben of te gaan ontwikkelen. Wel kwam uit de groepsbijeenkomst met deze respondenten naar voren dat er behoefte bestaat aan een 'organisationele inbedding' voor samenwerking, 'netwerken' en belangenbehartiging. Uit de telefonische na-interviewronde bleek dat een nieuw samenwerkingsconcept van twee respondenten voor het andere werkveld van creatieve organisatietrainingen tot stand is gekomen naar aanleiding van de groepsbijeenkomsten.

Aldus kan worden besloten dat de filosofische thema's uit de theoretische analyse relevant zijn voor de praktijk. De dialoog met de onderzochte praktijk heeft mij als onderzoekster geholpen de relevantie van filosofische thema's voor de praktijk op een meer verstaanbare wijze te verwoorden dan ik in eerste instantie geneigd ben te doen. Hierdoor is mijn begrip niet alleen van de onderzochte praktijk verdiept, maar ook van de filosofische thema's zelf. Bovendien hebben deze thema's door het veldonderzoek een met de 'praxis' verrijkte betekenis verkregen. Deze laatste conclusie ten aanzien van de dialectiek tussen filosofie en praktijk vormt het centrale thema van het zesde hoofdstuk. 


\subsection{Inleiding:}

Het laatste hoofdstuk is gewijd aan reflectie over het afgelegde onderzoekspad. Daartoe worden de onderzoeksresultaten uit het veldonderzoek teruggeplaatst in het filosofische kader dat aan de onderzoeksopzet ten grondslag ligt. Centraal staan de vragen hoe de verhouding tussen het onderzoekskader en de onderzochte praktijk door het gevolgde onderzoekstraject is veranderd en wat filosofie en empirie voor elkaar hebben betekend.

Het onderzoekspad ziet er in vogelvlucht als volgt uit. De onderzochte creatieve trajecten in het kader van therapie en organisatietrainingen zijn in het eerste hoofdstuk als vormen van 'metaforische praktijkkennis' geïntroduceerd. Daarbij heb ik aangegeven hoe de onderzoeksvraagstelling naar de 'meerwaarde' van deze kennisvorm zowel een methodologische als een ideologie-kritische betekenis heeft. Met behulp van de hermeneutiek is de 'middenkoers' uitgezet tussen een eenzijdige romantisch-intuittieve en een eenzijdige rationalistisch-positivistische benadering van de onderzoeksvraag. De hermeneutische middenpositie is in het vierde hoofdstuk filosofisch uitgewerkt tot een 'dialogische grondhouding'. Aan de hand van het zich aldus gevormde onderzoekskader is de 'metaforische kennisvorm' zowel theoretisch via een literatuuranalyse in hoofdstukken twee en drie als praktisch onderzocht in de vorm van het in het vijfde hoofdstuk beschreven veldonderzoek. Hoe de theoretische en de praktische analyse, hoe hermeneutiek en empirie zich in het kader van dit onderzoek tot elkaar hebben verhouden, vormt het onderwerp van dit laatste hoofdstuk.

Een reflectie op het afgelegde onderzoekspad, waarbij de fundamentele betekenis van de dialoog centraal staat, volgt in de tweede paragraaf. In de derde paragraaf wordt de dialogische wending naar de praktijk voor het filosofische denken uitgewerkt. Vervolgens is de vierde paragraaf gewijd aan de betekenis van de dialoog voor creatieve therapie. Hoe de dialoog de creatieve ondersteuning van organisatieprocessen kan verrijken staat in de vijfde paragraaf. Daarna volgt in de zesde paragraaf een toelichting op de gemeenschappelijke basis van de onderzochte creatieve trajecten in therapie en training onder de noemer van 'narratief ervaringsgestuurd leren'. In de zevende paragraaf mondt het dialogische perspectief op de creatieve trajecten in therapie, training, coaching en advisering uit in 
enkele aanbevelingen voor de praktijk. Samenvatting en conclusie sluiten het boek af.

\subsection{Een dialogische wending in organisaties, therapie en filosofie}

Wanneer ik het afgelegde onderzoekstraject beschouw komt als centraal thema de dialoog naar voren. Deze grondslag voor de 'creatieve trajecten' in therapie en organisaties is primair filosofisch uitgewerkt. Vanuit de dialoog is het mogelijk om eenzijdige intuittief-romantische èn opportunistisch-instrumentele benaderingen van veranderingsprocessen te voorkomen of tegen te gaan. In dit onderzoek is de typische wijze van interactie via de taal van het creatieve medium opgevat als het genereren van retorische betekeniseffecten door middel van 'levende metaforen' in een dialogische context met het oog op organisatorische of therapeutische doelstellingen.

De literatuuranalyse in hoofdstukken twee en drie laat voor beide onderzochte sectoren een analoog maar complementair beeld zien. In de context van creatieve therapie betekent de dialoog de toevoeging van een reflectief-communicatief moment aan de gevoelsmatig-intuittieve therapeutische interventies. Onder invloed van maatschappelijke veranderingen en reorganisaties in de (geestelijke) gezondheidszorg zijn er alternatieve benaderingen van creatieve therapie ontstaan ten opzichte van de van oorsprong dominante humanistische oriëntatie. Een belangrijke ontwikkeling vormt de toegenomen belangstelling voor een instrumentele en pragmatische aanpak van therapeutische veranderingsprocessen. In dat verband is gesteld dat de dialogische invalshoek eveneens een drempel opwerpt tegen een te eenzijdige interpretatie van deze benadering, leidend tot een opportunistischstrategische optiek. Als conclusie uit de literatuuranalyse is gesteld dat de ontwikkeling van de derde kunstgecentreerde invalshoek op creatieve therapie het meeste recht doet aan de 'eigen aard' van het interactieproces via het creatieve medium. In praktische zin betekent de dialoog een 'richtsnoer' voor de ontwikkeling van communicatieve en leidinggevende kwaliteiten van de creatief-therapeut, ten behoeve van interdisciplinaire samenwerking, onderhandelen en beleidsmatig denken in de context van de gereorganiseerde gezondheidszorg. Als conclusie uit het derde hoofdstuk, de literatuuranalyse van het organisatie-discours, is naar voren gekomen dat de dialoog een veiligheidsmarge inbouwt tegen eenzijdig opportunistisch metafoorgebruik. De dialogische communicatievorm, zoals die bijvoorbeeld in 'het 'Socratische gesprek' een procedurele vorm heeft gekregen, geeft aan hoe een structureel communicatief (onder)handelend moment een buffer biedt om de 'kolonialisering' van metaforische benaderingen van organiseren door de instrumentele rede tegen te gaan. Het kunstgerelateerde medium, als 'derde gesprekspartner' in (non)verbale interactieprocesen in creatieve trajecten in organisatietrainingen, geeft structureel vorm aan het dialogische moment van 'openheid' en 'betrokkenheid' in communicatie. Voor beide contexten draagt de dialoog aldus op verschillende wijze bij aan de vorming van een thumanistisch 
communicatiekader' om communicatieve waarden uit de leefwereld te verzoenen met eisen van een dominante organisatorische systeem-rationaliteit.

Vanuit de dialogische invalshoek is in het vijfde hoofdstuk in het kader van het veldonderzoek het verschil tussen de 'creatieve trajecten' in beide sectoren gerelativeerd als verschillende toepassingen van een fundamenteel overeenkomstige vorm van 'narratief ervaringsgestuurd leren'. De evidente verschillen tussen de organisatorische en de therapeutische vorm van 'ervaringsleren' zijn vanuit een kritisch-humanistisch gezichtspunt veeleer contextueel van aard. Als zodanig definieert een 'therapie'- of een 'trainings'-doelstelling de contextuele vormgeving van een 'creatief traject': er wordt in beide contexten weliswaar een andere taal gesproken en er spelen andere vraagstukken, maar overeenkomstig is de fundamentele existentiële aard van (non)verbale communicatie- en interactieprocessen. Een 'creatief traject' geeft met andere woorden aan deze existentiële grond een aan de betreffende doelgroep en doelstelling aangepaste vorm. Om het dialogische fundament van het 'narratieve ervaringsgestuurde leren' te concretiseren zijn op basis van het uitwisselingsproject concrete metaforen uitgewerkt: de zijnskwaliteiten-metafoor, de spelmetafoor en vier ontologische metaforen. Aan de hand van deze metaforen is de kritisch-humanistische vormgeving van de dialoog gethematiseerd als een vorm van 'narratief ervaringsleren' in het kader van therapie en organisatietrainingen. Aldus is er een empirische herinterpretatie gegeven van de hermeneutische speelruimte door de tegenstelling tussen een 'naïef humanisme' en de in organisaties dominante 'strategische optiek' uit te balanceren tot een kritische vorm van authentieke communicatie. Zijnskwaliteiten zoals plezier, vitaliteit, openheid, speels denken, humor, verbeelding, betrokkenheid en bezieling kleuren de existentiële grond en een door trainer en therapeut belichaamde vorm van 'authenticiteit' houdt de communicatieruimte open.

De 'empirische winst' uit het veldonderzoek heeft de dialoog als filosofisch fundament 'aangekleed' en toegesneden aan de hand van concrete metaforen, organisatie- en levensverhalen. Fundamenteel voor de dialogische balans tussen communicatieve en instrumentele waarden is een kritisch humanistische 'dimensie van zingeving' die het conventionele (therapeutische of organisatorische) referentiekader in de betreffende organisatie 'transcendeert'. Vanuit die ruimere zingevingsdimensie worden spelelementen in relatie tot systeemelementen gebracht. Soms komen de ludieke elementen van plezier en (ont)spanning in de creatieve werkvorm op de voorgrond; soms staat de organisatorische of individuele 'leerdoelstelling' voorop en zijn ludieke elementen veeleer dienstig daaraan. De vanuit een kritisch-humanistische zingevingsdimensie vormgegeven creatieve werkvorm markeert de ideologische krachtenmeting tussen strategisch en communicatief handelen; ze activeert een methodische balans tussen zingeving en zinspeling. Op basis van het veldonderzoek is zicht gekomen op organisatorische, methodologische en ideologische randvoorwaarden voor het realiseren van die balans. Hiermee is empirisch inhoud gegeven aan de filosofische uitkomst van het onderzoek dat de professionele vormgeving van 'creatieve trajecten' balanceert 
tussen een dionysische gevoelsmatig-intuïtieve houding van overgave aan en een appolinische beheersend-reflectieve afstand tot de praktijk. De systeem-rationele eisen waaraan therapeutische of organisatorische doelstellingen worden afgemeten zijn op basis van de ruimere zingevingsdimensie principieel gerelativeerd: ze verkrijgen op basis van het kritisch humanisme een toegemeten plaats en een existentiële, aan het creatieve medium gerelateerde betekenis.

\subsection{Speels denken en het andere van de rede}

Wat betekent de dialogische wending voor onderzoek en voor filosofie? In plaats van de traditionele supprematie van theorie boven praktijk is er in dit onderzoek een dialoog tussen beide ingesteld. Bij gevolg is de onderzoeksopzet niet voorafgaande aan en los van de onderzochte praktijk opgesteld, maar in wisselwerking ermee. De dionysische 'kerncompetentie' van de respondenten betekende een uitnodiging aan de onderzoekster om minder ernstig met filosofische grondvragen om te gaan, om speelser te denken en beeldend-buigzame concepten te vormen. Voor de filosofie betekent de dialogische wending naar de praktijk dat zij een spiegel voorgehouden krijgt waarin de bespiegelende geest zijn eigen denkbeweging kan begrijpen. Nu de filosofie niet langer aan haar traditionele 'mission statement' is gehouden om als onbewogen geest te reflecteren over menselijke zieleroerselen, is er plaats ingeruimd voor bevlogenheid en bewogenheid. De filosofische zoektocht hoeft zich niet meer te richten op een eeuwig en onveranderlijk ijkpunt buiten de aarde, waaraan de bewegingswetten van aardse veranderingen kunnen worden afgemeten.

Waar is het beginpunt in de kringloop van smeltend gletsjer-water, van de brede rivieren die naar zee stromen, waar regenwolken weer terug naar het land drijven en boven de bergen eeuwige sneeuw laten vallen? IJken is een zich verplaatsend rustpunt in de eeuwige kringloop door ijs ijs te noemen, water water en een sneeuwlucht lucht. 'IJken' komt van het latijnse aequare, het gelijk-maken van wijncultuur en handel, stroomopwaarts langs de rivieren de Rijn, de Maas en de Moezel. IJken is het gelijk-maken van wat gelijkt op of grenst aan maar niet is. Door niet alleen maar met de stroom van het water mee te gaan, maar met de boot voor anker en met je voeten in het water, kun je de stroming en haar kracht voelen.

Wanneer de filosofie trouw aan de aarde wordt figureren de lang buiten het academische pantheon gesloten goden en godinnen Dionysos, Bacchus, Aphrodite en Artemis weer naast Apollo en Athena. Pas dan kan de filosoferende geest de eigen beweging èn bewogenheid in beeld en tot begrip brengen. Het traditionele beeld voor de dynamiek van de geest is een rechtlijnige ontwikkelingstrap omhoog die voor alle mensen en alle culturen gelijkelijk zou gelden. De trap leidt van het kinderlijke en primitieve beelddenken naar een volwassen en westers geestelijk stadium van abstract denken tot aan de transgressieve kruisbestuivingen van bio- 
technologie en kunstmatige intelligentie. Langs een rationalistische meetlat heeft men culturen en 'tijdgeesten' afgemeten en tegen elkaar afgewogen, waardoor er een 'opmars der beschaving' leek plaats te vinden. Hierbij scoren 'mannelijke exemplaren' van de soort, vooral die uit noordelijke en westelijke regionen, hoger dan 'vrouwelijke', vooral wanneer ze uit zuidelijke en oosterse werelddelen stammen. De gestrengheid en rechtlijnigheid waarmee deze meetlat gehanteerd is, maakt het verleidelijk om haar romantisch om te keren en 'de vrouwelijk intuitie', 'de oosterse mystiek' en 'de zuivere ziel van natuurvolken' positief te discrimineren. Zo heb ik mij door ideeën van een Indiaanse natuurfilosofie en van Heideggers 'zijnsdenken' laten inspireren, tot de daad-werkelijke ontmoeting met mensen uit andere culturen mij heeft aangespoord om Nietzsche's gedachte van een 'herijking' van traditionele waarden serieus te nemen en ruimte te maken voor andere ontwikkelingsbeelden.

Tegen deze achtergrond heeft de dialoog met de onderzochte praktijk, vooral de creatief-therapeutische speelse dialoog met de verbeelding, met gevoelsbeelden en beelddenken, mij gewezen op het belang van de incarnering van ideeên. De metafoor heb ik als 'model' gebruikt om een voorstelling te maken van deze tegenbeweging, deze 'tegenoverdracht' van een 'materialisering en emotionalisering van de geest'. Uit de onderzoeksdialoog is gebleken dat deze modelmatige voorstelling op te zware filosofische concepten steunt. De verbinding van conceptuele kennis met de door creatieve, 'nondiscursieve' kennispraktijken uitgedragen 'kennis van het hart' kan tot een lichtvoetiger filosoferen inspireren. De dialoog tussen filosofie en empirie creẻert een dubbele onderzoekende beweging van idealisering èn materialisering. Een gelijkwaardig gesprek tussen filosofische stemmen en de weerbarstige praktijk laat een weefsel ontstaan met als schering denkbeelden en abstracte concepten en als inslag gevoelsbeelden en beeldnarratieven. Een empirisch verankerde filosofie berust op een krachtenspel van regressieve, progresieve en transgressieve (schijn)bewegingen van de geest en daadwerkelijke bewogenheid, tot een dans van intuïtie en ratio, van verbeelding en verwoording, van eindigheid en oneindigheid, van goden en mensen. Door die dans herkent de geest zich in wat niet meer is en in wat ooit zal zijn, een eeuwig worden...

\section{Ecce homo}

Jal Ich weiss, woher ich stamme!

Ungesättigt gleich der Flamme

Gluhe und verzehr ich mich.

Licht wird alles, was ich fasse:

Kohle alles, was ich lasse:

Flamme bin ich sicherlich.'

1. Nietzsche: Die Frohliche Wissenschaft in: Werke II 306. 
Kleuren en vormen spreken de geest aan. De geest spreekt zich met expressieve beelden uit. Met het krassen op papier, het vormen van de klei, het schaven van het hout 'be-tekenen zich' lichaam en geest. Het beeldende vormgeven is de dialoog tussen lichaam en geest met stemmen van emoties, ideeën, lichamelijke gewaarwordingen, verbeelding, intuitties, gedachten en aandriften. De beeldende beweging op en in het materiaal creëert een spanning tussen beelddenken en denkbeelden. Dit spanningsveld genereert beeld- en begripsvorming, leidt tot bevlogenheid en beweegredenen. Lichaamsbeweging, emotionaliteit en verbeelding spreken een andere taal dan de rede met rationeel afgemeten woorden en begrippen. De rationele geest wil weten of de taal van vormen, kleuren en beeldnarratieven 'a-' of 'irrationeel' is. Om deze 'nondiscursieve' taal niet tot verbale, discursieve en rationele registers te reduceren moeten we haar eerst leren verstaan. In creatief therapeutische en trainingstrajecten geven deelnemers aan de dialoog van lichaam en geest een stem. Dan kan het gesprek tussen ons lichamelijk en geestelijk zijn leiden tot een kleuren- en vormenspel, zoals de wind het water beweegt. Soms dreigt dit polyfone spel in een strijd te ontaarden en wil de kracht der rede haar 'achterkant' overwinnen door 'het redeloze' te overstemmen. De ratio komt wellicht als verliezer uit die strijd tevoorschijn omdat de aan het lichaam gebonden krachten de taal van de ongetemde natuur spreken. Een ludieke krachtenmeting tussen lichaam en geest via de dialoog met creatieve middelen creèert de speelruimte om ons met het absurde, het tragische en het extatische van het bestaan te verzoenen, uitmondend in natuurbeelden, kosmische mythen en in de dramatiek van levensverhalen.

Om die krachtenmeting evemin in koude oorlog of in strijd te laten omslaan is er een dubbele beweging nodig, een verankering van de geest in het lichaam èn een lichaamsbewustwording. Dan ontstaat er ruimte voor andere ontwikkelingsnarratieven die niet uitgaan van de supprematie van 'de Westerse beschaving'. ${ }^{2}$ Deze dubbele beweging vooronderstelt een 'angstvrije staat van zijn' zoals die bijvoorbeeld door Krishnamurti is gekarakteriseerd in het citaat aan het einde van het derde hoofdstuk. ${ }^{3}$ We kunnen immers het samenspel van regressieve, progressieve en transgressieve krachten slechts ogenschijnlijk beheersen. Dionysos vraagt om pure overgave aan het natuurgeweld in en om onszelf. Apollo biedt tegenspel zodat de krachtenmeting als dynamiek in beeld komt. Hermes cultiveert ontvankelijkheid èn expressiviteit in dialoog met dit krachtenspel. Deze balanceerkunst voegt beweging en bewogenheid, waarneming en gewaarwording, beelddenken en denkbeelden tot een meanderende stroom aan één. Wanneer ik de krachten in en rond mij voel, mij bewust word van de stromingen waarin lichaam en geest zijn opgenomen, van de vele stemmen in en om mijzelf, van alle gewaarwordingen in en aan mijn lichaam, van 'hetgeen' of 'degene' die zich hiervan bewust wordt... verschijnt daar niet Hermes vanuit het hart om te bemiddelen tussen kosmos en het

2. Bijvoorbeeld Gebser: Ursprung und Gegenwart I, II. Forbes: Columbus and Other Cannibals.

3. Zie p. $145-146$ 


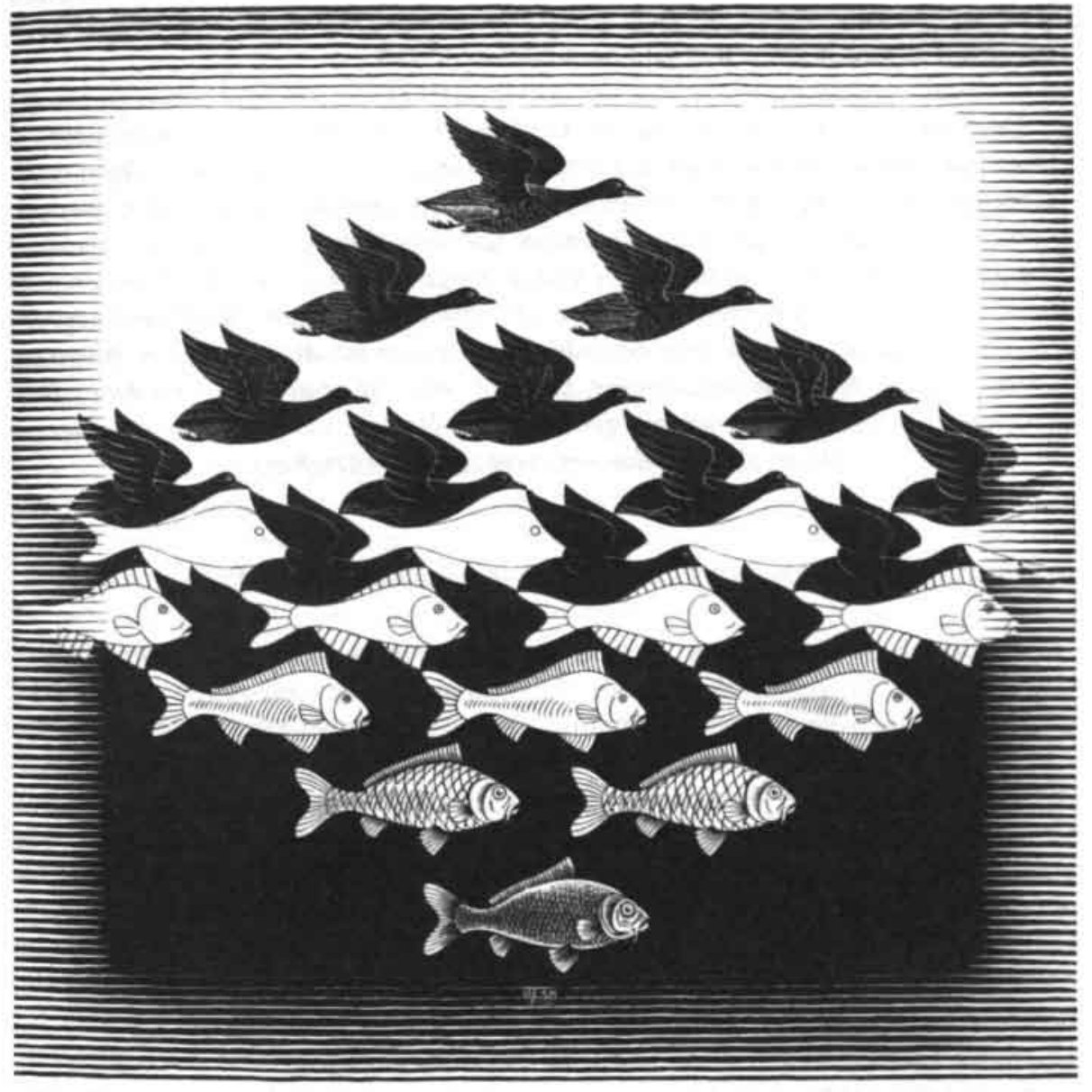


ondermaanse, tussen goden en mensen, tussen hemel en aarde, tussen eeuwigheid en tijd? Hermes verbindt de eeuwige en volmaakte goddelijke wereld met het veranderlijke en tijdelijke zijn in het ondermaanse; hij is bemiddelaar in de strijd tussen goden en mensen. In Griekse mythen wordt vaak verteld hoe goden op mensen vertoornd raakten wanneer zij in overmoed en hovaardij de menselijke maten overschrijden. Sisyphus gewaagde het met de Dood te spelen en werd daarvoor, zoals bekend, met een zware 'Sisyphus-arbeid' bestraft. Arachne had de arrogantie om met de goddelijke weefkunst te wedijveren en te spotten, waarmee zij de woede van Athena op zich afriep. Haar metamorfose tot een spin was het resultaat. Hermes is soms met zijn bemiddeling te laat.

Daar zie ik Hermes met zijn herdersstaf, die net de grens van het moerassige therapieland nadert nadat hij de rebelse provincie van organisatiekundigen met hun fallische creativiteitstotem heeft verlaten. Hij heeft zijn missie volbracht om

vrede te stichten tussen de rivaliserende heersers Koning Logos en Koningin Metaphora. Nu gaat hij op het puntje van de enige rots in het moeras zitten en pakt

zijn panfluit. Ik voel een huivering als hij zijn melodie inzet. Beloftevolle en troostrijke klanken snijden door de stille nacht. Boven het drassige water vliegt een roepende uil. De echo van Hermes' panfluit versterft en de laatste nachtnevels verdwijnen in het prille ochtendgloren. Als ik Hermes wil begroeten ligt daar alleen zijn staf die weet van zijn aanwezigheid...

\subsection{Naar een dialogische intuïtie voor creatieve therapie}

De dialogische wending in de context van creatieve therapie biedt een richtsnoer zowel binnen de therapiekamer als daarbuiten om de eenzijdige romantische oriëntatie op een gevoelsmatige intuìtie aan te vullen met structurele momenten van reflectie en communicatie, zonder in een opportunisme door te schieten. 'Binnenskamers' heeft de dialoog gestalte gekregen in het (non)verbale gesprek van cliënt, therapeut en creatief medium. Deze dialoog wordt geverbaliseerd in de vorm van zogenaamde 'nabesprekingen' van beeldende werkstukken en de 'cliëntenevaluaties' over de creatief therapeutische behandeling. De specifieke dialoogvormen en behandelprocedures worden afgestemd op de (on)mondigheid van de cliëntenpopulatie, op de eigen aard van de psychische problematiek en op de organisatorische setting. Binnen de therapiekamer is de creatief therapeut in het algemeen zeer autonoom zodat $z(h) i j$ de beeldend-therapeutische dialoog met de cliēnt en het creatieve medium naar eigen intuittie en inzicht kan vormgeven. Hoe deze dialoog 'buitenskamers' (in)formeel met collega's en medebehandelaars wordt gevoerd is sterk afhankelijk van de 'organisatiecultuur' en het behandelbeleid van de betreffende instelling. Het is bijvoorbeeld niet overal vanzelfsprekend dat creatief therapeuten structureel aanwezig (mogen) zijn op overleg- en besluitvormings-momenten. Voor zover zij dat wel zijn wordt de creatief-therapeutische dialoog veelal 'vertaald' in het dominante psycho-therapeutische referentiekader. De ontwikkeling van een 'beeldend' referentiekader en een profes- 
sionele visie op het vak is van belang om 'buitenskamers' tegenwicht te bieden tegen een mogelijk onderdrukkende en beperkende invloed vanuit de organisationele context. Daarnaast heeft 'de dialoog' betrekking op intercollegiale uitwisseling ten behoeve van de professionalisering van creatieve therapie (zoals studiedagen, workshops, werkgroepen, onderzoek, nascholing, etc.) om het vak als een vakdeskundigheid boven het niveau van 'intuittief handelen' en 'creatieve hobbyvorming' uit te tillen. Resumerend vertegenwoordigt 'de dialoog' de noodzaak van reflectie op, systematisering en profilering van de metaforische praktijkkennis van creatief therapeuten.

De ontwikkeling van een dialogische intuitie is van belang voor de vraag wat de organisatorische plaats en status van creatieve therapie zal zijn na de huidige reorganisatie van de zorg. Hebben de 'beeldnarratieven' die cliënten in het kader van creatieve therapie ontwerpen daadwerkelijk een therapeutische werking ten behoeve van het genezingsproces 'bovenop' het plezierig 'creatief bezig zijn'? Omdat de geschiedenis van het vak reeds ('klinisch') heeft bewezen dat creatieve therapie een therapeutische waarde heeft moet deze vraag anders worden geformuleerd. Om de therapeutische waarde 'waar te maken' is er een bewustwordingsproces ten aanzien van de organisatorische context onder creatief therapeuten nodig zodat zij een breed 'politiek draagvlak' kunnen genereren om deze therapievorm een (gelijk)waardige en duidelijke plaats binnen de instelling te geven. Met behulp van een 'beeldend' referentiekader kan 'de toegevoegde waarde' van creatieve therapie aan cliënten, collega therapeuten, behandelaars, verzekeraars en politieke groeperingen verstaanbaar worden gemaakt op een wijze die recht doet aan de 'eigen-aard(ig)-heid' en de humaniserende waarde van het creatieve medium.

Andersom creëert een door de instelling uitgedragen zorgvisie de ruimte dat creatief therapeuten een humanistisch communicatiekader kunnen (blijven) bieden voor cliënten. Een zorgvisie kan paal en perk stellen aan de alomtegenwoordige marktwerking, die nu ook binnen instellingen tussen de veschillende (para) medische en therapeutische disciplines is doorgedrongen. De achterliggende idee is om op basis van 'het marktdenken' de gezondheidszorg weer financiëel en organisatorisch gezond te maken. Deze maatregel schiet haar doel voorbij wanneer patiëntenzorg geheel vertaald wordt naar een kwantificerend en doel-rationeel kader. De legitimeringsvraag ten aanzien van 'alternatieve' behandelvormen wordt vanuit dat kader tot een rekensom met betrekking tot de relatieve 'patiëntenload' teruggebracht. Door die rekensom wordt de patiënt een klant die als consument 'op maat gesneden zorgpakketten' inkoopt. Die klant mag dan wel koning wezen, evenwel wordt er, vanuit kritisch humanistish perspectief beschouwd, aan 'de mens' achter de consument onrecht aangedaan.

De dialoog tussen beleidsmakers en creatief therapeuten is een aangewezen weg om binnen de instelling een humanistisch geïnspireerd èn kritisch antwoord te geven op de rationalisering van de zorg. Het kritisch humanisme ziet de mens als 
een wezen dat 'meer' is dan 'consument' en 'producent' van 'creatieve producten' en (geestelijke) gezondheid als wezenlijk anders dan 'produceerbare waar'. Wanneer humanistische waarden, van hun 'romantische stempel' bevrijd, in de 'reorganisatorische dialoog' worden gerehabiliteerd, kan er een adequaat antwoord op de legitimeringsvraag worden gegeven. De huidige (geestelijke) gezondheidszorg vraagt van creatief therapeuten om 'de romantische oorsprong' van creatieve therapie in haar geschiedenis mee te nemen, zonder in het andere extreem van opportunisme en strategisch handelen te vervallen.

Een laatste betekenis krijgt 'de dialoog' gegeven de huidige maatschappelijkpolitieke constellatie om een Europees en wellicht een globaal toekomstperspectief op creatieve therapie te formuleren. De vervaging van landsgrenzen ten gevolge van globalisering, de vluchtelingen-problematiek en andere ('achterkant'-) aspecten van de 'multiculturele samenleving' nopen daartoe. Andersom vertegenwoordigt creatieve therapie in potentie een lands- en cultuurgrenzen overschrijdende waarde om psychische noden van onze tijd te beantwoorden. Dit is een aantrekkelijk en zinvol maar niet eenvoudig toekomscenario voor creatieve therapie. De sociale, economische en politieke drempels die bij de invoering van de Euro in het kader van de 'eenwording van Europa' opdoemen, lijken mij een lichte afschaduwing te zijn van de problematiek en compexiteit die in verband met de internationalisering van creatieve therapie aan de orde zullen zijn. ${ }^{4}$

\subsection{De dialogische verrijking van de organisatorische rede}

Het resultaat uit de literatuuranalyse in het derde hoofdstuk wijst op het belang van een dialogische aanvulling van de eenzijdige instrumentele oriëntatie in het organisatie-discours. Als een antwoord op deze eenzijdigheid in het benaderen van organisatie-vraagstukken is er 'een dialogisch principe' geformuleerd, dat aan democratische besluitvorming in onderhandelingsprocessen bijdraagt. In deze hoedanigheid helpt de dialoog voorkomen dat metaforen als managementtools op 'dictatoriale' wijze voor organisatiedoeleinden worden ingezet. Uit het veldonderzoek is gebleken dat de vertaling van het filosofische fundament tot een concrete dialoogvorm voor de betreffende organisatie 'op maat' gesneden zou moeten worden. Aan de operationalisering van 'de dialoog' tot communicatieprocedures en reglementen met betrekking tot organisatorische besluitvormingsprocessen (bijvoorbeeld in de vorm van inspraakmiddagen, congressen, teamvergaderingen, werkgroepen, enz.) kleeft het gevaar dat de 'filosofische blauwdruk' dusdanig geinstrumentaliseerd wordt dat aan haar communicatieve doel voorbij geschoten wordt. Met het oog op dit gevaar ken ik aan haar filosofische betekenis, de oningevulde en daardoor tot concretisering uitnodigende 'open en betrokken gesprekshouding' het primaat toe. Aspecten hiervan worden in de onderzochte creatieve trainingstrajecten gecultiveerd en bieden als zodanig een

3. Zie bijvoorbeeld: Waller: Towards a European Art Therapy. 
tegenwicht tegen de tot in extremo doorgevoerde rationalisering van ons werkleven.

In het vierde hoofdstuk is het dialogische principe hermeneutisch uitgewerkt tot een dialogische grondhouding als filosofische grondslag voor de creatieve trajecten. In dat verband is beschreven hoe rationaliseringsideeën oorspronkelijk een bevrijdingsmetafoor bevatten. Door de ontwikkeling van onze ratio verkrijgen we kennis en macht om de ketenen te verbreken waaraan wij door traditie, bijgeloof en overheersing door machthebbers gebonden zijn. Daarmee zouden we tevens een humanere samenleving creëren. Vanuit die optiek gaat rationalisering hand in hand met een humanisering van mens en maatschappij. Het rationaliseringsideaal heeft tot maakbaarheidsideeën geleid die aan grootheidswaanzin grenzen. De Romantische onttroning van de Rede geeft een 'apocriefe' versie van deze mythe van de 'Rationele Menswording' met antihelden en een tegengestelde plot. Vooral onder invloed van humanistische benaderingen in de psychotherapie heeft 'de romantische onderstroom' zodanige vormen aangenomen dat ze meer is dan alleen een reactionaire tegenbeweging tegen het bewind van Logos. De oude rationaliseringsen humaniseringsidealen van weleer hebben door inflatie aan macht en betekenis ingeboet. In allerlei nieuwe tijdse vormen, interculturele varianten en wereldlijke vertalingen liggen de ontwikkelingsnarratieven binnen ieders handbereik op de welzijnsmarkt. Door te gaan shoppen op de exotische New Age markt kunnen we Germaanse, Indiaanse, Afrikaanse, Hindoeïstische en Boeddhistische mythen en heldenverhalen tot nieuw leven wekken. We zouden de weg van de krijger en het pad van de held kunnen bewandelen, de oude wildeman in ons kunnen vinden of ons bij een heksenkring aansluiten. Een nieuw pantheon omzoomt de weg naar bevrijding en licht ons op onze reis voor. Ligt er een nieuw spiritueel bevrijdingsideaal in het verschiet? Hoe ijken we een 'multiculturele' en 'trans-religieuze' mix zodat er geloofwaardige nieuwe ontwikkelingsnarratieven kunnen ontstaan? Kan een kritisch-humanistisch ontwikkelingsperspectief zorgdragen voor een zodanige vormgeving en exportering van psychotherapeutische en creatieve diensten naar andere maatschappelijke sectoren, dat humanistische waarden niet tot consumeerbare waar uithollen? In de context van organisatietrainingen moet de introductie van zingeving, psychologische ondersteuning en creativiteit immers in balans worden gebracht met instrumenteel denken en een winstgevend bedrijfskader.

In het vierde hoofdstuk is een filosofische weg gewezen om tussen het Scylla van een metafysische versluiering en het Charybdis van een post-modern nihilisme door te koersen. Hier wil ik op de maatschappelijke porté van deze vraag wijzen. Het gevaar bestaat namelijk dat we met de humanisering van ons (werk)leven van de regen in de drup terecht komen en tussen romantische bevrijdingmythen, spirituele cocktails en versluierende idealen blijven ronddobberen. Er is dus een nieuw kompas of een eigentijds oriëntatiepunt nodig. Op basis van de middenpositie zouden we kunnen laveren tussen het conserveren van tradititionele waarden en het opportunistisch 'zappen' tussen culturen en ontwikkelings- 
narratieven. Mijn stelling luidt aldus dat wanneer we geen gemeenschapsvormen cultiveren waarbinnen een dialogische gesprekshouding en authentieke communicatievormen worden ontwikkeld, wij stuurloos blijven ronddolen tussen modegevoelige alternatieve trends èn traditionele hiërarchische lichtbakens voor het besturen van organisaties. Het belang van 'dialogische communicatie' zou op de politieke agenda van organisaties moeten komen. Dan worden de 'creatieve ontwikkelingstrajecten' zodanig in organisaties geïmplementeerd, dat zij authenticiteit, autonomie en integriteit in communicatie- en samenwerkingspatronen helpen ontwikkelen. Dat zou leiden tot een toekomstperspectief waarin de rehabilitering van humanistische waarden tegenwicht kan bieden tegen ziekmakende factoren op de werkvloer en daarmee helpt voorkómen dat mensen langdurig ziek, overspannen of 'burn out' geraken. De onderzochte creatieve trajecten in organisatietrainingen, coaching en loopbaanbegeleiding leveren hieraan een bijdrage voor zover ze op een kritisch humanisme berusten.

In het vijfde hoofdstuk is aangegeven hoe door de narratieve vormgeving van creatieve trajecten de 'dialogische randvoorwaarden' voor authentieke communicatie worden geconcretiseerd. Deze randvoorwaarden dienen weliswaar binnen het instrumentele kader van een managementdoelstelling te worden geoperationaliseerd, maar ze vinden hun 'oorsprong' in een existentiële dimensie, die vorm krijgt door de dialoog met het creatieve medium. Beide extreme oriëntaties kunnen dialogisch met elkaar in balans worden gebracht vanuit een ruimere dimensie van zingeving. Het gestelde primaat van het filosofische resp. het kritisch humanistische fundament mag evenwel niet leiden tot een 'blinde vlek' voor praktische sociaal-psychologische aspecten van de dialoog. Dit is bijvoorbeeld duidelijk geworden met betrekking tot het machtsvraagstuk en de status quo van normen en waarden in organisaties. De psychologische begeleiding en motivatie van deelnemers bij het invoeren van een dialogische communicatievorm zijn cruciaal voor het welslagen ervan. Wanneer deze sociaal-psychologische en organisatorisch-maatschappelijke 'randvoorwaarden' voor dialogische communicatie uit het oog worden verloren, kan de 'blauwdruk' er op papier nog zo mooi uitzien, maar vertelt de praktijk een ander verhaal. Een Zweeds project illustreert dit, waarin op basis van Habermas' communicatietheorie een experiment was opgezet ter verbetering van de 'communicatieve infrastructuur', hetgeen zou bijdragen aan de vernieuwing van organisatorische processen en aan werknemerparticipatie. Dit zogenaamde LOM-programma (dat staat voor 'Leiderschap, Organisatie en Medezeggenschap') was zeer groots en ambitieus opgezet, maar vertoonde in haar uitvoering een fundamentele zwakke plek die vooral te maken had met een gebrek aan structurele psycho-sociale ondersteuning van het beoogde veranderingsproces. ${ }^{5}$

4. Naschold (c.a.): Constructing the New Industrial Society, Social science for social action: toward organizational renewal 106-131. 


\section{6 (G)één maat voor metaforen?}

In het kader van het 'uitwisselingsproject' is het vanzelfsprekende onderscheid wat betreft de professionele identiteit tussen creatief therapeut en creatieve organisatietrainer ter discussie gesteld. Beide professies zijn gespecialiseerd in de creatieve vormgeving resp. in metaforische communicatie met betrekking tot psychische problemen of problematische situaties op het werk. Het oordeel van de ondervraagde professionals is echter dat er een fundamenteel verschil tussen beide blijft bestaan. Mijn kanttekening hierbij - dat dit verschil meer te maken zou kunnen hebben met de context van toepassing - wordt in deze paragraaf toegelicht als vraag naar de maat voor metaforen in communicatie en interactie. Voor zover de dialoog maatgevend is voor de aard van 'metaforische communicatie', geeft dit criterium geen 'maat' in de traditionele zin van het woord. Aldus dynamisch gerelativeerd aan een dialogisch proces, verschijnt dit ijkpunt vanuit kritischhumanistisch perspectief als (g)één maat van 'authenticiteit' in communicatie- en veranderingsprocessen.

Mijn stellingname impliceert dat het verschil tussen een therapeutische en een organisationele vormgeving secundair is ten opzichte van de primaire psychodynamische en creatieve processen die in het kader van het 'narratieve ervaringsgestuurde leren' plaatsvinden. In beide gevallen genereert de 'dialogische vormgeving' van het 'ervaringsleren' via het creatieve medium een 'narratieve leeromgeving', die hier als 'therapeutische dienstverlening' en daar als 'organisatietraining' wordt verkocht. Is er een principieel verschil op het fundamentele humanistische niveau van existentiēle zingeving wat betrreft de 'dialogische interactie' tussen deelnemers en creatief medium? Welk verschil bestaat er op dit basale niveau van authentieke communicatie wanneer er bijvoorbeeld met muzikale middelen een bedrijfsworkshop 'leren leidinggeven' wordt gegeven of wanneer er wordt gewerkt aan de therapeutische behandeldoelstelling 'het versterken van het gevoel van eigenwaarde'? Zou het kunnen gaan om een contextueel verschil in doelgroepen en doelstellingen? Het is evident dat de therapeutische taal met betrekking tot behandeldoelstellingen verschillend is van de taal die in bedrijven gesproken wordt en dat de beleidsplannen en managementconcepten die beide organisatorische contexten definiëren zich eveneens van elkaar onderscheiden. Niettemin blijkt uit de praktijk dat de overstap naar het andere werkveld met een 'methodische vertaalslag' kan worden gemaakt. $^{6}$ De verhouding tussen beide organisatorische contexten kenmerkt zich onder meer door een verschil in functieomschrijving en een aanzienlijk verschil in inkomstenderving. Bovendien worden er aan deze verschillen allerlei waarde-oordelen en een statusverschil verbonden, zowel voor degene die de therapie of training geeft als degene die haar ondergaat.

5.Volgens respondenten uit het uitwisselingsproject en zie hiervoor ook het themanummer van het Tijdschrift voor creatieve therapie, over Creatieve therapie en de markt (2000) $\mathrm{nr} .4$. 
De professionele inkadering van een creatief traject krijgt hierdoor een retorische lading en een politieke gevoeligheid. Dit kan ertoe leiden dat mensen liever verzwijgen dat ze in therapie zijn en eer behalen met het volgen van organisatietrainingen en coaching.

Het bezwaar van respondenten tegen deze visie is invoelbaar want de geschetste verschillen zijn ogenschijnlijk evident. Niettemin blijt de filosofische vraag bestaan of ze 'fundamenteel' of 'contextueel' van aard zijn. Bovendien wordt het onderscheid tussen 'fundament' en 'context' geproblematiseerd in het licht van dit onderzoek, dat wijst op de 'fundamentele impact' van de 'context' op de aard van de plaatsvindende dialoog. Hierdoor dreigt de vraag (te) academisch te worden. Wat is de filosofische èn praktische porté van de relativering van het commonsense oordeel over het evidente verschil tussen beide professies? Wat heeft tot de relativerende vraagstelling gemotiveerd?

De relevantie van deze onderzoeksvraag is vervat in de met dit onderzoek aannemelijk gemaakte samenhang tussen ideologische en methodologische aspecten van de toepassing van creatieve communicatie- en veranderingsinstrumenten in therapie en organisaties. In het licht van de praktische invalshoek op de 'meerwaarde' van creatieve middelen - bijvoorbeeld als zijnde geïndiceerd voor 'verbaal minder ontwikkelde cliënten' - past het door de respondenten aangegeven bezwaar tegen de relativering van de grens tussen beide professies. Dat bezwaar verwijst naar het feit dat veel doelgroepen in een therapeutische behandelsetting in de regel niet in staat zijn tot een zelfstandig en 'normaal' maatschappelijk bestaan, terwijl deelnemers aan organisatietrainingen en loopbaanbegeleiding als werknemers een psychologisch 'gezond' en maatschappelijk 'geaccepteerd' leven leiden. Wat deze bedenking betreft lijkt er mij niet zozeer sprake te zijn van een absoluut verschil maar veeleer van een glijdende schaal: waar ligt de grens tussen werknemers met klachten van stress, overspannenheid, oververmoeidheid, langzaam opgebouwde burn out, onoplosbare conflicten op de werkvloer, het vastlopen in de loopbaan en mensen die met dergelijke psychische klachten aankloppen bij de hulpverlening? De 'absolute' grens die categoriëen als 'geestelijk gezond' en 'maatschappelijk normaal functionerend' versus 'pathologisch' en 'handelingsonbekwaam' suggereren, is het resultaat van sociale praktijken met een sterke ideologische lading, de 'normaliserende en disciplinerende' machtspraktijken in onze maatschappij. Hier tegenover stelt een kritischhumanistisch perspectief op existentiële zingeving en 'authentieke communicatie' dat er door beide groepen professionals ten aanzien van cliënten in alle gevallen recht moet worden gedaan aan de individuele mens die de therapie of training ondergaat. Dit fundamentele kritisch-humanistische uitgangspunt dient evenwel te worden geoperationaliseerd door middel van een methodische toespitsing van 'authentieke communicatie' op basis van 'vormgevingsverschillen' tussen beide sectoren en 'typen' cliënten. Aan de hand van dergelijke 'contextuele verschillen' wordt de dialoog via het creatieve medium aangepast aan de specifieke hulpvraag in een psychiatrische setting resp. in het kader van coaching, loopbaanbegeleiding, 
training of outplacement. Vanuit dit ruimere perspectief van zingeving blijkt hoe innig methodologische en ideologische aspecten van de omstreden 'meerwaarde' van de creatieve werkvorm met elkaar verweven zijn.

Het onderzoek geeft, tegen de achtergrond van deze discussie, zicht op de fundamentele samenhang tussen methodologische en ideologische aspecten van de onderzoeksvraagstelling naar de 'meerwaarde' van creatieve communicatie- en veranderingsinstrumenten. Creatieve middelen lijken vooral praktisch te worden verkozen wanneer ze methodisch beter op de doelstelling toegesneden zijn dan reguliere of verbale middelen. Ze worden evenwel altijd in het kader van heersende management- en therapeutische doelstellingen toegepast en vertegenwoordigen derhalve ook een 'ideologische waarde'. Wat betreft het ideologische aspect van communicatie is de toepassing van creatieve middelen in beide contexten 'van oorsprong' ingebed in een humaniseringsideaal. De humaniserende 'meerwaarde' kan worden verzilverd wanneer de therapeutische resp. de managementdoelstelling kritisch wordt getoetst aan fundamentele humanistische waarden. Organisatietrainers en therapeuten dragen hiertoe bij wanneer zij creatieve communicatie- en veranderingsinstrumenten niet 'geïsoleerd' methodisch vormgeven maar in de context van de heersende ideologie op 'kritische' wijze toepassen. Dit betekent dat juist op basis van een ideologie-kritische invalshoek het 'narratieve ervaringsgestuurde leren' een verantwoorde methodologisch toegespitste vorm verkrijgt: aan de mens 'achter' de cliënt, in elke context-specifieke setting, moet immers altijd zoveel mogelijk worden recht gedaan.

'Humanisering' krijgt in een therapeutische context evenwel een andere lading dan in de context van het bedrijfsleven, wanneer ze daar als een surplus fungeert voor het (nog) gesmeerd(er) laten verlopen van ons werkleven. De vraag naar het verschil tussen beide sectoren in ideologisch opzicht, wijst op een prangend maatschappelijk probleem. Er dreigen immers steeds meer mensen blijvend van deelname aan het arbeidsproces te worden buitengesloten met als vooruitzicht een bestaan als 'drop out' van de maatschappij op te bouwen. Ook de hulpverlening blijkt vaak wat betreft blijvende en structurele hulp aan deze groepen te kort te schieten. Daarom is het van maatschappelijk belang dat er voor de diverse doelgroepen een zodanig aangepaste variant van 'narratief ervaringsgestuurd leren' wordt gevormd, dat de methodische toepassing integraal met een ideologiekritische toetsing van de organisationele context resp. de behandeldoelstelling plaatsvindt. Langs die weg kunnen eenzijdigheden van de heersende ideologie in organisaties kritisch worden gerelativeerd door middel van humanistisch-communicatieve waarden. Onder die voorwaarde helpt het 'narratieve ervaringsgestuurde leren' een 'humanisering van ons werkleven' bewerkstelligen waardoor werkgerelateerde psychische klachten, zoals stress en burn out, op de lange termijn kunnen verminderen.

7. Een studente creatieve therapie heeft als afstudeeropdracht de beeldende methodiek geoperationaliseerd voor deze cliěntengroep in dit nieuwe werkveld en past dit in haar huidige werkpraktijk toe. 
De samenhang tussen methodologische en ideologische aspecten van creatieve communicatiemiddelen in therapie en training treedt vanuit de omvattende 'dimensie van zingeving' aan het licht. Op basis van het veldonderzoek is deze samenhang gethematiseerd als een kritisch humanisme dat een existentiële interpretatie geeft aan communicatie- en interactieprocessen in therapie en organisatie. Vanuit een positie van 'non-dualiteit' verschijnen belangen en (leer)doelen van individu tegenover organisatie in hun wederkerigheid en afhankelijkheid. Beschouwd vanuit dit ruimere perspectief op beide sectoren, treedt er in het 'narratieve ervaringsleren' een ander relevant onderscheid aan het daglicht dat dwars door de contextuele verschillen heen gaat. Dit heeft betrekking op de vraag: wordt er met de creatieve trajecten entertainment of een leerdoel beoogd? De 'homo ludens' blijkt een Januskop te hebben: Gaat het om een ludiek evenement of om training? Is het doel een plezierige dagbesteding of een (therapeutisch of organisatorisch) veranderingsproces? De in creatieve trajecten geënsceneerde 'levende metaforen' geven een zinspeling aan het leerproces, waardoor er met de gebruikelijke therapeutische en organisatorische doelstellingen een loopje wordt genomen. De indirecte leervorm met haar speelse inslag van plezier, ontspanning en esthetisch genoegen is een flagrante schending van onze calvinistische arbeidsmoraal, waarin 'arbeid adelt, 'de plicht roept' en men zijn brood moet verdienen 'in het zweet uws aanschijns'. De zinspeling treedt pregnant op de voorgrond wanneer het element van entertainment overheerst en leerervaringen naar de achtergrond verschuiven. Vanuit een calvinistische optiek of een ander beperkt referentiekader zou gesteld kunnen worden dat het element van zingeving in die op het genereren van (groeps)plezier gerichte vorm ontbreekt. Op grond van de hermeneutisch ontsloten ruimere 'dimensie van zingeving' blijkt er in de onderzochte creatieve werkvormen soms sprake te zijn van een bijzondere 'configuratie' waardoor zin in en zinvol samenvallen. Aldus volgt er uit dit onderzoek een vernieuwend inzicht dat er in de verschillende vormen van 'training tot entertainment' vanuit een balans tussen zingeving en zinspeling een zodanige vormgeving van communicatie via het creatieve medium kan worden gegenereerd dat ze een 'dialogische grondhouding en 'authentieke communicatie' helpen cultiveren. Of deze balans inderdaad op deze wijze gerealiseerd wordt is echter afhankelijk van de trainer of therapeut die deze kritisch-humanistische grondslag al dan niet belichaamd.

\subsection{Naar een narratieve leeromgeving in organisaties en therapie?}

Deze paragraaf is gewijd aan de vraag welke praktische betekenis 'de dialogische wending' heeft voor de onderzochte 'nondiscursieve kennispraktijken'.

In het proces van professionalisering en profilering van creatieve therapie zijn de volgende belangrijke stappen reeds gezet. De oprichting van een beroepsvereniging en van een vaktijdschrift. De erkenning van de $\mathrm{HBO}$-opleidingen door de overheid. 
Er zijn mogelijkheden voor kwaliteitstoestsing georganiseerd met het ontwerpen en valideren van een beroepsprofiel, alsmede door de organisatie Stichting Register Creatief Therapeuten. Belangrijk voor patiëntenorganisaties, zorgverzekeraars en de inspectie is de instelling van een klachtencommissie en in politiek-maatschappelijk opzicht is de strategische zet relevant om zitting te nemen in de CONOkamer in samenwerking met de vereniging voor psycho motorische therapie ${ }^{8}$. Toelating tot de BIG-wet in verband met de bescherming van de titel en standaard vergoedingsmogelijkheden door zorgverzekeraars zouden volgende belangrijke stappen op de ingeslagen weg kunnen betekenen. Dat er nu een informatieve, professioneel ogende en aansprekende folder over beeldende therapie is uitgegeven, dat de beroepsvereniging een betaalde beleidsmedewerker sinds 1 maart 2000 in dienst heeft en dat is bedongen dat de contributie van leden aan de beroepsvereniging door werkgevers in de geestelijke gezondheidszorg betaald dient te worden, zijn resultaten van de ingezette koers.

Overigens is deze weg van 'externe' samenwerking en belangenbehartiging ook een eenzijdige route, die uiteindelijk zou kunnen leiden tot de ontwikkeling van een dominante instrumentele oriëntatie. Gelukkig zijn creatief therapeuten zich daarvan ook bewust. Op 22 juni 2000 is door de beroepsvereniging een studiedag over de gaande zijnde ontwikkelingen in de geestelijke gezondheidszorg georganiseerd onder de naam Creatieve therapie in beweging: van proces naar product!? De vragen die op deze dag centraal stonden luiden:

- Is procesmatig werken nog passend in deze tijd?

- Hoe gedetailleerd moeten producten beschreven worden?

- Wanneer wordt het een te strak keurslijf?

- Hoe past mijn CT-aanbod in de programma-ontwikkeling?

Het volgende citaat geeft een typerende reactie van scepsis weer op de voorgeschreven beleidsverandering naar een protocolaire behandelvorm:

Protocollen 'ja of nee': Ja.

Waarom: to be or not to be.

Een heerlijk gevoel, zo'n stukje duidelijkheid, dat meteen gevolgd wordt door het vage besef dat je helemaal nog niets beantwoord hebt, maar dat je enkel alle vragen een stukje vooruitschuift: kun je, en zo ja, hoe kun je als vaktherapeut functioneren binnen deze nieuwe structuur, zonder je eigenheid, de essentie van je vak te verliezen?"

Inmiddels is er een stuurgroep module ontwikkeling ingesteld. Voor verdergaande bewaking en verbetering van de professionaliteit is er naast deze 'externe aan-

8. Dit is het orgaan dat advies uitbrengt aan het ministerie over nascholing in de GGZ, zie verslag in Tijdschrift voor creatieve therapie (2000) nr.2, 30 .

9. Ibid. 25. 
sturing' ook een 'intern perspectief' en een vorm van samenwerking nodig die verder strekt dan het niveau van strategisch handelen. Dit kan mogelijk worden gemaakt wanneer de grondslaggevende communicatief-humanistische waarden met betrekking tot creatief therapeutische processen ook als ijkpunt voor (externe) samenwerking en professionalisering worden gehanteerd. ${ }^{10}$ Dit te realiseren, gegeven de huidige 'tijdgeest' van rationalisering van de zorg, betekent een ware uitdaging voor creatief therapeuten.

Welke praktische aanbevelingen volgen uit het gewonnen inzicht? Ten eerste zijn er mogelijkheden tot verdere professionalisering op het gebied van onderzoek en onderwijs. Inspelend op de ontwikkelingen in het werkveld zou er een nieuwe afstudeerrichting binnen de HBO-opleidingen Creatieve Therapie kunnen worden geformeerd voor een opleiding tot 'creatieve organisatietrainer'. Daarnaast is het van belang dat er meer vervolgonderwijstrajecten ${ }^{11}$ met het oog op om- en bijscholing en verdere professionalisering van (creatief) therapeuten ontstaan. Bovendien dat er contacten en samenwerking met het Wetenschappelijk Onderwijs worden gecreëerd. De succesvolle opzet van een 'masters-opleiding' in het kader van een samenwerkingsproject tussen twee opleidingscentra creatieve therapie beeldend in Nederland en een Engelse universiteit ${ }^{12}$ heeft dit in experimenteel verband vormgegeven. Helaas kreeg dit project onvoldoende organisationele en financiële steun 'van hoger hand' om er een structurele vorm aan te kunnen geven. Ook het coördineren van (wetenschappelijk) onderzoek kan voor creatief therapeuten in het veld een steun betekenen om tegemoet te komen aan de vraag naar 'meetbaar effect', die vanuit de organisatorische context van de (geestelijke) gezondheidszorg steeds vaker wordt gesteld. In dit verband zou de vorming van een landelijk centrum voor (wetenschappelijk) onderzoek in een behoefte onder creatief therapeuten voorzien. De bestaande onderzoeksschool van de HBOopleiding te Nijmegen blijkt in de vorm van onderzoekspublicaties vruchten af te werpen en zou hierin het voortouw kunnen nemen. Aan de onderzoekswerkgroep van de beroepsvereniging zou eveneens nieuw leven ingeblazen moeten worden om onderzoek in het werkveld door creatief therapeuten zelf te stimuleren, te coördineren en te begeleiden. De bestaande 'bottom up' ontwikkelde netwerken, de intervisie- en supervisiegroepen, de beroepsgerichte bijscholingscursussen zijn belangrijk voor uitbouw en uitwisseling van professionele kennis en ervaring. Deze collegiale overlegvormen, professionele netwerken en samenwerkingsorganen dragen bij tot de systematisering, toetsing en verdieping van professionele kennis. Een dergelijke, vanuit een 'intern perspectief' gedragen, vorm van 'externe samenwerking' van creatief therapeuten creëert de voorwaarde voor de ontwikkeling van een 'eigen' beeldend referentiekader.

10. Muijen: Creatief Buitenskamers in: Tijdschrift voor creatieve therapie (1999) nr. 4, 13-21

11. Zoals de 'post-HBO' praktijkopleiding voor beeldende creatieve therapie van Meyer en Dinklage in Amersfoort.

12. De HBO-opleiding Nijmegen, het Centrum voor Expressieve en Kreatieve therapie van A. Brederode in Amsterdam met het Hertfordshire College London, van 1991 tot 1994, waaruit 'één lichting' afgestudeerde 'masters' is voortgekomen. 
Wat betreft de professionalisering van de nieuwe markt van creatieve bedrijfstrainingen is de volgende vraag relevant. Hoe is het mogelijk dat de creatieve organisatietrainers zich een zodanige autonomie ten aanzien van vormgeving en marketing van hun 'creatieve product' kunnen veroorloven dat ze zich niet vereenzelvigen met het in bedrijven en in organisaties veelal overheersende instrumentele referentiekader? Voor deze andere sector geldt een geheel andere uitgangssituatie dan voor creatieve therapie. Geen gevecht tegen een 'tijdgeest van rationalisering' maar openheid voor een nieuwe 'humanistische' pioniersgeest. Niettemin stelt de organisationele context van het bedrijfsleven een belangrijke randvoorwaarde om functionele 'creatieve producten' te ontwikkelen. Hiermee dienen organisatietrainers terdege rekening te houden, opdat men zich niet 'uit de markt prijst'. Mogelijk vertegenwoordigt deze gecombineerde instrumentele- èn humanistische insteek de 'formule' voor een succesvolle implementatie van 'creatieve leertrajecten' in organisaties. Het in dit onderzoek gesignaleerde 'groepsverschil' tussen de twee groepen professionals kan wellicht mede worden toegeschreven aan verschillen tussen beide maatschappelijke contexten waarin ze hun 'creatieve product' moeten verkopen. In de 'profit-sector' blijkt er immers geld en tijd genoeg te zijn voor congressen, seminars en trainingen voor en door managers, goeroe's, consultants en adviseurs. Mijn vooronderstelling op basis van dit onderzoek is evenwel dat dit verschil evenmin alleen met deze 'organisatorische en ideologische' randvoorwaarden samenhangt. Hoewel de creatieve organisatietrainers, als vrijgevestigde dienstverleners, zich een autonome positie ten opzichte van bedrijfsbelangen kunnen veroorloven, slagen zij er niettemin in hun 'humanistische dienstverlening' feitelijk in te passen in het overkoepelende instrumentele organisatiekader. De creatieve training moet met het oog op een managementdoelstelling functioneel en effectief zijn, dat wil zeggen ze moet 'scoren' door direct waarneembaar effect. Dat de creatieve organisatietrainers aldus humanistische èn instrumentele waarden met elkaar weten te verzoenen beschouw ik als een vrucht van een door hen gerealiseerde 'dialogische grondhouding' en 'hermeneutische balanceerkunst'. Wanneer een trainer niet zelf als individu autonomie, integriteit en authenticiteit heeft ontwikkeld, kan z(h)ij evenmin deze kwaliteiten bij deelnemers van een creatieve organisatietraining helpen bevorderen. 'Humanisering' door middel van de implementatie van creatieve trajecten in organisaties is derhalve afhankelijk van de vraag of de trainer een humanistische basisoriëntatie daadwerkelijk vertegenwoordigt èn kritisch toepast in het instrumenteel gerichte bedrijfskader.

Wellicht slanken de creatieve organisatietrainingen zonder deze, door de persoon van de trainer belichaamde, kritisch-humanistische grondslag af tot 'creatieve producten', die met 'repressieve tolerantie' in het heersende doel-rationele bedrijfskader worden binnengehaald. Naarmate dat zij strakker instrumentalistisch worden ingekaderd, ontberen zij de dialogische grondslag die kan voorkomen dat ze, 'strategisch' vertaald in een 'stappenplan', als nieuwe 'succesformule' of als 'alternatief managementconcept' op de markt worden gelanceerd. Zonder het kritische 
fundament vertegenwoordigt de 'creatieve invalshoek' op organi-satieprocessen weliswaar een succesvolle managementhype en een 'groeimarkt' voor organisatietrainingen. Zolang de 'hype van creativiteit' duurt zal er veel geld worden verdiend aan boeken, tijdschriftartikelen, congressen en websites met materiaal voor managers over hoe creëer ik een narratieve leeromgeving in mijn organisatie? Met 'flow-charts' en 'c-d-rom', inclusief multimedia-ondersteuning voor 'de narratieve organisatie in tien stappen'. Echter gaat het 'strategische succes' hand in hand met de uitholling van 'oorspronkelijke' humanistische waarden.

De tweede aanbeveling heeft derhalve betrekking op de vraag hoe het 'toekomstscenario' in de bedrijfssector zodanig kan worden omgebogen dat creatieve trajecten met een kritisch-humanistische inslag worden bewaard en bewaakt. Op deze wijze kan er aan de creatieve ondersteuning van organisatieprocessen waarde worden toegekend, anders dan op grond van de 'wet van vraag en aanbod'. Ook in deze sector dreigen 'weerloze waarden' door de survival of the fittest te verdwijnen en geeft de marktwerking een economische stem aan de wet van de jungle. Het zou jammer zijn wanneer alleen evenementen met een hoog 'Tjakka-gehalte' het imago van de nieuwe dienstverlening gaan bepalen. Daarom volgt uit dit onderzoek als tweede aanbeveling dat creatieve organisatietrainers een organisatorische vorm creëren voor belangenbehartiging en samenwerking vanuit het aangegeven 'interne perspectief'.

Op basis van het uitwisselingsproject en gezien de professionele verwantschap èn de contextuele verschillen tussen creatief therapeuten en creatieve organisatietrainers, wordt als derde aanbeveling gegeven dat beide beroepsgroepen gaan samenwerken. De 'win-win-doelstelling' die aan het uitwisselingsproject ten grondslag lag kan dan een meer structurele en verdiepte vorm krijgen. Als vrucht van die samenwerking zou er een keurmerk kunnen worden ontwikkeld, zoals in het eerste hoofdstuk is aangegeven, om op de bonte markt van organisatietrainingen het kaf van het koren te scheiden. Voor een toegesneden kwaliteitswaarborg is het nodig dat 'contextuele' organisatorische randvoorwaarden met betrekking tot effectiviteit, winstgevendheid en functionaliteit dialogisch in overeenstemming worden gebracht met grondslaggevende humanistische waarden. Misschien kan langs de weg van interdisciplinaire samenwerking uiteindelijk de titel van 'creatieve organisatietrainer' en 'creatief therapeut' worden beschermd; volgt er een verbetering van status en functiewaardering van creatief therapeuten en kunnen er nieuwe afzetmarkten succesvol èn humanistisch verantwoord worden aangeboord.

Wanneer blijkt dat creatieve trainers, adviseurs en loopbaanbegeleiders hiervoor inderdaad te individualistisch zijn, zoals uit het uitwisselingsproject naar voren kwam, luidt de laatste aanbeveling dat er voor de groepscohesie een nieuwe 'internationale' worde gecomponeerd, waarvoor reeds pakkende titels door respondenten zijn gesuggereerd: Leve(n)de Metaforen! en Wij Metaforisten... 


\subsection{Samenvatting en conclusie}

In het laatste hoofdstuk is het afgelegde onderzoekspad gereconstrueerd aan de hand van twee vragen: Hoe is de verhouding tussen onderzoekskader en onderzochte praktijk gaandeweg het onderzoekstraject veranderd? Wat hebben in dat opzicht filosofie en empirie voor elkaar betekend? Zowel met betrekking tot de betrokken beroepsgroepen als voor de onderzoekster geeft 'de dialoog' een moment aan van (her)overweging. Voor alle deelnemende partijen aan het onderzoek heeft 'de dialoog' een wending gegeven aan het gebruikelijke professionele handelen en aan conventionele referentiekaders. De dialoog overbrugt de traditionele kloof tussen empirie en filosofie. Ze geeft op democratische wijze vorm aan de onderzoeksmatige communicatie- en interactieprocessen tussen onderzoekster en professionals, tussen onderzoekskader en onderzochte praktijk.

Wat houdt de dialogische wending in voor het filosofische onderzoekskader? In dialectische termen is er een 'spiegel' aan de bespiegelende geest voorgehouden. Daarin herkent de filosofie zichzelf, ze ziet zich in 'het andere', in wat ze niet is. ${ }^{13}$ In de westerse, academische filosofische traditie gelden materialiteit, emotionaliteit en lichamelijkheid als 'het andere' van de geest. De traditionele filosofische bespiegeling is gebaseerd op een onderzoekende beweging van buitensluiting van dit 'andere' uit de eigen essentie. De geest zou immaterieel, het filosoferen een zuiver geestelijk proces zijn. Door een 'dialogische wending' kan de filosofie zich voor 'het andere' openstellen, namelijk door een ontmoeting waarbij de tegendelen elkaar raken en in wisselwerking met elkaar staan. In de ontmoeting met 'het andere' herkent de filosofie niet alleen 'het bewogen worden door emoties en lichamelijkheid' als het andere 'van zichzelf' maar zij verandert door de ontmoeting ook zelf. Het gesprek als ontmoeting heb ik in dit onderzoek tot een communicatieve dialoogvorm filosofisch uitgewerkt. De dialoog geeft een draai an het traditionele primaat van de theorie ten opzichte van de praktijk, resp. een herschikking van de waardering van theoretische kennis ten opzichte van praktijkkennis. Deze draai is geen romantische omdraaiing waardoor intuittie en empathie boven ratio en empirie tronen. In plaats van een hiërarchische supprematie of onderschikking van de emotioneel-lichamelijke betrokkenheid bij hetgeen onderzocht wordt, geeft de dialoog vorm aan een horizontale krachtenmeting. Hierdoor worden beide gesprekspartners aan de dialoog hermeneutisch verrijkt.

Vanuit de dialogische invalshoek kunnen creatief therapeutische en trainingspraktijken de filosofie leren hoe intultieve gewaarwording, verbeelding en gevoelens een nondiscursieve taal voor de geest ontsluiten. Door dit onderzoek is zicht gekomen op hoe anders deze taal is in vergelijking met de discursieve en verbale van de ratio. Het analoge en creatieve taalspel berust op emotionele, zintuiglijke en lichamelijke communicatievormen. In en door het samenspel van

13. Böhme: Das Andere der Vermunft. 
beide taalspelen en 'interactieve registers' worden identiteiten gedefinieerd. Er is een 'identiteitsdiscours' nodig waarin de gewaarwordingen van lichaam, geest en ziel verdisconteerd zijn om recht te doen aan de constitutie van 'het subject'. In 'authentieke communicatie', in een dialectisch spanningsveld tussen verbeelding en conceptualisering, ontstaan (denk)beelden over mens, organisatie, maatschappij en wereld, die open staan voor onderhandeling en amendementen.

Met dit onderzoek is betoogd dat een 'retorische invalshoek' op communicatie, van waaruit communicatie verschijnt als een vorm van betekenisdisseminatie op basis van een oneindig reproductieproces van tekens, niet noodzakelijkerwijs tot een 'post-moderne' conclusie van een stuurloos proces van betekenisgeving en nihilisme hoeft te leiden. De kompasnaald kan weliswaar niet op God, op ons Authentieke Zelf of op de Realiteit geijkt worden, maar een ijkpunt wordt dynamisch gevonden in de wijze waarop wij met elkaar spreken en (onder)handelen. Hiertoe is in dit onderzoek een 'dialogische grondhouding' geoperationaliseerd tot een 'authentieke communicatievorm', De dialogische wijze van beantwoorden en verantwoorden, van vragen en getuigen, van besluiten en bekritiseren, genereert een zodanige spanning tussen afstand en betrokkenheid en een dialectiek tussen verbeelding en verwoording, dat de communicatie tussen deelnemers aan de dialoog open èn geëngageerd blijft. De dialogische wending van de filosofie naar de empirie betekent dat het proces van betekenisgeving principieel pluriform is, voortgestuwd door een onafgesloten proces van betekenistransgressie. Maar 'communicatie' is meer dan een onzinnige reproductie van tekens en een voortdurende betekenisverschuiving van traditionele beelden. De mogelijkheid van 'authentieke communicatie' blijft bestaan. Het onderzoek heeft getoond hoe deze mogelijkheid wordt gerealiseerd wanneer de dialoog tussen beelddenken en denkbeelden, tussen filosofie en empirie, tot een ontmoeting van tegendelen leidt die beide polen niet onberoerd laat. De 'open gesprekshouding' met betrekking tot de eigen emoties, intuïties, lichaamsgewaarwordingen, verbeelding en denkbeelden geeft de voorwaarde hiervoor, biedt de grond voor een gelijkwaardige ontmoeting met anderen. 'Authenticiteit' verkrijgt in deze zin zowel een psychologische als een filosofische betekenis.

Voor de onderzoekspraktijk betekent de dialoog dat ik mij als onderzoekster niet op een theoretisch bevoorrecht standpunt heb geplaatst. Het onderzoek naar de wijze waarop metaforen methodisch èn als 'drager van ideologische betekenis' worden gehanteerd, is in de dialoog met de geïnterviewde professionals tot stand is gekomen. Door de dialoog met de respondenten kwam naar voren dat het 'model van de metafoor' voor de spelende mens als een 'systeem' werkt waarin 'de kennis van het hart' te hard wordt gemaakt. Dit gaf een dialogische wending in mijn filosofische positionering: wees minder ernstig in het behandelen van filosofische grondvragen en speel meer met, in en op deze grond! De dialoog met de praktijk heeft mij als onderzoekster uitgenodigd om de filosofische concepten zachter, buigbaarder, beweeglijker en speelser te maken. 
In dit hoofdstuk is voorts gereflecteerd op de betekenis van de dialogische wending voor de praktijk van creatieve trajecten in therapie en organisaties. Ook 'het onderwerp' van onderzoek ondergaat een verandering door de ontmoeting met de filosofie. De filosofische dialoog heeft voor de praktijk een waarde als middel tot professionalisering van creatieve therapie en creatieve trainingen. 'De dialoog' als voorstel om op een andere wijze met de verhouding 'denken en voelen', 'ratio en intuitie' om te gaan dan in termen van een conflictmodel. In plaats van het gebruikelijke uitgangspunt van een strijd tussen 'rationele' en 'irrationele' vermogens, kan er een dialoog tussen beide ontstaan. Creatieve trajecten stimuleren en cultiveren dialogische communicatie tussen de vele stemmen in en om onszelf. Als zodanig vertegenwoordigen ze een humanistisch communicatiekader, waarin op zodanige wijze ontwikkelingsnarratieven worden gegenereerd, dat leefwereld en systeem met elkaar in evenwicht zijn. Tussen 'zelfactualisering' als een romantische illusie die machtsmisbruik versluiert en openlijk tentoongespreide organisatorische machtsmiddelen om 'neuzen de zelfde kant op te krijgen' bestaat de mogelijkheid van 'authentieke communicatie'. De open en betrokken grondhouding ontsluit een communicatie- en onderhandelingsruimte tussen 'manipulatie' en 'versluiering'. Ze legt de basis voor 'een narratieve leeromgeving' in therapie en organisaties, waarin metaforische richtingaanwijzers voor ontwikkelingsprocessen gearticuleerd worden. De creatieve werkvorm is derhalve te beschouwen als een humanistisch communicatiekader, waarin waarden van 'authenticiteit', 'integriteit' en 'autonomie' op kritische wijze in wisselwerking met instrumentele doelstellingen worden gebracht. Op basis van deze wisselwerking resulteert de dialoog met het creatieve medium in een existentiële afbakening van de 'dimensie van zingeving' ten opzichte van conventionele referentiekaders op organisaties en therapie. Hierdoor kan er een ontmoeting en uitwisseling plaatsvinden tussen binnen- en buitenwereld, tussen mens en organisatie, tussen een oriëntatie op 'de realiteit' en op 'utopische' ontwikkelingen. De dialoog vooronderstelt èn bewerkstelligt een positie van non-dualiteit waarmee 'conventionele' tegenstellingen en belangenconflicten in een ander licht komen te staan. Binnen het dialogische kader vertegenwoordigen creatieve trajecten een 'vrijplaats voor zinspeling en zingeving', waarbinnen bestaande gezins-, organisatorische en maatschappelijke structuren een herschikking ondergaan. De ontwikkeling van 'autonomie', 'authenticiteit en 'integriteit' in het kader van creatieve trajecten draagt daarmee tevens bij aan het cultiveren van humanistische waarden binnen gezinspatronen en organisationele samenwerkingsverbanden. Met enkele praktische aanbevelingen is de waarde van 'de dialoog' voor beide groepen professionals geconcretiseerd.

Op grond van mijn hermeneutische onderzoeksbenadering is naar voren gekomen dat niet zozeer de verbale, beeldende, muzische, technische of rituele vorm telt waarin de dialoog gevoerd wordt maar: c'est le ton qui fait la musique. Aldus staat niet de cognitieve boodschap noch het creatieve medium als zodanig voorop, maar de wijze waarop het emotionele, esthetische en interactieve 'materiaal' wordt geěnsceneerd tot een 'levende metafoor'. De dialogische wijze waarop deze meta- 
forische vormgeving plaatsvindt, is doorslaggevend voor de vraag of een creatieve werkvorm bijdraagt aan de ontwikkeling van humanistische waarden. De dialogische wijze van spreken en handelen genereert in samenspraak met het creatieve medium een narratieve context van vertellers en toehoorders. De betekeniselementen voor de verhalen over onszelf, over onze organisatie, over maatschappij en wereld krijgen we als traditionele beelden en narratieven doorgespeeld en we geven er onze eigen draai aan. Vanuit de kritisch-humanistische 'dimensie van zingeving' verschijnt het verschil tussen de creatieve trajecten in therapie en in organisaties als contextueel en minder relevant dan vanuit conventionele therapeutische en organisatorische referentiekaders. Creatieve therapie en creatieve organisatietrainingen geven een existentiële herinterpretatie aan een hulpvraag die vanuit een conventioneel referentiekader als een psychologisch of organisationeel 'probleem' is gedefinieerd. Vanuit het ruimere zinverlenende perspectief wordt dit 'probleem' herkaderd als een stagnatie in communicatie- en interactieprocessen tussen 'de probleemhouders', die binnen de dialogische context weer in beweging worden gebracht door middel van het expliciteren, confronteren en uitbalanceren van de ontwikkelingsnarratieven van betrokkenen. De creatieve werkvorm creëert door middel van de dialectiek van beelddenken en denkbeelden een balans tussen zingeving en zinspeling en maakt daarmee 'de homo ludens' in ons wakker. Wanneer creatieve trajecten aldus een dialoog realiseren, waarin wij op authentieke wijze betekenis geven aan onszelf in relatie tot anderen en organisaties, vertegenwoordigen zij een kritisch èn ludiek vormgevingskader om in het licht van ons mens-zijn ontwikkelingsmogelijkheden te exploreren.

Ik sluit het boek af met het uitspreken van de hoop dat het onderzoek ook voor de lezers een dialogische waarde zal hebben zoals het dat voor mij heeft gehad. In een gesprek laten wij ons aanspreken of sluiten ons af, voelen we ons meer of minder betrokken bij de gesprekspartners en de zaak waarover gesproken wordt en leggen we verantwoording af over hetgeen we doen, nalaten en zeggen (te doen). Door verbeelding, bespiegeling en in gesprek krijgen de beelden een narratieve vorm, maar uiteindelijk vertellen we met het daadwerkelijk geleefde leven ons levensverhaal. De laatste wending aan het verhaal geeft het einde en de 'afloop' van dit onderzoeksverslag vindt in de context van de promotieplechtigheid plaats. Mijn conclusie is derhalve dat wij ons verhaal nooit geheel kunnen (na)vertellen maar hiervoor fundamenteel aangewezen zijn op anderen. 

Aamodt, G. (1999) Applied Industrial Organizational Psychology. Brooks/ Cole, Pacific Grove.

Abma, T. A. (1996) Responsief evalueren. Proefschrift, Erasmus Universiteit Rotterdam. Abma, T. A. (2000) Responding to ambiguity, responding to change the value of a responsive approach to evaluation in: Pergamon. Evaluation and Program Planning. (23) 461-470.

Abma, T.A. (2000) Stakeholder conflict: a case study. Pergamon. Evaluation and Program Planning. (23) 199-210.

Achterhuis, H (1980) De mankt van welzijn en geluk. Baam.

Adams, D.C. False Metaphors. Sports, competition and the new leadership paradigm in health care. Hospitals Health Care Networks. 5 nov. 1995, 42-44.

Albert, H. Probleme der Wissenschaftslehre in der Sozialforschung in: König, R. (ed.) (1967) Handbuch der empirischen Sozialforschung. Ferdinand Enke Verlag, Stuttgart.

Allen, R.E. (1997) Winnie-de-Poeh en Management. Uitgeverij Sirius en Siderius, Den Haag.

Ankersmit, F.R (1994) History and Tropology. The Rise and Fall of Metaphor. University of California Press, Berkeley.

Ankersmit, F.R. \& Mooij, J.J.A. (1993) Knowledge and Language. (vol III) Metaphor and Knowledge Kluwer Academic Publishers, Dordrecht.

Arbnor, I \& Bjerke, B. (1997)Methodology for Creating Business Knowledge. Sage.

Argyris, C. \& Schōn, D. (1978) Organizational Leaming. Reading, Mass. Addison-Wesley. Argyris, C. \& Schön, D. (1974) Theory in Practice. San Francisco, Jossey-Bass.

Armenakis, A. \& Bedeian, A. The Role of Metaphors in Organizational Change Group \& Organizational Management. Vol 17 (3) 1992, 242-248.

Baalen, P.J. van (1995) Management en hoger onderwijs: De geschiedenis van het academisch managementonderwijs in Nederland. Proefschrift, Erasmus Universiteit Rotterdam.

Bacon, F. (1964) The Refutation of Philosophies. in: Farrington, B. The Philosophie of Francis Bacon. Liverpool University Press, 121.

Bacon, F. (1988) Het nieuwe Atlantis. Ambo, Baarn.

Barry, D. \& Elmes, M. (1997) Strategy retold: toward a narrative view of strategic discourse in: Academy of Management Review. Vol 22 (2) 429-452.

Bataille, G. (1989) De innerlijke ervaring. Gooi \& Sticht, Hilversum.

Bataille, G. (1986) De tranen van Eros. SUN, Nijmegen.

Baudrillard, J. (1985) De fatale strategieën Duizend en Een, Amsterdam.

Bauduin, D. (red) (1993) Inspiratie. De invloed van hedendaagse filosofische stromingen op de theorie en praktijk van de geestelijke gezondheidszorg. NcGv, Utrecht.

Beek, van W. (red.) (1988) Mimese en geweld. Beschouwingen over het werk van René Girand. Kok Agora, Kampen.

Beelen, F., Oelers, M., Muller, E.A. (1989) Interactief. Kreatieve Therapie met Groepen. Van Loghum Slaterus, Deventer.

Behn, R.D. (1992) Management and the Neutrino: The Search for Meaningful Metaphors. In: Public Administration Review. Vol 52 (5) 409-419.

Benneker, R. \& Stelt, I. v.d. (1994) Organiseren om te overleven Tijdschrift voor kreatieve therapie (4) 134-136. 
Bergen, A. van (2000) De lessen van Bum Out. Het Spectrum.

Bergen, a van, Metaforen aan de macht Elsevier. 06-12-1997.

Berman, A. (1998) Perspectief voor Creatieve Therapie? Trends en ontwikkelingen in de gezondheidszorg. In: Tijdschrift voor Creatieve Therapie. (2) 20-23.

Berns, E. (1979) Jacques Derrida en de taalfilosofie in Berns (e.a.) in: Denken in Parijs. Alphen a.d. Rijn, 139-169.

Bernstein, D. (1984) Company image and reality. A critique of corporate communications. Holt, Rinehart and Winston. Eastborne.

Bernstein, R.J. Beyond Objectivism and Relativism. Oxford, Basil Blackwell, 1983.

Beroepsprofiel van de Kreatief Therapeut (1995) Uitgave van de Nederlandse Vereniging voor Kreatieve Therapie. Utrecht.

Bertels, J. (1995) Kernbeelden tot leven brengen. De kar-trekker leren om op de bok te zitten. Magazine Opleidingen. (4) 28-31.

Bertels, J.E. (1993) Ins en Outs van Out of Door Training Magazine Opleidingen. (6) 24-27. Binsbergen, W. van 'Culturen bestaan niet' Het onderzoek van interculturaliteit als een openbreken van vanzelfsprekendheden. in: Rotterdamse Filosofische Studies. Inaugurele Rede, 21 jan. 1999, Erasmus Universiteit Rotterdam.

Black, M. (1993) More on Metaphor. In: Ortony, A. Metaphor and Thought. Cambridge University Press, 19-46.

Black, M. (1962) Models and Metaphors. Studies in Language and Philosophy. Cornell University Press, Ithaca, New York.

Boden, M. A. (1994) Dimensions of Creativity. Bradford, Massachusetts.

Boden, M. A. (1991) The Creative Mind. Myths \& Mechanisms BasicBooks.

Boer, Th. De E.a. (1988) Hermeneutiek. Filosofische grondslagen van mens- en cultuurwetenschappen. Boom Meppel, Amsterdam.

Boer, Th. de, (1980) Grondslagen van een kritische psychologie. Ambo, Baarn

Bohme, G. (1985) Anthropologie in pragmatischer Hinsicht. Suhrkamp, Frankfurt am Main.

Böhme, G. (1986) Philosophieren mit Kant. Suhrkamp taschenbuch wissenschaft, Frankfurt am Main.

Böhme, G. \& Böhme, H. (1985) Das Andere der Vermunft. Zur Entwicklung von Rationalitätsstrukturen am Beispiel Kants. Suhrkamp, Frankfurt am Main.

Boje, D.M. (1995) Stories of the storytelling organization: a postmodern analysis of Disney as 'Tamara-land'. Academy of Management Joumal. Vol.38 (4), 997-1035.

Bookman, R. Ignite Team Spirit in Tired Lions Hrmagazine, June 1990, 106-108.

Boozer, R.W. (e.a.) (1992) Using metaphor to create more effective sales messages The Joumal of Business and Industrial Marketing. Vol. 7 (1) p.19-27.

Bovee, C.L. (e.a.) (1993) Management. McGraw-Hill, Inc. New York.

Boyce, ME. (1995) Collective Centring and Collective Sense-making in the Stories and Storytelling of One Organization Organization Studies. Vol 16 (1) 107-137.

Braembussche, van den A.A (1996) Denken over kunst. Een kennismaking met de kumstfilosofie. Dick Coutinho, Bussum.

Braidotti, R. (1990) Beelden van de Leegte. Vrouwen in de hedendaagse filosofie. Kok Agora, Kampen.

Brenters, M. (1999) De organisatie als netwerk. Hoe mensen onganisaties veranderen en organisaties mensen. Samson, Alphen aan de Rijn.

Brink, T. L. Corporate Cultures: A Color Coding Metaphor Business Horizons. Sept-Oct. 1991, 39-44.

Broekstra, G. (1996) The Triune-Brain Metaphor: The Evolution of the Living Organism. In: Grant, D. \& Oswick, C. Metaphor and Organizations. Sage, London. 
Brom, M. M. (1984) Over de kreatief Proces Theorie en haar toepassingsmogelijkheden. Middeloo, Amersfoort.

Bruyn, J. de \& Vilder, J. de (1995) In de greep van het eten. Beeldende kreatieve groepstherapie voor vrouwen met eetproblemen Tijdschrift voor Creatieve Therapie (3) 12 e.v.

Budde, E. (1989) Creatieve therapie in praktijk. Opdrachten en werkwijzen voor beeldende creatieve therapie. Van loghum Slaterus, Deventer.

Bulhof, L.N. (1988) Darwins Origins of Species: Betoverende wetenschap. Ambo.

Burack, E. (e.a.) (1994) New Paradigm Appraoches in Strategic Human Resource Management Group \& Organization Management. Vol 19 (2) 141-159.

Buys, R. (1999) Metaforiseren. Naar een procesgerichte visie op metaforen. Doctoraalscriptie Bedrijfskunde, Erasmus Universiteit Rotterdam.

Callewaert, L. \& Gevers, B. (1997) Traditie in transitie $M$ \& O. (3) 61-78.

Camp, P. \& Erens, F. (1996) De Negensprong. Overleven als kunst. Contact, Amsterdam.

Camp, P. (1992) De kracht van de matrix. Een model om veranderingsprocessen in beeld te brengen en doeltreffend aan te pakken. Contact, Amsterdam-Antwerpen.

Carrière Week. Studieweek (46) 1998.

Case, J. The great Game Across the Board. nov./ dec. 1995.

Cassirer, E (1972) An essay on man. Yale University Press.

Cassirer, E. (1965) Philosophie der symbolischen Formen. II Wissenschaftiche Buchgesellschaft, Darmstadt.

Chia, R. Metaphors and metaphorization in organizational analysis: thinking beyond the thinkable. in: Grant, D. \& Oswick, C. (ed.) (1986) Metaphor and Organization. London, Sage Publications.

Cleary, C. \& Packard, Th. (1992) The Use of Metaphors in Organizational Assessment and Change Group \& Organization Management. Vol 17 (3) 229-241.

Clegg, B. \& Birch, P. (1998) DisOrganization. The handbook of creative organizational change. Pitman Publishing, London.

Clegg, S.R. (ed.) (1996) Handbook of Organization Studies. Sage, London.

Cooper, D.J. (a.o.) (1996) Sedimentation and Transition in Organizational Change: The Case of Canadian Law Firms Organization Studies. 17 (4) 623-647.

Coppoolse, P. (1984) Teamvorming. Werkboek over sociaal-emotionele processen in samenwerkingsverbanden $\mathrm{H}$. Nelissen, Baarn.

Couger, J. D. (1993) (Un)Structured Creativity in Information Systems Organizations MIS Quarterly. Dec, 375-397.

Covey, S. (1999) De zeven eigenschappen van effectief leiderschap. Contact, Amsterdam.

Covey, S. (1994) Stop the Clock, Incentive. sept. 45.

Cranen, W. (e.a.) (1996) Rituelen in het dagelijks leven van mensen, in het bijzonder van mensen met een verstandelijk handicap. Damon, Best.

Czarniawska-Joerges, B. \& Jacobsson, B. (1995) Political Organizations and Commedia Dell'Arte Organization Studies. Vol 16 (3) 384-387.

Dalley, T. (ed.) (1996) Art as Therapy. An introduction to the use of art as a therapeutic technique. London: Routledge.

Dalley, T. (ed.) (1994) Images of Art Therapy. New Developments in Theory and Practice. Routledge, London \& New York.

Daniels, D. (1996) Leadership lessons from championship basketball Joumal for Quality and Participation. June, 36-48.

De Bruyn, R. \& Zegers, D. (1998) Paradijservaringen tegenover bedrijfsbelangen. Creatieve agressie, creatieve regressie, creatieve progressie. Atelier Windekind Rumst. 
De Bruyn, R. Het Stimuleren van Creatief Denken en het Verwerven van een Creatieve Denkhabitus Centrum voor de Ontwikkeling van het Creatief Denken, Creatief Atelier Windekind, Rumst.

De Groot, P.A. (1996) Dr. Scheppende processen en psychopathologie Ateliers van de ziel Museum De Stadshof, Zwolle.

De Haas, G. van BttMP Music Affairs Nederlands Tijdschrift voor Bedrijfopleidingen april 1998.

De Mul, J. Het romantische verlangen in (post)moderne kunst en filosofie. in: Rotterdamse Filosofische Studies nr. XI, Erasmus Universiteit Rotterdam, 1990.

Debats, D. (red.) (1992) Psychotherapie en zingeving. Een spectrum van visies. Servire.

Denzin, K.N. \& Lincoln, Y.S. (1994) Handbook of Qualitative Research. Sage, Thousand Oaks.

Denzin, K. N. (1978) The Research Act. A Theoretical Introduction to Sociological Methods. McGraw-Hill.

Derks, L. \& Hollander, J (1997) Essenties van NLP. Sleutels tot persoonlijke verandering. Servire.

Derrida, J. (1989) De stem en het fenomeen. Ambo, Baarn.

Derrida, J. (1979) Grammatologie. Frankfurt a.M.

Derrida, J. (1972) Marges de la Philosophie. Paris.

Derrida, J. Le retrait de la metaphore Poesie. No 7, 1977-1978, 103-126.

Descartes, R. (1916) Discours de la méthode. Nelson, Paris.

Deshpande, R. \& Webster, F.E. (1989) Organizational Culture and Marketing: Defining the Research Agenda Joumal of Marketing. Vol.53, 3-15.

Diamond, M. Psychoanalytic Phenomenology and Organizational Analysis $P A Q$ Spring 1990, 32-42.

Dijksterhuis, E.J. (1985) De Mechanisering van het Wereldbeeld. Meulenhoff, Amsterdam. Doorn, van J.A.A. \& Lammers, C.J. (1966) Modeme Sociologie. Systematiek en analyse. Aula, Utrecht.

Doorne, F. van \& Korthals, M. (1986) Filosofie en maatschappijkritiek. In debat met Habermas. Boom Meppel, Amsterdam.

Drift, I. van der (1994) Kindertekeningen en kindergedrag. Toetsing van de OT-index als instrument voor het meten van het gedrag van kinderen. Doctoraalscriptie pedagogiek, R.U.Utrecht.

Duintjer, O. D. (1988) Hints voor een diagnose. Naar aanleiding van Kant. Ambo, Baam.

Duintjer, O.D. (1988) Rondom metafysica. Boom Meppel, Amsterdam.

Eeden, C.J.A.M. van, (2001) Waamemen als besturingsopdracht. Governance, hermeneutiek en het vraagstuk van levensbeëindigend handelen. een model voor beeldvorming van maatschappelijk-politieke problemen Proefschrift, Erasmus Universiteit Rotterdam.

Elias, N. (1976) Ueber den Prozess der Zivilisation. Surhkamp, Frankfurt am Main.

Emmet, E.R. (1965) Logisch denken. Aulaboeken, Utrecht.

Engeldorp Gastelaars, $\mathrm{Ph}$. van \& Leede, E. de, Over het doen van bedrijfskundig onderzoek.

Een inleiding in de methodologie, methoden en technieken van bedrijfskundig onderzoek. (I)

ServicePost, Nieuwekerk a/d IJssel.

Engeldorp Gastelaars, Ph. van (e.a.) (1986) Bedrijfskunde en methodologie. Eburon, Delft.

Engeldorp Gastelaars, Ph. van, m.m.v. Berkel, J.P.van (1995) Bedrijfskundige sociologie. Een inleiding in de sociologie voor bedrijfskundigen. Rotterdam.

Engeldorp Gastelaars, $\mathrm{Ph}$. van (1997) Ondememing, mens, samenleving. Sociale wetenschappen in bedrijfskundig perspectief. Delft.

Engeldorp Gastelaars, Ph. van, (1984) Lopen over water? Eburon, Delft. 
Essen-Cox, v.d. E.A.M. (1995) Onderzoek naar effecten van Muziektherapie op communicatie bij patiënten met gevorderde dementie. Roermond.

Essers, J. Naar een kritiek van de organisatorische rede. Proefschrift Bedrijfskunde, Erasmus Universiteit Rotterdam, in druk.

Fange, E.K. von (1962) Creativiteit in het beroep. Prisma, Het Spectrum.

Feder, E. \& Feder, B. (1986) The Expressive Arts Therapies. Prentice Hall.

Fish, S. Interpretive Research: a New Way of Viewing Organizational Communication PAQ Spring, 1990, 67-74.

Forbes, J.D. (1992) Columbus and Other Cannibals. Autonomedia, New York.

Forester, J. No planning or Administration without Phenomenology PAQ Spring, 1990, 67. 74.

Foucault, M. (1986) Geboorte van de kliniek. Een archeologie van de medische blik. SUN, Nijmegen.

Frazer, J.G. (1996) De Gouden Tak. Contact, Amsterdam, Antwerpen.

Freud, S. (1953) Abriss der Psychoanalyse. Das Unbehagen in der Kultur. Fischer, Frankfurt.

Freud, S. (1984) Leonardo da vinci. A memory of his childhood. Ark Paperbacks, London. Frijda, N.H. (1988) De emoties. Een overzicht van onderzoek en theorie. Uitgeverij Bert Bakker, Amsterdam.

Gadamer, H-G. (1975) Wahrheit und Methode, Tubingen.

Garud, R. \& Kotha, S. Using the Brain as a Metaphor to Model Flexible Production Systems in: Academy of Management Review. Vol 19 (4) 691-698.

Gebser, I (1978) Ursprung und Gegenwart. I, II, Novalis.

Gerrickens, P. (1997) Kwaliteiten. Een verfrissende kijk op eigen-aardigheden. Gerrickens training \& advies, Den Bosch.

Geurts, J. \& Caluwé, L. de Spelsimulaties voor organisatieverandering $M . \& O$. (3) junijuli 1997, 43-60.

Geurts, J., Caluwé, L, Buis, D., Stoppelenburg, A. (1996) Gaming: Organisatieverandering met spelsimulaties. Delwel Uitgeverij, Den Haag.

Geurts, J.P.M. Feit en Theorie. Kemproblemen in de wetenschapsleer. Van Gorcum, Assen, 1984.

Gibbs, R.W. (1993) Process and products in making sense of tropes. In Ortony, A. Metaphor and Thought. Cambridge University Press, 252-276.

Gieles, J.B. (e.a.) (1997) Van Profileren naar samenwerken. Vincent van Gogh Instituut, Venray.

Gilroy, A. \& Dalley, T. (1989) Pictures at an exhibition. Routledge, London \& New York. Gils, W. van (1986) Realiteit en illusie als schijnvertoning. Over het werk van Jean Baudrillard. SUN, Nijmegen.

Glaser, B.G. \& Strauss, A.L. (1967) The Discovery of Grounded Theory: Strategies for Qualitative Research. Chicago, Aldine.

Goddijn, H.P.M. (1980)Max Weber. Zijn leven, werk en betekenis. Ambo, Baarn.

Goia, D.A. \& Chittipeddi, K. (1991) Sensemaking and sensegiving in strategic change initiation Strategic Management Journal. Vol.12, 433-448.

Goleman, D. (1995) Emotional Intelligence. Bloomsbury, London.

Goodall, J. (1971) Mijn leven met chimpansees. Elsevier, Amsterdam.

Goodman, M. (1995) Creative Mangement. Prentice Hall, London.

Goodman, N. (1976) An Approach to a Theory of Symbolism. Harvard University Press.

Goosen, A. Breaking out of the Box. The Logic and Art of Creativity and Business. Doctoraalscriptie Bedrijfskunde Erasmus Universiteit Rotterdam, aug. 1999.

Grant, D. \& Oswick, C. (eds) (1996) Metaphor and Organizations. Sage, London. 
Grant. D. \& Oswick, C. (eds.) (1996) Organisation Development Pitman Publishing. Greenberg, D. (1995) Blue versus Gray: A Metaphor Constraining Sensemaking Around a Restructuring in: Group \& Organization Management. Vol 20 (2) 183-209.

Griensven, L. van, Creatief Therapeuten en Professionalisering. Doctoraalscriptie Gezondheidswetenschappen, R.U. Limburg, Maastricht, 1995.

Grunwald, D. (1993) Creativiteit in Organisaties Effectief managen in een minder lineaire wereld. Kluwer Bedrijfswetenschapppen, Deventer.

Guba, E.G. \& Lincoln, Y.S. (1989) Fourth Generation Evaluation. Sage, London.

Gustavson, B. (1992) Dialogue and Development. Van Gorcum.

Haak, N.v.d. (1999) Metafoor en Filosofie. Proefschrif, Nijmegen.

Hamilton, P.M. (1997) Rhetorical Discourse of Local Pay. Organization. Vol 4 (2) 229-254.

Harmon, M. Applied Phenomenology and Organization PAQ Spring 1990, 10-17.

Hegel, (1976) Grundlinien der Philosophie des Rechts. Suhrkamp, Frankfurt am Main.

Heidegger, M (1976) Zur Sache des Denkens. Max Niemeyer, Tubingen.

Heidegger, M. (1957) Der Satz vom Grund. Neske, Pfullingen.

Heidegger, M. (1984) Sein und Zeit. Niemeyer, Tübingen.

Heidegger, M. (1967) Vortrage und Aufsätze. Neske, Pfullingen.

Heidegger, M. (1954) Was heisst Denken? Max Niemeyer, Tubingen.

Hellendoorn, J. \& Harick, F.J.H. (1987) Therapeutisch spel: proces en interactie. Proefschrift, Rijks Universiteit Leiden, Swets \& Zeitlinger, Lisse.

Hellendoorn, J. (e.a.) (1994) Play and Intervention. State University of New York Press.

Hellendoorn, J. (e.a.) (1992) Beeldcommunicatie. Een vorm van kinderpsychotherapie. Bohn Stafleu Van Loghum, Houten.

Hempel, C.G. (1965) Typologische Methoden in den Sozialwissenschaften In: Topisch, E (ed) in: Logik der Sozialwissenschaften. Kiepenheuer \& Witsch, Köln, 85-101.

Hendrikse, G.W.J. \& Muijen, A.S.C.A. (1998) Metaphors, Communication and Change in: Graan, de G. B.K. \& Volmer, F.G. (red.) in: Performance Budgeting. Eburon, Delft, 155178.

Hesse, M. (1993) Models, Metaphors and Truth in: Ankersmit, F.R. \& Mooij, J.J.A. in: Knowledge and Metaphor. Dordrecht, 49-67.

Hirschman, E.C. (1993) Ideology in Consumer Research, 1980 and 1990: A Marxist and Feminist Critique. in: Journal of Consumer Research. Vol 19, 537-555.

Hoogendijk, A. (1995) Filosofie voor managers. Contact, Amsterdam.

Hoom, J.F. (1997) Metaphor and the Brain: Behavioral and Psychological Research into Literary Metaphor Processing. Proefschrift, Vrije Universiteit Amsterdam.

HP/De Tijd, 27-11-1992.

Huizinga, J. (1974) De Homo ludens: proeve ener bepaling van het spelelement der cultuur. Tjeenk Willink.

Hulspas, M. (1997) Genezende beelden Intermediair 32e jg. no 5, 31.

Hutschemaekers, G. \& Neijmeijer, L. (1999) Beroepen in beweging. Professionalisering en grenzen van een multidisciplinaire GGZ. Bohn Stafleu Van Loghum, Trimbosinstituut, Utrecht.

IJsseling, S. (1990) Mimesis. Over schijn en zijn., Ambo, Baarn.

Isseling, S. (1975) Retoriek en Filosofie. Wat gebeurt er wanneer er gesproken wordt? Ambo, Bilthoven.

Janesick, V.J.(1994) The Dance of Qualitative Research Design. Metaphor, Methodolatry and Meaning. in: Denzin, K.N. \& Lincoln, Y.S. Handbook of Qualitative Research. Sage, Thousand Oaks.

Jansen, E.R. (1998) De beeldentaal van het Hindoeisme. Goden, verschijningsvormen en hun betekenis. Binkey Kok, Havelte. 
Jansen, E.R. (1999) Het Boeddha-boek. Boeddha's, godheden en rituele symbolen. Binkey Kok, Havelte.

Jaspers, K. (1985) Psychologie der Weltanschauungen. Piper, München/ Zürich.

Jaspers, K. (1983) Vom Ursprung und Ziel der Geschichte. Piper, München/ Zurich, Johnson, M. (1987) The Body in the Mind. University of Chicago Press, Chicago.

Jonker, J. (1993) In Termen van Beelden. Een kwalitatief onderzoek naar het ontstaan van adviesrelaties. Proefschrift, Katholieke Universiteit Nijmegen.

Jung, C.G. (1988) Psychologische typen. Servire, Katwijk.

Jung, Symboliek van de Mandala. Beelden uit het onbewuste. Lemniscaat, Rotterdam.

Junker, J. \& Rijdt, F. van (1995) Creatieve Therapie met ouderen Hogeschool Nijmegen.

Kaas, A.J. (1942) Een vergelijkend onderzoek naar de beeldende kunst van gezonden en geesteszieken Proefschrift, Utrecht.

Kahn, M. (1999) De Tao van het gesprek. De kunst van het luisteren. Rainbow Pockets, Maarten Muntinga bv, Amsterdam.

Kant, I. (1974) Kritiek der reinen Vermunft. Suhrkamp, Frankfurt am Main.

Karsten, L. \& Veen, van K. (1998) Managementconcepten in beweging: tussen feit en vluchtigheid. Van Gorcum.

Kessels, J. (1997) Socrates op de markt. Filosofie in Bedrijf. Boom Amsterdam.

Kets de Vries, M.F.R. (1995) Organizational Paradoxes. Clinical Approaches to Management. Routledge, London \& New York.

Kieser, A. (1999) How Management Science, Consultancies and Business Companies (Do not) Leam from Each Other (paper) King's College, London.

Kilduff, M. \& Mehra, A. (1997) Postmodernism and Organizational Research in: Academy of Management Review. Vol. 22, No. 2, 453-481.

Kimmerle, H. (1988) Derrida. Zur Einfühnung. Junius, Hamburg.

Klages, L. (1968) Ausdrucks-bewegung und Gestaltungskraft. Dtv, Munchen.

Knibbe, H. (1999)De niet-herkende Boeddha. Mos Z\&Z uitgevers bv Utrecht.

Koningsveld, H. (1980) Het verschijnsel wetenschap. Boom, Meppel-Amsterdam.

Korthals, M. \& Kunneman, H. (1992) Het communicatieve paradigma. Mogelijkheden en beperkingen van Habermas' theorie van het communicatieve handelen. Boom Meppel, Amsterdam.

Korting, M. (1999) De creatief therapeut als brugwachter. Het gebruik van beeldspraak en metaforen in creatieve therapie Tijdschrift voor Creatieve Therapie. (1) 6-10.

Kouwenhoven, L. (1986) Organisatietrasformatie: vrienschap met de draak $M . \& O$ vol. 2, 152-173.

Kreatieve Therapie Beeldend. Acht methodieken. (1990) Sectie Beeldend - Vereniging voor Kreatieve Therapie, Alblasserdam.

Krishnamurti, J (1979) Waarheid en Werkelijkheid, Ankh-Hermes bv. Deventer.

Kuiper, P.C. (1989) De mens en zijn verhaal. Athenaeum, Amsterdam.

Kuiper, P.C. (1988) Ver heen SDU, Den Haag.

Kunneman, H. \& Keulartz, J. (1985) Rondom Habermas. Analyses en kritieken. Boom, Amsterdam.

Kwakkel-Scheffer, J.J.C.( 1983) Beelden in woorden. De term 'beeld' in theorie en praktijk van de beeldcommunicatie. Swets \& Zeitlinger b.v., Lissen.

La Mettrie, J. (1978) De mens een machine. Boom, Meppel.

Lakoff, G \& Johnson, M. (1980) Metaphors we live by. Univsersity of Chicago Press.

Lakoff, G. (1987) Women, Fire and Dangerous Things. What Categories Reveal about the Mind. University of Chicago Press, Chicago.

Landgraten, H.B. (1989) Family An Psychotherapy. A clinical guide and casebook. Brunner/ Mazzel, New York. 
Langer, S. (1948) Philosophy in a New Key. A study in the Symbolism of Reason, Rite and Art. Pelican, New York.

Larwood, L. (1992) Don't Struggle to Scope Those Metaphors Yet. in: Group \& Organization Management. Vol 17 (3), 249-254.

Leede, de E. \& Engeldorp Gastelaars, Ph. van (1999) Naar een methodologie van de kunde. Een pleidooi voor een context-afhankelijke methodologie in: Reemsdijk, M.J. van, (red.) Dilemma's in de bedrijfkundige wetenschap. Van Gorcum, Assen, 141-163.

Leeuw, de A.C.J. (1993) Een boekje over bedrijfskundige methodologie. Management van onderzoek. Van Gorcum, Assen.

Leopold, M. Vervoeging van zijn. Seismogram, Bosch \& Keuning, Baarn.

Levine, E, (1992) Tending the fire. Studies in Ant, Therapy and Creativity. Palmerston Press, Toronto.

Levine, S.K. (1992) Poiesis. The language of Psychology and the Speech of the Soul. Palmerston Press, Toronto.

Levine, S.K. \& Levine, E.G. (1996) Foundations of Expressive Arts Therapy. Jessica Kingsley Publishers, London.

Lievegoed, B.C.J. (1970) Organisaties in ontwikkeling. Zicht op de toekomst. Lemniscaat, Rotterdam.

Locher, H. Metafoor en Beeldtaal II (cursusmateriaal 1999-2000) Gemeentemuseum Den Haag.

Long, J. The Wilderness Lab Comes of Age Training and Development Joumal. March 1987, 30-39.

Lowell Jay Arthur, Birthdays, not deadlines Software Magazine. april 1992, 98-99.

Lubbers, R. (1988) Psychotherapie door beeld en begripsvorming. Het grensoverschrijdend verstaan van de hermeneutiek. Dekkers \& Van de Vegt, Nijmegen.

Lyotard, J.-F.( 1987) Het postmoderne weten. Kok Agora, Kampen.

Marcuse, H. (1972) Vertoog over bevrijding. Bijleveld, Utrecht.

Marissing, L. van. (1999) Huid en Ziel. Studies in zichtbaar maken. Amsterdam.

Marshak, R.J. (1996) Metaphors, Metaphoric Fields and Organizational Change. In: Grant \& Oswick (ed.) Metaphor and Organizations. Sage, London, 147-166.

Maruszewski, T. (ed.) (1995) A cognitive view on creativity. Eburon, Delft.

Marx, K. (1969) Das Kapital, Ullstein, Frankfurt.

Mattimore, B.W. Breakthroughs Creatively Destroying the Barriers to Business Innovation Success. Nov. 1988, 44-50.

McNiff, Shaun (1981) The arts en Psychotherapy. Springfield.

Meijer, R. Employability-vraagstuk zorgt voor onrust. Flexabiliteit gaat ten koste van zekerheid' Erasmus Magazine, Erasmus Universiteit Rotterdam, (6), nov 1997.

Mintzberg, H. (1998) Organisatiestructuren. Prentice Hall, Schoonhoven.

Moerland, B. De Sleutels der Kennis. Een inleiding tot de gnostiek. (in druk) Mirananda, Den Haag,

Mooij, J.J.A. (1976) A Study of Metaphor: On the Nature of Metaphorical Expressions, with Special Reference to their Reference North Holland, Amsterdam.

Moreno, J.L. (1947) The Future of Man's World. New York, Psychodrama monographs.

Morgan (ed.) (1983) Beyond Method: Strategies for Social Research. Sage, Beverly Hills.

Morgan, G. (1986) Images of Organization. Sage, Thousands Oaks.

Morgan, G. (1993) Imaginization: The Art of Creative Management. Sage, London.

Morgan, G. \& Burrell, G. (1979) Sociological Paradigms and Organisational Analysis.

London, Heinemann.

Morgan, G. \& Ramirez, R. (1983) Action Leaming: A Holographic Metaphor for Guiding Social Change Human Relation Vol. 37, (1) 1-28. 
Morgan, G. (1982) Cybemetics and Organization Theory: Epistemology or Technique? In: Human Relation Vol. 35 (7) 521-537.

Morgan, G. (1983) More on Metaphor: Why We Cannot Control Tropes jn Administrative Science Administartive Science Quarterly. Vol. 28 601-607.

Morgan, G. (1982) Rethinking Corporate Strategy: A Cybemetic Perspective in: Human Relation Vol. 35 (7) 521-537.

Muijen, A. Pit and Pitfalls of Metaphors in Organization (theory) in: Organizational Discourse: Pretexts, Subtexts and Contexts ed. Combes, Grant, Keenoy, Oswick, proceedings of the conference 29-31 july 1998, King's College, University of London

Muijen, H Managing Creativity?! De 'hype van creativiteit' in filosofisch perspectief, ter publicatie aangeboden aan: Filosofie in Bedrijf

Muijen, H. Creatief buitenskamers! De appèlwaarde van de verzakelijkte zorg in: NVKT (4), 1999, 13-21

Muijen, H. (1997) Metaforen, creativiteit en therapie in filosofisch perspectief in: Management report series No 5 (13) Erasmus Universiteit Rotterdam.

Muijen, H. Metaforiek en metaforen in: Tijdschrift voor Creatieve Therapie. (2) 1997, 10 18.

Muijen, H. Sportmetaforen: De retoriek van competitie of de imperatief van 'fair play'. In: Filosofie in Bedrijf. Jg. 10, nr. 36, 2000/1, 20-37.

Muijen, H. (1989) Verbeeldingskracht, voorstelling en metafoor. Doctoraalscriptie Wijsbegeerte, Erasmus Universiteit Rotterdam.

Mul, J. de (1990) Het romantische verlangen in (post)moderne kunst en filosofie. Rotterdamse Filosofische Studies, E.U.R., Rotterdam.

Naess, A. (1978) Elementaire argumentatieleer. Ambo, Baarn.

Nafzger, J. \& Gaalen-Oordijk, I. van (1999) Eindrapport arbeidsmarktonderzoek creatieve therapie. CINOP.

Naschold, F. (a.o.) (1993) Constructing the New Industrial Society. Social science for social action: toward organizational renewal. Van Gorcum, Assen/ Maastricht.

Naumburg, M. (1973) An Introductrion to Art Therapy. Studies of the "Free" Art Expression of Behavior Problem Children and Adolescents as a Means of Diagnosis and Therapy. Teachers College Press, Columbia University.

Neijmeijer, L. (e.a.) (1996) Beroep: Vaktherapeut/vakbegeleider. Een verkennend onderzoek naar persoon, werk en werkplek van vaktherapeuten en vakbegeleiders in de gezondheidszorg. NcGv, Utrecht.

Nelson, G. (1993) Das sokratische Gespräch: Erfahrungen in philosophischen Hochschulseminaren. Philosophisch-Politische Akademie, Bonn.

Nietzsche, F. (1984) Die fröhliche Wissenschaft in: Werke II Ullstein Materialien, Frankfurt a.M.

Nietzsche, F. (1984) Ueber Wahrheit und Lüge im aussermoralischen Sinn in: Werke III. Ullstein Materialien, Frankfurt am Main.

Nietzsche, f. (1984) Jenseits von Gut und Bose in: Werke III, Ullstein, Frankfurt a.M.

Norris, Ch. (1994) The truth about postmodermism. Blackwell Publishers, Oxford.

Ofman, D. (1992) Bezieling en kwaliteit in organisaties. Servire, Cothen.

Ojemann, P.C. (1988) Woordblindheid en beelddenken. Van Loghum Slaterus, Deventer.

Olav Koss, J. \& Thlen, B.-M. \& H. (1997) Effect. Over communicatie en teambuilding. Elmar, Rijswijk

Olthof, J. \& Vermetten, E. (1994) De mens als verhaal. Narratieve strategieèn in psychotherapie voor kinderen en volwassenen. De Tijdstroom, Utrecht.

Oostering, H.A.F. \& Prins, A. W. (1988) La Chair. Het vlees in filosofie en kunst in: Rotterdamse Filosofische Studies. VIII. Erasmus Universiteit Rotterdam. 
Oosterling, H. (1989) De opstand van het lichaam. Over verzet en zelfervaring bij Foucault en Bataille. Sua, Amsterdam.

Oosterling, H.A.F. \& Prins, A.W. (red.) $(1992,1994)$ Filosofie en Kunst. (deel I en II) in: Rotterdamse Filosofische Studies XIV en XVII. Faculteit der Wijsbegeerte, Erasmus Universiteit Rotterdam.

Orosz, J.F. (1994) The Language of State Agency Executive Transitions. American Review of Public Administration. Vol. 24 (1) 43-66.

Ortony, A. (1993) Metaphor and Thought. Cambridge University Press.

Ortony, A. (a.o.) (1988) The cognitive structure of emotions. Cambridge University Press. Cambridge.

Palmer, I. \& Dunford, R. (1996) Conflicting uses of Metaphors: reconceptualizing their use in the field of organizational change Academy of Management Review. Vol.21, 691-717

Parekh, B. (1989) Gandhi's Political Philosophy. A Critical Examination. London, Macmillan Press.

Pawlowski, T. (1980) Begriffsbildung und Definition. Walter de Gruyter, Berlin.

Perelman, (1979) Retorica en argumentatie. Ambo, Baarn.

Peters, J.M. (1973) Retoriek van de communicatie. Communicatiemiddelen, communicatievormen, communicatie-technieken. Tjeenk Willink, Groningen.

Peursen, C.A. van, (1980) De Opbouw van de Wetenschap. Een inleiding in de wetenschapsleer. Boom Meppel, Amsterdam.

Piaget, J. (1971) Genetic Epistemology. Norton, New York.

Pinder \& Bourgeois: Controlling Tropes in Administrative Science Administartive Science Quarterly. Dec. 1982.

Plato (1980) Verzameld werk I. vertaling X. de Win, Gorgias, Ambo.

Plokker, J.H. (1962) Geschonden Beeld. Beeldende expressie bij schizophrenen. Mouton \& Co, 's Gravenhage-Parijs, Proefschrift.

Polanyi, M. (1975) Meaning. From perception to metaphor University of Chicago Press.

Pott, H. (1992) De liefde van Alcibiades. Over de rationaliteit van emoties. Boom, Amsterdam.

Ramondt, J. (1996) Organisatie diagnostiek. Een methode voor vraaggericht onderzoek. Academic Service, Schoonhoven.

Ramondt, J. Verborgen macht, de verankering van de machtsrol in hedendaagse organisaties. $M \&$ \& O. 54e jg. juli/ aug. 2000, 23-38.

Reemsdijk, M.J van (1999) Dilemma's in de bedrijfskundige Wetenschap. Van Gorcum, Assen.

Reger, Rh. (e.a.) (1994) Creating earthquakes to change organizational mindsets Academy of Management Executive. Vol 8 (4) 31-46.

Reijen, van W. (1987) De onvoltooide rede. Modem en Postmodern. Kok Agora, Kampen.

Reuchlin, M. (1970) Methoden in de psychologie. Boom, Meppel.

Richards, I.A. (1936) The Philosophy of Rhetoric. Oxford University Press, New York.

Ricoeur, P. (1975) La métaphore vive. Du Seuil, Paris.

Ricoeur, P. (1983-1985) Temps et Recit. Du Seuil, Paris. (1984) Time and Narrative. University of Chicago Press.

Ritskes, R.R. (1992) Meer Zen in Management. De Driehoek, Amsterdam.

Robinson, A. \& Stern, S. (1998) Corporate Creativity. How Innovation and Improvement Actually Happen. B-K Publishers, San Francisco.

Rutten-Saris, M. (1990) Basisboek Lichaamstaal. HBO-reeks Gezondheidszorg/ Welzijn, Van Gorcum-Assen.

Ryle, G. (1990) The concept of mind. Penguin, Harmondsworth.

Sacks, Sh. (ed.) ( 1979) On Metaphor. University of Chicago Press. 
Sanders, C. (e.a.) (1989) De cognitieve revolutie in de psychologie. Kok Agora, Kampen.

Sartre, J.-P. (1965) Esquisse d'une théorie des émotions. Hermann, Paris.

Sartre, J.-P. (1988) La transcendance de l'ego. VRIN, Paris.

Schaverien, J. (1994) The scapegoat and the talisman: transference in art therapy. In: Dalley, T. (ed.) Images of Art Therapy. New Developments in Theory and Practice.

Schierbeek, B. (1973) Het dier heeft een mens getekend. De Bezige Bij, Amsterdam.

Scholten, J. (1990) Retoren en demokratie. Proefschrift, Groningen.

Schön, D. (1993) Generative metaphor: A perspective on problem setting in social policy in: Ortony, A. Metaphor and Thought. Cambridge University Press, 254-284.

Schö, D. (1999) The Reflective Practioner. How professionals think in action. Ashgate, Alderschot.

Schuster, M. (1993) Kunsttherapie. Die heilende Kraft des Gestaltens. Dumont, Köln.

Schwandt, Th. A. (1994) Constructivist, Interpretivist Approaches to Human Inquiry, in: Denzin, N.K. \& Lincoln, Y.S. (ed.) Handbook of Qualitative Research. Sage, Thousand Oaks, 118-137.

Schwarz-Winklhofer, I \& Biedermann, H. (1972) Das Buch der Zeichen und Symbole. Knaur, Monchen.

Schwitters, C. (1996) In de ban. De betekenis van symbolen en symbolische rituele handelingen in de beeldende therapie met incestoverlevenden in: Bruijn, C. de (e.a.) Symbolen in de creatieve therapie 73-83.

Scott Armstrong, The profitability of winning in: Chief Executive. jun. 1994, 61-63.

Scott Poole, M. \& Van de ven, A. (1999) Using paradox to build management and organizational theories Academy of Management Review. Vol. 14 (4) 562-578.

Sechehaye, M.A. (1972) Terug naar het nulpunt. Symbolische realisatie als geneeswijze voor de schizofreen. Lemniscaat, Rotterdam.

Senge, P. e.a. (1994) The fifth discipline fieldbook, Doubleday (New York) Nicholas Breadley, London.

Simhoffer, H. (1995) Ik heb nou allemaal dingen in mijn hoofd... Een antropologie van kunst en creatieve therapie. HBO-reeks Gezondheidszorg/ welzijn, Van Gorcum.

Slangen, J. (1994) Van Koningsplein naar Lazarnsklap. Fragmenten uit de geschiedenis van Psychiatrisch Centrum Joris te Delft (+/-1394-1994) Eburon, Delft.

Smeijsters, H. Creatieve therapie: creatief of therapeutisch? Een kritische reflectie over het gedachtegoed van de creatieve therapie. Tijdschrift voor Creatieve Therapie. 1998/4, 4-10.

Smeijsters, H. (2000) Handboek Creatieve Therapie. Coutinho, Bussum.

Snijders, F. (1985) Procesdenken. Angumenten voor een interaktieve opvatting van de werkelijkheid. HES Uitgevers, Utrecht.

Spek, J. van der (1933) Hermes en Psyche (overdruk Maandblad Administratieve Arbeid) Rotterdam.

Spender, J.-C. Pluralist Epistemology and the Knowledge-based Theory of the Firm Organization. Vol. 5(2) 233-256.

Spiggle, S. Analysis and Interpretation of Qualitative Data in Consumer Research Joumal of Consumer Research. Vol. 21 dec. 1994, 491-503.

Staal, J. (1998) School voor Imaginatie. Amsterdam Nederlands Tijdschrift voor Bedrijsopleidingen. Jg. 3, nr. 12, 6-10.

Szasz, S. (1972) Geestesziekte als mythe. Lemniscaat Rotterdam.

Teunissen, W. (1995) Andere Zorg voor dementerenden. Van instelling naar zorgonderneming. Verpleeghuis Hogewey, Weesp.

Thompson, C. (a.o.) The Spoken and the Unspoken: A Hermeneutic Approach to Understanding the Cultural Viewpoints That Underlie Consumers' Expressed Meanings Joumal of Consumer Research. Vol.21, dec. 1994, 432-452. 
Tiemersma, D. (1985) Ricoeur's hermeneutics of action and schematheory Phenomenological Inquiry 9, 58-71.

Togt, v.d. R. (1996) De innerlijke bron. Integratie van Kunstzinnige therapie en Psychosynthese. in: Symbolen in de creatieve therapie NvKt, Utrecht, 83-84.

Tsoukas, H (1991) The missing link: a transformational view of metaphors in onganizational science in: Academy of Management Review. Vol. 16 (3) 566-585.

Tsoukas, H (ed.) (1994) New Thinking in Organizational Behaviour. Oxford

Tsoukas, H. (1993) Analogical Reasoning and Knowledge Generation in Organization Theory Organisation Studies. 14/ 3, 323-346.

Tsoukas, H. (1991) The missing link: a transitional view of metaphors in organizational science Academy of Management Review. Vol 18, Nr. 3, 566-585.

Ulmann, G. (1968) Kreativitat. Neue amerikanische Ansätze zur Erweiterung des Intelligenz-konzeptes. Weinheim, Berlin.

Van Dongen, e.a. (1996) Een kwestie van verschil. Conflicthantering en onderhandeling in een configuratieve integratietheorie. Eburon, Delft.

Vanden Berghe, G. (1997) Confucius voor Managers. Chinese meesters over durven en doen in het menselijk bedrijf. Lannoo, Tielt.

Vanden Berghe, G. (1997) Machiavelli voor Managers. Lannoo, Tielt.

Vernooij, $\mathrm{Ph}$. Samen en toch alleen. Cliënten met een borderlinestoornis in beeldende therapie Tijdschrift voor Creatieve Therapie (3), 1998, 16-23.

Volberda, H.W. Blijvend Strategisch Vernieuwen: concurreren in de 21 eeuw. Kluwer, Deventer, 1998.

Vos, M. Confronteren is beter dan vermijden. Directief- en gedragstherapeutische uitgangspunten bij gestagneerde rouw Tijdschrift voor Creatieve Therapie (4) 1993, 116-122.

Vroon, P. \& Draaisma, D. (1985) De mens als metafoor. Ambo, Baarn.

Vugt, A. (1996) Het gouden ei. Werken met symbolen in de behandeling van psychotici en zeer vroeg ontwikkelingsgestoorde patiënten. in: Symbolen in Creatieve therapie NvKt, Utrecht. 62-73.

Wadeson, H. (1987) The Dynamics of Art Psychotherapy. Wiley-interscience publications, London.

Waller, D. (1998) Towards a European Art Therapy. Open University Press, BuckinghamPhiladelphia.

Walter, K. Bring on the Entertainment Personnel Journal. July 1995, 84-90.

Watts, A.W. (1976) Zen-Boeddhisme. Bert Bakker, Amsterdam.

Watzlawick a.o. (1974) De pragmatische aspecten van de menselijke communicatie, Bohn Stafleu Van Loghum, Houten/ Zaventem.

Weber, M. (1975) Een keuze uit het werk van. Van Loghum Slaterus, Deventer.

Weick, K.E. (1995) Sensemaking in Organizations. Sage, Thousand Oaks.

Weick, K.E. (1999) Theory Construction as Disciplined Imagination in: Academy of Management Review. vol.14, No 4, 516-531.

Weick, K. ( 1979) The Social Psychology of Organizing. Reading, Mass, Addison Wesley.

Wertheim-Cahen, T. (1991) Getekend bestaan. Beeldend-creatieve therapie met oorlogsgetroffenen. Icodo, Utrecht.

White, J.D. Phenomenology and Organization Development $P A Q$. Spring 1990, 76-85.

Widdershoven, G. (2000) Empirische ethiek: op sleeptouw bij de medische technologie? Tge. Vol 10 (3) 77-82.

Widdershoven, G. (2000) Ethiek in de kliniek. Hedendaagse benaderingen in de gezondheidsethiek. Boom.

Widdershoven, G. (1987) Handelen en Rationaliteit. Proefschrift, Utrecht. 
Widdershoven, G. Principe of praktijk. Een hermeneutische visie op gezondheid en zorg Inaugurele rede Rijksuniversiteit Limburg, 24 nov. 1995.

Widdershoven, G. (2000) Psychotherapie als praktische wetenschap in: Tijdschrift voor Psychotherapie. Nr. 26, jg. 6 nov., 395-402.

Widdershoven, G.A.M. \& Mooij, A.W. M. (red.) (1997) Hermeneutiek en politiek. Eburon, Delft.

Wit, H. de (1988) Contemplatieve psychologie. Kok Agora, Kampen.

Wit, H de (1998) De lotus en de roos. Boeddhisme in dialoog met psychologie, godsdienst en ethiek. Kok Agora, Kampen.

Wit, H. de (1993) De verborgen bloei. Over de psychologische achtergronden van spinitualiteit. Kok Agora, Kampen.

Wittgenstein, L. (1979) Bemerkungen über die Farben. Bibliothek Suhrkamp, Baden Baden. Wittgenstein, L. (1977) Philosophische Untersuchungen. Suhrkamp, Frankfurt am Main.

Wollheim, R. (1993) Metaphor and Painting in: Ankersmit, F.R. \& Mooij, J.J.A. Knowledge and Metaphor. Dordrecht, 113-127.

Wooding, Ch. J. (1984) Geesten genezen. Ethnopsychiatrie als nieuwe richting binnen de nederlandse antropologie. Uitgeverij Konstapel, Groningen.

Yanow, D. (1992) Supermarkets and Culture Clash: The Epistemological Role of Metaphors in Administrative Practice American Review of Public Administration. Vol. 22, No 2, 89109.

Zaltman, G. (1996) Metaphorically Speaking. New Technique uses multidisciplinary ideas to improve qualitative research Marketing Research. Vol. 8 (2) 13-20. 
Abstract 65, 111, 113, 127, 154, $167,174,179,226,231,249-250$, $252,262,266,272-273$

- abstractie 141, 193

- abstrahering 108, 142, 155 , $179,180,227,263$,

Acting out 92-93, 182, 225, 245

Action research 116, 142, 204

Activiteitenbegeleiding 23, 209, 238

Adhocratie 107, 109-110

Afstemming, afgestemdheid, grondstemming 54-55, 59-60, 64, 67, 157-158, 180-182, 185-186, 176, 197-198, 200

Alternatief, -ve 21, 38, 41, 47-48, $139,142-143,148,195,208,270$, 277, 280

Ambivalent(ie) 123-124, 129, 233, 249

Analogie 123, 30-31, 44-45, 59, 68, $77,87,150,162-163,259$

- analoog 21, 30-31, 44, 62, 74, $81-82,84,97,99,101,125,127$, $133,136,159,170,176-179$, $181,187,198,200-202,206$, $215,224,226,241,251,259$, 261, 270, 289

Antropologie, -isch 15-16, 24-25, 59, 64, 71-74, 83, 85-88, 90-91, 93, 95, 100-101, 103-104, 174

Antropomorf, -isme, 111

Apollinisch 226, 228

Archaïsch 73

Arbeidstherapie 23, 238, 259

Archetype, -isch 37, 73, 90, 175

Art as therapy 28, 57, 225

- in therapy 28

Assertiviteitstraining 36
Authenticiteit 27, 65, 70, 140, 169, 197-198, 202, 233-236, 245-246, $259,262-265,271,281,287,290-$ 291

- Authentieke communicatie, betekenisgeving, expressie $61,69-70,88,93-94,103$, $151,196,198-202,232-$ $234,245,247,257,263-$ $264,271,280-282,284$, 290-292

- ' 'kern', 'mens-zijn' 27, 86, 88, 97-98, 168, 190-191, $198,236,290$

Autonomie 27, 48, 188, 234-235, $248,259,262,264-265,280,287$, 291

Bedrijfskunde 47, 105-106, 108, 111-112, 114-116, 119, 136, 147, $178,163,183,210,218,261$

- bedrijfskundig $18,38,65,105$ $106,108-112,114,117-118$, $138,141,146-147$

Beeld

-communicatie 78, 83, 87, 165 , 225

-denken 70, 101, 103, 151, 185, 188 , 191-193, 198, 202, 227 $228,262,272-274,290,292$ -narratief 93, 153, 168, 171, $225,252,266,273-274,277$, 292

-spraak 17, 21, 40, 45, 107, 110, $113,147,149-150,155,161-$ $162,168,253,255,257$ -taal 80, 90, 132, 170, 175, 193, 148,158 -waarde 92, 225 -vorming 33, 156, 207, 272, 274 


\section{Beleving}

-sbeeld 171, 222

-organisatie $83,126,142,165$, $168,222,227-228,246$ -wereld 132

Belichaamd 131, 236, 271, 284, 287 - beeld $92,153,225$

Beroepsprofiel 31-32, 34, 285

Betrokkenheid 56-58, 65, 160, 163 164, 180-182, 186, 200-201, 207, $213,217-219,223,245-247,256$, 265-266, 270-271, 289-290

Beweging 157, 164, 167, 170, 174, $177,180,191,202,206,272-273$, $285,289,292$

-sbeeld 170-171, 222-225, 236 -therapie 23

Bewustzijn 42, 71, 75-76, 94, 107 -sstructuur 59, 90, 176 -toestand, dynamiek 173-175 - onbewuste $42,71,90,175,184$

Bureaucratie109-110, 184, 219 Cliché(-beeld) 136, 169, 177, 225 Cliënt-gecentreerde therapie 27 Coaching 18, 33, 35-37, 62, 201, $204,214,259,269,280,282$

Cognitie(f) 61, 127, 136, 138, 153$154,156,158,162-163,170-171$, $174,184,199-200,222,225,228$, 230, 246, 291

Communicatie -f handelen 45, 139, 270-271

- ve waarden 139, 146, 148, 271 -ve rationaliteit $15,33,106,133$, $139,141,145,148,286$ -kloof 217. 242-243, 247-248, $251,259,267$

- model 106, 141-142, 144, 146, 148

Conceptualisering $30,89,116,135$, $138,146,151,161-162,179,193$, 202, 290

-Conceptuele (kennis, ervaring) $16,55,60-61,88,106,108-111$,
$120,151,157-158,161-168$, $173-174,179,182,184,191-$

193, 196, 201, 228

- preconceptuele (kennis, ervaring) 67,90

Concreet, concretisering 65, 68-69, $79,81,116,127,130-131,140-141$, 147-148, 150-152, 180-181, 199, $201,217,226-227,231,236,243-$ 244, 248-253, 255, 261-267, 271, 278, 280, 291

Constructivisme

- constructivisten, -isch 113-

114, 134, 147, 182, 207

- non-constructivisten, -isch

113-114, 147

Conventionele (kennis, referentiekader) 69,106 129, 161$162,165-166,196,225,271,289$, 291-292

- onconventionele 110

Creatief

-proces 18, 28-29, 75, 83, 151, 177,281

-denken 18, 38

-leren 43-44, 46, 200-201, 244, 252-253, 265-266, 287

Creatieve benadering, trend 33-34, $47,50,63,65,124,134,288$

- houding, vermogens 123, 191, 200

- pro-actief 123

- reactief 123

Creativiteit 15, 17-19, 22, 27, 29$30,34-35,38-39,43,50-51,53,63$, $65,173,175,177,189,206,210$, $213,231,235,236-237,249,276$, 288

Dans(en) $38,60,85,183,186-187$, 198-199, 202, 273

-therapie 18, 20, 216

-metafoor 183, 205-206, 208, 261-266

Deconstructie 121, 136 
Democatisch, democratisering 24 , $48,52,98,104,120,124,144,208$, $263,267,278,289$

Derde weg, onderzoeksroute, perspectief $20,54,58,61-64,98$, $101-102,105,145,148-149,151$, $154-155,158,160,170,201,205$, 270

- gesprekspartner 25-26, 146, $148,154,158,160,270$

- (midden)positie, grondhouding 58, 61, 63, $65,135,146,256,205-206$, 219-220, 222, 251-252, $260,269,279$

Diagrammatisch (beeld) 92, 153, 225, 236

Dialectiek

- dialectische wisselwerking $52,62,64,138,151,164$, 185, 187-188, 205, 207, 217,228

- dialectische spanningsveld, speelruimte 178, 194, 213, 290

Dialoog

- beginsel, principe 25-26, 55 , $65,144-146,148,151,154,158-$ $159,180,201,228,278-279$ - grondhouding, grondslag 65 , $145-146,148,206,252,263$, 265-267, 269, 279-280, 284, 287,290

- machtsvrije dialoog 106, $139,141,148$

- multiloog 132, 147, 220

- trialoog 154

Dichotomie 19, 58, 60, 123 - dichotomisering 58-59, 61-62, $64,150,180,226,263,267$

Dichter(lijk), poëtisch 176, 191, 196-197, 255, 257

-metafoor 252, 255-258, 260, 266-267

Digitaal, digitalisering 15, 153, 164
Dionysisch 88, 206, 222, 226, 272

Discipline(s) 204, 209-211, 215 -

216, 238, 241-243, 259, 277

- interdisciplinair 208, 211, $215,217,220,235,244$, $250,256-257,270,288$

- multidisciplinair 212 -disciplinering, gedisciplineerd $33,60,85,186,216,263,282$

Discursief 46, 154, 170, 272, 289 - nondiscursief $25,44,54,60$, $63,273-274,284,289$

Dubbelzinnig(heid) $68,83,86,93$, $96,118,129-130,176-177,187-190$ Eclectisch 28, 37, 147-105, 121-122 Effectiviteit 47, 53, 77-78, 133, 235,288

-effect(ief) 26, 28-29, 36, 41, 43, $47,78-80,83,97,107,110,121$, $128,134,147,150,154,171$, $195,205,222,228,235,238$, $246,251,258,286-287$

Efficiënt(ie) $31,39,47,49,53,78$, $80,121-122,189,201,214$ Emotionaliteit 30, 59, 61, 69, 106, $133-143,156,168,184,224,274$ Empathie

- empathisch 20, 30, 53, 56-59, 60-62, 64, 145-146, 149, 151, $160-161,180-185,187,192$, 198, 200-201, 206, 226, 252. 289

Empirisch(e) (- winst ) 20, 30-31, $33,39,47,55-56,60,64,66,77-79$, $85,95,107,111,116,119-120$, $140-142,144,146,153,155-161$, $172,184-185,194,201,205,219-$ $220,228,230,252-253,257,261$, 263, 266-267, 271, 273

Employability 51-52, 80, 118-119, 131-132, 213, 233

Empowerment 52, 118, 123, 144, 208

Enactment 92-93, 129, 142, 225, 245 
Entertainment 35, 201, 284

Entertrainment 35, 201

Epistemologie

- epistemologisch $61,86,93$, $105,107,134,157,160,179$, 194-195

\section{Ervaring}

- ervarings(gestuurd) leren 43, 199-200, 244, 246-247, 251$253,269,271,281,283-284$

- kennis 144-145, 185, 191194

- $\quad$ werkelijkheid $17,72,85$ $86,99,193,208,218,254-255$, 257

Esthetisch(e) 23, 25, 31, 45, 61, $111,133,146,148,159-160,236$, 284,291

- Esthetisering 41, 51, 151, 188, 193, 195-196, 202

Ethisch 33, 50, 109, 120-121, 131, $144-145,147-148,154,180,182$, 189,195

Etymologie

Evocatie

- etymologisch 166

- evoceren 99, 176, 257

Existentie

- filosofie 59

- existentieel 50-51, 58-60, 62, 93, 99-101, 124, 170, 187-189, $191,233-235,238,247,259$, 261-267, 271, 280-282, 284, 291-292

- betekenisveld 165,168 , $174,200,222,227-228$

Expressie(f) 26, 30, 70, 274, 286

Extern (perspectief, verhouding) 27, $101-102,135,182-183,203,232$, $252,257,259,262-263,285-286$

Fenomenologie -isch 24, 31, 54-55, 57-59, 61, $63,67,78,82,143,182-183$

Fetisj 91, 118, 227
Figuurlijk 26, 42, 70, 100-104, 111, $117,146,149,161,165-166,227$

- (con-, pre-)figureren 107, $110-111,115,124,135$, $140,142-143,155,161$, $194,202,222,272$

- $\quad$ stijlfiguren $107,136,138$, 146,149

Flexibiliteit, flexibilisering 109 , $118,132,138,220,231,233,236$, 259

Functionaliteit 116, 127, 138, 140, 214,288

- functioneel 84, 86-87, 93-94, $101,117,128-129,135,231$, $254,263,282,287$

- functionalistisch 100, 116-117, 135

Gedrag

- gedragstherapie $28,69,77,87$,

94-95

- gedragsmatig 128, 200

Gezondheidszorg 18, 20, 31-33, 49, $64,94,104,70,74,78-79,85,204$, $209,212-213,216,242,256-258$, $267,270,277-278,285-286$

Handelen

- doelrationeel, instrumenteel, strategisch $162,184,214,278,286$

- intuïtief handelen, handelingsintuittie 185,187 , $218,226,277$

-professioneel 85, 207, 255, 260, 289

-handelingscontext 92-93, 222, 225

-handelsmerk 232-233, 245, 247,257

-onderhandelen, -ing 142-145, $160,180-181,187,207,217$, $221,263,266,270,290-291$

Hermeneutiek

- hermeneutische (onderzoeks)benadering 57,63, 
$179,181,202,205,222,226-$

$227,254-256,260-261,265-$

266, 291

- cirkel 191, 202, 207-208, 228

Heuristiek 146, 211, 220

- heuristisch 112-113, 116

Homo Ludens 65, 122, 233-234, 244, 252-253, 260, 266, 284, 292

- ludiek 18, 35, 37, 41-46, 131,

$133,164,201,204,222,231$,

244-245, 252-253, 257, 271,

$274,284,292$

Humanisering 19-20, 22, 48-49, 51$53,57,60,63-64,122-123,128-$ $129,133,139,140,144,177,187-$ $188,190,199,202,205,214,266-$ $267,279,283,287$

Humanisme 15, 53, 61

Naief - 19, 48, 54, 61-63, 271

Kritisch - 48, 57, 59, 61-64, 198, 201, 244, 261-267, 272, $277,280,284$

Humanistisch(e)

Naïef $-48,63,65,141,168$, 199-201

Kritisch - 19, 65, 135, 145, 148, 157-159, 178, 185, 196-200, $202,234,236,245-247,252$, $259,262,264,266,269,271$, $277,279,281-282,284,287-$ 288, 292

Hybride(n) 17, 106, 109, 118-119, 146

Hyperrealiteit 195, 202

- hyperreëel 15

Ideologie(ën) 41, 48, 53, 63, 85-86,

$123,134,177,214,242,257$

-kritiek

-kritisch 18, 20, 34, 47, 53, 63, $122-124,145,147,205,214$, $234,236,263,269,283$

Ideologisch 17, 19, 47-48, 51, 57, $60,62,105-106,111,114,119-122$, $133,135,145,146,148,157-159$,
$214,238,247,249,256,271,282-$

284,290

Ideosyncratisch 169,225

Illusie, illusoir 97,111, 151, 169, $192,195,226,291$

Imago 40, 47, 124, 238, 241, 249, 253,288

Incarnering 227,273

Innerlijk(e) 23-24, 37, 52, 69, 75$76,79,81-84,99,101-102,104$, $107,109,116,122,129,133,138$, 145,157

Instrumenteel $19,47,62,70,84-85$, $103,109,121,124,131-133,135$, $139,141,143-148,149,168,181-$ 182, 199-201, 214, 218-219, 251, 253-254, 256-257, 262-263, 268, 270-271, 278-280, 285, 287, 291 Integriteit 46,244-247, 262, 264, $280,287,291$

Interactie(f, ve) 44-45, 47-48, 93, $122,136,138,113,158,163-164$, $170,199-201,222-223,225,242$, 247, 290-291

Interdependent(ie) 123, 235, 243, 260

Intern (perspectief, verhouding) 34 , $39,45-46,69,101-102,114,126$, $134,140,150,182-183,228,256$, $263,286,288$

Interpretatie

- interpretatieve benadering, methode, -proces 54, 61, 115 $117,135,183-185,199,202$, 205

- kader, 62-63, 100, 184-185, 192,202

Intuitie 58, 60-61, 64, 69, 111-112, $125-126,133,260,273-274,276-$ 277, 289-291

- intuìtief verstaan $57,61,69$, $182,184,186,269-270,272$, 277,289

- intuittieve kenwijze, benadering 19-20, 53-54, 57-58, 60, 62, 64, 
$160,184-185,194,222,226$, 260,277

Ironie, ironiseren $149,154,164$, $171,173,195,199$

Isomorf(ie) 224

Journalist-metafoor 252, 255-256, 258

Kennis

- romantische (intuitieve)

praktijk 17, 19-20, 53-55, 57-64,

$67,128,142-145,153-154,160$, $163,178-179,183-187,191-$ $192,194,199,227,273,284$, 289-290

- rationalistische (theoretische) wetenschappelijke 19-20, 53, $55,57-58,60-61,67,107,112$, 133, 141-142, 145, 178-181, 183-188, 198-191, 194-195, $219,273,289$

Kennispraktijk(en) 18-19, 25, 54, $57,62-63,116,120,135,146,149$ $150,167,184-185,195,273,284$ Kerncompetentie 230, 260, 272 Kunst 17-19, 23, 25, 28, 31, 35, 38$41,44-45,47,51,60-61,82-83,86-$ $88,97-98,102-104,109,131,143$, $146,150,152,160,164,168,170$, 174-175, 178-182, 186-188, 190191, 195-196, 199, 201, 214, 220, $226,231-232,245,248,255,260$, $265,274,276,287$

-georiënteerd, gerelateerd, kunstzinnig 18, 22-23, 28,46, 64, 70-71, 76-77, 80-82, 84-85, 97-98, 100-104, 216, 265, 270

- kunstmatig, gekunsteld 155 , $177,183,273$

- kunstzinnige therapie 28

Leefwereld 139, 271, 291

Leidinggeven(de) $35,38,45,117$ $119,124,126,129,141,147,163$. $170,172,201,211,239,248,270$, 281
Lerende organisatie $52,213,132$, 237,242

Letterlijk(e) 26, 40, 42, 64-70, 72, 82-83, 91, 99-104, 108, 111, 114, $116-117,146-147,149,155,157$ $158,161-162,165-168,172-173$, $177,190-193,198,232,254-255$, 258,265

Logica

- van de metafoor 120, 151-152, $155,159,163,228$

- van het beeld 39, 159

Maakbaarheid(sgeloof) 41, 189$190,199,262,279$

Maatschappij 17, 19, 39-40, 42, 48, $64,85,145,184,195,200,279$, 282-283, 290, 292

-beeld(en) 16-17, 196, 202, 265

- maatschappelijk 16-19, 21-22, 9327, 31-34, 47-49, 51, 53, 62 $63,152,183-188,200,270,278-$ $280,282-283,287,291$

Macht 40, 48, 52, 72, 89, 112, 120, 129, 141, 144, 163, 201, 241, 243, $263,265,279$

- machts- 47-48, 52, 57, 71, 105, $120,141,144,147,173,219$, $257,279-280,282,291$ -machtsvrije dialoog 106, 139, 141,148

Management 17-18, 35-36, 38, 42, $47,49,105-110,112,114,117-125$, $127-129,132-133,135,138-139$, $141,146-147,153,162-163,172-$ $173,179,209,211,213-214,217-$ 218, 231-234, 238-239, 242, 247248, 250-251, 259-260, 262, 267 Magie 72, 97, 126, 196, 278, 280281, 283, 287-288 - magisch(e) 15-16, 60, 71-72, 82-83, 86-87, 91-94, 96-97, 109$111,126,174-176,196$

Mandala 73 
Meer

-duidig(heid) 88, 100, 123, 172, $175,225,258$

-waarde 18, 20, 22, 25-26, 31, $45,47,53,60,62,69,80,92$, $114,120,138,149,158,164$, $167,199-200,209-212,228$, $234,248,2532-258,264,266-$ $267,269,282-283$

Meetbaar(heid) $31,78-80,97,124$, 209, 214, 246, 286

Mensbeeld, -visie 16-17, 28, 223, 235

Metafoor

- benaderingen, theorieèn 138 , 161

Metaforen

- biologische, organische $110,114,138,238,254-256$

- mechanische, instrumentele $50,116,128,136-138,253$, 256

- hermeneutische dialogische, narratieve 50, 65, 97-98, $100,102,116-117,198-$ $199,202,261-264$

Metaforiek 71, 83, 100-104, 131, $164,260,265$

Metaforisch(e)

- adequaatheid, treffen 157160,228

- benadering 106, 117, 120, $123,133-134,138,145$, $148,156,184,210,213$, 270

- communicatie 149, 151, $153,157-158,160-162$, 168-173, 201, 204, 213, 217, 221-224, 227-228, $231,235,244,261-262$, 266,281

- denken, ervaringsmodus 67, $83,86,91,93-94,99-100$, $125,174-177,228$
- kennis(vorm) 114, 120, $126,144-145,149,163$, $183-185,187,191-192$, $199,221,228,252,261$, $264,269,277$

- Metaforisering 98, 109, 151, 161$162,167,193-194,202$

- Metaforologie 134, 167

Metafysica(kritiek) 19, 59, 88, 104, 159, 191-192, 194, 196, 265

- (niet-)metafysisch 88, 103$104,149,151,157,160,177$, $189,191-194,197,202,228$, 263-265, 279

Methodisch 20-21, 27-29, 32, 34, $37,44-47,53-54,154,167,180-$ $182,184,199-201,221-222,227-$ $228,232,247,249,265,271,281$ 284,290

- concepten, uitgangspunten 29 , $32,77,182-183,186,187,227$

- model 114, 184, 214, 238, 260

- socratisch 106, 140, 148, 270

- metaforisch 105, 135, 145, 148

- Model van metaforische communicatie 213, 217, 221-228, 231, 244, 248252,266

- methodiekontwikkeling 21, 29$31,47,227$

Methodologie

- wetenschaps-142, 146, 185-186, 194, 206, 210, 212

- (hermeneutische) methodologie van de kunde $141,182,184,187,202$, 205-207, 211, 213, 215, 219-220, 269, 282-284

Metonymie, metonymisch 89, 149 Missie 126, 129, 232-233, 276 - mission statement 118, 128 
Modern

- modernisten 109, 113-114119,

125,147

- moderniteit 109, 113-114, 147,

187, 190

Modaliteit

- multimodaal 199

- $\quad$ transmodaal 228

Muziek

- zintuig- 171

-metafoor 45, 163, 171, 186, $197,199,222,226,228,232$, 253

-therapie 18, 20-21, 68, 216, $225,241,243,260$

-training 40, 42, 44-45, 170-171, 200

Mythisch (-magisch) 15-17,72, 83

178,190

Narrativiteit

- Narratieve(n) 60, 91-93, 9899, 153-154, 170-172, 184, 199, 201, 261-267, 269, $271,273-374,277,279$ $280,288,291$

- narratief, -ve ervaringsleren, leeromgeving 199-200, 271, 280-281, 283-284, 288, 291

Onderzoek

-sdialoog 205, 213, 217-218, 220-221, 223, 227, 231, 238, $244,250,252,256,266,268$ -houding 56, 174, 182, 186-187, 202, 206, 219 -methode 143-144, 205-208, 210-211, 266

- responsieve methode 144, 207 208,220

Ontologie

- ontologisch(e) $61,134,155$,

$157-158,160,192,195,254-257$

- metaforen 254-257, 267, 271
Ontwikkeling

- smetaforen 69-70, 72, 86-87, $90,97-98,100-104,177,187$, 190

-sperspectief $86,96,98,100$, $168,179,200,267$

-spsychologie, -isch 27, 30

-snarratief, beeld 272-274, 279 -

280, 291-292

Oorlogsmetafoor 108, 122, 128,

136, 158, 242, 274

Oorspronkelijk(heid) 19, 69-71, 74, $83,86-87,89-90,93,98,101,103$, $108-109,165-168,177,188-191$, $204,210,214,238,245,261,265$, 279,288

Openheid 43, 56, 65, 146, 148, 154, 159-160, 180, 197, 232, 236-237, $246,253,265,270-271,287$

Operationaliseren 77-78, 81, 138, 141-142, 145-148, 220, 228, 236, $244,259,261,266,278,282,290$

Organisatie

- beeld, concept 37, 116-120, 132, 147, 151, 193, 196, 202, 213

-discours 105-108, 110-111, $113,118,122-124,124,133$, $146,149,270,278$

-metaforen 116, 149, 213 -onderzoek, (analyse, diagnose) $45,65,105-106,114,134$, $142,209,239$

- cultuur- ontwikkeling, verandering $36,42,46,63,65$, $84,114,117,124,127,130$, $132,134,145,213,234,236$, $239,242-243,259-260,276$ -structuren, vormen 48-49, 78, 109-110, 236

Organisch(e) 50, 99, 101-102, 123, 253-255

Outward bound-trainingen 50 
Overdracht 82, 91-94

- intuitieve, metaforische

(magische) 57, 69, 92, 155, 158,

$162,201,228,247$

- kennis 107, 161-161, 222, 247

- therapeutische $26-28,37,40$,

$44-47,76,81,92-93,273$

- overdrachtelijk $69,72,101$ -

$102,110,116,129,138,155$,

$166,172,158$

Overeenstemming 73, 196

Empirische (conceptuele) - 39,

$153,158,228$

Metaforische (muzikale) - 158,

197,256

Paradigma 16, 106, 115-116, 135, 142

-paradigmatisch 116-117, 122, 135,146

Paradox 172, 245

- paradoxaal 25, 109-110, 129, $150,162,171-172,257$

Pathologie 22, 24-25, 27, 175

- pathologisch, pathologisering

$75,84,174,177$

Personificatie 136

Pluriform(iteit) 28-29, 34, 38, 44, $50,68,94,105,107,116132,140$, $163,208,215-216,220,230-231$, 234, 237-239, 247, 290, 292

Positivistisch 95, 142, 156, 179, 186, 210, 220, 269

Post-humanisme 63

-modern(isme) 15-17, 53-54, 59, $63,88,106,108-109,112-114$, $119,121,124-126,134,147$, $183,279,290$

Pragmatisme 111, 121, 183

- pragmatisch $31,58-59,84$, $101,103,106,114,117,121$, $129,147,160,186-187$

- benadering 70,74, 78-81, 84-85, 97, 100-101, 103$104,151,270$
Primitief $17,16-17,23-24,44,68-$ 74, 83-84, 86-88, 94-98, 100-104, 174-177, 201, 272

Privé

-sfeer, sector 49-53, 139

Professie

- professional 111, 146, 150, $185,204,210-211,215,227$, $231,237,250,267,281-282$, 287, 290-291

- professionalisering 20-21, 23, 29-34, 47, 78-80, 85, 94-95, $211,222,227,239,246,251-$ 251, 259-260, 277, 284-287, 291 - professioneel 109, 129, 154, $170,187,200,204,207-209$, 213-215, 217-218, 221, 226$227,230,232-233,234-235$, $237,239,243,245,247,251$, $255,260,263-264,268,271$, 281-282, 286, 288, 289

- professionele motto's 231-234, $236,239,245,253,257,268$ - profilering 125, 239, 246-248, $212,218,277,284$

Progressie 38, 117

- (progressieve) ontwikkelingsdynamiek 68 , $70,82-84,100,103,173$, 176-177, 273-274

Psychiatrie 22, 24, 73, 78, 85, 200 - psychiatrisch 22-24, 49, 73, $78,95,282$

Psycho

-analyse, -isch 68-69, 74-75, 81, $87,90-91,94,96,175$

-drama 37

- logisering 41, 51

-motorische (therapie) 23, 170 , 285

-sociaal 45, 55, 71, 133, 142, $162-164,170,222,242,280$ -therapie 17, 25, 28, 37, 79, 204, 279 
Publiek(e) (sector) 49, 51-53, 139 , $150,152-153,220$

Rationalisme, rationalistisch 20,53 , $62,64,87,101,140,145-146,148$ $149,151-152,160,167,177-179$, 182, 186-191, 193-194, 199-202, 269,273

- rationalisering 19-20, 39, 48$52,63,78,80-81,85,94,141$, $148,286-287,277,279$

- rationaliteit $61-62,95,106$, $120,124,133,136,139-141$, $143-145,148,165,183-184$

- (doel-systeem)rationeel $184,219,271,274,277$ $279,287,291$

- pre-, niet-rationele $87-90,175$, $190,194,274,291$

Regressie 17, 28, 38, 68, 72, 74-75, $83,90,94-95,103,140,151,167$, 195

- regressieve (ontwikkelings)dynamiek $38,70,82-84,100,140$, 173-174, 176-177, 273-274

Reïficatie 143, 202

-(de)reïficeren 102, 104, 109, $132,134,143,162,178,192-$ $193,226-228$

Relativisme 19, 88, 134, 194-195

- relativerend, -ing, -sch 93, 151, $162,171,179,181,183,190$, 193-194, 197, 202, 206, 262, $265,267,271-272,281-283$

Retoriek

- retorische

(betekenenis)effecten 44-46, $114,116,118-119,123-124$, $126,133,147,153,156-157$, 161-162, 166-169, 172-173, $192,201,270,282$

- perspectief, invalshoek 34 , $39-40,45-46,65,93,119$ $120,140,151-163,168$, $171-173,201,149,290$
Ritueel 16, 73-74, 90, 96-97, 101, $174-175,225,245$

- ritualiseren, rituele 71-72, 83$85,90-95,97-98,100,163-164$, 174-175, 279, 291

Rogeriaanse (therapie) 27, 68

Romantiek, -isch 20, 53-65, 62, 64, $67,69-71,74,80,83-87,89-90,93$ $95,97,100-104,135,145-146,148-$ $149,151,160,177-179,187,191$, 193-194, 201-202, 205-206, 214 , $222,226,251-256,260,263,265$, 269-270, 273, 276, 278-279, 289, 291

-post-romantisch 54-55, 57-62, 149,186

Samenwerking 31-32, 38, 41, 45$46,48-49,125,139,200,211-212$, $218,222-223,225-226,228,235-$ 236, 242-243, 251, 262, 268, 270, 280, 285-286, 288, 291

Script (-waarde) 26, 92-93, 101, 225

Simile 136, 149

Sofisten(kunst) 34, 38-41, 150 - sofistisch 40, 45

Spel, spelen, speels $15,39-40,42-$ $45,60,97,110,117,120-121,123-$ $129,131,152-153,163-168,170-$ $173,175-181,186,198,200,202$, 206, 211-212, 222-223, 225-226, 228, 233-234, 238-239, 244, 247, $250,252,256-257,259,265,271-$ $274,276,284,286,289-290$

- speelruimte 84, 96-98, 164, 178-179, 194, 271, 274

- tijd-speelruimte 101-102 - spelmetaforen 121-122, 133, 206, 211-212, 244, 25 3-254, 256-257, 260-267, 271

- speltherapie 29, 78, 96, 238

- spelregels 55,181-182, 198, 206, 256-266

Spiritualiteit 42, 175 
- spiritueel 19, 38, 41, 49, 55, 159-160, 168-169, 175, 204, 263,279

Sportmetaforen 106, 121-124, 131, $147,160-162,172,211,213$

Status quo 17, 47-48, 109, 145, 204, 242,280

Strategie, strategisch $80,206,214$, $221,263,265,270-271,278,285-$ 288

- kennisstrategie $56-67,88,116$,

179,220

- leerstrategie 199-200

- organisatiestrategie 51,197 -

$109,117,239,241$

- retorische strategie $89,93,171$

- sportstrategie 109, 122

Survival

- of the fittest 114, 288

- tochten, training 35-37, 42, 225

Symbiose, symbiotisch 102,180 , 255-256

Symbool(en) 15-16, 30-31, 90 , $110,122,169,175,178,225,246$, 257

- symbolisch, symboliseren 16 , $29,107,118,136,153,174$, 211,246

Symptoom 30, 52, 94, 96, 174-175, 184

- symptomatisch 29,68

Synecdoche 136, 149, 162

Systeem 200, 218, 226, 242, 271, 290-291

-therapie 28

- rationeel (-aliteit) 139, 219, 271-272

Taboe, getaboeïseerd 46, 61, 71-72, $85,112,158,242,245$

Talisman 91-92, 94-95, 118

Teambuilding $37,47,117,200,234$ Techn(olog)isch 19, 56, 61, 129, $145,148,151,273,291$
Tegen

-beweging $19,48,53,63,202$, $210,273,279$

-hanger $64,93,123,127,177$, 190,256

-beeld 20, 270

Transcenderen (-ent-ie) 26,190 , $262,267,271$

-transcendentaal 61

Transgressie 46, 70, 82, 84, 101, 162

- transgressieve

(ontwikkelings)dynamiek 82-84, 98, 173, 272-274, 290

Uiterlijke (werkelijkheid) 23-24, 45 , $109,118,128$

Vaktherapie 204, 238

Verabsolutering 58, 64-65, 101$102,178-179,191,193-194,265$

Verandering

-skunde 132, 145

-veranderingsmetaforen 132 , $212,242,244,247-248,250$, 267

- veranderingsmodellen 64,69 $70,84,86,96,98,103-104$ Verbaal(e) 22, 25, 43-44, 46-47, 63, $69,72,85,88,90,167-168,199$. $208,211,246,250,258,274,282-$ $283,289,291$

- non-verbaal $25,31,40,44,72$, $153,165,170,201,238,240$, $255,258,270-271,276$

Verbeelding 16-17, 22, 26, 40, 42, $60,106,117,120,133,143,147$, $156-157,160,168,173,181,195$, 216-217, 230, 233, 244, 250, 255, 257, 271, 273-274, 289-290, 292

Verlichting 59, 88, 169-170, 188 190-192

-sdenken 53, 55, 63, 189-190

-sideaal 53, 63, 188-189

Vergelijking 114, 149, 163, 173

Vertolking 54, 60, 157, 164, 171, 261, 255 
Verwoording 67, 88, 94, 98-104, $216,249,255,257-258,260,290$ Verzakelijking $32,48,93,70,78$ $79,85,204,213,240-242,247$, 256-257

Virtueel (- virtualisering) 15, 108 Voedsel/ing-metafoor 212, 253255

Vooruitgang 19, 68, 84, 102 -vooruitgangsgeloof, -optimisme $15,19,84,190$

- sdenken 96-97, 101

Wetenschap-metafoor 252, 255256, 258

Wereldbeeld(en) 15-17, 50, 55, 62, $64,126,151,178,187,191,193-$ 196, 202, 265-266

Werkelijkheid -servaring 15-17, 193, 196, 199 -beleving $17,95,87-88,94,99$ 100,162

Win-win-(doelstelling van gezamelijk gewin) 208, 210, 213$215,217,238,244,251,267,288$ Zelf -beeld(en) 151, 191, 193, 202, 225,266

-ervaring 199, 264

Zenleraar-metafoor 252, 255-256, 258

Zieke organisatie 211, 213, 237, 242, 246, 248

Zijn

-skwaliteiten 236, 246, 263, 271

-metafoor 65, 192, 235-236,

244-247, 250, 252, 268, 271

-sorde(ning) 16, 85-86, 103-104,

157

-servaring 191, 197

-sgrond 160, 165, 192, 196

Zin

-geving $26,48,51,53,55,61$

- (ruimere context van)

zingeving (-sdimensie) 260 ,
262-267, 271-272, 279-284, 291-292

-speling 165, 167-168, 193, 271, 284, 291-292

Zondebok 91-92, 101

Zorgvisie 32, 241-242, 255, 277 
Abma 106, 141-143, 207-210

Argyris 144-145, 148

Ankersmit 113, 138, 150

Apollo 88, 222, 260, 272, 274

Aristoteles 61, 150, 152-153, 183

Bacon 56-57, 149, 188

Bataille 15

Baudrillard 195, 202

Bergen, van 38, 52

Berman 18

Bernstein 118, 140

Black 113, 136

Boden 177

Boeddha 168-169

Boer, de 54

Böhme 55, 188, 289

Braidotti 17, 60

Brom 27

Budde 67, 79

Bulhof 158

Cassirer 15, 59, 61, 91, 174

Dalley 57, 67, 80, 91, 97, 225

Daniels 124

Denzin 143, 182

Derrida 111, 121, 134-135, 156, 164, 167,261

Descartes 42, 185

Dionysos 88, 222, 272, 274

Dongen, van 107, 142, 227

Drift, van der 29, 31, 68

Duintjer 55, 260

Elias 50

Engeldorp Gastelaars, van 61, 141, 183

Feder 68,87

Forbes 274

Foucault 53, 141

Frazer 15, 91, 174

Freud $28,75,90,94,175$
Gadamer 54, 89, 92, 164, 183, 202

Gandhi 120, 132-133, 178

Gebser 15, 274

Goodall 57

Goodman 92, 117

Grant 110, 134, 136, 208, 210

Griensven, van 30

Guba 143, 207, 209, 228

Gustavson 139

Habermas 53, 61, 106, 139, 141, $143-144,148,183,280$

Hegel 50

Heidegger 17, 54, 59, 88, 165-166, 197

Hellendoorn 83

Hermes 107-108, 178-181, 191, 201, $220,222,260,265,274,276$

Hesse 113

Huizinga 122

Husserl 59

Hutschemaekers 78

Jaspers 15, 17, 55, 260

Johnson 136, 184

Jung 73, 82, 90, 175, 177

Kaas 23

Kahn 159, 169, 181

Kant 19, 55, 61, 144, 188, 197

Klein 81, 96

Knibbe 168

Krishnamurti 145-146, 274

Kunneman 61, 141

La Mettrie 17, 137

Lakoff 136, 184

Langer 174

Leopold 196-197

Levine $68,72,81,88$

Lievegoed 36

Lincoln 143, 182, 207, 209, 228

Lubbers 54,89 
Lyotard 264

Marissing 99

Marx 50, 133

McNiff 74, 99

Mintzberg

Moerland 261

Mooij 113, 138, 150, 161

Moreno 37

Morgan 54, 156, 185

Mul, de 19, 109, 190

Naschold 139, 280

Neijmeijer 78

Merleau-Ponty 184

Nietszsche 88-89, 111-112, 131,

$136,189-190,194,197,199,202$,

222,273

Oosterling 179

Ortony $116,134,136,184$

Oswick 110, 134, 136, 208, 210

Plato $39-40,67,150,156-157,160$,

169,192

Plokker 23

Pott 184

Prins 179

Ramondt 48, 120

Ricoeur 45, 54, 136, 150, 164-166, 261

Rutten-Saris 30, 60, 98

Sartre 59

Schaverien 91-92

Schön $36,106,132,136,141-142$,

144-145, 148

Simhoffer 25, 30

Smeijsters 27, 29-30, 80

Smitskamp 28

Socrates 34, 140, 150, 270

Tiemersma 164

Tsoukas 114, 133, 162

Watts 169, 176

Watzlawick 59, 126, 104

Weber $50,110,184$

Weick 107, 129, 133, 142

Widdershoven $61,98,182-183,159$

Winnicott 28, 81, 96

Wit, de 169
Wittgenstein 184

IJsseling 150 
In het eerste hoofdstuk wordt het onderzoeksonderwerp geïntroduceerd: de recentelijk toegenomen belangstelling voor de factor creativiteit in therapie en organisaties. De ontwikkeling van creatieve therapie in Nederland wordt beschreven, waarna er een verslag volgt van een vergelijkbare trend in het kader van loopbaanbegeleiding, coaching en organisatietrainingen om gebruik te maken van creatieve en ludieke werkvormen. Voor zover de toepassing van kunstgerelateerde (non) verbale communicatiemiddelen in veranderingsprocessen, zoals beelden, dramatechnieken en muziekmiddelen, een in de praktijk gegroeide kundigheid is, wordt ze in dit onderzoek beschouwd als een vorm van intuitieve praktijkkennis.

Creatieve therapie is vooral ontstaan vanuit een humanistische opvatting over persoonlijke groei en geestelijke gezondheid. In de 'profit-sector' wijst de ontwikkeling van creatieve trainingen op het centraal stellen van de mens en de factor creativiteit binnen de extreem gerationaliseerde bedrijfsprocessen. Ogenschijnlijk draagt de toepassing van creatieve middelen in beide sectoren aldus bij aan de humanisering van ons (werk)leven en biedt ze een tegenwicht tegen 'de onttovering van ons wereldbeeld'. Het zou echter getuigen van een naiieve opvatting van humanisme wanneer daar zonder meer vanuit wordt gegaan. De toepassing van alternatief ogende, psychologische en creatieve 'technieken' biedt als zodanig geen garantie voor de daadwerkelijke humanisering van mens en organisatie. Als 'humanistische make up' zou de trend van creativiteit een subtiele maar verregaande voortzetting kunnen inluiden van de rationalisering van organisaties, van ons privé-leven en van de samenleving in haar geheel. Derhalve wordt deze ontwikkeling in dit onderzoek 'ideologie-kritisch' getoetst.

Deze kritische invalshoek wordt vervolgens in verband gebracht met een method(olog)ische onderzoeksvraag naar de omstreden 'meerwaarde' van de toepassing van creatieve middelen. Tegenover de intuïtief-gevoelsmatige wijze waarop praktijkkennis in het kader van creatieve therapie en creatieve organisatietrainingen tot stand komt, staat de 'empirisch-rationele' weg van wetenschappelijke kennisvergaring. De methodologische tegenstelling met het rationaliseringsproces, de bedding van onze moderne wetenschapsbeoefening, suggereert dat een romantisch perspectief op kennisontwikkeling aan de basis van de onderzochte praktijkkennis staat. Om niet in een dichotomiserende beantwoording van de onderzoeksvraag te geraken is de vraagstelling verschoven naar de moge-lijkheid van een derde 'middenweg' tussen een rationalistisch-beheersende versus een romantisch-empathische benadering van het onderzochte. Het is echter de vraag hoe wij als 'post-moderne' wereldburgers toegang kunnen verkrijgen tot een 'romantische' benadering van de werkelijkheid. Door gebruik te maken van 
fenomenologische en hermeneutische onderzoeksmethoden is het mogelijk om zicht te verkrijgen op de een 'post'-romantische grondhouding, van waaruit intuittieve praktijkkennis geboren wordt. De toepassing van creatieve communicatiemiddelen wordt aldus vanuit een fenomenologisch-hermeneutische invalshoek geïnterpreteerd, waarbij het begrip van 'de metafoor' centraal staat teneinde 'de eigenheid' van de intuittieve kennisvorm te articuleren. Langs deze weg zou er aan gene zijde van een romantisch opgevat naïef humanisme enerzijds en dominante rationaliseringsideologieēn anderzijds zicht kunnen komen op een derde, 'bemiddelende' grondhouding. Op basis van deze grondhouding zal een kritischhumanistische grondslag voor de toepassing van het creatieve medium in veranderingstrajecten geformuleerd worden.

In hoofdstuk 2 wordt een analyse van creatief therapeutische literatuur gegeven. Niettegenstaande de pluriformiteit van deze vakliteratuur is er een overeenkomstige vooronderstelling aangetroffen: namelijk dat de cliënt door middel van de dialoog met het creatieve medium in een 'metaforische ervaringsmodus' geraakt. Ten opzichte van de 'alledaagse' common sense en de 'wetenschappelijke' conceptuele kennis kan de in creatieve therapie verkregen 'metaforische' ervaringskennis als preconceptueel worden aangemerkt. Vanuit het hermeneutische onderzoekskader vormt deze gemeenschappelijke vooronderstelling de achtergrond om de in de vakliteratuur (impliciet of expliciet) ingenomen theoretische posities te interpreteren. Drie posities zijn getypeerd aan de hand van de wijze waarop de 'metaforische ervaringsmodus' in de vakliteratuur wordt benoemd en geduid:

(1) Vanuit een 'antropologisch' perspectief wordt de dialoog met het creatieve medium opgevat als een symbolisch-rituele betekenisgevende praktijk, die overeenkomt met een 'primitieve' ontwikkelingsfase van de mensheid. Deze wijze van betekenisgeving, die daadwerkelijk nog in sommige 'niet-westerse' culturen zou zijn aan te treffen, vertegenwoordigt volgens deze optiek een 'authentiekere' zijns- resp. kenwijze dan de 'rationalistische' van onze westerse cultuur.

(2) Vanuit een 'psycho-therapeutische' invalshoek wordt de metaforische ervaringsmodus eveneens opgevat als een 'primitief' stadium in de psychische ontwikkeling. Er vindt evenwel een accentverschuiving plaats in de interpretatie van de creatief therapeutische beelden: van een 'authentieke expressievorm' met symbolische betekenis naar een symptomatische expressie van een 'pathologische ontwikkeling'. Bijvoorbeeld wordt 'magisch denken' bij volwassenen beschouwd als een fixatie van de ontwikkeling in een kinderlijk stadium, aangezien het 'logische denken' tekenend voor een 'gezond, volwassen stadium' zou zijn.

Deze invalshoek berust op een instrumentele benadering van creatieve therapie, namelijk om van de 'primitieve' expressievorm gebruik te maken teneinde de psychische ontwikkeling van cliënten weer te normaliseren. Een extreme variant van deze instrumentele invalshoek is de 'pragmatische 
benadering', waarin creatieve therapie door middel van 'praktijkhandleidingen' met opdrachten, therapeutische interventies en technieken met het oog op een gedragsmatige behandeling van psychiatrisch gediagnostiseerde ziektebeelden 'eclectisch' en 'functioneel' wordt ingezet.

(3) Volgens een 'kunstgeoriënteerd' interpretatiekader vindt er in creatieve therapie een analoog proces plaats van 'innerlijke' en 'uiterlijke' vormgeving, resp. van 'psychische' en 'esthetische' expressie. Derhalve worden beeldendtherapeutische processen niet als een 'symbolisch ritueel proces' noch als een 'normalisering' via een tijdelijke 'regressie' in de ontwikkeling met het oog op een 'progressief' psychisch herstel gezien. Dit derde perspectief interpreteert het 'analoge' psychisch-esthetische proces' als een betekenistransgressie via de dialoog met het medium.

Deze drie benaderingen gaan elk uit van een ander perspectief op psychische gezondheid en ontwikkeling van waaruit de creatief-therapeutische processen een karakteristieke duiding verkrijgen. De eerste twee benaderingen van creatieve therapie zijn in dit hoofdstuk gekarakteriseerd als een therapeutisch interventiekader, gericht op het uitlokken van een regressieve resp. een progressieve psychische dynamiek, die tot een achteruitgang resp. een vooruitgang in de ontwikkeling leidt. Vanuit het derde ontwikkelingsperspectief wordt beeldende expressie, direct aan de waarneembare actualiteit gekoppeld: aan de zichtbare interactie van de cliënt met het creatieve medium en met de therapeut. Deze derde benadering van creatieve therapie wijst op een transgressieve dynamiek in het proces van betekenisgeving als spil van psychische veranderingsprocessen.

De drie benaderingen in de vakliteratuur corresponderen met de historische ontwikkeling van creatieve therapie: van de 'romantische pioniersfase' tot de huidige 'instrumentele oriëntatie' in het kader van de verzakelijkte gezondheidszorg. De eerste fase is schatplichting aan een romantisch antropologisch wereldbeeld, van waaruit 'ont-wikkeling' een teruggang betekent naar een 'natuurlijke' zijnswijze en een 'authentieke' wijze van betekenisgeving, op grond van een minder gerationaliseerde verhouding tot de werkelijkheid. De tweede fase correspondeert met een rationalistisch beeld van ontwikkeling als een vooruitgang door de vermeerdering van onze rationele vermogens. Zowel de rationalistische als de romantische benadering veronderstelt een rechtlijnige ontwikkelingsmetafoor, als het ware een trap of een ladder om naar boven en vooruit resp. weer naar beneden en achteruit te gaan. De derde kunstgeoriënteerde benadering gaat uit van een ontwikkelingsmetafoor met een andere dynamiek, die veeleer als een slingerende beweging of een spiraal kan worden voorgesteld. Vanuit dit derde perspectief verschijnt de dialoog met het creatieve medium 'meanderend' langs een parallelle ordening van beeldende en psycho-sociale processen.

Ten slotte is de literatuuranalyse betrokken op de onderzoeksvraagstelling naar 'de meerwaarde' van de toepassing van het creatieve medium als (non-)verbaal 
communicatiemiddel in therapie. Hoe wordt deze vraag verhelderd vanuit de drie ontwikkelingsperspectieven? De 'metaforische ervaringsmodus' stoelt, volgens de derde 'kunstgeoriënteerde' invalshoek, op een dialectiek tussen woord- en beeldtaal, tussen een 'letterlijk' en een 'figuurlijk' interpretatieniveau. Terwijl de twee andere benaderingen berusten op een ontwikkelingsmetafoor die één van deze 'polen' in het proces van betekenisgeving prioriteert, stelt de derde benadering de wisselwerking centraal: 'betekenis' is het 'hermeneutische' resultaat van een dialectiek tussen zintuiglijk present stellen resp. beeldend tonen en verbaal representeren in een conceptuele vorm. Het proces van (creatief therapeutische) betekenisgeving berust op beide pijlers van een 'analoge' en een 'conceptuele' vertolking van de werkelijkheid. Als conclusie volgt uit dit hoofdstuk dat het derde veranderingsmodel op basis van een kunstinvalshoek het meest adequaat is om de beeldend-therapeutische processen vanuit hun 'eigenheid' te beschrijven en te interpreteren.

In hoofdstuk 3 volgt een analyse van de populariteit van creativiteit en metaforen in het organsatiediscours. De rol van metaforen als onderzoeks- en interventiemiddel en de waarde van creativiteit voor organisatieprocessen wordt zeer verschillend beschreven en beoordeeld. Er zijn wat dit betreft drie genres onderscheiden aan de hand van het werk van Morgan. Op meta-theoretisch niveau organiseert de metafoor, vergelijkbaar met het 'paradigmabegrip', het denken over organisaties en management. Op wetenschappelijk niveau fungeert de metafoor als een onderzoeksinstrument, waarmee organisatievormen en managementstijlen getypeerd worden. Op het praktische niveau van toepassing en interventies in organiatieprocessen functioneert de metafoor als een 'managementtool' ter ondersteuning van communicatie- en interactieprocessen op de werkvloer.

In de praktische managementcontext is de waarde van creativiteit voor de ondersteuning van organisatieprocessen veelal instrumenteel en opportunistisch afgemeten. De 'creatieve trajecten' in training, coaching en advieswerk bieden ogenschijnlijk een alternatief ten opzichte van dominante benaderingen van organisatieprocessen. Vanuit de 'ideologiekritische' onderzoeksvraagstelling lijken ze echter veeleer als succesvolle en lucratieve handlanger dan als tegenhanger van de instrumentele rede te fungeren. (Hoe) kunnen metaforen en creativiteit niet eenzijdig 'strategisch' met het oog op bedrijfsbelangen worden toegepast? In dialoog met de (populaire) managementliteratuur is hiertoe een randvoorwaarde uitgewerkt, aan de hand van een 'deconstructieve analyse' van het succesvolle basketbalteam, een managementmetafoor voor een nieuwe stijl van leiding geven in het Informatie Tijdperk. Een reflectief-communicatief moment in managementinterventies maakt het mogelijk om aan gene zijde van opportunistisch metafoorgebruik 'een metaforische benadering' van organisatieprocessen te stoelen op een 'alternatief' rationaliteitsconcept.

Deze conclusie uit de literatuuranalyse is niet inhoudelijk uitgewerkt maar voorwaardelijk aangeduid in de vorm van een 'dialogische grondhouding'. Vanuit 
de dialoog zijn verschillen in (interpretaties van) organiseren niet opportunistisch 'om het even' zolang ze maar 'werken' of 'functioneel' zijn. Evenmin wordt er een 'onpartijdig' standpunt voorondersteld dat 'metafysisch' boven alle betrokken partijen zou staan, van waaruit de verschillende standpunten in organisaties gewaardeerd kunnen worden. Een 'dialogische grondhouding' vertegenwoordigt veeleer de ideologische en communicatieve randvoorwaarde om (metaforische) interpretaties van processen in organisaties steeds opnieuw in de 'organisatorische dialoog' in te brengen en tegen elkaar af te wegen.

De dialogische grondhouding is niet gestoeld op consensus, noch in een voorwaardelijke zin noch als een gewenst einddoel. Veeleer is de dialoog zelf voorwaardelijk om een 'emotioneel-sociale' communicatieruimte resp. een ideologische krachtenmeting te organiseren, waardoor de pluriformiteit van 'de organisatorische werkelijkheid' tot haar recht komt. Het in dit hoofdstuk aangegeven verband tussen de 'meerwaarde' van (non)verbale communicatiemiddelen met de dialogische grondslag resulteert met betrekking tot de analyse van het organisatiediscours in een belangrijk inzicht. Om het onderscheid te markeren tussen een 'metaforische benadering' en het technische gebruik van metaforen in een 'instrumentele context van strategisch handelen' is in het verlengde van de analyse van creatief therapeutische literatuur gesteld, dat het creatieve medium een gelijkwaardige stem in de dialoog vertegenwoordigt. Deze 'derde gesprekspartner' staat voor 'openheid en betrokkenheid' in communicatie resp. voor het communicatief-reflectieve moment dat aan de instrumentele rede moet worden toegevoegd teneinde niet in opportunistisch metafoorgebruik te vervallen. Aan de hand van praktijkvoorbeelden van dialoogvormen uit de literatuur (het Socratisch gesprek, Habermas' machtsvrije dialoog en het communicatiemodel van Argyris en Schön) is als conclusie aangegeven hoe 'de dialogische grondhouding' de gezochte grondslag voor een 'metaforische benadering van organisatieprocessen' vertegenwoordigt. Deze is tot slot met betrekking tot communicatieprocessen in organisaties getypeerd als een 'open en betrokken gesprekshouding van deelnemers aan een dialoog waarin beslissingen worden genomen op basis van een vrij, gelijkwaardig en geïnformeerd standpunt van alle gesprekspartners'.

In hoofdstuk 4 is de 'derde weg' naar de dialogische grondslag van intuîtieve praktijkkennis ingeslagen via een hermeneutische interpretatie van creatieve trajecten in therapie en organisatietrainingen. Een retorische invalshoek op communicatie is te hulp geroepen om de rationalistische eenzijdigheid van een logisch perspectief op communicatie aan te vullen. Met betrekking tot de karakteristieke communicatiewijze via het creatieve medium zijn er drie vormen van 'metaforische communicatie' onderscheiden:

1) het inlassen van metaforen in een discursief vertoog,

2) de metaforische vormgeving van een verhaal 
De derde, meest uitgesproken vorm van metaforische communicatie is typerend geacht voor de zintuiglijk-gevoelsmatige kennisoverdracht die in creatieve trajecten plaatsvindt. Kenmerkend hiervoor is het gegeven dat 'de metaforische verplaatsing' niet zozeer cognitief van een bepaald kennisdomein naar een ander kengebied plaatsvindt maar veeleer emotioneel-interactief van een domein van professionele en/ of persoonlijke vaardigheden naar een 'analoog domein' van creatieve vaardigheden en vice versa. Deze derde vorm van metaforische communicatie zou derhalve op de dialogische grondhouding gestoeld moeten worden teneinde de empathisch-intuïtieve praktijkkennis in het kader van creatieve therapie en organisatietrainingen een kritisch-humanistische signatuur te geven.

De hermeneutiek koerst tussen een rationalistische devaluering van de metafoor als instrument voor kennisvergaring èn een romantische verabsolutering als een 'intuïtieve kennisvorm' in. Wanneer de intuittieve kennisoverdracht vanuit een 'hermeneutische middenpositie' wordt geïnterpreteerd, verschijnt ze als een 'systematisering van ervaringskennis' (Lakoff en Johnson), die gefundeerd is in 'de leefwereld' (Habermas). Aldus emotioneel-lichamelijk verankerd in ons zijnin-de-wereld geeft 'de dialoog' de wijze aan waarop er vanuit die 'ervaringsgrond' kennis gegenereerd wordt. De 'dialogische kenwijze' genereert een dialectiek tussen de rationalistische beweging van abstrahering en conceptualisering en een 'romantische tegenbeweging' van incarnering van kennis. 'Tussen' de rationalistische loskoppeling van kennis van de persoon en van de concrete situatie èn de operationalisering van kennis in de persoonlijke ervaring en de lichamelijkheid, heeft de 'dialogische grondhouding' verwantschap met een door anderen gezochte 'middenpositie', bijvoorbeeld 'de integratie van kennis van het hoofd en kennis van het hart' (Gandhi), Ricoeurs 'ontologie van de metafoor', een weg 'tussen objectivisme en subjectivisme' (Lakoff en Johnson), tussen 'objectivisme en relativisme' (Bernstein), tussen 'paternalisme en romantiek' (Abma), tussen een 'binnenperspectief en een buitenperspectief' (Habermas), tussen 'empirisme en intellectualisme' (Widdershoven).

De dialogische 'middenpositie' mag niet worden misverstaan als een 'grijs midden' of een compromis-standpunt. Aan een ontologisch-epistemologische positionering die leidt tot een wetenschappelijke of een intütieve benadering van de werkelijkheid gaat een hermeneutisch 'spel' van grondhoudingen vooraf. De 'middenweg' vertegenwoordigt een 'dialectische speelruimte', waarin een 'ideologische krachtenmeting' ten aanzien van kennisvergaring plaatsvindt. In deze 'bemiddelingsruimte' kunnen fundamentele (humanistische) waarden die in communicatie en interactie gestalte krijgen, op kritische en speelse wijze tegen elkaar worden afgewogen en uitgedragen. De dialoog houdt deze ruimte open, waarin ideologische keuzes vanuit de 'facticiteit' van de gesprekssituatie worden gemaakt. Deze keuzevrijheid betekent geen willekeur maar openheid. Openheid grenst aan willekeur, maar de scheidslijn is een gesprekshouding waarin ontvankelijkheid is 
gekoppeld aan speelse nieuwsgierigheid. De dialogische openheid vooronderstelt èn bewerkstelligt een radicale vorm van (zelf)kritiek vanuit betrokkenheid, wat leidt tot een speelse en onderzoekende gesprekshouding.

De dialoog biedt in de gestelde zin een bodem waarop zelf-, organisatie-, maatschappij- en wereldbeelden op 'authentieke' wijze kunnen worden ver(ant)woord. Hierdoor krijgen onze beelden over de werkelijkheid een kritisch-humanistische verankering in 'de leefwereld': in 'authentieke communicatie' bestaat de mogelijkheid de gegeven definities over de (therapeutische en organisatorische) werkelijkheid te herroepen maar men blijft er te allen tijde op aanspreekbaar. De hermeneutiek heeft hiermee een 'dialogische weg' gewezen hoe een humanistische grondslag in de zin van 'authentieke communicatie' in creatieve trajecten kritisch vorm gegeven kan worden. Voor zover het creatieve medium als derde gesprekspartner de bewaker is van de dialogische 'openheid en betrokkenheid' is hiermee tevens het wenselijke reflectief-communicatieve moment gekarakteriseerd dat de eenzijdigheid van de instrumentele rede op speelse en kritische wijze vermag aan te vullen. Aan de hand van een drietal metaforische typeringen van de 'opbouwende' aard van het dialogische communicatieproces is er invulling gegeven aan de notie van 'authentieke communicatie'. Deze 'niet-metafysische' interpretatie kan als alternatief 'ijkpunt' dienen voor een dialogische vormgevig van creatieve trajecten in therapie en organisatietrainingen. Behalve met betrekking tot een romantisch naïeve opvating van authentieke communicatie markeert dit ijkpunt ook de scheidslijn met een 'postmoderne' nihilistische conclusie ten aanzien van het proces van betekenisgeving als een oneindig en willekeurig proces van betekenisdisseminatie. Als conclusie uit dit hoofdstuk is er een kritisch humanistisch gerehabiliteerde vorm van authentieke communicatie in de plaats gesteld van deze postmoderne gedachte over de 'esthetisering van ons bestaan'.

In hoofdstuk 5 is de literatuuranalyse in verbinding gebracht met een veldonderzoek naar de praktijk van creatieve therapie en creatieve organisatictrainingen. Het onderzoeksverslag heeft de vorm gekregen van een reconstructie van een 'uitwisselingsproject' tussen de twee groepen professionals die met creatieve middelen werken. De 'win-win-doelstelling' die voor dit project was geformuleerd, betekent met betrekking tot creatief therapeuten de zorg om het 'creatieve kind' niet met 'het badwater' van verzakelijking van de gezondheidszorg weg te gooien. Hier tegenover staat het risico in de 'harde' sector van het bedrijfsleven dat de van oorsprong 'softe' middelen in de greep van de instrumentele rede geraken, waardoor er 'schuimig badwater' zonder 'creatief kind' overblijft. De uitwisselingsgedachte is vervat in de vraag of beide beroepsgroepen gezien deze ontwikkelingen iets voor elkaar kunnen betekenen. Het onderzoeksproject bestond uit een serie individuele diepte-interviews, twee homogene groepsbijeenkomsten om de resultaten uit de interviews te valideren en te verdiepen, een heterogene groepsbijeenkomst gericht op uitwisseling van kennis en ervaring, en een telefonische evaluatieronde. 
De volgende bevindingen zijn uit het veldonderzoek voortgekomen waarmee met betrekking tot de filosofische analyse 'de emprische winst' is opgemaakt. In de eerste plaats is het belang van concrete metaforen voor de therapeutische en organisatorische praktijk onderstreept, zoals 'de homo ludens', de 'zijnskwaliteitenmetafoor' en veranderingsmetaforen met betrekking tot de communicatiekloof tussen management en werkvloer. In de tweede plaats is er zicht gekomen op een dimensie van zingeving, die zowel de conventionele therapeutische en organisatorische referentiekaders transcendeert àls het abstracte filosofische kader van 'metaforische betekenisgeving' concretiseert. Door de dialoog met de praktijk resp. met het creatieve medium wordt er een verbinding gelegd met een existentieel betekenisgevend veld vanuit de directe ervaring. De concrete metaforen over mens en organisatie, de management- en levensverhalen vinden in dit existentiële veld hun humanistische oorsprong, wat met de term 'narrativiteit' is aangegeven. De dialogische communicatie via het creatieve medium genereert een kritisch moment ten aanzien van deze 'humanistische oorsprong' vanuit een ruimere dimensie van zingeving. Hiermee verkrijgen de communicatieve waarden van 'authenticiteit', 'autonomie' en 'integriteit' in het kader van creatieve trajecten een concrete operationele vorm en een 'niet-metafysische' betekenis.

Wanneer deze 'empirische winst' uit het uitwisselingsproject weer op de filosofische uitkomst van het onderzoek wordt betrokken, is de conclusie dat een dualistische zienswijze van 'de mens' tegenover 'de organisatie' niet adequaat is om de 'meerwaarde' van creatieve trajecten met betrekking tot hun grondslag te begrijpen. Een non-dualistische optiek, van waaruit beide partijen in hun onderlinge verwevenheid en interdependentie veschijnen, is met de uitkomsten uit het theoretische en het praktijkonderzoek in overeenstemming. De conclusie luidt derhalve dat de creatieve trajecten een narratieve ervaringsgestuurde leerruimte genereren voor zover ze op een kritisch humanistisch vormgegeven dialoog gestoeld zijn. Cruciaal hiervoor is een dynamisch in het constructieve dialogische proces geworteld ijkpunt voor 'authenticiteit' en een door de trainer of therapeut uitgedragen visie over de 'autonomie' van individuele deelnemers ten opzichte van bedrijfsbelangen. Met deze slotsom uit dit hoofdstuk is aangegeven hoe een kritisch humanisme berust in een door creatief therapeuten en creatieve organisatietrainers uitgedragen en belichaamde vorm van 'integriteit'.

In het zesde hoofdstuk is gereflecteerd op het gevolgde onderzoekstraject en aangegeven hoe onderzoekskader en onderzochte praktijk zich tot elkaar hebben verhouden. Wat is de waarde geweest van de filosofische interpretatie van creatieve therapie en creatieve trainingen als metaforische vormen van 'intuitieve praktijkkennis', en andersom, wat betekent deze dialogische wending naar de praktijk voor de filosofie?

In de context van creatieve therapie biedt de dialogische wending een richtsnoer zowel binnen de therapiekamer als daarbuiten hoe de eenzijdige romantische orièntatie op intütief gevoelsmatig handelen aan te vullen met reflectie en com- 
municatie, zonder in het andere extreem van strategisch handelen door te schieten. In dialoog met cliënten, met de organisatie en met vakgenoten dienen creatief therapeuten hun professionele handelen te ver(ant)woorden, hetgeen voorwaardelijk is voor de professionalisering van deze discipline. In de context van het organisatiediscours biedt filosofische reflectie een buffer tegen opportunistisch metafoorgebruik. In de vorm van een structureel reflectief-communicatief (onder) handelend moment draagt zij bij aan de vorming van een ideologische vrijplaats resp. krachtenmeting om humanistische waarden uit de leefwereld te verzoenen met eisen van een dominante systeemrationaliteit. Andersom geeft de middenpositie in de gestalte van de homo ludens een dialogische wending aan de (filosofische) onderzoekspraktijk. Hierdoor vindt er een herschikking in de traditionele supprematie van theoretische kennis ten opzichte van praktijkkennis plaats. In overeenstemming hiermee is er niet voorafgaande aan en los van de onderzochte praktijk een onderzoeksmethodologie opgesteld, maar is deze uit de gevoerde dialoog met de praktijk voortgekomen. De 'homo ludens' heeft de onderzoekster uitgenodigd om minder ernstig en rechtlijnig met filosofische grondvragen om te gaan, om speelser te denken en beeldend-buigzame concepten te vormen.

Vanuit de dialogische middenpositie is het verschil tussen creatieve therapie en creatieve trainingen gerelativeerd als verschillende varianten van een fundamenteel overeenkomstige vorm van narratief ervaringsgestuurd leren. Spelend met en kritisch ten opzichte van traditionele ideëen over rationalisering en humanisering biedt de 'narratieve leernuimte' in therapie en organisaties een kader voor de articulatie van 'alternatieve ontwikkelingsnarratieven'. Niettemin dienen de creatieve werkvormen en de funderende humanistische waarden ingebed te worden in het instrumentele kader van een organisatorische werkelijkheid. Uit het onderzoek is gebleken dat het mogelijk is in creatieve trajecten een zodanige (hermeneutische) balans tussen zingeving en zinspeling te bewerkstelligen, dat deze extremen met elkaar worden verzoend. Daartoe is het wenselijk dat de professional kan balanceren tussen een dionysische gevoelsmatig-intuitieve overgave aan en een appolinische reflectieve afstand tot de praktijk. Deze professionele balaceerkunst concretiseert de hermeneutische middenweg tussen een rationalistische en een romantische benadering van de werkelijkheid.

Met het oog op actuele maatschappelijke ontwikkelingen met betrekking tot beide professies is het belang van de dialoog ook in praktische zin aangegeven. Als belangrijkste aanbeveling is naar voren gekomen dat het in het voordeel van beide beroepsgroepen zou strekken wanneer zij een organisationele vorm voor samenwerking creëren: bijvoorbeeld in opleidingsverband en door een gezamenlijke belangen- of beroepsvereniging. Hiermee zou de 'win-win-constellatie' van het uitwisselingsproject voor beide beroepsgroepen kunnen worden bestendigd. Cruciaal hiervoor is de wijze waarop dergelijke 'externe' vormen van samenwerking worden gedragen vanuit een integrerend 'intern' perspectief. Het belang hiervan en de dialogische wijze waarop dit kan worden gerealiseerd zij met dit onderzoek aangegeven. 
In the first chapter the research subject is introduced: the increasing popularity of creativity in organizational and therapeutic processes. The developing body of knowledge about creative processes is interpreted as a form of intuitive practical knowledge in which art media are applied. The history, the social context and methods of this practical knowledge are described first. Then the 'philosophical roots' of highlighting creativity in therapy and organizations are investigated. It is often assumed that humanistic values play a key role in these developments. This 'naive' evaluation is examined by means of the critical question: are creative processes in therapy and organizations being used as a psychological technique in the process of rationalization or as an enhancement of humanistic values? Parallel to this critical analysis a methodological research route is operationalized: what is the foundation of intuitive practical knowledge compared to the rationalistic roots of scientific knowledge? From this methodological point of view a 'romantic' ontology seems to represent the philosophical foundation we are looking for. To avoid a dichotomizing answer of the research question a 'third route' between 'romanticism' and 'rationalism' is proposed by means of a hermeneutical analysis of the creative processes in therapy and organisations. The aim of this research route is to demarcate a form of 'critical' humanism in order to establish intuitive knowledge and shed light on the practical and ideological 'value' of applying nonverbal tools in communication processes.

In the second chapter an analysis of literature on art therapy is given. In spite of the plurality of this literature there seems to be a common presupposition: the application of art media and creative methods leads to a 'metaphoric form of communication' as a typical mode in which reality is being experienced. Three different theoretical positions in literature are being outlined based on how this 'metaphorical mode' is interpreted:

1. An anthropological perspective interprets 'metaphoric communication' as a symbolic-ritualistic way of communicating and interacting with the world, being of a more 'authentic' character and belonging to a more 'primitive' developmental phase in comparison with our 'rationalistic western culture'.

2. A psycho-therapeutic perspective interprets 'metaphoric communication' as symptomatic of a pathological development. A pragmatic stance in art therapy is an extreme species of this position.

3. An art centered perspective which postulates an analogy of psychic and esthetic expression in metaphoric communication. 
These three perspectives are grounded on a typical model of psychological development, focusing on psychological dynamics of 'regression', 'progression' and 'transgression' respectively. These different models represent three historic stages in the development of art therapy: a romantic initial phase, the stage of 'professionalization' towards an instrumental orientation in health care, and an 'esthetic perspective', corresponding to the historical fact that professional artists were at first hired in hospitals to apply art methods in therapy. This third perspective seems to focus mainly on the 'creative processes' involved in art therapy, interpreting them as a dialectics between a discursive and an analogical way of communication. Therefore this third therapeutic model seems to be most adequate to shed light on the 'practical value' of 'metaphoric communication' from a methodological point of view.

In the third chapter an analysis of organizational and management literature is given. There are three levels of analysis in organizational discourse: metatheoretical reflections on organisation theory, generating scientific models and theories, and the level of management applications. In each of these three levels there is a different focus on creativity and metaphors. Opposite to the theoretical scepticism in scientific discourse there is the pragmatic and opportunistic way of using metaphors and art methods with regard to management applications. The question therefore is: (how) would it be possible to found the application of creativity and metaphors on critically evaluated humanistic values in communication in order to replace the romantic ideology of 'naive humanism' as well as the instrumentalist view of rationalism?

As a possible answer to this question a 'dialogical attitude' is circumscribed by means of relevant communication models found in organizational literature. Three models developed by Socrates, Habermas and Argyris \& Schön help to articulate the conditions for the application of art methods in communication processes based on a 'critical humanism'. Preconditional for dialogical communication is an open attitude to the 'voice of otherness' and personal engagement to others and the topic at stake. As a conclusion of this chapter a conditional mode for 'dialogical communication' is presented: 'the possibility of free choice and informational symmetry to engage as an equal participant in the dialogue resulting in procedures of organizational negotiations and decisions'.

In the fourth chapter a hermeneutical analysis of metaphoric communication is presented. The analysis starts with the introduction of a rhetoric perspective on communication to focus on shortcomings and onesidedness in analysing communication from a logical point of view. Three forms of 'metaphorical communication' are differentiated from the rhetorical point of view:

1) the substitution of (verbal) metaphors in discourse;

2) the metaphorization of a (part of a) story into a parable or allegory;

3) the application of a nonverbal medium of communication in a metaphorical way; 

art and metaphors are applied in therapy and organization processes.

Hermeneutics is introduced as a 'third way' between a rationalistic and a romantic way of generating knowledge about therapeutic and organizational processes. Crucial for developing a hermeneutical way of research in order to generate knowledge on therapy and organizations is a dialectics between openness and engagement towards the research topic. This third way leads to, ànd presupposes, a 'dialogical attitude'. Based on this attitude it is possible to integrate an open mind and engagement with a critical stance towards every given definition of 'self', 'organisation' and the 'world', so that relevant definitions are linked to 'the world of personal experience' (Habermas). This integration leads to an 'authentic' operationalization of the philosophical blue print of 'dialogical communication'.

In the fifth chapter the theoretical analysis is confronted with a practical research project of 'exchanging knowledge and experience' of two groups of professionals: art therapists and 'art trainers'. Two research findings are formulated on which the conclusion of this chapter is based. First: the abstract concept of 'metaphoric communication' should be reformulated in terms of concrete metaphors in order to be 'comprehensible' and 'motivational' for the professionals involved. Second: the importance of 'a context of meaning' is being stressed. A 'context of meaning' transcending the 'conventional' knowledge about organizational and therapeutic processes as well as operationalizing the abstract philosophical concept of metaphorical communication. These research findings lead to a final conclusion: the fundamental interrelatedness between organization and man, 'environment' and 'human beings', follows from this encompassing 'context of meaning', which is dichotomized in 'conventional' knowledge. This 'encompassing' point of view is crucial to give meaning to the concept of 'authentic communication' based on a critical humanism, in order to see the complexity of organizational and therapeutic problems instead of giving partial and dichitomizing solutions.

The sixth chapter is devoted to reflective remarks on the research route itself: the value of philosophical reflection for the practical situation of art therapists and art trainers, and the 'dialogical' turn towards empiricism for philosophy. For both parties the dialogue with 'the other' can be enriching for the traditional self concept. From this 'dialogical point of view' the difference between therapeutic and organizational processes of change is related to a common ground of 'a narrative context for experience centered learning' in therapy and organizations. Finally some practical recommendations for the professionals involved are formulated. 


Heidi S.C.A. Muijen werd in 1959 te Rotterdam geboren. Zij behaalde in 1979 in Den Haag het staatsexamen VWO. Aan de universiteiten van Utrecht, Leiden en Rotterdam studeerde zij wijsbegeerte met bijvakken psychologie, milieukunde, kunst- en cultuurwetenschappen. Na het behalen van het doctoraalexamen in 1989 was zij als mede-oprichtster enkele jaren betrokken bij het Rotterdamse Filosofen Café en werkzaam als docente aan de Haagse Academie voor Filosofie. Op basis van de post-H.B.O.-opleiding aan het 'ICTEP', het instituut voor creatieve therapie \& expressieve psychotherapie in Amersfoort, heeft zij enige tijd als creatief therapeute in de ouderenzorg gewerkt. Het promotie-onderzoek heeft plaatsgevonden in het kader van een A.I.O.-aanstelling aan de bedrijfskunde faculteit van de Erasmus Universiteit Rotterdam / Rotterdam School of Management. 
In de geestelijke gezondheidszorg heeft creatieve therapie inmiddels in behandelprogramma's een vaste plaats veroverd. In bedrijven en organisaties is de toepassing van creatieve en ludieke middelen evenwel een omstreden ontwikkeling: Natuurlijk bieden theatertechnieken, schilderen, zenmeditatie, muziekworkshops en paardrijden momenten van plezier en ontspanning op de overspannen bedriffsagenda. Maar vertegenwoordigen zij ook creatieve 'leermomenten' in het kader van organisatietrainingen? Vooralsnog is het onduidelijk of de trainingsdoelen van deze creatieve trajecten daadwerkelijk worden behaald. Betekent de implementatie van creativiteit in organisaties en therapie een kentering in ons overgerationaliseerde bestaan en een opleving van humanistische waarden en idealen?

Metafoor tussen magie en methode beschrijft een filosofisch en praktijkonderzoek over deze vragen. De auteur vindt het een romantische maar naieve visie te geloven dat de populariteit van creativiteit in het bedrijfsleven op zichzelf een humanisering inluidt. Kunst en ludieke middelen kunnen immers ook 'humanistische make up' zijn die de voortgaande verzakelijking van ons werk-leven tot in de psychologische vertakkingen van de maatschappij maskeert. De auteur pleit voor een kritisch humanisme, waarbij creativiteit en ludieke momenten dialogisch samengaan met reflectie en bezinning.

Heidi Muijen heeft het hier beschreven promotie-onderzoek uitgevoerd aan de bedriffskundefaculteit van de Erasmus Universiteit Rotterdam/Rotterdam School of Management.

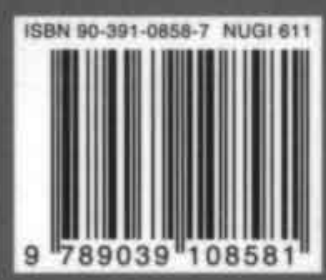

